
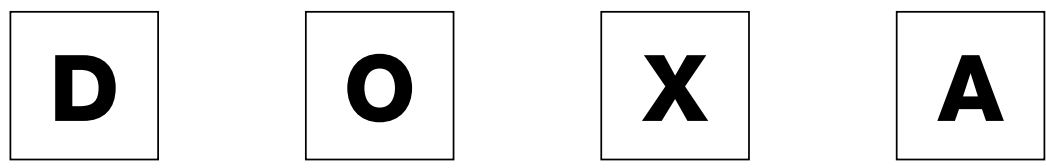

CUADERNOS DE

FILOSOFÍA DEL DERECHO

http://doxa.ua.es 
DOXA Cuadernos de Filosofía del Derecho ha sido reconocida con el Sello de Calidad de la Fundación Española para la Ciencia y la Tecnología (FECYT) y está recogida e indexada en ANEP, CARHUS PLUS+, Dialnet, DICE, ESCI, IN-RECJ, ISOC, Latindex, MIAR y PIO.
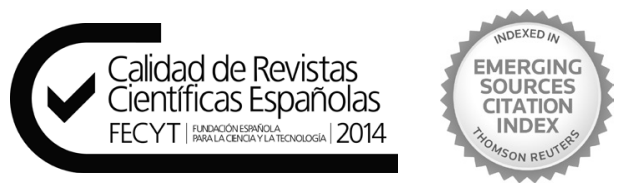

«Doxa. Cuadernos de Filosofía del Derecho» es una publicación de carácter anual que, desde 1984, trata de servir como vehículo de comunicación e intercambio entre los filósofos del Derecho latinoamericanos y los de Europa latina.

Esta edición de DOXA Cuadernos de Filosofía del Derecho ha contado con una ayuda económica del Vicerrectorado de Investigación y Transferencia del Conocimiento de la Universidad de Alicante.

Quedan rigurosamente prohibidas, sin la autorización escrita de los titulares del «Copyright», bajo las sanciones establecidas en las leyes, la reproducción total o parcial de esta obra por cualquier medio o procedimiento, comprendidos la reprografía y el tratamiento informático, y la distribución de ejemplares de ella mediante alquiler o préstamo públicos.

(C) DEPARTAMENTO DE FILOSOFÍA DEL DERECHO UNIVERSIDAD DE ALICANTE

(C) MARCIAL PONS EDICIONES JURÍDICAS Y SOCIALES, S. A.

San Sotero, 6 - 28037 MADRID

- (91) 3043303

www.marcialpons.es

I. S. S. N.: 0214-8676

Depósito legal: M-27.661-1989

Fotocomposición: Josur Tratamiento DE TeXTos, S. L.

Impresión: ELECÉ, Industria Gráfica, S. L.

Polígono El Nogal - Río Tiétar, 24 - 28110 Algete (Madrid)

MADRID, 2017

Printed in Spain 
Departamento de Filosofía

del Derecho

Universidad de

Alicante

Alicante, 2017 

ÍNDICE 



\section{Cuestiones de teoría del Derecho}

François Ost:

¿Para qué sirve el Derecho?... para contar hasta tres

What is Law for?... to Count up to Three....

José Antonio Ramos Pascua:

Lagunas del Derecho y positivismo jurídico. Un examen de la concepción de las lagunas de $C$. Alchourrón y E. Bulygin

Legal Gaps and Legal Positivism. C. Alchourrón and E. Bulygin's Conception of Gaps under Examen

Rodrigo Coloma Correa:

Bases de un modelo conceptual para decidir hechos

Basis for a Conceptual Model for Decisions on Facts

María Beatriz Arriagada Cáceres:

Normas de competencia y normas acerca de la competencia. Eludiendo las reglas constitutivas

Norms of Competence and Norms about Competence. Escaping from the Constitutive Rules.

Rafael Hernández Marín:

El control de la actividad judicial y las teorías jurídicas actuales

The Control of Judicial Activity and Current Legal Theories

Joaquín Rodríguez-Toubes Muñiz:

Sobre la opacidad referencial y la ambigüedad de dicto/de re en el Derecho

On Referential Opacity and De Dicto/De Re Ambiguity in the Law. 


\section{Perspectivas históricas de la filosofía del Derecho}

Benjamín Rivaya:

El exilio iusfilosófico español (1936-1977/1981)

The Spanish Iusphilosophical Exile.

Oriol Farrés Juste:

La filosofía del derecho de Alexandre Kojève

Alexandre Kojève's Philosopby of Law

Leopoldo José Prieto López:

La soberanía en Vitoria en el contexto del nacimiento del Estado moderno: algunas consideraciones sobre el De potestate civili de Vitoria

The Sovereignty in Vitoria in the Birth of the Modern State: some Considerations on the De potestate civili of Vitoria

Luis Lloredo Alix:

Muertes y resurrecciones del positivismo jurídico: una crisis de doscientos años de duración

Deaths and Resurrections of Legal Positivism: a Two Hundred Years' Crisis

\section{Notas}

Roberto Lara Chagoyán:

Decidir, argumentar y engrosar: el caso Martín del Campo

Voting, Arguing and Drafting: Producing a Judgment to the Martín del Campo Case...

Alberto Carrio Sampedro:

Hasta que la muerte los separa. Legítima, derecho de propiedad y prohibición de disposición del titular de los bienes: un ejemplo práctico de inconsistencia normativa

Until Death do Them Part. Legitimate Portion, Ownership and the Ban on the Disposal of Goods by the Property Holder: a Practical Example of Normative Inconsistency.

Sebastián Reyes Molina:

Sobre derecho y la averiguación de la verdad

On Law and the Ascertainment of Truth

Tasia Aránguez Sánchez:

¿Es necesario un giro aretaico de la teoría de la argumentación jurídica?

Is it Necessary an «Aretaic Turn» in the Theory of Legal Argumentation? 
Miguel Fernández Núñez:

La ponderación: análisis de la situación del debate en España

Balancing: Analysis of the State of the Debate in Spain....

\section{Entrevista}

Manuel Atienza:

Entrevista a François Ost

Interview to François Ost. 

CUESTIONES DE TEORÍA DEL DERECHO 



\title{
¿PARA QUÉ SIRVE EL DERECHO?... PARA CONTAR HASTA TRES*
}

\author{
François Ost \\ Université Saint-Louis-Bruxelles \\ ost@fusl.ac.be
}

RESUMEN. En las páginas que siguen, el autor, asumiendo sucesivamente una perspectiva propia de las ciencias sociales, una propia de la Teoría del Derecho y, finalmente, una de filosofía del Derecho, defiende una concepción del Derecho como una institución secundaria. Hablamos, así, de una reformulación o formulación de segundo grado de las relaciones sociales de base que introduce además el «escenario del tercero»; llevando a todos y a cada uno de los actores - tanto externa como internamente- a una auto-superación o trascendencia, colocándolos en una suerte de mundo simbólico donde hasta el propio Derecho se autocuestiona (es esta la naturaleza fuertemente interrogativa del mismo). Así caracterizada, esta institución secundaria cumple una serie de funciones sociales y unas finalidades que le son propias. Además y a través del "escenario del tercero» ( que nos lleva a la dimensión de la normatividad y de la justicia) tales se presentan como intrínsecamente unidas a la emancipación de los seres humanos respecto de los poderes puramente fácticos.

Palabras clave: reformulación, formulación de segundo grado, institución secundaria, escenario del tercero, naturaleza interrogativa, funciones, finalidades, función de limitación, función de pilotaje.

\section{What is Law for?... to Count up to Three}

ABSTRACT. Assuming a social science approach as well as, successively, a legal theoretical and a legal philosophical one, the author reconstructs the Law as a secondary institution. We speak both of a reformulation or a second degree formulation of social relation and of the introduction of the third person's scenario, Agents are lead to a sort of symbolic world in an exercise of selfovercoming and transcendence. The Law itself is controversial, under-question (we refer here to its profoundly interrogative nature). Under these terms, this secondary institution serves its proper social functions and purposes. Particularly, the resort to the third person's scenario (and thus the realm of normativity and justice) makes these functions and purposes be intrinsically connected to the emancipation of agents against purely factual powers.

* Fecha de recepción: 23 de septiembre de 2016. Fecha de aceptación: 16 de febrero de 2017.

Traducción de Victoria RocA.

$N$. de la T.: En la versión original en francés del título del trabajo «A quoi sert le droit?... à compter jusque'à trois», el autor juega con la rima —que a su vez toma la típica estructura de los juegos de palabras de niños- que resulta de la unión de Droit y trois y transmite así de forma sintética exactamente la idea que recorre el trabajo: esos tres momentos que definen el tránsito a la juridicidad [de las relaciones y reglas sociales de base (1) a su reformulación jurídica (2) y después a la resolución de litigios así formulados en un escenario en el que está presente la figura del juez o tercero (3)]. El núm. 3 está vinculado entonces con esos tres pasos a lo jurídico y también con la idea del «él» o tercero intrínseca al mismo y que hace del Derecho un instrumento que fuerza a los actores a tomar una distancia (tanto externa como interna respecto de sí mismos) y a trascender a un mundo en el que rige la idea de imparcialidad y, también, en consecuencia, la de balanza o equilibrio. 
Keywords: reformulation, second degree formulation, secondary institution, third person's scenario, interrogative nature, functions, purposes, limitative function, pilotage function.

\section{INTRODUCCIÓN}

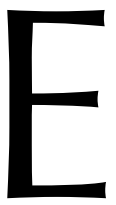

n un libro reciente formulé la pregunta «¿para qué sirve el Derecho?» ${ }^{1}$. Trataba en él de ofrecer una respuesta distinguiendo entre su uso por gobernantes y gobernados, las funciones técnicas que le son propias y, por último, las finalidades que persigue cuando es puesto al servicio de la justicia y de la democracia. De esta manera, recurría sucesivamente a un enfoque propio de las ciencias sociales, a uno propio de la teoría de Derecho y, finalmente, al tipo de análisis que caracteriza a la filosofía del Derecho. No menos de 570 páginas llegué a compilar intentando dar respuesta a un interrogante que es al tiempo básico y complejo.

Y, entonces, finalmente ¿para qué sirve el Derecho? Pues bien, si me detengo y doy un paso hacia atrás lo que respondería aquí y ahora, aun a riesgo de una simplificación excesiva, sería lo siguiente: «Para contar hasta tres». Esta respuesta, que puede parecer tan aventurada como provocadora, traduce sin embargo la lógica profunda de la tesis que el trabajo trata paulatinamente de articular. Y es así que pasando sucesivamente del uso del Derecho a sus funciones y, por último, a sus finalidades, doy cuenta de cómo el Derecho al ponerse en funcionamiento arranca la relación social de base (sea económica, política, familiar, etc.) de su particular registro (uno que está siempre bajo la amenaza de la fuerza), para inscribirla en la esfera pública y general del Derecho. Esta reformulación no satisface, sin embargo, las exigencias de la justicia salvo que se haga bajo la consideración de un tercero, de la ley común y de la figura del juez que está por encima de las partes.

Tres etapas recorren mi intento por mostrar en las páginas que siguen lo anterior. Primero me entrego a una forma de pensar de naturaleza fenomenológica, que consiste en preguntarse qué cambia en el momento en que dos personas, o un grupo, deciden «recurrir al Derecho» (1). A continuación reformulo la pregunta pero ahora ya desde la perspectiva de la teoría jurídica, presentando el Derecho, de esta manera, como una reformulación (2). Por último, muestro que esta solo viene a garantizar verdaderamente la justicia en la medida en que el marco en que se produce esa reformulación es un escenario donde aparece la figura de un tercero haciendo funciones de tal (3).

En definitiva, la función propia del Derecho es hacer surgir y luego garantizar un mundo social en tres dimensiones donde la referencia estructural a un tercero será lo que venga a interconectarlas. Ese es el inestimable valor añadido que el Derecho puede aportar a la vida social, siempre y cuando el mismo logre zafarse de la manipulación de lo único e idéntico a sí mismo.

\footnotetext{
1 F. Ost, A quoi sert le droit? Usages, fonctions, finalités, Bruxelles, Bruylant, 578 pp.
} 


\section{1. ¿QUÉ CAMBIA CUANDO UNA RELACIÓN SOCIAL PASA A ESTAR JURIDIFICADA?}

Este interrogante, que fue el que me impulsó a dedicar tres años en la redacción de «¿Para qué sirve el Derecho?», lo abordé, casi en su totalidad, de esa forma puramente intuitiva propia del método fenomenológico. Pese al riesgo (asumido) de caer en la especulación finalista y en la proyección esencialista, no dejo de preguntarme, esforzándome por dejar en suspensión fenomenológica mi acervo (epochè) ¿qué es lo que se transforma en ese momento en que una sociedad, un grupo, o incluso simplemente dos individuos, toman la decisión de «recurrir al Derecho»? Quiero decir, toman la decisión de apelar al Derecho, de confiarse al mismo, de poner en funcionamiento los mecanismos destinados a juzgar, a regular, a certificar, previstos en esa cosa en particular a la que denominamos Derecho.

¿Qué cambio específico tiene lugar cuando dos seres que viven una pasión amorosa se deciden a formalizar su relación (por ejemplo, pasando de la cohabitación de hecho al vínculo matrimonial) o cuando, pasando en cierto sentido a un registro diferente, resolvemos oficializar un acuerdo (el apretón de manos de los regateadores en la plaza del mercado, el acuerdo entre caballeros en el seno de una reunión diplomática, el acuerdo informal entre dos socios mercantiles...), cuando con un consentimiento más o menos claro renunciamos a tomarnos la justicia por nuestra cuenta y decidimos someternos a un juez? $\mathrm{O}$, por poner otros ejemplos, ¿con qué novedad nos encontramos en el momento en que sustrayéndose a una relación caracterizada por estar basada en la fuerza y, sin embargo, por lo general muy desigual, los protagonistas acuerdan someterse a una u otra ley común, comprometiéndose el más fuerte, a pesar de su superioridad, a obedecer la misma, al tiempo que el más débil hace igual, aun pudiendo tener todas las razones para resistirse? (pienso en especial en las cartas de privilegios concedidas por el señor feudal a los burgueses, esos nuevos habitantes de las ciudades).

Seamos conscientes del alcance exacto de estos interrogantes: no se trata simplemente de que nos preguntemos qué cambia en una relación cuando la misma pasa a depender de una regla, puesto que en todos mis ejemplos ya existía una regla; aunque es cierto que esa regla era de otra naturaleza antes de que se diera el tránsito a lo jurídico. El compromiso de vivir juntos es vivido con frecuencia como algo más personal, más fuerte y más auténtico que el contrato matrimonial. La confianza de los vendedores es bien sólida y no precisa de papel alguno. La relación de fuerza está sólidamente regulada al encontrar su fundamento en la «ley del más fuerte». La pregunta es: ¿qué cambia en el momento en el que la regulación toma prestada la forma jurídica? Como ejemplo, y por ofrecer una respuesta muy simple, podríamos señalar que lo que cambia es que ha pasado a haber una cierta distancia, puede incluso que se haya instalado un cierto distanciamiento entre los protagonistas cuando optan por tomar la decisión de renunciar o dirigirse a un tercero para que sea él quien «demuestre» un hecho, «haga constar» un acuerdo. ¿Qué significa tal distanciamiento?

He de apuntar que toda vez que me he librado a esta suerte de pensamientos he tenido en mente el ejemplo histórico de la ley de las XII Tablas que los patricios romanos otorgaron a la plebe en el año 450 a. C. Tal referencia histórica contribuye, 
sin duda, a que la reflexión se vuelva algo menos especulativa. Al mismo tiempo no se trata de que pensemos solo en la misma, ya que haciéndolo correríamos el riesgo de reducir el alcance de la experiencia; y es que, finalmente, apenas sabemos nada de tal documento del que el eminente romanista A. SCHIAVONE escribió que se trataba de un texto «memorable y casi legendario cuyo recuerdo se confunde con lo que fueron los orígenes de la comunidad republicana» ${ }^{2}$.

Retomemos entonces nuestra pregunta pensando (aun si no de forma exclusiva) en este ejemplo privilegiado: ¿Qué cambia cuando avanzamos hacia lo jurídico? Desde un punto de vista material, la plebe, sin duda no debió de sufrir cambios ni espectaculares ni tampoco significativos en su propia condición: siguió siendo esa clase explotada a quien se excluía tanto de las responsabilidades como de los beneficios. Y, aun así, se había dado un cambio cualitativo, poco perceptible al principio, exclusivamente simbólico o casi, y de cuyas inmensas consecuencias a largo plazo no se tuvo entonces conciencia. Intentemos identificar todos y cada uno de los elementos constitutivos de ese cambio.

\subsection{El comienzo del reconocimiento recíproco}

Primer elemento de la respuesta: al otorgar una carta de derechos, darle forma escrita a un acuerdo, pasar a gobernar a un grupo por medio de la ley, lo que estamos haciendo, en primer lugar, es conceder un mínimo reconocimiento recíproco, instaurar un comienzo de simetría entre unos protagonistas que antes se diferenciaban en todo. Esa otra parte con quien firmo un tratado de armisticio, el terrorista con quien negocio, el apátrida a quien se le concede un amparo ante una instancia judicial, Yahvé con quien el pueblo judío se unió en alianza, Mefisto con quien Fausto pacta, no son más «meros otros»; el intercambio jurídico nos compromete recíprocamente, jurídico nos compromete recíprocamente, aunque solo sea un poco, en un inicio de común identificación, un comienzo de igualación (me reconozco, aunque sea un poco, en ese otro con el que celebro un contrato).

Contrafácticamente: ¿Celebraríamos un contrato con animales, robots o marcianos? -las ficciones que nos permiten imaginar un ejercicio semejante lo hacen mediando una cuasi-total antropomorfización del «otro»-

Doy cuenta además del hecho esencial de que al menos en la mayoría de los casos un comienzo de reconocimiento tal resulta más de la autoafirmación de los débiles, de un arranque de dignidad, de una reclamación hecha al Derecho, que de la repentina generosidad de los fuertes. Y tal fue el caso de Nelson Mandela y de sus compañeros de cautiverio en Robben Island cuando entablaron su largo combate jurídico para exigir un cinturón con el que poder sujetar sus pantalones - y es que, en efecto, para reivindicar nuestros derechos hace falta poder mantenernos en pie-: el «status» (del latín stare, «mantenerse erguido») implica la idea de hombres en pie, conscientes de su dignidad.

2 A. SChiavone, Ius. L'Invention du droit en Occident, traducido por G. y J. Bouffartigue, Paris, Belin, 2008,371 . 


\subsection{La inserción en el «escenario de un tercero»}

El tránsito al Derecho implica entonces que la relación social, privada o pública, intersubjetiva o colectiva, tiene éxito a la hora de insertarse en otro escenario, el de «aquello considerado justo». Más allá de pensar en la complicidad inmediata, pienso en un plan más remoto, más abstracto y virtualmente más generalizable, como si nos colocáramos bajo la mirada de un tercero-árbitro. Se trata de un pequeña diferencia, de un imperceptible desenfoque - pero un mundo simbólico - entre el vínculo ordinario, practicado y vivido por sus protagonistas, y el nuevo escenario de referencia, el plano de la justicia y del Derecho, donde a partir de entonces se inscribe la medida común que regula tal relación. Basta, por ejemplo, con pensar en el seísmo que se produce cuando, en conformidad con una primera ley de «trabajadores domésticos», la relación amo-criado (criada), aunque solo sea potencialmente, deja de pertenecer al universo doméstico; y cuestiones tradicionales tales como el salario y las vacaciones de los trabajadores de este ámbito son a partir de entonces reguladas a la luz y con la ayuda de esa ley común.

En estas condiciones, cada uno, trátese de actor público o del actor privado, pasa a ser virtualmente justiciable, y ello debido a la existencia de ese escenario de «aquello considerado justo». Quienes detentan el poder, si bien no se vuelven indefensos, tampoco tienen las manos completamente libres. Aun así continúa habiendo una asimetría en la relación, no pueden ya ser totalmente arbitrarios, y un control mínimo de sus acciones se vuelve, al menos en principio, posible (es de lo que trata la célebre novela de Michaël KolHAAS DE VON KLEIST: el tratante de caballos acaba por sacrificar su vida en una lucha porque el daño que el terrateniente le ha causado se traduzca en justicia ya que, en principio, no ha de haber privilegio jurisdiccional alguno). Sin duda, donde quiera que sea y en todo supuesto, la espada del poder cargará pesadamente uno de los platos de la balanza, pero, como ha sido puesto de manifiesto por San ELLMAN en sus trabajos sobre Sudáfrica durante la época del apartheid, sucede que, incluso bajo los regímenes más coercitivos, la legitimidad de la justicia y del Derecho trasciende esa manera en que la institución judicial participa de hecho de la injusticia del poder. Este desenfoque, o des-implicación, es también lo que caracteriza al tránsito de la justicia privada a la justicia pública; lo que, fundadamente, P. RICOEUR considera como una verdadera revolución que sella el tránsito al Derecho ${ }^{3}$. Acordamos que a partir de entonces no va a ser solo «entre nosotros» que resolvamos los conflictos, sino que decidimos que, a partir de ahora, acudiremos a ese tercero a quien se le ha conferido el poder de hacer justicia. El conflicto privado pasa a insertarse en lo que se considera un espacio público - aunque hayan hecho falta siglos y no se haya llegado a materializar jamás - provocando así una sana forma de distanciamiento que obliga a las partes a traducir sus quejas y reclamaciones al lenguaje formal de la ley común y, bajo la salvaguarda del juez, a iniciar un desenfoque. De su parte, tal desenfoque permite establecer un comienzo de universalización, y que los puntos de vista pasen a ser expresados de forma desinteresada. Traduciendo lo que H. ARENDT denominaba una forma de «pensamiento libre», el juzgador se entrega al difícil ejercicio que consiste

\footnotetext{
3 P. RicoeuR, «L'acte de juger», en Le juste, Paris, Editions Esprit, 1995, 190.
} 
en ponerse en el lugar del otro ${ }^{4}$. Toma distancia, da un paso atrás y somete el litigio a un ejercicio abstracto de intercambio de posiciones: ¿Qué tenemos entre manos desde el punto de vista del otro, no importa de qué otro, de la sociedad en su conjunto, de futuros potenciales justiciables?

Entrar en la esfera de la juridicidad es, por tanto, convertir el vínculo social en algo que virtualmente puede ser objeto de la justicia (eventos judicii, allí donde un juez podrá intervenir). Esto que poco a poco va surgiendo es algo así como una «formulación de segundo grado» de la relación social — quiero decir, una reformulación reflexiva respecto de la cual la distancia a la que apenas me he referido era el signo, y la «doble institucionalización» (infra, 2) es la formulación teórica-.

\subsection{Justicialidad y justificabilidad}

El tránsito al Derecho viene acompañado además de otros efectos, como lo vimos a partir del arquetipo del dictado de las XII Tablas. Sabemos que desde el momento en que el vínculo social y político puede ser potencialmente inscrito en el escenario de «aquello considerado justo» pasa a ser virtualmente justiciable. Y ahora podemos añadir que esta situación implica, por una parte, la obligación de justificar nuestro comportamiento en el marco de ese escenario, pero también la ventaja de poder tomar de él, en contrapartida, una cantidad inagotable de recursos justificativos y legitimadores. Por expresarlo de esta forma, justo al día siguiente de haber dado el paso a lo jurídico, nuestro mundo deja de ir completamente por su cuenta, ya no procede sencillamente de un orden natural, tradicional o revelado (tres de las principales modalidades de heteronomía), sino que pasa, al menos en parte, a pensarse a sí mismo como un convenio, un contrato social que conviene justificar al tiempo que el mismo es fuente de justificación. Tal mundo pasa así a apoyarse en el frágil logos; implicando esto que nos referiremos al mismo para que una determinada acción sea autorizada y sea, por tanto, aceptable: hará falta dar cuenta de las razones, logon didonai. Aun si es cierto que los patricios no dejaron de explotar a la plebe, si uno de estos últimos presentaba queja, entonces los otros se veían obligados a argumentar a partir del texto al que habían acordado atenerse; y a la inversa, en la medida en que su comportamiento quedara, en mayor o en menor medida, dentro del marco de la ley, no podían ser cuestionados. Insisto una vez más, para que esto llegue a generalizarse se necesita tiempo; hizo falta mucho tiempo, por ejemplo, para que los procesos se articularan en torno a pruebas fácticas (más que ordalías, a «juicios de Dios», y a otras pruebas dependientes de una mentalidad pre-lógica) y a argumentos racionales, más que remitiendo a confrontaciones entre performativos destinados a movilizar fuerzas amigas y enemigas (imprecaciones, maleficios, juramentos) $)^{5}$.

${ }^{4}$ H. ARENDT, Juger. Sur la philosophie politique de KANT, traducido por M. Revault D’Allones, Paris, Seuil, 1991, 72.

5 Para un estudio de este lenguaje performativo con fundamentos mágicos en la tragedia griega, $c f r$. F. Osт, Raconter la Loi. Aux sources de l'imaginaire juridique, Paris, Odile Jacob, 2004, 136. 


\subsection{El Derecho: límites y fuentes, factor de paz y vector de conflicto}

Por su parte, esta distancia reflexiva que supone el Derecho en relación con la relación social primaria (afectiva, comercial, política...) pone de manifiesto dos rasgos esenciales del carácter específico del Derecho, de su valor añadido o de esa propiedad emergente trae aparejada en contraste con una regulación ordinaria meramente inmanente a lo social. El Derecho tiene dos caracteres en conflicto: por una parte, su carácter reversible, en principio, por otro, su carácter polemógeno al tiempo que irenológico. A partir del momento en que pasa a ser ley común entre el débil y el fuerte, el poderoso y el plebeyo, el primus et secundus - a partir del momento en el que ocupa la posición de un tercero que puede ser invocado tanto por el uno como por el otro (y esto sucede, aun si, con frecuencia, también nos encontramos con que su contenido es más favorable a uno que al otro)—, el Derecho funciona igual de bien como límite coactivo que como recurso liberador, es tanto escudo para la defensa como arma de combate. Todos han de poder recurrir a él, ya sea como demandantes o como defensores, como acusadores o como acusados. Tal y como apunta L. ISRAËL, siguiendo a muchos otros que le precedieron (entre ellos R. IHERING que hablaba de «la lucha por el Derecho»), si bien podemos constatar que la connivencia que se da en mayor medida es la del Derecho con el poder, es posible, sin embargo, hacer que el Derecho vaya contra el poder, y que la justicia se vuelva contra el Estado ${ }^{6}$. Es esto lo que viene a ilustrar la lucha de esos abogados activistas de los derechos humanos comprometidos con la construcción de «causas» (cause lawyering, cause lawyers). Repito: aun si el Derecho carga con frecuencia uno de los lados (adivinamos cuál), esa movilidad que tiene en tanto que instrumento de medición asegura su capacidad de registrar las más justas ponderaciones de intereses. Tanto los gobernantes como los gobernados pueden solicitarlo, y pueden hacerlo tanto para defender el statu quo (el orden social impuesto o el derecho subjetivo cuya titularidad habían adquirido) como para llevar a cabo un cambio (reivindicar un derecho nuevo, o imponer un nuevo orden social).

Esta primera reversibilidad dialéctica acarrea una segunda, igualmente esencial: aun siendo factor de orden, de paz y de seguridad, el Derecho es también, y en la misma medida, factor de protesta, de impugnación, y de conflicto. Tal y como observa J. FREUND, si bien el Derecho es «solución de conflictos» es, de forma muy frecuente, «el motivo» de los mismos, de manera que es preciso reconocerle tanto funciones «polemogénicas» como «irenológicas» ${ }^{7}$. Sin duda, al actuar haciendo oficial un determinado estado de las relaciones sociales, la regla jurídica pacifica un estado de cosas imponiendo una suerte de tregua ante la afrenta constante que suponen las relaciones de fuerza e interés; pero, por otra parte, al hacer visible el conflicto del que emana y darles a los protagonistas instituciones y procedimientos para su preservación o su mejora acaba por instaurar con ello una «paz armada». Bajo un régimen jurídico, la paz que caracteriza una sociedad no significa ausencia de conflictos, sino más bien el establecimiento de mecanismos susceptibles de resolverlos pacíficamente: un estado «agonal», «civil» en cuyo seno se hacen valer unas reglas del juego que son las que presiden la confrontación entre los protagonistas. «Paz armada», el oxímoron traduce

\footnotetext{
6 L. IsRael, L'arme du Droit, Paris, Les presses de sciences Po, 2009.

7 J. FreUnD, «Le droit comme motif et solution des conflicts», en ARSP, 1974, 47 y ss.
} 
bien la paradoja dialéctica del Derecho: un Derecho del que nadie puede apoderarse por completo, y que trae siempre consigo orden y seguridad.

\subsection{Formalización, abstracción, generalización}

Volvamos a las XII Tablas y sigamos nuestro ejercicio fenomenológico. Antes de su dictado, las relaciones entre plebeyos y patricios se regían por la moral y por la política, por los valores y por las relaciones de fuerza. De acuerdo con la ética, cada quien se encuentra ante su conciencia colocándose en un cara a cara del que la empatía no está excluida (hecho que, en última instancia, finalmente, está fuertemente condicionado por la atmósfera religiosa). Según la política, a cada quien se le imponen límites distintos, y así es, uno es potencialmente objeto de explotación, de amenazas, de indiferencias, o de favoritismos y apoyos. La característica común de estos dos registros, es la inmediatez, la imprevisibilidad, la ilimitación: fusión o explotación, colaboración o exclusión, todo es directo e inmediato. Sea que se trate de favores, de regalos, de perdones o, a la inversa, de chantajes, amenazas, o de violencia no cabe hablar aquí propiamente de arbitrariedad puesto que falta el criterio de corrección con el que medir la acción. Por el contrario, cuando nos trasladamos al ámbito del Derecho, todo está formalizado: ya no hay arreglos, sino procedimientos, no más favores, sino derechos, no más amenazas, sino sanciones. Estamos ante un tercero y hemos de atender a una serie de criterios; si se echa la vista atrás se trata de caer bajo una determinada línea jurisprudencial o bajo la sombra de un texto; si se mira hacia adelante, se trata de intentar sentar jurisprudencia. Naturalmente, las relaciones éticas y políticas de base subsisten, pero ahora ya inscritas en el escenario de «lo considerado justo», sujetas a un límite o exigencia que se presenta menos directamente disponible para las partes y con la que se las habrán de componer.

Si el escenario del Derecho y de la Justicia se imponen como un nivel de referencia que no está directamente a disposición de las partes, es porque afecta a la vez a una generalidad abstracta de sujetos; $\mathrm{y}$ a un conjunto indeterminado de relaciones sociales dependientes de sectores de lo más variados («sub-grupos funcionales» en el sentido de LUHMANN, «ciudades» en el sentido de BOLTASKI y de THÉVENOT, «campos» en el sentido de BOURDIEU, «esferas de la justicia» en el sentido de WALZER). En este nivel no es suficiente con registrar de forma pasiva tal o cual estado de una relación social, sino que, a medida que el nivel jurídico se autonomiza, se trata de componer una regulación de conjunto que posicione a la totalidad de los actores sociales y que al mismo tiempo articule el conjunto de esos diferentes juegos que tienen lugar en el terreno social. Por tanto, no se trata solamente de que el Derecho ocupe una posición de árbitro en relación con un determinado juego u otro, sino de que realiza un arbitraje de juegos diversos, que se va haciendo cada vez más complejo en función de la evolución social y de la diferenciación entre las distintas esferas, tal y como señalaba Max WEBER. Y, a decir verdad, el desafío es considerable; lo que está en juego es la capacidad de una sociedad de realizar arbitrajes a nivel macro-social que sean susceptibles de producir resultados tales como el interés general o el bien común, trascendiendo los intereses particulares de una determinada clase de actores y la lógica propia de un campo u otro. Que tales arbitrajes raramente sean imparciales (y, por tanto, que no se trate verdadera- 
mente de la perspectiva de un tercero frente a relaciones de fuerza e interés) no es una razón, desde esta perspectiva de pensamiento desde la que ahora me pronuncio, para negarle al Derecho esa capacidad derivada de su naturaleza propiamente normativa: alcanzar el deber ser —o, dicho de otra forma, alcanzar eso que en determinado contexto es considerado deseable-.

Otro efecto significativo de esa transición al Derecho es que la relación humana subyacente queda a partir de ese momento despersonalizada. El mundo de la ética, como el de la política, son universos cálidos, eminentemente personales: ahí todo se mueve por los sentimientos, por la influencia, la simpatía, la identificación, la antipatía y el odio. Por el contrario, el mundo del Derecho y de la justicia son universos fríos donde los protagonistas se expresan y actúan en un mundo impersonal. El vínculo entre el esclavo y el amo, el hijo y el padre, el gobernante y el gobernado no es ya solo el vínculo entre un tal Juan y un tal José, esa alianza personal en que consiste la relación entre el vasallo y el señor feudal, sino un vínculo abstracto entre personas fungibles, sustituibles, vistas ahora bajo el ángulo de su estatus o del rol que ocupan en el escenario jurídico. Incluso si algo así resulta, en una primera reflexión, contra-intuitivo tal despersonalización, sin embargo, es lo que caracteriza por encima de cualquier otra cosa la idea de justicia conforme al Derecho. «¿Quién se refleja en el espejo de la justicia?» se pregunta P. RICOEUR, «no se trata de ti, identificado a partir de tu rostro, sino cada uno de nosotros en tanto que terceros» ${ }^{8}$. «Cada uno», ese cada uno a quien el Derecho atribuye la responsabilidad que le corresponde (suum cuique tribuere), en conformidad con una medida común, que no hace acepción de persona alguna'. Y si entendemos la justicia como la aplicación a cada quien de su justa medida nos daremos cuenta de que, precisamente, es el elemento impersonal de la relación o del actor el que es susceptible de medida o de comparación (de forma contraria a los elementos irreductiblemente personales que dependen del afecto y del rechazo). Además, podemos ver con claridad que es este elemento primitivo de impersonalidad el que contiene el germen del movimiento hacia la generalización; esto es, hacia esa universalización que tras milenios de evolución y de una considerable ampliación del universo jurídico condujo a la idea de los derechos del hombre de los que todos somos potencialmente titulares.

Además, este adolescente o esta esposa que se encuentra aplastada bajo la asfixiante gravedad de las relaciones domésticas, este trabajador inmigrante explotado por un empleador o por esos otros que, sin vergüenza alguna, se dedican a alquilar habitaciones por horas en pisos patera, este responsable político cuya vida privada es puesta a merced del público por los medios amarillistas - todas estas personas inmersas en sus respectivas «ciudades» («ciudades» en el sentido de BOLTANSKI y THÉVENOT: mundos específicos dotados de sus propios principios de acción y de juicio: ciudad doméstica, ciudad comercial e industria, ciudad de la fama ${ }^{10} \ldots$... - encontrarán quizá gracias al Derecho (que es «nivel» y no «ciudad», como señalaré más adelante) una puerta de salida, una vía de escape que, al permitirles acceder a otro escenario, les asegurará

8 P. RiCOEUR, «Qui est sujet de droit?», Le juste, op. cit., 37-38.

9 L. LEGAZ Y LACAMBRA, «Les fonctions du droit; introduction générale», en ARSP, Die Funktionnen des Rechts, op. cit., 6.

10 L. Boltanski y L. Thevenot, De la justification. Les économies de la grandeur, Paris, Gallimard, 1991. 
una rehabilitación, nuevas capacidades, les ofrecerá algo así como la posibilidad de relanzar la partida.

Esta operación implica poder sustraerse al determinismo inherente a cada una de las ciudades, poder tomar distancia respecto de las muy fuertes relaciones personales que prevalecen ahí, y poder reposicionarse bajo otra forma y en un terreno diferente, que es el que permite la formulación de la reclamación y la reivindicación de otra condición ${ }^{11}$. Tal es precisamente el efecto de la técnica jurídica que asegura doblemente tanto ese «engrandecimiento» de las personas, como que las mismas pasen necesariamente a ponerse una suerte de disfraz para pasar a ser vistas bajo un nuevo y más justo ángulo. Por una parte, el Derecho confiere a cada uno su propia personalidad jurídica, y por otra, inserta a los sujetos dentro de categorías y colectivos que transforman los litigios individuales en causas potencialmente generales. La personalidad jurídica confiere a cada uno una identidad abstracta, asegurando a la persona que jamás será reducida ni a su condición natural ni a los status fijos que prevalecen en el seno de cada ciudad; es un tipo de máscara (persona, máscara de teatro en latín) que a la vez disimula, protege, y apoya a la persona, y es tan significativa para ella que, cualquiera que sea el rango de la persona en el seno de la ciudad en la que se mueva, nunca estará totalmente confinada a la misma, ni tendrá asignado un status totalmente inalterable. Por lo demás, al unir a esas personas mediante el juego de calificaciones jurídicas bajo categorías generales y colectivos acreditados (la asociación, el sindicato, la acción de interés colectivo...), el Derecho formula un marco que, al tiempo que convierte el conflicto en anónimo, le confiere una apariencia general, haciendo del mismo una «causa». En este nivel, la pretensión del Derecho, ciñéndose a un «medio jurídico», y tomando prestada tal o cual «voz jurídica» (acción legal), se presenta como «jugada» válida dentro del juego jurídico que, al tiempo, es susceptible de modificar la naturaleza de los compromisos y arbitrajes que en él prevalecen. El mal que afectó a X o a Y en las confinadas profundidades de la ciudad se convierte en una reclamación generalizable, y será tratada por la autoridad jurídica en relación con la situación de no importa qué otra persona jurídica y teniendo en cuenta cualesquiera que sean los intereses y valores que prevalecen dentro de todas las ciudades, A o B, pero también C o D.

\subsection{Desdoblamiento, adelanto, superación de sí mismo}

Esta impersonalidad jurídica llega tan lejos que afecta al sujeto de Derecho mismo quién en el escenario jurídico se ve atribuir un status (derechos y deberes) y, por tanto, un rol que se superpone a su identidad narrativa personal (su personalidad concreta, evolutiva, interrogativa, alterada por el tiempo y por los demás) y que en sus relaciones políticas en la ciudad conduce a un desdoblamiento entre individuo y ciudadano. Lejos de ser una debilidad de la que avergonzarse o una inútil complejidad, este desdoblamiento es condición misma de éxito de la constitución jurídica de todo el montaje político.

En este sentido, RoussEAU explica bien que para que un individuo esté sujeto en tanto que ciudadano al contrato social de asociación constitutivo de la relación política

${ }^{11}$ En tal sentido, ibid., 374 y ss. 
ha de contratar consigo mismo ${ }^{12}$. Esta aparente incongruencia se explica evidentemente a partir del hecho de que el sujeto figura bajo dos conceptos distintos en el contrato: como individuo ordinario, sujeto a sus relaciones socio-económicas, políticas y afectivas pre-jurídicas, y como ciudadano potencial que, de alguna forma, se eleva a la potencia de la institución, estando a la altura de esa soberanía de la que participa. Esta superación de sí mismo, es propiamente el signo de la operación de «autotrascendencia», del paso a la potencia superior, la anticipación de una institución que habría existido siempre - todo lo necesario para el establecimiento de una fundación jurídica de lo político- ${ }^{13}$.

Este salto cualitativo (toma de distancia respecto de sí mismo, desdoblamiento, o auto-adelantamiento) tiene como resultado una «propiedad emergente», una lógica del «complemento» que explica también por qué ROUSSEAU puede escribir que la voluntad general es algo más y también algo distinto a la suma de la voluntad de todos. Este «complemento» ha de verse como una proyección de los actores hacia esa situación que anuncia la promesa. Una promesa que los actores se hacen a sí mismos en la Constitución, y de la que el juez constitucional es hoy en día el guardián. En ocasiones sucederá que ese juez irá en contra de la «voluntad de todos» al tener que censurar una ley por apartarse la misma de tales compromisos.

Esta misma operación se observa entre simples contratantes particulares desde el momento en que los promisores se refieren, más allá del compromiso concreto y de la mayor o menor confianza que puedan concederse recíprocamente, a la institución «promesa», que precede, da contexto y funda su compromiso personal ${ }^{14}$. Una institución cuya autoría no corresponde a nadie en particular y que, en este sentido, escapa a toda manipulación, aun si pudiera llegar a darse el caso de que el uso que los contratantes hacen en algún caso fuera el propio del juego sucio. Es así que empezamos a aprehender en qué consiste la especificidad del valor añadido que aporta lo jurídico a la relación social (económica, moral y política) primaria —un distanciamiento ínfimo que hace posible que nos refiramos a una unidad de medida que es a la vez común e indisponible- - Una referencia fundadora en el doble sentido de que ella hace posible el juego social (aquí el de la promesa), lo instituye, lo constituye (el sentido también de las reglas constitutivas, tanto del lenguaje como del Derecho) y, al mismo tiempo, establece los límites y las prohibiciones que habrán de operar en su seno.

Son estos los primeros resultados a los que llegamos a través del experimento mental consistente en tratar de identificar la naturaleza de la transformación que se opera en el momento en el que la relación social pasa a ser jurídica. La experiencia inversa no es menos significativa: ¿Qué cambia cuando tomamos la decisión de des-formalizar la relación, abandonar el Derecho para retornar a la espontaneidad del vínculo inicial? Es posible adivinar con facilidad las ventajas y los inconvenientes de esta elección. Por un lado, a la hora de maniobrar nos encontramos con una libertad que nos permite co-

12 J. J. Rousseau, Du contrat social. Ou principes du droit politique, Paris, Bordas, 1972, 77.

13 En un sentido similar, $c f r$. L. BOLTANSKI, L'amour et la justice comme compétences, Paris, Editions Matailié, 1990, 74.

14 Fr. JACQUES, «La promesse et le pardon», en Ethica e pragmatica. Archivio di filosofia, 1987, 1-3, 328; P. RiCOEUR, «Les implications de la théorie des actes de langage pour la théorie générale de l'éthique», en Théorie des actes de langage, éthique et droit, bajo la dirección de P. AMSELEK, Paris, PUF, 1986, 103-104. 
menzar con más facilidad contactos o flujo de asuntos o, a la inversa, que nos permite desentendernos de los mismos sin consecuencias adversas; llegamos así a felicitarnos de poder confiar el uno en el otro, y a veces incluso a enorgullecernos de «resolver nuestros asuntos sin intermediarios», sin degradarnos teniendo que recurrir a las autoridades oficiales, incluso nos vanagloriamos de cómo en la mediación familiar evitamos los formalismos y los excesos jurídicos. Por otra parte, renunciar al Derecho (o estar obligados a renunciar al mismo) supone evidentemente privarse de las garantías jurídicas, procedimentales o sustanciales, y exponerse a la ley del más fuerte.

De forma recurrente aparece la idea de que el vínculo social no es nunca natural u originariamente jurídico; de llegar a serlo es solo en un momento posterior, cuando se va tejiendo una necesidad de seguridad, de publicidad, o de durabilidad. Todo esto pone de manifiesto que si acaso hay un «valor añadido» cuando damos ese paso a lo jurídico, no se mide en términos de eficacia, rapidez, intensidad de la regulación. Si de esto se tratara, serían otras formas de regulación las que, sin duda, resultarían más operativas: así, y principalmente, los límites políticos y morales subyacentes.

Admito que estos primeros análisis todavía no dan una respuesta directa a la pregunta de para qué sirve el Derecho, pero lo que sí hacen es ofrecernos valiosos elementos que nos permiten ir dibujándola: de un lado, la idea del Derecho como reformulación reflexiva de la relación social primaria, sobre la que voy a profundizar ahora desde la dimensión propia de la teoría del Derecho y, de otro, la idea de que tal reformulación se produce bajo la égida de un tercero, de la que me ocuparé después desde la perspectiva de la filosofía del Derecho.

\section{DE «UNO» A «DOS», EL DERECHO COMO REFORMULACIÓN}

El filósofo C. CASTORIADIS dice del Derecho que es «una institución de segundo grado» ${ }^{15}$; todo sucede como si, apareciendo siempre en un segundo momento y colocándose en un escenario a un nivel «meta», asegurara una reflexividad a la relación social primaria sin cambiar realmente con ello la sustancia de la misma. ¿Quiere esto decir que esta reformulación es un simple calco, una repetición inútil? Para nada: esta reformulación es una superación que, si bien no modifica la sustancia de la relación social, transforma profundamente su apariencia. Podríamos llegar a entender esta idea si recurrimos a la metáfora del «pilotaje» que ejerce el Derecho — recordando que todo el vocabulario de la «gobernanza» deriva del latín gubernaculum, timón-. ¿Cuál es exactamente la función de un piloto (pienso, por ejemplo, en los pilotos apostados en el Canal de La Mancha para asegurar el acceso de las embarcaciones comerciales a los puertos de Amberes y de Rotterdam)? El Estado impone que estos suban a bordo con el fin de que aconsejen al capitán sobre la ruta a seguir en aguas tan peligrosas como frecuentadas: en tanto que funcionario, el piloto no sustituye al capitán, que es el «único maestro a bordo»; sin embargo, su presencia es obligatoria. Es guía oficial y ordena la conducta que se ha de seguir en los pasos marítimos más delicados. El piloto es «prestado» por el Estado; durante varias horas es parte y, sin embargo, al tiempo no

15 C. Castoriadis, L' institution imaginaire de la société, Paris, Seuil, 1975, 174. 
lo es, de la tripulación. Desempeñándose como un «complemento», se une a la tripulación y cubre la posible falta de experiencia de la misma. En su función de «pilotaje» social, el Derecho «complementa» — reformula y supera— las instituciones sociales preexistentes.

«Complemento» de lo real, el Derecho lo reformula sin ser, sin embargo, una simple copia del mismo, se trata de una reformulación pasiva en modo técnico. Su secundariedad es una forma activa y creativa, no solamente receptiva; su reflexividad juega en el plano simbólico y no solamente en el funcional. El Derecho oficializa el pacto alcanzado y la costumbre vinculante; muestra de esta manera las reglas que están en vigor en una determinada sociedad y, en una segunda instancia, introduce mecanismos que permiten de forma expresa su transformación. Igualmente, organiza procedimientos oficiales de resolución de litigios e instituye autoridades represivas con el fin de llevar a la práctica sus decisiones. En estas diferentes funciones se habrá reconocido la acción de aquello a lo que HART, de manera significativa, denomina, «normas secundarias» (infra). Esta secundariedad, sin embargo, no es más que funcional e instrumental: a medida que las sociedades se hacen más complejas y que el orden jurídico se automatiza, el universo simbólico propio del Derecho (la referencia a un tercero, que se traduce, centralmente, en publicidad, en su carácter contradictorio, en abstracción y en generalidad) tiene como efecto marcar la relación social primaria con ese rasgo de «terceridad» (infra, 3).

Lo primero que deriva de lo anterior es este efecto que ha sido frecuentemente mal entendido por la crítica social y por la justicia ordinaria: el trato jurídico y judicial de lo real supone una diferenciación «centralmente lingüística» en relación con esa realidad cotidiana, generando un efecto de alienación (ser convertido en extranjero) y un sentimiento de desposesión ${ }^{16}$. Tomando un conflicto social y denominándolo a su manera, el Derecho lo canaliza a través del complejo juego de sus procedimientos; lo transforma (lo «desnaturaliza» a ojos de sus protagonistas primarios que, a partir de entonces, se convierten en demandante y en defensor, en demandado, en acusado, en parte civil...). Y, con todo, si llegara a resolverlo, no será sino al precio de esa manipulación realizada con la ayuda de sus propias ficciones y de ese tratamiento altamente formalizado. De tal manera, esta diferenciación, si bien es signo de alienación, es también indicio de la creatividad propia del tratamiento jurídico de lo real; es decir, que no es sino bajo la condición de esta autonomización de las construcciones jurídicas respecto de los datos sociales de partida que el Derecho llega a desplegar su propia eficacia. Es mediante sus operaciones internas que el Derecho recrea el mundo exterior y le da la forma de sus propias ficciones de las que espera un impacto en el mundo real. El romanista Yan THOMAS, en su obra dedicada a las operaciones del Derecho, subraya con intensidad que el Derecho romano, tejido a base de ficciones, se construyó por completo mediante esta diferenciación deliberada en relación con la naturaleza: «Una radical desvinculación de la institucionalidad de ese otro mundo de las cosas de la naturaleza», «en las antípodas de toda verdad tangible» ${ }^{17}$. Al asumir explícitamente sus propias ficciones como una suerte de contra-verdades, el Derecho naciente subrayaba de tal manera su diferencia con respecto al hecho; hecho que es constitutivo de lo jurídico y

16 Cfr. G. Simenon, Lettre à mon juge, Paris, Presses de la Cité, 1947.

17 Y. ThOMAs, Les opérations du droit, Paris, EHESS-Gallimard-Seuil, 2011, 136-137. 
condición de la eficacia del Derecho sobre la realidad. Si asumimos estas condiciones, entonces, tal y como bien subraya G. TEUBNER, reprocharle al Derecho que carece de sentido de la realidad supone directamente errar el blanco; como sucede en el arte con sus construcciones imaginarias, le corresponde precisamente a las ficciones jurídicas tomar distancia de los límites de la realidad, para liberar otros mundos posibles —esos que «al quedar fuera del marco», pueden dar salida al litigio bloqueado- ${ }^{18}$. Tal es la eficacia de la quaestio facti.

\subsection{Doble institucionalización}

La teoría del Derecho ofrece diferentes instrumentos y teorías para pensar la reformulación jurídica de lo social. La denominada teoría de la «doble institucionalización» describe el pasaje de lo social, institución primaria, a lo jurídico, institución secundaria; la teoría de «la articulación de las normas primarias y secundarias», ya mencionada, prolonga este análisis en el plano de la normatividad. Por lo que a mí se refiere, y en el plano de las funciones, lo que propongo es distinguir las «funciones primarias» de las «funciones secundarias» que cumple el Derecho, y ello según que funcione prioritariamente sobre lo social, o que lo haga solo indirectamente regulando prioritariamente su propio funcionamiento ${ }^{19}$.

Fue el antropólogo P. BOHANNAN quien acuñó y difundió el término de «doble institucionalización» para referirse a la entrada en la esfera del Derecho y a la especificidad de este en relación con las instituciones sociales primarias ${ }^{20}$. En el marco de las sociedades sin Estado y con una sola cultura, nos explica que son las costumbres compartidas (tradiciones, modos, usos) las que aseguran «que las instituciones sociales cumplen sus tareas y que la sociedad sobrevive». En tanto que inherentes a las mismas instituciones, y al apoyarse en la reciprocidad (yo anticipo que el otro se comportará de forma similar a como me pide a mí que me comporte), estas costumbres no necesitan una formulación explícita. Por lo demás, los litigios no son objeto de «decisiones»; se solucionan mediante «pactos», con una formulación más bien vaga, y no son «ejecutados» sino «aceptados», y ello porque los protagonistas comparten una misma cultura ${ }^{21}$.

Cuando transitamos al Derecho las costumbres son objeto de una reformulación explícita y más precisa; y ello gracias a la iniciativa de agentes especializados y en un contexto que puede ser bien identificado debido al procedimiento que a partir de entonces va a regir. De otra parte, los litigios pasan a ser dirimidos por las autoridades, que también están especializadas.

Las instituciones jurídicas, que son así establecidas, presentan dos particularida$\mathrm{des}^{22}$. Por un lado, cuentan con mecanismos específicos que les permiten intervenir en

18 G. TEUBnER, «Les multiples aliénations du droit: sur la plus-value sociale du douzième chameau», en Droit et Société, núm. 47, 2001, 801.

19 F. Ost, A quoi sert le Droit?, op. cit., 191 y ss.

20 P. BoHAnnAn, «The Differing Realms of the Law», en American Anthropologist, vol. 67, diciembre de 1965, 33-42.

21 Ibid., 35.

22 Ibid., 36. 
el funcionamiento de instituciones primarias, y ello con el fin de despejar aquel caso que presente problemas. Después de un tratamiento particular en el plano jurídico pasan a intervenir otros mecanismos cuyo objetivo es recolocar la solución resultante en el mundo primario de las instituciones de base.

Por otra parte, precisa BOHANNAN, las reglas propias de las instituciones jurídicas son desde ese momento de dos tipos: las reglas «adjetivas» o de procedimiento, que hacen referencia al funcionamiento mismo de las instituciones, y las reglas «sustantivas» o de fondo, que son una reescritura o transformación de las costumbres imperantes del nivel primario.

El modelo de la transición al Derecho no tuvo que esperar a BOHANNAN para ser pensado bajo la forma de una reformulación. Testimonio de esto mismo es, principalmente, el relato que desde el siglo XII hasta nuestros días constituye el fundamento de la filosofía política moderna: la fábula del paso del estado de naturaleza al estado civil. De HOBBES a KANT, de LOCKE a RouSSEAU, la misma historia se fue transmitiendo: en su origen, la humanidad vivía en un estado de naturaleza aun si carente de reglas, sí con reglas inciertas y privadas de respaldo en caso de ser transgredidas. Estando así las cosas, los hombres fueron poco a poco convenciéndose del interés de dotarse de instituciones específicas con el fin de adoptar oficialmente reglas, de modificarlas en caso de necesidad y, sobre todo, de aplicarlas mediante el recurso a la fuerza caso de ser necesario. Un estado civil viene así a reformular, precisar y garantizar las reglas consuetudinarias que prevalecían en el estado de naturaleza ${ }^{23}$ — podemos ver que es una lógica funcional (que responde a necesidades estructurales surgidas en el estadio anterior) la que explicaría entonces según esta fábula el desarrollo del Derecho moderno-.

Este relato canónico recibe una formulación más precisa de la mano de los padres fundadores de la sociología. Principalmente de E. DURKHEIM, que arroja luz sobre un proceso histórico generalizado de diferenciación social: mientras que las sociedades primitivas viven en una visión holista del mundo, careciendo de la distinción entre lo que denominamos Derecho, religión, mores y moral, la evolución nos lleva a una lenta desintrincación de estas esferas que con el tiempo concluirá en una laicización del Derecho. En el curso de esta evolución, esta disciplina social, asumida en su origen bajo la forma de un sentimiento interior de obligación, no dejará de exteriorizarse, tomando el camino de una codificación oficial de las reglas y de un sistema de límites exteriores e impersonales ${ }^{24}$. La solidaridad (mecánica) por similitud, presente en las pequeñas sociedades cimentadas por una conciencia colectiva fuerte da lugar, en el mejor de los casos, a una solidaridad (orgánica) por diferenciación y complementariedad, el debilitamiento de la conciencia colectiva es sustituido en este modelo por la disciplina jurídica y por la educación cívica. Finalmente, vuelve al Derecho («cristalización de la conciencia colectiva») ${ }^{25}$ la función general de la normalización de las relaciones sociales.

23 Cfr. principalmente, J. LoCKE, Deuxième traité du gouvernement civil, trad. por B. GILSON, Paris, Vrin, 1977, 146 y ss. En ese pasaje, LOCKE se ocupa de forma bien expresa de los tres tipos de funciones que las reglas secundarias de HART, tres tipos igualmente, están llamadas a cumplir.

24 Para una reformulación de esta tesis en relación con el fenómeno de la complejización de las sociedades, cfr. A. KoJeve, Esquisse d'une phénoménologie du droit, Paris, Gallimard, 1981, 124 y ss.

25 E. DurKHEIM, De la división du travail social (1893), Paris, PUF, 1973, 28. 
En la misma línea, F. TÖNNIES y M. WEBER introducen la célebre distinción entre comunidad (Gemeinschaft) y sociedad (Gesellschaft): mientras que en el seno de la primera la conciencia de uno mismo se desdibuja ante el «nosotros», las solidaridades están muy activas y las funciones poco diferenciadas, en el seno de la segunda, la división del trabajo y la especialización de las competencias van estableciéndose poco a poco, de manera que una organización social más racional va a ir imponiéndose bajo la forma de una disciplina jurídica (se trata sobre todo de garantizar el respeto de los compromisos y de que se respete aquello a lo que pasa a denominarse la propiedad).

Estos diferentes análisis convergen: al principio, las reglas de comportamiento, de naturaleza tradicional y costumbrista, permanecen por lo general sin recibir formulación alguna. Uno está a merced de las reacciones espontáneas y difusas del grupo para asegurarse así de que es respetado por el mismo. En un momento posterior, y a causa y bajo el efecto de factores muy diversos (crecimientos demográficos como entendía DURKHEIM, aumento de la diferenciación de tareas, conquista extranjera acompañada de recaudación fiscal y conscripciones militares...) se procede, en una primera fase, a conferir a determinadas instituciones la capacidad para resolver conflictos y, en una segunda, se les otorga la competencia para modificar las reglas vigentes de forma inmediata y deliberada.

La doble institucionalización estaba de esta forma en marcha. Sin lugar a dudas, una buena parte de las reglas así consagradas se limitaban a reformular las costumbres en uso. Esto no impide que la acción de las instituciones judiciales, «parlamentarias» y ejecutivas puestas en marcha fueran cada vez más visibles, y que se multiplicaran las reglas «secundarias» que les conferían tal misión. La autonomía de este segundo mundo normativo no iba a dejar de crecer y ello hasta el punto de llegar a ocultar progresivamente el terreno sobre el que se edificaba.

Si bien bajo formas diversas, la tesis de la doble institucionalización se ha visto favorecida por un amplio consenso en las ciencias jurídicas contemporáneas. J. CHEVALLIER, por ejemplo, escribe: «La regla de Derecho entra en segundo lugar en relación con otras categorías de normas, la normatividad se sumaría a la normatividad ya presente, socialmente reconocida ${ }^{26}$. Este autor ha dado cuenta del amplio movimiento de juridificación de las conductas: «El Derecho progresivamente ha ido picoteando de la esfera extra-jurídica, ampliando la superficie que ocupa en el seno del orden social: nos encontramos entonces con que numerosas normas han sido atraídas a su órbita al haber sido formuladas a partir de un determinado momento en términos jurídicos» ${ }^{27}$. Entre los dos niveles de normatividad, las relaciones, por lo demás, no son más que una suerte de préstamo puro y simple. Los análisis relativos a la inter-normatividad han puesto de manifiesto que entre esos sistemas de normas se establecen toda suerte de interacciones, de interpenetraciones y de imbricaciones — fenómenos que se dan con mayor facilidad por la naturaleza maleable de las normas jurídicas en tanto que continentes de un contenido ampliamente indeterminado-.

26 J. CheVALLIER, «L'internormativité», en Les sources du droit revisitées, vol. 4. Théorie des sources du droit, sous la dir. de I. HaCHEZ, F. Ost et al., Bruxelles, Presse s L'Université Saint-Louis, 2013, 697. Cfr. también D. LOSCHACK, «Droit, normalité et normalisation», en CURAPP, Les droit en procès, Paris, PUF, 1983, 69.

${ }^{27} \mathrm{Ibid}$. No obstante, el autor evita caer en la panjuridicidad y observa también el fenómeno de retirada de lo jurídico. 
Los filósofos y sociólogos del Derecho suscriben igualmente, bajo las modalidades que les son propias, el ideal-tipo de la «doble institucionalización». Tal es el caso de HABERMAS, quien retoma los análisis de T. PARSONS hablando del Derecho como «institución de segundo grado» que interviene en caso de problema sobrevenido «en el nivel de los comportamientos sociales institucionalizados en primer grado». A la vista de las transformaciones de las que ha sido objeto el Derecho desde sus formas elementales (costumbre, venganza, arbitraje...), HABERMAS escribe: «El Derecho es un orden legítimo que ha pasado a ser reflexivo en relación con el proceso de su institucionalización». Y, cuando observa la evolución del Derecho «desde la perspectiva de su función propia» (la cursiva es mía), el filósofo da cuenta de la aparición de «normas jurídicas secundarias que permiten establecer y modificar las normas de comportamiento primarias» (la alusión a HART, si bien este autor no es citado, es clara, mientras que el resto de la frase continua haciendo referencia a «la organización del ejercicio de la justicia» y a la «puesta en funcionamiento del Derecho») ${ }^{28}$. Dando un paso que complementa lo anterior, HABERMAS observa que, durante esta fase secundaria y reflexiva, el Derecho entra en una relación dialéctica de codesarrollo con el Estado: «Un Derecho sancionado por el Estado y un poder político ejercido (añado: y legítimo), por su parte, bajo la forma jurídica, se invocan de esta manera el uno al otro» ${ }^{29}$.

Así entonces, concebir el Derecho como reformulación y doble institucionalización viene a ser el núcleo compartido en la teoría del Derecho. Observo, sin embargo, que cuando se trata del Derecho en red * y de la mundialización, esta teoría, si bien puede resultar fuerte y operativa, se ha mostrado, a pesar de las diversas aclaraciones a las que la hemos sometido, poco matizada y, en relación con determinadas cuestiones, reduccionista y tramposa. Exige precisiones y rectificaciones sobre diversos puntos importantes, si es que queremos utilizarla todavía para pensar el Derecho de hoy en día, que es un Derecho plural, desterritorializado, y ampliamente separado de su base estatal. Llevada a su presentación estándar —esa vulgata con la que corremos el riesgo de quedarnos-, la teoría sugiere que el Derecho se construye incorporando un cierto número de normas que han sido institucionalizadas en los registros sociales primarios (político, económico, social...). El movimiento sería entonces a un tiempo unidireccional e irreversible, natural y consensual, incorporado y estabilizado, consciente y reflexivo, propio del Derecho estatal, concentrado en la esfera legislativa, receptivo y pasivo.

En mi trabajo entro a discutir cada una de estas afirmaciones que llevan la marca de modelo «piramidal» clásico, estatal, jerárquico, legalista ${ }^{30}$. Al final de mi ejercicio, el movimiento general de la demostración no resulta cuestionado, pero pasa a ser concebido como reversible (viene acompañado de retrocesos y de situaciones en las que lo jurídico se retira voluntariamente) y, con frecuencia, conflictivo e indirecto (la «lucha

28 J. Habermas, Droit et démocratie. Entre faits et normes, trad. por R. RoCHLITZ y Chr. BOUCHINDHOMME, Paris, Gallimard, 1992, 88-89.

29 Ibid., 89.

* N. de la T.: ante las transformaciones del Derecho en las últimas décadas, Ost habla en su obra de la necesidad de dejar de concebir el Derecho como una pirámide para pasar a verlo como una red. La metáfora de la red permite así dar cuenta de un mundo jurídico multipolar; una multitud de fuentes del Derecho que interactúan, donde ninguna tiene ni la primera ni la última palabra.

30 F. Ost, A quoi sert le droit?, op. cit., 58 y ss. 
por el derecho» no es un largo y tranquilo río, y ello en la medida en que han de institucionalizarse esferas diferentes sometidas a lógicas a veces opuestas), no necesariamente deliberado (muchas reglas efectivamente practicadas permanecen, como en la materia de la práctica lingüística, sin formular y fuera del nivel consciente), sin limitarse tampoco ni al Derecho estatal (muchos subsistemas institucionales se organizan, comprendiéndose aquí también en el plano jurisdiccional, dotándose también, como pone de manifiesto TEUBNER, de normas constitucionales) ${ }^{31}$, ni a la iniciativa del legislador, ni a la mera normatividad clásica (la economía y la ética, están sin duda presentes, pero también los medios de comunicación, la salud, las finanzas, la tecnología)..., finalmente creativo y no mera copia pasiva.

\subsection{Normas primarias y normas secundarias}

La teoría de la articulación de las normas primarias y secundarias continúa sobre un plano más técnico estos primeros análisis. Nadie desconoce que la distinción entre normas primarias y secundarias así como su articulación en una teoría completa fue propuesta por H. HART en su Concepto de Derecho ${ }^{32}$. Con las precisiones hechas especialmente por BOBBIO ${ }^{33}$, esta teoría se beneficia igualmente de un extenso consenso dentro de la teoría del Derecho y ha demostrado ser extremadamente operativa. Se inscribe, además, en el núcleo de nuestra problemática en la medida en que responde prioritariamente a cuestiones funcionales - la función propia de las reglas secundarias era para HART paliar los fallos aparecidos en la dimensión de las reglas primarias-. Inscrita en la prolongación natural de la teoría de la «doble institucionalización», la distinción entre reglas primarias y secundarias tiene por objetivo precisar de la forma más clara posible la ventaja funcional de una institucionalización reformulada.

Corresponde en efecto a partir de ahora a las reglas secundarias identificar las normas primarias en vigor, derogarlas, dictarlas, modificarlas, establecer, definitivamente, que han sido violadas y garantizar, llegado el caso, la imposición de la sanción.

A los tres defectos señalados en una sociedad pre-jurídica (incertidumbre en relación con las reglas primarias que están en vigor, ausencia de procedimiento de reglamentación de los conflictos, falta de autoridades susceptibles de ejecutar las decisiones), corresponden entonces tres tipos de reglas secundarias. Las reglas de reconocimiento se ocupan de identificar los criterios de pertenencia a aquello que pasa a ser un «sistema jurídico», y suministran al tiempo un criterio de validez certero a las reglas a las que se refieren. Las reglas de cambio establecen mecanismos de adopción, de derogación y de modificación de las reglas en vigor. Y, finalmente, las reglas de adjudicación que habilitan a ciertas autoridades para que resuelvan autoritativamente la cuestión de saber si una regla primaria ha sido transgredida; reglas ellas mismas completadas, en un segundo momento, por una segunda serie de reglas de decisión,

31 G. TEUBNER, Fragments constitutionnels. Le constitutionnalisme sociétal à l'ère de la globalisation, trad. por I. Aubert, Paris, Classiques Garnier, 2016.

32 H. HART, Le concept de Droit, trad. por M. van DE Kerchove, Bruxelles, Presses de l'Université SaintLouis, 1976, 103-125.

33 N. BobBIO, «Nouvelles réflexions su les normes primaires et secondaires», en La règle de droit, Estudios publicados por Ch. PERELMAN, Bruxelles, Bruylant, 1971, 116 y ss. 
relativas esta vez a la aplicación de sanciones, que se convierten así en objeto de un sistema público y centralizado, monopolizado por los jueces («monopolio de la violencia legítima», dijo M. WEBER) ${ }^{34}$.

Aquí de nuevo, igual que sucedió con la «doble institucionalización», la teoría de las normas secundarias solicita ser reajustada en el marco del Derecho contemporáneo. El ejercicio hace aparecer una extensión del campo de las normas secundarias mucho más allá de lo que HART señaló; pone de manifiesto también cuántas han dejado de ser monopolio de las autoridades estatales. Tienen principalmente como objeto capacitar a los individuos y a las personas jurídicas para que logren resultados institucionales, que funden y organicen colectivos, que litiguen ante los tribunales. Además, ponen en funcionamiento procedimientos complejos y todos los regímenes de prueba; encuadran la acción administrativa en sus diversos aspectos; proponen pautas de interpretación, criterios de validez en el tiempo y en el espacio, exigencias de calidad que han de satisfacer las leyes (eficiencia, proporcionalidad, subsidiariedad...): las 1.001 formas de organizar el Derecho contemporáneo como una red.

\subsection{Funciones primarias y funciones secundarias}

Siempre en ese intento por dar cuenta de la secundariedad del Derecho, pero esta vez para responder a la cuestión de los roles asumidos por el mismo, lo que hago en el trabajo es proponer la reagrupación de las diversas funciones del Derecho en dos categorías: primarias y secundarias. Las primarias se refieren, por decirlo brevemente, a la relación que el Derecho tiene directamente con la materia social, las secundarias a las relaciones que el Derecho tiene consigo mismo (y solo de forma indirecta con lo social) $)^{35}$.

Las funciones primarias consisten en extraer, reformatear y consagrar jurídicamente una norma social, reformateado y consagración jurídicas de una norma social, ella misma primaria ( $c f r$. supra). Bajo este aspecto, el Derecho ejerce un rol general de pilotaje, estando aquí implicadas tanto las normas como los valores. En el primer caso, hablo de pilotaje por codificación: se trata de darle forma jurídica (una forma que se autonomizará rápidamente, como hemos visto) a diferentes normas sociales (morales, económicas, técnicas...). En el segundo caso, hablo de pilotaje por anclaje, en la medida en que se trata de consagrar (a veces de sacralizar) un cierto número de valores fundamentales de la sociedad (de ahí la referencia a un anclaje estabilizador). No contempladas ya sobre su vertiente interna y jurídica, sino sobre su vertiente externa y social, estas funciones tienen como efecto guiar a los agentes en el primer caso, legitimarlos en el segundo (en la medida, por supuesto, en que su comportamiento sea conforme a los valores del Derecho).

Por lo que se refiere a las funciones secundarias reagrupan cuatro sub-categorías: función de encuadramiento (trabajo de definición, de calificación, de institución conceptual), función de identificación (trabajo de identificación de las fuentes vigentes y

\footnotetext{
34 Sobre todo esto, H. HaRT, Le concept de droit, op. cit., 120-123.

35 F. Ost, A quoi sert le droit?, op. cit., 224 y ss.
} 
habilitación de los agentes creadores de Derecho), una función de archivo (trabajo de memorización y de constatación de los hechos y actos jurídicos) y, finalmente, una función de arbitraje (trabajo de enjuiciamiento y de ejecución de las sanciones).

Por último, incrementando un poco el nivel de generalidad, pongo de manifiesto que el Derecho, al implementar esas distintas funciones, cumple dos macro-funciones: renovar los vínculos y fijar los límites — tejer y delimitar, dos vertientes de una función primordial que derivan de la medición- Y Y tal es así que en el nivel interno de una relación social queda una inmanencia marcada por la simplicidad y la mismidad: no es necesario ahí fijar límites y tejer vínculos. Es con la salida de esta inmanencia, y al tomar en cuenta una sociabilidad más amplia, que comienza a plantearse la pregunta acerca de los límites de la acción, los vínculos con los otros agentes y con los otros campos que representan al Derecho.

Entonces es el Derecho quien teje los vínculos y fija los límites; haciendo esto, es la medida de lo social. Y lo es para bien o para mal — se da el caso de que cada una de sus meta-funciones de medición, tejido y delimitación puede responder a usos diferentes-; así todavía hará falta pensar, bajo la égida esta vez de la cifra tres, las condiciones para un buen uso del Derecho (infra 3).

Pilotando la acción colectiva (pilotaje), el Derecho establece una primera medida de la misma al seleccionar los comportamientos deseados, fijar los prohibidos, y renovar los vínculos pertinentes; y luego lo hace una segunda vez con ocasión del juicio particular o de la medida administrativa individual, confrontando entonces el caso particular con la regla. En el primer supuesto, esto es, en el plano general, esta medición tiene la forma de las operaciones de la agrimensura (establecer proporciones, tejer relaciones) y, en el segundo, en el plano particular, la del calibraje (tomar una medida específica usando el patrón general). De esta manera, la rigidez relativa de las operaciones de agrimensura es compensada, en el nivel de la aplicación (que, desde luego, no deja de repercutir sobre el primero), por la relativa flexibilidad del arbitra$j e$ - el caso nunca se deja formatear simplemente por la regla - ${ }^{36}$, de manera que el calibraje es todo menos una operación mecánica.

P. AMSELEK se centró en desarrollar esta tesis del Derecho como medida en el doble sentido de instrumento de referencia para guiar la acción y modelo de inspiración de la misma, y de patrón o referencia a partir del cual se juzga el caso particular ${ }^{37}$. Esta medición entre intereses que compiten y hombres «que se miden» adquiere la forma de la fijación de límites (limitación) y la del establecimiento de vínculos (tejido).

La función más antigua con la que se ha asociado el Derecho es con la de proferir mandatos - algo que sucedió mucho antes de que Moisés trajera las Diez Tablas del Sinaí-. Sabemos que la institución de lo humano pasa por reconocer unos límites que eviten que el sujeto incurra en la locura de creerse omnipotente o, lo que viene a ser lo mismo, de creerse el autor de la ley. Y ya hemos visto que el Derecho, por la vía de la doble institucionalización y, principalmente, porque tiene capacidad de arraigar en su

36 Cfr. el número temático de la Revue interdisciplinaire d'études juridiques, 2014-73, Penser par cas, y las contribuciones de J. VAN MEERBEECK («Pensar a partir del caso y a partir de principios», 77 y ss.) y de F. OST («Penser par cas: la littérature comme laboratoire expérimental de la démarche juridique», 99 y ss).

37 P. AmseleK, Méthode phénoménologique et théorie du Droit, Paris, LGDJ, 1964, 257. 
propio fundamento, se dispone a asumir estos mandatos, aun si se trata de secularizarlos o de permitir una interpretación plural de los mismos.

Pero hace falta también poner de manifiesto que en gran medida este papel de límite funcionaba a través de un modo menos represivo y mucho más amplio bajo la forma de un encuadramiento llevado a cabo por el Derecho mediante el juego de sus definiciones (de-finir es trazar los límites) y calificaciones, cada vez que imponía sus convenciones específicas, su propio modo de institucionalización de lo real.

Trátese de prohibir, o simplemente de definir, la cuestión es que el Derecho traza los límites de esa esfera en cuyo seno el juego es llamado a ser jugado.

En fin, le corresponde al Derecho además establecer toda suerte de vínculos entre las entidades definidas: relaciones entre las personas y las cosas, los sujetos de derecho y sus actos, los sujetos de derecho entre ellos, los gobernantes y los gobernados, los colectivos privados o públicos. S. GUTWIRTH tiene razón cuando escribe que «el rol del Derecho (role of law más que el rule of law) consiste en establecer el vinculum iuris, el missing link: mantener las cosas unidas, incluso cuando todo se descompone» ${ }^{38}$. Vínculo fundador, al comienzo; vínculo residual, como conexión última, cuando el conflicto se desata. Reenlazar: encadenamiento, tejido — pero también remiendo, y reembrague — ${ }^{39}$. «El Derecho es una máquina para re-embragar», escribe B. LATOUR ${ }^{40}$, si bien son muchas las razones que pueden llevar a desembragar y a calar. En términos médicos, podríamos hablar de bypass (establecimiento de circuitos artificiales de derivación en caso de bloqueo de los circuitos naturales) — por ejemplo, el Derecho movilizará una caución solidaria en caso de fallar el deudor principal—. Lo importante, en todos esos casos, es que la deuda circule, que el vínculo resista, que siga habiendo comunicación.

El vínculo jurídico presenta múltiples formas; es centralmente documental, metodológico, procedimental. Documental puesto que une todos los textos jurídicos, desde la Constitución hasta el más modesto contrato privado, desde la convención de los derechos del hombre a la más modesta ordenanza municipal. El Derecho, como la sangre del organismo, circula por todos estos canales, los irriga con un significado que se revitaliza, se diversifica y se refuerza con cada paso dado. Que es enorme intertextualidad, que todo lo absorbe, y que todo lo recicla; que es saber milenario y, sin embargo, el más actual-Cicerón, mi compañero-.

El jurista es el tejedor infatigable que va tejiendo esa red de innumerables nudos. Su método consiste en anudar por siempre aquello que amenaza permanentemente con soltarse. Los textos, naturalmente, pero también los acuerdos y sus firmantes, los actos y sus comparecientes, los hechos y sus autores, las competencias y sus titulares. Es el Derecho el que habilita a X a ejercer tal función, el que imputa a Y la responsabilidad de tal privilegio ${ }^{41}$. Frágiles y, sin embargo, resistentes como el hilo de la araña, los

38 S. GUTWIRTH, «Providing the missing link: law after Latour' passage», en K. MCGEE (ed.), Latour and the Passage of Law, Edinburgh University Press, 2015.

39 B. Latour utiliza todas esas metáforas (La fabrique du droit, Paris, Éditions La Découverte, 2002, 276, 298, 294).

40 B. Latour, Enquête sur les modes d'existence, Paris, Éditions La Découverte, 2013, 368.

41 En este sentido, $c f r$. B. LATOUR, La fabrique du droit, op. cit., 294 y ss. 
vínculos jurídicos así tejidos forman un techo invisible que asegura la continuidad de la vida social en ese preciso momento en el que la misma corre el riesgo de disolverse; o la funda, al comienzo, cuando se trataba de tender puentes en el vacío ${ }^{42}$.

Documental y metodológico, el vinculum iuris es además (¿ante todo?) procedimental.

Es esta progresión tortuosa y sin embargo persistente seguida por el proceso, justo desde la presentación de la demanda hasta la decisión «vertida en forma de cosa juzgada». Este trabajo de traducción que se abre una vía de paso que va desde los hechos brutos hasta el dispositivo jurídico que dirimirá «conforme a Derecho» —en la medida en que el demandante haya podido encontrar «la vía legal» que le convenga- De la misma forma en que un explorador se abre camino, el jurista, habiendo identificado la reclamación que cuenta jurídicamente como daño (una pretensión jurídicamente codificable), moviliza una acción válida, solicita un «medio» que resulte admisible, y termina por extraer una medida favorable. Antes de que su adversario, que se habrá abierto otro camino, invocado otro medio, presentado otra acción, llegue en segunda instancia a convencer al juez de la tesis opuesta. Los medios difieren, los argumentos se oponen, pero el procedimiento y también esa común referencia al texto ${ }^{43}$ permiten trazar el vínculo. Qué importa si la Corte de casación anula la decisión dictada en apelación, si Estrasburgo opina también en sentido contrario, y si la doctrina, por su parte, se inmiscuye. Se trata de que el juego no tenga fin, y de que el asunto A sirva o bien de precedente, o bien para rechazar una línea de decisión para ese caso B que se está armando. Como si cada instancia se interesara prácticamente por todas las causas que fueran a surgir; como si el justiciable que lo apuesta todo en este proceso no fuera más que el colaborador involuntario y anónimo de ese infinito proceso del Derecho en movimiento.

Los aspectos de este tejido jurídico son innombrables. Desde la perspectiva de la identificación de los jugadores, el Derecho es el que autentifica los linajes («te hemos dado un padre y una madre» le dijeron las Leyes a Sócrates). En el nivel de las asignaciones, es el Derecho el que lleva a cabo las particiones (compartir es dividir pero, por encima de ello, es hacer que otros participen en ese compartir). En el plano de los movimientos autorizados, esto es, de los actos jurídicos constituidos por la ley y propuestos a los jugadores, es el Derecho el que sigue asegurando el encadenamiento al revestir de fuerza vinculante los compromisos contractuales (tales contratos pasan a ser vinculantes al poder ser presentados ante un juez). De ese vínculo que, sin duda, es verbal y textual y, sin embargo, también sólido, decía LOYSEL que estas cadenas que unen a los bueyes: «Han atado a los bueyes por los cuernos, y a los hombres por las palabras». Palabras del Derecho, palabras consagradas, esto es, performativas. En el nivel de los movimientos prohibidos, daños civiles y faltas penales, el Derecho une más todavía al ordenar esa indemnización que establece la igualdad, la sanción que subsana - remiendos aproximados, parches simbólicos, todo mejor que la discontinuidad-.

42 «Origen» y «vacío» que, sin embargo, son relativos, dado que, como sabemos, el Derecho entra en un «segundo» momento.

43 «Asombroso bypass que injerta el conjunto del Derecho en un asunto minúsculo», según escribe B. LATOUR (Enquête sur les modes d'existence, op. cit., 364). 
En fin, en el nivel más fundamental de los fines del juego (¿por qué jugamos?) sucede que el Derecho, gracias a su facultad de anclaje, y en el momento en que la necesidad se presenta, pone sobre la mesa los valores que nos hemos asignado (A. GARAPON habla de los jueces como «guardianes de promesas») — como una forma de vincular de nuevo a la comunidad jurídica con su propia historia-. En este sentido, DwORKIN describe a los jueces como quienes aseguran la coherencia narrativa de la línea de precedentes, como una suerte de «narradores morales del país», autores de una «novela en cadena». Pero el anclaje es también una forma de resistencia a las corrientes y vientos contrarios y, en este sentido, la función de vinculación se une a una función de limitación que nos recuerda las prohibiciones y los límites del juego. En fin, el Derecho asegura el registro de todo esto; se trata además de una manera de vincularlo, esta vez, a la memoria en ese tiempo que transcurre.

\subsection{Usos positivos o negativos}

En esta fase del análisis (el paso de «uno» a «dos», cuando la cuestión del tercero está todavía pendiente), y de ello somos conscientes, no se trata más que de funciones y no de finalidades ideales. Es preciso entonces repetirlo una vez más: cada una de las funciones que he mostrado es susceptible de estar al servicio tanto de lo mejor como de lo peor, y ello según el uso que de ella hagan los actores y de las finalidades que asignen al Derecho.

Así la medición, función primera, puede entenderse tanto como forzar, en cuanto que sea emprendida por un poder parcial (falsificadores de monedas, socio leonino, juez parcial, administración corrupta), como paciente equilibrio (cuando el Derecho tiene como finalidad tomar constancia del conjunto de los intereses relevantes). El pilotage jurídico, según las circunstancias y los regímenes, puede también comprenderse como tercera vía, una suerte de justo medio entre intereses rivales y fuerzas en conflicto $\mathrm{o}$, al contrario, como puro y simple alinearse con uno de tales intereses o fuerzas - sea con la revelación religiosa en los regímenes teocráticos o con las fuerzas del mercado en un mundo ultra-liberal. En un contexto autoritario y donde se priorice la seguridad, la función de limitación puede traducirse en una avalancha de prohibiciones y en el levantamiento de fronteras, pasando estas a ser más muros que lugares para transitar. Por el contrario, en los regímenes hiper-individualistas, la función de límite cae, la norma se difumina, y todas las limitaciones se desvanecen - tal y como se dice, al individuo pasan a faltarle «referentes», al tiempo que la violencia amenaza en el horizonte-. De la misma manera el encadenamiento puede convertirse o bien en cadena o, a la inversa, si el vínculo resulta estar demasiado relajado, en algo que se desmorona y que genera desarraigo. La función de arbitraje tampoco está a salvo de estas derivas -la literatura está llena de testimonios de jueces que distorsionan las ponderaciones de la justicia y ello puede ser bien por exceso de rigor, o a la inversa, por falta de fidelidad-.

Así, en esta fase nada garantiza que el paso al plano dual de lo jurídico vaya a suponer una búsqueda de justicia o la garantía de la libertad. Solo el paso a la «tercera» potencia, la inscripción en lo que se conoce como el escenario del tercero, tiene una naturaleza tal que permite asegurar esas propiedades emergentes. 


\section{DE «DOS» $\mathrm{A}$ «TRES». UNA REFORMULACIÓN HECHA BAJO LA ÉGIDA DE UN TERCERO}

¿Para qué sirve el Derecho?... para contar hasta tres. Esta respuesta, bajo su aire de juego de palabras*, viene a poner de manifiesto un desafío importante. Salir de la unicidad y de la mismidad e inscribirse en un régimen dual supone de por sí un reto considerable; elevarse al cubo, pensar en tres dimensiones, imaginar el paso a una tercera vía; ante lo que estamos es ante una autosuperación. Ha tenido lugar una revolución con la generalización del cálculo binario, es la de la inteligencia artificial, que viene a contarnos el mundo combinando el 1 y el 0 . Otra revolución bastante más compleja presupone la capacidad de pensar el mundo social articulando las relaciones de 1 , de 2 y de 3 .

Esta tesis supone un giro antropológico propuesto en mi trabajo (Interlude. Quel homme pour quel droit?) ${ }^{44}$; se inspira en la «hermenéutica del sujeto» de P. RICOEUR y tiene como base la «constitución simbólica de la intersubjetividad» (la construcción social de la relación) bajo la forma de la «gramática de los pronombres personales» ${ }^{45}$. En una demostración brillante, RiCOEUR explica que el hombre solo ocupa un lugar en la sociedad como sujeto de Derecho libre y responsable, capaz de interacción y de uso de la palabra y, por tanto, también capaz de tener iniciativas y susceptible de asumir responsabilidad si, superando la relación de tú a tú, recurre a la perspectiva del tercero imparcial que se encuentra en «cada uno» y en el «él» colectivo.

El giro antropológico (sobre este punto me permito reenviar a mi libro) nos conduce directamente al Derecho. Nos enseña que los límites, vínculos y medidas que el Derecho establece no se libran ni de la instrumentalización de los campos primarios ni de los «yo» hegemónicos, salvo a condición de inscribirse bajo la égida de un tercero imparcial, en la tercera dimensión de lo indisponible, en el espacio público de una reflexividad que prácticamente no tiene fin.

La mejor fórmula que podríamos darle es extraída del viejo Derecho procedimental: auditur et altera pars ${ }^{46}$ - escucha igualmente a la otra parte- El precepto es procedimental y condiciona el debate contradictorio; a un nivel más profundo, da cuenta de la naturaleza del Derecho al instarle siempre a unir los dos polos de lo humano, donde la «otra parte», esa de la diferencia que crece en el seno de uno mismo, tendrá el primer lugar. En su conjunto, el Derecho no es más que la puesta en escena y la construcción de la trama de ese debate continuo. Más importante todavía: la estructura ternaria de este procedimiento. Si el 1 ha de comprender al 2 la prueba se llevará a cabo en la escena jurídica bajo los auspicios de un tercero (la sociedad, el juez). De tal forma, en los términos de esta fascinante aritmética social resulta que el

* N. de la T.: la pregunta y respuesta, que aparecen ya en el título de este trabajo, tienen, en la versión original en francés, la sencillez y la sonoridad propias de los juegos de palabras-adivinanzas para niños. Algo similar a si, a partir de la idea de distanciamiento o de trascendencia implicada en la idea del escenario de un tercero o en la idea de los tres pasos implicados por la juridificación de las relaciones sociales, dijéramos: ¿Para qué sirve el Derecho?... para distanciarnos un trecho.

44247 y ss.

45 P. RICOEUR, Soi-même comme un autre, Paris.

$46 \mathrm{O}$ audi alteram partem. 
1+1 presupone el 3 al mismo tiempo que lo produce. Aquí encontramos la propiedad emergente, la lógica contrafáctica, el bootstraping (auto-superación, o salto a la trascendencia) al que el Derecho presta sus funciones cuando se pone a escuchar lo humano. La cifra 3 (o la institución del tercero imparcial) es una suerte de garantía de que jamás el 1 se va a encerrar en sí mismo, o de que el 2 jamás va a absorber al 1; el 3 es la garantía de que la brecha sigue presente, que la diferencia está operando, que la palabra circula, que, de nuevo (el evento, el proyecto, la historia, el sentido...) sigue en marcha.

Sabemos lo frágil que es este proyecto y cuán tenaz la ambición de todo tipo de dirigentes (clérigos, expertos, poseedores...) a la hora de refrenar esta praxis imaginativa de la que el Derecho es garante y ello posibilitando la certeza a la hora de implementar una determinada programación social: después de los fantasmas de la ciudad de los reyes filósofos de PLATÓN hasta las regulaciones tecnocráticas de hoy (big datas y nudges, principalmente) pasando por los autómatas políticos minuciosamente descritos por HoвBES, se reproduce siempre el mismo sueño. Tal es: reducir a cero el riesgo de indeterminación y trazar con seguridad las rutas del futuro colectivo. Un rasgo distingue de forma indefectible estos modelos: rechazan el lugar estructural del tercero. Ese tercero que no es solo el sabio por encima de las partes, el portador de la palabra de la ley, el +1 que siempre podemos unir a la serie y que impide que gire en torno a sí misma. Tertium non datur, el «tercero excluido» —es este el signo por el que transitan las lógicas, numerosas y variadas que se apartan del auditur et altera pars hasta oponerse radicalmente a él一.

\subsection{Tres finalidades propias del Derecho}

La tercera parte de la obra, que bebe de una filosofía del Derecho normativa, trata de despejar qué finalidades ha de perseguir el Derecho si pretende cumplir con este programa ${ }^{47}$. He llegado a la conclusión de que tres - y las menciono inmediatamente-: se trata de tres finalidades dialécticamente vinculadas que no pueden pensarse de manera independiente, al tiempo que esa unión entre ellas responde solo a esa idea de las finalidades del Derecho. Asumamos la siguiente formulación: un orden jurídico susceptible de acceder al nivel del tercero (1) define un equilibrio social general con vocación operativa, (2) susceptible de ser impuesto mediante coacción controlada generadora de confianza, y (3) con una naturaleza tal que le lleva a ser cuestionado, al menos hasta cierto punto, en el marco de procedimientos determinados.

Mi propósito ahora en el marco de esta contribución no es ni justificar esta elección, ni desarrollar las importantes implicaciones de los tres fines. Mi objetivo es más bien indicar en qué sentido estos fines, solo en tanto que están dialécticamente vinculados (que no son satisfactorios mas que si están en equilibrio), contribuyen directamente a la constitución del espacio institucional del tercero imparcial.

$47 \quad 329$ y ss. 


\subsubsection{Definir un equilibrio social general}

Entendámoslo como la función general de mediación o de arbitraje entre los diferentes intereses sociales que se presentan en conflicto en el espacio social.

La búsqueda del equilibrio es consustancial al Derecho: la balanza evoca tal equilibrio, igual que lo hace el principio de proporcionalidad que domina el razonamiento jurídico de hoy en día igual que dominó el de ayer. Lo que es Derecho está en ángulo recto, tal y como nos lo recuerda la etimología de la norma (norma, ángulo recto). Y su sentido más primitivo, el Derecho es medida, equilibrio, ponderación. Entre todas las pretensiones que le llegan, tales como los intereses que reclaman protección, los valores que entran en conflicto, el Derecho arbitra o, más bien, propone los instrumentos para un arbitraje que, sin añadir nuevo peso en la balanza (en este sentido, tal y como hemos visto, el Derecho no es una «ciudad» sino un «nivel»), asegura la regularidad de la operación (la eleva al «nivel» de la imparcialidad: al no tener una parte en juego, puede asegurar el equilibrio de la distribución) ${ }^{48}$. Desde el punto de vista pragmático de la gobernanza social, el reto está en coordinar los más diversos actos y proyectos del mayor número de actores; en el plano ético, el reto de esta inclusión generalizada es el reconocimiento de la individualidad (y, por tanto, de la dignidad) del mayor número de personas.

Estas exigencias han pasado a ser todavía más imperativas hoy que ayer y ello en la medida en que los desafíos a los que hacen frente nuestras sociedades se presentan bajo la forma de problemas «indivisibles» o incluso «indeterminados». Cuestiones tales como el desarrollo, la seguridad y el medio ambiente se encuentran haciendo frente simultáneamente a múltiples lógicas que desafían «la autonomía de las diferentes esferas de intervención pública», llamando así a una pormenorizada coordinación de los instrumentos y de los objetivos jurídicos. P. DuRAN, quien emite este diagnóstico, hace una llamada al Derecho en este contexto — un Derecho del que subraya la «importancia de su papel mediador» y respecto del que considera que «sigue siendo indispensable por la capacidad de coordinación de la que puede ser portador»— ${ }^{49}$.

Podríamos decir que, dentro de esta función de integración social general, el Derecho funciona como un dispositivo de traducción asegurando de esta forma la circulación entre los discursos prevalecientes en cada una de las esferas especializadas, y restableciendo la comunicación cada vez que haya amenaza de interrupción ${ }^{50}$. Es en estos términos que HABERMAS, en su monumental Droit et Démocratie ${ }^{51}$, se compro-

48 Recuerdo una vez más que los análisis emprendidos en esta Tercera parte derivan de una perspectiva normativa. También la objeción atendiendo a la cual el Derecho tiene, sin duda, parte en el asunto: los intereses socialmente dominantes; algo que, si bien es correcto desde el punto de vista constatativo (volvemos entonces al estudio de los usos del Derecho), no invalida la tesis defendida en el texto: la imparcialidad del Derecho tiene que ver con su vocación normativa y nutre su fuerza simbólica, que explica, por lo demás, y esta vez en el plano constatativo, que el Derecho puede servir en determinadas ocasiones como arma para la emancipación de los más débiles (en este sentido, cfr. M. GARCÍA-VILLEGAS, Les pouvoirs du droit. Analyse comparée d'études sociopolitiques du droit, Paris, LGDJ-Lextensoéditions, 2015, 69 y ss.).

${ }_{49}$ P. DuRAN, «L'(im)puissance publique, les pannes de la coordination», en La puissance publique: Travaux de L'Association française de droit administratif, Paris, Lexis Nexis, 2012, 27-28.

50 F. OsT, Le droit comme traduction, Quebec, Presses de l'université de Laval, 2009.

51 J. Habermas, Droit et démocratie. Entre faits et normes, trad. por R. ROCHLITZ y Chr. BOUCHINDHOMme, Paris, Gallimard, 1997, 64 y ss. [N. de la T.: editado en español bajo el título Facticidad y Validez, trad. por Manuel JimÉnEZ REDONDO, Trotta, 1998]. 
mete a restaurar el alcance normativo del Derecho, contrariamente a una «sociología funcionalista y sistemática [...] que arroja por la borda los últimos restos del normativismo [...] y que se muestra incapaz de aprehender el sentido que tiene el Derecho para la integración social». El Derecho toma aquí el relevo del lenguaje ordinario en su rol de traductor generalizado traduciendo a su lenguaje normativo propio los mensajes del mundo vivido y en dirección a los subsistemas especializados. Haciendo esto «el Derecho funciona en algún sentido como un transformador que impide que se rasgue el tejido de la comunicación a escala del conjunto de la sociedad» ${ }^{52}$.

¿Podría suceder entonces que en el cruce de las diferentes «ciudades» (en el sentido de BOLTANSKI y de THÉVENOT) el Derecho desarrolle compromisos susceptibles de superar sus principios sectoriales? Nuestros autores no niegan esto, pero se muestran escépticos en relación con compromisos que «renuncien a clarificar el principio del acuerdo» y que se muestren frágiles al aparecer como «mecanismos sin fundamento» en la medida en que «no existe ciudad alguna de rango superior en la que mundos incompatibles, unidos en un compromiso, puedan converger ${ }^{53}$. Sin embargo, BOLTANSKI vino a modificar su posición de manera significativa diez años más tarde, afirmando esta vez que «el Derecho es la esfera o lugar mismo del compromiso pues no está inscrito en una ciudad específica, conserva el registro de las diferentes definiciones legítimas del bien común, es llevado sin cesar a remodelarlas reduciendo así las tensiones entre las exigencias heterogéneas que componen su trama» ${ }^{54}$ —en efecto, no podría ser dicho de mejor manera-.

Se entiende entonces que los arbitrajes y los compromisos construidos por el Derecho no deben verse como si fueran una suerte de mediocre instrumento que, finalmente, no dejaría de ser reduccionista. Las concesiones impuestas, lejos de recortar los intereses presentes, son de una naturaleza tal que generan una dimensión que trasciende a todos, los sobrepasa y los reafirma al mismo tiempo: esa es la dimensión del interés general, o el bien común. Hace falta saber redescubrir el misterio y la energía que recubre a estos dos términos de apariencia moralizante y desgastados por siglos de empleo rutinario. ¿Sin embargo, qué hay de más improbable, de más vulnerable que un interés general? Y, aún así, cómo imaginar una ciudad (una ciudad global y no solamente las «ciudades» sectoriales de BOLTANSKI y de THÉVENOT) sin la posibilidad de acceder, al menos en determinadas ocasiones, a ese nivel del tercero? ${ }^{55}$ Dos importantes ejemplos habrán de ilustrar este punto. Tomo prestado el primero del pensamiento del contrato social de Rousseau, y el segundo de los fines de la justicia de RiCOEUR.

¿Cómo se construye una ciudad? Esa es la pregunta que RousSEAU se formula y de la cual el contrato social es la respuesta. Una respuesta compleja, por lo demás y ello en la medida en que jamás el interés general surgirá del simple acuerdo de voluntades. Inmanente a los intereses en conflicto, tal convenio no sabrá ni acomodarlos, ni tras-

52 Ibid., 70-01; y al autor continúa: «No es más que en este lenguaje del Derecho que los mensajes de contenido normativo pueden circular a escala de la sociedad en su conjunto».

53 L. BOLTANSKI y L. THEVEnOT, De la justification, op. cit., 408 y 338.

54 L. BOLTANSKI y E. CHIAPELlo, Le nouvel esprit du capitalisme, Paris, Gallimard, 199, 500.

55 Puede verse un inspirador estudio de este problema en la tragedia y la ciudad griegas (con la insistencia del juego de niveles y la superación de uno mismo bajo la forma de auto-trascendencia), cfr. Y. BAREL, La quête du sens. Comment l'esprit vient à la cité, Paris, Seuil, 1987. 
cenderlos, ni garantizarlos. Hace falta introducir ahí otra dimensión, una profundidad metafísica (no encuentro otra palabra) ${ }^{56}$ —esa misma que genera la disociación entre el individuo (egoísta) y el ciudadano (virtuoso) y que hará emerger la voluntad general que es más, y al tiempo diferente, que la voluntad de todos, de manera que la multitud desligada pasa a ser pueblo soberano-. Mientras que la voluntad de todos no representa más que la suma o la media de las voluntades individuales, la voluntad general implica la superación o la transformación de estas voluntades individuales; cambiando de nivel pasan a ser del todo - el todo de la ciudad que, al tiempo, supera e integraEn la medida en que tiene éxito esta «autosuperación», el soberano aparece al tiempo como interno y externo a cada sujeto (algo que explica que en el contrato social cada uno contrate también consigo mismo), y la obediencia al Derecho pasa a ser una manifestación de libertad ${ }^{57}$. Estamos entonces a cien leguas de un moralismo complaciente con el bien común; se trata de una condición de posibilidad: sin esta construcción social en dos niveles, sin este desdoblamiento y esta referencia a un tercero, no hay sociedad política («ciudad»), sino un simple agregado destinado a perseguir fines particulares.

Tomo prestado de Paul Ricoeur mi segundo ejemplo de subida al nivel tercero del interés general; concretamente de su célebre análisis de los dos fines de la justicia. Tras llevar a cabo una suerte de fenomenología del juicio, el filósofo distingue en relación con este entre una finalidad pequeña «en virtud de la cual juzgar significa decidir con vistas a poner fin a una situación incierta», de una finalidad grande «a saber, la contribución del juicio a la paz pública» ${ }^{58}$. En el primer sentido, la «sentencia» pone fin a un debate prácticamente interminable mediante una decisión que será definitiva cuando llegue a su fin el periodo para presentar recurso y para cuya ejecución prestará ayuda la fuerza pública. Haciéndolo así, el juez habrá cumplido una primera función. Habrá atribuido a cada uno la parte que le corresponde; y ello en aplicación del viejo adagio según el cual los romanos designaban el rol del Derecho: suum cuique tribuere. El juez habrá asignado las partes o rectificado aquellas indebidamente tomadas por uno o por el otro - en una palabra: habrá llevado a cabo una re-distribución-. De esta forma, funciona como una institución esencial de la sociedad, presentada precisamente por J. RAWLS como un vasto sistema de distribución de bienes. En este primer sentido, juzgar es entonces el acto de dividir, de redistribuir (en alemán, Urteil, juicio, está expresamente formado a partir de Teil, que significa la parte).

Pero el acto de juzgar no se agota en esta función de separación. Algo más importante es que si es cierto que se produce sobre un trasfondo de conflicto social y de violencia larvada, entonces hace falta que el proceso, y el juicio que pone fin al mismo, persigan una función mayor, una alternativa institucional a la violencia, comenzando por la violencia de la justicia que uno se infringe a sí mismo. En estas condiciones, sigue P. RicoEuR, «solo aparece el horizonte del acto de juzgar; algo que finalmente es más que la seguridad: la paz social $\rangle^{59}$. No se trata solamente de la pacificación provisional

56 L. BOLTANSKI habla igualmente en este contexto de «capacidad metafísica» mediante la cual la libertad se sobrepasa a sí misma (L'amour et la justice comme compétences, Paris, Éditions Métailié, 1990, 74).

57 J.-J. Rousseau, Du contrat social. Ou principes du droit politique, Paris, Bordas, 1972, 84.

58 P. Ricoeur, «L'acte de juger», en Le juste, Paris, Ed. Esprit, 1995, 185.

59 Ibid., 190. 
que deriva de un arreglo impuesto por la ley del más fuerte, sino también una armonía restablecida a partir del hecho de que se ha producido un reconocimiento mutuo: cada uno de los protagonistas, cualquiera que sea el tipo de acción que lleve a cabo, ha de poder admitir que la sentencia no es un acto de violencia, sino de reconocimiento de los respectivos puntos de vista. En este nivel, ascendemos a una concepción superior de la sociedad: no ya solo un sistema de distribución de bienes, sinónimo de justicia distributiva; sino la sociedad como esquema de cooperación: mediante la distribución, pero más allá de la misma, mediante el procedimiento, pero más allá del mismo, se deja entrever algo así como un «bien común» que, precisamente, hace de vínculo social. Un bien paradójicamente hecho de valores que eminentemente se pueden compartir. En este punto, la dimensión comunitaria ha tomado el relevo de la dimensión procedimental incapaz por sí misma de conjurar la violencia. Podríamos evocar aquí el ejemplo sud-africano de las comisiones de Verdad y Reconciliación, que «más que juzgar la historia, intenta aligerarla de la semilla del resentimiento que guarda en sus flancos y que puede hacer que se repita» ${ }^{60}$. Estos procedimientos, que son calificados como ejercicios de justicia «reconstructiva» o mejor «transicional», tratan sin duda de proteger la memoria y los derechos de las víctimas, pero también y, sobre todo, de garantizar aquellas condiciones que vendrían a constituirse en una especie de conjuro para evitar el retorno del pasado.

En resumen, la distribución judicial es a un mismo tiempo tanto la adjudicación de unos bienes (que nos separan), como lo que nos hace ser parte de la misma sociedad, esto es, aquello que nos acerca ${ }^{61}$. De esa distribución surge una propiedad emergente que es más importante que la parte que se le ha conferido a cada uno; tal es la armonía re-establecida, la cooperación reactivada.

\subsubsection{La imposición de este equilibrio mediante la coacción generadora de confianza}

La segunda finalidad intrínseca que le hemos de reconocer al Derecho es que asegura que el equilibrio definido en virtud de la primera finalidad sea operativo; no se trata aquí, en efecto, de una discusión académica, sino de la regulación en concreto de los grupos humanos. El compromiso jurídico tiene por vocación tener influencia sobre la realidad y guiar realmente las conductas. Bajo esta dimensión, el Derecho es indisociable de la coacción: ha de poder imponerse por la fuerza si fuera necesario. Se adivina, sin embargo, que el Derecho jamás se distinguiría de la fuerza al desnudo y de la violencia bruta si no sometiera el ejercicio de la fuerza a una regulación susceptible de someterla al control de un tercero. La evolución del Derecho, principalmente del Derecho público, ha de comprenderse en este sentido como una profundización constante de la disociación entre la persona del Príncipe que detenta el poder y las concretas prerrogativas asignadas a este poder. El Estado de Derecho, o el régimen del Imperio de la Ley no son sino esta imposición del tercero jurídico en el núcleo del ejercicio de la coacción y de los juegos de poder.

60 A. GARAPOn, Peut-on réparer l'bistoire? Colonisation, esclavage, Shoah, op. cit., 10.

61 Ibid., 191. 
De esta forma, la segunda finalidad a retener (imposición de la coacción) también es susceptible de producir propiedades emergentes (en este caso, el Estado de Derecho basado en la confianza) en la medida en que el mismo acompañe asimismo el movimiento de inscripción en el escenario de un tercero. Y es que la fuerza que moviliza y la paz que produce no son resultado de una fuerza bruta que se imponga sin mediación. Por consiguiente, y al contrario que su imperium, toma prestadas las formas y procedimientos del Derecho. A partir de textos preestablecidos y de roles instituidos, el ejercicio de este poder está, por definición, sujeto a limitaciones y a control. Mejor dicho, no es ejercido sino en el marco de esta habilitación legal, de manera que los gobernantes, que son solo mandatarios públicos, permanecen sometidos al Derecho. En términos de constitución simbólica, esto significa que los mandatos ordenados por los «tú», así como las eventuales sanciones que los acompañan, no son edictos personales que valdrían solo para sus destinatarios (como todos esos de los que los personajes de KAFKA se imaginan ser víctimas, de la misma forma que lo era él en su relación con su padre) ${ }^{62}$, sino la actualización de una legislación que se imputa a «él». y en relación con la que los «tú» son asimismo destinatarios en el momento en que la situación en que se encuentren caiga bajo la prevista por la ley.

Un beneficio suplementario se desprende de esta inflexión que lleva a la autoridad a la perspectiva del tercero: deja entrever la posibilidad de un «cambio de posiciones» (todos potencialmente pueden acceder a las posiciones de poder) en la medida en que esta autoridad encuentra su origen en el respeto a la prescripción legal (el «él») y no en el hecho de tener una cualidad personal (condición natural o estatuto hereditario). Platón y ROUSSEAU, entre otros, han subrayado esta inmensa ventaja del reino de las leyes. PLATÓN: «En una ciudad donde reine la ley sobre los jefes y donde los jefes pasen por esclavos de la ley, es la salud lo que puedo entrever en el horizonte» ${ }^{63}$; ROUSSEAU: «Un pueblo libre tiene jefes y no amos. Obedece a las leyes, pero no obedece más que a las leyes, y es mediante la fuerza de las leyes que no obedece a los hombres» ${ }^{64}$. A la inversa de lo que sucedía con la madre priora de BERNANOS que pretendía salvaguardar la ley, cuando estamos bajo un régimen jurídico es la ley quien cuida de los hombres ${ }^{65}$.

\subsubsection{Permitir cuestionar, dentro de las formas, este equilibrio}

Una tercera finalidad completa el dispositivo: la posibilidad siempre abierta de cuestionar, si bien dentro de las formas y procedimientos legales, el compromiso definitivo. Apunto aquí a la «justiciabilidad» de las normas jurídicas, la capacidad para cuestionarlas, en la que J. CARBONNIER veía, y con razón, la característica por antono-

62 F. KAFKA, «Un message impérial», en Oeuvres complètes, t. II, trad. por A. VIALETTE, Paris, Gallimard, Bibliothèque de la Pléiade, 1980, 483: «El Emperador — se dice- te ha enviado a ti en particular, a ti lamentable sujeto, precisamente a ti el Emperador te ha enviado un mensaje»; id., Journal, trad. por M. ROBERT, Paris, Grasset, 1994, 414: «Justo estoy leyendo algo sobre tu caso», dice el jurista cuando el comerciante va a consultarle; id., Lettre au père, trad. por M. RoBERT, Paris, Gallimard (Folio bilingüe), 1995, 39: «O bien yo obedecía tus órdenes y era vergonzoso puesto que eran válidas solo para mí, o bien».

63 Platon, Les Lois. $1949,36$.

64 J.-J. RoussEAU, «Huitième lettre écrite de la montagne» (1764) en Oeuvres complètes, Paris, Seuil,

${ }_{65}$ G. Bernanos, Les dialogues des carmélites, Paris, Seuil, 1949, 36. 
masia del Derecho: «La mejor caracterización de la norma jurídica es que la misma puede ser sometida a discusión, tiene una cierta naturaleza interrogativa. Lo característico del Derecho es que el mismo consiste en una institucionalización de esa discusión, es una institución de contestación organizada» ${ }^{66}$.

El favor del que disfruta la dimensión «de confrontación» del Derecho contemporáneo - una cierta naturaleza interrogativa y como si estuviera siempre en suspensoha de comprenderse en un contexto marcado por tres fenómenos entretejidos: una concepción de la Democracia basada en la dignidad de los individuos más que sobre la soberanía de los Estados, un importante ascenso del poder de los jueces (y la pérdida correlativa del monopolio del legislador en la determinación del interés general), y también la importancia creciente de las instancias y jurisdicciones supranacionales en la producción del Derecho - los tres fenómenos se fortalecen mutuamente por la presencia de los otros-.

Fundamentando estos tres fenómenos: la prevalencia reconocida de los derechos del hombre. Con ellos, el Derecho positivo ha integrado como propios esos valores que en otro momento proporcionaban instrumentos externos a él para la impugnación del que era objeto. Al tiempo indeterminados en su contenido, y de un alcance que no termina de extenderse (principalmente por lo que a sus exigencias añadidas se refiere, la efectividad y la igualdad de disfrute), los derechos del hombre se han convertido en una palanca poderosa para cuestionar el Derecho positivo, y particularmente la ley, cuya validez se ha visto precarizada y aparece desde entonces condicionada a ellos.

En este contexto, es precisamente el desarrollo de los derechos llamados «procedimentales» el que es espectacular, algo que no deja de alimentar y reforzar la naturaleza auto-interrogativa del Derecho contemporáneo: derecho a la información (acceso a los documentos, transparencia y motivación de las decisiones...), a la participación, a los recursos - tanto útiles jurídicos propios de nuestro tercer fin, como de instrumentos de construcción de un espacio público, cada vez más transnacional, en cuyo seno se desarrolla un uso público de la razón a partir de los derechos fundamentales reconocidos por los individuos-.

Todo sucede, por tanto, como si el Derecho hiciera todo lo posible para darle una segunda oportunidad al debate, ya no al nivel superior de la adopción de la ley, sino a la escala individual del caso. Esta distinción de planos y funciones, que no ha estado vigente ni siempre ni por todos lados (con frecuencia una misma asamblea estaba investida con dos funciones, legislativa y ejecutiva, incluso tres: legislativa, ejecutiva y judicial), puede entenderse como un progreso del Derecho. Como si el Derecho, en función de una lógica realmente exponencial, edificara en todo momento escenarios de terceros, comprendiendo aquí sus propias instituciones; algo así como una puesta en escena constante, una «representación» para someter a debate su propia dramaturgia, una reformulación de sus propios actores, como si estuvieran siempre obligados a responder de sus acciones ante un controlador superior o más distanciando.

En todas estas hipótesis, lo que conviene poner bajo el foco de atención y estudiar es la brecha, el carácter operativo y productivo que genera esta distancia crítica que

${ }^{66}$ J. CARBonnier, Sociologie juridique, Paris, A. Colin, 1972, 135. 
el Derecho no ceja de cavar en relación consigo mismo. Algo que es fuertemente subrayada es la capacidad que manifiesta el Derecho en la auto-distancia: una capacidad reflexiva que se transforma a veces en procedimiento crítico volcado contra sí mismo. ¿No está acaso aquí el sentido profundo que se atribuye al adagio romano que todo jurista debería sin cesar guardar en el alma: summum iu, summa iniuira —el Derecho llevado al límite es el colmo del mal-? También J. CARBONNIER con buena inspiración escribe que «el Derecho es una máquina de generar dudas» ${ }^{67}$. Es esto también lo que le permite escribir que la exigencia de efectividad — una efectividad integral de la normativa- es «excesivamente peligrosa» ${ }^{6}$.

$\mathrm{Al}$ inscribirse en esta perspectiva, el Derecho reactiva, en un sentido posiblemente emancipador, las calificaciones acordadas y las pruebas de juicio, que, en caso de cristalizar definitivamente, cerrarán a las personas y a las situaciones en escenarios intangibles y jerarquías alienantes. BOLTANSKI y THÉVENOT subrayan este riesgo inherente a las pruebas de juicio, y a las economías de la grandeza que les acompañan en las diferentes «ciudades» ${ }^{69}$. En relación con este riesgo muy real, me parece que el Derecho, multiplicando los procedimientos de apelación y los mecanismos correctores de toda suerte, estimulando las controversias doctrinales, reservando un lugar a las correcciones tradicionales y dejando siempre abierta la puerta a las transformaciones legislativas, multiplica los instrumentos que permiten redistribuir las cartas y reactivar el juego. En este sentido creo que son simplistas y tramposos los análisis que retienen solo las funciones de dominación del Derecho; así como M. FOUCAULT escribe: «El sistema de Derecho y el campo del Derecho judicial son el vehículo permanente de las relaciones de dominación, de técnicas de subyugación polimorfas; el Derecho, es preciso verlo, creo, no desde el lado de una legitimidad que ha de ser consolidada, sino del lado de los procedimientos de dominación que pone en marcha» ${ }^{70}$.

Sin duda, la dialéctica obliga, «los replanteamientos» autorizados por el Derecho siguen siendo relativos, y su resultado nunca está garantizado; según los periodos y los lugares, es cierto que la finalidad de orden y la de aplicar la coacción ha supuesto que las controversias y las críticas se hayan reducido a unas pocas cosas. Pero es importante comprender que, en el régimen que estudiamos (la hipótesis favorable donde el Derecho se propone poner en marcha sus funciones al servicio de la justicia y de la democracia), el Derecho no se reduce a un rule by law, a un uso instrumental al servicio del poder o de la planificación, sino a un rule of law, que significa siempre una distancia entre quien lo utiliza y el instrumento, como si el Derecho tuviera su autonomía, su lógica propia, y fuera susceptible de ser revisado independientemente de la voluntad del agente. Eso que se deja entrever no es otra cosa más que una cierta indisponibilidad, una resistencia a la instrumentalización del escenario de un tercero, y del bien común del que es espacio para su construcción. De ahí que permita, al menos hasta cierto punto, el ejercicio del recurso con vocación «emancipatoria», el Derecho puede

67 J. CARBONNIER, «Il y a plus d'une définition dans la maison du droit», en Droit, 11/2, «Définir le droit», PUF, 1990, 6.

68 J. CARBonnier, Flexible droit, Paris, LGDJ, 1971, 102. Una adaptación completa del hecho al Derecho se traduciría en un régimen policial; y, a la inversa, una adaptación total del Derecho al hecho priva al Derecho de su rol transformador y pedagógico.

${ }^{69}$ L. BOLTANSKI y L. THEVENOT, De la justification. Les économies de la grandeur, op. cit., 431-433.

70 M. Foucault, Il faut défendre la société. Cours au Collège de France, 1975-1076, Paris, Seuil, 2012, 24. 
así ser visto, contrariamente a lo que sostiene FOUCAULT, «desde la perspectiva de una legitimidad a ser consolidada».

Las formas jurídicas que «ese cuestionamiento» toma prestadas son extremadamente diversas: peticiones, debates parlamentarios, revisión de tratados, renegociaciones de contratos, recurso a la justicia, control de constitucionalidad y de convencionalidad, cambios de jurisprudencia, controversias doctrinales... El Derecho acumula técnicas de adaptación y de corrección de sus reglas (por no hablar de los criterios de interpretación, de los que CARBONNIER decía que era la forma elemental de desobediencia): la ponderación de intereses, la implementación de los principios generales, las «acomodaciones (arreglos) razonables» en el sentido canadiense (traer excepciones a una regla general a favor de ciertos grupos minoritarios si la aplicación de tal regla se muestra indirectamente discriminatoria en relación con esos grupos), el «margen nacional de apreciación» en el Derecho europeo, la excepción de orden público en el Derecho internacional (que suspende la aplicación de tal o cual regla de Derecho extranjero en la medida en que resulta en un absurdo en el caso en cuestión), la teoría del abuso de derecho (que deniega a un particular el beneficio de un derecho subjetivo cuando el uso concreto que reclama del mismo se manifiesta como irrazonable), las diferentes teorías jurisprudenciales realizan una forma de equidad para el caso particular (equidad que si bien es muy real, rara vez se admite)... los casos son innombrables.

$\mathrm{Al}$ revés de la idea que nos hacemos de la rigidez de la dogmática jurídica y del rigor asociado a la coacción pública, es preciso admitir que estas acumulan mecanismos de puesta en cuestión, e incluso a veces de auto-neutralización. Más allá de los recursos jurisdiccionales clásicos y de los debates parlamentarios, todo sucede como si el Derecho, a través de todas sus ramas, multiplicara los mecanismos de corrección, las posibilidades de excepción, de derogación o de atenuación de las soluciones, las técnicas de auto-neutralización de sus opciones. Como si, marcado por la reversibilidad que conocemos tuviera que poder revisar su trayectoria en todo momento.

\section{CONCLUSIONES}

¿Qué cambia en el momento en que dos personas deciden dar un paso a la esfera del Derecho? Esa era mi pregunta al comenzar. El Derecho, así he respondido, pone sus finalidades (medición, limitación, entretejido) al servicio de la relación social primaria. Tiene lugar una reformulación, funcionalmente operativa, pero nada garantiza todavía que esa formalización ponga de manifiesto un deseo de justicia, o satisfaga la libertad, la igualdad y la dignidad de sus protagonistas. Hace falta para ello que esta juridificación sea inscrita en un plano superior, esa a la que denomino la escena de un tercero; siendo la construcción progresiva del Estado de Derecho y del justo proceso sus manifestaciones más notables.

Pero este ascenso del «uno» al «dos»y al «tres» es una operación inestable respecto de la que nada nos puede garantizar que sea perenne aun si se inscribiera en instituciones y se grabara en el mármol de las Constituciones. En todo momento la regresión está al acecho cuando el «dos» de la instancia técnica es directamente instrumentalizado por el «uno» de la relación social primaria y por el menos escrupuloso de 
sus actores. Un bucle negativo entra en funcionamiento, de manera que, lejos de aportar un valor ulterior, el Derecho, prestando sus formas, su legitimidad y su coacción a un poder desnudo, agrava aún más el déficit de justicia de la situación. Esta fragilidad revela la naturaleza normativa del Derecho, que es al tiempo donde está su fuerza y su fragilidad: se inscribe en el orden de lo que es deseable, y no en el registro determinado de lo que es real. Deriva del valor y no solo del hecho. Igualmente conserva y con razón una desconfianza crítica en relación consigo mismo: summum ius, summa iniuria.

Esto me sugiere una última precisión, esencial. El tercero del que se trata a lo largo de todo este estudio ¿qué rostro, qué contenido darle? La pregunta es legítima y, sin embargo, hace falta saber resistir a la tentación de llenar algo que ha de seguir siendo un lugar vacío. El tercero de quién aquí se habla funciona como una referencia estructural, un operador dialéctico que impide al «uno» o al «dos» encerrarse en sí mismos. Podremos movilizarlo poniéndolo al servicio de tal verdad dogmática, podremos reclutarlo bajo la bandera de tal poder indiscutible, y será así que lo estaremos privando instantáneamente de esa posición trascendente e indisponible que le es propia. 


\title{
LAGUNAS DEL DERECHO Y POSITIVISMO JURÍDICO \\ Un examen de la concepción de las lagunas de C. Alchourrón y E. Bulygin*
}

\author{
José Antonio Ramos Pascua *** \\ Universidad de Salamanca \\ ascua@usal.es
}

\begin{abstract}
RESUMEN. En este artículo se hace un recorrido por la cambiante actitud del positivismo jurídico frente al problema de las lagunas del Derecho, cuya existencia negó inicialmente, pero que finalmente reconoció, confiando su integración a la discrecionalidad judicial. Especial atención y valoración crítica se dedica a una de las más influyentes doctrinas positivistas sobre las lagunas, la defendida por C. AlChOURRón y E. BULYGIN en Normative systems. Se discute aquí, entre otras cosas, su distinción entre lagunas de conocimiento y de reconocimiento, normativas y axiológicas, y sus implicaciones en la concepción positivista del Derecho como sistema de normas autosuficiente e independiente de la moral.
\end{abstract}

Palabras clave: lagunas del Derecho, positivismo jurídico, discrecionalidad judicial, lagunas axiológicas, sistema jurídico.

\section{Legal Gaps and Legal Positivism.}

\section{AlChourrón and E. Bulygin's Conception of Gaps under Examen}

ABSTRACT. This article conducts an analysis on the variant attitude of legal positivism towards legal gaps, whose existence initially denied, but finally recognised, entrusting their integration to judicial discretion. Special attention and critical assessment is devoted to one of the most influential positivist theories about legal gaps, the one defended by C. ALCHOURRón and E. BULYGIN in Normative Systems. Their distinction between knowledge and recognition gaps, and between normative and axiological gaps is discussed, as well as their implications in the positivist conception of the law as a self-sufficient system of norms, independent of morals.

Keywords: legal gaps, legal positivism, judicial discretion, axiological gaps, legal system.

\footnotetext{
* Fecha de recepción: 16 de junio de 2016. Fecha de aceptación: 16 de febrero de 2017.

Este trabajo se inserta en el Proyecto de Investigación DER2016-74898-C2-1-R, financiado por el Ministerio de Economía y Competitividad, AEI y FEDER.

*** Facultad de Derecho, Paseo de F. Tomás y Valiente, s/n, 37007, Salamanca.
} 


\section{INTRODUCCIÓN}

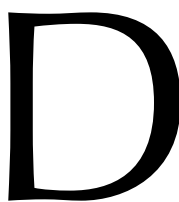

esde siempre se ha sabido que el Derecho positivo no puede tener prevista una solución específica para todos los innumerables conflictos jurídicos que las relaciones sociales, plagadas de intereses contrapuestos, provoquen en el futuro. Esta idea sobre los límites de las previsiones de cualquier legislador es casi un tópico del pensamiento jurídico. Es forzoso aceptar que en la práctica del Derecho surgirán controversias o casos nuevos, derivados de nuevas realidades vinculadas, por ejemplo, a los avances científicos y tecnológicos que pueden transformar la vida social. Baste pensar en los avances que se han venido produciendo en los últimos tiempos en el campo de la biotecnología, abriendo posibilidades de actuación humana previamente impensables y que obviamente el Derecho no regulaba, tales como la gestación subrogada o la manipulación genética con fines eugenésicos.

Más frecuentes son los casos subsumibles en supuestos de hecho que el Derecho positivo regula en términos generales, pero que presentan peculiaridades, propiedades o circunstancias particulares dignas de ser tomadas en consideración, y, sin embargo, no contempladas por el legislador. Se trata de lagunas especialmente problemáticas porque están enmascaradas, en la medida en que el Derecho impone una consecuencia jurídica al supuesto de hecho general del que el caso es una manifestación concreta. Pero esa solución es insatisfactoria porque hay buenas razones para suponer que si el legislador hubiera previsto la particularidad del caso, habría introducido una excepción a la consecuencia jurídica prevista en general para los de su mismo género. Hay quien denomina lagunas axiológicas a estas lagunas especialmente problemáticas, que, por cierto, son muy frecuentes en la práctica jurídica. Hasta el punto de que puede afirmarse que, si no todas, la mayor parte de las lagunas son axiológicas, porque su identificación como tales lagunas remite al sistema valorativo inherente al Derecho.

En realidad, las lagunas que parecen evidentes, como por ejemplo la que existió cuando ninguna ley regulaba la gestación subrogada a pesar de que ya era técnicamente viable y comenzaba a practicarse, también son problemáticas, porque siempre cabe alegar que si el Derecho no regula una conducta o actividad es porque no la considera relevante $\mathrm{y}$, por tanto, la deja fuera de su radio de acción, reconociéndola así como libre, permitida, o, al menos, no prohibida. Como veremos, esta argumentación fue durante mucho tiempo uno de los principales recursos en la estrategia de cierto sector del positivismo jurídico para zanjar el incómodo problema de las lagunas, que amenazaba uno de sus dogmas más preciados: el de la plenitud hermética del Derecho ${ }^{1}$.

Una prueba evidente de que el problema de las lagunas siempre ha estado presente en la mente de los juristas se puede extraer de la existencia, frecuente en todas las

${ }^{1}$ El dogma de la plenitud, normalmente atribuido al positivismo legalista, tuvo en realidad su origen en el iusnaturalismo moderno, que intentó construir deductivamente, a partir de ciertos principios racionalmente válidos, un sistema completo de normas capaz de ofrecer solución para cualquier problema jurídico. Este ideal se tradujo históricamente en la codificación del Derecho positivo, que a su vez dio lugar a la aparición de algunas de las primeras corrientes positivistas, como la francesa Escuela de la exégesis. No es exagerado afirmar, en consecuencia, que el positivismo legalista fue una especie de hijo rebelde del iusnaturalismo ilustrado. Sobre el proceso de formación y desarrollo del dogma de la plenitud o compleción del Derecho, vid. M. A. RoDiLLA, Teoría del Derecho, Salamanca, Ratio Legis, 2013, 348 y ss. 
épocas y sistemas jurídicos, de órdenes de prelación de fuentes de Derecho aplicables. Cuando el legislador dispone que en los casos no previstos por sus leyes se aplique, por ejemplo, la costumbre, o el Derecho romano, o el canónico, o la equidad, o los principios del Derecho natural, está admitiendo de forma implícita la previsible existencia de lagunas en su legislación ${ }^{2}$. Una realidad tan obvia como la inevitabilidad de las lagunas del Derecho, que apenas mereció comentarios doctrinales durante siglos, se convirtió en cuestión fuertemente polémica a finales del siglo XIX y principios del XX, coincidiendo con el predominio del positivismo jurídico legalista.

\section{EL PROBLEMA DE LAS LAGUNAS EN LA TRAYECTORIA HISTÓRICA DEL POSITIVISMO JURÍDICO}

Esta proteica corriente de pensamiento fue, al menos en sus orígenes, decididamente estatalista, identificando el Derecho con la ley, entendida como expresión de la voluntad del poder político soberano en un Estado. El positivismo legalista no estaba dispuesto a poner límites a la voluntad de las autoridades del Estado reconociendo validez a otras fuentes incontrolables del Derecho, y menos aún si estas se presentaban en forma de etéreas leyes naturales o inseguros principios morales con pretensiones de validez universal o simplemente social. La defensa de esa concepción del Derecho como un bloque o sistema de normas autosuficiente, independiente y cerrado a la invasión de cualquier otro sistema normativo, empujó a un sector relevante de autores positivistas a postular el dogma de la plenitud hermética del Derecho, que implicaba, entre otras cosas, la negación de las lagunas. Si el Derecho era un sistema cerrado de normas no podía tener lagunas, porque si las tuviera sería difícil demostrar su independencia frente a aquellos otros órdenes normativos, como la moral, a los que sería casi inevitable acudir para rellenarlas ${ }^{3}$. Admitir la existencia de lagunas sería tanto como reconocer que el espléndido aislamiento del Derecho postulado por el positivismo legalista no era más que una ficción interesada tendente a asegurar el monopolio del control social por parte del poder político del Estado.

No era fácil demostrar, frente a la realidad evidente de casos no previstos por el Derecho legislado, la inexistencia de lagunas en el mismo. Fue necesario un apreciable

2 F. Tomás y VALIEnTE, Manual de historia del Derecho español, Madrid, Tecnos, 2012, 4. a ed., 150, advierte, por ejemplo, en relación con los fueros extensos de la Edad Media, que «no todos los problemas reales podían estar resueltos por el fuero, a pesar de pretenderlo así quienes lo redactaron». De ahí que algunos fueros se remitieran al albedrío del juez para resolver los casos no previstos. Otros, como el de Soria, preveían el nombramiento de una comisión de cuatro caballeros para que buscaran una solución justa para el caso, solución que se añadiría al fuero para resolver otros casos futuros semejantes. A pesar de esa conciencia, presente en todas las épocas, de la insuficiencia previsible del Derecho positivo, como observa J. GILISSEN, «Le problème des lacunes du droit dans l'évolution du droit médiéval et moderne», en Ch. PERELMAN (ed.), Le problème des lacunes en droit, Bruxelles, E. Bruylant, 1968, 197, el problema de las lagunas apenas ha sido estudiado por los historiadores del Derecho, porque solo comienza a plantear dificultades reales a partir del siglo XIX, es decir, a partir del momento en que se desarrolla la teoría de la necesaria plenitud del Derecho positivo.

3 Cfr. N. BobBio, Teoría general del Derecho, trad. por E. Rozo, Bogotá, Temis, 1987, 212, para quien admitir la existencia de lagunas sería tanto como admitir que los jueces tendrían que recurrir a fuentes jurídicas extraestatales, como la costumbre, la equidad, la naturaleza de las cosas, etc., y eso amenazaría la omnipotencia jurídica del Estado. Por eso, la concepción del Derecho como orden completo de normas representa el punto central («il cuore del cuore») del positivismo jurídico (N. BoBBIO, Il positivismo giuridico, Torino, Giappichelli, 1979, 244). 
derroche de ingenio para conseguirlo. Son bien conocidas las principales doctrinas con las que se defendió la concepción del Derecho como un sistema de normas completo y carente de lagunas: la doctrina del espacio vacío de Derecho y la de la norma general exclusiva, norma negativa, o norma de clausura ${ }^{4}$.

La primera doctrina, expuesta, entre otros, por K. BERGBOHM, uno de los positivistas más conocidos del siglo XIX, y por S. ROMANO5 ${ }^{5}$ ya en el siglo XX, parte del supuesto de que el Derecho no regula ni pretende regular todos los casos imaginables. Pues bien, aquellos hechos, actos o relaciones que deja sin regular deben considerarse irrelevantes jurídicamente, puesto que quedan fuera de los límites de su ordenamiento. Los deberes que conlleva la amistad, por ejemplo, no vienen impuestos por nuestro ordenamiento jurídico, pero eso no constituye una laguna del mismo. Supongamos que se plantea ante los tribunales un conflicto sobre tal materia irrelevante o indiferente para el Derecho español: por ejemplo, que una persona demanda a un amigo y le exige una indemnización por el daño moral que le hizo sufrir al no recibir su felicitación de cumpleaños. En tal caso, el juez simplemente tendría que desestimar la demanda.

La existencia de materias irrelevantes para un determinado sistema jurídico puede admitirse sin dificultad. Lo inadmisible es la afirmación de que todos los casos no previstos por él pertenecen al espacio vacío de Derecho y son, por tanto, irrelevantes. Habrá materias que el Derecho en cuestión no regule ni pretenda regular, en cuyo caso no existiría verdadera laguna, y otras que no regule pero que deba regular, porque sean relevantes jurídicamente. Serán casos respecto a los cuales exista una fundada expectativa o exigencia de regulación jurídica, derivada del conocimiento de los fines, principios y valores plasmados en las normas jurídicas y en los que se evidencie la voluntad del legislador. Estos casos cuya regulación es justificadamente esperable o fundadamente exigible, porque resulta necesaria para que se realice plena y congruentemente la voluntad del legislador o el espíritu de la ley, son los que ponen en evidencia la existencia de lagunas en el Derecho; lagunas que son perfectamente compatibles con la existencia de espacios jurídicamente irrelevantes.

La segunda doctrina, la de la norma de clausura, que es similar pero no idéntica a la primera, fue propuesta por E. ZITELMANN, quizá el primer autor que dedicó un estudio monográfico al problema de las lagunas, y posteriormente desarrollada por otros autores positivistas, como D. DONATI o H. KELSEN ${ }^{6}$. Actualmente está bastante desacreditada, por más que haya querido dignificarse presentando tal norma como un

4 Estas doctrinas representan la reacción del positivismo legalista en defensa de la tesis de «la plenitud hermética del ordenamiento jurídico», como denomina C. CossIO, La plenitud del ordenamiento jurídico, Buenos Aires, Losada, 1947, 23, a la que todavía representa para él una «magna conquista del pensamiento iusfilosófico contemporáneo». Como explica M. A. RoDILla, Teoría del Derecho, op. cit., 358 y ss., en su transparente exposición y crítica de dichas doctrinas, su formulación fue la respuesta a los ataques que dirigieron contra aquella tesis, a finales del siglo XIX y comienzos del XX, movimientos tales como el del Derecho libre, la Jurisprudencia de intereses o la Escuela de la investigación científica del Derecho, que abrieron una puerta trasera a la irrupción del Derecho natural, con el consiguiente peligro de arbitrariedad judicial e inseguridad jurídica.

5 Vid. K. BergbOHM, Jurisprudenz und Rechtsphilosophie, Leipzig, 1892; S. Romano, Osservazioni sulla completezza dell'ordinamento statale, Modena, 1925.

6 E. Zitelmann, Lücken im Recht, Leipzig, Duncker \& Humblot, 1903; D. Donati, Il problema delle lacune dell'ordinamento giuridico, Milano, 1910; H. KELSEN, Teoría pura del Derecho, trad. de la 1. a ed. de 1934 a cargo de G. Robles y F. F. SÁnChEZ, Madrid, Trotta, 2011, 107 y ss. En la edición definitiva de 1960 de la Reine Rechtlebre (trad. por R. J. VERNENGO, México, UNAM, 1982, 254 y ss.), KELSEN evita referirse a la existencia 
principio de libertad que cierra el sistema jurídico frente a cualquier restricción no explícita de la conducta. En opinión de los autores que defienden esta doctrina, un hecho solo tiene consecuencias jurídicas si el Derecho se las atribuye. Luego, todo aquello que el Derecho no regule no tendrá consecuencias jurídicas y podrá realizarse o no realizarse libremente. Como esto parece de pura lógica, de ahí deducen los autores citados que existe en cualquier sistema jurídico una norma complementaria implícita conforme a la cual lo no prohibido (ni exigido) por las normas jurídicas vigentes está permitido, y en consecuencia el juez habrá de desestimar las demandas de quienes exijan su realización o su omisión.

Es cierto que alguna regla de clausura puede estar vigente en un determinado orden jurídico o sector del mismo, que en ese caso en principio no tendría lagunas. Se ha observado, con razón, que el principio de legalidad penal, nullum crimen sine lege, funciona en el ámbito del Derecho penal como regla de clausura o norma general exclusiva, porque viene a significar que todas aquellas conductas que la ley no prohíba como delictivas deben considerarse lícitas. En realidad esto no significa que en el Derecho penal las lagunas sean imposibles. Imaginemos que una reforma del Código penal introdujera un nuevo delito, pero no precisara la pena correspondiente a quien lo cometiera. En tal caso, existiría una laguna técnica evidente.

En definitiva, el principio de legalidad penal excluye lagunas, pero no las excluye todas. Por otra parte, se trata de un principio del llamado Estado de Derecho, característico de las democracias liberales, que no está presente en todos los sistemas jurídicos, aunque seguramente debería estarlo. Aparte de no ser extensible a todos los sistemas jurídicos, el principio de legalidad penal tampoco es extensible a todo el ordenamiento. En el ámbito del Derecho civil, por ejemplo, el recurso a la analogía, excluido del Derecho penal, se emplea con frecuencia, y puede tener como consecuencia que conductas no expresamente prohibidas ni exigidas por la ley resulten prohibidas o exigidas por la aplicación analógica de alguna norma reguladora de un caso similar al no regulado. Más aún, en el Derecho administrativo, al menos en los ordenamientos jurídicos liberales, suele regir un principio contrario al de la norma general exclusiva en lo referente a las atribuciones o facultades de los funcionarios públicos. En este ámbito, no suele ser verdad que lo no prohibido esté permitido, sino todo lo contrario. Aquello que el Derecho no permite expresamente a los funcionarios en el ejercicio de sus funciones debe considerarse prohibido para ellos. Su actividad normalmente está sujeta a un régimen de prerrogativas expresas. En esa interdicción de la arbitrariedad se traduce aquí el principio de legalidad o imperio de la ley; exigencia de seguridad jurídica y de justicia que, por cierto, como sostendré más adelante, también debe considerarse extensible a los jueces y su supuestamente inevitable discrecionalidad frente a las lagunas del Derecho.

Se ha observado también que la doctrina de la regla de clausura juega con la ambigüedad del término «permitido» en las proposiciones normativas ${ }^{7}$. Permitido puede

de una norma general exclusiva, pero eso no significa que abandone la idea de fondo. Vid., al respecto, J. RuIZ MANERO, Jurisdicción y normas, Madrid, C. E. Constitucionales, 1990, 40 y ss.

7 Cfr. G. vON Wright, Norma y acción, trad. por P. G. ${ }^{a}$ FerRero, Madrid, Tecnos, 1970, 100 y ss.; C. ALCHOURRÓn y E. BulYGin, Normative Systems, Wien/New York, Springer Verlag, 1971. Cito por la trad. de los mismos autores: Introducción a la metodología de las ciencias jurídicas y sociales, Buenos Aires, Astrea, 1974, 
significar autorizado por el Derecho en el sentido de garantizado o protegido, pero también puede significar algo de menor alcance: que un acto no esté prohibido. Quien afirme que lo no prohibido está permitido en este segundo sentido, está expresando una simple tautología. Sin embargo, quien afirme que lo no prohibido está permitido en el primer sentido, en el sentido de protegido o autorizado por el Derecho, está afirmando algo que podría ser verdadero en un determinado sistema jurídico, si existen en él normas que conceden el permiso en cuestión, pero que también podría ser falso, si tales normas permisivas no existen. Y ello porque, como ya hemos adelantado, puede ocurrir que una conducta no exigida ni prohibida por norma jurídica alguna resulte exigible o ilícita cuando le sea aplicable por analogía una norma prevista para regular conductas distintas pero semejantes en lo esencial a la primera.

Allí donde sea obligado o posible aplicar el Derecho por analogía no habrá lugar para la regla de clausura. La razón de fondo es que lo no prohibido ni exigido expresamente por la ley puede estarlo por un principio no expreso que se haga patente a través de la analogía, en cuanto que inspire otras leyes reguladoras de casos similares. En síntesis, la regla de clausura tiene un alcance limitado a aquellos sistemas jurídicos o sectores del Derecho en los que dicha regla se haya dictado válidamente, y por tanto no excluye la existencia de lagunas en general, pues no es verdad que esté implícita en todo Derecho.

No fueron los anteriores los únicos argumentos esgrimidos para negar la existencia de las lagunas. Se alegó también, entre otras cosas, que estando los jueces sometidos a la prohibición de denegar justicia y teniendo el deber inexcusable de resolver todos los casos que se les presenten aplicando el sistema de fuentes establecido (como establece, por ejemplo, el art. 1.7 del CC español), es forzoso suponer que el Derecho positivo carece de lagunas, pues de lo contrario no sería posible que los jueces cumplieran ese deber como de hecho lo cumplen ${ }^{8}$. Este argumento, o el argumento de que el sistema jurídico dispone de recursos suficientes para rellenar cualquier laguna, no parece muy convincente a efectos de demostrar la inexistencia de lagunas en el Derecho. Solo demuestra que las lagunas pueden y deben ser colmadas sin que paralicen la aplicación del Derecho, pero no demuestran su inexistencia. Negar la existencia de lagunas porque existen jueces que deben resolver conforme a Derecho los casos no previstos es «lo mismo que afirmar que un traje no puede tener agujeros porque el sastre siempre puede remendarlos»?.

171 y ss., 184 y ss. y 220 y ss.; R. GUASTINI, Interpretar y argumentar, trad. por S. ÁLVAREZ, Madrid, CEPC, 2014,157 y ss.

8 U. KLUG, «Observations sur le problème des lacunes en droit», en Le problème des lacunes en droit, op. cit., 92-93, observa, frente a la idea de aquellos positivistas para quienes la prohibición de denegación de justicia garantiza la inexistencia de lagunas, que esa prohibición es solo contingente y no una exigencia lógica de todo orden jurídico.

9 Cfr. C. AlChOURRÓn y E. Bulygin, Introd. a la metodología..., op. cit., 182. En el mismo sentido se manifiesta C. LuZzATTI, La vaghezza delle norme. Un'analisi del linguaggio giuridico, Milano, Giuffrè, 1990, 413-414, para quien un vacío que no existe no necesita colmarse. Si se establecen en un Derecho medios de integración de lagunas es porque las lagunas existen. Como dice K. LARENZ, Metodología de la ciencia del Derecho, trad. por M. R. Molinero, Barcelona, Ariel, 1994, 398, negar la existencia de lagunas porque del sistema jurídico se pueden extraer nuevas normas para resolverlas es tanto como ignorar «el momento creador propio de todo desarrollo del Derecho, en especial de la integración de lagunas». Las lagunas pueden ser colmadas por el juez creando nuevas normas, pero «una norma jurídica que primero ha de ser creada, no existe todavía». También 
Pese al esfuerzo de algunos autores positivistas, empeñados en negar la existencia de lagunas con el fin de proteger su ideal de un sistema jurídico completo e independiente, que no necesitara recurrir a la ley natural ni a la moral social para integrarse, las lagunas siguieron manifestándose en la práctica jurídica con la tozudez de los hechos. El mismo Derecho positivo reconoce sus límites previendo la posible presencia de lagunas y ofreciendo soluciones. Luego, negar su existencia es casi contradictorio para un positivista. Es inevitable, en definitiva, constatar el fracaso de ese primer positivismo legalista o estatalista en su lucha quijotesca contra la posibilidad misma de que existieran lagunas, y contra sus implicaciones subversivas. Unas implicaciones que desbarataban la ficción de un Derecho estatal pleno, y que, como ya indicamos, fueron apuntadas a finales del siglo XIX y comienzos del XX por diversos autores críticos con la concepción positivista del Derecho, tales como F. GÈnY, H. KanTOROwICZ o Ph. HeCK ${ }^{10}$.

En el tema que nos ocupa, el positivismo jurídico dio un giro notable en la segunda mitad del siglo XX. Un giro que podríamos denominar «lingüístico», no ya porque tenga su origen en la obra de un destacado filósofo analítico del lenguaje como H. L. A. HART, sino porque relaciona el problema de las lagunas, más que con vacíos o ausencias de regulación, con la inevitable vaguedad o indeterminación del lenguaje en que se expresan las normas jurídicas. A diferencia del positivismo legalista continental, HART, que pertenece a una tradición positivista diferente, la Jurisprudencia analítica inglesa, iniciada por J. BENTHAM y J. AUSTIN, reconoce abiertamente la existencia en el Derecho de incontables lagunas o, mejor, indeterminaciones de límites, derivadas de la textura abierta del lenguaje jurídico. Este concepto alude al carácter inevitablemente incompleto e incierto de cualquier intento de guiar la conducta humana mediante reglas abstractas, llenas de términos genéricos ${ }^{11}$. A fin de garantizar la separación conceptual entre el Derecho y la moral exigida por el positivismo jurídico, y al mismo tiempo hacer posible la necesaria integración o compleción del Derecho, HART optará por reconocer a los jueces un cierto margen de discrecionalidad para resolver, frente a las circunstancias de cada caso, las indeterminaciones de las normas jurídicas. Esa discrecionalidad no equivale a arbitrariedad sino a buen juicio, e implica que los jueces deben apoyar sus decisiones en pautas razonables, que bien podrían ser principios morales, aunque no formen parte del Derecho ${ }^{12}$.

La admisión de la discrecionalidad judicial a fin de superar las lagunas o indeterminaciones de las normas jurídicas resultaba en principio extraña como doctrina

\footnotetext{
V. ITURRALDE SESMA, «Análisis de algunas cuestiones relativas al problema de las lagunas jurídicas», en Anuario de Filosofía del Derecho, n. e., vol. V, 1988, 362 y ss., y M. SEGURA ORTEGA, «El problema de las lagunas en el Derecho», en Anuario de Filosofía del Derecho, n. e., vol. VI, 1989, 300, critican la teoría que cifra la compleción del sistema jurídico en la obligación que tienen los jueces de resolver todos los casos. SEGURA ORTEGA observa (p. 298) que esa teoría confunde dos nociones diferentes de laguna: como ausencia de regulación para un caso y como imposibilidad de hallarle solución.

${ }_{10}$ Cfr. P. ChIASsoni, Técnicas de interpretación jurídica. Breviario para juristas, Madrid/Barcelona, Pons, 2011, 199 y ss.; M. J. García SAlgado, La jurisprudencia de intereses de Philipp Heck, Granada, Comares, 2011,180 y ss.

${ }_{11}$ Cfr. H. L. A. HaRT, El concepto de Derecho, trad. por G. R. CARRIÓ, Buenos Aires, Abeledo Perrot, 1963,155 y ss.

${ }_{12}$ Cfr. H. L. A. Hart, Essays in Jurisprudence and Philosophy, Oxford, Clarendon Press, 1983, 6 y ss., 103 y ss., 140, etc. Recientemente se ha publicado un borrador inédito de HART en el que explora la noción de discrecionalidad: «Discrecionalidad», trad. por J. R. DE PÁRAMO, en Doxa, 37 (2014), 85-98.
} 
positivista ${ }^{13}$. Hay que tener en cuenta que el positivismo de HART, a diferencia del positivismo legalista anterior, no tiene como trasfondo ideológico inmediato la defensa de una teoría del Derecho estatalista. Expresa más bien la adopción de una actitud metodológica descriptiva y no prescriptiva o valorativa en la concepción del Derecho. Es la diferencia, destacada por BoBBIO, entre el positivismo jurídico entendido como teoría estatalista del Derecho o como simple actitud descriptiva, objetiva o neutral éticamente, en la determinación del Derecho ${ }^{14}$. Por ello, no es sorprendente que HART acepte un recurso, la discrecionalidad judicial, que sería inadmisible para el viejo positivismo estatalista. Inadmisible, entre otras cosas, porque los jueces no representan la voluntad del titular de la soberanía y, en consecuencia, no están autorizados para crear Derecho. Otra explicación puede encontrarse en la práctica jurídica del Common law con la que HART está familiarizado, y en la que los jueces tienen un papel más decisivo o creativo que en los sistemas jurídicos de tipo romano-germánico.

Una aportación muy destacable a la concepción positivista de las lagunas del Derecho es la representada por la obra de C. ALCHOURRÓn y E. BulYGIN: Normative Systems ${ }^{15}$, que ha ejercido y sigue ejerciendo gran influencia, especialmente en el mundo de habla hispana. La concepción de estos autores puede situarse en una línea equiparable a la de HART, aunque ellos, a diferencia de este último, no hacen profesión de fe expresa en el positivismo jurídico (al menos, no en Normative Systems). De hecho, criticaron de forma aguda y convincente la doctrina del viejo positivismo legalista, todavía defendida por KELSEN; una doctrina que negaba la existencia de lagunas basándose en la errónea o ambigua idea de que lo no prohibido debe considerarse permitido por el Derecho. Igualmente rechazaron el dogma de la plenitud hermética del Derecho, por considerarlo mera ilusión puesta al servicio de objetivos ideológico-políticos. En realidad, más que descartar del todo ese postulado básicamente positivista, lo reformularon en términos más aceptables, presentándolo como un ideal puramente científico que solo expresa la razonable exigencia de que los sistemas jurídicos sean completos ${ }^{16}$.

Lo anterior sugiere que, como HART, ALCHOURRÓN y BULYGIN tratan de elaborar una teoría puramente descriptiva y no valorativa de su objeto de estudio, en este caso las lagunas del Derecho, excluyendo del sistema jurídico cualquier valoración externa que lo ponga en relación necesaria con la moral. También como aquel, reconocen lo inevi-

13 A. CaTAnia, Il problema del diritto e l'obbligatorietà, Napoli, Ed. Scientifiche It., 1983, observa que el positivismo jurídico no había aceptado nunca la discrecionalidad judicial. También N. BobBIO, Il positivismo giuridico, Torino, Giappichelli, 1979, 244, afirma que uno de los presupuestos fundamentales del positivismo jurídico es que el juez no puede crear Derecho. KELSEN, sin embargo, pese a negar la existencia de lagunas en el Derecho, reconoce un amplio margen de discrecionalidad judicial.

${ }_{14}$ Cfr. N. BobBIo, Iusnaturalismo y positivismo jurídico, Madrid, Trotta, 2015, 105 y ss.

15 Op. cit., nota 6.

16 Cfr. C. Alchourrón y E. Bulygin, Introducción a la metodología..., op. cit., 25. Cuando aluden expresamente al positivismo jurídico en esa obra (pp. 240-241) tienen en mente el legalismo del siglo XIX, frente al que toman clara distancia. En cuanto a la versión del positivismo como actitud no valorativa en la concepción del Derecho, en Normative Systems no se encuentran pronunciamientos expresos sobre el problema clave de la relación entre Derecho y moral, aunque sí implícitos, puesto que sus autores asumen implícitamente la idea positivista de que el punto de vista moral es un punto de vista externo respecto al Derecho positivo. Expresamente afirman que las normas jurídicas positivas son convencionales (p. 234); aunque con limitaciones, porque de hecho al sistema jurídico se le suele exigir la satisfacción de algún ideal de justicia (p. 235). La inclinación hacia el positivismo jurídico, dudosa o ambigua en Normative Systems, se hace ya inequívoca en la obra posterior de E. BuLYGIN. 
table del recurso a la creación judicial de Derecho para resolver un problema, el de las lagunas, que pone en cuestión la concepción del orden jurídico como un verdadero sistema normativo. Sin embargo, a diferencia de HART, no reducen el fenómeno de las lagunas a las indeterminaciones derivadas de la textura abierta del lenguaje abstracto de las normas jurídicas. Para ellos, tales indeterminaciones no son propiamente lagunas, o si lo son deben distinguirse claramente de las lagunas normativas, típicas del Derecho ${ }^{17}$. Vamos a dedicar el resto del trabajo a examinar críticamente su concepción de las lagunas, valorando sobre todo la solidez de la misma como concepción básicamente positivista, en un contexto, el actual, en el que el positivismo jurídico parece encontrarse en crisis.

\section{LA CONCEPCIÓN DE ALCHOURRÓN Y BULYGIN SOBRE LAS LAGUNAS Y SUS CLASES}

Como ya se ha dicho, en el tema de las lagunas del Derecho, ALCHOURRÓn y BulYGIN han realizado aportaciones valiosas y su trabajo se ha convertido en punto de referencia casi obligado para los tratadistas actuales. Una de sus muchas observaciones certeras es que los juristas solo suelen interesarse por las lagunas que afectan a determinados microsistemas, como una ley o un código; mientras que la preocupación por las lagunas del ordenamiento en su conjunto es característica de los iusfilósofos ${ }^{18}$. La idea puede entenderse como una explicación de la distinción tradicional entre lagunas de la ley, que siempre se han admitido, y lagunas del Derecho en su conjunto, cuya posibilidad se ha considerado con frecuencia discutible, y que quizá represente un problema mal planteado. No voy a examinar aquí en detalle el complejo pensamiento de AlCHOURRÓn y BULYGIN sobre el problema de las lagunas. Examinaré únicamente y de forma sumaria su concepto, clases y propuestas de solución.

Ellos sitúan el concepto de laguna en la encrucijada o interrelación de tres elementos, un universo de casos, un universo de soluciones y un sistema jurídico que imputa las soluciones a los casos. Si las soluciones previstas por las normas de un sistema jurídico no alcanzan a resolver todos los casos, diremos que ese sistema jurídico tiene lagunas. $\mathrm{O}$, en palabras de ALCHOURRÓN y BULYGIN, cuando un caso no encuentra solución en las normas de un sistema jurídico «se dirá que ese caso es una laguna» ${ }^{19}$.

Conviene advertir que nuestros autores distinguen entre casos genéricos y casos individuales ${ }^{20}$. Casos genéricos son los supuestos de hecho abstractos regulados o

17 Ibid., 64.

18 Cfr. C. Alchourrón y E. Bulygin, Introd. a la metodología..., op. cit., 23. En la 122, n. 13, añaden que eso es precisamente lo que hace estériles los análisis de los iusfilósofos en este tema.

19 Ibid., 41. Merece comentario esa identificación entre caso y laguna, que es peculiar de ALCHOURRÓN y BULYGIN, y que muchos otros autores han adoptado siguiendo su ejemplo. En realidad apenas es algo más que una cuestión de estilo, o de forma de expresarse, pero quizá no sea del todo precisa y convenga replanteársela. En puridad, una cosa son las lagunas y otra los casos. Los casos no son lagunas, aunque su solución no esté prevista. Un caso puede verse afectado por una laguna, puede estar inmerso en una laguna, puede poner de relieve la existencia de una laguna, pero si queremos expresarnos con propiedad, un caso no puede ser una laguna. La laguna es la carencia de solución, no es el caso carente de solución. La laguna es el vacío normativo, no el caso afectado por ese vacío. De hecho, los casos individuales afectados por una determinada laguna pueden ser muchos, y sin embargo los distintos casos no serán distintas lagunas, sino que estarán inmersos en la misma.

${ }^{20}$ Cfr. Introd. a la metodología..., op. cit., 51 y ss. 
no regulados por las normas de un sistema jurídico; mientras que casos individuales son los conflictos jurídicos reales, las manifestaciones concretas y empíricas de los supuestos de hecho abstractos. El caso genérico está constituido por una serie de propiedades o características identificadas por las normas jurídicas (si es que lo regulan). El caso individual es un conflicto de la vida real que presenta las propiedades características del caso genérico. Cuando un caso individual es subsumible en un caso genérico regulado por un sistema jurídico, será merecedor de la solución o consecuencia jurídica prevista para el caso genérico. Esta distinción es importante porque, en opinión de AlChOuRRón y Bulygin, el problema de las lagunas del Derecho se plantea en el nivel de los casos genéricos y no en el de los casos individuales ${ }^{21}$. Si existen lagunas en el Derecho no es, contrariamente a lo que suele afirmarse, porque el legislador no puede prever la infinita diversidad de casos individuales que la vida social puede llegar a plantear, sino porque no ofrece solución para determinados casos genéricos, o porque no ofrece solución para todas las posibles combinaciones de propiedades de los casos genéricos que él mismo ha seleccionado como relevantes al regularlos.

Puede ocurrir, por ejemplo, que un caso genérico jurídicamente relevante, como el de la gestación subrogada, no haya sido regulado por el Derecho. En tal caso existiría una laguna normativa. Puede ocurrir igualmente que la gestación subrogada esté regulada en un sistema jurídico, pero que este nada disponga sobre alguna cuestión relevante con arreglo a los propios criterios de relevancia manifestados por el legislador. También sería un supuesto de laguna normativa. ¿Pero qué ocurriría si se planteara ante los tribunales un caso individual de gestación subrogada que presentara cierta particularidad, característica o propiedad no relevante con arreglo a los criterios de relevancia seleccionados por el legislador, pero que sería digna de tomarse en consideración con arreglo a determinados criterios valorativos? Aquí no existiría una verdadera laguna normativa, para ALCHOURRÓn y BULYGIN, sino en todo caso una laguna axiológica. Con la distinción entre lagunas normativas, que son auténticas carencias de regulación del sistema jurídico, y lagunas axiológicas, que solo son carencias del sistema jurídico para quien adopte ciertos criterios valorativos, nuestros autores hacen viable una concepción positivista de las lagunas, porque permite excluir las valoraciones, morales o ético-políticas, del sistema jurídico, y no reconocer que forman parte inherente al mismo.

Para tratar de confirmar esta tesis vamos a profundizar algo más en la distinción clave entre lagunas normativas y lagunas axiológicas. En realidad no son los dos únicos tipos de lagunas identificados por ALCHOURRÓN y BULYGIN. Ellos apuntan al menos otros dos, que denominan lagunas de conocimiento y lagunas de reconocimiento. Existiría una laguna de conocimiento cuando no es posible determinar si un caso individual pertenece o no a un caso genérico, porque no se conocen bien las propiedades del hecho $^{22}$. No es posible determinar, por ejemplo, si la muerte de un ciclista es un homici-

21 Ibid., 59.

22 Ibid., 63. Debe advertirse que AlCHOURRÓn y BULYGIN son perfectamente conscientes de que este tipo de «lagunas» poco tiene que ver con las lagunas normativas del Derecho, que se suscitan al nivel de los casos genéricos. Las llamadas lagunas de conocimiento serían simples problemas empíricos que se producen en la aplicación de las normas a los casos individuales (p. 61). 
dio imprudente o un simple accidente del que nadie es responsable, porque no se sabe bien cómo se produjo. Este tipo de problemas no suele ser tratado por los estudiosos de las lagunas del Derecho, y no es sorprendente, porque se trata de lagunas pero no del Derecho. Es cierto que afectan al Derecho, y este trata de superarlas mediante pruebas, presunciones, etc., pero la carencia que representan no está en las normas jurídicas, sino en la fijación de los hechos que se juzgan. Aunque son lagunas relevantes «para» el Derecho, no son lagunas «del» Derecho.

Distinto es el caso de las lagunas de reconocimiento, aunque ALCHOURRÓn y BULYGIN también ponen en duda su cualidad de verdaderas lagunas. Las caracterizan como casos individuales en los cuales, por falta de precisión semántica de los conceptos que caracterizan a un caso genérico, no se sabe si pertenecen o no al caso genérico en cuestión. Denominar lagunas del Derecho a estas situaciones de penumbra supondría el uso de una terminología poco afortunada, que puede dar lugar a confusiones si no se distingue claramente entre indeterminaciones semánticas y verdaderas lagunas normativas. La diferencia estriba, según explican, en que en las indeterminaciones no se echa en falta norma alguna, sino una mayor precisión en la norma existente ${ }^{23}$. Esta deficiencia se debe a una limitación de la que adolece el lenguaje en general, y que HART, siguiendo a otros filósofos del lenguaje, denominó textura abierta.

ALCHOURRÓN y BULYGIN no profundizan mucho en el concepto de las lagunas de reconocimiento, coherentemente con su idea de que no son lagunas del Derecho en sentido estricto. Sin embargo creo que el tema merecería una reflexión más detenida. Es cierto que existen indeterminaciones en las normas jurídicas que sería impropio designar como lagunas. A esa categoría pertenecen, por ejemplo, las indeterminaciones derivadas de la posible oscuridad o ambigüedad del lenguaje normativo; o las que se producen cuando el legislador delega en el juez la concreción de una regulación, para que pueda ajustarse mejor a las circunstancias de cada caso. Pero no todos los casos de penumbra son así. En muchos de ellos, detrás de una aparente indeterminación puramente lingüística se esconde una insuficiencia de regulación por parte del legislador. Es decir, una auténtica laguna de la ley.

Pensemos en el archiconocido ejemplo de la norma que prohíbe la entrada de vehículos en los parques públicos. Como no sabemos si el término vehículo, por su carácter abstracto, incluye a las bicicletas o a los monopatines, no sabemos si a estos artefactos les afecta o no la prohibición. ¿Pero realmente radica el problema en el significado de la palabra «vehículo», o en que el caso genérico previsto por la norma presenta una selección de propiedades tan poco afinada que no es posible saber si muchos casos individuales son o no subsumibles en el caso genérico? ${ }^{24}$. En otras palabras, muchos de los problemas que parecen derivarse de la textura abierta del lenguaje, en realidad se derivan de la falta de regulación de ciertas propiedades relevantes de un

${ }^{23}$ Ibid., 63-65.

${ }^{24}$ Según explican C. AlCHOURRÓn y E. BuLYgin, Intr. a la metodología..., op. cit., 145, cuando el universo de casos no es muy fino, y esto ocurre cuando el número de propiedades que lo integran es escaso, pueden aparecer lagunas. R. DwORKIN, «La complétude du droit», en P. AMSELEK y Ch. GRZEGORCZYK (eds.), Controverses autour de l'ontologie du droit, Paris, PUF, 1989, 135, sugiere que la cuestión de si se puede circular en bicicleta en el parque a pesar de la ley que prohíbe el acceso a los vehículos no encierra un problema lingüístico sino valorativo, que se resuelve reflexionando sobre el fin de la ley, que seguramente sería evitar la contaminación y el ruido en el parque. 
caso genérico. Es decir, son problemas de lagunas normativas. Un indicio a favor de esta impresión puede extraerse del enfoque que suele recibir el problema de las lagunas del Derecho en el mundo anglosajón, donde tiende a identificarse con el problema de la textura abierta del lenguaje. Si allí no se necesita recurrir al concepto de laguna normativa es porque el concepto de indeterminación lingüística puede ser más amplio de lo que suponen ALCHOURRÓN y BULYGIN.

Centrémonos ahora en la distinción entre lagunas normativas y lagunas axiológicas. Como veremos, solo las primeras son verdaderas lagunas del Derecho realmente existente. Las segundas son lagunas únicamente si se confronta el Derecho tal y como es con el Derecho tal y como debería ser (según los criterios valorativos adoptados por algún intérprete). Es decir, las lagunas axiológicas, tal y como las conciben ALCHOURRÓN y BULYGIN, no son verdaderas lagunas del Derecho, sino expresión de valoraciones sobre aquello que el Derecho debería regular y no regula.

Como buenos especialistas en lógica, AlCHOURRÓN y BULYGIN definen el concepto de laguna normativa en los siguientes términos: $x$ es una laguna normativa de $\alpha$ en relación a UCi y USmaxj si, y solo si, $x$ es un elemento de $U C i$ y no pertenece al dominio de $R(\alpha, U C i, U S \max j)^{25}$. Dicho llanamente: existe laguna normativa cuando un caso relevante jurídicamente no encuentra solución en las normas de un sistema jurídico. La clave del concepto está en la idea de relevancia jurídica. ¿Cómo distinguir qué es relevante en un sistema jurídico, de manera que su falta de regulación constituye una laguna, y qué no es relevante y por tanto pertenece al espacio vacío de Derecho (allí donde se sitúa todo aquello que el sistema jurídico no regula ni pretende regular)? Para responder a esta pregunta, conviene introducir una distinción que tiene un papel muy importante en la concepción de las lagunas de ALCHOURRÓN y BULYGIN. La distinción entre tesis de relevancia e hipótesis de relevancia.

La tesis de relevancia es la descripción de todas aquellas propiedades o características de casos que el sistema jurídico ha seleccionado como merecedoras de su regulación. En otras palabras, la tesis de relevancia establece descriptivamente los criterios de lo que el Derecho existente pretende regular. Una hipótesis de relevancia, por su parte, es una prescripción de propiedades que deberían considerarse relevantes jurídicamente con arreglo a determinados criterios valorativos ${ }^{26}$. Esos criterios valorativos pueden ser puramente subjetivos y expresar las preferencias personales del intérprete, pero también pueden ser objetivos, y expresar convicciones ético-políticas socialmente compartidas o principios de justicia universalmente válidos. Cuando las normas no solucionan casos, o no regulan propiedades de casos, que son relevantes con arreglo a la tesis de relevancia de un sistema jurídico, estaremos ante verdaderas lagunas normativas de ese sistema jurídico. Cuando las normas no solucionan casos o propiedades que deberían considerarse relevantes con arreglo a alguna hipótesis de relevancia referida al sistema jurídico de que se trate (o a todo sistema jurídico), estaremos ante lagunas axiológicas.

25 Ibid., 101. J. L. RoDRíGuEZ, Lógica de los sistemas jurídicos, Madrid, CEPC, 2002, 65, ofrece una definición más clara. Dice que un caso $C i$ de un universo de casos $U C j$ es una laguna del sistema normativo $\alpha$ con relación a un universo de soluciones si, y solo si, $\alpha$ no correlaciona $C i$ con ninguna solución de ese universo de soluciones.

${ }^{26}$ Cfr. C. Alchourrón y E. Bulygin, Intr. a la metod..., op. cit., 145 y ss. 
Otra diferencia destacada por ALCHOURRÓN y BULYGIN es que en las lagunas normativas el sistema jurídico no ofrece solución para determinados casos; mientras que en las lagunas axiológicas el sistema jurídico sí ofrece solución, pero es una solución insatisfactoria para el intérprete, porque este cree que debería considerarse relevante algún caso o propiedad al que el legislador no atribuye la relevancia que merece ${ }^{27}$. Como ya he anticipado, esta concepción de las lagunas axiológicas como desacuerdos valorativos con los criterios de relevancia del sistema jurídico las sitúa en el mundo de las especulaciones sobre lo que debería ser Derecho, y por tanto las excluye del Derecho realmente existente ${ }^{28}$.

\section{VALORACIÓN CRÍTICA DE LA CONCEPCIÓN POSITIVISTA DE LAS LAGUNAS DE ALCHOURRÓN Y BULYGIN}

La concepción expuesta en el apartado anterior, de forma inevitablemente simplificada, plantea diversos problemas. Voy a destacar solo los que afectan más claramente a su sesgo positivista. Los principales son tres: el primero consiste en la necesidad de reconocer que algunos criterios axiológicos (los que expresan los valores asumidos, y a veces declarados expresamente e impuestos por el propio legislador) forman parte de la tesis de relevancia del sistema jurídico. En consecuencia, debe admitirse que al menos algunas lagunas axiológicas son intrasistemáticas. Son lagunas del Derecho existente y no meras idealizaciones de un Derecho más completo. El segundo problema está relacionado con el anterior. Si la tesis de relevancia del sistema jurídico puede incluir criterios valorativos, no parece defendible la idea de que es posible determinar las lagunas normativas de forma puramente descriptiva y al margen de toda valoración. El tercer problema radica en la difícil justificación jurídica, al menos en los Estados de Derecho, de la discrecionalidad judicial como medio para colmar las lagunas.

En cuanto al primer problema, a diferencia de lo que ocurría en la época de Normative Systems, hoy pocos ponen en duda la existencia e importancia, en la mayor parte de los sistemas jurídicos actuales, de principios de justicia, valores morales y derechos fundamentales que, expresamente consagrados en la Constitución, forman parte importante del Derecho vigente y con frecuencia funcionan como criterios de validez

${ }^{27}$ Ibid., 158: «Para la existencia de una laguna axiológica es necesario que el caso tenga una solución. De lo contrario se trataría de una laguna normativa». Así como no deben confundirse las lagunas normativas con las axiológicas, tampoco se deben confundir las lagunas axiológicas, que suponen la no consideración como relevante de un caso o propiedad que debería ser relevante de acuerdo con cierto criterio axiológico, con los simples desacuerdos valorativos que se producen cuando las consecuencias jurídicas previstas por las normas se consideran injustas (pp. 158 y 161). Ciertamente, esos desacuerdos no suponen la existencia de lagunas. Si acaso podrían suponer la existencia de conflictos entre normas y principios o valores del Derecho.

28 D. Mendonca y R. A. Guibourg, La odisea constitucional. Constitución, teoría y método, Barcelona/ Madrid, Marcial Pons, 2004, 136 y 143, asumiendo el concepto de laguna axiológica de ALCHOURRÓN y BuLYGIN, suponen que con él se denuncia un procedimiento utilizado para cambiar subrepticiamente el sistema normativo, porque permite al intérprete excavar un hueco en el sistema jurídico para rellenarlo después con el material de su preferencia. Esta interpretación confirma que las lagunas axiológicas no son, en la concepción de AlCHOURRÓN y BULYGIN, verdaderas lagunas del sistema jurídico sino pretextos para modificarlo. En realidad, ellos no son tan drásticos. Reconocen que llamar lagunas a las axiológicas «no es del todo arbitrario», porque puede ser verdad que el legislador hubiera ofrecido una solución distinta a un caso que presenta una propiedad determinada, si la hubiera previsto (Introd. a la metod., 158). 
de las restantes normas jurídicas. Estos principios y valores, que integran un sistema de criterios axiológicos, constituyen la base, no ya de meras hipótesis de relevancia, sino de la tesis de relevancia del sistema jurídico. No es posible determinar qué es relevante jurídicamente en un ordenamiento sin tener en cuenta ese entramado de valoraciones. Con esto afirmamos que al menos algunas lagunas axiológicas, las que se derivan de los criterios valorativos del propio legislador, son auténticas lagunas del Derecho existente; no lagunas que el Derecho tendría si fuera como el intérprete cree que debería ser.

J. L. RODRíGUEZ, seguidor de ALCHOURRÓN y BULYGIN que ha profundizado en el estudio de las lagunas axiológicas, parece confirmar las conclusiones antes apuntadas, socavando quizá involuntariamente los cimientos de la concepción de sus maestros sobre las lagunas del Derecho. Reconoce que quien afirma la existencia de una laguna axiológica formulando una hipótesis de relevancia puede estar tratando, no ya de expresar sus propias valoraciones personales, sino de reconstruir el sistema axiológico presupuesto por el legislador. En otras palabras, afirmar que existe una laguna axiológica puede significar «no solamente que cierta propiedad debe ser considerada relevante en el sistema normativo $\alpha$ según un cierto sistema axiológico $\beta$, aun cuando no lo ha sido, sino además que el sistema axiológico $\beta$ coincide con el sistema axiológico del legislador» ${ }^{29}$. Lo anterior implica que «la hipótesis de relevancia tendrá carácter descriptivo» ${ }^{30}$, y eso es tanto como admitir que formará parte de la tesis de relevancia del sistema jurídico, porque determinará lo que «es» relevante, y no solo lo que debería ser considerado relevante.

Habría que distinguir, por tanto, dos tipos de lagunas axiológicas: las concebidas por ALCHOURRÓN y BULYGIN, a las que ya nos hemos referido, y las descritas por RODRÍGUEZ, que se producen cuando se presenta una determinada propiedad de un caso, irrelevante con arreglo al Derecho legislado, pero relevante con arreglo al sistema axiológico presupuesto (o proclamado en forma de valores y principios constitucionales) por el legislador. Lo peculiar de estas lagunas es que, a diferencia de las de ALCHOURRÓN y BULYGIN, no son lagunas extrasistemáticas que reflejan consideraciones valorativas ajenas al sistema jurídico sobre lo que debería considerarse jurídicamente relevante, sino que son lagunas intrasistemáticas, porque reflejan consideraciones valorativas que forman parte, implícita o expresamente, del Derecho ${ }^{31}$. No son lagunas imaginarias sino verdaderas lagunas del Derecho existente, al igual que las lagunas normativas. Lo que hace RODRíGUEZ, acertadamente a mi juicio, es reintroducir las lagunas axiológicas en el interior del Derecho, del que ALChOuRRÓn y BulYGin las habían expulsado ${ }^{32}$. Con ello reintroduce también en el Derecho el sistema axiológico

29 Cfr. J. L. RodRíGuez, Lógica de los sistemas jurídicos, op. cit., 75-76. «Toda autoridad normativa parte de un determinado sistema axiológico» (p. 75); sistema axiológico que se puede reconstruir a partir de las normas dictadas por dicha autoridad.

30 Ibid., 76. Cfr. también J. L. RoDRígueZ, «Lagunas axiológicas y relevancia normativa», en Doxa, vol. 22, $1999,357$.

31 Una idea similar maneja M. A. RoDILlA, Teoría del Derecho, op. cit., 346, al afirmar que la laguna axiológica se manifiesta cuando la aplicación de una norma a un caso produce resultados que colisionan con los principios informadores y fundamentadores de las leyes e instituciones del sistema jurídico.

32 Como observa F. ATRIA, «Sobre las lagunas», en Lagunas en el Derecho. Una controversia sobre el Derecho y la función judicial, Madrid/Barcelona, Marcial Pons, 2005, 23, las lagunas axiológicas, tal y como las conciben ALCHOURRÓN y BULYGIN, no son lagunas jurídicas de acuerdo con la tesis positivista de las fuentes sociales del Derecho, puesto que hay solución jurídica en esas fuentes. 
del legislador, y por consiguiente, la conexión necesaria entre el Derecho y la moral (al menos la moral del legislador), entreabriendo así la puerta a una concepción no positivista del Derecho.

El segundo problema que plantea la concepción de ALCHOURRÓN y BULYGIN afecta a la posibilidad de identificar las lagunas normativas de forma puramente descriptiva, prescindiendo de todo juicio de valor. Hemos visto que existe una laguna normativa cuando un caso o propiedad jurídicamente relevante no encuentra solución alguna en un determinado sistema jurídico. Si el caso fuera irrelevante pertenecería al espacio vacío de Derecho y no estaría afectado por una laguna del Derecho. Por tanto, la determinación de la relevancia es decisiva para la identificación de las lagunas. ¿Es posible decidir qué es relevante jurídicamente sin realizar ningún tipo de valoración? ${ }^{33}$. Ya el estudio de las lagunas axiológicas antes apuntado puso de relieve que la tesis de relevancia de cualquier sistema jurídico tiene que contar con el sistema axiológico del legislador, y por tanto, no puede estar libre de valoraciones que son inherentes al Derecho mismo.

A una conclusión similar llegó R. CARACCIOLO después de cuestionar la posibilidad, defendida por ALCHOURRÓN y BULYGIN, de una determinación objetiva, en el sentido de puramente descriptiva, y no prescriptiva o valorativa, de las lagunas. ¿Sería posible ofrecer una descripción libre de valoraciones de la relevancia jurídica de un caso no previsto por el Derecho? Los criterios utilizados tradicionalmente para determinar si un caso es relevante y, en consecuencia, debe ser regulado por el Derecho, nunca han estado libres de juicios de valor. El significado mismo del término «relevante» expresa ya una valoración y prefigura una prescripción de lo que debe regularse. ALCHOURRÓN y BULYGIN podrían alegar que es posible limitarse a describir las valoraciones de otras personas (las del legislador, en este caso) sin participar en ellas. Pero quien intenta determinar si un caso es relevante no puede limitarse a describir los criterios valorativos del legislador, sino que él mismo ha de asumir esos criterios para expresar un juicio de valor que se traduciría en el enunciado prescriptivo: «El caso $\mathrm{C}$ debe considerarse relevante en el sistema $\mathrm{S}$ y por tanto debe estar regulado». Si la determinación de las lagunas normativas obliga a realizar juicios de valor, concluye CARACCIOLO, la distinción entre lagunas normativas y axiológicas no puede ser tan nítida como la presentan AlCHOURRÓN y BULYGIN ${ }^{34}$.

33 F. ATRIA, «Sobre las lagunas», op. cit., 22, considera imposible diferenciar, sin argumentos valorativos, los casos que el Derecho no trata de regular y en los que el demandante carece de fundamento jurídico para litigar, de los casos afectados por lagunas normativas. También C. S. NinO, Algunos modelos metodológicos de ciencia jurídica, México, Fontamara, 1993, 72, cree que el concepto central de laguna es de índole valorativa: expresa la falta de solución normativa para un caso que debería tenerla. En la misma línea, C. W. CANARIS, «De la manière de constater et de combler les lacunes de la loi en droit allemand», en Le problème des lacunes en droit, loc. cit., 174, sostiene que la constatación de una laguna resulta de un juicio de valor, pero no puramente subjetivo sino expresivo de la valoración contenida en el orden jurídico. Se trata, pues, de un proceso teleológico (basado en la ratio legis o teleología inmanente en la ley) y no de lógica formal. Incluso A. Ross, Teoría de las fuentes del Derecho, trad. por J. L. MuÑoz DE B., A. DE PRADA y P. LóPEZ, Madrid, CEPC, 1999, 410, 414, reconoce que, antes de la aplicación del Derecho, solo es posible identificar la existencia de una laguna a partir de un criterio político o material, que consistiría en valorar si la aplicación formal de una ley contraviene o no un Derecho más profundo situado tras la ley.

34 Cfr. R. CARACCIOLO, «El concepto de "laguna”. Descripción o prescripción», en La noción de sistema en la teoría del Derecho, México, Fontamara, 1994, 27-36, donde ofrece sutiles argumentos para respaldar su tesis. Un sofisticado intento de rebatir la objeción de CARACCIOLO, tratando de demostrar que la noción de 
En efecto, la distinción entre lagunas normativas y lagunas axiológicas (intrasistemáticas) resulta borrosa, porque ambas presuponen operaciones valorativas. No es posible determinar qué casos o propiedades de casos son relevantes jurídicamente sin atender a los fines u objetivos que el legislador se propone conseguir con sus diferentes normas e instituciones, ni sin tener en cuenta los principios y valores que les dan sentido y justificación ${ }^{35}$. Conclusiones similares a esta, que identifican lo que es jurídicamente relevante por referencia a los fines y valores del Derecho, y en consecuencia conciben las lagunas normativas en términos axiológicos, son frecuentes en la doctrina tradicional. ALCHOURRÓN y BULYGIN critican la concepción de las lagunas de varios autores alemanes, como K. ENGISCH, K. LARENZ o J. ESSER, por caracterizarlas a partir de criterios valorativos, expresados en fórmulas vagas y vacuas, como la referencia al fin inmanente de la ley, a principios supralegales, a la idea del Derecho o a la naturaleza de las $\operatorname{cosas}^{36}$. Puede que no todas esas fórmulas sean igualmente afortunadas, pero todas apuntan a una realidad incuestionable que, no solo ALCHOURRÓN y BULYGIN, sino el positivismo jurídico en general, se resisten a aceptar. La realidad de que el Derecho persigue fines y se inspira en valores, y que esa carga teleológica y valorativa forma parte de su contenido, y es lo que permite, en primer lugar, detectar las lagunas del Derecho, y en segundo lugar, rellenarlas justificada y congruentemente.

Es cierto que en el Derecho existen lagunas que pueden detectarse sin realizar juicios de valor, y quizá sean estas las que tuvieron en mente ALCHOURRón y BULYGIN para definir su concepto de laguna normativa. Me refiero a las llamadas lagunas técnicas y a otras similares. Tales lagunas se manifiestan cuando no resulta posible la aplicación de una norma jurídica, porque carece de elementos imprescindibles para llevarla a cabo ${ }^{37}$. Si, por ejemplo, una ley que reforma el Código Penal tipifica como delito una conducta determinada, pero no especifica la pena correspondiente, no sería necesaria ninguna operación valorativa para detectar ahí una laguna. La evidencia de la laguna se desprende de la propia lógica interna de la regulación. Lo mismo ocurre cuando una ley no puede aplicarse porque requiere un desarrollo reglamentario que aún no se ha producido, o cuando el legislador olvida regular alguna combinación poco frecuente de propiedades que previamente ha fijado como relevantes. Pero estas lagunas, y en especial las conocidas como técnicas, no son las más significativas en el mundo del Derecho. Concebir las lagunas normativas, que en teoría deberían constituir el tipo central de lagunas del Derecho, como lagunas técnicas sería reduccionista $^{38}$. Sería una forma de eludir los problemas de verdadero interés que plantean las

\footnotetext{
laguna normativa no tiene por qué presuponer juicio de valor alguno, la realiza J. L. RODRíGUEZ, «Lagunas axiológicas y relevancia normativa», op. cit., 362-365.

35 Como convincentemente sostiene J. Ruiz Manero, «Algunas concepciones del Derecho y sus lagunas», en Lagunas en el Derecho. Una controversia sobre el Derecho y la función judicial, loc. cit., 123, las lagunas son déficits del sistema de reglas en relación con exigencias derivadas de los principios que las justifican.

${ }^{36} \mathrm{Cfr}$. C. AlChOURRón y E. BulYGin, Intr. a la metod..., op. cit., 61 y ss.

37 Vid. un análisis más detallado del concepto de laguna técnica en V. ItURRALDE SESMA, «Análisis de algunas cuestiones relativas al problema de las lagunas jurídicas», op. cit., 375 y ss. A. G. ConTE, Saggio sulla completezza degli ordinamenti giuridici, Torino, Giappichelli, 1962, 43, destaca la particularidad de las lagunas técnicas presentándolas como lagunas «en» el Derecho, y no lagunas «del» Derecho como las otras. La laguna técnica o teleológica, como CONTE la denomina, sería la laguna por antonomasia, porque imposibilita la acción del Derecho (p. 48).

38 Algo similar sostiene NiNO, Algunos modelos metodológicos de la ciencia jurídica, op. cit., 72, para quien el concepto descriptivo de laguna diseñado por $A \& B$ no es lo suficientemente amplio como para cumplir una
} 
lagunas del Derecho cuya detección obliga a realizar juicios de valor, reduciéndolas a la categoría de lagunas axiológicas, que en el pensamiento de ALCHOURRÓN y BULYGIN remiten a criterios valorativos externos al sistema jurídico ${ }^{39}$.

El tercer problema antes apuntado radica en el recurso a la discrecionalidad judicial como medio para colmar las lagunas del Derecho. En un principio, el positivismo jurídico, al menos el de la Europa continental, rechazaba la discrecionalidad judicial, pues aún formaba parte de su ideología la aversión de los pensadores ilustrados a la arbitrariedad de la que con frecuencia habían abusado los jueces en el Antiguo Régimen. Posteriormente, se generalizó la idea de que el reconocimiento de la discrecionalidad judicial formaba parte de las tesis centrales del positivismo jurídico ${ }^{40}$. Los comentaristas de la obra de ALCHOURRÓN y BULYGIN también suelen atribuirles la aceptación de la discrecionalidad judicial como inevitable remedio frente a las lagunas normativas.

Sin embargo, en Normative Systems las cosas no están tan claras en este punto. Ciertamente, allí se reconoce como una práctica judicial frecuente en los casos de lagunas la modificación del sistema jurídico mediante la creación de una nueva norma general ${ }^{41}$. Unas páginas más adelante, cuando ALCHOURRÓN y BULYGIN se plantean directamente la pregunta de cómo puede el juez fundamentar su decisión en caso de laguna, responden que habrá de modificar el sistema, pero para ello, observan, tendrá que estar autorizado; cosa que solo ocurre en algunas legislaciones, como ejemplifica el famoso art. 1 del CC suizo, que autoriza al juez para actuar como un legislador. Si al juez le está prohibido modificar el Derecho, entonces el problema es irresoluble. En todo caso, en Normative Systems, queda claramente apuntada la idea de que si el juez quiere decidir con arreglo a Derecho un caso de laguna, debe integrar el sistema jurídico creando una norma que colme la laguna y solucione el caso (genérico) ${ }^{42}$.

función importante en la actividad que los juristas realizan en el orden jurídico. «La completitud que interesa a los juristas es la completitud relativa a los casos que deben ser considerados relevantes».

39 Así ocurre, por ejemplo, en el caso de la flagrante laguna del antiguo Código Penal alemán en su regulación sobre el aborto, que no contemplaba el aborto por prescripción médica para salvar la vida de la madre. En opinión de ALCHOURRÓN y BULYGIN, no existía laguna normativa en ese caso, sino meramente axiológica, porque el Código contenía una regulación, pero tal regulación no se consideraba axiológicamente satisfactoria. Cfr. Introd. a la metodología..., op. cit., 162-163. En mi opinión, sería igualmente posible afirmar que el Código no regulaba el aborto terapéutico, un fenómeno sustancialmente distinto del aborto doloso y, por tanto, tenía una laguna que podría considerarse tanto axiológica como normativa. En general, nuestros autores conciben como lagunas axiológicas las llamadas lagunas secundarias o derivadas, es decir, aquellas que se manifiestan como consecuencia de cambios en la situación fáctica debidos, por ejemplo, al progreso técnico o al cambio de sensibilidad moral (cfr. 165-167) ¡Pero esas son precisamente las lagunas que más interesan a los juristas!

40 Cfr. H. L. A. HART, «El nuevo desafío al positivismo jurídico», trad. por L. HiERRO, F. LAPORTA y J. R. PÁRAMO, en Sistema, vol. 36, 1980, 5: «La tercera tesis positivista la llamaré la tesis de la discrecionalidad judicial. Sostiene que en todo sistema jurídico habrá siempre ciertos casos no previstos y no regulados legalmente [...] y, en consecuencia el Derecho es parcialmente indeterminado o incompleto. [...] Si el juez ha de llegar por sí mismo a una decisión en tales casos y no a inhibir su jurisdicción o (como BENTHAM defendía) remitir el asunto al legislativo, debe ejercitar su discrecionalidad y crear Derecho para el caso». E. BULYGIN, «Creación y aplicación del Derecho», en Lagunas en el Derecho..., loc. cit., 44, apoyándose precisamente en la autoridad de HART, afirma que la discrecionalidad judicial es uno de los pilares de la doctrina positivista.

${ }^{41}$ Cfr. Introd. a la metodología..., op. cit., 211 y 213 (n. 16).

${ }^{42}$ Ibid., 218, 222-223: «De hecho, los jueces tratan siempre de solucionar el caso genérico, ya sea por aplicación analógica o extensional de alguna norma existente, ya sea creando una nueva norma (procediendo como legislador)». 
En escritos posteriores, E. BULYGIN asume la discrecionalidad judicial de forma más inequívoca y decidida. En su opinión, el juez puede resolver discrecionalmente los conflictos jurídicos en caso de laguna. Ahora bien, para que su decisión no sea arbitraria debe apoyarse en una norma general que el propio juez habrá de crear previamente. Dicha norma reflejará la valoración del juez, pero esa valoración no tiene por qué expresar necesariamente sus preferencias personales. Puede expresar valoraciones socialmente compartidas o principios morales que el juez considere universalmente vá$\operatorname{lidos}^{43}$. Conviene advertir que lo anterior solo sería aplicable a las lagunas normativas, es decir, a los casos que carezcan de solución en el sistema jurídico. Pero si se presenta un caso afectado por una laguna axiológica, y por tanto existe una solución prevista en el sistema jurídico, por más que algunos la consideren insatisfactoria por no realizar ciertas distinciones que valoran como necesarias, lo que debe hacer el juez, a juicio de BULYGIN, es aplicar al caso la solución existente, pues las hipótesis de relevancia axiológica son externas al sistema jurídico y en el fondo meros subterfugios para burlar las exigencias del Derecho vigente ${ }^{44}$.

En mi opinión, ambas propuestas de solución son problemáticas. La segunda, la que afecta a las lagunas axiológicas, resulta insatisfactoria por insensible a unas demandas que pueden ser razonables y justificadas, especialmente si se fundan en los criterios axiológicos del legislador, en cuyo caso ignorarlas sería una obstrucción abiertamente antijurídica al hallazgo de una solución justa. La primera solución, la que apela a la discrecionalidad judicial para colmar las lagunas normativas es también profundamente antijurídica, por varias razones ${ }^{45}$. En primer lugar, porque supone la aplicación retroactiva de nuevas normas a casos que se produjeron previamente, cuando tales normas no existían. Se vulnera así el derecho que tiene cualquier persona a la seguridad jurídica de que se le apliquen las normas que él pudo conocer y a las que se atuvo, y no otras elaboradas ex post facto, que le impondrían deberes nuevos improvisados por el juez. En segundo lugar, porque vulnera uno de los principios básicos del Estado de Derecho, el de división de poderes, que atribuye la potestad de crear Derecho al poder legislativo, en representación del pueblo soberano que lo ha elegido, y no al poder judicial, que solo estaría legitimado para aplicar a los casos individuales

${ }^{43}$ Cfr. E. Bulygin, Introducción a Lagunas en el Derecho..., loc. cit., 12. En el mismo sentido se pronuncia en «Creación y aplicación del Derecho», op. cit., 35, 40 y ss.; «Los jueces ¿crean Derecho?», en J. MALEM (ed.), La función judicial, Barcelona, Gedisa, 2003, 32 y ss.; y «En defensa de El Dorado. Respuesta a F. Atria», en Lagunas en el Derecho..., loc. cit., 73 y ss. Resulta paradójico que BULYGIN sostenga la necesidad de la creación discrecional de una norma general por parte del juez para que su decisión del caso pueda basarse en ella y así no ser arbitraria. ¿Pero cómo no va a ser arbitraria una decisión basada en una norma creada arbitrariamente? Si se responde que la creación de esa norma no es arbitraria sino jurídicamente justificable, entonces no habrá existido creación sino hallazgo del Derecho aplicable, que por cierto es lo que debe hacer el juez para colmar las lagunas. Pero si se reconoce que la creación de la nueva norma no se puede justificar jurídicamente, sino solo prudencial o razonablemente, entonces no dejará de ser una norma jurídicamente arbitraria.

44 Ibid., 74-75.

${ }^{45}$ Como observa A. RóDENAs, Los intersticios del Derecho. Indeterminación, validez y positivismo jurídico, Madrid-Barcelona-Buenos Aires, Marcial Pons, 2012, 25, el recurso a la discrecionalidad judicial frente a las lagunas choca con la communis opinio de los juristas, que en los casos afectados por lagunas normativas exigen que las decisiones judiciales estén tan fundadas jurídicamente como en cualquier otro caso, y en los casos afectados por lagunas axiológicas tienden a pensar que puede tratarse de excepciones implícitas en las normas jurídicas, que las convertirían en derrotables. Un punto de vista similar defiende J. RUIZ MANERO, «Algunas concepciones del Derecho y sus lagunas», op. cit., 110 y ss. 
el Derecho previamente establecido por el legislador legítimo ${ }^{46}$. No parece la solución ideal, aunque podría ser impuesta por el legislador en algún sistema jurídico, que se autorice a los jueces para llenar las lagunas creando normas generales a partir de sus propias apreciaciones subjetivas, por muy sensatas que sean. No son las apreciaciones de los jueces las que deberían imponerse, sino las valoraciones socialmente compartidas, en las que el propio Derecho hunde sus raíces y en las que se encuentra su sentido y justificación.

Finalmente, es contrario a la racionalidad jurídica que se ignore la potencialidad del Derecho y de la argumentación para extraer respuestas justificadas a cualquier controversia jurídica a partir del complejo entramado de normas, valores y principios que integran el ordenamiento, sin necesidad de inventarlas discrecionalmente. Decían ALCHOURRÓN y BULYGIN en Normative Systems, criticando una idea de EsSER, que «si la existencia de las lagunas depende de la decisión de la voluntad, toda discusión racional del tema se hace imposible» ${ }^{47}$. Igualmente podría afirmarse, parafraseando lo anterior, que si la solución de las lagunas normativas depende de la decisión de la voluntad del juez, se hace imposible toda discusión racional de la jurisdicción, y de la naturaleza de Derecho en general.

\section{CONCLUSIONES}

1. El problema de las lagunas representa un desafío para el positivismo jurídico, porque amenaza la sostenibilidad de su concepción del Derecho como sistema cerrado de normas, autosuficiente y por tanto independiente de la moral o de valoraciones ético-políticas. Para defender esa concepción el positivismo jurídico adoptó una estrategia cambiante. Comenzó negando la existencia de lagunas, apoyándose en las doctrinas del espacio vacío de Derecho y de la norma de clausura, que hoy se consideran poco convincentes. Posteriormente admitió la posible existencia de indeterminaciones y lagunas, pero al confiar su compleción a la discrecionalidad judicial evitó reconocer la necesaria apertura del Derecho a otros sistemas normativos.

2. En esa segunda actitud cabe situar la posición de ALCHOURRÓn y BULYGIN, quienes admiten la existencia de lagunas, aunque de forma un tanto restrictiva, porque excluyen del sistema jurídico las lagunas axiológicas, como expresión de meras hipótesis de relevancia asumidas por los intérpretes; y además reducen a la categoría de axiológicas todas aquellas lagunas cuya detección obliga a realizar valoraciones (que son la mayoría). El intento de mantener las valoraciones, especialmente morales, fuera del Derecho positivo fracasa porque una de las posibles hipótesis de relevancia es la que expresa el sistema axiológico del legislador, inmanente en el sistema jurídico. Esa hipótesis de relevancia inherente al Derecho, basada en sus fines, principios y valores, declarados o implícitos, tendrá que formar parte de la tesis de relevancia, resultando así insostenible la distinción entre lagunas normativas y lagunas axiológicas intrasistemáticas, que serán en todo caso auténticas lagunas del Derecho.

46 Estos argumentos y otros similares fueron apuntados por R. DwORKIN en diversos lugares de su obra. Vid., por ejemplo, «Los casos difíciles», en Los derechos en serio, trad. por M. GuASTAVINO, Barcelona, Ariel, 1984,150 y ss.

47 Cfr. Introd. a la metodología, op. cit., 164 
3. Las lagunas, que son en su mayoría fenómenos relativos a determinados fines o valores inmanentes al Derecho, y que por tanto tienen un componente axiológico difícil de soslayar, obligan a reconocer la apertura del Derecho, al menos a un sistema axiológico determinado, el del legislador, que coincidirá normalmente con la moral socialmente dominante, cuya conexión con el Derecho quedaría así evidenciada.

4. Una forma de evitar esta conclusión abiertamente no positivista consiste en remitir la solución del problema de las lagunas, no al sistema axiológico inherente al Derecho, sino a la discrecionalidad judicial. Es una solución posible pero implausible, por incongruente con el propio sentido de la función jurisdiccional. Autorizar a un juez a decidir casos discrecionalmente es tanto como inducirle a abdicar de su papel institucional como aplicador y no creador del Derecho. Especialmente si se tiene en cuenta que el Derecho ofrece siempre, si no una orientación inequívoca, sí múltiples indicaciones en forma de fines, principios, valores, etc., capaces de guiar su decisión. Naturalmente, el juez hará bien en ejercer su discreción y buen juicio en el cumplimiento de sus obligaciones, pero si puede (y siempre puede) escoger entre una racionalidad extrajurídica, orientada por máximas prudenciales o preferencias personales, y una racionalidad jurídica orientada, aunque de forma difusa, por las razones subyacentes del Derecho, lo congruente con su deber institucional como aplicador del Derecho, es inclinarse por esta última. Si, como hemos defendido, la existencia de la mayor parte de las lagunas es relativa a ciertos fines, principios o valores del Derecho ¿no será lo más apropiado y congruente que sean esos mismos elementos inherentes al Derecho los que orienten la solución de los casos afectados por ellas? 


\title{
BASES DE UN MODELO CONCEPTUAL PARA DECIDIR HECHOS*
}

\author{
Rodrigo Coloma Correa $* *$ \\ Universidad Alberto Hurtado \\ rcolomacorrea@gmail.com
}

RESUMEN. El presente texto se ocupa de algunos problemas que afectan la gestión de las pruebas y de los argumentos probatorios en sede judicial. Al respecto se proponen las bases de un modelo conceptual, en cuanto recurso que estandariza las posibilidades de ejecución de las tareas propias de un campo de trabajo. En el mundo de los jueces y de los abogados, los modelos conceptuales simplifican los problemas por la vía de declarar irrelevantes asuntos de detalle y, coetáneamente, de organizar eficientemente los distintos componentes implicados en la toma de decisiones. El concepto básico desde el cual se sugiere construir un modelo para gestionar los problemas probatorios es el de «hecho (probado)», entendido como un artefacto lingüístico que adscribe conductas jurídicamente relevantes y que supera un proceso de validación institucional.

Palabras claves: conceptos probatorios, hechos probados, modelo conceptual, pruebas.

\section{Basis for a Conceptual Model for Decisions on Facts}

ABSTRACT. The paper addresses some of the issues concerning the use of evidence and their arguments in courts. It offers the basis for a conceptual model as a tool that standardizes the possibilities of executing tasks within a certain field of activity. In the world of judges and lawyers, conceptual models simplify issues by declaring irrelevant matters of details and, at the same time, efficiently organizing the elements involved in decision making. The basic concept upon which the model for managing problems related to evidence should be built is «fact proven", understood as a linguistic artifact that ascribes behaviors legally relevant and overcomes a process of institutional validation.

Keywords: evidential concepts, facts proven, conceptual model, evidence.

\footnotetext{
* Fecha de recepción: 5 de julio de 2016. Fecha de aceptación: 28 de febrero de 2017.

Este trabajo es uno de los resultados de proyecto financiado por el Fondo Nacional de Desarrollo Científico y Tecnológico, FONDECYT 1140986 «Conceptos fundamentales del Derecho Probatorio en Chile».

** Facultad de Derecho de la Universidad Alberto Hurtado (Chile).
} 
—¿Qué tal Bill? —saludó el hombrecillo—. Te presento a George Mallory, el tío que ha subido a lo alto del Everest.

—Bueno, no del todo —objetó George-. De hecho...

-No te preocupes por los hechos, George — dijo Keedick, volviéndose hacia Mallory-. Aquí en Nueva York, nadie lo hace.

Jeffrey ARCHER, La senda de la gloria

\section{INTRODUCCIÓN ${ }^{1}$}

L

os argumentos que vierten tanto jueces como abogados difieren en su estructura y profundidad, según sea la problemática a la que refieran. Una muestra palmaria de aquello se observa en la manera de presentar argumentos que sirven de soporte a hechos o bien a interpretaciones de textos normativos. Cuando se enfrentan a asuntos de prueba, abogados y jueces, rara vez, desarrollan argumentos ${ }^{2}$ de una sofisticación equiparable de los que son capaces de producir si de lo que se trata es de dar cuenta de problemas de identificación o de atribución de significados a disposiciones normativas ${ }^{3}$. El asunto llama a la perplejidad, sobre todo porque en los últimos siglos, en aquellas disciplinas comprometidas, primordialmente, con la búsqueda de «lo verdadero» se ha logrado un desarrollo mucho más espectacular que en las que aspiran a identificar «lo bueno» ${ }^{4}$. ¿Qué ha pasado? Sin hacerme cargo de la pregunta en toda su magnitud, cabe intuir que una de las variables responsable de la precariedad en la gestión de los asuntos probatorios es la inexistencia de modelos conceptuales 5 .

Me propongo, en lo que sigue, esbozar las bases de un modelo conceptual para gestionar problemas de prueba o, más precisamente, para decidir hechos. Por cierto, lo que presento se aprovecha de discusiones académicas contemporáneas sobre esa clase de asuntos (las que aclaran bastantes cosas); y a la vez, toma en cuenta prácticas exitosas de abogados y jueces tendientes a la optimización de recursos probatorios, tanto si

1 Una versión preliminar se presentó en el seminario de investigación de Filosofía del Derecho de la Universidad de Alicante, en un curso de Argumentación de la Facultad de Derecho de la Universidad CastillaLa Mancha (Albacete) y en el seminario de la Facultad de Derecho de la Universidad Austral de Chile. Valoro todas las observaciones que allí me fueron hechas. Agradezco, especialmente, la minuciosa lectura realizada por Juan Carlos BAYÓN y Flavia CARBONELL, como también el eterno inconformismo de Claudio AGÜERO que me llevó a revisar varias veces algunos problemas que ingenuamente consideraba que estaban resueltos.

2 Con ello refiero a la mayor o menor fortaleza de las conexiones entre lo que no se encuentra problematizado (la base) y la conclusión a la que se llega. Una estructura argumental sólida reduce los saltos carentes de justificación y, en ese sentido, cuenta con credenciales para ser tomada en cuenta por los especialistas, más allá de los ocasionales desacuerdos. En el caso de los problemas de prueba, los argumentos, ya sea de abogados o de jueces, suelen ser difíciles de reducir a una forma estándar. En el caso de los problemas de identificación e interpretación normativas, si bien son frecuentes los desacuerdos (de fondo), hay una manera relativamente estandarizada de hacerse cargo de los problemas y de formular soluciones.

3 No se trata, por cierto, que los últimos sean sencillos (no lo son). De lo que se trata es que para jueces y abogados resulta mucho más familiar desenvolverse en territorios que los fuerzan a proponer, fortalecer, refutar o validar argumentos normativos, antes que en los que requieren definir conjeturas factuales, presentar pruebas y valorarlas.

${ }^{4}$ La analogía debiera resultar evidente: los problemas probatorios se aproximan a formas de operar en disciplinas comprometidas con la búsqueda de «lo verdadero», y los problemas normativos se conectan, de manera relativamente estrecha, con escenarios de búsqueda de «lo bueno».

5 Una explicación que asume cuestiones de cultura jurídica puede verse en COLOMA, 2016b: 273-275. 
de lo que se trata es de influir como de adoptar decisiones respecto de los hechos que se discuten en un juicio. Una de las claves para enfrentar satisfactoriamente el desafío anunciado radica en la acertada identificación de un concepto central en torno al cual construir el modelo. La presente propuesta asume que el modelo debe formularse en torno al concepto de «hechos». Los demás conceptos elegidos tienen una estrecha relación con el concepto de «hechos», y se ordenan según las etapas probatorias en las que adquieren especial protagonismo.

\section{MODELOS CONCEPTUALES PARA EL «MUNDO DEL DERECHO»}

\subsection{Entre el arte y la técnica}

En algunas disciplinas la estrecha comunicación entre ciencia y tecnología ha favorecido avances extraordinarios ${ }^{6}$. Aquella relación promueve que el progreso no dependa de la lenta dinámica del ensayo y error (¡la ciencia es útil!), como también facilita el constante escrutinio de las teorías científicas en la vida cotidiana ( $¡$ la ciencia se somete a contrastación!) 7 . Dicho en otras palabras, el tránsito desde la artesanía (que se desentiende de la ciencia) hacia la tecnología (que usa la ciencia), supone que cada nuevo desafío al que se haga frente no dependa de cálculos a «ojo de buen cubero», sino de la aplicación de fórmulas derivadas de teorías que, en caso de estar bien hechas, no tendrían por qué fracasar ${ }^{8}$.

En el campo ${ }^{9}$ de las ciencias jurídicas la aplicación tecnológica de los saberes disciplinarios pareciera encontrarse fuera de lugar ${ }^{10}$. De hecho, la competencia considerada como la más representativa de los jueces y abogados ${ }^{11}$ - y a la que con orgullo aludimos como razonar jurídicamente ${ }^{12}$ - no parece, en principio, susceptible de fortalecerse por vías que difieran de la observación rigurosa, de la práctica constante de tareas propias del campo jurídico y/o de la asimilación y adaptación de los consejos de los

\footnotetext{
${ }^{6}$ El alto prestigio que se reconoce a disciplinas como la física, la biología o la química depende —en gran medida - de la exitosa transferencia hacia procesos tecnológicos de lo que en ellas se encuentra validado a nivel teórico. Por cierto, no toda disciplina aspira al uso de sus teorías en la solución de problemas prácticos, como ocurre con la filosofía.

7 Esto incide en que si los productos no funcionan se revisará la tecnología utilizada y, en caso que los fallos perseverasen, se revisará la validez de los enunciados científicos que le sirven de soporte.

8 Hay, por cierto, un costo aparejado en la solución de los problemas mediante aplicaciones tecnológicas, esto es, la renuncia de asuntos de detalle. KOYRÉ, 1994: 117-145.

9 El campo de los juristas es un espacio de la interacción social en el que se les reconoce una posición preferente/exclusiva para la delimitación, gestión y solución de problemas jurídicamente relevantes, tanto desde una perspectiva teórica como práctica. El campo (de trabajo) de los juristas se ha dividido tradicionalmente en lo que se conocen como ramas del derecho. ColOMA, 2016b: 255-261.

${ }_{10}$ La tecnología resulta ocasionalmente visible en la fase de generación de información útil para el proceso probatorio (algunas pruebas periciales) y en la organización de la prueba disponible. Respecto de esto último cabe destacar desarrollos producidos a partir del chart method, propuesto originariamente por John Henry WigMORE.

11 El panorama posiblemente cambiará en el futuro. Así, por ejemplo, los avances en el rastreo de datos son cada vez mayores, aun cuando no se encuentren a la fecha muy difundidos. Los programas más avanzados permiten no solo encontrar palabras claves, sino identificar relaciones entre personas y secuencias de acontecimientos. Se prevé que las máquinas a partir de la revisión de miles de casos podrán recomendar estrategias judiciales, tal como lo haría un litigante experimentado. CARR, 2015: 138-139.

12 Vid. SCHAUER, 2013: 17-27.
} 
pares más aventajados. El asunto no es de extrañar pues la conducta humana —que, en último término, es lo que interesa al Derecho- no es fácil de medir, ni de reducir a regularidades. El análisis cualitativo que a diario se lleva a cabo por los jueces y los abogados se resiste a prescindir de los matices ${ }^{13}$. De esa manera, en ese mundo es difícil escapar de las prácticas propias de la ya aludida lógica del «a ojo de buen cubero».

Muchos jueces y abogados, sin embargo, no se sienten del todo cómodos operando en un mundo tan poblado de particularidades. Así, en la medida de lo posible, buscan algunas regularidades que faciliten las tareas que les corresponde ejecutar y/o disminuyan la responsabilidad (eminentemente moral) ${ }^{14}$ que viene aparejada por la toma de decisiones no derivables desde un patrón de comportamiento comunitariamente consensuado ${ }^{15}$.

Del instrumental utilizado por los jueces y los abogados, son los modelos conceptuales los que, probablemente, más se aproximan a una aplicación tecnológica ${ }^{16}$. Los modelos conceptuales son herramientas que sirven para organizar tareas de identificación y procesamiento de datos en casos concretos y, a la vez, para canalizar reflexiones teóricas. De esa manera, los modelos contribuyen a la solución de enigmas con un aceptable nivel de estandarización. La utilización de modelos conceptuales se traduce en que los problemas se simplifican, en términos de favorecer las comparaciones y/o igualaciones. El uso de los modelos conceptuales es, además, funcional a la generación de productos no dependientes de una manera especialmente fuerte de las habilidades personales de los sujetos que se enfrentan a distintos enigmas jurídicos. El precio a pagar, entonces, es un empobrecimiento de la realidad (se deja de poner atención en múltiples detalles) ${ }^{17}$ y a la vez, en una parcial reconfiguración de la profesión jurídica (más de técnica y menos de arte) ${ }^{18}$.

\subsection{El uso de los modelos conceptuales}

La elaboración de explicaciones que conectan acciones, eventos y/o fenómenos se ve beneficiada por una labor más/menos intensa de conceptualización que lleva a cabo

13 Esto explica, en parte, la resistencia hacia el uso de mecanismos de adjudicación aleatorios, aun cuando las diferencias respecto a lo que se pueda obtener si se recurre, en cambio, a un (costoso) análisis de la situación concreta, sea probablemente mínima. Vid. DuXBuRY, 1999: 137.

14 Whitman, 2008: $10 \mathrm{y} \mathrm{ss.}$

15 La comunidad de jueces, abogados y académicos —o si se prefiere, la cultura jurídica interna— no es tan homogénea al respecto. Así, mientras hay algunos que aspiran a la justicia del caso a caso y que, por tanto, no se sienten aproblemados si ante casos similares llegan a soluciones diferentes (en la medida que existan matices que los distingan); hay otros que tienden a la justicia de la regla, es decir, a la búsqueda de universalidades y, por tanto, no tienen reparos ante los intentos de simplificar los términos del debate fijando la atención en lo que consideran medular.

16 Una diferencia que parece insalvable entre las aplicaciones tecnológicas y los modelos conceptuales concierne a la evaluación de los resultados obtenidos, a partir del uso de cada uno de ellos. En el caso de las primeras, la evaluación se hace depender de su utilidad (sirve/no sirve); en cambio, en el caso de los segundos, se carece de criterios independientes de los procesos de construcción (se justifica/no se justifica, etc.). Lo expresado redunda en que las razones para el abandono o modificación de un modelo se determinarán en una importante medida por variables que podrían considerarse como políticas.

17 Cfr. Mosterín, 2013: 132.

18 Cfr. Twining, 1997: 63 y ss. 
una comunidad que ocupa un lugar de privilegio en lo que atañe a la producción y validación de un cúmulo de saberes en un campo de trabajo determinado ${ }^{19}$. Aquello implica ir mucho más allá de lo que es propio del sentido común. ${ }^{20}$ No es de extrañar, entonces, que quienes operan en el mundo del derecho coincidan —al menos, ocasionalmenteen formas de trabajo estandarizadas ${ }^{21}$ al momento de hacer frente a problemas concretos.

En el mundo del derecho se dispone de algunas teorías y modelos conceptuales útiles para enfrentar distintos enigmas que jueces, abogados y académicos deben gestionar y/o resolver ${ }^{22}$. El tipo de problemas a los cuales me refiero atañe, principalmente, al de las posibilidades de acoplar el mundo de las normas con el mundo de la experiencia. Dicho en otras palabras, se espera que los modelos conceptuales faciliten - directa o indirectamente - la operación de adscribir ${ }^{23}$ conductas (u omisiones) a determinados sujetos, en términos de que puedan hacerse calzar con la condición de aplicación de una norma jurídica. Esta tarea es muy importante, y de ella depende que la ideología de la aplicación de las normas jurídicas ${ }^{24}$ sea un proyecto viable y no, simplemente un artilugio retórico cuya dudosa utilidad estaría dada por el encubrimiento de la responsabilidad (moral/jurídica) de quienes crean soluciones ad hoc en cada nuevo caso que se les presenta ${ }^{25}$.

Los modelos conceptuales tienen como criterio de éxito primordial su efectivo uso en la elección de respuestas a problemas jurídicamente relevantes, como también en la explicación de los resultados alcanzados. Los modelos, entonces, no son descriptivos, es decir, no viene al caso evaluarlos desde la perspectiva de su verdad o falsedad ${ }^{26}$

19 Roberto TORRETTI ha llamado la atención sobre este punto en el campo de las ciencias. En sus palabras: «Si los filósofos naturales y los científicos, en vez de desarrollar sistemas intelectuales novedosos, se hubieran dado por contentos con el repertorio de nociones del sentido común precientífico, jamás habrían llegado a asociar fenómenos aparentemente tan dispares como las manzanas que caen, los satélites que orbitan y las galaxias que huyen, ni hacer que cada uno ilumine a los otros y les confiera una necesidad relativa. Aplicando su pensamiento innovador a los hechos observados, han logrado producir inferencias explicativas que de veras acrecientan nuestro entendimiento». TORRETTI, 2012: 73.

20 Respecto a las posibilidades que ofrece, por ejemplo, el uso de la inteligencia artificial, vid. TwINING, 2007: 169-185.

21 Las formas de trabajo estandarizadas, en ocasiones redundan en la consolidación de géneros textuales. Así, por ejemplo, pese a sus diferencias evidentes las sentencias penales dictadas por los tribunales chilenos conforman un género discursivo reconocible. AGÜERO, 2014: 15-18.

${ }^{22}$ Me refiero con ello, primordialmente, a las distintas ramas del derecho, en cuanto técnica para la fragmentación del campo de los juristas.

${ }^{23}$ Csaba VARGA distingue entre describir («está lloviendo») y adscribir («él lo hizo», «esto es mío»). Para lo primero cabe aplicar directamente el juicio verdadero o falso; en cambio, para lo segundo, se requiere de un marco institucional que coloca al sujeto en una determinada posición, desde la cual puede ser juzgado, principalmente, desde la perspectiva de su responsabilidad. VARGA, 1995: 126-127. Por cierto, para la decisión de adscribir conductas, algunas variables propias de un juicio puramente descriptivo pasan a ser relevantes (por ejemplo, que un sujeto haya muerto o que exista un objeto); lo que no obsta a que sea útil mantener diferencias claras entre ambas operaciones. Esto explica, por ejemplo, que para la adscripción sea muy importante contar con estándares de prueba que permitan zanjar definitivamente si un sujeto puede ser o no considerado como el autor de una conducta (en las descripciones suele no ser tan problemático dejar abiertos los enigmas). Vid. también WiTTGENSTEIN, 2004: 9.

24 Vid. nota 44.

25 Hay también modelos disponibles para resolver problemas lógicos de un sistema normativo. Su foco es la detección de lagunas, contradicciones y redundancias, lo que supone una simplificación de la tarea interpretativa que hace posible que distintos enunciados sean comparables. Vid. AlCHOURRón y BulYGIN, 1993.

26 Vid. COMANDUCCI, 2009: 77. Quien utiliza un modelo puede no creer lo que en él se plantea, basta que lo acepte por conducir a respuestas suficientemente buenas. MOSTERÍN, 2008: 224. 
(falta de ajuste a la realidad). Esto, por cierto, no obsta a que si se pretende operar adecuadamente en la cotidianeidad se requiera tener en cuenta cómo se entiende socialmente que son las $\operatorname{cosas}^{27}$. Los modelos conceptuales tampoco son directamente prescriptivos, es decir no constituyen pautas acerca de cómo debemos comportarnos, más allá de que se promueva su uso. Los modelos funcionan como reglas técnicas, esto es, proponen medios para alcanzar ciertos fines. Así las cosas, un modelo conceptual simplifica el mundo, por la vía de tener en cuenta algunas variables y silenciar otras, o bien de transitar desde una lógica que reconoce las categorías de «lo posible» o de «lo probable» hacia una lógica binaria que solo considera las opciones sí/no ${ }^{28}$; ello, en la medida, que sea instrumentalmente útil para alcanzar el fin propuesto.

Di Robilant distingue cuatro usos del término «modelo» en los escritos de filosofía del derecho. El primero refiere a un esquema representativo de un fenómeno de la realidad social; el segundo corresponde a un prototipo, a un ejemplo de un determinado fenómeno; el tercero da cuenta de un cierto esquema de comportamiento que debiera ser seguido; el cuarto a una construcción artificial para el análisis de un fenómeno de la realidad social ${ }^{29}$. El sentido en que aquí se usa el término modelo es el último de los señalados. De esta manera, el éxito o fracaso depende de las posibilidades de uso que el modelo propuesto ofrece.

\subsection{El concepto de «delito» como ejemplo de modelo conceptual ${ }^{30}$}

Como se sabe, los penalistas comprenden el delito como una «acción (u omisión) típica, antijurídica y culpable». Dicho modelo ha sido posible a base de teorizaciones (análisis cualitativo) y acuerdos alcanzados en el seno (vertiente dominante) de la respectiva comunidad disciplinaria. Un hito en cuanto a la definición de planes comunes (cohesión) de los penalistas fue la publicación de Dei delitti e delle pene de Beccaria ${ }^{31}$. El modelo conceptual, propiamente tal, fue propuesto por Ernst VON BELING a comienzos del siglo $\mathrm{XX}^{32}$ y se ha ido perfeccionando en su operatividad con el paso del tiempo. Así, el concepto de delito hace posible que enfrentados a ciertos enigmas, jue-

27 Para estos efectos, la idea de realidad y de cómo son las cosas está fuertemente determinada por la interacción cotidiana con los otros. El problema, entonces, no es tanto el de cómo son las cosas en sí, sino de las representaciones que permiten operar adecuadamente en contextos sociales de las cotidianeidad («experiencias cara a cara»). En estos se excluye de lo real, por ejemplo, a los sueños o a las experiencias reconocidamente simuladas, como lo sería la del teatro. Vid. BERGER y LuCKMAN, 2006: 34-63.

28 Esto, por ejemplo, es una función propia de los estándares de prueba que distribuyen ejemplares situados en la zona de penumbra de una categoría, hacia las respuestas probado/ no probado.

29 Di Robilant, 1968: 67 y ss.

30 Otro ejemplo de modelo conceptual exitoso se da respecto del concepto de acto jurídico de los civilistas. Probablemente, es la existencia de un modelo a cuyo uso se encuentran habituados los jueces y abogados lo que explica parte importante de las dificultades a las que se han visto enfrentados quienes han propuesto su reemplazo por el concepto (y teoría) del negocio jurídico.

31 Uno de los grandes méritos de la propuesta de BECCARIA (y también, la de FEUERBACH) es que fija la atención en una clase de problema que era posible de responder por la comunidad de los penalistas, esto es, ¿qué es delito? No ocurría lo mismo con otras interrogantes como era el caso de ¿qué es malo? o ¿qué es dañoso? Gunther JAKOBS con miras a identificar el factor determinante para atribuir un estatus científico a la ciencia penal —que él entiende que es la respuesta al problema de su legitimación— atribuye a FEUERBACH (y también a HEGEL) un papel clave para el nacimiento de la ciencia penal moderna. JAKOBS, 2008: 28-46. Agradezco a Luis Emilio ROJAs haberme señalado tempranamente el papel clave de FEUERBACH en el sentido indicado.

32 BELING, por cierto, perfecciona los desarrollos previos de otros penalistas. Así, se habla también de la teoría del delito de VON LiszT-BeLing. Vid. un panorama más completo en AmBOS, 2007. 
ces, abogados y académicos coincidan metodológicamente en la manera de construir una solución (lo harán en la tipicidad, en la antijuridicidad o en la culpabilidad). Una vez identificada la categoría apropiada, el penalista se sitúa en un ámbito más específico, como podría ser error de tipo, legítima defensa o inimputabilidad. Por cierto, los penalistas tienen discrepancias. Sin embargo, la fortaleza de los lazos que genera la aplicación del modelo común lleva a que sus explicaciones se hagan cargo de lo que dicen sus colegas para ciertos puntos específicos, independientemente de las discrepancias que puedan tener en los asuntos más gruesos del Derecho penal.

El modelo conceptual del delito implica una serie de simplificaciones respecto de las valoraciones de la conducta que se juzga. $\mathrm{O}$, lo que vendría siendo lo mismo, supone consensos respecto de lo que hay que considerar como irrelevante. Véanse un par de ejemplos para ilustrar lo señalado:

a) Al estipular que la tipicidad es condición para la existencia de un delito o cuasidelito (categorías de las que se hace depender la legitimidad de la aplicación de penas penales), se declaran irrelevantes la peligrosidad o el parentesco como razones para castigar ${ }^{33}$. De la misma manera, al exigir la concurrencia de dolo o culpa a los efectos de calificar como delito doloso o delito culposo, se trazan fronteras con pretensiones de nitidez entre lo doloso ${ }^{34}$, lo culposo y lo fortuito, aun cuando nuestras experiencias se resistan a ser descritas recurriendo a esas categorías tan toscas (la intención, la negligencia y el acaso son graduables), las cuales en muchos casos se superponen.

b) $\mathrm{Al}$ asociar la imputabilidad a una determinada edad se declara irrelevante algo obvio - y que sí tenemos en cuenta en otras circunstancias de la vida—, esto es, no todos maduramos al mismo tiempo, ni tampoco alcanzamos los mismos niveles de comprensión acerca de lo injusto de nuestras acciones y omisiones.

\section{LA DECISIÓN DE LOS HECHOS COMO PRINCIPAL PRODUCTO DEL MODELO CONCEPTUAL}

El dominio de conceptos disciplinarios — unido al desarrollo de competencias analíticas y estratégicas - constituye una de las condiciones primordiales para que jueces y abogados aborden exitosamente distintos desafíos que se les plantean en los procesos judiciales ${ }^{35}$. La atención, en lo que sigue, se dirigirá hacia el uso de los conceptos probatorios. Los conceptos desempeñan un rol determinante en la forma en que los participantes fijan su atención e interpretan los acontecimientos, ya sea en la fase de investigación como en el juicio mismo ${ }^{36}$. Asimismo, los conceptos

33 Como se sabe, aquello no ha sido históricamente así.

34 Para gestionar algunos casos dudosos se crean las subcategorías de dolo de las consecuencias seguras y eventual. Ellas, a su vez, generan nuevos problemas bastante difíciles, aunque algo más manejables.

35 TORRETTI, 2012: 60-66 (especialmente).

36 Además de llamar la atención respecto a los usos que hacemos del lenguaje (utilizando su conocida metáfora de la caja de herramientas), WITTGENSTEIN subraya el papel de los conceptos como instrumentos para hacer ciertas cosas. Dice textualmente: «Los conceptos nos conducen a investigaciones. Son la expresión de nuestro interés, y guían nuestro interés». WITTGENSTEIN, 2004: 359. Sobre relaciones entre significado y empleo de las palabras, vid. también WiTTGENSTEIN, 2004: 193-199. 
orientan el uso que conviene dar a los recursos probatorios disponibles, llegado el momento de construir o de destruir argumentos. En pocas palabras, los conceptos determinan, en una importante medida, cómo observan ${ }^{37}$, cómo piensan ${ }^{38}$ y cómo argumentan los jueces y los abogados. Así, por ejemplo, ante un sujeto sentado en una silla que emite sonidos en lengua castellana y gesticula con sus manos, es previsible que tanto jueces como abogados presten atención más o menos a lo mismo y, a la vez, se desentiendan, más o menos, de iguales $\operatorname{cosas}^{39}$. La confluencia perceptual e interpretativa entre los participantes no depende de las propiedades de las cosas o de los acontecimientos en sí. Al realizar actos observacionales o inferenciales, los jueces y los abogados tienen en cuenta conceptos tales como relevancia o estándar de prueba. De esta manera, cada oración pronunciada por los testigos será escrutada a la luz de la relevancia que quepa asignarle, tanto para la corroboración o refutación de la conjetura que se debate, como por su utilidad para dar (o no) por superado el estándar de prueba aplicable. Sin esos conceptos, las actuaciones de los abogados y de los jueces serían muy distintas. Un fenómeno similar ocurre al momento de formular los alegatos de clausura (o de dictar la sentencia). Conceptos tales como valor probatorio, credibilidad y estándar de prueba determinarán lo que los abogados y jueces competentes usarán o dejarán de lado a partir de las distintas aseveraciones que formule un testigo.

La mayoría de los conceptos útiles para la gestión de las pruebas y argumentos que se producen en los procesos judiciales son comunes a los que se usan en otros contextos (no jurídicos) en que, también, se trata de probar o de refutar conjeturas ${ }^{40}$. Según es fácil advertir, el significado que se atribuye a varios de ellos no experimenta cambios considerables dependiendo del contexto en que se opere. Hay otros, en cambio, que se encuentran más afinados (o simplificados) en los textos jurídicos, en las sentencias, o en las conversaciones entre especialistas. Un listado incompleto, pero que da cuenta de la mayoría de los problemas que se presentan en el contexto probatorio, sería el siguiente: admisibilidad, carga de la prueba, estándar de prueba, hecho (probado), medio de prueba, pertinencia, presunción, relevancia y valoración de la prueba. A ellos debiesen sumarse otros tales como credibilidad, fuerza probatoria (o valor probatorio) y justificación (fáctica), los cuales sin perjuicio de ser especificaciones de otros más genéricos (valoración de la prueba), su análisis por separado resulta de bastante utilidad. Un caso similar se daría con el concepto de hechos a probar (conjetura) estrechamente

37 Lo expresado es una manifestación del fenómeno que HANSON identificó como de «carga teórica de la observación», es decir, aquello que vemos se encuentra moldeado por nuestro lenguaje y, en general, por nuestros conocimientos previos. HANSON, 1977: 99. Un anticipo de ello puede verse en KANT, 1973: 1. ${ }^{\mathrm{a}}$ parte, párr. 8, 192; BENTHAM, 1971: 49-53.

38 Vid. TORRETTI, 2012: 84 y ss.

39 En otras palabras, los abogados y los jueces se focalizarán en ciertas partes del relato y no en otras; se preocuparán en los gestos del testigo ante determinadas preguntas y no en otras, etcétera. Las coincidencias, por cierto, no serán absolutas.

40 La coincidencia parcial entre las tareas que llevan a cabo los juristas, los analistas, los historiadores, etcétera lleva a que sea más que sensato fijar la atención en una lógica de las pruebas independiente de las reglas específicas estipuladas en cada sistema jurídico. El punto es importante ya que obliga a los juristas a permanecer atentos a desarrollos que ocurren en otros campos de trabajo. Un buen ejemplo de los usos que pueden darse de los avances externos puede verse en ANDERSON et al., 2015:33-78. Sobre el giro que se detecta en los artículos publicados en revistas norteamericanas, desde lo doctrinal hacia lo interdisciplinario, vid. PARK y SAKS, 2006: 952. 
ligado al juicio de pertinencia ${ }^{41}$. Hay por cierto, muchos otros conceptos que podrían calificarse como secundarios ya que están en una relación de dependencia con algunos de los conceptos ya señalados, como sería el caso de convicción, corroboración, interrogatorio, perito, prueba ilícita, sana crítica, testigo, etcétera ${ }^{42}$.

Las posibilidades de asociación entre los conceptos son múltiples, aunque limitadas. Así, por ejemplo, el juicio de admisibilidad — que es determinante para la aceptación de algunos medios de prueba y la exclusión de otros- presupone un análisis de relevancia, el que, a su vez, requiere de un juicio de pertinencia. Hay otras relaciones que son más problemáticas, como sería el caso que se da entre presunción y fuerza probatoria. En lo que sigue, se explica por qué el concepto de hechos (probados) debiese constituir la base del análisis y cumplir funciones ordenadoras del resto.

\subsection{Algunas cuestiones a aclarar respecto de los dispositivos factuales}

Como se sabe, la influencia de los sistemas jurídicos en la vida cotidiana depende, en gran medida, de la clase de respuestas que los órganos de adjudicación habitualmente suministran. Lo expresado redunda en un elevado interés ( $y$, a la vez, dificultad) de los juristas para trazar una distinción entre validez y eficacia normativa (o lo que vendría siendo casi lo mismo, entre el derecho en los libros y el derecho en acción). La brecha entre ambas categorías no debiese ser demasiado ancha ya que, en caso contrario, sería expresiva de una patología del sistema normativo que llevará a fin de cuentas a plantearse, ya sea si lo dicho en los libros o bien, si las prácticas de los órganos autoritativos, constituyen realmente derecho ${ }^{43}$.

Una forma de mantener controlada la brecha entre validez y eficacia supone suscribir - y esforzarse en actuar conforme a- lo que WRÓBLEWSKI llamó la ideología de la aplicación judicial del Derecho ${ }^{44}$. Para ello resulta esencial la legitimación de los procesos de identificación y atribución de significados a las disposiciones jurídicas, como también la validación de las rutinas de adscripción de conductas en sujetos en quienes se harán recaer determinadas consecuencias jurídicas ${ }^{45}$. Aquello merece ser observado con atención, pues los órganos de adjudicación cuentan con facultades tanto para fijar autoritativamente el derecho en el caso concreto ${ }^{46}$, como también para

${ }^{41}$ Parafraseando a HANSON (vid. nota 37), se ha sostenido que «en el área de nuestro interés, tendría que decirse que los enunciados fácticos corren, además, el riesgo de estar cargados de derecho». ANDRÉs, 1992: 265. La afirmación es ilustrativa respecto de lo que se espera con la prueba de los hechos.

${ }^{42}$ Un glosario bastante completo y que da cuenta además de una terminología útil para los efectos de ordenar las piezas de prueba (bajo una lógica sofisticada) puede verse en ANDERSON et al., 2015: 445-451.

43 Vid., por todos, Holmes, 2012: 59 y ss.

44 Esto ocurre de manera especialmente fuerte en la categoría que el mismo WRÓBLEWSKI llama ideología de la decisión vinculada y, en menor medida, en la de la ideología de la decisión legal y racional. No ocurre, en cambio, si se suscribe la ideología de la libre decisión. WRÓBLEWSKI, 1989: 67-84.

${ }^{45}$ Lo expresado es una manifestación de que lo que hacen los órganos de adjudicación no se limita a imponer cargas u otorgar beneficios, sino que supone realizar otras tareas aledañas de carácter no prescriptivo y que culturalmente se entienden necesarias para la adjudicación. Esto lleva a HART a sostener que lo que impulsa a centralizar la fase de adjudicación en órganos dotados de competencia no se reduce a interrogantes acerca de qué hacer con un sujeto sobre el que recae una determinada acusación, sino principalmente a si ha habido una violación a una norma jurídica. Vid. HART, 1995: 113-122.

46 Esto, por cierto, no exonera al tribunal de recibir críticas por la elección de textos normativos o por la interpretación que de ellos ha realizado. 
decidir los hechos ${ }^{47}$. Para dar cuenta de las relaciones entre las normas y las conductas (acoplamientos) es usual recurrir a expresiones tales como «subsunción»o «justificación interna» ${ }^{48}$. Aquello facilita que dicho tramo del razonamiento sea susceptible de reconstruirse bajo una estructura propia de la lógica deductiva ${ }^{49}$. Tanta sincronía, sin embargo, debe mirarse con sospecha. Su aceptación sin las debidas precauciones incide en que los problemas serán transferidos hacia el «patio trasero» del razonamiento, esto es, a la justificación externa ${ }^{50}$.

A diferencia de lo que ocurre con las normas cuyo significado se hace depender de debates que se dan en distintos foros (revistas académicas, seminarios, aula de clases, estudios de abogados, sentencias, etc.), los hechos constituyen un producto que depende fundamentalmente de lo que suceda en cada proceso judicial. Ni el proceso formativo de los futuros jueces y abogados, ni el nivel de producción científica en asuntos probatorios resulta equiparable al que es propio de las cuestiones que se relacionan con la validez e interpretación de formulaciones normativas ${ }^{51}$. Los problemas de prueba desencadenan, principalmente, tensiones y desacuerdos en la fase de validación de aquellas conjeturas que adscriben conductas («hechos a probar») sobre ciertos sujetos. El resultado procesal, se supone, dependerá, por una parte, de lo manifestado a través de los medios de prueba disponibles; y por la otra, de lo que cabe inferir desde diversas generalizaciones cuyo uso está procedimentalmente previsto ${ }^{52}$.

Dejando de lado una serie de restricciones que afectan al proceso probatorio ${ }^{53}$ la pregunta que, en principio, pareciera pertinente contestar para los efectos de conferir el estatus de «probadas» a una o más conjeturas — presentadas bajo la etiqueta de los hechos a probar-asume formas tales como: ¿qué ha pasado o ¿cómo es el mundo? ${ }^{54}$. La razón aparenta ser de Perogrullo: las conductas que cabe adscribir a las personas deben ser restringidas a aquellas que efectivamente han ejecutado ${ }^{55}$. Bajo tal supuesto, la dirección de ajuste esperada sería desde las palabras al mundo (el mundo permanece invariable; las palabras, en cambio, estarán llanas a modificarse cada vez que sea necesario).

Lo que sucede en los procesos judiciales difiere, sin embargo, en no poco con las expectativas recién planteadas. Pese a los esfuerzos desplegados por sus distintos

47 La distinción entre quaestio juris y quaestio facti no es en la práctica tan nítida como la que aquí se presenta. Vid., entre otros, Allen y PARDO, 2003; 1769 y ss.; Fox, 1899: 551.

48 WRÓBLEWSKI, 1974: 33-46.

49 La decisión, por cierto, es siempre un acto de voluntad. De lo que se trata cuando se habla de esta manera es de reconstruir lo realizado en términos de verificar si la conclusión a la que se llegó era o no lógicamente derivable de sus premisas. AlCHOURRÓn y Bulygin, 1991: 303-304.

50 Sin perjuicio de lo señalado, la subsunción puede prestar ayuda en el control del razonamiento si se entiende como una reconstrucción posible que exige atención a la construcción de sus premisas. Vid. MACCORMICK, 2007: 321-334.

51 Coloma, 2016a: 56-67.

52 Las generalizaciones son necesarias aunque peligrosas, dando lugar a una serie de desacuerdos al momento de utilizarlas. ANDERSON et al., 2015: 321-350. Aquello se traduce en una serie de perplejidades, por ejemplo, respecto a lo que implica valorar la prueba conforme a la sana crítica, o a nivel de mayor detalle, a cómo se reconoce (o construye) una máxima de la experiencia. COLOMA y AGÜERO, 2014: 673-703.

53 Vid., por ejemplo, GASCÓN, 1999: 125 y ss.; y LAUDAN, 2013: 173 y ss.

54 Dice WRÓBLEWSKI: «La decisión de la prueba es la constatación judicial de que el hecho F existe en el tiempo t y en el lugar p. En la aplicación del derecho se deben hacer constataciones de este tipo fundadas en las pruebas». WRÓBLEWSKI, 1989: 70.

55 Así, por ejemplo, entiende TWINING que ocurriría con la tradición racionalista en la que se inscribe una larga lista de autores como Bentham y Wigmore. Twining, 1990: 73. 
participantes, al término de un proceso las preguntas de ¿cómo es el mundo? o ¿qué ha pasado? no se encuentran en condiciones de ser respondidas en toda su complejidad $^{56}$. Aquello es consecuencia —entre otras cosas- de que: i) los recursos probatorios (pruebas y argumentos) que se encuentran en condiciones de ser provistos, ya sea por las partes o por el Estado, son limitados; ii) el tiempo del cual se dispone para zanjar controversias es finito, y iii) los problemas a los que se enfrentan los tribunales en un elevado número de casos no son reducibles a regularidades (conducta humana). Así las cosas, el contexto en el que se mueven los tribunales es el propio de la toma de decisiones bajo incertidumbre o, en el mejor de los casos, bajo riesgo ${ }^{57}$.

William Twining distingue cinco perspectivas que desafían a las tradiciones racionalistas de la prueba. Entre ellas, por ejemplo, se encuentra la de los escépticos filosóficos que ponen en duda la posibilidad de determinar válidamente cómo es el mundo (el conocimiento, los argumentos racionales o los valores objetivos constituyen una imposibilidad); la de los escépticos ideológicos que cuestionan la neutralidad de las investigaciones (las perspectivas racionalistas ocultan propósitos represivos, etc.); e, incluso, la de quienes cuestionan la factibilidad de contar con instituciones, procedimientos y reglas que maximicen la rectitud de las decisiones ${ }^{58}$.

Una explicación de la pervivencia en el tiempo de la brecha existente entre las expectativas cognoscitivistas que recaen oblicuamente ${ }^{59}$ sobre el sistema de adjudicación y aquello a lo que este se encuentra en condiciones de proveer, pudiera ser el siguiente: La pregunta ¿qué es lo que ha sucedido? o ¿cómo es el mundo? no admite ser respondida, al menos en un sentido fuerte. En vista de ello, es sustituida por otras respecto de las cuales los jueces sí pueden hacerse cargo ${ }^{60}$. La sustitución que se lleva a cabo no es transparente, es decir la nueva pregunta se presenta como un equivalente a la original con lo cual no es claro lo que se ha perdido con la transformación realizada ${ }^{61}$. Las movidas de los juristas suponen una distinción inicial entre diferentes

56 En ese sentido, CELANO sostiene que los jueces tienen una obligación de «buscar la verdad», pero no de encontrarla. CELANO, 1995: 146.

57 La explicitación de estándares de prueba, por ejemplo, constituye un reconocimiento de que la pregunta que deben responder los tribunales a los efectos de decidir si los hechos están probados no es (al menos en un sentido fuerte) si cierto evento ha sucedido o no.

58 TwINING, 1994: 131-133.

59 Utilizo la expresión «oblicuamente» para matizar las expectativas cognoscitivistas. Los autores que las defienden rara vez desconocen las restricciones a las cuales estas se encuentran expuestas. En ese sentido, no son expectativas radicales, sino moderadas.

60 En un libro exitoso, el matemático George PÓLYA aconseja que si uno no puede resolver un determinado problema debiera comenzar por hacerse cargo de otro (relacionado) que sí le resulte accesible (PóLYA, 1973: xvii). Los psicólogos Amos TVERSKY y Daniel KAHNEMAN han transferido dicha sugerencia hacia otros contextos para así dar cuenta de un mecanismo al que habitualmente se recurre para no tener que abstenerse de dar respuesta a distintos enigmas que se plantean, en situaciones de escasa información. Dice KANNEMAN: «Nos preguntábamos cómo la gente puede hacer juicios de probabilidad sin conocer con precisión lo que es la probabilidad. Concluimos que la gente tiene que simplificar de algún modo esta tarea imposible, y nos pusimos a buscar cómo lo hace. Nuestra respuesta fue que cuando se le pide juzgar probabilidades, la gente realmente juzga algo y cree que ha juzgado probabilidades». KAHNEMAN, 2012: 132-135. Un análisis de la epistemología de la producción de los hechos en contextos judiciales puede verse en Ho, 2010: 85-171.

61 En la vida cotidiana preguntas tales como: ¿qué ha pasado?, son transformadas por el interlocutor por otras más sencillas, como sería el caso de: ¿qué recuerdo haber observado?, ¿qué me ha dicho la gente que ha sucedido? o ¿cómo puedo explicar que el vidrio del baño se haya trizado? Por cierto, el interlocutor, rara vez, hará explícita la sustitución. A su vez, quien formuló la pregunta original debiese estar consciente de que una pregunta tan compleja como podría llegar a ser: ¿qué ha pasado?, será sustituida por su interlocutor. 
clases de hechos, lo que da también espacio a diferentes formas de validación. Así, la pregunta original ¿qué es lo que ha pasado?, muta en diferentes preguntas sustitutivas. Las diferencias resultan explicables dado que en cada categoría creada hay diferentes valores en juego que debilitan en distintos niveles las pretensiones cognoscitivas. Así, las preguntas sustitutivas aluden a circunstancias variadas, esto es, al silencio de los litigantes, al acuerdo entre ellos, a la existencia de presunciones legales y a la cantidad y calidad de las pruebas disponibles para el caso concreto.

Para aludir a cada categoría utilizaré la locución «dispositivo factual». Con ello quiero enfatizar que al otorgarse el estatus de «hechos» a distintos enunciados, lo que se busca es disponer de un soporte argumentativo para una decisión que implica cargas y/o beneficios para las partes en conflicto. La palabra dispositivo ${ }^{62}$ resulta bastante neutral para los efectos señalados, la que unida al calificativo de «factual» da cuenta de que dicho dispositivo permite adscribir conductas. Acorde con lo indicado, las categorías de hechos ${ }^{63}$ que se presentan en las sentencias serían las siguientes:

a) Dispositivo factual de lo no problematizado (Hechos no problematizados). Este dispositivo se hace cargo de la pregunta: ¿Hay o no conflicto entre las partes respecto de las conductas que pretenden adscribírseles ${ }^{64}$ ? De acuerdo a este dispositivo, si las partes nada hacen, entonces es válido adscribirles las conductas propuestas, ya sea en la conjetura definida por el tribunal (hechos a probar), o bien en el relato presentado por una o ambas partes por separado.

b) Dispositivo factual de lo consensuado (Hechos consensuados). Este dispositivo es útil para hacer frente a la pregunta: ¿Hay acuerdo expreso entre las partes respecto de la conducta que cabe adscribir a cada una de ellas? Si las partes convienen las conductas que deben serles adscritas, entonces aquellas adquieren el estatus de «hechos» ${ }^{65}$.

Los dos dispositivos recién indicados se construyen interviniendo en las cargas de alegar que el legislador impone sobre las partes ${ }^{66}$. En rigor, la circunstancia de que una o ambas partes no controvierta una determinada forma de reconstruir acciones no dice

62 Según el diccionario de la Real Academia de la Lengua Española, uno de los significados de la palabra «dispositivo» es «mecanismo o artificio para producir una acción prevista». La definición viene bien para lo que aquí se quiere comunicar.

63 Agradezco a Claudio AGÜERO sugerirme la distinción que a continuación se realiza en el texto principal. Las tres primeras categorías dan cuenta de hechos que los procesalistas sostienen que no requieren probarse. Sus clasificaciones, en todo caso, suelen ser más detalladas. Vid. CouTuRE, 2014: 183-194.

${ }^{64} \mathrm{La}$ pregunta que aquí se formula podría ampliarse si con ella se quiere dar un cuenta de una categoría de hechos intermedios - a la que brevemente me refiero más adelante- como lo es la de los hechos públicos y notorios. En tal caso podría preguntarse si hay o no discrepancias sociales respecto de acontecimientos que han podido ser observados y/o discutidos por una cantidad importante de sujetos. En caso de recibir respuesta negativa podría pensarse en un dispositivo factual de lo público y notorio.

65 En otros contextos, los consensos o la inexistencia de razones para problematizar también son importantes para dar cuenta de lo que se reconoce como un saber (o en lo que aquí interesa «hechos»). WITGENSTEIN da el siguiente ejemplo: «Imaginemos que el alumno preguntara en realidad: ¿Existe también la mesa cuando me doy vuelta o cuando nadie la ve? En este caso, ¿debería el maestro tranquilizarlo y decirle: “¡Por supuesto que existe!"? Es posible que el maestro se impaciente un poco, pero pensará que el alumno dejará de hacer tales preguntas. Es decir, el maestro tendría la sensación de que esta no es una pregunta en absoluto legítima». WITTGENSTEIN, 2000: 40c.

66 Siguiendo a Ronald ALLEN, «[1] as cargas de alegar especifican las condiciones bajo las cuales las pretensiones fácticas/jurídicas serán consideradas para su inclusión en un litigio». ALLEN, 2013: 41. 
demasiado en términos de que las cosas hayan ocurrido de una cierta manera ${ }^{67}$. Sabemos que el silencio de una o ambas partes puede obedecer a una multiplicidad de razones escasamente vinculadas a que «la realidad» haya sido de una cierta manera y no, de otra. En ocasiones, las partes no alegan por pereza, porque los costos económicos de hacerlo son elevados, por temor a desagradar, u otras razones por el estilo. De este modo, el consenso de las partes tiene múltiples orígenes que no siempre son acordes a lo que cabe entender como epistémicamente validado ${ }^{68}$. Hay, por cierto, restricciones a esta forma de construir dispositivos factuales que apuntan a que, en determinadas circunstancias, el Estado no está dispuesto a correr el riesgo de que las disposiciones jurídicas sean burladas. Así, por ejemplo, hay procedimientos en que no se acepta que las partes negocien hechos y, también algunos en que los acuerdos requieren del visto bueno de un juez ${ }^{69}$.

c) Dispositivo factual de lo presumible (Hechos presumidos). Este dispositivo se hace cargo de la pregunta: ¿Hay hechos (conductas) que el legislador autorice que se presuman desde ciertas premisas? Si el legislador establece que de la existencia de ciertos hechos pueden/deben colegirse otros y se aprueba la existencia de tales hechos iniciales, entonces aquellos que sean derivados (presumidos) adoptarán la forma de dispositivos factuales.

Salvo en el caso de las presunciones de derecho (no admiten prueba en contrario $\mathrm{y}$, en rigor, corresponden a una cierta manera de formular reglas), el dispositivo factual de lo presumible se utiliza para alterar cargas de persuasión y de producción de pruebas. Esto implica que si la parte que soporta las cargas de producción y de persuasión nada hace, el hecho respectivo se dará por probado (lo cual no ocurriría en los casos de inexistencia de la presunción $)^{70}$.

d) Dispositivo factual de lo probado (Hechos probados). Este dispositivo hace frente a la pregunta: ¿Hay pruebas suficientes que validen la conjetura de que uno o más sujetos ha(n) realizado determinada(s) acción(es)? ${ }^{71}$. Si tales pruebas son calificadas institucionalmente como suficientes, entonces serán hechos los que el juez esté autorizado a inferir desde las pruebas rendidas y de las generalizaciones que sean aplicables.

Este dispositivo factual no difiere demasiado de los hechos que se validan en otros contextos cuando se trata de sortear la pregunta acerca de ¿cómo es el mundo?

67 TARuffo, 2008: 129-151. Vid. especialmente las páginas 148-150 en que llega a la misma conclusión aquí indicada (aunque por una vía argumental diferente), en cuanto a que, a fin de cuentas, lo que está en juego son las cargas de probar.

68 El reconocimiento de estas dos categorías de dispositivos factuales resulta más propia de un Estado escasamente perfeccionista, antes que de uno preocupado por imponer planes de vida a los ciudadanos. El primero reconoce a las partes un rol clave para la construcción de los hechos, incluso si aquello conduce a un alejamiento de lo que se entiende como probado en otros contextos. Vid. DAMASKA, 2000: 193-197. chileno)

${ }_{69}$ Así, por ejemplo, ocurre en el procedimiento abreviado (arts. 406, 409 y 410 del Código Procesal Penal

70 Un análisis más detallado puede verse en AlLEN, 2013: 44-48. Vid. también SCHAUER, 2013: 228-232, quien entiende el problema de las presunciones como un asunto de carga de la prueba.

${ }^{71}$ La pregunta va acompañada de una de carácter negativo y que apunta a la insuficiencia de las pruebas que refuten la conjetura. La determinación de la suficiencia probatoria tiene en cuenta aspectos tanto cuantitativos como cualitativos. Cfr. FERRER, 2005: 27-38. 
Los elementos más obvios de nuestras creencias mediante los cuales hacemos frente (indirectamente) a la pregunta de ¿cómo es el mundo? son: i) un contenido (lo que se cree); ii) una actitud que puede tener distinto grado de intensidad y que puede ir desde la certeza hasta un punto ligeramente superior al de la no creencia, y iii) un conjunto de razones para la creencia. ${ }^{72}$ Los sistemas jurídicos se hacen cargo de estos tres elementos ya que en algún momento del proceso se define: i) la conjetura desde la que se extrae en último término el contenido proposicional de los hechos; ii) la intensidad de la convicción o de los soportes evidenciales ${ }^{73}$ con que cuenta el tribunal en términos de definir si un hecho está probado (cumple) o no probado (no cumple), y iii) la clase de razones que pueden presentarse como soporte de los hechos probados (deben derivarse de pruebas admisibles, valoradas conforme a la sana crítica, etc.).

De las distintas categorías de hechos que se incorporan en las sentencias la que resulta más desafiante desde una perspectiva conceptual y metodológica - $\mathrm{y}$, por regla general, la que es más relevante en la práctica- es la de hechos probados. A esta categoría refiere el acápite siguiente ${ }^{74}$.

Un punto del que no me haré cargo, pero que al menos será útil dejar anunciado se relaciona con algunas ambigüedades de la palabra «hechos» utilizada en la argumentación que es propia de los procesos judiciales. Aparte del sentido que aquí interesa —el cual supone su directa relación con una o más normas que estipulan las consecuencias que se hacen recaer sobre el demandado o acusado-, se puede hablar de hechos para dar cuenta de otros enunciados que no adscriben directamente conductas, pero fijan sus presupuestos ${ }^{75}$. Así por ejemplo, hechos tales como Edipo mató a su padre Layo, o Antonio está ocupando sin título alguno la casa X de Próspero, admiten, respectivamente, ser acopladas con el tipo penal de parricidio y con la norma que estipula la reivindicación. Aun cuando están formulados parcamente, es fácil observar que suponen otros hechos tales como «Layo ha muerto», «Edipo es hijo de Layo», «Antonio ocupa la casa X», o «Próspero es dueño de la casa $X »$. Tales enunciados no adscriben conductas o si lo hacen, no son de aquellas que admiten acoplarse con normas jurídicas desde las que se extraerá la solución que interesa. Estos hechos también son producidos en las sentencias (en ellas se dan por probados) y, en términos generales, cabría llamarlos hechos intermedios. Incluso es posible que se den por probados estos hechos sin que en la respectiva sentencia se lleguen a adscribir conductas, lo que ocurriría, por ejemplo, si se da por probado el hecho punible, pero no la participación del acusado ${ }^{76}$.

72 PEPPER, 1942: 11-12.

73 La actitud requerida de parte de los tribunales de justicia pueden depender tanto de la subjetividad de sus miembros (por ejemplo, íntima convicción), como de la aceptabilidad de la conjetura en conformidad a esquemas culturalmente validados (dentro de estos últimos podría situarse el uso del cálculo probabilístico). Vid. LAUDAN, 2005: 98 y ss.

${ }_{74}$ De aquí en adelante, cuando se hable de los hechos me estaré refiriendo a los hechos probados.

75 Más aún, entre jueces y abogados también habría un tercer sentido en que se podría hablar de hechos. Su relevancia es menor y podría denominársele como hecho-acontecimiento. Respecto de ellos es indiferente que alguien lo sostenga e, incluso, que los advierta. Por ejemplo, son hechos-acontecimientos los sonidos que emite el testigo y que el auditorio interpreta como una respuesta, como también que el testigo haya dado 25 pasos entre el umbral de la puerta y la silla donde se sentó. El hecho-acontecimiento es considerado como «lo dado».

76 Esto se puede hacer calzar con la distinción que autores como T. ANDERSON, D. SCHUM y W. TwINING - siguiendo a J. H. WIGMORE- hacen entre probandum intermedio, penúltimos probanda y probandum último o final. ANDERSON et al., 2015: 449. 


\subsection{El concepto de hecho como concepto ordenador del derecho probatorio}

Los hechos (probados) son el producto (principal) extraíble desde las pruebas rendidas en un proceso judicial y de la actividad argumentativa que en él se produce. Al adscribirse conductas a determinados sujetos (decisión de los hechos), los tribunales se encuentran autorizados/obligados a vincularlos autoritativamente con una o más normas jurídicas. De esta manera, los hechos son claves para justificar el razonamiento práctico de los jueces. Antes de que se dicte una sentencia es institucionalmente aceptable que coetáneamente se afirme, por parte de algunos, que Aurora adeuda 500.000 dólares a Victoria y, por parte de otros, que Aurora nada adeuda a Victoria. Ambas afirmaciones, prima facie, son merecedoras del mismo respeto. En cambio, dependiendo de lo que se haya dado por probado, una vez dictada la respectiva sentencia, solo se considerará seriamente, ya sea que Aurora adeuda o que no adeuda cierta cantidad de dinero. Esto es importante, ya que solo a partir de ese momento Aurora pasará a desempeñar una posición jurídica que es propia de sujetos que adeudan $— \mathrm{o}$ no adeudan - a otro una determinada cantidad de dinero.

La adscripción (o negativa de adscripción) de una conducta no garantiza que los hechos en un juicio sean resistentes a intentos de falsación provenientes desde fuera del sistema jurídico. Así, la garantía que la prueba de los hechos otorga es intra-sistémica, lo que no libera al proceso judicial de la necesidad política de ser deferente, en la medida de lo posible, con lo epistémicamente exigible en otros contextos (prestigiosos). Esta expectativa de deferencia, sin embargo, no es suficiente como para poner en duda el estatus de hecho probado/no probado de un determinado enunciado, mientras se opere en el sistema jurídico.

Pese a su relevancia, el concepto de «hecho probado» o más sencillamente el concepto de «hecho» ha sido escasamente problematizado dentro de la comunidad de los juristas. El concepto de «hecho» tiene un carácter eminentemente operacional. De esta manera, su comprensión se hace depender de las tareas que permita llevar a cabo en el contexto de un proceso ${ }^{77}$. Más concretamente, los hechos importan en la medida que sirven de soporte a argumentos útiles para la distribución (o negación) de cargas y/o beneficios. Así las cosas, los hechos (en las sentencias) ${ }^{78}$ son artefactos lingüísticos ${ }^{79}$ cuya función es la adscripción de acciones u omisiones jurídicamente relevantes sobre uno o

77 Este punto es clave para comprender mis diferencias con conceptualizaciones como las que, por ejemplo, propone Daniel GONZÁLEZ LAGIER. Él advierte el carácter complejo de los hechos, en cuanto articulan elementos observacionales y normativos. Desde su perspectiva, la tarea interpretativa opera sobre datos sensoriales, y se encuentra determinada de manera gravitante por los conceptos utilizados. GONZÁLEZ, 2013: 77-79. De esta manera - a diferencia de lo aquí sugerido- para entender los hechos no se asigna un valor central al acoplamiento que se espera lleguen a tener los hechos con las normas jurídicas que pretenden aplicarse, pues el foco está puesto en las posibilidades que ofrecidas por los datos sensoriales pasados por el tamiz de las interpretaciones.

78 Al hablar de hechos en las sentencias me hago cargo de ambigüedades de dicha palabra en el contexto de un proceso judicial. Así, por ejemplo, en las distintas fases del juicio se habla de los hechos queriendo referirse con ellos a diferentes cosas. Hablo en la mayor parte de este artículo de hechos a secas, pues aquellos son los ejemplares más importantes en el proceso judicial y en la reconstrucción del razonamiento jurídico.

79 Respecto de la discusión acerca de qué tipo de enunciado son los hechos en la sentencia, los entiendo como eminentemente constitutivos, aclarando que dicho carácter no los exime de un juicio crítico cuando no se han satisfecho (pudiendo haberlo hecho) exigencias que se entienden más propias de los enunciados descriptivos. Cfr. FERRER, 2005: 19 y ss. 
más sujetos. Dicha condición es común a los distintos dispositivos factuales que previamente se han identificado en este texto. Como ya ha sido dicho, la forma de validación de cada uno de ellos es diferente, siendo de especial interés la categoría de los hechos probados. Esta última, hace depender el otorgamiento del estatus de hecho probado a los resultados de un proceso de contrastación sobre una conjetura (factum probandum) que adscribe conductas jurídicamente relevantes a los partícipes de un juicio ${ }^{80}$.

Uso la expresión artefacto lingüístico con miras a enfatizar, por una parte, que los hechos de la sentencia (los que se califican jurídicamente) no corresponden a un fragmento de la realidad o a algo que ocurrió, como tampoco a un fragmento específico del texto de la sentencia, aun cuando se requiera de este último para su constitución. La noción de artefacto da cuenta de la funcionalidad del dispositivo decidido por los tribunales de justicia (sirve para hacer cosas), admitiendo ser reconstruido de distintas maneras por sus intérpretes (no es el símbolo en sí, sino su significado). Su carácter constitutivo incide en que los hechos en la sentencia se entiendan como definitivos, a pesar de que fuera del espacio de lo jurídico pueda no quedar del todo resuelto el problema de la determinación de lo que habría ocurrido ${ }^{81}$.

Es usual que en las sentencias los hechos se expresen mediante un relato que un intérprete competente debiera ser capaz de reconstruir en términos de verificar si calza o no con la norma aplicada en la misma sentencia. Cabe advertir, eso sí, que no es infrecuente que el aludido relato incluya oraciones que, en último término, resultarán irrelevantes para los efectos de la calificación jurídica, y que, por tanto, es dudoso conferirles el estatus de hechos ${ }^{82}$. A la vez, el relato no siempre es suficientemente completo en la identificación de la conducta que se adscribe a una parte y que se hace calzar con la condición de aplicación de una norma. Para tales efectos, el intérprete suele buscar en distintas partes de la sentencia aquello que falta al fragmento del que no duda que contiene hechos probados.

La circunstancia de que los hechos sean decididos autoritativamente por los tribunales no los libera de que, ocasionalmente, padezcan de algunas patologías ${ }^{83}$. Entre

${ }^{80}$ Que los hechos sean constituidos no debiese resultar mayormente sorprendente, salvo que se suscriba a una corriente realista desde la perspectiva científica. Incluso para quienes defiendan formas de objetivismo, el entender que los hechos no son algo dado sino constituido, no representa un obstáculo. Vid. TORRETTI, 2010: 15-32 (esp. 15-17). Por cierto, el carácter de los hechos es especialmente fuerte en el mundo de los tribunales de justicia en los que se opera con reglas de exclusión de prueba y de limitación de los debates mucho más restrictivas que en otros contextos.

${ }^{81}$ Esta circunstancia incide en que no sea adecuado reconstruir los hechos como sucesos del pasado o fragmentos de la realidad. Parafraseando un texto de KELSEN en que aboga por el carácter constitutivo de los hechos (KELSEN, 1997: 249) puede sostenerse que no son los sucesos en sí sino los artefactos lingüísticos validados los que se acoplan con las normas. Aquello no resulta desafiado porque según nuestras formas usuales de hablar digamos, por ejemplo, que Ronnie fue encarcelado «porque asaltó un tren», en lugar de decir (más correctamente) «porque un tribunal competente, luego de seguir un procedimiento institucionalmente establecido, declaró que Ronnie asaltó un tren».

82 En ocasiones, las sentencias incorporan fragmentos discursivos escasamente comprometidos con aquello que resulta relevante desde la normativa aplicable. En casos así, pareciera que los tribunales: i) asumen una posición en la que se muestran interesados no solo en la solución del caso, sino en la reconstrucción de una experiencia de vida, o ii) no se ocupan de filtrar aquello que los testigos, peritos o abogados incorporan en el proceso, sin tener en consideración lo que desde la perspectiva procedimental resulta especialmente importante que aporten.

${ }^{83}$ Los sistemas actuales han resuelto otra importante patología — la suspensión de la toma de decisión factual— por la vía de consagrar el llamado principio de inexcusabilidad. 
ellas hay algunas que tienen un carácter eminentemente procedimental y otras que parecieran concernir directamente a los resultados alcanzados. La existencia de mecanismos correctivos de las patologías procedimentales ${ }^{84}$ no afecta el estatus de artefactos lingüísticos que cabe reconocer a los hechos. Se trata simplemente de que los requisitos para su validación no han sido cumplidos y, por ende, no es admisible relacionarlos con las normas que en términos generales y abstractos estipulan cargas y/o beneficios.

Las patologías concernientes a resultados para las que el sistema jurídico prevé remedios, son excepcionales. Los cambios a los cuales dan lugar (desde probado a no probado o viceversa) debilitan la idea de que la decisión acerca de los hechos es puramente constitutiva ${ }^{85}$. Las patologías de resultados suelen presentarse como de falsos positivos (se da por probado un hecho del cual hay buenas razones para sostener que no ocurrió) y de falsos negativos (se da por no probado un hecho del cual se carece de buenas razones para sostener que sí ocurrió). No es de extrañar, entonces, que la aparición de nuevos antecedentes incompatibles con la participación de uno o más sujetos a quienes se han adscrito conductas, o bien la deficiente motivación de una sentencia (escasamente sustentada en la prueba rendida) desafíen el estatus decisional de los hechos.

Aun cuando ocurra excepcionalmente, la privación de su estatus de definitividad que afecta a los hechos validados en una sentencia, constituye una razón para poner en duda la comprensión de los hechos como artefactos lingüísticos. Las sospechas — según es posible atisbar- apuntarían en el sentido de que si las razones invocadas no tienen que ver con problemas procedimentales sino con falsos positivos o con falsos negativos, los hechos no serían decididos, sino serían reconocidos. El asunto, sin embargo, no hace tambalear la conceptualización propuesta, aun cuando fuerza a realizar algunas precisiones adicionales.

El sistema jurídico cuando reconoce un medio de impugnación (recurso de revisión) respecto de aquello que se entendía que tenía el estatus de cosa juzgada, lo que hace es complejizar la secuencia de pasos requeridos para validar hechos. Así, es posible salir airoso de una objeción que aparece como del todo razonable y que refiere a que la definitividad de las decisiones supone ciertos límites en situaciones en las que perseverar en lo que ya ha sido dicho resultaría demasiado costoso, en términos de legitimidad. En rigor, para revisar las sentencias cuando ocurre algo inesperado - por ejemplo, aparece quien había sido declarado víctima de un homicidio - no prima tanto el reconocimiento de un falso positivo, sino la inconveniencia de perseverar en la consideración de un artefacto lingüístico que entra en abierta tensión con la prueba actualmente disponible.

${ }^{84}$ No se profundizará en las patologías procedimentales ya que no desafían la noción de artefacto lingüístico que es la que aquí interesa evaluar. Basta aclarar que ellas se producen, por ejemplo, cuando la decisión se funda en prueba inadmisible, no se respeta la forma institucionalizada de valorar la prueba, etc. Las modificaciones a las que dan lugar no se vinculan a qué se decidió, sino a cómo se decidió.

${ }^{85} \mathrm{Si}$ se le preguntase a tres árbitros acerca de cómo se determina la existencia de un gol, el primero podría indicar que él los cobra cuando un equipo los anota; el segundo, que los cobra cuando los ve; y el tercero, que no hay goles mientras él no los cobre (con esto parafraseo a POSNER, 2011: 98). Un sistema de recursos que ponga la atención en lo puramente procedimental, en principio, implicaría una concepción de los hechos cercana al tercer árbitro (no se cumplieron las condiciones para hacer el cobro), siendo compatible también con la del segundo árbitro (no consideró lo que debió haber visto). Los reparos focalizados en el resultado son más próximos a la perspectiva del primer árbitro (hubo un gol y no se cobró). 
Para entender mejor el problema precedente, vale la pena introducir un par de conceptos en tensión: me refiero a los de seguridad cognitiva y de responsabilidad cognitiva. El primero es útil para hacer frente al inmovilismo que va aparejado a un estado de duda permanente (la seguridad cognitiva aspira a la clausura de futuras problematizaciones respecto de un punto de vista aceptado). El segundo, en cambio, propende a la realización de la mayor cantidad de instancias de corroboración y de refutación posibles para la aceptación o rechazo de una conjetura. Cuando se trata de problemas teóricos, la responsabilidad cognitiva suele ocupar un lugar de privilegio: solo en aquello en que se ha sido altamente responsable, se debiera adoptar una actitud de seguridad en términos cognitivos. Cuando se trata de problemas prácticos, la seguridad cognitiva requerida fija los niveles de responsabilidad. El éxito de los hechos probados supone un adecuado equilibrio entre perspectivas en las que se hace predominar un estado de alta seguridad cognitiva a costa de una responsabilidad cognitiva comparativamente baja y aquellas, en que la responsabilidad cognitiva es alta, pero la seguridad cognitiva es reducida ${ }^{86}$. Un estado equilibrado de seguridad cognitiva implica gestionar la incertidumbre en términos de que no resulte inmovilizadora a los efectos de tomar una decisión. Un estado de equilibrio en lo que atañe a la responsabilidad cognitiva implica ejecutar esfuerzos suficientes para detectar errores salvables en la fase probatoria. Conforme a lo señalado, la seguridad cognitiva es requerida para los efectos de que las decisiones tomadas por los tribunales de justicia redunden en cargas y/o beneficios que permanezcan estables en el tiempo para los intervinientes en un proceso judicial. El límite es el de una responsabilidad cognitiva básica que implica revisar aquello que socialmente resulta insostenible, a la luz de los nuevos antecedentes de los cuales se dispone. En otras palabras, el artefacto lingüístico que representan los hechos admite ser puesto en entredicho en una nueva fase que el sistema, en la medida de lo posible, preferiría evitar. Así, las cosas los hechos nunca se desentienden de su dimensión procedimental.

\section{ETAPAS PROBATORIAS Y CONCEPTOS A CONSIDERAR EN CADA UNA DE ELLAS}

La decisión de los hechos probados supone la superación de exigencias previstas en una sucesión de etapas institucionalmente definidas. Un hito del proceso probatorio está representado por la fijación de una conjetura o hipótesis (hechos a probar). Esta resulta clave a los efectos de determinar la manera en que se llevará a cabo la rendición de pruebas y la discusión entre las partes ${ }^{87}$. El paso siguiente supone la realización de una serie de actividades que apuntan de lleno, ya sea a la demostración o bien, a la refutación de la conjetura. Aquello supone la participación no solo de jueces y abogados, sino de distintos sujetos que asumen la responsabilidad de proveer información útil en

\footnotetext{
86 PEPPER, 1942: 44-45. El rol de los estándares de prueba resulta muy claro en este orden de cosas.

${ }^{87}$ No se debe entender conjetura o hipótesis en el sentido de una corazonada, sino como una cierta forma de relacionar lo que ofrecen demostrar las partes y lo que requiere el tribunal para legitimar la imposición de una carga sobre la demandada o acusada. En ese sentido, la determinación de los hechos a probar es una forma de ordenar lo que cabe presentar como prueba y aquello que vale la pena argumentar. Vid. PEPPER, 1942: 71 y ss.
} 
el contexto del proceso. El estatus de hecho probado se alcanza solo al momento en que se pronuncia una decisión autoritativa que declara superado el estándar de prueba institucionalmente establecido.

Un modelo conceptual para decidir hechos probados debe distinguir, entonces, tres etapas o niveles sucesivos: etapa preparatoria, etapa de producción de pruebas y argumentos y etapa de decisión/justificación ${ }^{88}$. En la primera de ellas, se adoptan decisiones útiles para la estructuración de las etapas que le sucederán; ello en una forma equiparable a la determinación de las reglas de un juego (las preguntas claves son: ¿qué debe probarse?, ¿quién debe probar? y ¿con qué se probará?) ${ }^{89}$. En la segunda etapa las partes despliegan sus recursos probatorios y argumentativos cuidando de no excederse del marco de actuación fijado en la etapa preparatoria, como tampoco de lo estipulado en algunas reglas procedimentales del sistema (las preguntas claves son: ¿es válida la prueba que se presenta?, ¿la prueba rendida corrobora o refuta lo que se busca probar? $)^{90}$. En la fase de decisión y de justificación el protagonismo lo adquiere el tribunal quien zanja la disputa y provee de las razones para su elección (las preguntas claves son: ¿qué se ha probado?, ¿cuánto se ha probado?, ¿cómo se ha probado?) ${ }^{91}$.

La secuencia seguida para validar un hecho se representa en el cuadro que se inserta a continuación. En la primera columna se incluyen los insumos institucionalmente reconocidos para enfrentar la respectiva etapa. En la segunda columna se da cuenta de la actividad principal de los jueces en la respectiva etapa. En la tercera columna se informa de los productos que resultan de la etapa. Por último, en la última de las columnas se anuncian los conceptos claves en cada etapa y se expresa brevemente cuál es la utilidad que prestan.

Según la secuencia precedente se estaría en condiciones de decir, por ejemplo, que en un sistema jurídico «un hecho se considera (válidamente) probado si la conjetura que fija su contenido en conformidad a un análisis de pertinencia ${ }^{92}$ se ha sometido a contrastación, mediante la rendición de pruebas relevantes, previamente declaradas

88 David ScHum distingue una etapa de descubrimiento, que, a la vez, se subdivide en generación y eliminación de hipótesis, como también de estructuración de los argumentos. La etapa siguiente es la de rendición de la prueba ante el tribunal; para terminar con una de deliberación y elección. Pese a la relevancia de la primera etapa de SCHUM, la he reducido al mínimo para focalizarme en el papel de los jueces. Estos, al menos bajo una lógica adversarial, cumplen un rol de guardianes de lo que puede y de lo que no puede hacerse. SCHUM, 1986: 831 y ss. Vid. también FerRer, 2007: 41-49; AlCALÁ-ZAMORA, 1965: 29.

89 La determinación de quién probará y cuánto probará vienen definidas por el procedimiento utilizado (carga de la prueba y estándar de prueba).

90 Las tensiones tradicionales en el análisis de los modelos adversariales e inquisitivos que eran vistos como dos formas absolutamente diferenciadas de enfrentar los problemas de prueba, pareciere haberse matizado en el último tiempo. TARUFFO, 2006: 249-271. Vid. también DAMAŠKA, 2000: 12-32.

91 En un texto que próximamente será publicado («Conceptos y razonamientos probatorios») se diferencian para cada etapa clases de razonamiento preponderantes del tribunal y, en ocasiones, también de los abogados. Las categorías que pueden diferenciarse a tales efectos son tres: razonamiento dogmático (propone/ controla interpretaciones de disposiciones normativas); razonamiento epistémico (propone/controla inferencias y asigna valor a piezas de información), y razonamiento lógico (propone/controla la narración que da cuenta de lo que se da por probado o por no probado).

92 El concepto de pertinencia, tal como se usa en esta oración, apunta a la necesidad de delimitar lo que requiere ser probado en virtud de posibles relaciones entre los relatos ofrecido por las partes y las normas que pretenden ser aplicadas. Se hace cargo, entonces, de la relevancia de los hechos propuestos por las partes desde la perspectiva de su eventual acoplamiento con la condición de aplicación de una o más normas. Vid. VÁZQUEZ, 2015: 28 , nota 8 . 
admisibles, y de su valoración (lo que supone haber tomado en cuenta su credibilidad y fuerza probatoria), concluyéndose de todo ello que el estándar de prueba respectivo ha sido superado, y de lo cual se da cuenta en un texto que así lo justifica».

El modelo de decisión de los hechos cuyas bases aquí se proponen, presta utilidad a jueces y abogados respecto de las preguntas claves que cabe formular en los procesos judiciales, esto es ¿qué se prueba? (pertinencia); ¿quién prueba? (carga de la prueba); ¿con qué se prueba? (admisibilidad, relevancia, valoración); ¿cómo se prueba? (valoración de la prueba: credibilidad / fuerza probatoria, presunción) ¿cuánto se prueba? (estándar de prueba) y ¿cómo se hace constar lo que se prueba? (justificación). El desarrollo del modelo con mayor nivel de detalle será tratado en un texto posterior, ya que — según ha sido indicado— aquí solo se presentan sus bases.

\begin{tabular}{|c|c|c|c|}
\hline \multicolumn{4}{|c|}{ ETAPA DE PREPARACIÓN } \\
\hline Insumos & Actividad del juez & Productos & Conceptos asociados \\
\hline $\begin{array}{l}\text { - Relatos de las partes } \\
\text { (demanda/contesta- } \\
\text { ción). } \\
\text { - Normas sustantivas } \\
\text { que prima facie co- } \\
\text { rresponde aplicar. } \\
\text { - Pruebas obtenidas } \\
\text { en fase de investiga- } \\
\text { ción (algunos proce- } \\
\text { dimientos). }\end{array}$ & $\begin{array}{l}\rightarrow \text { Formular conje- } \\
\text { tura que se some- } \\
\text { terá a validación } \\
\text { en etapas siguien- } \\
\text { tes. } \\
\end{array}$ & $\begin{array}{l}\rightarrow \text { Artefacto provi- } \\
\text { sional: HECHOS } \\
\text { A PROBAR (con- } \\
\text { jetura). }\end{array}$ & $\begin{array}{l}\text { Pertinencia: orienta decisión so- } \\
\text { bre el tipo de conexiones que se } \\
\text { deben establecer entre los relatos } \\
\text { que ofrecen las partes y lo esti- } \\
\text { pulado en las normas que preten- } \\
\text { den aplicarse. } \\
\text { Carga de la prueba: anticipa cuál } \\
\text { de las partes será derrotada si no } \\
\text { presenta suficiente prueba en su } \\
\text { favor (relación estrecha con es- } \\
\text { tándar de prueba). }\end{array}$ \\
\hline $\begin{array}{l}\text { - Hechos a probar. } \\
\text { - Propuesta medios de } \\
\text { prueba. } \\
\text { - Reglas de admisibi- } \\
\text { lidad. }\end{array}$ & $\rightarrow \begin{array}{l}\text { Aceptar/rechazar } \\
\text { pruebas a rendir. }\end{array}$ & $\rightarrow \begin{array}{l}\text { MEDIOS } \\
\text { PRUEBA } \\
\text { tidos. }\end{array}$ & $\begin{array}{l}\text { Relevancia: orienta decisión sobre } \\
\text { valor probatorio mínimo exigible } \\
\text { a las fuentes de información que } \\
\text { ofrecen las partes, para ser admi- } \\
\text { tidas como medios de prueba. } \\
\text { Admisibilidad: indica propieda- } \\
\text { des que el sistema jurídico esti- } \\
\text { pula deben satisfacer los medios } \\
\text { de prueba que se presentarán. }\end{array}$ \\
\hline
\end{tabular}

\begin{tabular}{|c|c|c|c|}
\hline \multicolumn{4}{|c|}{ ETAPA DE PRODUCCIÓN DE PRUEBAS Y ARGUMENTOS } \\
\hline Insumos & Actividad del juez & Productos & Conceptos asociados \\
\hline $\begin{array}{l}\text { - Medios de prueba } \\
\text { que se presentan en } \\
\text { audiencia probatoria } \\
\text { y gestiones de aboga- } \\
\text { dos (interrogatorio, } \\
\text { contrainterrogatorio } \\
\text { de testigos, alega- } \\
\text { tos, etc.) } \\
\text { - Reglas de conduc- } \\
\text { ción de audiencias. }\end{array}$ & $\begin{array}{l}\rightarrow \text { Conducir audien- } \\
\text { cias. Aceptar/ } \\
\text { rechazar objecio- } \\
\text { nes. }\end{array}$ & $\begin{aligned} & \rightarrow \text { PRUEBA VÁ- } \\
& \text { LID A M ENTE } \\
& \text { RENDIDA (re- } \\
& \text { gistros). Propues- } \\
& \text { tas de VALORA- } \\
& \text { CIÓN DE LA } \\
& \text { PRUEBA (alega- } \\
& \text { tos de abogados). }\end{aligned}$ & $\begin{array}{l}\text { Valoración de la prueba: indica } \\
\text { formas válidas de construir in- } \\
\text { ferencias con la prueba rendida } \\
\text { (sana crítica, íntima convicción, } \\
\text { prueba tasada). } \\
\text { Credibilidad: orienta decisión } \\
\text { sobre valor que debe reconocer- } \\
\text { se a cada medio de prueba, de- } \\
\text { pendiendo de la fiabilidad de la } \\
\text { información. }\end{array}$ \\
\hline
\end{tabular}




\begin{tabular}{|c|c|c|c|}
\hline \multicolumn{4}{|c|}{ ETAPA DE DECISIÓN Y JUSTIFICACIÓN } \\
\hline Insumos & Actividad del juez & Productos & Conceptos asociados \\
\hline $\begin{array}{l}\text { - Prueba rendida. } \\
\text { - Alegatos de aboga- } \\
\text { dos. } \\
\text { - Reglas de valoración. } \\
\text { - Estándar de prueba. } \\
\text { - Reglas de motiva- } \\
\text { ción. }\end{array}$ & $\begin{array}{|lr|}\rightarrow \text { Aceptar/rechazar } \\
\text { adscripción r } & \text { de } \\
\text { conductas. } & \text { Re- } \\
\text { dactar texto justi- } \\
\text { ficativo. }\end{array}$ & $\begin{array}{l}\rightarrow \text { Artefactor lin- } \\
\text { gǘstico defini- } \\
\text { tivo (HECHOS } \\
\text { PROB A DOS / } \\
\text { NO PROBA- } \\
\text { DOS) JUSTIFI- } \\
\text { CACIÓN de de- } \\
\text { cisión probatoria } \\
\text { (sentencia). }\end{array}$ & $\begin{array}{l}\text { Valor probatorio (fuerza probato- } \\
\text { ria): orienta decisión sobre la in- } \\
\text { cidencia que debe reconocerse a } \\
\text { una o más pruebas rendidas para } \\
\text { demostrar/refutar la conjetura. } \\
\text { Estándar de prueba: orienta la de- } \\
\text { cisión de dar por probados o no } \\
\text { probados los hechos en el caso } \\
\text { concreto según suficiencia de la } \\
\text { prueba y diferenciando según el } \\
\text { tipo de procedimiento. }\end{array}$ \\
\hline
\end{tabular}

\section{CONCLUSIONES}

1. Los modelos conceptuales que se construyen en el ámbito jurídico, si bien no corresponden a aplicaciones tecnológicas estrictas de lo que teóricamente se encuentra validado, resultan útiles para que jueces y abogados enfrenten satisfactoriamente los distintos desafíos que se les presentan en el ejercicio de sus funciones.

2. A partir del concepto de «los hechos» es factible proponer un modelo conceptual para la gestión de problemas probatorios. Los hechos admiten diferenciarse en distintas categorías, siendo la de «hechos probados» la de mayor utilidad para los efectos de organizar el modelo.

3. Los hechos son un artefacto lingüístico que adscribe (1) acciones u omisiones jurídicamente relevantes sobre uno o más sujetos, (2) y que habiendo sido sometido a un proceso de comprobación/refutación (3) ha superado el estándar de prueba institucionalmente establecido.

4. La decisión o fijación de los hechos (probados) admite reconstruirse en tres niveles. En cada uno de ellos hay conceptos que depurar: $a$ ) el primer nivel es preparatorio. Corresponde a la construcción de una conjetura bajo la forma de un texto que atribuye conductas normativamente relevantes a uno o más sujetos, a lo que se suma la determinación de los medios de prueba a utilizar. En este nivel deben tenerse especialmente presentes los conceptos de pertinencia, relevancia, admisibilidad y carga de la prueba; $b$ ) el segundo nivel es de producción de pruebas y argumentos. Corresponde a la fase de contrastación de la conjetura con los medios de prueba y con las generalizaciones legal/culturalmente asentadas. En este nivel emergen algunos conceptos propios de la valoración de la prueba, como son los de fuerza probatoria y credibilidad, y c) el tercer nivel es de evaluación. Implica el paso institucional desde lo provisional hacia lo definitivo (los hechos), haciéndose cargo de lo que se ha generado en el proceso de demostración/refutación. En esta etapa son especialmente significativos los conceptos de estándar de prueba y de justificación (probatoria). 


\section{BIBLIOGRAFÍA CITADA}

AGÜERO, C., 2014: «¿Conforman las sentencias penales un género discursivo?», Estudios Filológicos, 53: 7-26.

Alcalá-Zamora, N., 1965: Estudios de Derecho Probatorio, Concepción: Universidad de Concepción.

Alchourrón, C., y Bulygin, E., 1991: «Los límites de la lógica y el razonamiento jurídico», en C. Alchourrón y E. Bulygin, Análisis lógico y derecho, Madrid: Centro de Estudios Constitucionales.

- 1993: Introducción a la metodología de las ciencias jurídicas y sociales (2. reimpresión), Buenos Aires: Astrea.

ALLEN, R., 2013: «Los estándares de prueba y los límites del análisis jurídicos», en C. VÁsQUEZ (ed.), Estándares de prueba y prueba científica, Madrid: Marcial Pons, 41-64.

Allen, R., y PARDO, M., 2003: «The Myth of the Law-Fact Distinction», Northwestern University Law Review, vol. 97, núm. 4.

Ambos, K., 2007: «100 años de la "teoría del delito" de Beling», Revista Electrónica de Ciencia Penal y Criminología. Disponible en bttp://criminet.ugr.es/recpc/09/recpc09-05.pdf (última visita: 29 de junio de 2016).

Anderson, T.; Schum, D., y Twining, W., 2015: Análisis de la prueba, Madrid: Marcial Pons.

ANDRÉs IBÁÑEZ, P., 1992: «Acerca de la motivación de los hechos en la sentencia penal», Doxa, 12: 257-299.

Bentham, J., 1971: Tratado de las pruebas judiciales, vol. 1, Buenos Aires: EJEA.

Berger, P., y Luckman, Th., 2006: La construcción social de la realidad (26. ${ }^{\text {a }}$ reimpresión), Buenos Aires-Madrid: Amorrortu.

CARr, N., 2015: Atrapados. Cómo las máquinas se apoderan de nuestras vidas, Bogotá: Taurus.

Celano, B., 1995: «Judicial decision and truth. Some remarks», en L. Gianformaggio y S. PAUlSON, Cognition and interpretation of law, Torino: G. Giappichelli.

Coloma, R., 2016a: «El Derecho Probatorio y su Torre de Babel. Sobre citas en revistas indexadas», Revista Derecho (Valdivia), 29 (2): 35-58.

— 2016b: «Las disciplinas jurídicas y su reinvención», Ius et Praxis, 22 (2): 253-298.

COlOMA, R., y AGÜERO, C., 2014: «Lógica, ciencia y experiencia en la valoración de la prueba», Revista Chilena de Derecho, 41 (2): 673-703.

Comanducci, P., 2009: Razonamiento Jurídico (2. ${ }^{a}$ reimpresión), México D. F.: Fontamara.

Couture, E., 2014: Fundamentos del Derecho Procesal Civil (5. ${ }^{a}$ reimpresión, 4. ${ }^{\text {a }}$ ed.), Montevideo: $\mathrm{B}$ de F.

DAmASKA, M., 2000: Las caras de la justicia y del poder del Estado, Santiago: Editorial Jurídica de Chile.

Di Robilant, E., 1968: Modelli nella filosofia del diritto, Bolonia: Il Mulino.

DuXbury, N., 1999: Random justice. On lotteries and legal decision-making, Oxford: Clarendon Press.

FERRER, J., 2005: Prueba y verdad en el derecho (2. ${ }^{\text {a }}$ ed.), Madrid: Marcial Pons.

- 2007: La valoración racional de la prueba, Madrid: Marcial Pons.

Fox, J., 1899: «Law and fact», Harvard Law Rev. (12).

GASCÓN, M., 1999: Los hechos en el Derecho. Bases argumentales de la prueba, Madrid: Marcial Pons. 
GONZÁLEZ, D., 2013: «Hechos y conceptos: sobre la relevancia de los conceptos para la prueba de los hechos», en D. GonZÁLEZ, Quaestio facti. Ensayos sobre prueba, causalidad y acción, México D. F.: Fontamara, 75-85.

HANSON, N., 1977: Patrones de descubrimiento. Investigación de las bases conceptuales de la ciencia, Madrid: Alianza.

Hart, H. L. A., 1995: El concepto de derecho, Buenos Aires: Abeledo-Perrot.

Ho, H. L., 2010: A Philosophy of Evidence Law (reimpresión), Oxford: Oxford University Press. Holmes, O. W., 2012: La senda del Derecho, Madrid: Marcial Pons.

JAKOBS, G., 2008: El derecho penal como disciplina científica (1. ${ }^{a}$ ed.), Navarra: Civitas.

Kahneman, D., 2012: Pensar rápido, pensar despacio (1. ed.), Buenos Aires: Debate.

KanT, I., 1973: Crítica de la razón pura (t. I, 7. ea ed.), Buenos Aires: Losada.

Kelsen, H., 1997: Teoría pura del derecho (9. ${ }^{a}$ ed., trad. R. Vernengo), México: Porrúa.

KoYré, A., 1994: «Del mundo del "aproximadamente” al universo de la precisión», en A. KoYRÉ, Pensar la ciencia, Barcelona: Paidós, 117-145.

LAUdAn, L., 2013: Verdad, error y proceso penal, Madrid: Marcial Pons.

— 2005: «Por qué un estándar de prueba subjetivo y ambiguo no es un estándar», Doxa, 28: 95-113.

MACCormick, N., 2007: «La argumentación silogística: una defensa matizada», Doxa, 30: 321 334.

Mosterín, J., 2008: Lo mejor posible. Racionalidad y acción bumana, Madrid: Alianza Editorial.

— 2013: «Modelos simples de un mundo complejo»», en J. MOSTERín, Ciencia, filosofía y racionalidad, Barcelona: Gedisa.

PARK, R., y SAKS, M., 2006: «Evidence Scholarship Reconsidered: Results of the Interdisciplinary Turn», Boston College Law Review (47): 949-1031.

PePper, S., 1942: World hypotheses (reimpresión), Berkeley: University of California Press.

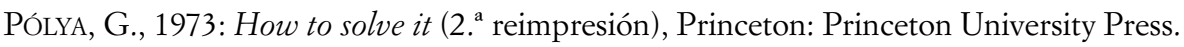

Posner, R., 2011: Cómo deciden los jueces, Madrid: Marcial Pons.

Schauer, F., 2013: Pensar como un abogado, Madrid: Marcial Pons.

Schum, D., 1986: «Probability and the Processes of Discovery, Proof, and Choice», Boston University Law Review (66).

TARufFo, M., 2006: «Poderes probatorios de las partes y del juez en Europa», Doxa (29): 249271.

- 2008: «¿Verdad negociada?», Revista de Derecho (Valdivia) (XXI), 1: 129-151.

TORRETTI, R., 2010: «La objetividad —en el sentido de Kant—», Estudios Filosóficos, 2007 2009, Santiago: Universidad Diego Portales, 15-32.

- 2012: Inventar para entender, Santiago: Universidad Diego Portales.

Twining, W., 1990: «The Rationalist Tradition of Evidence Scholarship», en W. TwINING, Rethinking Evidence, Evanston: Northwestern University Press.

- 1994: «Some scepticism about some scepticisms», en W. TwINING, Rethinking Evidence, Evanston: Northwestern University Press.

- 1997: «Pericles and the plumber», en W. Twining, Law in context, Oxford: Clarendon Press.

— 2007: «Argumentation, stories and generalizations: a comment», Law, Probability E Risk, vol. 6, Issue 1-4: 169-185.

VARGA, C., 1995: Theory of the judicial process. The establishment of facts, Budapest: Académiai Kiadó. 
VÁZQUeZ, C., 2015: De la prueba cientifica a la prueba pericial, Madrid: Marcial Pons.

Whitman, J., 2008: The origins of reasonable doubt. Theological roots of the criminal trial, New Haven \& London: Yale University Press.

WitTGENSTEIn, L., 2000: Sobre la certeza (2. reimpresión), Barcelona: Gedisa.

- 2004: Investigaciones Filosóficas (3. ${ }^{\mathrm{a}}$ ed.), Barcelona: Crítica.

WRÓBLEWSKI, J., 1974: «Legal syllogism and rationality of judicial decision», Rechtstheorie, 4: $33-46$.

- 1989: «Ideología de la aplicación judicial del Derecho», en J. WRóBLEWSKI, Sentido y hecho en el derecho, San Sebastián: Universidad del País Vasco, 67-84. 


\title{
NORMAS DE COMPETENCIA Y NORMAS ACERCA DE LA COMPETENCIA. ELUDIENDO LAS REGLAS CONSTITUTIVAS*
}

\author{
María Beatriz Arriagada Cáceres *** \\ Universidad Diego Portales \\ mbeatriz.arriagada@gmail.com
}

\begin{abstract}
RESUMEN. El objetivo de este trabajo es mostrar que para ofrecer una adecuada explicación de las normas jurídicas de competencia no es necesario ni conveniente considerar que ellas son reglas constitutivas. En la primera y segunda parte del texto se analizan críticamente dos diversas estrategias que los teóricos del derecho han usado para explicar estas normas en función de la noción de regla constitutiva poniendo de relieve por qué ninguna de ellas es adecuada. En la tercera parte del texto, se introducen las bases de una explicación que, al prescindir de la noción de regla constitutiva, es más apropiada para elucidar las normas jurídicas de competencia y para distinguirlas de las normas que regulan el ejercicio de la competencia que denomino normas jurídicas acerca de la competencia.
\end{abstract}

Palabras clave: normas de competencia, normas regulativas, reglas constitutivas.

\section{Norms of Competence and Norms about Competence. Escaping from the Constitutive Rules}

ABSTRACT. The aim of this article is to show that, in order to provide an adequate explanation of the legal competence norms, it is neither necessary nor convenient to consider that they are constitutive rules. In the first and second part of the text, two different strategies that law theorists have used to explain these norms in terms of the notion of constitutive rule are critically analyzed, highlighting why none of them are adequate. The third part of the text introduces the basis for an explanation which, by dispensing with the notion of constitutive rule, is more appropriate to elucidate the legal norms of competence and to distinguish them from the norms regulating the exercise of competence which I call legal norms about competence.

Keywords: competence norms, regulative norms, constitutive rules.

* Fecha de recepción: 19 de enero de 2017. Fecha de aceptación: 10 de marzo de 2017.

Este trabajo corresponde a resultados del proyecto financiado por el Fondo Nacional de Desarrollo Científico y Tecnológico, FONDECYT de iniciación núm. 11150372 «Análisis de la tensión entre el concepto y el fundamento de los derechos fundamentales a partir de las ideas de Fernando Atria sobre las diferencias entre los derechos civiles y políticos y los derechos sociales».

$* *$ Doctora en derecho por la Universidad de Chile. Profesora e investigadora de la Facultad de Derecho de la Universidad Diego Portales, Santiago Chile. Investigadora del Centro de Investigaciones de Filosofía del Derecho y Derecho Penal, Escuela de Derecho, Universidad de Valparaíso, Chile. 


\section{INTRODUCCIÓN}

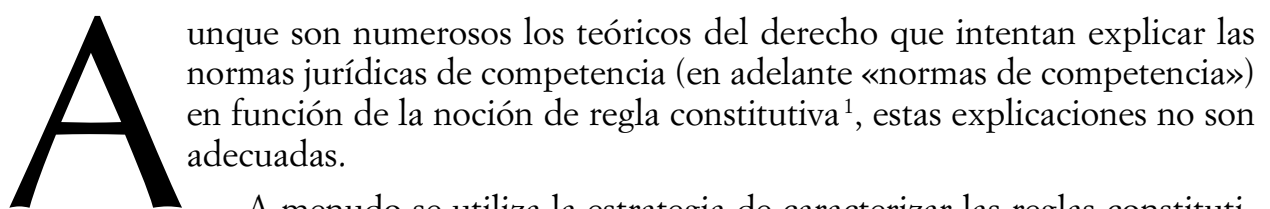

A menudo se utiliza la estrategia de caracterizar las reglas constitutivas por oposición a las reglas regulativas para luego afirmar que las normas de competencia son una especie de las primeras. Esta estrategia, seguida por autores como ROSS, HART, ALCHOURRÓN y BULYGIN, presenta el problema de que no logra superar la controversia sobre cuál es el criterio correcto para distinguir las reglas constitutivas de las regulativas; concretamente, si la diferencia reside en el modo en que las reglas se relacionan con las acciones o actividades a que se refieren o en las acciones o actividades referidas por las reglas. Por otra parte, aunque estos autores diferencian claramente las normas de competencia de las normas que regulan el ejercicio de la competencia, ninguno consigue ofrecer una explicación sistemática de las normas de competencia.

El esfuerzo más sistemático dirigido a explicar las normas de competencia en función de la noción de regla constitutiva utiliza una estrategia diferente. En lugar de caracterizar las reglas constitutivas por oposición a las regulativas, adopta un determinado concepto de regla constitutiva para luego explicar, en función de ese concepto, las normas de competencia. Me refiero al trabajo de Jordi FERRER Las normas de competencia. Un aspecto de la dinámica jurídica ${ }^{2}$. Esta estrategia falla porque, al extender el concepto de competencia y el de normas de competencia a los actos que no son normativos en sentido estricto, amplía inapropiadamente los conceptos de validez e invalidez y, al excluir de los conceptos de competencia y de normas de competencia los límites procedimentales y sustantivos de la validez, no logra explicar claramente qué tipo de normas son las que establecen tales límites.

Las razones por las cuales estas estrategias fracasan justifican ensayar una explicación de las normas de competencia que prescinda de la noción de regla constitutiva.

Antes de comenzar, debo aclarar que, al hablar de normas o reglas ${ }^{3}$, asumo las siguientes tesis:

i) Una norma no es equivalente a las palabras que se usan para su formulación ${ }^{4}$. Se deben distinguir las normas de las disposiciones normativas en que se expresan ${ }^{5}$.

ii) Que una expresión lingüística sea la formulación de una norma y el tipo de norma que ella expresa no depende de su aspecto sino del modo en que se usan las palabras ${ }^{6}$.

${ }^{1}$ Como me interesan los esfuerzos de los teóricos del derecho por explicar las normas jurídicas de competencia en función de la noción de regla constitutiva, no analizo, o al menos no directamente, los trabajos de filósofos que, con objetivos diversos, estudian las reglas constitutivas, por ejemplo, CONTE, 1989, 1995 y 2001, CARCATERRA, 1979 y 2014 y ROVERSI, 2014, o la diferencia entre reglas constitutivas y regulativas, por ejemplo, SEARLE, 1964, 2007 (1969) y 1997 (1995), y VON Wright, 1970 (1963): $26-27$ y (1979) [1971]: 177-179.

2 FERRER, 2000.

3 Usaré los términos «regla» y «norma» como sinónimos.

${ }^{4}$ VON WRIGHT, 1970 (1963): 109.

5 GUASTINI, 2014 (2013): 77-78.

6 VON Wright, 1970 (1963): 110 y 117-119. Asumo que las normas son el resultado de cierto uso del lenguaje; AlCHOURRÓN y BuLYGIN, 1991 (1981): 122-123. Pero comparto que: i) no es plausible que una norma 
iii) El significado de una disposición y, por tanto, la norma que ella expresa depende de un acto de interpretación ${ }^{7}$ y de la práctica interpretativa ${ }^{8}$.

\section{LAS NORMAS DE COMPETENCIA COMO REGLAS CONSTITUTIVAS, DIFERENTES E IRREDUCTIBLES A LAS REGLAS REGULATIVAS: ROSS, HART, ALCHOURRÓN Y BULYGIN}

Una de las estrategias para explicar las normas de competencia en función de la noción de regla constitutiva consiste en: i) caracterizar las reglas constitutivas por oposición a las reglas regulativas, y ii) argumentar que las normas de competencia son una especie de las primeras. El objetivo de esta parte es analizar críticamente esta estrategia y explicar por qué no es adecuada.

\subsection{La propuesta de Ross}

\subsubsection{Dos criterios diversos para distinguir las reglas constitutivas de las reglas regulativas}

Aunque en su libro más conocido Ross defendió la tesis reduccionista de que las normas de competencia son normas de conducta indirectamente expresadas ${ }^{9}$, más tarde habría cambiado de opinión para afirmar que ellas son una especie de las reglas constitutivas, diferentes e irreductibles a las normas de conducta que ahora denomina regulativas.

La distinción entre tipos de reglas es presentada como una que se funda en el modo en que las reglas se relacionan con la actividad a la que se refieren. Pero este criterio parece confundirse con otro diferente: el tipo de actividad al que las reglas se refieren:

Aparcar un coche es una actividad «natural»; quiero decir con esto que es una actividad cuya ejecución es independiente lógicamente de las reglas que la gobiernan. Los coches eran aparcados antes de que existieran reglas de aparcamiento, y sería un absurdo obvio si yo dijera que no podía aparcar mi coche a causa de no haber reglas de aparcamiento en esa ciudad. En cambio, jugar al ajedrez no es una actividad «natural». Jugar al ajedrez es realizar ciertas acciones de acuerdo con las reglas del ajedrez. Las acciones del juego consisten en «movimientos» que no tienen significado ni propósito excepto el de reglas del ajedrez. Un movimiento se realiza moviendo una pieza de madera sobre un cuadrado. Que la pieza de un peón, y que su cambio de lugar sea un «movimiento» solo puede entenderse si se interpreta la acción en términos de las reglas del ajedrez ${ }^{10}$.

sea identificada con un acto lingüístico; ii) la concepción expresiva responde a la pregunta de ante qué condiciones podemos afirmar que una norma existe, pero no a la pregunta de qué tipo de entidad es una norma. Tiene por objeto el proceso de producción de normas, pero nada dice sobre la naturaleza del producto; iii) ese producto es una entidad del lenguaje (un enunciado significante), y iv) los significados (las normas) dependen de la interpretación de los enunciados; GUASTINI, 2014 (2013): 293 y ss.

7 GUASTINI, 2014 (2013): 79. La existencia de una norma depende de un acto lingüístico de formulación y de un acto lingüístico de interpretación; GUASTINI, 2014 (2013): 302.

8 Los signos solamente pueden servir de guía en la medida que exista un uso estable, una práctica; WITTGENSTEIN, 2008 (1953): parágrafos 199 y 202.

9 Ross, 2005 (1958): 58-60, 78-79, 109-114 у 205-207.

10 Ross, 2000 (1968): 68-69. 
La diferencia esencial recién descrita puede expresarse, según Ross, llamando a las reglas de aparcar regulativas y a las reglas del ajedrez constitutivas ${ }^{11}$.

En el caso de las reglas constitutivas, los dos criterios (el modo en que las reglas se relacionan con la actividad a que se refieren y el tipo de actividad referida por las reglas) son en realidad uno: como las acciones del juego son constituidas por las reglas del ajedrez, las acciones de este juego no son naturales.

Como las reglas del ajedrez definen el juego como institución y suministran las condiciones lógicamente necesarias para hacer los movimientos en que el juego consiste, no pueden, en estricto sentido, ser violadas. Su no seguimiento implica que no se está jugando ajedrez ${ }^{12}$. En este contexto, Ross afirma que los actos jurídicos como promesas, testamentos, leyes, juicios o actos administrativos no son naturales sino actos concebibles solamente como constituidos por reglas jurídicas ${ }^{13}$. Las normas que confieren competencia jurídica para realizar estos actos serían entonces una especie de las reglas constitutivas.

Aunque la distinción entre tipos de reglas aparenta ser clara, para comprobar que no lo es basta observar que Ross no precisa de qué modo las reglas regulativas se relacionan con la actividad a que ellas se refieren. Solo afirma que se refieren a actividades naturales cuya ejecución es independiente lógicamente de las reglas que las gobiernan.

La cuestión es importante porque permite dudar que el criterio para distinguirlas de las reglas constitutivas sea el modo en que se relacionan con la actividad a que se refieren. Este criterio no puede, en este caso, fundirse con el que apela al tipo de actividad al que las reglas se refieren. Si el criterio es el modo en que las reglas se relacionan con la actividad, las reglas regulativas podrían referirse tanto a actividades naturales como no naturales. Faltaría precisar de qué modo se relacionan con estas actividades: qué significa gobernar una actividad. Si el criterio es, en cambio, el tipo de actividad referida por las reglas, las reglas regulativas no podrían referirse a actividades que no son naturales.

Aunque Ross no descarta explícitamente que las reglas regulativas puedan referirse a actividades no naturales, su caracterización de estas reglas permite suponer que esta posibilidad está excluida. Esto sugiere que el criterio para distinguir reglas es el tipo de actividad al que ellas se refieren. Como consecuencia, si hubiera reglas que se refieren a conductas no naturales, tendrían que ser constitutivas. Pero esta conclusión no puede obtenerse de manera segura porque Ross está utilizando de manera confusa dos criterios diversos para trazar la distinción entre tipos de reglas.

\subsubsection{ROSS y SEARLE}

Llegados a este punto la referencia obligada es a SEARLE, no porque haya sido el responsable de que la distinción entre reglas regulativas y constitutivas se pusiera de

\footnotetext{
11 Ibid., 69.

12 Ibid., 69-70.

13 Ibid., 72.
} 
moda ${ }^{14}$, sino porque Ross afirma que, después de haber escrito sobre esta distinción, encontró la misma en John SEARLE ${ }^{15}$.

El criterio searliano para distinguir estos dos tipos de reglas es el tipo de conducta al que las reglas se refieren. Las reglas constitutivas no solamente constituyen conductas cuya existencia es lógicamente dependiente de tales reglas. También regulan las conductas por ellas constituidas:

Some rules regulate antecedently existing forms of behavior. For example, the rules of polite table behavior regulate eating, but eating exists independently of these rules. Some rules, on the other hand, do not merely regulate but create or define new forms of behavior: the rules of chess, for example, do not merely regulate an antecedently existing activity called playing chess; they, as it were, create the possibility of or define that activity. The activity of playing chess is constituted by action in accordance with these rules. Chess has no existence apart from these rules [...]. Regulative rules regulate activities whose existence is independent of the rules; constitutive rules constitute (and also regulate) forms of activity whose existence is logically dependent on the rules ${ }^{16}$.

Las reglas constitutivas: i) crean o definen nuevas formas de conducta; ii) pueden ser parafraseadas naturalmente de la forma «X cuenta como $\mathrm{Y}$ en el contexto C» (donde $Y$ es un término de especificación, no de apreciación), y iii) pueden aparecer como una verdad analítica basada en el significado de la actividad que ellas definen porque tienen un carácter casi tautológico. Estas características permiten diferenciar a las reglas constitutivas (que también regulan) de las reglas que, en cambio, son puramente regulativas ${ }^{17}$.

SEARLE no afirma que las reglas constitutivas sean, a la vez, reglas regulativas, como cree BULYGIN $^{18}$, sino que las reglas que constituyen actividades también regulan esas actividades. El problema es, como afirma RAZ, que no explica de qué manera lo hacen ${ }^{19}$. SCHAUER ensaya una explicación argumentando que, si bien las instituciones son establecidas por conjuntos de reglas constitutivas, estas pierden su carácter constitutivo dentro de esas instituciones y sirven para regular conductas previamente definidas ${ }^{20}$. Al decir esto parece distinguir, como VON WRIGHT, la perspectiva del juego (los movimientos correctos) de la perspectiva de la actividad de jugarlo (los movimientos permitidos, prohibidos y obligatorios) ${ }^{21}$. Pero esto tampoco es lo que SEARLE quiere decir.

El hecho de que SEARLE no explique de qué manera las reglas constitutivas regulan la conducta que ellas mismas constituyen es un indicio de que el criterio para distinguir tipos de reglas no es el modo en que estas se relacionan con la actividad a la que se refieren sino el tipo de actividad referida por las reglas. Esto se confirma si se examina la conexión que existe entre la distinción de reglas puramente regulati-

14 Bulygin, 1991 (1988): 492.

15 Ross, 2000 (1968): 69, nota 10 de ese trabajo. La referencia es a SEARLE, 1964.

16 Searle, 1964: 55. Lo destacado es mío. Vid. también SEArLe, 2007 (1969): 43.

17 SEARLE, 2007 (1969): 43-45.

18 Según este autor, SEARLE no aclara cómo es posible que las reglas constitutivas sean, por un lado, definiciones o enunciados analíticos basados en el significado de los términos así definidos y, por el otro, reglas regulativas de las actividades por ellas definidas; BULYGIN, 1991 (1988): 492.

19 RAZ, 1991 (1975): 127.

20 SCHAUER, 2004 (1991): 63.

21 Von Wright, 1970 (1963): 26. 
vas y constitutivas y la de hechos brutos e institucionales. Los hechos brutos, como conducir un automóvil, son aquellos cuya existencia no depende lógicamente de la existencia de ninguna regla aunque pueden ser regulados por reglas regulativas como la que ordena conducir por el lado derecho de la calzada. Necesitan del lenguaje para que podamos enunciarlos, pero su existencia no depende del lenguaje ni de ninguna otra institución. Los hechos institucionales, como el dinero, las promesas, el juego de ajedrez o una acción legislativa, solo pueden existir dentro de las instituciones humanas. Su existencia depende lógicamente de la existencia de una regla o sistema de reglas constitutivas ${ }^{22}$.

SEARLE explica de qué manera las reglas constitutivas, cuya forma lógica es «X cuenta como Y», crean hechos institucionales ${ }^{23}$. Sin embargo, como Ross, no explica qué significa que una regla regulativa regule un hecho bruto. Tampoco explica el modo en que las reglas constitutivas regulan los hechos institucionales que ellas crean. Una regla que regula la conducción (ordenando hacerlo por el lado derecho de la calzada) es regulativa porque la conducción puede existir antes de la existencia de esa regla. Las reglas del ajedrez son, en cambio, constitutivas porque no regulan una actividad previamente existente sino crean la posibilidad misma de realizarla. Lo que sea jugar ajedrez queda en parte constituido por la actuación según esas reglas y no seguirlas implica no jugar ajedrez ${ }^{24}$.

El evidente descuido del aspecto regulativo de las reglas constitutivas y del modo en que las reglas regulativas se relacionan con los hechos brutos admite ser interpretado como una opción por un criterio para distinguir entre reglas regulativas y constitutivas: el tipo de actividad o hecho al que las reglas se refieren.

Si la distinción de Ross es, como cree, la misma que la de SEARLE, tendríamos que concluir que, de acuerdo con Ross, las reglas regulativas solamente pueden referirse a actividades naturales (hechos brutos) y que, en consecuencia, toda regla que se refiere a una actividad no natural (hecho institucional) es constitutiva ${ }^{25}$.

La cuestión es importante para las normas de competencia si estas son, como sugiere Ross, constitutivas en el mismo sentido de SEARLE. Si toda regla que se refiere a

22 SEARLE, 1964: 54-58; 2007 (1969): 43, 58-61, y 1997 (1995): 44-47.

23 La creación de estos hechos consiste en asignar a algunos fenómenos o entidades (X) un nuevo estatus (Y) y con él una función o un conjunto de funciones cuyo cumplimiento no depende de los rasgos intrínsecos del fenómeno sino de nuestro acuerdo o aceptación. Crear una función de estatus consiste en conferir un poder nuevo o ejecutar alguna operación veritativo-funcional sobre la creación de un poder. Como en la base de la estructura jerárquica de los hechos institucionales siempre hay hechos brutos, en el primer desplazamiento el término $\mathrm{Y}$ impone a X un estatus que va más allá de sus propiedades físicas. El paso siguiente impone funciones de estatus a entidades a las que ya se había impuesto una función, especialmente actos de habla. Luego estos se usan para imponer funciones de estatus a entidades que no son actos de habla, por ejemplo, a la gente; SEARLE, 1997 (1995): 58-65, 67-68, 72, 83-89, 94-96, 98, 108 y 116.

24 Ibid., 45. Esto parece confirmar que la distinción de SEARLE entre hechos brutos e institucionales es ontológica, como afirma GUASTINI, 1984: 306.

${ }_{25}$ Podría argumentarse que, aunque Ross distingue, como SEARLE, las actividades naturales de las instituciones, no sugiere que las actividades institucionales sean ontológicamente distintas de las naturales. Son simplemente acciones a las cuales las reglas constitutivas confieren significado; GUASTINI, 1984: 308 . Pero el hecho de que Ross omita decir el modo en que las reglas regulativas se refieren a las actividades naturales, permite seguir afirmando que Ross está usando dos criterios diferentes para distinguir a las reglas constitutivas de las regulativas. 
un acto jurídico (no natural o institucional) es constitutiva, el carácter constitutivo de las normas de competencia se deriva del tipo de acto al que ellas se refieren. Si las reglas constitutivas también regulan las actividades que constituyen, como afirma SEARLE, la constitución de tales actividades admite ser vista como un mero paso intermedio en el trayecto dirigido a su regulación. ¿Qué tan diferente es esto a decir que las normas de competencia son normas de conducta indirectamente expresadas? ¿Es plausible que Ross no haya cambiado realmente de opinión?

\subsection{3. ¿Las normas de competencia como reglas constitutivas?}

La interpretación de las normas de competencia como normas de conducta indirectamente expresadas es posible, según Ross, si las normas de competencia tienen como efecto la anulabilidad o la responsabilidad. Lo primero significa que los tribunales deben aplicar solo las reglas de conducta creadas de acuerdo con las condiciones establecidas en las normas de competencia descartando, como nulas, las que no ha cumplido dichas condiciones. Lo segundo significa que los tribunales deben ordenar sanciones contra el responsable por el exceso en la competencia ${ }^{26}$. La interpretación de las normas de competencia como normas diferentes e irreductibles a las normas de conducta supone, en cambio, que ellas son distinguibles por la diversa consecuencia que se sigue de su respectiva observancia e inobservancia: invalidez y responsabilidad. Precisamente porque el criterio para distinguirlas es el modo en que se relacionan con los actos a que se refieren, las normas de conducta también pueden referirse a actos jurídicos:

Las reglas de competencia definen cuáles son las condiciones necesarias para crear una nueva norma legal. Si un intento de legislación no satisface estas condiciones, se dice que el resultado es inválido o nulo. Un conjunto de reglas de competencia constituye una unidad que puede dividirse usualmente en tres partes: (1) reglas que determinan la competencia personal, indicando qué personas están calificadas para participar en el proceso creador de nuevas leyes; (2) reglas que determinan la competencia de procedimiento, pues definen el procedimiento a seguir; y (3) reglas que determinan la competencia de materia, indicando aquellos asuntos de los que puede ocuparse el directivo en cuestión ${ }^{27}$.

Es importante comprender esta distinción entre la norma de competencia y la norma de conducta que regula el ejercicio de tal competencia. Mientras que exceder la norma de competencia produce invalidez, violar la norma de conducta no afecta a la validez del acto jurídico, sino que encierra una responsabilidad, como cualquier otra violación de una obligación ${ }^{28}$.

Además de distinguir la competencia de su regulación mediante normas que imponen deberes, Ross afirma que las normas de competencia definen las condiciones necesarias y suficientes para crear nuevas normas ${ }^{29}$. Su propuesta tiene dos virtudes: i) diferencia tres tipos de normas de competencia (personal, procedimental y material), y ii) distingue claramente estas normas de las normas que regulan el ejercicio de la competencia.

\footnotetext{
26 Ross, 2005 (1958): 78.

27 Ross, 2000 (1968): 124.

28 Ibid., 168-169.

29 Ross 1991b (1961): 77; 1991c (1969): 43, y 1991d (1972): 111.
} 
El reconocimiento de que las normas regulativas pueden referirse a actos jurídicos que producen normas muestra que las normas de competencia rossianas no son constitutivas en el sentido de SEARLE. La pregunta es entonces si pueden considerarse constitutivas en el sentido de Ross. Este cree que sí porque, a su parecer: i) los enunciados en los que se ejercita la competencia se llaman actos jurídicos y un acto jurídico es, como un movimiento de ajedrez, un acto humano que nadie puede realizar como ejercicio de sus facultades naturales, y ii) las normas de competencia son, como las reglas de los juegos, constitutivas ${ }^{30}$. Sin embargo, hay dos razones que desaconsejan la consideración de las normas de competencia como una especie de las reglas constitutivas en la explicación de Ross.

La primera es que esta consideración nos devuelve al problema inicial: Ross utiliza de manera confusa dos criterios diversos para distinguir entre reglas regulativas y constitutivas. Como consecuencia, su afirmación de que las reglas regulativas se refieren a actividades naturales cuya ejecución es lógicamente independiente de las reglas que las gobiernan, conduce a la conclusión inconsistente de que las normas de conducta que regulan el ejercicio de la competencia no son regulativas sino constitutivas.

La segunda razón es que la explicación rossiana parece ignorar que las normas de competencia son diferentes a las reglas constitutivas de los juegos por lo que aquellas tienen en común con las normas jurídicas regulativas.

Ross compara las reglas constitutivas de los juegos con las que llama cuasi-mandatos. La forma en que define e ilustra a estas últimas (reglas legales que son directivos heterónomos como la prohibición de homicidio) es indicativa de que está pensando en normas jurídicas regulativas. A su parecer, ambas reglas son semejantes porque son impersonales, esto es, no derivan su autoridad de ninguna persona sino de un sistema de normas. La diferencia reside en que mientras los cuasi-mandatos son heterónomos, esto es, impuestos al individuo con independencia de su aceptación o reconocimiento, las reglas constitutivas de los juegos son autónomo-heterónomas ${ }^{31}$. La pregunta pertinente es si esta característica de las reglas de los juegos está presente en las normas de competencia.

Ross parece creer que sí desde el momento en que afirma que: i) algunas reglas legales constituyen actos jurídicos del mismo modo en que un movimiento de ajedrez es constituido por las reglas del ajedrez ${ }^{32}$, y ii) los directivos impersonales y heterónomo-autónomos no solamente incluyen las reglas de los juegos sino también otras regulaciones semejantes fundadas en el acuerdo recíproco ${ }^{33}$. Pero para responder a la pregunta planteada se debe prestar atención a la razón por la cual las reglas de los juegos se consideran autónomo-heterónomas. Son autónomas porque se cumplen por un sentimiento espontáneo o voluntario de obligación que se deriva de la aceptación recíproca de los jugadores y son heterónomas porque, una vez acordadas, los jugadores no pueden modificarlas unilateralmente ${ }^{34}$.

\footnotetext{
30 Ross, 2000 (1968): 168.

31 Ibid., 62-68.

32 Ibid., 72.

33 Ibid., 68.

34 Ibid., 64, 70-71.
} 
Esto sugiere que Ross, a diferencia de SEARLE, apunta en la misma dirección de VON WRIGHT: una vez que se está jugando, los movimientos incorrectos se entienden como prohibidos y cuando existe un único movimiento correcto, este se entiende como obligatorio $^{35}$. Las reglas de los juegos tendrían entonces una dimensión regulativa que depende de que se quiera jugar el juego ${ }^{36}$. Sin embargo, no puede decirse lo mismo de las normas de competencia. Aunque estas puedan considerarse autónomas en el sentido de que su dimensión regulativa o la «obligación» de someterse a ellas solamente surge cuando alguien quiere producir una norma válida, ellas no pueden, en general, modificarse por acuerdo. Podrían modificarse por el acuerdo de las autoridades que las han emitido, pero lo mismo podría decirse de las reglas jurídicas regulativas.

El hecho de que Ross no advierta que las reglas constitutivas del ajedrez son diferentes a las normas de competencia por lo que estas tienen en común con las reglas jurídicas regulativas sumado a la comprobación de que confunde dos criterios diversos para distinguir las reglas constitutivas de las regulativas sugiere que, para ofrecer una adecuada explicación de las normas de competencia no es necesario ni conveniente considerar que son una especie de las reglas constitutivas. Antes de llegar a esta conclusión examinemos otro de los esfuerzos más conspicuos de justificar esta consideración.

\subsection{La propuesta de HART, AlChOURRón y BULYGIN}

El esfuerzo más importante por distinguir las reglas constitutivas de las regulativas en función del modo en que se relacionan con las acciones o actos a que se refieren es iniciado por HART y continuado por AlCHOURRÓN y BULYGIN. Aunque HART aparenta seguir una senda como la aquí sugerida (prescindir de la noción de regla constitutiva para explicar las normas de competencia), su propuesta, como lo confirman sus continuadores, implica la tesis de que las normas de competencia son reglas constitutivas o, en sus términos, definiciones.

\subsubsection{La propuesta de HART}

HART distingue las reglas que imponen deberes de las reglas que confieren poderes en función del modo en que ellas se relacionan con las acciones o actos a que se refieren. Mientras las primeras exigen que las personas actúen de determinados modos, las segundas definen la manera de realizar válidamente ciertos actos ${ }^{37}$.

35 VON WRIGHT, 1970 (1963): 26. Tengo, en cambio, bastantes dudas de si VON WRIGHT compartiría la idea rossiana de que las reglas de los juegos son autónomas en el sentido de que surgen de la aceptación de los jugadores.

36 Por eso se parecen a las reglas técnicas, GonZÁlez LAGIER, 2001: 51-52. No es claro, sin embargo, que VON WRIGHT haya mantenido que las reglas definitorias o constitutivas tienen una dimensión (o pueden ser vistas desde una perspectiva) regulativa. Posteriormente se refirió a la distinción entre normas regulativas y constitutivas en términos de reglas primarias y secundarias sin hacer referencia al punto de vista que autoriza a ver las acciones que integran la práctica social definida por reglas constitutivas como prohibidas, obligatorias o permitidas, VON WRIGHT, 1979 (1971): 177-179.

37 HART, 2009 (1961): 34-35. 
Esta diferencia se manifiesta en la diversa consecuencia que se sigue de su respectiva inobservancia: sanción y nulidad. Cuando se trata de reglas que imponen deberes, es posible distinguir claramente la regla que obliga a determinada conducta de la sanción establecida en caso de su transgresión. Cuando se trata, en cambio, de una regla que confiere poderes, no es lógicamente posible distinguir la regla (que establece condiciones para la validez jurídica) de la nulidad; esta es parte de la regla misma de este tipo de una manera distinta a como el castigo está ligado a una norma que impone deberes $^{38}$.

Lo que HART no aclara es si la necesaria vinculación que existe entre las reglas que confieren poderes y la nulidad se puede afirmar en sentido inverso: si la nulidad está necesariamente conectada con estas reglas.

Parte del problema se origina porque HART no profundiza en el análisis de las reglas que confieren poderes ni sistematiza su clasificación. En diferentes pasajes se refiere a ellas como reglas que confieren potestades públicas o privadas a determinados sujetos $^{39}$, reglas que condicionan el ejercicio válido de potestades previamente conferidas $^{40}$ o reglas que establecen las condiciones de la validez de ciertos actos ${ }^{41}$. En otros pasajes afirma que las mismas reglas que confieren poderes definen o podrían definir el procedimiento $\mathrm{u}$ otras condiciones para su ejercicio válido ${ }^{42} \mathrm{y}$, a veces, en sentido opuesto, sostiene que los diversos aspectos de las potestades públicas y privadas (la potestad misma, el procedimiento, otras condiciones de su ejercicio y sus efectos) estarían entregados a diferentes tipos de reglas pertenecientes a una misma categoría ${ }^{43}$.

De lo que, sin embargo, no cabe duda es que el criterio para distinguir las reglas que confieren potestades de las que imponen deberes no es el tipo de acción o acto al que las reglas se refieren. El reconocimiento de que los actos cuya realización válida es definida por normas que confieren poderes pueden ser adicionalmente normados por reglas que imponen deberes ${ }^{44}$ evidencia que el criterio usado para distinguir estos tipos de reglas es el modo en que ellas se relacionan con los actos o acciones a que se refieren.

El asunto se complica cuando se introduce la distinción de reglas primarias y secundarias que es solo aparentemente coincidente con la de reglas que imponen obligaciones y reglas que confieren poderes ${ }^{45}$. Aunque HART afirma que las reglas primarias imponen deberes y las secundarias confieren potestades públicas o privadas, no parece posible dejar de notar que la regla secundaria de reconocimiento no confiere potestad alguna y que su no seguimiento no produce nulidad sino la imposibilidad de identificar las normas del sistema ${ }^{46}$. Incluso es dudoso que esta regla sea secundaria porque no se

38 Ibid., $43-44$

39 Ibid., 35, 36, 48, 99.

40 Ibid., 38 y 39 .

${ }^{41}$ Ibid., 35 y 44

42 Ibid., 40, 45, 46, 47, 51,119 y 120.

${ }^{43}$ Ibid., 36, 37 y 39 .

44 Ibid., 37.

${ }^{45}$ La distinción entre normas que imponen deberes y que confieren poderes en términos de reglas primarias y secundarias también se encuentra en RUIZ MANERO, 2005: 64-66.

46 FerRer, 2000: 79-80. En contra, Vilajosana, 2010: 104-105. 
refiere a reglas primarias sino a las secundarias al definir los criterios últimos de validez jurídica ${ }^{47}$.

Esta clasificación de las reglas en primarias y secundarias trae consigo una clasificación de las acciones o actos:

Las reglas del primer tipo se refieren a acciones que implican movimiento o cambios

físicos; las del segundo prevén actos que conducen no simplemente a movimiento o cambio

físico, sino a la creación o modificación de deberes u obligaciones ${ }^{48}$.

Como todas las acciones son indudablemente físicas, la diferencia residiría en si son puramente físicas o son, además de físicas, conducentes a la creación o modificación de deberes. El criterio para distinguirlas parece ser si su realización y las consecuencias que de ello se siguen han sido previstas o definidas por reglas secundarias. Por su parte, mientras las reglas secundarias definen algo (las condiciones y límites de la validez de ciertos actos o los criterios últimos de validez del sistema), las reglas primarias que imponen deberes exigen comportarse de cierto modo.

El criterio para diferenciar estas reglas no es el tipo acción o acto al que ellas se refieren porque las reglas primarias pueden referirse tanto a acciones puramente físicas como a actos conducentes a la creación de derechos y obligaciones ${ }^{49}$. Pero el criterio tampoco puede ser el modo en que las reglas se relacionan con las acciones o actos a que se refieren porque la regla secundaria de reconocimiento no se refiere a acciones o actos. La clave parece ser restringir el análisis a las reglas secundarias que confieren poderes excluyendo la regla de reconocimiento. Esta es justamente la estrategia de ALCHOURRÓN y BULYGIN.

\subsubsection{La propuesta de ALCHOURRÓN y BULYGIN}

ALCHOURRÓN y BulYGin distinguen claramente las normas (de conducta, regulativas o prescriptivas) de las definiciones ${ }^{50}$. Aunque ambas se asemejan porque son expresiones de un acto de voluntad, en el discurso jurídico desempeñan funciones muy diferentes ${ }^{51}$. Como las normas cumplen una función prescriptiva (guiar conductas), es esencial que sea posible cumplirlas e incumplirlas. Tienen entonces que ser sintéticas, esto es, referirse a situaciones o estados de cosas contingentes, no necesarias o imposibles. Las definiciones, en cambio, crean siempre una imposibilidad y dan lugar a enunciados necesarios o analíticos. Como no se refieren a conductas o hechos, no podrían ser obedecidas o violadas ${ }^{52}$.

Las definiciones también pueden diferenciarse de las normas usando la distinción entre nulidad y castigo que sirvió a HART para deslindar las reglas que confieren poderes de las reglas primarias de obligación. Si una definición establece los requisitos que debe reunir un acto, un documento o una norma, su ausencia determinará la nulidad

\footnotetext{
47 Vid. HART, 2009 (1961): 119 y 132 y ss., y 1980: 5 y 7.

48 HART, 2009 (1961): 101.

49 Ibid., 120.

50 AlCHOURRÓn y Bulygin, 1991 (1983): 439-441.

51 Ibid., 454-455.

52 Ibid., 457-461.
} 
de ese acto, documento o norma. Cuando, en cambio, se trata de normas que imponen obligaciones, o incluso de normas permisivas, no tiene sentido hablar de nulidad. El argumento hartiano de que la nulidad es parte de la regla secundaria mostraría que, en las reglas secundarias, o al menos en las que confieren potestades, hay un ingrediente que no se deja reducir a reglas de conducta porque pertenecen a la categoría de las reglas conceptuales o determinativas, a las definiciones ${ }^{53}$. Aquí se aprecia claramente que la regla de reconocimiento es diferente de las demás reglas secundarias porque no confiere potestades ${ }^{54}$.

$\mathrm{Al}$ argumentar que las definiciones no se refieren a conductas o hechos contingentes, estos autores parecen apuntar en la misma dirección de Ross y SEARLE: las definiciones, a diferencia de las normas, no podrían referirse a actividades naturales o hechos brutos cuya existencia es independiente de las reglas que los gobiernan. Pero ¿es plausible considerar que un acto nulo no es una conducta o que un documento nulo no es un hecho?

Aunque la forma en que lo expresan no es particularmente clara, ALCHOURRÓn y BULYGIN no distinguen las normas de conducta de las definiciones o reglas conceptuales por el tipo de actividad a que ellas se refieren sino por el modo en que se relacionan con la actividad referida. Los requisitos para que un acto o un documento sea válido son necesarios (no contingentes) en el sentido de que, al estar definidos por reglas que confieren poderes, su falta determina la imposibilidad de que ese acto o ese documento sea válido. Pero la realización del acto o la ejecución del documento es tan contingente como aparcar un automóvil.

La localización del criterio de distinción en la norma y no en la actividad referida por ella es posteriormente confirmada por BULYGIN, cuya tesis es que las normas de competencia son una especie del género de las definiciones ${ }^{55}$. Allí afirma que, pese a que autores como HART y ROSS no han extraído todas las consecuencias que se siguen de sus afirmaciones, sus análisis permiten concluir que las normas de competencia definen ciertos tipos de conducta (HART) y son reglas constitutivas (ROSS). Mientras las normas de conducta (equivalentes a las prescripciones de VON WRIGHT) son el paradigma de lo que ROSS y SEARLE llaman reglas regulativas porque regulan la conducta humana al exigir, excluir o autorizar ciertas acciones o actividades, las reglas conceptuales (equivalentes a las reglas determinativas de VON WRIGHT) son constitutivas en el sentido que ROSS y SEARLE dan a este término porque definen modelos de conducta que no existen fuera de esas reglas ${ }^{56}$.

BULYGIN prefiere decir que las reglas conceptuales, determinativas o constitutivas definen modelos de conducta que no existen fuera de esas reglas en lugar de afirmar que se refieren a conductas que no son naturales (hechos brutos). Como el foco no está en el tipo de conducta sino en la regla, nada impide decir que las reglas regulativas pueden regular conductas definidas por reglas constitutivas. De modo semejante a

53 Ibid., 461-463. (1976)

${ }^{54}$ La regla de reconocimiento es simplemente una definición, una regla conceptual, BuLYGIN, 1991

55 Bulygin, 1991 (1988).

56 Vid. BulYGin, 1991 (1988): 487-495, y VON WRIGHT, 1970 (1963): $27-27$. 
como HART distingue las acciones que implican movimiento o cambios físicos de los actos que, al ser previstos por reglas secundarias, también conducen a la creación o modificación de deberes u obligaciones» ${ }^{57}$, BULYGIN distingue los actos ordinarios de los actos jurídicos como contratos o testamentos cuya forma es definida por normas de competencia, afirmando que estos últimos pueden ser prohibidos o permitidos por normas de conducta ${ }^{58}$.

Finalmente, junto con reiterar la relación que existe entre la distinción entre reglas regulativas y constitutivas y la de proposiciones sintéticas y analíticas, BULYGIN retoma el argumento hartiano sobre la imposibilidad de asimilar la noción de nulidad a la de sanción para afirmar, dando el paso que HART no dio, que la noción de la nulidad solo tiene sentido en relación con las reglas constitutivas que definen un cierto concepto o una actividad como el juego del ajedrez ${ }^{59}$. Esto implica que entre reglas constitutivas y nulidad existe una doble relación necesaria: i) la existencia de la regla que define las condiciones para que una norma, acto o documento sean válidos depende de la nulidad porque sin esta no habría tal definición (el argumento hartiano), y ii) solo tiene sentido hablar de nulidad en relación con las reglas constitutivas que definen tales condiciones ${ }^{60}$.

$\mathrm{Al}$ decir que la noción de la nulidad solamente tiene sentido en relación con las reglas constitutivas que definen un cierto concepto o una actividad como el juego del ajedrez, BULYGIN abre un espacio para la crítica porque hay conceptos definidos por reglas que no se refieren a actividades como el juego de ajedrez sino a clases de cosas (bien mueble), clases de sujetos (menor de edad) o clases de acciones (homicidio) respecto de los cuales no tiene sentido predicar validez o invalidez ${ }^{61}$.

A esta crítica puede responderse que la referencia al ajedrez cumple el acotado papel de aclarar que la nulidad está necesariamente conectada con las reglas que definen conceptos o actividades como la producción de normas jurídicas que, en lo que importa, se asemeja al juego de ajedrez. La tesis de BuLYGIN es que las normas jurídicas de competencia no solo definen, como sugiere HART, las condiciones necesarias para producir normas jurídicas válidas, sino también las condiciones suficientes, como afirma Ross. Pero para defender esta tesis basta decir que la nulidad tiene sentido en relación con las normas que definen la producción de normas jurídicas porque los actos jurídicos normativos y sus resultados (las normas) pueden ser calificados como válidos o inválidos según esas normas, así como los movimientos del ajedrez y sus resultados pueden ser calificados como válidos o inválidos según las reglas de ese juego ${ }^{62}$.

BULYGIN apunta en la dirección correcta cuando piensa en las normas de competencia como normas que definen modelos de conducta que no existen fuera de esas

57 HART, 2009 (1961): 101.

58 BuLYGIN, 1991 (1988): 489-490.

59 Ibid., 495-496.

60 Bulygin, 1991 (1988): 496.

61 La crítica a la que me refiero toma solamente una parte de la ya formulada en contra de ALCHOURRÓN y BuLYGIN consistente en que ellos desdibujan la distinción entre las definiciones y las reglas que confieren poderes; vid., por ejemplo, AguiLó, 1990: 277-280.

62 Desde esta perspectiva, cualquier concepto puede estar conectado con la noción de nulidad si forma parte de un enunciado acerca de la producción de normas; por ejemplo «un contrato celebrado por un menor de edad sin autorización de su representante legal es nulo». 
reglas, pero no advierte que, para defender esta tesis, es necesario negar que las normas de competencia son constitutivas en el sentido que ROSS y SEARLE dan a ese término. A diferencia de BulYGIN, SEARLE distingue las reglas regulativas de las constitutivas por el tipo de actividad a que ellas se refieren y Ross confunde este criterio de distinción con el defendido por BULYGIN.

\subsection{Para concluir esta sección}

El análisis crítico de la estrategia de ROSs, HART, ALCHOURRÓn y BULYGIN muestra que ella no es adecuada para explicar las normas de competencia. El intento de hacerlo en función de la noción de regla constitutiva fracasa porque no consigue superar la discusión sobre cuál es el criterio correcto para distinguir las reglas constitutivas de las reglas regulativas.

Por otra parte, aunque estos autores distinguen claramente las normas de competencia (constitutivas) de las normas que gobiernan el ejercicio de la competencia (regulativas), ninguno de ellos realiza un análisis sistemático de las normas de competencia. El único que avanza en esta dirección es Ross al diferenciar tres diversos tipos de normas de competencia. Pero su propuesta es justamente la más problemática porque, al confundir dos criterios diversos para distinguir las reglas constitutivas de las regulativas, admite la conclusión de que las normas que regulan el ejercicio de la competencia no son regulativas sino constitutivas.

La solución de la controversia sobre el criterio correcto para distinguir a las reglas constitutivas de las reglas regulativas ha sido avanzada por GONZÁLEZ LAGIER ${ }^{63}$ al introducir la distinción gradual entre descripciones que interpretan y descripciones que no interpretan la conducta. Desde esta perspectiva: i) las descripciones naturales pueden ser no interpretativas (flexionar un dedo sobre el gatillo) o interpretativas (matar); ii) las descripciones institucionales son siempre interpretativas (cometer un homicidio, jugar al ajedrez), y iii) las descripciones en términos de movimientos corporales están siempre disponibles para cualquier conducta. Esto permitiría: i) distinguir dos tipos de conducta conforme a una regla: la que puede ser descrita de una manera interpretada exista o no la regla en cuestión y la que solamente puede ser descrita de una manera interpretada si existe la regla, y ii) reformular la distinción entre reglas regulativas y constitutivas como una distinción gradual según la cual las reglas constitutivas tienen más fuerza constitutiva que las reglas regulativas:

Una regla es regulativa cuando la conducta conforme con ella puede ser descrita como una conducta no interpretada, como una acción natural interpretada o como una acción institucional. Una regla es constitutiva cuando la conducta conforme con ella solo puede ser descrita como una conducta no interpretada o como una acción institucional ${ }^{64}$.

Aunque GONZÁLEZ LAGIER apunta en la dirección correcta, su perspectiva no sirve para explicar diferenciadamente las normas de competencia y las que regulan el ejercicio de la competencia porque tanto unas como otras serían constitutivas, además de que seguiría pendiente una explicación sistemática de las normas de competencia.

\footnotetext{
63 GonZÁlez Lagier, 1995: 259-263.

64 Ibid., 263.
} 


\section{ELUDIENDO LA DISTINCIÓN ENTRE REGLAS CONSTITUTIVAS Y REGLAS REGULATIVAS: LA PROPUESTA DE JORDI FERRER}

El esfuerzo más sistemático por explicar las normas de competencia en función de la noción de regla constitutiva ha sido desarrollado en el libro Las normas de competencia. Un aspecto de la dinámica jurídica de Jordi FERRER. Aunque la manera en que este entiende las reglas constitutivas consigue eludir la controversia sobre cuál es el criterio correcto para distinguir las reglas constitutivas de las regulativas, su estrategia tampoco es adecuada. El objetivo de esta parte es explicar por qué.

\subsection{Las normas de competencia como reglas constitutivas: eludiendo la controversia sobre el criterio para distinguir las reglas constitutivas de las regulativas}

Las normas de competencia son, según FERRER, reglas constitutivas, pero ellas no se distinguen por el tipo actividad o conducta a que se refieren ni por el modo en que se relacionan con la actividad o conducta referida. Son reglas constitutivas en el sentido de que son emitidas mediante un uso performativo u operativo del lenguaje ${ }^{65}$. Ellas no constituyen actividades o conductas sino el hecho institucional «ser competente» ${ }^{66}$.

Aunque FERRER encuadra este concepto de regla constitutiva en la tipología contiana afirmando que las normas de competencia pertenecen a la clase de las reglas noético-constitutivas ${ }^{67}$, su propuesta es principalmente deudora de una fracción muy acotada de la teoría de SEARLE.

FERRER se aparta de la interpretación de las reglas constitutivas searlianas como definiciones para utilizar, además de la idea muy general de que la creación de hechos institucionales depende de reglas constitutivas, la breve explicación que SEARLE ofrece de los casos en que estas reglas permiten la creación de hechos institucionales mediante la simple declaración de que una función de estatus $(\mathrm{Y})$ se impone a un acto de habla $(\mathrm{X})^{68}$.

El argumento de FERRER es que, como la producción de hechos institucionales depende de la existencia de reglas constitutivas y la emisión de estas depende de actos en los que se hace un uso performativo del lenguaje, se podría decir que, transitivamente, la producción de hechos institucionales (como el hecho de ser competente) depende de la realización de aquellos actos lingüísticos. Las normas de competencia son constitutivas porque constituyen al sujeto de las mismas en competente atribuyéndole la propiedad de «ser competente» para realizar un determinado acto jurídico sobre cierta materia. Como la atribución de una competencia ilimitada o inespecífica carecería de sentido, el aspecto personal de la competencia está siempre unido al aspecto material

65 FERRER, 2000: 147-148.

66 Ibid., 151.

67 Ibid., 152-154.

68 SEARLE, 1997 (1995): 51-52, 70-71 y 127-128. FERRER exagera la importancia del tema al decir que SEARLE sostiene que la producción de hechos institucionales depende, en la mayoría de los casos, de enunciados performativos, FERRER, 2000: 151. Lo que SEARLE afirma es que un gran número de hechos institucionales pueden ser creados mediante expresiones performativas. 
en una misma disposición o al menos conectado indirectamente mediante el recurso a diversas disposiciones jurídicas ${ }^{69}$.

La competencia es definida como la capacidad, atribuida por reglas de un determinado sistema, de producir actos jurídicos válidos de acuerdo con ese mismo sistema. De ello se extraería que: i) la competencia es siempre relativa a un sistema jurídico, y ii) las normas de competencia amplían las posibilidades de actuación de los sujetos poniendo a su alcance resultados institucionales que antes no podían conseguir. FERRER argumenta, siguiendo a SEARLE, que la competencia es una propiedad disposicional institucional que se distingue del mero poder porque depende de la existencia de determinadas reglas ${ }^{70}$.

Respecto del objeto de la competencia, FERRER se aparta de la tesis habitual de que las normas de competencia tienen por objeto actos normativos en sentido estricto para incluir también a los actos jurídicos que no crean ni derogan normas. Esta definición más amplia permitiría dar cuenta de algunas intuiciones básicas de los juristas. Se podría afirmar, por ejemplo, que el secretario judicial es competente para firmar las sentencias junto al juez, que la policía es competente para detener a individuos en determinadas circunstancias, que los funcionarios de las prisiones son competentes para ejecutar las condenas privativas de libertad emitidas por los jueces y que el rey es competente para sancionar y promulgar leyes ${ }^{71}$.

En cuanto a la relación entre competencia y validez, FERRER afirma que las normas de competencia no permiten identificar los actos jurídicos válidos ni las normas jurídicas válidas. De la validez de un acto o de una norma se puede derivar la competencia del sujeto que lo realizó o la dictó, pero no es correcto el paso inverso. La competencia del sujeto que realiza el acto o emite una norma es una condición necesaria pero no suficiente de la de validez de ese acto o norma. Para que esta se dé son necesarias otras condiciones que denomina «condiciones de actualización de la competencia»: observancia de las reglas procesales y el requisito de que no pertenezcan al sistema normas superiores y contradictorias con la que se pretende dictar ${ }^{72}$.

Como las normas de competencia solamente atribuyen a un sujeto la propiedad de «ser competente»: i) ellas confieren competencia para realizar todo tipo de actos jurídicos, y ii) la validez de esos actos no depende exclusivamente de la observancia de las normas de competencia. La consecuencia de i) es que las normas constitutivas de la competencia no pueden distinguirse de las normas regulativas por el tipo de acto al que se refieren. La consecuencia de ii) es que las normas constitutivas de la competencia no pueden distinguirse de las normas regulativas por el modo en se relacionan con los actos a que se refieren.

FERRER rechaza la tesis de que las normas de competencia son constitutivas en el sentido de definiciones de validez ${ }^{73}$. Se aparta del argumento hartiano de que la nuli-

69 FERRER, 2000: 124-125, 127-147 y 151.

70 Ibid., 129-135.

71 Ibid., 144.

72 Ibid., $135-143$ y 154

73 La crítica incluye a HART, Ross, Alchourrón y Bulygin, con especial énfasis en este último, cuya tesis, según FERRER, obligaría a forzar demasiado el sentido y fuerza de las normas de competencia para decir 
dad es parte de la norma de competencia para afirmar, en cambio, que la validez de una norma es una calificación externa al sistema que depende de lo previsto por el criterio de identificación del mismo que, a su vez, se remite a las normas de competencia y a las normas que condicionan su actualización ${ }^{74}$. Los sistemas jurídicos están integrados, según FERRER, por tres elementos: normas, definiciones y reglas constitutivas, aunque se podría sostener una clasificación con solo dos elementos: normas y reglas constitutivas porque, como prácticamente todas las definiciones legales son estipulativas, ellas serían una sub-categoría de las reglas constitutivas ${ }^{75}$.

Este panorama conceptual lo conduce a concluir que es posible distinguir tres tipos de normas acerca de la competencia: i) normas de competencia; ii) reglas que condicionan la actualización de la competencia, y iii) normas de conducta acerca del ejercicio de la competencia. Paralelamente, podrían distinguirse tres motivos de irregularidad de los actos jurídicos: i) haber sido realizados por un sujeto incompetente; ii) no haber seguido las reglas que indican las condiciones de actualización de la competencia, y (iii) ser un acto prohibido al menos para el sujeto que lo realizó. Los dos primeros tipos de irregularidad producen la invalidez del acto, mientras el tercero puede implicar que el sujeto deba ser sancionado ${ }^{76}$.

\subsection{Crítica al concepto de competencia}

Para demostrar que la propuesta de FERRER no es adecuada para explicar las normas de competencia, argumentaré que su concepto de competencia y, por tanto, su concepto de normas de competencia es, por un lado, demasiado amplio y, por otro lado, demasiado restringido.

\subsubsection{Demasiado amplio}

FERRER cree que las normas de competencia constituyen la competencia para realizar actos jurídicos normativos en sentido estricto, pero también actos jurídicos que no crean ni derogan normas. La supuesta ventaja de esta definición más amplia de competencia es que podría funcionar en ciertas situaciones en las que, conforme a las intuiciones básicas de los juristas, corresponde poder afirmar la competencia de los sujetos ${ }^{77}$. Pero esta definición implica una extensión del campo de aplicación del concepto de validez que no parece adecuarse a las mismas intuiciones. Un acto jurídico como conducir un automóvil realizado por un sujeto «competente» podría ser válido si cumple con las condiciones formales de actualización de la «competencia» ${ }^{78}$.

que cada una es una definición parcial del órgano competente, de la forma en que se pueden emitir normas válidas p del propio concepto de norma válida, ibid., 101-107 y 152.

74 Ibid., 137 y $155-156$.

75 La extensión de las reglas constitutivas no se agotaría en las normas de competencia debiendo también incluirse, por ejemplo, las normas derogatorias, ibid., 152 y nota 277 de ese trabajo.

76 Ibid., 157.

77 Ibid., 144.

78 Excluyo la condición sustantiva de actualización de la competencia porque, según FERRER, ella solo se aplica a la competencia para emitir normas, ibid., 138. Pero no veo inconveniente en que, desde la óptica de 
El argumento de FERRER es que la validez no solamente se predica correctamente de los actos que integran la actividad de producción y eliminación de normas válidas sino también de los que integran la actividad de aplicación de las normas válidas ${ }^{79}$. Pero este argumento pasa por alto que todos los actos que aplican normas válidas producen o integran la producción de normas válidas porque los actos jurídicos que no producen normas válidas no aplican ni integran la aplicación de normas validas; simplemente las acatan ${ }^{80}$.

La firma de las sentencias por el secretario y la sanción y promulgación de las leyes por el rey son efectivamente actos que integran la aplicación de normas válidas precisamente porque forman parte de un conjunto de actos que se dirigen a la producción de normas válidas. Pero no se puede decir lo mismo de la detención policial de individuos o la ejecución de una condena privativa de libertad que son actividades naturales o hechos brutos cuya existencia es independiente de toda regla, equivalentes a aparcar un coche o a conducir por el lado derecho de la calzada ${ }^{81}$. Su ejecución, aunque puede ser calificada por el derecho, no produce ni aplica normas jurídicas.

Es cierto que todos los actos jurídicos presuponen, como afirma FERRER, la realización de acciones naturales por parte de los sujetos ${ }^{82}$, pero allí no reside la posibilidad de diferenciar los actos naturales o físicos (como entregar dinero, conducir un automóvil, detener o poner en prisión a individuos) que pueden tener significado jurídico ${ }^{83}$ o ser interpretables en términos institucionales ${ }^{84}$ en cuanto son supuestos de hecho de normas que puramente disciplinan sus naturales efectos ${ }^{85}$ de las actos que, además, son normativos en el sentido que producen, modifican o derogan normas jurídicas válidas y, en consecuencia, aplican normas jurídicas válidas. Si la diferencia existe (como FERRER admite cuando advierte que su definición de competencia es más amplia que lo habitual), no parece posible dejar de notar que ella tiende a desdibujarse si el concepto de competencia se amplía en el sentido propuesto.

La importancia de esta diferencia dice relación con la muy diversa función que, en los discursos jurídicos, cumplen las nociones de licitud e ilicitud, por un lado, y las de validez e invalidez, por el otro. Los actos como la detención policial de individuos o la ejecución de una condena privativa de libertad pueden ser lícitos, si de acuerdo con el derecho son obligatorios o están permitidos y pueden ser ilícitos, generalmente sancionables, si de acuerdo con el derecho, se encuentran prohibidos o han sido ejecutados con infracción de las normas autorizantes ${ }^{86}$. Pero no tiene sentido afirmar que

\footnotetext{
este autor, el ejercicio de la competencia para realizar actos jurídicos no normativos pudiera estar sustantivamente limitado por normas superiores.

79 Ibid., 155. Al hacerlo apunta en la misma dirección de AGUILÓ, 1990: 280, y HART, 1982: 194 y ss.

80 Por esta razón se considera que solamente la producción y la aplicación del derecho son funciones jurídicas en un sentido más estricto y específico, KELSEN, 1991 (1960): 246.

81 Vid. Ross, 2000 (1968): 68, y SEARLE, 1997 (1995): 45.

82 FERRER, 2000: 145.

83 La acción de matar a otro puede tener el significado jurídico de «homicidio» e incluso el significado jurídico de la ejecución de una «pena de muerte», pero «matar a otro» sigue siendo una acción que puede ser realizada, descrita y comprendida sin referencia a las normas que la califican como homicidio o como pena de muerte, KELSEN, 1991 (1960): 15-16.

84 GONZÁLEZ LAGIER, 1995: 259-264.

85 FERRAJOLI, 2011 (2007): 464-465.

86 «Sancionables» por el tradicional vínculo que existe entre el concepto de ilicitud (entendido como violación de una obligación) y el concepto de sanción, KELSEN, 1991 (1960): 54, 126 y 130. «Generalmente san-
} 
son válidos o inválidos como los actos normativos en sentido estricto. El juez aplica una norma cuando dicta la que ordena la ejecución de una sentencia condenatoria, pero el funcionario que ejecuta la sentencia solamente acata la norma que le impone esa obligación ${ }^{87}$.

Un acto válido de producción de normas puede ser lícito si, siendo obligatorio, es realizado, y un acto inválido de producción de normas puede ser ilícito si, estando prohibido, es realizado. Incluso es posible, como FERRER admite, que un acto de producción de normas sea válido y prohibido (ilícito) ${ }^{88}$, como también sería posible que fuera obligatorio (lícito) e inválido. Pero un acto que no produce, modifica o deroga normas, como la ejecución una condena privativa de libertad, puede ser solamente lícito o ilícito. No puede ser válido o inválido.

Aunque de acuerdo con algunas intuiciones pueda parecer plausible afirmar que los funcionarios de las prisiones son competentes para ejecutar estas condenas, la consecuencia que se sigue es implausible, salvo que estemos dispuestos a aceptar que los juicios de validez e invalidez no están reservados para las normas y los actos que las producen aplicando otras normas y, por consiguiente, a aceptar que en el derecho no hay espacio para los juicios de mera licitud e ilicitud.

\subsubsection{Demasiado restringido}

Si la noción de validez está siempre conectada con la producción de normas, la validez y la invalidez se predican correctamente de los actos (legislativos, administrativos o judiciales) que producen normas y de las normas producidas por ellos.

Aunque en sentido estricto las condiciones formales de validez se refieren a los actos de producción de normas y las condiciones sustantivas de validez a las normas o disposiciones interpretadas ${ }^{89}$, no parece haber inconveniente en hablar siempre de validez (formal y sustantiva) de las normas que son el resultado de los actos que las producen.

Se puede convenir que las condiciones formales de la validez de una norma son tres: i) producción por el órgano competente; ii) observancia del procedimiento establecido para su producción, y iii) referencia de la norma a determinado ámbito material de regulación y no a otros. La validez sustantiva es, en cambio, una sola: el contenido de la norma no puede ser contradictorio con lo establecido en una norma superior ${ }^{90}$.

Usando un esquema parecido, FERRER descarta que las condiciones necesarias y suficientes de la validez de una norma sean definitorias de la competencia del sujeto que la ha creado. El concepto de competencia solamente incluye los aspectos personal

cionables» porque hay quienes afirman que también son ilícitos los actos puramente naturales que el derecho ha prohibido sin establecer una sanción, FERRAJOLI, 2011 (2007): 475-476.

87 KELSEN, 1991 (1960): 129-130.

${ }^{88}$ El ejemplo es tomado de HART y SPAAK y se refiere a la validez de la venta de cosas robadas, FERRER, 2000: 136.

${ }^{89} \mathrm{La}$ validez y la invalidez no pueden afirmarse, salvo de manera impropia, de disposiciones o formulaciones normativas no interpretadas ni de documentos normativos, sino exclusivamente de actos de producción (validez formal) y de normas o disposiciones interpretadas (validez sustantiva), ORUNESU, RODRíGUEZ y SUCAR, 2001: $23-24$.

90 Prieto Sanchís, 2009: 76-78. 
y material de la validez quedando excluidos (como «condiciones de actualización de la competencia»): i) el aspecto formal referido al procedimiento para producir normas, y ii) el aspecto sustantivo: el contenido de la norma creada no puede ser contradictorio con normas superiores.

Las disposiciones que regulan el procedimiento tienen, según FERRER, una cierta independencia de las normas de competencia. La razón más importante es que, si la competencia es la capacidad de producir ciertos resultados institucionales de acuerdo a las previsiones del sistema normativo, resulta irrelevante, a los efectos de determinarla, cuál sea el procedimiento que la autoridad competente debe seguir para producir el resultado (actualizar su competencia). Lo único necesario es que el sistema le ofrezca algún modo para producirlo. Así, si cambian las normas procesales, no cambian los órganos a los que se atribuye competencia ni la competencia sino únicamente las condiciones en que la competencia se puede actualizar ${ }^{91}$.

La constatación de que las reglas del procedimiento inciden en la competencia y en la validez de los actos o normas no autorizaría a concluir que las reglas procesales son definitorias de la propia competencia y hasta del órgano. Además, no todas las reglas procesales establecen condiciones de actualización de la competencia porque algunas imponen meras obligaciones cuyo incumplimiento no incide en la validez de los actos o normas dictadas ${ }^{92}$.

$\mathrm{El}$ argumento de FERRER no parece suficiente para derrotar la intuición (presente en Ross, HART, AlchourRón y Bulygin) de que la atribución de una competencia a un sujeto está condicionada al seguimiento de determinado procedimiento ${ }^{93}$. Como sugiere SEARLE, los pasos procedimentales para crear derechos y obligaciones son funciones de estatus o estatus deónticos condicionales ${ }^{94}$. Eso significa que cuando forman parte de un conjunto de actos que se dirigen a la producción de normas, se puede afirmar la competencia del sujeto que los realiza, como en el caso del secretario o del rey.

La importancia de la diferencia entre conferir una competencia y establecer las condiciones de su ejercicio no debe exagerarse hasta el punto de excluir las reglas procedimentales de la definición de competencia. Sobre todo, si para ello hay razones semejantes a las esgrimidas en favor de la conexión de los aspectos personal y material de la competencia. Basta recordar que reglas tan relevantes como las que establecen el quórum para aprobar normas son procedimentales. Si un órgano competente no las observa, los juristas estarían de acuerdo en que actuó fuera de su competencia que es igual a decir que era incompetente para hacer lo que hizo.

El concepto de competencia de FERRER es también demasiado restringido porque del mismo se excluyen los límites sustantivos de la validez de las normas.

Su primer argumento afirma que, si se concibe el principio lex superior como limitador de la competencia, un órgano sería únicamente competente para emitir normas

91 FERRER, 2000: 138 y 145.

92 Ibid., 138.

93 Incluso se sostiene que el no seguimiento de todas o algunas de las reglas de procedimiento, podría producir, antes que la invalidez de las normas creadas, la consecuencia más grave de inexistencia jurídica; GUASTINI, 1999 (1996): 320, 331-332, y 2001b: 60.

94 SEARLE, 1997 (1995): 111-115 y 121. 
que no fueran contrarias a lo dispuesto por normas superiores. Su consideración como condición de actualización de la competencia tendría, en cambio, la ventaja de ofrecer un rendimiento explicativo superior al de autores como HART, ROSS, o ALCHOURRÓN y BULYGIN porque permitiría dar cuenta de instituciones como la presunción de constitucionalidad de las leyes, la presunción de legalidad de los actos administrativos o el valor de cosa juzgada en las sentencias ${ }^{95}$.

Este argumento no es convincente porque la distinción entre validez y existencia ${ }^{96}$ permite dar perfecta cuenta de las instituciones mencionadas. Como FERRER cree, en cambio, que la validez es una calificación externa al sistema, a su juicio, el principio lex superior impide que la nueva norma se incorpore al sistema si ella no es válida ${ }^{97}$.

El segundo argumento consiste en que la exclusión del principio lex superior de la definición de la competencia tendría la ventaja de otorgar cierta estabilidad a la competencia que se atribuye a cada sujeto. Dicha competencia podría ser afectada solo por reglas constitutivas (de competencia o disposiciones derogatorias), mientras las reglas regulativas, sean acerca del ejercicio de la competencia o no, afectarían únicamente a las condiciones de actualización de la competencia ${ }^{98}$.

Este argumento incurre en la falacia de asumir implícitamente lo que pretende demostrar. FERRER asume, sin dar razones, que los límites sustantivos de la validez de las normas están establecidos en reglas regulativas, cuando esta es una conclusión que únicamente puede obtenerse a partir de la previa demostración de que tales límites no forman parte de la competencia constituida por reglas constitutivas. Por otra parte, si las normas superiores que establecen estos límites son regulativas tendría sentido pensar que, en lugar de normas que condicionan la actualización de la competencia, son normas de conducta acerca del ejercicio de la competencia cuya inobservancia implica una sanción. Pero FERRER está más bien asumiendo, nuevamente sin dar razones, que la invalidez es una consecuencia que puede seguirse de la inobservancia de normas regulativas ${ }^{99}$. El problema se origina principalmente porque nunca aclara qué entiende por reglas regulativas.

A falta de razones para excluir los límites sustantivos de la validez del concepto de competencia, hay una buena razón para defender la tesis opuesta. Si la validez formal y la validez sustantiva hacen referencia a cuestiones tan diferentes ${ }^{100}$, la común afirmación de validez jurídica en uno y otro caso no parece encontrar una mejor explicación que el hecho de que ella tiene un único y mismo sentido en el concepto de competencia cuya configuración está condicionada al cumplimiento de requisitos formales y sustantivos.

La circunstancia de que FERRER no lo advierta se deja explicar porque su definición de competencia acentúa la idea de que las normas de competencia amplían las

95 FERRER, 2000: 140.

96 GUASTINI, 2004: 254.

97 FERRER, 2000: 137-138.

98 Ibid., 138-139.

99 De hecho, FERRER afirma que una ley que vulnera lo establecido por una norma constitucional es inválida, ibid., 138-140.

${ }^{100}$ La primera solo puede afirmarse de los actos de producción de normas. La segunda solamente puede afirmarse del significado de las disposiciones normativas. 
posibilidades de actuación de los sujetos, obviando que del carácter institucional de la competencia también se extrae que las normas de competencia limitan sus posibilidades de actuación. El aspecto material de la competencia es un límite de la competencia personal porque vincula los diferentes tipos de normas a un ámbito material de regulación ${ }^{101}$. Alude a las cosas para las cuales se otorga competencia sin las cuales esta sería inconcebible seriamente ${ }^{102}$. Tanto es así que los vicios de incompetencia material pueden considerarse determinantes de un tipo invalidez o inconstitucionalidad formal ${ }^{103}$. Si este aspecto forma parte de la competencia, no parece haber razones suficientes para no decir lo mismo de los límites sustantivos de la validez y de las reglas procesales.

FERRER no ofrece buenas razones para concluir que las normas procedimentales y sustantivas cuya inobservancia determina la invalidez de los actos realizados por sujetos competentes no son normas de competencia sino normas que condicionan su actualización. Pero el problema más grave es que no aclara qué tipo de normas son. Esto permite discutir la consistencia de sus tesis sobre las reglas constitutivas y la validez jurídica.

Entre las razones de menor importancia que justificarían la independencia de las reglas de procedimiento respecto de las normas de competencia, FERRER menciona su heterogeneidad y las distintas consecuencias que se atribuirían al no seguimiento de cada uno de los tipos que existen pudiéndose al menos postular la existencia de reglas procesales constitutivas y reglas procesales que establecen obligaciones ${ }^{104}$. Si entiendo bien, estas últimas no podrían ser normas que condicionan la actualización de la competencia sino normas de conducta acerca del ejercicio de la competencia que, en consecuencia, no incidirían en la validez. Por su parte, las reglas procesales constitutivas condicionarían la actualización de la competencia, pero FERRER no aclara en qué sentido serían constitutivas. Esto es importante porque si no constituyen la competencia del sujeto para producir actos válidos, habría que admitir que son definiciones parciales de validez internas al sistema, lo que contradice los conceptos de regla constitutiva y validez jurídica defendidos por FERRER. Decir que ciertas reglas procesales condicionan la actualización de la competencia no es diferente a decir que, para que el ejercicio de la competencia sea válido, es necesario seguir cierto procedimiento. ¿Acaso esto no es una definición parcial e interna de validez?

Respecto de las normas superiores contrarias a la que se pretende dictar, FERRER tampoco es claro. Su argumento para considerar al principio lex superior como condición de actualización de la competencia asume, como hemos visto, que tales normas superiores son reglas regulativas y que de su inobservancia puede seguirse la invalidez. Como no ofrece razones que justifiquen estas asunciones pues no aclara qué entiende por reglas regulativas, hay dos opciones que parecen más plausibles para explicar estas normas superiores: i) son normas de conducta acerca del ejercicio de la competencia, en cuyo caso no inciden en la validez, y ii) son definiciones parciales e internas de

101 PRIETO SANCHÍs, 2009: 77.

102 CARRIÓ, 1994: 254.

103 Vid. PRIETO SANCHís, 2009: 77, y EzQUiaga, 2001: 68.

104 La otra razón sería que la normal complejidad de los procedimientos requeriría de un buen número de disposiciones para identificarlos paso por paso, FERRER, 2000: 126 y 152 y nota 224 de ese trabajo. 
validez, lo que contradice los conceptos de regla constitutiva y de validez defendidos por FERRER.

\subsection{Para concluir esta sección}

Aunque FERRER consigue eludir la discusión sobre cuál es el criterio correcto para distinguir las reglas constitutivas de las regulativas afirmando que las normas de competencia solamente constituyen la competencia de un sujeto para realizar actos jurídicos válidos en determinada materia, su tesis presenta dos problemas.

El primer problema es que, al asumir que la competencia no se constituye únicamente para realizar actos jurídicos normativos en sentido estricto sino también actos jurídicos que no producen, modifican ni derogan normas, se amplía inapropiadamente el campo de aplicación de los conceptos de validez e invalidez.

La supuesta ventaja de esta definición más amplia de competencia es que podría funcionar en algunas situaciones en que, conforme a las intuiciones básicas de los juristas, corresponde poder decir que los sujetos son competentes y la razón que justificaría estas intuiciones es que la validez no solo se predica correctamente de actos que integran la producción de normas válidas sino también de los que integran la aplicación de normas válidas. Pero FERRER se equivoca al desconocer que todos los actos jurídicos que aplican normas válidas (como la firma de las sentencias por el secretario y la sanción y promulgación de leyes por el rey) también producen normas válidas porque los actos que no las producen (como la detención policial de individuos o la ejecución de una sentencia condenatoria) tampoco aplican normas validas; simplemente las acatan. Como consecuencia, no advierte que los actos jurídicos no normativos solamente pueden ser lícitos o ilícitos, pero nunca válidos o inválidos.

El segundo problema de la tesis de FERRER es que obliga a considerar que las normas procedimentales y sustantivas cuya inobservancia determina la invalidez de los actos realizados por sujetos competentes no son normas de competencia sino normas que condicionan su actualización. La consecuencia que de ello se sigue es que la competencia se considera un requisito necesario, pero no suficiente de la validez que es una definición externa al sistema. La estrategia de FERRER fracasa porque no consigue explicar qué tipo de normas son las que condicionan la actualización de la competencia. Esta falta de claridad permite considerar que ellas pueden ser normas de conducta acerca de la competencia que, en consecuencia, no inciden en la validez o reglas constitutivas en un sentido que contradice las tesis de FERRER sobre las reglas constitutivas y la validez jurídica.

\section{BASES PARA UNA EXPLICACIÓN DE LAS NORMAS DE COMPETENCIA PRESCINDIENDO DE LA NOCIÓN DE REGLA CONSTITUTIVA}

Las razones por las cuales los esfuerzos de explicar las normas de competencia en función de la noción de regla constitutiva fallan sugieren que es necesario, o al menos conveniente, abandonar esta estrategia. Pero el objetivo de mostrar que, para ofrecer 
una adecuada explicación de estas normas, no es necesario ni conveniente considerarlas una especie de las reglas constitutivas no puede cumplirse plenamente sin mostrar que es posible una estrategia diferente.

En lo que sigue, expondré las bases de lo que, en mi opinión, podría ser una mejor explicación de las normas de competencia prescindiendo de la noción de regla constitutiva.

\subsection{Distinguiendo tipos de normas}

Dejando de lado la discusión sobre la distinción entre reglas regulativas y constitutivas, me parece que el criterio correcto para distinguir las normas regulativas de las normas de competencia es el modo en que ellas se relacionan con la actividad o las acciones a que se refieren y, por consiguiente, las diferentes consecuencias que se siguen de su observancia e inobservancia ${ }^{105}$.

Aunque no todas las normas regulativas y ni siquiera todas las que obligan imponen sanciones, el clásico vínculo entre los conceptos de obligación y sanción ${ }^{106}$, nos da una pista sobre la muy diversa función que, en los órdenes jurídicos, cumplen las normas regulativas y las normas de competencia. Como afirma BOBBIO, las normas secundarias sobre la sanción se dirigen a la conservación del sistema porque impiden la disolución de las normas de primer grado (que guían o controlan el comportamiento) a través de una continua inobservancia. Las normas sobre la producción normativa se dirigen, en cambio, a la transformación del sistema porque predisponen los mecanismos para la modificación consciente y tempestiva de las normas de primer grado ${ }^{107}$.

Como no siempre hay normas de segundo grado que impidan la disolución de las de primer grado, las normas regulativas pueden definirse como aquellas que, en un sistema jurídico, califican la realización o abstención de determinadas acciones o la consecución o no consecución de determinados fines ${ }^{108}$, como consecuencia de lo cual de su respectiva observancia e inobservancia no se sigue nunca la validez e invalidez. Por su parte, las normas de competencia pueden definirse como aquellas que, en un sistema jurídico, definen las competencias o potestades para producir, modificar o derogar normas jurídicas válidas o participar en su producción, modificación o derogación, como consecuencia de lo cual de su observancia e inobservancia se sigue siempre y respectivamente la validez y la invalidez ${ }^{109}$.

105 Hay una captación de una regla que se manifiesta, de caso en caso de aplicación, en lo que llamamos «seguir la regla» y en lo que llamamos «contravenirla», WITTGENSTEIN, 2008 (1953): parágrafo 201.

106 Vid., por ejemplo, KELSEN 1991 (1960): 129-131.

107 BOBBIO, 1990: 317-318. La distinción entre normas primarias que imponen obligaciones y derechos y las normas secundarias que estipulan una sanción para el caso de incumplimiento de las primeras se encuentra también en VON WRIGHT, 2010 (1983): 22.

108 Como al decir «califican» quiero significar «ordenan o permiten» esta parte de mi definición coincide con la caracterización que VON WRIGHT hace de las prescripciones o regulaciones, salvo porque aquí se considera que el contenido de las normas no está circunscrito únicamente a acciones y actividades, pues la autoridad normativa puede prescribir la obtención o la abstención de la obtención de fines, VON WRIGHT, 1970 (1963): 26-27, 87-107. 113.

109 He trazado esta distinción en términos similares aunque no idénticos en ARRIAGADA, 2015: 110, 112 - 


\subsection{Distinguiendo tipos de actos}

Como todos los actos humanos son naturales, físicos o brutos, el criterio para distinguir tipos de actos es si su realización y las consecuencias que de su realización se siguen han sido o no definidos por normas de competencia ${ }^{110}$ :

i) Los actos físicos que no son normativos pueden ser realizados, descritos y comprendidos sin referencia a norma alguna, aunque pueden ser calificados por normas jurídicas regulativas.

ii) Los actos son, además de físicos, normativos cuando su realización y las consecuencias que de ello se siguen han sido definidos por normas de competencia, de suerte que solamente pueden ser realizados, descritos y comprendidos de acuerdo con ellas ${ }^{111}$.

Nada de esto impide que, una vez definidos, los actos normativos sean calificados por normas regulativas ${ }^{112}$. Por eso conviene hablar de normas de competencia y normas acerca de la competencia.

\subsection{Normas de competencia y normas acerca de la competencia}

Mi definición de normas de competencia implica las siguientes subtesis ${ }^{113}$ :

i) Una norma es jurídicamente «válida» cuando ha sido producida de conformidad con las normas (de competencia) que, en un sistema jurídico, definen las potestades o competencias para producirla ${ }^{114}$.

ii) La «competencia» es la posibilidad que ciertas normas de un sistema jurídico atribuyen a un sujeto de producir, modificar o derogar en las condiciones definidas por esas mismas normas, normas jurídicas válidas. Esta posibilidad incluye la de participar en dichas producción, modificación o derogación ${ }^{115}$.

110 Una distinción similar es la de «actos informales» y «actos formales» propuesta en FERRAJOLI, 2011 (2007): 464-465. El análisis que mejor da cuenta de la distinción entre tipos de acciones dependiendo de si han sido definidas o no por normas de competencia, así como de la distinción entre estas normas y las regulativas es el de HOHFELD sobre las posiciones jurídicas subjetivas, HOHFELD, 2010 (1913) y 2010 (1917). Me he referido al uso implícito que hace HOHFELD de estas distinciones en ARRIAGADA, 2016: 154-157. Una aplicación de las mismas distinciones al análisis de los derechos fundamentales puede verse en ARRIAGADA, 2015.

111 Por ejemplo, los actos que el ordenamiento jurídico prevé para el otorgamiento de un testamento o la dictación de una ley o una sentencia judicial.

112 La facultad, potestad o capacidad de producir derecho conferida a un individuo puede ser simultáneamente obligatoria, KELSEN, 1991 (1960): 132. Las potestades pueden ser reforzadas mediante deberes, HART, 2009 (1961): 37 y 120. La permisión es algo puede darse tanto respecto de actos ordinarios como respecto de actos jurídicos, Bulygin, 1991 (1988): 489. Una cosa es conferir un poder (normativo) y otra es regular el ejercicio de ese poder, ATIENZA y RUIZ MANERO, 2004: 84.

113 ARRIAGADA, 2015: 112-113.

114 La validez es un juicio según un sistema de normas, un juicio jurídico que aplica normas jurídicas a determinados hechos, Ross, 1991a (1961): 23. La validez de una norma hace referencia a su creación regular o sin vicios y depende de la conformidad con normas de jerarquía superior, ORUNESU, 2012: 119-120, y GUASTINI, 2001b: 60. Es lo que KELSEN denomina el fundamento de validez, KELSEN, 1991 (1960): 201-208.

115 La competencia no solo comprende el poder jurídico de los órganos públicos para producir normas generales o individuales, sino también la capacidad, que el orden jurídico confiere a los individuos, de participar en la producción de normas generales o individuales, KELSEN, 1991 (1960): 159-161 y 151-157. 
En principio es razonable considerar que las normas de competencia son básicamente de dos tipos. Las del primer tipo podrían denominarse «normas que confieren competencia» porque atribuyen a determinados sujetos la competencia para producir normas jurídicas válidas en determinado ámbito material de regulación. Las del segundo tipo podrían llamarse «meta-normas de competencia» pues definen las condiciones para el ejercicio de las competencias conferidas por las normas del primer tipo. Ellas incluyen tanto las normas que definen el procedimiento para su ejercicio como las que definen los límites de contenido que las normas producidas no pueden sobrepasar.

Los tipos y subtipos descritos pueden expresarse o estar implícitos en una o más disposiciones o fragmentos de disposiciones normativas. La clasificación propuesta no supone aceptar la idea de que una norma de competencia completa debe contener todos los aspectos de la competencia ${ }^{116}$ porque las normas de competencia podrían determinar exclusivamente el órgano o individuo que producirá las nuevas normas ${ }^{117}$.

Llegados a este punto, puede decirse que las normas de competencia son definiciones de validez jurídica internas al sistema y que estas definiciones son formales o sustantivas. Pero esta subdivisión y, por consiguiente, la subdivisión propuesta dentro de las normas de competencia del segundo tipo se justifica únicamente por razones didácticas.

Como KELSEN ha puesto de relieve mediante la distinción entre la «constitución en sentido formal» y la «constitución en sentido material» a la luz del objetivo de la jurisdicción constitucional, el aspecto procedimental y los límites sustantivos de la competencia (y de la validez) representan dos formas de mirar una única y misma cosa.

La constitución en sentido formal expresa una decisión de autolimitación en cuya virtud las medidas que afectan una determinada esfera de intereses solo son posibles en virtud de un acuerdo entre mayoría y minoría. Es el documento que contiene disposiciones según las cuales las normas contenidas en él no pueden ser derogadas o modificadas como simples leyes sino solo bajo condiciones más difíciles. Estas disposiciones configuran la forma de la constitución y sirven para estabilizar las normas de la constitución en sentido material que, en cambio, constituyen el fundamento y estrato superior jurídico-positivo de todo orden jurídico estatal al regular la producción de normas jurídicas generales ${ }^{118}$. Dicho de otro modo: i) las normas constitucionales no puedan ser modificadas del mismo modo que las demás normas, y ii) la conformidad con las normas constitucionales es una condición de validez de cualquier norma de suerte que una norma que pretenda modificar la constitución es inválida ${ }^{119}$.

Que la distinción es únicamente una cuestión de sentido se hace evidente cuando KELSEN explica que la jurisdicción constitucional en relación con las normas de inferior jerarquía solamente es posible cuando las normas materialmente constitucionales son también formalmente constitucionales. Esto significa que la decisión de anular una norma inconstitucional por razones de «contenido» no se fundamenta en la norma misma

116 En contra, AtienZa y Ruiz MANero, 2004: 85-86.

117 Así lo cree KELSEN al referirse a la norma superior que determina la producción de una norma inferior o de normas facultativas que son no independientes porque solamente determinan una de las condiciones a las cuales una norma independiente enlaza el acto coactivo, KELSEN, 1991 (1960): 68 y 245.

118 KeLSEN, 2009a (1929): 140-142, y 1991 (1960): 232-233.

119 GuASTINI, 2001a: 188-189 y 193. 
sino en el «hecho» de no haber sido producida por el órgano y conforme al procedimiento de reforma constitucional. La jurisdicción constitucional consiste simplemente en que una norma debe ser anulada en su validez general (para todos los casos) o particular (para un caso concreto) porque el hecho concreto de su producción se encuentra en contradicción con la norma que regula ese hecho y que por ello es una norma superior ${ }^{120}$.

Cuando las cortes constitucionales controlan la constitucionalidad de normas generales emanadas de la legislación (en abstracto o en concreto) ${ }^{121}$ o la constitucionalidad de normas particulares producidas por órganos administrativos ${ }^{122}$, solamente deben verificar que las normas que dispongan medidas que afectan a una esfera de intereses cuya regulación exige una reforma constitucional hayan sido producidas por el órgano y mediante el procedimiento para realizar esa reforma. Esto implica que la validez de una norma cuya producción ha sido, por razones sustantivas o de contenido, reservada a la competencia de determinado órgano y condicionada al seguimiento de cierto procedimiento, depende únicamente de que haya sido producida por ese órgano y conforme a ese procedimiento.

Si la validez y la competencia sustantiva se disuelven en la validez y la competencia formal, las normas de competencia son simplemente definiciones internas de validez jurídica. Por su parte, las normas que califican la realización de los actos normativos definidos por normas de competencia son normas regulativas acerca de la competencia.

\section{BIBLIOGRAFÍA CITADA}

Aguiló, J., 1990: «Sobre definiciones y normas», Doxa, 8: 273-282.

Alchourrón, C., y BuLYGin, E., 1991 (1981): «La concepción expresiva de las normas», en C. Alchourrón y E. Bulygin, Análisis lógico y derecho, Madrid: Centro de Estudios Políticos y Constitucionales, 121-153.

- 1991 (1983): «Definiciones y normas», en C. AlCHOURRÓn y E. BulYgin, Análisis lógico y derecho, Madrid: Centro de Estudios Políticos y Constitucionales, 439-463.

ARRIAGADA, M. B., 2015: «Las cortes constitucionales frente a los "derechos civiles y políticos". Una mirada desde la teoría analítica del derecho», Revista española de derecho constitucional, 105, septiembre-diciembre: $105-136$.

- 2016: «Conceptos de derecho subjetivo», Eunomía. Revista en cultura de la legalidad, 11, Universidad Carlos III de Madrid: 152-162.

Atienza, M., y Ruiz Manero, J., 2004: Las piezas del derecho, Barcelona: Ariel.

BobBio, N., 1990: Contribución a la teoría del derecho, Madrid: Debate (trad. de A. Ruiz Miguel).

BulYgin, E., 1991 (1976): «Sobre la regla de reconocimiento», en C. AlCHOURRón y E. BulYGIN, Análisis lógico y derecho, Madrid: Centro de Estudios Políticos y Constitucionales, $383-391$.

- 1991 (1988): «Sobre las normas de competencia», en C. AlCHOURRÓn y E. BulYGin, Análisis lógico y derecho, Madrid: Centro de Estudios Políticos y Constitucionales, 485-498.

120 KeLSEN, 2009b (1931): 311-314. Para una explicación de la dificultad que tendría obligar a un órgano legislativo colectivo a no dictar normas inconstitucionales, vid. KELSEN, 1991 (1960): 155-156 y 234.

121 Invalidación de una norma general con efectos generales (inconstitucionalidad) o limitados al caso concreto (inaplicabilidad), ibid., 313-314.

122 Actos del Gobierno, especialmente los decretos, KELSEN, 2009b (1931): 302. 
CARCATERRA, G., 1979: La forza costitutiva delle norme, Roma: Bulzoni.

- 2014: Le norme costitutive, Torino: Giappichelli.

CARRIÓ, G., 1994: Notas sobre derecho y lenguaje, Buenos Aires: Abeledo Perrot.

Conte, A. G., 1989: Filosofia del linguaggio normativo I, Studi 1965-1981, Torino: Giappichelli.

- 1995: Filosofia del Linguaggio Normativo II, Studi 1982-1994, Torino: Giappichelli.

- 2001: Filosofia del linguaggio normativo III, Studi 1995-2001, Torino: Giappichelli.

EzQuiaga, F. J., 2001: «Sobre inconstitucionalidad y derogación», Discusiones, 2: 65-78.

Ferrajoli, L., 2011 (2007): Principia iuris. Teoría del derecho y de la democracia, Madrid: Trota (trad. de P. Ibáñez, C. Bayón, M. Gascón, L. Prieto Sanchís y A. Ruiz Miguel).

FERRER, J., 2000: Las normas de competencia. Un aspecto de la dinámica jurídica, Madrid: Centro de Estudios Políticos y Constitucionales.

GonZÁlez LagIer, D., 1995: Acción y norma en G. H. Von Wright, Madrid: Centro de Estudios Políticos y Constitucionales.

- 2000: G. H. Von Wright y los Conceptos Básicos del Derecho, México D. F.: Fontamara.

GuAstini, R., 1984: «Teorías de las reglas constitutivas. Searle, Ross y Carcaterra», Revista de Ciencias Sociales, 25 (Alf Ross, Estudios en su homenaje): 297-315.

- 1999 (1996): Distinguiendo. Estudios de teoría y metateoría del derecho, Barcelona: Gedisa (trad. de J. FERRER).

- 2001a: Estudios de teoría constitucional, México D. F.: Fontamara.

— 2001b: «Cinco observaciones sobre validez y derogación», Discusiones, 2: 59-63.

— 2004: «Proyecto para la voz "ordenamiento jurídico" de un diccionario», Doxa, 27: 247-282 (trad. de M. Atienza y J. Ruiz MAnero).

— 2008 (2010): «Fundamentos de una teoría escéptica de la interpretación», en I. LIFANTE (ed.), Interpretación jurídica y teoría del derecho, Lima: Palestra (trad. de D. MORENO CRUZ), 147-172.

- 2014: Interpretar y argumentar, Madrid: Centro de Estudios Constitucionales (trad. de S. ÁLVAREZ).

- 2014 (2013): Otras distinciones, Bogotá: Universidad Externado de Colombia (trad. de D. DEL VeCChi, P. CABAllero y A. CALZETTA).

HART, H. L. A., 1962 (1953): «Definición y teoría en la ciencia juridical», en Derecho y moral. Contribuciones a su análisis, Buenos Aires: Depalma (trad. de G. CARRIÓ), 93-130.

- 1980: «El nuevo desafío al positivismo jurídico», Sistema, 36 (trad. de F. LAPORTA y J. R. PÁRAMO), 3-18.

- 1982: «Legal powers», en Essays on Bentham. Studies in Jurisprudence and Political Theory, New York: Oxford University Press, 194-219.

- 2009 (1961): El concepto de derecho, Buenos Aires: Abeledo Perrot (trad. de G. CARrió).

HOHFELD, W., 2010 (1913): «Some fundamental legal conceptions as applied in judicial reasoning», en W. WHEELER COOK (ed.), Fundamental legal conceptions as applied in judicial reasoning, New Heaven and London: Yale University Press, 23-64.

- 2010 (1917): «Fundamental legal conceptions as applied in judicial reasoning», en W. WHEELER COOK (ed.), Fundamental legal conceptions as applied in judicial reasoning, New Heaven and London: Yale University Press, 65-114.

Kelsen, H., 1991 (1960): Teoría pura del Derecho (2. ${ }^{a}$ ed.), México D. F.: Porrúa (trad. de R. VERNENGO).

- 2009a (1929): De la esencia y valor de la democracia, Oviedo: KRK Ediciones (trad. de J. L. REQUeJo). 
— 2009b (1931): «¿Quién debe ser el defensor de la Constitución?», en C. SCHMiTT y H. KELSEN, La polémica Schmitt/Kelsen sobre la justicia constitucional: El defensor de la Constitución versus ¿Quién debe ser el defensor de la Constitución?, Madrid: Tecnos (trad. de R. J. BRIE), 289-366.

Orunesu, C., 2012: Positivismo Jurídico y sistemas constitucionales, Madrid: Marcial Pons.

Orunesu, C.; Rodríguez, J., y Sucar, G., 2001: «Inconstitucionalidad y derogación», Discusiones, 2: 11-58.

Prieto Sanchís, L., 2009: Apuntes de Teoría del Derecho, Madrid: Trotta.

RAZ, J., 1991 (1975): Razón práctica y normas, Madrid: Centro de Estudios Constitucionales (trad. de J. RuIZ MANERO).

Ross, A., 1991a (1961): «El concepto de validez y el conflicto entre el positivismo jurídico y el derecho natural», en El concepto de validez y otros ensayos, México: Fontamara (trad. de G. CARRIÓ y O. PASCHERO), 7-29.

- 1991b (1961): «Sobre los conceptos de "Estado" y "Órganos del Estado" en Derecho Constitucional», en El concepto de validez y otros ensayos, México: Fontamara (trad. de E. VÁSQUEZ), 73-92.

- 1991c (1969): «Sobre la auto-referencia y un difícil problema de derecho constitucional», en El concepto de validez y otros ensayos, México: Fontarama (trad. de E. BulYGin y E. Garzón VALDÉs), 43-71.

- 1991d (1972): «Grandeza y decadencia de la doctrina de las expresiones realizativas», en El concepto de validez y otros ensayos, México: Fontarama (trad. de E. Bulygin y E. Garzón VALDÉs), 93-115.

- 2000 (1968): Lógica de las normas, Colmares: Granada (trad. de J. HiERro).

- 2005 (1958): Sobre el derecho y la justicia, Buenos Aires: Eudeba (trad. de G. CARRIÓ).

Roversi, C., 2014: «Conceptualizing institutions», Phenomenology and the Cognitive Sciences, 13, 1: 201-215.

RUiz MANERO, J., 2005: «Una tipología de las normas constitucionales», en J. AGUILÓ, M. ATIENZA y J. RuIZ MANERO, Fragmentos para una teoría de la constitución, Madrid: Iustel, 63-112.

SEARLE, J., 1964: «How to derive "ought" from "is”», The Philosophical Review, vol. 73, núm. 1, 43-58.

- 1997 (1995): La construcción de la realidad social, Barcelona: Paidos (trad. de A. DomènECH).

- 2007 (1969): Actos de habla. Ensayo de Filosofía del Lenguaje, Madrid: Cátedra (trad. de L. M. VALDÉs VilLanueva).

Schauer, F., 2004 (1991): Las reglas en juego, Madrid: Marcial Pons (trad. de C. Orunesu y J. RODRÍGUEZ).

Vilajosana, J., 2010: El derecho en acción. La dimensión social de las normas jurídicas, Madrid: Marcial Pons.

VON Wright, G., 1970 (1963): Norma y acción. Una investigación lógica, Madrid: Tecnos (trad. de P. García Ferrero).

- 1979 (1971): Explicación y comprensión, Madrid: Alianza.

- 2010 (1983): Normas, verdad y lógica, México D. F.: Fontarama (trad. de C. AlarCón CABRERA).

WiTTGENSTEIN, L., 2008 (1953): Investigaciones filosóficas, Barcelona: Crítica (trad. de A. GARCÍA SuÁreZ y U. MOULines). 



\title{
EL CONTROL DE LA ACTIVIDAD JUDICIAL Y LAS TEORÍAS JURÍDICAS ACTUALES*
}

\author{
Rafael Hernández Marín*** \\ Universidad de Murcia \\ rafaber@um.es
}

RESUMEN. El pensamiento jurídico actual está dominado por teorías acerca de diferentes aspectos de la actividad judicial que no permiten controlar si los jueces cumplen o no las obligaciones que el Derecho les impone. Entre dichas teorías figuran teorías acerca de cuáles son las obligaciones de los jueces, teorías acerca de la motivación de las decisiones judiciales, teorías ontológicojurídicas acerca de la naturaleza del Derecho, teorías relacionadas con la aplicación del Derecho y teorías de la interpretación del Derecho.

Palabras clave: motivación de las decisiones judiciales, aplicación del Derecho.

\section{The Control of Judicial Activity and Current Legal Theories}

ABSTRACT. Current legal thinking is dominated by theories about different aspects of judicial activity that do not allow one to control whether judges comply with the obligations imposed upon them by the law. These theories include theories about the obligations of judges, theories about the motivation of judicial decisions, ontological-legal theories about the nature of law, theories related to the application of law and theories of interpretation of law.

Keywords: motivation of judicial decisions, application of law.

* Fecha de recepción: 11 de diciembre de 2016. Fecha de aceptación: 15 de marzo de 2017.

La investigación realizada en este trabajo se inscribe en el marco del proyecto de investigación DER201674898-C2-1-R, «Conflictos de derechos, tipologías, razonamientos, decisiones», financiado por el Ministerio de Economía y Competitividad del Gobierno de España, AEI y FEDER.

** Catedrático de Filosofía del Derecho, Universidad de Murcia. 


\section{INTRODUCCIÓN}

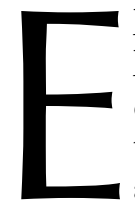

1 respeto a la legalidad es esencial en un Estado de Derecho. Y, para que la legalidad sea respetada, es necesario que los jueces cumplan las obligaciones que el Derecho les impone. Si los jueces no cumplieran sus obligaciones castigando a quienes delinquen, a quienes incumplen un contrato o causan daño a otro, la legalidad no sería respetada.

Por esta razón, es importante, desde el punto de vista teórico, saber si los jueces cumplen o no sus obligaciones. Es importante, podemos decir también, controlar a nivel teórico si en un caso determinado un juez determinado cumple o no las obligaciones que el Derecho le impone. Pero a este respecto tropezamos con la dificultad siguiente: el pensamiento jurídico actual está dominado por teorías acerca de diferentes aspectos de la actividad judicial que no permiten controlar si los jueces cumplen o no las obligaciones que el Derecho les impone. Dicho de otro modo, si esas teorías dominantes fueran verdaderas, sería imposible decir que un juez ha hecho algo mal en casos en los que parece evidente que el juez ha hecho algo mal.

Entre esas teorías relativas a diferentes aspectos de la actividad judicial figuran teorías acerca de cuáles son las obligaciones de los jueces, teorías acerca de la motivación de las decisiones judiciales, teorías ontológico-jurídicas acerca de la naturaleza del Derecho, teorías relacionadas con la aplicación del Derecho y teorías de la interpretación del Derecho.

\section{TEORÍAS ACERCA DE LAS OBLIGACIONES DE LOS JUECES}

El Derecho prevé que los jueces intervengan en asuntos diversos: procedimientos de jurisdicción voluntaria, juntas electorales, autorizaciones de registros domiciliarios o escuchas telefónicas, etc. Sin embargo, muchas de estas actuaciones podrían ser encomendadas por el Derecho a otros órganos o instancias. Lo que es consustancial a la condición de juez es su intervención en la resolución de un litigio o controversia entre dos partes que tiene lugar en un juzgado.

En un litigio dirimido en un juzgado, un juez está obligado por el Derecho a realizar esencialmente tres actividades: una actividad procesal, una actividad decisoria y una actividad justificatoria.

La actividad decisoria consiste en dictar una decisión que resuelva el litigio que ha llegado al juzgado. Es la actividad esencial del juez en un litigio. Pues la obligación fundamental de un juez es juzgar; y juzgar consiste precisamente en dictar una decisión que resuelva un litigio.

Esa decisión, según muchos ordenamientos jurídicos actuales, entre ellos el español, ha de ir acompañada de una motivación. De ahí que otras de las actividades que un juez realiza y está obligado por el Derecho a realizar en un litigio es una actividad justificatoria, justificatoria de la decisión que ha dictado para resolver el litigio, justificatoria de su actividad decisoria. 
Aunque, previamente a la actividad decisoria y a la actividad justificatoria, el juez ha de realizar una actividad procesal, integrada por diferentes actos procesales, que varían según cuál sea el tipo de proceso y el ordenamiento jurídico de que se trate. La actividad procesal del juez es estudiada por la dogmática-jurídica procesal y su análisis no es relevante para los temas de los que me voy a ocupar. Me referiré solo a la actividad decisoria y a la actividad justificatoria del juez.

Las ideas que acabo de exponer acerca de cuáles son las actividades de un juez en un litigio son pacíficas, según creo. Pero sí es discutida, aunque pueda parecer lo contrario, la siguiente observación relativa a la actividad decisoria del juez: la actividad decisoria realizada por un juez para resolver un litigio no puede consistir en dictar una decisión cualquiera. Ciertamente, dictando una decisión cualquiera, el juez cumple su obligación de juzgar. Pero el Derecho exige algo más a la actividad decisoria del juez. Exige que la decisión dictada por el juez para resolver un litigio cumpla ciertos requisitos.

No se trata de que esa decisión del juez haya de ser conforme a ciertas normas o principios morales o éticos, extra-jurídicos. Las teorías que plantean estas exigencias extra-jurídicas a las decisiones judiciales pueden ser incluidas entre esas teorías, a las que he aludido inicialmente, que no permiten controlar la actividad judicial, puesto que dichas exigencias diluyen las obligaciones que el Derecho impone a los jueces en normas o principios morales, de los cuales lo menos que se puede decir es que su contenido es impreciso.

Es el propio Derecho el que establece cómo han de ser las decisiones dictadas por los jueces para resolver los litigios. El Derecho impone ciertas exigencias a las decisiones que los jueces dicten al juzgar. De una decisión judicial que satisface o cumple esas exigencias puede decirse que es una decisión conforme al Derecho o jurídicamente correcta.

Por esta razón, sostengo que, al margen de las actividades u obligaciones procesales, el Derecho impone a los jueces tres obligaciones básicas, que son las siguientes: juzgar o decidir los litigios, decidirlos conforme al Derecho y motivar sus decisiones.

Más adelante me detendré en esa segunda obligación básica de los jueces, la de decidir los litigios conforme al Derecho. Lo que ahora deseo destacar es que, en la jurisprudencia y en obras doctrinales, esta segunda obligación de los jueces queda medio oculta bajo una capa de hojarasca terminológica, que impide visualizarla con nitidez. Allí se atribuye a los jueces la obligación de dictar decisiones basadas en el Derecho, o justificadas según el Derecho, o de justificar (basar) sus decisiones en el Derecho, o de fundamentar o motivar en el Derecho sus decisiones, etc. Es difícil saber si estas diversas locuciones, no necesariamente equivalentes entre sí, se refieren a la obligación de dictar decisiones que sean conformes al Derecho o a la obligación de motivar las decisiones judiciales o bien a una obligación híbrida entre esas dos obligaciones. En cualquier caso, el Derecho no impone a los jueces tal obligación híbrida.

Esa falta de claridad terminológica respecto a lo que yo considero que es la segunda de las obligaciones básicas de los jueces, la obligación de decidir los litigios conforme al Derecho, refleja la situación del pensamiento jurídico actual respecto a la actividad judicial. Pues tanto los procesalistas, como los constitucionalistas, así como los filósofos del Derecho, que desde hace varias décadas vienen estudiando la actividad 
judicial, e incluso los jueces cuando analizan su propia actividad, saltan de la obligación de decidir los litigios a la obligación de motivar las decisiones, pasando por alto la obligación de que las decisiones dictadas sean conformes al Derecho.

Este olvido lo observamos en C. E. AlChOURRÓn, cuando este afirma que son «principios» de una «sociedad contemporánea» los tres siguientes: $\left.1 .^{\circ}\right)$ los jueces deben decidir los casos que son sometidos a su consideración («principio de inexcusabilidad», lo llama AlCHOURRÓN; yo lo llamaría «obligación de juzgar»); $2 .^{\circ}$ ) las decisiones judiciales deben ser fundadas (principio de justificación, según ALCHOURRÓN), y $3 .^{\circ}$ ) el fundamento de las decisiones judiciales han de ser normas jurídicas (principio de legalidad, según el propio ALCHOURRÓN $)^{1}$. ALCHOURRÓN no menciona, ni como obligación de los jueces ni como principio, el decidir los casos litigiosos conforme al Derecho. Pero es esto, el decidir los casos litigiosos conforme al Derecho, y no el fundamentar las decisiones en el Derecho, lo que exige, dicho en términos convencionales, el principio de legalidad.

El mismo olvido se observa en R. ALEXY, cuando este dice que «el análisis de las decisiones jurídicas es el análisis de las fundamentaciones» ${ }^{2}$. Según esta tesis, el único aspecto importante de una decisión judicial es su motivación. Y, si se acepta esta idea, es comprensible que se afirme que la corrección de una decisión judicial depende de su motivación. Esto es lo que hace A. NIETO, al escribir que el fallo, o sea, la decisión judicial que resuelve un litigio, no es por sí mismo correcto o incorrecto. Estos calificativos solo se aplican a la argumentación, o sea, a la motivación. Una decisión judicial será correcta o incorrecta, dice NIETO, en la medida en que lo sean sus argumentos de apoyo ${ }^{3}$.

Yo no comparto las tesis que acabo de exponer, que hacen depender la corrección de una decisión judicial de la corrección de su motivación. Pienso que una decisión judicial correcta es una decisión judicial jurídicamente correcta, o sea, conforme al Derecho. Pero lo peor de esas tesis son, en mi opinión, las consecuencias que resultan cuando dichas tesis se unen a las teorías dominantes acerca de la motivación de las decisiones judiciales. Voy a exponer y comentar a continuación estas teorías.

\section{TEORÍAS DE LA MOTIVACIÓN DE LAS DECISIONES JUDICIALES}

\subsection{Concepciones de la motivación de las decisiones judiciales}

Según opinión doctrinal mayoritaria, la motivación de una decisión judicial consiste en un razonamiento justificatorio de la decisión o en una justificación racional de la decisión.

Ciertamente, en la actualidad todas o casi todas las sentencias judiciales contienen razonamientos justificatorios de las decisiones contenidas en sus fallos respectivos, ya sean razonamientos en sentido estricto, ya sean, como es lo más frecuente, conjuntos o cadenas de razonamientos. Pero sostener que toda justificación racional de una deci-

\footnotetext{
1 AlChOURRÓN, 1996: 333.

2 AleXy, 2003: 10.

3 Nieto, 2000: 273-274.
} 
sión judicial constituye una motivación tropieza con las dificultades que voy a exponer a continuación.

Supongamos que Carmen ha matado a alguien, es acusada ante un juez de homicidio y no existe duda acerca de su culpabilidad, ni concurren circunstancias eximentes, etc. Y supongamos también que el juez dicta una decisión condenatoria, que castiga a Carmen a una pena de doce años de prisión, y justifica esta decisión con el razonamiento siguiente:

[1] Los homicidas deben ser castigados con una pena de prisión de diez a quince años [primera premisa] ${ }^{4}$; Carmen es una homicida [segunda premisa]. Por tanto, Carmen debe ser castigada a doce años de prisión [conclusión].

Este razonamiento [1] es un razonamiento justificatorio de la decisión condenatoria que constituye su conclusión o una justificación racional de esa decisión. Y parece que no se puede dudar de que ese razonamiento sea una motivación de dicha decisión condenatoria. Sin embargo, la realidad es que sí pueden existir dudas al respecto. Estas dudas surgen cuando nos imaginamos la posibilidad de que, en ese mismo supuesto de la homicida Carmen, el juez hubiera dictado una decisión absolutoria y hubiera justificado su decisión alegando que Carmen tiene dos hijos de corta edad, que dependen económicamente de la madre, quien siempre ha cuidado de sus hijos, los cuales estarán mejor atendidos por la madre que por los servicios sociales y que existen numerosos preceptos jurídicos que exigen proteger a los menores de edad por encima de todo (cabría invocar el «principio del interés superior del menor»). Es decir, supongamos que, en el caso citado, el juez dicta una decisión absolutoria y justifica esta decisión mediante el razonamiento siguiente:

[2] Los menores deben ser protegidos [primera premisa]; los hijos de Carmen estarán mejor atendidos por su madre que por los servicios sociales [segunda premisa]. Por tanto, Carmen debe ser absuelta [conclusión].

Qué duda cabe de que también este segundo razonamiento es un razonamiento justificatorio de la decisión absolutoria que constituye su conclusión. Y si la motivación de una decisión judicial consiste solamente en eso, en un razonamiento justificatorio de la decisión, es innegable que también este razonamiento [2] es una motivación de la decisión absolutoria que constituye su conclusión. No es posible, pues, distinguir a este respecto entre los razonamientos [1] y [2].

Incluso si se precisara, como a veces se hace, que la motivación de una decisión judicial es un razonamiento justificatorio de la decisión, que consiste en dar las razones fácticas y jurídicas del por qué de una decisión ${ }^{5}$, también habría que decir que el razonamiento [2] es una motivación. Pues, al formular este razonamiento, el juez ha dado las razones fácticas («Los menores estarán mejor atendidos por la madre que por los servicios sociales») y jurídicas («Los menores deben ser protegidos») de su decisión absolutoria.

La cuestión que estoy ahora planteando, la de si esos dos razonamientos constituyen motivaciones, no puede ser solventada diciendo que, en el segundo ejemplo, la

\footnotetext{
4 Esta es la pena prevista para el homicidio en el Código Penal español (art. 138).

5 Cabría invocar a este respecto el inicio del art. 218.2 de la LEC («Las sentencias se motivarán expresando los razonamientos fácticos y jurídicos»).
} 
decisión absolutoria no es correcta y, por ello, ese segundo razonamiento no es una motivación. Pues si se piensa, como yo opino, que la corrección de una decisión judicial y su justificación o motivación son recíprocamente independientes, el que esa decisión sea incorrecta no implica que la justificación que la acompaña no sea una motivación. Y si se piensa, como las teorías de las que acabo de hablar, que la corrección de una decisión judicial depende de la corrección de su motivación, y aceptamos que la motivación de una decisión judicial consiste en una justificación racional de la decisión, la consecuencia sería la siguiente: el razonamiento [2], al ser una justificación racional de la decisión absolutoria que constituye su conclusión, es una motivación, o incluso una motivación correcta, de dicha decisión; y, al ser correcta esta motivación, la decisión que constituye su conclusión también es correcta.

Tampoco es posible evitar la conclusión de que el razonamiento [2] es una motivación de la decisión absolutoria que constituye su conclusión partiendo de lo que los altos Tribunales españoles entienden por «motivación».

Por ejemplo, el Tribunal Constitucional, en su Sentencia 123/1997, de 1 de julio, FJ $3 .^{\circ}$, dice que la motivación consiste en «una exteriorización del razonamiento que conduce desde los hechos probados y las correspondientes consideraciones jurídicas al fallo». Si la motivación de una decisión judicial consiste en esto, el razonamiento [2] es una motivación indudablemente. Lo mismo se puede decir si partimos de la concepción de la motivación expresada en la STC 212/2014, de 18 de diciembre, en cuyo FJ $3 .^{\circ}$ se afirma que una sentencia judicial está motivada cuando contiene «los elementos y razones de juicio que permitan conocer cuáles han sido los criterios jurídicos que fundamentan la decisión». Y tampoco la STS, de la Sala de lo Civil, 233/2013, de 25 de marzo, permite evitar la conclusión de que el razonamiento [2] constituye una motivación; pues en su FJ 4. ${ }^{\circ}$ se lee lo siguiente: «El deber de motivación de la sentencia se resume en la exigencia de una respuesta judicial fundada en Derecho, que se anude con los extremos sometidos por las partes a debate».

A mi juicio, ninguna de las concepciones o caracterizaciones examinadas acerca de lo que es la motivación de una decisión judicial resulta satisfactoria. Esencialmente porque son tan poco exigentes, incluso con frecuencia tan imprecisas, que cualquiera de ellas permite considerar como motivación de una decisión judicial casi cualquier razonamiento justificatorio de una decisión, como el razonamiento [2]. Y cuando a estas concepciones de la motivación de las decisiones judiciales se les añade la tesis de ALEXY, antes citada, conforme a la cual el análisis de las decisiones judiciales se reduce al análisis de sus motivaciones, o sea, la tesis de que lo único importante de una decisión judicial que resuelve un litigio es la motivación que la acompaña, la consecuencia es la siguiente: si la justificación de una decisión judicial dictada en un caso determinado no contiene ningún disparate, el juez habrá cumplido en ese caso todas las obligaciones que el Derecho le impone. Una consecuencia, a mi juicio, devastadora, pues anula cualquier posibilidad de controlar la actividad judicial. Por ejemplo, conforme a dichas tesis, en ese caso de la homicida Carmen del que antes hablaba, el juez que dicta una decisión absolutoria y la justifica mediante el razonamiento [2] habría cumplido todas sus obligaciones.

Mi concepción de la motivación de las decisiones judiciales parte de las reflexiones siguientes. Consideremos los razonamientos «Ayer no fui a trabajar, porque estuve 
enfermo» $\mathrm{y}$ «Date prisa, porque es tarde». De ellos cabría decir que son razonamientos justificatorios de sus conclusiones o justifican racionalmente sus conclusiones («Ayer no fui a trabajar» $\mathrm{y}$ «Date prisa», respectivamente), pero no intentan probar cosa alguna. En cambio, el razonamiento «Pienso, luego existo» y el razonamiento «Todos los hombres son mortales; Sócrates es hombre. Por tanto, Sócrates es mortal» son razonamientos justificatorios de sus respectivas conclusiones en el sentido preciso de que intentan probar que sus conclusiones respectivas son verdaderas.

Nuestros razonamientos de la vida diaria son de los dos tipos. Pero los razonamientos técnicos o científicos solo son del segundo tipo. Y creo que también la motivación de una decisión judicial tendría que ser un razonamiento de este tipo, un razonamiento que pretende probar algo. Concretamente, y dado que el Derecho obliga a los jueces a dictar decisiones que sean conformes al Derecho, la motivación de una decisión judicial es, o al menos debería ser, un razonamiento que intentara probar que la decisión es conforme al Derecho.

Si la motivación de una decisión judicial es entendida de este modo, resulta evidente la relación que existe entre la segunda de las obligaciones básicas de los jueces, la de decidir conforme al Derecho, y la tercera de esas obligaciones, la de motivar las decisiones. Pues dicha relación no consiste en que el Derecho imponga a los jueces una obligación híbrida entre ellas: la obligación de dictar decisiones basadas o justificadas en Derecho, o justificables según el Derecho, o de motivar las decisiones en Derecho, etc. Consiste en que la tercera de esas obligaciones, la obligación de motivar, es un intento de probar el cumplimiento de la segunda, un intento de probar que la decisión dictada es conforme al Derecho.

La conclusión final de un razonamiento que pretende probar que una decisión judicial es conforme al Derecho ha de ser un enunciado asertivo, o sea, un enunciado verdadero o falso, que afirma que la decisión es conforme al Derecho (del mismo modo que la conclusión final de un razonamiento que pretende probar que hay agua en Marte, o del que pretende probar que Dios existe, solo puede ser un enunciado asertivo que afirma que hay agua en Marte, o que Dios existe, respectivamente). Pero esto no ocurre en los razonamientos [1] y [2]. Ninguno de estos dos razonamientos tiene como conclusión un enunciado asertivo, que afirma que una decisión determinada es conforme al Derecho. Por ello, dichos razonamientos no pretenden probar que una determinada decisión es conforme al Derecho y no son, por tanto, motivaciones, en mi opinión, aunque sean considerados así usualmente.

En resumen, la teoría de la motivación que sostengo, que evita considerar el razonamiento [2] como una motivación, tiene también como consecuencia que tampoco el razonamiento [1] sea una motivación.

\subsection{Razonamientos integrantes de la motivación de una decisión judicial}

Otro aspecto de la motivación de las decisiones judiciales que ha suscitado multitud de teorías que dificultan el control de la actividad judicial es el de los razonamientos integrantes de la motivación. 
Este asunto ha dado lugar en las tres o cuatro últimas décadas a una temática conocida como «argumentación jurídica», «razonamiento jurídico», etc. Los términos «argumentación», «argumento», «razonamiento», «inferencia», etc., significan todos lo mismo: secuencia de enunciados, formulados con la pretensión o creencia de que uno de los enunciados de la secuencia, denominado «conclusión», es apoyado por los restantes, denominados «premisas». Pero el adjetivo «jurídico(a)» acompañando al sustantivo «razonamiento» o «argumentación» siempre me ha causado perplejidad. Los trabajos dedicados a este tema raramente afrontan directamente la cuestión de en qué se diferencian los razonamientos jurídicos de los razonamientos no jurídicos. Y los que sí se plantean este problema no lo resuelven satisfactoriamente.

Por ejemplo, en el capítulo introductorio de SCHAUER, 2013, titulado «¿Existe el razonamiento jurídico?», el autor anuncia que el objetivo de esa obra es distinguir los razonamientos jurídicos de los no jurídicos. Sin embargo, en las escasas ocasiones en las que el autor usa las palabras «premisa» o «conclusión» a lo largo del libro, nunca es para distinguir los razonamientos jurídicos de los no jurídicos, a pesar de que lo que distingue a un razonamiento de otro, o a una forma de razonamiento de otra, solo puede ser alguna diferencia relacionada con sus respectivas premisas o conclusiones. Tengo la impresión de que la mayoría de los juristas piensan que los razonamientos jurídicos son razonamientos integrado por enunciados (premisas y conclusiones) que se refieren a algún asunto jurídico ${ }^{6}$. Pero esto es como decir que los razonamientos utilizados para desvelar la composición de una sustancia son razonamientos químicos o los de un oculista, oftalmológicos.

La confusión aumenta cuando, sin haber aclarado previamente qué es un razonamiento jurídico, los autores disputan acerca de si el razonamiento jurídico es o no una especie de razonamiento moral o de razonamiento práctico, también sin haber aclarado previamente qué es un razonamiento moral o un razonamiento práctico. Mas, cualquiera que sea el sentido y solución de estas disputas, me parece que esos razonamientos jurídicos, morales, prácticos, etc., de los que se habla no son razonamientos ordinarios, es decir, razonamientos integrados exclusivamente por enunciados asertivos. No son razonamientos como «Pienso, luego existo» y «Todos los hombres son mortales; Sócrates es hombre. Por tanto, Sócrates es mortal». En cualquier caso, lo que sí parece claro es que, según las ideas dominantes en el pensamiento jurídico actual, la motivación de una decisión judicial está integrada, al menos parcialmente, por razonamientos no ordinarios.

Ello tiene la consecuencia siguiente. En el caso de los razonamientos ordinarios existen criterios, de los que voy a hablar enseguida, para decidir si un determinado razonamiento ordinario es o no válido o correcto. Pero esos criterios no existen tratándose de razonamientos no ordinarios. Respecto a los razonamientos integrados exclusivamente por enunciados prescriptivos, en casi setenta años la lógica de normas no ha

6 Así entiende los razonamientos jurídicos HernÁNDEZ GIL, 1975: 61, en el siguiente pasaje, en el que aborda expresamente el problema de la distinción entre razonamientos jurídicos y razonamientos no jurídicos: «El razonamiento jurídico es una variante del razonamiento en general y el razonamiento del abogado una modalidad o especie y, en algún sentido, una fase del razonamiento jurídico. En ambos supuestos (el del razonamiento jurídico respecto del general o de otros tipos de razonamiento y el peculiar del abogado respecto del jurídico) la variación especificativa viene determinada principalmente por la materia y la función». 
conseguido consolidar un criterio que permita determinar si esos razonamientos son o no válidos o correctos. $\mathrm{Y}$, en cuanto a los razonamientos mixtos, como el denominado «silogismo judicial», prototipo de razonamiento jurídico, o los razonamientos [1] y [2], en los que figuran enunciados asertivos y enunciados prescriptivos, ni siquiera existen intentos de hallar tales criterios ${ }^{7}$. Por ello, si un juez, en la motivación de una decisión, usa o formula uno de estos razonamientos no ordinarios carecemos de criterios, al menos a primera vista, para saber si el juez está haciendo bien o mal su trabajo, no tenemos criterios para controlar ese aspecto de la actividad judicial.

No existen tales criterios, acabo de decir, a primera vista. Pues sí existe, al menos en la legislación española, un criterio legal, que permite pronunciarse sobre todos los razonamientos integrantes de la motivación de una decisión judicial. Es el art. 218.2 de la Ley de Enjuiciamiento Civil («LEC», en adelante), que exige que los razonamientos integrantes de la motivación se ajusten siempre a las reglas de la lógica y la razón.

Las reglas de la lógica (como la regla modus ponendo ponens, la regla de eliminación de la conjunción o la de introducción del cuantificador existencial) son formas de razonamiento válidas deductivamente. Y las reglas de la razón son ante todo las reglas de la razón científica, que exigen decir o al menos buscar la verdad. Por ello, entiendo que el artículo de la LEC que acabo de citar exige que todos los razonamientos integrantes de la motivación de una decisión judicial sean, como los razonamientos científicos, razonamientos ordinarios válidos deductivamente o al menos inductivamente; es decir, exige que todos los razonamientos integrantes de la motivación de una decisión judicial sean razonamientos tales que sea imposible, o al menos improbable, que sus premisas sean verdaderas y su conclusión, falsa.

Pero, aparentemente, los altos Tribunales españoles no saben qué son las reglas de la lógica. La STC 135/2003, de 30 de junio, en su FJ 3..$^{\circ}$, razona de la manera siguiente: «resulta conforme a las reglas de la lógica concluir, a partir de la presencia de las huellas dactilares del recurrente en el lugar de los hechos, su participación en los mismos». Este razonamiento es válido, válido inductivamente. Pues siendo verdadera su premisa («Hay huellas dactilares del recurrente en el lugar de los hechos»), es muy probable que también lo sea su conclusión («El recurrente participó en los hechos»). Pero el razonamiento no es válido deductivamente, puesto que, aunque su premisa sea verdadera, su conclusión podría ser falsa. Y dado que las reglas de la lógica son formas de razonamiento válidas deductivamente, el razonamiento citado no es conforme a las reglas de la lógica. Mayor desconocimiento de lo que son estas reglas se aprecia en la STS, de la Sala de lo Civil, 888/2010, de 30 de diciembre, en cuyo FJ 2. ${ }^{\circ}$ aparece el pasaje siguiente, repetido en numerosas sentencias posteriores de la misma Sala: «La lógica a que se refiere el art. 218.2 LEC es la de la argumentación —entramado argumentativo-, exposición de razones o consideraciones en orden a justificar la decisión». Pues lo que viene a decir el Tribunal Supremo en este pasaje es que cualquier

7 La única excepción que conozco es un artículo reciente: VRANAS, 2016. En este trabajo, el autor presenta una definición de validez de los razonamientos, cualquiera que sea el tipo de discurso, asertivo o prescriptivo, de las premisas y la conclusión del razonamiento. Sin embargo, los puntos de partida de este trabajo son muy discutibles, y mucho más lo son sus conclusiones. Me limitaré a citar una de ellas. Según VRANAS, un ejemplo de razonamiento mixto válido es el siguiente, que cito textualmente: «Marry me. So: Possibly, there is a reason for you to marry me». 
argumento o razonamiento tendente a justificar una decisión judicial es conforme a las reglas de la lógica. Una tesis que, si fuera verdadera, enervaría la obligación de motivar que el Derecho impone a los jueces.

Mas, al margen de cuáles sean las opiniones de los altos Tribunales españoles acerca de las reglas de la lógica y de la razón, lo cierto es que los razonamientos [1] y [2] no respetan dichas reglas, dado que no son válidos, ni deductiva, ni inductivamente ${ }^{8}$. Por ello, infringen el precepto procesal comentado. De manera que, si dichos razonamientos fueran motivaciones, serían motivaciones ilegales.

\section{TEORÍAS ONTOLÓGICO-JURÍDICAS}

La segunda de las obligaciones básicas de los jueces es dictar decisiones que sean conformes al Derecho. Y esta observación nos conduce inevitablemente a la cuestión más antigua y difícil de la filosofía jurídica: el problema de la naturaleza del Derecho.

En mi opinión, el Derecho de un país está integrado solo por los enunciados, esto es, expresiones bien formadas y con sentido completo, que aparecen en cuerpos jurídicos, o sea, en leyes, en decretos, en la constitución, etc. Pero no es esta la opinión dominante en el pensamiento jurídico. Para exponer algunas de las teorías ontológico-jurídicas actuales y sus consecuencias, es útil comentar la STS 76/2015, de 17 de febrero.

En esta sentencia, se afirma que en «términos de estricta legalidad vigente no existe duda respecto de la decisión adoptada por la sentencia recurrida, conforme a lo dispuesto en el artículo 109 del Código Civil, artículo 53 y siguientes de la Ley de Registro Civil». No obstante, y a pesar de que la sentencia recurrida en ese procedimiento de casación se ajustaba estrictamente a la legalidad, según opinaba el propio Tribunal Supremo, este casó la sentencia «en aplicación del principio del interés superior del menor», diciéndolo brevemente; un principio que, según dicho Tribunal, «late» en toda la normativa internacional, nacional y autonómica. Mediante esta metáfora, el Tribunal Supremo expresa la tesis ontológico-jurídica de que existe un principio jurídico determinado. Pero esta tesis, por sí sola, no basta para comprender el proceder del Tribunal Supremo en esta sentencia. Pues, aceptada la existencia de tal principio, cabe preguntarse por qué el Tribunal Supremo considera evidente, tan evidente que no necesita ninguna justificación, que el elemento del Derecho que ha de ser aplicado en el litigio en cuestión es dicho principio, y no esos enunciados contenidos en el Código Civil y en la Ley de Registro Civil, que también son elementos del Derecho, y que el propio Tribunal cita en su sentencia. Cabría añadir que el Tribunal considera que los principios son superiores a las leyes. Pero esta tesis complementaria, que afirma la existencia de una determinada relación jerárquica entre los principios y las leyes, además

8 Conviene advertir respecto al razonamiento ([1] respecto al razonamiento [2], una observación similar sería ociosa), que ni siquiera sería válida ni deductiva, ni inductivamente, el razonamiento resultante de sustituir en [1] los enunciados prescriptivos que figuran en él, los enunciados «Los homicidas deben ser castigados con una pena de prisión de diez a quince años» y «Carmen debe ser castigada a doce años de prisión», por sus correspondientes enunciados asertivos (o sea, por los enunciados «Los homicidas son castigados con una pena de prisión de diez a quince años» $\mathrm{y}$ «Carmen es castigada a doce años de prisión», respectivamente). 
de gratuita, es insuficiente para entender el comportamiento del Tribunal Supremo en dicha sentencia.

Se trata de una tesis gratuita, es decir, carente de justificación, al menos en la más elaborada de las concepciones jerárquicas del Derecho, que es la de H. Kelsen. Pues KELSEN sostiene una concepción normativista del Derecho, en la que los principios no tienen sitio.

Por otra parte, aunque la afirmación «Los principios son superiores a las leyes» fuera verdadera, dicha afirmación no implica la prescripción «Los jueces han de aplicar los principios antes que las leyes»; del mismo modo que, aunque aceptemos la tesis de que las leyes son superiores a los reglamentos, esta tesis no implica la prescripción «Los jueces han de aplicar las leyes antes que los reglamentos». Si aceptamos este último enunciado, es porque lo entendemos, no como una prescripción, sino como una aserción que afirma que existe un elemento del Derecho, concretamente, un enunciado jurídico (contenido en el art. 6 de la Ley Orgánica del Poder Judicial), según el cual los jueces han de aplicar las leyes antes que los reglamentos. Por todo ello, para entender el proceder del Tribunal Supremo en esa sentencia, hay que suponer que dicho Tribunal admite la existencia de un elemento del Derecho, que no puede ser otra cosa que un principio, un principio muy particular, llamémosle «P», que exige a los jueces aplicar los principios antes que las leyes. Pero los principios en general y este principio $P$ en particular, además de ignorar lo que nos enseñaron la vida y obras de PlATÓN, crean numerosos problemas prácticos y teóricos.

Uno de esos problemas prácticos consiste en que ese principio $P$, que exige aplicar los principios antes que las leyes, sustituye el imperio de la ley por la tiranía, e incluso el despotismo, de los principios (y uso estos términos en el sentido estricto de un poder que ha sido usurpado al gobierno legítimo de las leyes, y es ejercido sin sujeción a leyes, ni control) ${ }^{9}$. Por otro lado, si esas teorías ontológico-jurídicas que admiten la existencia de principios jurídicos fueran verdaderas, algunos aspectos esenciales de la actividad judicial serían incontrolables. Pues no solo en el caso resuelto en la sentencia del Tribunal Supremo que acabo de comentar, sino también en otros muchos casos no es difícil invocar algún principio que exija algo opuesto a lo que exige claramente un enunciado jurídico. Por lo cual sería muy difícil, en todos estos casos, saber qué es lo que el Derecho exige a un juez y si su decisión es conforme al Derecho.

En cuanto a los problemas teóricos que suscitan los principios en general y ese principio $P$ en particular, son numerosos.

El fundamental de todos ellos, aunque lo dejaré a un lado, es el de la naturaleza de esos principios, de qué están hechos, puesto que solo pueden ser entidades ideales.

Una segunda cuestión, epistemológica, es la de cómo se conoce su existencia y cómo se determina su contenido, o sea, cómo saber qué es lo que exigen los principios. Los magistrados de los altos Tribunales, en especial, de los Tribunales constitucionales, parecen tener a este respecto un don especial; como el que exhibían

9 «Llamo tirano al usurpador de la autoridad real, y déspota al usurpador del poder soberano. Un tirano es aquel que se pone contra las leyes a gobernar según ellas; un déspota, el que se hace superior a las mismas leyes. Así es que un tirano puede no ser déspota, pero todo déspota siempre es tirano» (RoUSSEAU, 1979: 479). 
aquellos juristas decimonónicos, que captaban las esencias de los conceptos jurídicos, siguiendo el método elaborado, y años más tarde ridiculizado, por R. v. IHERING. La seguridad con la que dichos magistrados saben cuáles son las exigencias de un principio jurídico determinado, la rotundidad de sus afirmaciones acerca del contenido de los derechos fundamentales, y su clarividencia al contemplar los valores constitucionales son pasmosas. Pues todos esos entes jurídicos constitucionales (principios, derechos, valores) tienen limitaciones en preceptos legales o reglamentarios, que son por esta razón inconstitucionales, aunque no son impugnados por nadie ${ }^{10}$; por ello, no es fácil saber qué es lo que dichos entes reclaman. De ahí los inevitables titubeos con los que afrontan estos temas juristas especializados en las ramas del Derecho correspondientes, en contraste con la determinación con la que los altos Tribunales se pronuncian respecto a esas cuestiones. Tampoco tienen dudas los altos Tribunales acerca de lo que es «razonable» en casos en los que los enunciados jurídicos dejan a los Tribunales un ámbito de discrecionalidad; en cambio, y también en contraste con ello, un especialista en una rama cualquiera del Derecho difícilmente pontificaría acerca de cuál es la decisión razonable en casos semejantes. Llama asimismo la atención la posición de los altos Tribunales cuando diferentes entes jurídicos constitucionales (principios, derechos, valores) confluyen en un mismo litigio. Pues si estos entes empujan en el mismo sentido, los altos Tribunales dejan traslucir su satisfacción. Pero, si presionan en sentidos opuestos, dichos Tribunales se sienten obligados a imponer a esos entes un orden, una jerarquía; cosa que, al mismísimo KELSEN, el mayor teórico de la jerarquía normativa, le sería difícil admitir, dado que él pensaba que todo lo que forma parte de una constitución se halla al mismo nivel. Aunque lo que KELSEN sería absolutamente incapaz de entender, pues desborda sus esquemas mentales, es el hecho de que esas relaciones jerárquicas entre diferentes entes constitucionales pueden experimentar variaciones, bien de modo ocasional, en atención a un caso concreto, bien con cierta vocación de permanencia, debido a un cambio de jurisprudencia. KELSEN sería incapaz de asimilar la idea de una jerarquía «móvil», como a veces se dice.

Precisamente a propósito de esas relaciones jerárquicas, los principios en general y en particular ese principio $P$, que exige aplicar los principios antes que las leyes, plantean otro problema teórico, que es el siguiente: ¿qué nivel jerárquico ocupan dichos principios, en particular el principio $P$, en esa jerarquía de niveles, en la que los enunciados jurídicos constitucionales ocupan un nivel superior al de los enunciados contenidos en las leyes, estos un nivel superior al de los enunciados contenidos en decretos del gobierno, etc.?; los principios en general y el principio $P$ en particular $¿$ son superiores a las leyes?; ¿tienen el mismo rango que la Constitución o son superiores a la Constitución?; ¿es superior el principio $P$ a todos los demás principios?; ¿cuál es el criterio para decidir en general, dados dos elementos cualesquiera del Derecho (enunciados, principios, etc.), cuál de ellos es superior al otro?

10 Por ejemplo, contra el art. 19 de la Constitución, que proclama, sin ninguna limitación, el derecho de los españoles «a circular por el territorio nacional», chocan leyes y reglamentos estatales, así como ordenanzas y actos administrativos municipales, que regulan el tránsito de vehículos y la seguridad vial. Sin embargo, la colisión entre dicho precepto constitucional y, por ejemplo, la norma que ordena detenerse ante un semáforo en rojo no ha sido hasta ahora, que yo sepa, motivo de recurso o cuestión de inconstitucionalidad. 
Un último problema teórico que plantean los principios tiene que ver con la temática del Derecho y el tiempo. Si el Derecho está integrado solo por los enunciados que componen los cuerpos jurídicos, como yo opino, la cuestión de en qué fecha un enunciado que forma parte de un cuerpo jurídico se incorpora al Derecho y en qué fecha deja de pertenecer a él tiene una respuesta inicial simple: un enunciado integrante de un cuerpo jurídico se incorpora al Derecho en la fecha de su publicación y deja de pertenecer a él en la fecha de su derogación o anulación (aunque determinar cuál es la fecha de derogación o de anulación de un enunciado jurídico no es un problema sencillo). Pero si se piensa que el Derecho está integrado también por principios, es imposible saber en qué fecha se incorpora al Derecho o deja de pertenecer a él un principio, dado que los principios no tienen una fecha de publicación, ni tampoco de derogación o anulación, puesto que no son publicados, ni derogados o anulados.

\section{LA CONFORMIDAD DE LAS DECISIONES JUDICIALES AL DERECHO}

Vuelvo a repetir la tesis de que la segunda de las obligaciones básicas de los jueces es dictar decisiones que sean conformes al Derecho. En el pensamiento jurídico existen discrepancias, no solo respecto a qué es el Derecho, sino también respecto a qué es una decisión judicial conforme al Derecho.

En mi opinión, las exigencias que el Derecho impone a las decisiones judiciales son de dos clases: procesales, referentes al proceso seguido por el litigio al que la decisión pone fin, y materiales, referentes al contenido de la decisión. El cumplimiento de las primeras determina el que una decisión judicial sea procesalmente conforme al Derecho; mientras que, si cumple las segundas, la decisión será materialmente conforme al Derecho. En resumen, la conformidad de una decisión judicial al Derecho tiene dos aspectos: conformidad procesal y conformidad material.

Creo que esta noción de conformidad al Derecho es pacífica. Lo más polémico es sin duda determinar qué es una decisión judicial materialmente conforme al Derecho. Como primera aproximación, se puede decir que una decisión judicial materialmente conforme al Derecho es una decisión que tiene el contenido que según el Derecho debe tener, una decisión que tiene el contenido que el Derecho exige a las decisiones judiciales. Y lo que el Derecho exige al contenido de las decisiones judiciales es que estas, ya sean estimatorias, ya sean desestimatorias, digan el Derecho. Esta exigencia está contenida en el art. 117.3 y 117.4 de la Constitución y el art. 2 de la Ley Orgánica del Poder Judicial, que establecen que la única función de los jueces y Tribunales es la función jurisdiccional, o sea, la función de decir el Derecho, al juzgar y ejecutar lo juzgado.

Aunque es preciso observar que, según una opinión muy extendida, lo que los artículos que acaban de ser citados establecen es la identificación de la actividad jurisdiccional con la actividad de juzgar. Una identificación que tiene como consecuencia inmediata la reducción de las obligaciones básicas de los jueces a dos: juzgar o decidir litigios y motivar sus decisiones; y, como consecuencia más remota, el hacer depender la corrección de una decisión judicial de su motivación, como en las teorías comentadas en páginas anteriores. 
Simplificando la cuestión, lo que significa dejar un lado alguna matización importante, se puede decir que una decisión judicial que dicte el Derecho es una decisión que aplica el Derecho.

A mi juicio, y también ahora dejo a un lado alguna opinión discrepante, aplicar el Derecho es aplicar un elemento del Derecho (no todos los elementos del Derecho). Y si los elementos del Derechos son, como yo opino, los enunciados integrantes de los cuerpos jurídicos, aplicar el Derecho es aplicar uno de estos enunciados; aplicar el Derecho es aplicar un enunciado jurídico.

Pero esta tesis tropieza con una dificultad, que tiene que ver con el tema central de este trabajo. Son muchos los autores que consideran que las normas o enunciados generales que los jueces formulan a veces en sus sentencias son normas jurídicas o enunciados jurídicos; y, por ello, sostienen que los jueces crean Derecho. Esta es una tesis aceptable. Lo cuestionable es si los jueces pueden o deben crear Derecho. Más adelante me referiré a esta cuestión. Lo que ahora deseo destacar es que si consideramos que los enunciados generales que los jueces formulan a veces en sus sentencias son enunciados jurídicos y decimos que aplicar el Derecho es aplicar un enunciado jurídico, la consecuencia es la siguiente: aplica el Derecho una decisión judicial $D$ que aplica un enunciado general $E$ formulado por el juez en la misma sentencia que contiene esa decisión $D$. Y podría ocurrir que $D$ fuera una decisión que estimara una petición $P$ absurda o carente hasta entonces de cualquier fundamento jurídico; y que el enunciado general $E$ formulado por el juez fuera un enunciado nuevo, creado ad hoc por el juez para prestar fundamento a esa petición $P$, y para presentar la decisión $D$, estimatoria de $P$ y que aplica el nuevo enunciado $E$, como una decisión que aplica el Derecho. El resultado de ello sería que no existiría ningún criterio, independiente del propio juez que dicta esa decisión $D$, para controlar si $D$ aplica el Derecho; y además la aplicación del Derecho se convertiría en una trivialidad.

Para evitar estas consecuencias, caben dos opciones. Una es negar que los jueces creen Derecho, o sea, sostener que los enunciados generales formulados por los jueces en sus sentencias no son jurídicos. Esta opción implica que una decisión judicial que aplica un enunciado creado por los jueces no aplica un enunciado jurídico y, por tanto, no aplica el Derecho. La otra opción es aceptar que los enunciados generales creados por los jueces son enunciados jurídicos y, por tanto, que una decisión judicial que aplica uno de estos enunciados aplica un enunciado jurídico. Pero entonces habría que corregir la noción de aplicación del Derecho y exigir, como condición necesaria para que una decisión judicial aplique el Derecho, que el enunciado jurídico aplicado por la decisión sea anterior a la decisión ${ }^{11}$.

\section{LA APLICACIÓN DE LOS ENUNCIADOS JURÍDICOS}

La tesis de que aplicar el Derecho es aplicar un enunciado jurídico ha de ser matizada de alguna de las maneras que acaban de ser sugeridas, a fin de que sea posible

${ }^{11}$ En sentido parecido se pronuncia GUASTINI, 1996: 380: «Las decisiones judiciales han de ser extraídas de reglas jurídicas preexistentes». 
controlar si una decisión judicial determinada aplica el Derecho, o sea, para controlar si una decisión judicial es materialmente conforme al Derecho, y, en definitiva, si un juez determinado cumple la segunda de sus obligaciones básicas.

Pero la posibilidad de realizar ese control depende también de las teorías que se sostengan en temas relacionados con la aplicación de los enunciados jurídicos. Y a este respecto cabe señalar que el pensamiento jurídico actual está dominado por teorías que no permiten saber si una decisión judicial determinada aplica o no un enunciado jurídico determinado, ni tampoco, por tanto, si un juez determinado cumple la segunda de sus obligaciones básicas.

En mi opinión, para que una decisión judicial aplique un enunciado jurídico determinado, es necesario que se cumplan ciertas condiciones, concretamente, tres. Aunque solo me referiré a dos de esas condiciones y a las teorías jurídicas que no permiten controlar el cumplimiento de esas dos condiciones.

Para exponer mis ideas, tomaré como ejemplo de enunciado jurídico el contenido en el art. 240.1 del CP español, que dice lo siguiente: «El culpable de robo con fuerza en las cosas será castigado con la pena de prisión de uno a tres años».

\subsection{Sobre los enunciados calificativos}

Una condición necesaria, en mi opinión, para que una decisión judicial aplique el enunciado jurídico que acaba de ser citado es que se haya cometido un robo con fuerza en las cosas, esto es, que haya ocurrido un caso comprendido bajo el supuesto de hecho de ese enunciado.

También se puede expresar esta misma idea usando la noción de enunciado calificativo. Un enunciado calificativo es un enunciado que es una concreción o instancia de sustitución del supuesto de hecho de un enunciado jurídico. Por ejemplo, el enunciado «Carlos es culpable de robo con fuerza en las cosas» es un enunciado calificativo, dado que es una concreción del supuesto de hecho de ese enunciado contenido en el art. 240.1 del CP español.

Podemos expresar la condición de la que estoy hablando de la manera siguiente: para que una decisión judicial aplique un determinado enunciado jurídico $E$, es necesario que sea verdadero un enunciado calificativo que sea una concreción del supuesto de hecho de $E$. De manera que, para que una decisión judicial aplique el enunciado contenido en el art. 240.1 del CP español, es necesario que sea verdadero un enunciado calificativo, como el enunciado «Carlos es culpable de robo con fuerza en las cosas», que sea una concreción del supuesto de hecho de dicho enunciado jurídico.

Y, conforme a la teoría semántica de la verdad elaborada por A. TARSKI e incorporada desde hace décadas a la metalógica, el que un enunciado calificativo, como el enunciado «Carlos es culpable de robo con fuerza en las cosas», sea verdadero o bien sea falso no depende de lo que diga un juez.

Estas ideas son rechazadas de una u otra manera por algunas teorías jurídicas actuales. A este respeto, podemos distinguir dos grupos de teorías: por un lado, las teorías conforme a las cuales nunca sería posible saber si un enunciado determinado es o 
no un enunciado calificativo verdadero; por otro lado, las teorías que hacen depender el que un enunciado calificativo sea verdadero de que lo que diga un juez.

Entre las primeras teorías mencionadas figuran ante todo aquellas que no permiten saber cuál es el supuesto de hecho de un enunciado jurídico. Obviamente, si no sabemos cuál es el supuesto de hecho de un enunciado jurídico $E$, tampoco podemos saber si un enunciado determinado es un enunciado calificativo, que es una concreción del supuesto de hecho de $E$. Las teorías a las que estoy aludiendo ahora son aquellas que afirman que los enunciados jurídicos, todos o algunos de ellos, son derrotables.

Según una definición ofrecida por C. E. AlCHOURRón, un enunciado condicional derrotable es un enunciado condicional que tiene excepciones implícitas ${ }^{12}$. Entendida de esta manera, la derrotabilidad de los enunciados jurídicos no plantea ninguna dificultad. No hay ningún inconveniente en aceptar que el enunciado jurídico penal español que he citado, que castiga al culpable de robo con fuerza en las cosas, es derrotable porque contiene implícitamente la excepción de que no concurra ninguna de las circunstancias que eximen de la responsabilidad penal.

Pero no es así como suele ser entendida actualmente la derrotabilidad de los enunciados jurídicos. Pues la tesis que está bastante extendida en trabajos de filosofía del Derecho es la de que los enunciados jurídicos son derrotables porque contienen excepciones implícitas que no pueden ser precisadas de una vez para siempre, puesto que esas excepciones varían de un caso a otro ${ }^{13}$. Esta tesis implica que no es posible saber en abstracto cuál es o qué significa el supuesto de hecho de un enunciado jurídico $E$, ni tampoco, por tanto, si un enunciado determinado es un enunciado calificativo, que es una concreción de dicho supuesto de hecho ${ }^{14}$.

Por ejemplo, a primera vista, diríamos que el enunciado «Carlos es culpable de robo con fuerza en las cosas» es una concreción del supuesto de hecho del enunciado jurídico contenido en el art. 240.1 del CP español. Sin embargo, en el caso de que ese enunciado fuera verdadero, pero Carlos hubiera robado, vamos a suponer, para dar lo robado a los pobres, algún partidario de la derrotabilidad de los enunciados jurídicos diría quizá que el supuesto de hecho del enunciado jurídico citado contiene implícitamente la excepción de que el producto del robo no sea para hacer obras de beneficencia; por lo cual el sentido de dicho enunciado jurídico sería el siguiente: «El culpable de robo con fuerza en las cosas, sin la finalidad de hacer obras de beneficencia, será castigado con la pena de prisión de uno a tres años». En consecuencia, este partidario de la derrotabilidad diría que el enunciado «Carlos es culpable de robo con fuerza en las cosas» es verdadero, pero no es un enunciado calificativo, porque no es una concreción del supuesto de hecho del art. 240.1 del CP español (ni de ningún otro enunciado jurídico). Este autor diría entonces que, en el caso que estamos considerando, un enunciado que es una concreción del supuesto de hecho de ese enunciado jurídico y, por tanto, un enunciado calificativo es el enunciado «Carlos es culpable de robo con fuerza

12 Alchourrón, 1996: 341.

13 Según BAYÓN, 2000: 91, una norma derrotable es «una norma sujeta a excepciones implícitas que no pueden ser enumeradas exhaustivamente de antemano, de manera que no sería posible precisar por anticipado las circunstancias que operarían como genuina condición suficiente de aplicación».

14 «Si una norma jurídica es realmente derrotable, entonces no es posible derivar de ella calificaciones normativas concluyentes para casos individuales» (BAYÓN, 2000: 113, nota 50). 
en las cosas, sin la finalidad de hacer obras de beneficencia». Pero, seguiría diciendo el mismo autor, este enunciado, aunque sería un enunciado calificativo, sería falso, dado que Carlos ha robado con la finalidad de hacer obras de beneficencia.

De manera que los partidarios de la derrotabilidad de los enunciados jurídicos introducen excepciones, vamos a decirlo así, en el supuesto de hecho de los enunciados jurídicos, en atención al caso litigioso de que se trate (normalmente por razones morales, aunque vengan disfrazadas de razones jurídicas, repletas de contenido moral) y que varían, por tanto, de un caso a otro. Y la consecuencia final es que, si esas teorías de la derrotabilidad fueran verdaderas, nunca sería posible saber en un litigio cualquiera si se da o no una condición que es, en mi opinión, necesaria para que una decisión judicial aplique un enunciado jurídico $E$ : la condición de que sea verdadero un enunciado calificativo que sea una concreción del supuesto de hecho de $E$.

Tampoco permiten saber si un enunciado determinado es o no un enunciado calificativo verdadero, o sea, si ha sucedido un caso comprendido bajo el supuesto de hecho de un enunciado jurídico, las teorías o autores que afirman que los enunciados calificativos, como «Carlos es culpable de robo con fuerza en las cosas», «Manuel es un homicida», «María ha causado un daño por negligencia», etc., son enunciados valorativos. Es difícil saber qué significa la afirmación de que los enunciados calificativos son enunciados valorativos. Pero me parece que esta afirmación implica que los enunciados calificativos no son verdaderos, ni falsos. Y su consecuencia es la siguiente:

Supongamos que una decisión judicial $D$ condena a Carlos, acusado de robo con fuerza en las cosas, a una pena de un año de prisión. En mi opinión, el que esa decisión $D$ aplique o no el art. 240.1 del CP español depende de que sea verdadero el enunciado calificativo «Carlos es culpable de robo con fuerza en las cosas». Pero si este enunciado no es verdadero, es decir, si no es verdad que Carlos es culpable de robo con fuerza en las cosas, no veo cómo se podría alcanzar la conclusión de que la decisión $D$ aplica dicho enunciado jurídico. Si el enunciado calificativo «Carlos es culpable de robo con fuerza en las cosas» no es verdadero, ni tampoco falso, quizá la conclusión tendría que ser que la decisión $D$ ni aplica, ni no aplica ese precepto penal.

El segundo grupo de teorías que he mencionado antes está integrado por aquellas que pueden aceptar que los enunciados calificativos son verdaderos o falsos, pero sostienen, de un modo u otro, que el que un enunciado calificativo sea verdadero o falso, el que haya ocurrido o no un caso comprendido bajo el supuesto de hecho de un enunciado jurídico, depende de lo que diga un juez.

A este respecto pueden ser citadas dos teorías, que ilustraré con el ejemplo del citado art. 240.1 del CP español («El culpable de robo con fuerza en las cosas será castigado con la pena de prisión de uno a tres años»).

Según una de esas teorías, el supuesto de hecho de este enunciado jurídico se refiere a los que roban. Pero el que un sujeto robe o no robe depende de que lo que diga un juez. Mientras un juez no se pronuncie al respecto, por ejemplo, durante la tramitación del procedimiento judicial en el que al acusado se le imputa un robo, el acusado solo es «presunto» autor del delito. Pero, una vez que el juez se pronuncia sobre esta cuestión, el acusado ya es indiscutiblemente o culpable del delito o inocente, según cual haya sido el pronunciamiento del juez. 
Otra de las teorías a las que aludo es la sostenida por H. KELSEN y tiene que ver con la interpretación, tema del que voy a hablar a continuación. KELSEN sostiene tesis según las cuales el supuesto de hecho de ese art. 240.1 del CP español no se refiere a los que roban, sino a los que un juez considera probado, conforme a las leyes procesales, que han robado ${ }^{15}$. Conforme a dichas tesis, un enunciado calificativo que sería una concreción del supuesto de hecho del art. 240.1 del CP español no sería el enunciado «Carlos es culpable de robo con fuerza en las cosas», sino el enunciado «Un juez considera probado, conforme a las leyes procesales, que Carlos es culpable de robo con fuerza en las cosas». Naturalmente, el que este enunciado sea un enunciado verdadero depende de que haya tenido lugar un determinado pronunciamiento judicial. Por tanto, si ese enunciado fuera un enunciado calificativo, como sostiene KELSEN, el que dicho enunciado calificativo fuera verdadero o falso, el que haya ocurrido o no un caso comprendido bajo el supuesto de hecho del citado art. 240.1 del CP español, dependería de lo que dijera un juez.

\subsection{Sobre la interpretación de los enunciados jurídicos}

Voy a referirme ahora a otro de los requisitos que es necesario, en mi opinión, para que una decisión judicial aplique un enunciado jurídico.

Llamo «enunciado interpretativo» a un enunciado que atribuye sentido a un determinado enunciado jurídico $E$ o que dice qué es lo que significa un determinado enunciado jurídico $E$.

Un ejemplo de enunciado interpretativo es el siguiente:

[3] El sentido del art. 240.1 del CP español es que los que cometan un robo con fuerza en las cosas serán castigados con la pena de uno a tres años de prisión.

Pero también es un enunciado interpretativo el siguiente enunciado:

[4] El art. 240.1 del CP español significa que los que cometan un robo con fuerza en las cosas serán castigados a cadena perpetua.

Mas, aunque ambos sean enunciados interpretativos, existe una diferencia evidente entre dichos enunciados: el primero de ellos es verdadero, mientras que el segundo es falso. Por ello, sostengo que los enunciados interpretativos son verdaderos o falsos, es decir, son enunciados asertivos; aunque frecuentemente tengamos dudas acerca de si un enunciado interpretativo determinado es verdadero o no. Y pienso también que el que un enunciado interpretativo sea verdadero o sea falso no depende de lo que diga un juez, al igual que ocurre en el caso de cualquier otro enunciado asertivo.

A mi juicio, para que una decisión judicial aplique un determinado enunciado jurídico $E$, es necesario que sea verdadero un determinado enunciado interpretativo acerca del sentido de $E$.

Por ejemplo, supongamos que el juez que juzga a Carlos, acusado de robo con fuerza en las cosas, dicta una decisión, llamémosla $\left\langle D_{1} »\right.$, que castiga a Carlos a una pena de dos años de prisión. Una de las condiciones necesarias para que esta decisión

15 Véase KelsEN, 1960: 245. 
aplique el enunciado jurídico contenido en el art. 240.1 del CP español es que sea verdadero el enunciado calificativo «Carlos es culpable de robo con fuerza en las cosas». Pero también es necesario que dicho enunciado jurídico signifique lo que significa, esto es, que sea verdadero el enunciado interpretativo [3]. Si el enunciado jurídico citado significara otra cosa, por ejemplo, si fuera verdadero el enunciado interpretativo [4], la decisión $« D_{1} »$ no aplicaría ese enunciado jurídico ${ }^{16}$.

Supongamos, en cambio, que la decisión dictada por el juez en el mismo litigio no fuera la decisión $\left\langle D_{1} »\right.$, sino una decisión $\left\langle D_{2} »\right.$, que castiga a Carlos a cadena perpetua. Esta decisión $« D_{2} »$ no aplicaría el enunciado contenido en el art. 240.1 del CP español, dado el sentido que este enunciado jurídico tiene. Pero sí lo aplicaría si el sentido de este enunciado jurídico fuera el que le atribuye el enunciado interpretativo [4], o sea, si este enunciado interpretativo [4] fuera verdadero.

Las ideas que acabo de exponer son opuestas a las que dominan en el pensamiento jurídico actual. Una idea muy difundida en la actualidad (a través especialmente de la denominada «escuela genovesa», liderada por R. GUASTINI) es que los enunciados interpretativos de los enunciados jurídicos no son verdaderos, ni falsos. Esta es una tesis general, refutada por los datos incuestionables de que el enunciado interpretativo [3] es verdadero, mientras que el enunciado interpretativo [4] es falso. Pero además, si el enunciado interpretativo [3] no fuera verdadero, y suponiendo que Carlos hubiera cometido un robo con fuerza en las cosas, no me imagino qué teoría de la aplicación de los enunciados jurídicos permitiría alcanzar la conclusión de que la decisión « $D_{1} »$ (que castiga a Carlos a una pena de dos años de prisión) aplica el art. 240.1 del CP español; del mismo modo, tampoco veo cómo sería posible concluir, en ese mismo caso del robo cometido por Carlos, que la decisión $\left\langle D_{2} »\right.$ (que castiga a Carlos a cadena perpetua) no aplica el mismo enunciado jurídico, si resulta que el enunciado interpretativo [4] no es falso. Esta teoría de la interpretación, que sostiene que los enunciados interpretativos no son verdaderos, ni falsos, también ha de ser incluida, por tanto, en esa lista de teorías que no permiten controlar la actividad judicial, concretamente, entre las que no permiten saber si una decisión judicial aplica o no un enunciado jurídico determinado.

Otra teoría de la interpretación que también hay que incluir en la lista citada es la que sostiene que la tarea de un intérprete de un enunciado jurídico $E$ no consiste, o no consiste solo, en formular un enunciado metalingüístico acerca del enunciado $E$, acerca del sentido E, como los enunciados [3] y [4]. Según la teoría a la que ahora aludo, muy difundida tácitamente en sentencias judiciales, la interpretación de un enunciado jurídico $E$ puede culminar con la formulación de un enunciado $X$, del mismo nivel lingüístico que $E$, referente al mismo asunto al que se refiere $E$, pero con un sentido

16 Para que la decisión $D_{1}$ aplique el art. 240.1 del CP español, son necesarios esos dos requisitos: que sea verdadero un determinado enunciado calificativo $F$, que sea una concreción del supuesto de hecho de dicho precepto, y que sea verdadero un enunciado interpretativo, que afirma que ese precepto significa (lo mismo que el enunciado) $I$. Pero, según he dicho antes, también es necesaria, en mi opinión, una tercera y última condición. Esta otra condición consiste en que ha de existir una determinada relación $R$ entre tres cosas, tres enunciados: el enunciado calificativo $F$ (que, al ser verdadero, describe lo que ha sucedido en el mundo), el enunciado $I$ (que expresa el sentido que tiene el precepto de cuya aplicación se trata) y la decisión $D_{1}$. Mas determinar en qué consiste esa relación $R$, que es el problema más complejo y polémico del tema de la aplicación de los enunciados jurídicos, es irrelevante en el presente contexto. 
distinto, quizá incluso opuesto, a lo que $E$ significa. Ese enunciado jurídico $X$ es presentado por la teoría de la interpretación de la que estoy hablando como un enunciado o norma que es producto de la interpretación, concretamente, como producto de una interpretación calificada como «correctiva».

Aunque cuando ese enunciado $X$ es formulado por un Tribunal en una sentencia, en particular por el Tribunal Supremo, puede ocurrir que dicho enunciado no sea presentado como producto de una labor interpretativa. Puede suceder que el citado enunciado $X$ sea presentado como «doctrina jurisprudencial», rótulo que cubre el resultado de esa actividad que a veces realiza el Tribunal Supremo y que consiste en crear normas o enunciados de carácter general.

Voy a citar a continuación un par de ejemplos de esas doctrinas jurisprudenciales del Tribunal Supremo español.

Una de ellas, bien conocida por los civilistas españoles, es la que dice que las obligaciones pueden ser solidarias, aunque no se pacte así expresamente ${ }^{17}$; justamente lo contrario de lo que dice el art. 1.137 del CC español ${ }^{18}$.

Pero más llamativo es este otro ejemplo. El art. 18.1 de la Constitución Española dice lo siguiente: «Se garantiza el derecho al honor, a la intimidad personal y familiar y a la propia imagen».

Por otra parte, el texto literal del art. 20 de la Constitución Española es el siguiente:

1. Se reconocen y protegen los derechos:

a) A expresar y difundir libremente los pensamientos, ideas y opiniones mediante la palabra, el escrito o cualquier otro medio de reproducción.

b) A la producción y creación literaria, artística, científica y técnica.

c) A la libertad de cátedra.

d) A comunicar o recibir libremente información veraz por cualquier medio de difusión. La ley regulará el derecho a la cláusula de conciencia y al secreto profesional en el ejercicio de estas libertades.

2. El ejercicio de estos derechos no puede restringirse mediante ningún tipo de censura previa.

3. La ley regulará la organización y el control parlamentario de los medios de comunicación social dependientes del Estado o de cualquier ente público y garantizará el acceso a dichos medios de los grupos sociales y políticos significativos, respetando el pluralismo de la sociedad y de las diversas lenguas de España.

4. Estas libertades tienen su límite en el respeto a los derechos reconocidos en este Título, en los preceptos de las leyes que lo desarrollen y, especialmente, en el derecho al honor, a la intimidad, a la propia imagen y a la protección de la juventud y de la infancia [cursiva añadida].

5. Sólo podrá acordarse el secuestro de publicaciones, grabaciones y otros medios de información en virtud de resolución judicial.

17 STS, de la Sala de lo Civil, 239/1998, de 18 de marzo, FJ 8. $:$ :Si la mancomunidad se pacta expresamente para unas, y para las otras no se dice nada, es que aquéllas se excepcionan del régimen de la solidaridad que se pretende como situación normal».

${ }_{18}$ El texto de este artículo es el siguiente: «La concurrencia de dos o más acreedores o de dos o más deudores en una sola obligación no implica que cada uno de aquéllos tenga derecho a pedir, ni cada uno de estos deba prestar íntegramente, las cosas objeto de la misma. Solo habrá lugar a esto cuando la obligación expresamente lo determine, constituyéndose con el carácter de solidaria». 
Con relación a estos textos constitucionales, el Tribunal Supremo ha formulado enunciados que dicen justamente lo contrario de lo que dice la Constitución Española: que es el derecho al honor el que está limitado por la libertad de expresión e información. La STS, de la Sala 1. ${ }^{a}, 234 / 2013$, de 25 de marzo, FJ 3. ${ }^{\circ}$, dice lo siguiente: «El derecho al honor, según reiterada jurisprudencia, se encuentra limitado por las libertades de expresión e información». Y lo mismo se observa en la STS, de la misma Sala 1. ${ }^{a}, 149 / 2015$, de 17 de marzo, FJ 2. ${ }^{\circ}$ : «La limitación del derecho al honor por la libertad de expresión e información tiene lugar cuando se produce un conflicto entre ambos derechos».

Respecto a esos enunciados generales formulados por el Tribunal Supremo, ya sean considerados productos de la interpretación, ya sean calificados como «doctrina jurisprudencial», hay que tener en cuenta: a) que cuando en un litigio un tribunal formula un enunciado general $X$ en sustitución, por así decirlo, de un enunciado jurídico $E$ previo, formulado por el legislador, el enunciado aplicado por la decisión dictada por el tribunal será $X$, el enunciado nuevo creado por el tribunal, no el enunciado $E$ anterior $^{19}, \mathrm{y} b$ ) según las tesis que he expuesto y justificado en el apartado $\mathrm{V}$, esta aplicación del nuevo enunciado $X$ no debería contar como aplicación del Derecho, aunque consideremos que $X$ es un enunciado jurídico.

Al comienzo de este trabajo, he dicho que es importante controlar a nivel teórico si en un caso determinado un juez determinado cumple o no las obligaciones que el Derecho le impone. Pero si lo que un juez está obligado a hacer en un caso determinado dependiera de la concurrencia de alguna circunstancia (por ejemplo, de la existencia o no de una norma, principio, etc.), que a su vez dependiera de una determinada conducta del juez (por ejemplo, de su actividad interpretativa, o de su doctrina jurisprudencial), respecto a la cual no existen criterios de control, la consecuencia inmediata sería la inexistencia de criterios teóricos que permitan controlar si en un caso determinado un juez determinado cumple o no las obligaciones que el Derecho le impone. Y la consecuencia final no sería la arbitrariedad, denunciada por MONTESQUIEU en los casos en los que, como los que ahora nos ocupan, el titular de la potestad judicial ejerce además la potestad legislativa ocasionalmente ${ }^{20}$. Sería algo más grave que eso. Pues la arbitrariedad es la conducta ilegal de los poderes públicos ${ }^{21}$; por lo cual una conducta arbitraria es una conducta contraria a una regla (legal), que funciona como criterio de control de las conductas y sirve para reprobar las conductas que se apartan de ella. Pero si de lo que se trata es que no existen criterios que permitan controlar la conducta de un juez, ni siquiera existe la posibilidad de reprobar dicha conducta.

$\mathrm{Al}$ margen de estas observaciones, me parecen equivocadas las teorías que aceptan esos enunciados generales formulados por el Tribunal Supremo, y que antes han sido citados, tanto si dichos enunciados son considerados productos de una interpretación correctiva del Derecho, como si son calificados como doctrina jurisprudencial.

19 Según SCHAUER, 2013: 126-127, «es característico del common law que las reglas sean cambiadas en el mero proceso de su aplicación». Pero esta es una descripción engañosa de lo que sucede en los sistemas del common law y de lo que sucede en nuestro Derecho. Pues la regla que es cambiada, esto es, que es sustituida por otra, no es la regla aplicada; la aplicada es la otra, la nueva regla creada por el juez.

20 Véase MONTESQuieu, 1922: 152.

21 «"Arbitrario" equivale a no adecuado a la legalidad», dice la STC 27/1981, FJ 10. ${ }^{\circ}$ 
Pues, por un lado, es imposible que un intérprete corrija lo que constituye su objeto de interpretación, a no ser que abandone su condición de intérprete. La tarea consistente en corregir un enunciado jurídico y sustituirlo por otro enunciado distinto y tal vez opuesto al primero es una tarea legislativa, que queda fuera de las competencias del intérprete del Derecho. En cualquier caso, quienquiera que realice esa actividad correctora, esta no consiste en atribuir sentido o significado a una expresión; e interpretar es precisamente eso, atribuir sentido o significado a una expresión. Si, a pesar de todo, se insistiera en que eso es interpretar, habría que decir que se trata de interpretaciones falsas; pues, por ejemplo, los textos constitucionales citados significan justamente lo contrario de lo que el Tribunal Supremo afirma que significan o desea que signifiquen. No sé si un dictamen pericial, emitido por el director de la Real Academia Española, bastaría para convencer al Tribunal Supremo a este respecto.

Pero el problema reside precisamente en que nuestros altos Tribunales, así como los juristas teóricos, raramente hablan de textos, enunciados, constitucionales, y de su sentido o significado, sino de los principios, derechos, libertades, valores, etc., «consagrados» o «reconocidos» en los enunciados constitucionales correspondientes. Pues estos juristas contemplan la Constitución, no como un documento integrado por enunciados, por entidades lingüisticas, a semejanza del reglamento hipotecario, sino como un conjunto, calificado a veces como sistema, cuyos elementos o miembros son valores, principios, derechos, etc. Y los enunciados constitucionales son, para dichos juristas, una mera manifestación material de aquellas entidades inmateriales. Mas explicar esta relación de manifestación, reconocimiento o consagración de un principio, un derecho o un valor en un enunciado constitucional es un problema añadido a los señalados en páginas anteriores respecto a los principios: ante todo, el problema ontológico y el epistemológico; pero también el de cómo hacer compatible esa ontología con la tesis de la jerarquía normativa y con la teoría acerca de las relaciones entre Derecho y tiempo.

En cuanto a la posibilidad, en segundo lugar, de considerar esos enunciados generales formulados por el Tribunal Supremo como doctrina jurisprudencial, es una cuestión menor la de si esos enunciados generales son jurídicos (y los jueces crean Derecho) o no lo son, y si, en el primer caso, el Derecho creado por el Tribunal Supremo es un Derecho de segunda categoría. Lo importante es que los jueces y Tribunales, incluido el propio Tribunal Supremo, deciden los casos litigiosos como si dichos enunciados generales fueran Derecho, no solo de primera categoría, al lado de la ley, sino incluso con una categoría superior a la de esta. Y ello me parece erróneo por las razones siguientes:

Al crear doctrina jurisprudencial, el Tribunal Supremo infringe numerosos preceptos de la Constitución Española. Infringe, en primer lugar, sus arts. 117.3 y 117.4, que antes han sido citados, y según los cuales la única función de los jueces y Tribunales es la jurisdiccional, que consiste esencialmente en aplicar el Derecho creado por otras instancias. La doctrina jurisprudencial del Tribunal Supremo atenta también contra la democracia como forma de gobierno, consagrada en el art. 1.1 de la Constitución, dado que un Tribunal Judicial carece de representatividad política para crear normas generales; y cuando esas normas generales creadas por el Tribunal Supremo son, como 
en los casos citados, contrarias a lo que de modo inequívoco establecen normas generales contenidas en una ley o en la Constitución, y creadas por quienes sí ostentan la representación de los ciudadanos, entramos ya en lo antidemocrático. La doctrina jurisprudencial del Tribunal Supremo viola también en varios aspectos el art. 9.3 de la Constitución, que «garantiza» la seguridad jurídica, así como la irretroactividad y la publicidad de las normas. A todo ello hay que añadir los repentinos e imprevisibles «cambios de jurisprudencia», además de los abusos frecuentes a que esa práctica judicial da lugar, como revelan los ejemplos antes citados.

Resulta sorprendente, en mi opinión, que el Tribunal Supremo, capaz de detectar la más leve infracción de la Constitución, no atisbe el menor indicio de inconstitucionalidad en su propia práctica de crear doctrina jurisprudencial, a pesar de que los indicios que existen de ello son numerosos y evidentes. Pero me sorprende más aún la naturalidad con la que la cultura jurídica acepta esa práctica judicial, la pasividad del pensamiento jurídico ante una práctica que atenta contra muchas cosas que los juristas, en particular, y los ciudadanos, en general, estimamos valiosas y que, por ello, la Constitución intenta proteger.

\section{EPÍLOGO}

Cualquiera de las numerosas teorías que he expuesto y comentado es suficiente para impedir que algunos aspectos esenciales de la actividad judicial sean controlados. Pero el pensamiento jurídico actual acerca de la labor de los jueces es precisamente una mezcolanza de todas esas teorías. Y la consecuencia de esta mescolanza de teorías es que los jueces ejerzan su profesión bajo un descontrol teórico absoluto. La pasividad del pensamiento jurídico ante prácticas judiciales claramente antijurídicas halla su explicación precisamente en la inexistencia de criterios teóricos que permitan enjuiciar el trabajo de los jueces o bien en el hecho, más grave, de que los criterios teóricos que existen justifican dichas prácticas.

\section{BIBLIOGRAFÍA}

Alchourrón, C. E., 1996: «On Law and Logic», Ratio Iuris, 9 (4): 331-348.

ALEXY, R., 2003: «Die logische Analyse juristischer Entscheidungen», en R. ALEXY, H.-J. KocH,

L. Kuhlen y H. Russmann, Elemente einer juristischen Begründungslehre, Baden-Baden: Nomos, 9-35.

BAYÓN, J. C., 2000: «Derrotabilidad, indeterminación del Derecho y positivismo jurídico», Isonomía, 13: 87-117.

Guastini, R., 1996: «Fragments of a Theory of Legal Sources», Ratio Iuris, 9 (4): 364-386.

HERNÁNDEZ GIL, A., 1975: El Abogado y el Razonamiento jurídico, Madrid.

KeLsEn, H., 1960: Reine Rechtslebre. Mit einem Anbang: Das Problem der Gerechtigkeit, Wien:

Franz Deuticke.

Montesquieu, 1922: De l'esprit des lois, avec de notes de Voltaire, de Crevier, de Mably, de la Harpe, etc., tome premier, Paris: Librairie Garnier Frères.

NiETO, A., 2000: El arbitrio judicial, Barcelona: Ariel. 
Rousseau, J. J., 1979: «El Contrato Social o Principios de Derecho Político», en J. J. Rousseau, Escritos de combate, traducción y notas de S. MASÓ, Introducción, Cronología y Bibliografía de G. BENREKASSA, Madrid: Ediciones Alfaguara, 393-526.

SCHAUER, F., 2013: Pensar como un abogado. Una nueva introducción al razonamiento jurídico, traducción al castellano de T. J. SCHLEIDER, Madrid-Barcelona-Buenos Aires-São Paulo: Marcial Pons.

VRANAS, P. B. M., 2016: «New foundations for imperative logic III: A general definition of argument validity», Synthese, 193, 1703-1753. 


\title{
SOBRE LA OPACIDAD REFERENCIAL Y LA AMBIGÜEDAD DE DICTO/DE RE EN EL DERECHO*
}

\author{
Joaquín Rodríguez-Toubes Muñiz** \\ Universidad de Santiago de Compostela \\ joaquin.rodriguez-toubes@usc.es
}

\begin{abstract}
RESUMEN. Los contextos lingüísticos llamados opacos ocultan la referencia de los grupos nominales y pueden causar ambigüedad, que al manifestarse en las leyes adquiere relevancia jurídica. La opacidad referencial se comprueba en enunciados que cambian su valor de verdad cuando se sustituye un nombre por otro con la misma extensión. En tales situaciones la intensión cobra protagonismo, y por ello formular enunciados jurídicos en contextos opacos hace más visible e inteligible la atribución intensional característica del derecho. Por otra parte, la opacidad referencial suscita un tipo especial de ambigüedad, de raíz pragmática y estructura lógica, en la que un mismo grupo nominal admite una lectura inespecífica o de dicto (según lo dicho) y otra específica o de re (según la cosa). Varios ejemplos tomados del Código Penal español muestran la importancia de percibir esta ambigüedad.
\end{abstract}

Palabras clave: interpretación jurídica, opacidad referencial, ambigüedad.

\section{On Referential Opacity and De Dicto/De Re Ambiguity in the Law}

ABSTRACT. The so-called opaque linguistic contexts hide the reference of the nominal groups and can cause ambiguity, which becomes relevant for the law when it appears in legislation. The referential opacity occurs in statements that change their truth value when a name is substituted by another with the same extension. Intension takes prevalence in those situations, and therefore formulating legal statements in opaque contexts makes more visible and intelligible the intensional attribution peculiar to law. Besides, referential opacity raises a special type of ambiguity, with pragmatic roots and logical structure, in which a given nominal group admits an unspecific or de dicto reading (about what was said), and also a specific or de re reading (about the matter itself). Several examples taken from the Spanish Criminal Code show the importance of perceiving of this ambiguity.

Keywords: legal interpretation, referential opacity, ambiguity.

* Fecha de recepción: 22 de julio de 2016. Fecha de aceptación: 16 de febrero de 2017.

Este trabajo se integra en el proyecto de investigación DER2016-74898-C2-2-R financiado por el MINECO y FEDER. Una versión inicial, titulada «Contextos jurídicos opacos», fue presentada en el I Congreso de Filosofía Jurídica para el Mundo Latino, celebrado en Alicante del 26 al 28 de mayo de 2016.

:*: Profesor Titular de Filosofía del Derecho de la Universidad de Santiago de Compostela (Facultad de Derecho, 15782 Santiago de Compostela). 


\section{INTRODUCCIÓN}

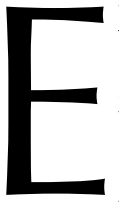

1 art. 248.1 del Código Penal español (CP) dice así: «Cometen estafa los que, con ánimo de lucro, utilizaren engaño bastante para producir error en otro, induciéndolo a realizar un acto de disposición en perjuicio propio o ajeno». ¿Quién es ese «otro» susceptible de engaño al que protege el artículo? En particular: ¿es una persona real o es una persona posible, una abstracción que pudiera no concretarse? ¿Comete ese delito quien teje un engaño lo bastante convincente para lograr que alguien le entregue dinero, aunque nadie haya caído en él? Comprobaremos que la respuesta doctrinal y jurisprudencial española es negativa (el engaño sin víctima se calificaría a lo sumo como tentativa de estafa), pero la letra del artículo admite ambas interpretaciones, porque es ambiguo en este punto. Esta ambigüedad se debe a que la palabra «otro» se usa tanto para referirse a una persona concreta («Pedro acusó a otro») como para hacer una referencia abstracta a alguien distinto del sujeto («Pedro fingió ser otro»). Pero es también una ambigüedad peculiar, que guarda relación con problemas de opacidad referencial que veremos discutidos por algunos filósofos y lingüistas, pero apenas por juristas. La explicación de la ambigüedad de la palabra «otro» en el art. 248.1 CP es atípica, porque es más lógica que etimológica. El doble sentido de «otro» en ese artículo se debe más a razones pragmáticas susceptibles de análisis lógico que a las causas semánticas que suelen estar tras las ambigüedades léxicas.

Tomemos otro ejemplo de oración ambigua: «Inés fue a Lugo a comprar una casa». Podemos entender que Inés fue a Lugo a comprar alguna casa (no se sabe todavía cuál) o cierta casa (ya se sabe cuál). La ambivalencia se comprueba fácilmente prolongando la frase: «Inés fue a Lugo a comprar una casa que le guste» (primera versión, que alude a una casa hipotética y requiere un subjuntivo); o «Inés fue a Lugo a comprar una casa que le gusta» (segunda versión, que alude a una casa real y pide un indicativo). Cabe dar cuenta de esta ambigüedad analizando los usos del artículo indeterminado «una»; pero es más informativa la explicación de los filósofos y lingüistas que distinguen entre una interpretación de dicto (sobre lo dicho) y otra de re (sobre la cosa). La oración «Inés fue a Lugo a comprar una casa» la interpretamos de dicto cuando entendemos que no se refiere a ninguna casa en particular; y en cambio la interpretamos de re cuando entendemos que se refiere a una casa específica. En oraciones así hay una oscuridad en la referencia que dificulta su comprensión, y de hecho es imposible saber el significado de este tipo de oraciones sin conocer el contexto pragmático en el que se formulan. Lo mismo ocurría con el art. 248.1 CP; y el doble sentido de «otro» en este artículo, con una acepción específica y otra inespecífica, lo capta bien la distinción lógico-lingüística entre lecturas de dicto y de re. Si se interpretan de re es porque se entiende referido a una realidad concreta: cierta persona física. En cambio, si se interpreta de dicto es porque se suspende el juicio sobre la referencia y esta es, a lo sumo, un ente abstracto o una mera hipótesis: una supuesta persona distinta del sujeto.

Esta situación de oscuridad referencial se da en diversas circunstancias lingüísticas, pero las más típicas son las expresiones de actitudes designadas con verbos como creer, querer y algunos otros. Por ejemplo, en oraciones como «Inés quiere comprar una casa en Lugo», la cual puede entenderse o bien de re, referida a una casa concreta, real y 
existente; o bien de dicto, referida a una casa abstracta, hipotética y acaso inexistente. $\mathrm{El} \mathrm{mismo} \mathrm{fenómeno} \mathrm{se} \mathrm{da} \mathrm{en} \mathrm{otros} \mathrm{contextos} \mathrm{prospectivos} \mathrm{(condicionales,} \mathrm{futuros...),} \mathrm{y,}$ por supuesto, tanto estos como los intencionales o proposicionales son muy frecuentes en el lenguaje del derecho, cuando regula acciones futuras intencionales. «Quien vaya a Lugo a comprar una casa podrá acceder al Registro municipal de viviendas», por ejemplo, sería una formulación legal típica y ambigua. Pues bien, aunque esta ambigüedad de dicto/de re tiene una importante presencia en el derecho, como tendremos ocasión de ver es excepcional que los juristas la reconozcan y más aún que la analicen y resuelvan en los términos lógicos y lingüísticos apropiados.

La oscuridad referencial creada por la ambigüedad de dicto/de re, muy presente en el lenguaje jurídico, guarda relación con la llamada «opacidad referencial» provocada por ciertas condiciones lingüísticas especiales que hacen prevalecer la intensión sobre la extensión, y que se manifiesta en enunciados donde no se da la sustitutibilidad salva veritate de términos correferentes. Las mismas condiciones que causan este fenómeno singular, que también puede reconocerse en el lenguaje jurídico, provocan la ambigüedad de dicto/de re, y de ahí que esta suela calificarse como un caso de opacidad referencial. Sin embargo, la opacidad referencial genuina oculta una única referencia, mientras que hay ambigüedad cuando la expresión admite más de una referencia, en este caso con un grado de especificidad distinto.

El primer apartado de este trabajo se dedica a atender al fenómeno de la opacidad referencial y de la formación de contextos opacos; y el segundo a la ambigüedad de dicto/de re en conexión con la ambigüedad inespecífico/específico.

\section{LA OPACIDAD REFERENCIAL}

Algunos lógicos —destacadamente Frege, Russell y Quine, a quienes acudiremos aquí- han identificado unas situaciones lingüísticas, conocidas como «contextos opacos», en las cuales al sustituir un nombre o un grupo nominal por otro con la misma referencia o denotación cambia el valor de verdad de la oración que lo contiene. Es decir, las oraciones opacas no conservan necesariamente su valor de verdad cuando en ellas se intercambian nombres que designan lo mismo (se aplican a lo mismo, tienen la misma extensión). En tales ocasiones los términos correferentes no cumplen una función puramente denotativa (designar algo), y por tanto no son plenamente intercambiables. Técnicamente se dice que estos contextos, como por ejemplo las informaciones sobre creencias, no cumplen el principio de sustitutividad, que QUINE (1961: 139) formula así: «Dado un enunciado de identidad verdadero, uno de sus dos términos puede ser sustituido por el otro en cualquier enunciado verdadero y el resultado será verdadero». Dicho de otro modo, en estos contextos los términos correferentes no son idénticos según el Principio de LEIBNIZ, pues solo lo son los que pueden intercambiarse salvaguardando el valor de verdad (Eadem sunt quorum unum in alterius locum substitui potest, salva veritate) ${ }^{1}$. QUINE (1961) pone este ejemplo:

${ }^{1}$ LeIBNIZ (ed. 1890: 219). Y sigue un ejemplo: «Ut Triangulum et Trilaterum». En palabras de RusselL (1905: 485): «Si $a$ es idéntico a $b$, lo que sea verdad de uno es verdad del otro, y uno de ellos puede ser sustituido por el otro en cualquier proposición sin alterar la verdad o falsedad de esa proposición». 
(1) Felipe cree que Tegucigalpa está en Nicaragua.

Aunque «Tegucigalpa» y «la capital de Honduras» tienen la misma referencia, no son expresiones sustituibles salva veritate, puesto que el enunciado (1) puede ser verdadero y no serlo este otro:

(2) Felipe cree que la capital de Honduras está en Nicaragua.

Lo que sucede aquí es que las expresiones «Tegucigalpa» y «la capital de Honduras» no se usan por su extensión (la ciudad de Tegucigalpa), sino por su intensión. Por eso estas situaciones se llaman también «contextos intensionales» y se dice que no son «transparentes» (no dejan ver la extensión) y que hay «opacidad referencial» ${ }^{2}$. Como recuerda QUINE, ya FREGE había hablado de estos contextos llamándolos «oblicuos» o «indirectos» (ungerade). Según FREGE (1892-2005: 31), normalmente se usan las palabras para hablar de su referencia, pero cuando se citan las palabras de otro indirectamente, en estilo indirecto, entonces la referencia del enunciado subordinado es un pensamiento o un sentido. Por ejemplo, cuando alguien habla del «lucero matutino» y reportamos sus palabras en estilo indirecto - «Dijo que veía el lucero matutino»—, la referencia de «lucero matutino» es el sentido que le dio el hablante, y no la que le damos nosotros. Por eso «Dijo que veía el lucero matutino» y «Dijo que veía Venus» no tienen necesariamente el mismo valor de verdad, aunque el «lucero matutino» es Venus.

Las condiciones que causan opacidad referencial son, destacadamente, las menciones o citas indirectas, las modalidades y las disposiciones o actitudes proposicionales.

\subsection{Citas}

La opacidad referencial de los contextos «indirectos» $\mathrm{u}$ «oblicuos» se puede explicar en algunos casos con la distinción entre uso y mención. Al formular oraciones acerca de nombres, ya sea en estilo directo o indirecto, seguimos reglas distintas que al usar esos mismos nombres. Como señaló Russell (1905: 486), «cuando se da $C$ estamos hablando de la denotación, pero cuando se da "C" se trata del significado». Supongamos que preguntamos a alguien cuándo llega y nos contesta: «El día 3». Si más tarde nos preguntan a nosotros cuándo llega podemos contestar con nuestras propias palabras («El día 3») o mencionando las suyas, ya sea en estilo directo («Sus palabras fueron: "El día 3"») o indirecto («Según sus palabras, el día 3»). Pues bien, el significado de «día 3» en estas respuestas no es necesariamente el mismo. La expresión cuando es usada tiene la referencia que nosotros le damos; y cuando es mencionada en una cita tiene la referencia que le dio el hablante citado. Y si la oración es ambigua

2 Explica QuiNE (1961: 139): «El principio de sustitutividad no debe extenderse a contextos en los que el nombre que va a ser sustituido aparece sin referir simplemente al objeto. Que falle la sustitutividad revela tan solo que el término a sustituir no es puramente referencial». A estos contextos los llamó QuINE (1961: 142; 1960: 144) «referencialmente opacos» por contraste con el término «transparente» usado por WHITEHEAD y RuSSELL (1927: 665), para quienes las proposiciones afirmadas («Sócrates es griego»), a diferencia de las mencionadas («Es verdad que Sócrates es griego»), son transparentes porque se dice algo a través de ellas, pero no acerca de ellas. Para adentrarse en la compleja temática de la opacidad referencial, véase en español la detallada introducción de GARCÍA SUÁREZ (1997: 251-312). 
(por ejemplo: «Me dijo que el día 3»), la expresión puede tener una u otra referencia según se interprete que se está usando o mencionando. Veamos esto con unos ejemplos jurídicos, basado en la Constitución Española (CE). El objetivo de este análisis será, en último término, comprender mejor el lenguaje del derecho y el derecho mismo.

\subsubsection{Estilo directo}

En primer lugar, comprobamos que en los contextos de estilo directo (citas literales) la sustitución de términos correferentes altera el valor de verdad.

(3) El artículo 12 CE dice: «Los españoles son mayores de edad a los 18 años».

(4) El artículo 12 CE dice: «Los españoles son mayores de edad a los 216 meses».

La oración (3) hace una cita correcta del artículo, y es verdadera. En la oración (4) se ha alterado la cita del artículo sustituyendo la expresión nominal «18 años» por otra con idéntica referencia («216 meses»), y el resultado es que la oración es falsa. Esto no es ninguna sorpresa, desde luego. Aunque 18 años son 216 meses, nadie pensará que «18 años» y «216 meses» son intercambiables en una cita literal. Y cualquier jurista sabe que hay que poner mucho cuidado al citar las leyes, porque en ellas no son lo mismo unas palabras que otras. Por eso no es fácil imaginar problemas jurídicos causados por la insustitutibilidad de los términos correferentes en el contexto de citas directas ${ }^{3}$.

\subsubsection{Estilo indirecto}

Cuando pasamos al estilo indirecto la cuestión se hace más compleja. Veamos estas dos oraciones:

(5) El artículo 12 CE dice que los españoles son mayores de edad a los 18 años.

(6) El artículo $12 \mathrm{CE}$ dice que los españoles son mayores de edad a los 216 meses.

El enunciado (5) describe fielmente el contenido del art. $12 \mathrm{CE}$ y podemos considerarlo verdadero. En cambio, es dudoso que el enunciado (6) sea igualmente verdadero, a pesar de que tiene el mismo contenido referencial. Ambos enunciados denotan lo mismo, pero no connotan lo mismo; y como consecuencia su valor de verdad podría ser distinto: (5) es verdadero, pero (6) puede serlo o no. El enunciado (6) es verdadero si usa la expresión «216 meses» por su extensión (18 años) y en el art. 12 CE la frase «18 años» se usa también por su extensión (18 años). En otro caso, la oración (6) es falsa, ya sea porque la cita que hace no es fidedigna o ya sea porque usa los términos tergiversando su significado. En virtud de esta ambigüedad, la oración (6) es un ejemplo de opacidad referencial en el derecho, y a su vez (por ello) una demostración de la

${ }^{3}$ Un ejemplo de dificultad (poco importante) podría ser cómo citar correctamente el art. 20.Uno.8. ${ }^{\circ}$ ) de la Ley 37/1992, de 28 de diciembre, del Impuesto sobre el Valor Añadido, según el cual están exentas de IVA las prestaciones efectuadas por entidades de Derecho público o de carácter social en servicios de «Educación especial y asistencia a personas con minusvalía». La dificultad viene por la disposición adicional $8 .{ }^{a}$ de la Ley 39/2006, de 14 de diciembre, de Promoción de la Autonomía Personal y Atención a las personas en situación de dependencia: «Las referencias que en los textos normativos se efectúan a "minusválidos" y a "personas con minusvalía”, se entenderán realizadas a "personas con discapacidad”. Así las cosas, ¿ cuál es la cita correcta del art. 20.Uno.8. ${ }^{\circ}$ c) de la Ley 37/1992: "minusvalía" o "discapacidad"?». 
fuerza de la intensión jurídica. Es dudoso si «18 años» aparece o no referencialmente en el art. 12 CE. Seguramente no, y por eso «18 años» y «216 meses» no son intercambiables. Si esto es así, la razón es que «18 años» en el art. 12 CE no solo denota una cantidad de tiempo, sino que tiene además una connotación y unas implicaciones peculiares que la distinguen de « 216 meses», aunque refieran lo mismo.

La opacidad referencial de los contextos indirectos crea incertidumbre en el derecho, porque una oración como (6) puede ser verdadera. Al contrario de lo que ocurría en las citas textuales en estilo directo, las afirmaciones indirectas sobre el contenido de las disposiciones jurídicas no necesitan ser fieles a la literalidad del texto para ser verdaderas. Esto es muy importante subrayarlo, porque es el sobreentendido habitual de los enunciados jurídicos, concebidos (en sentido kelseniano) ya como descripciones doctrinales de las normas válidas de un ordenamiento, o ya como pronunciamientos jurisprudenciales que dicen el derecho ${ }^{4}$. En algunos casos, incluso, la literalidad estorba. Por ejemplo, el art. 49 CE comienza así: «Los poderes públicos realizarán una política de previsión, tratamiento, rehabilitación e integración de los disminuidos físicos, sensoriales y psíquicos». Considérense ahora estos enunciados jurídicos sobre el art. 49 CE:

(7) El artículo 49 CE dice que los poderes públicos realizarán una política de integración de los disminuidos psíquicos.

(8) El artículo 49 CE dice que los poderes públicos realizarán una política de integración de las personas con discapacidad psíquica.

Ningún jurista dudará que si (7) es verdadera también (8) lo es, a pesar de que (7) es fiel a la letra del art. 49 CE y (8) no. Es más, probablemente hoy se prefiere (8) a (7) para describir el derecho en ese punto. En esta ocasión intercambiar términos correferentes («disminuidos» y «discapacitados») en un contexto indirecto no cambia el valor de verdad del enunciado. A pesar de la relevancia de los textos legales y de la importancia de ser fieles a sus palabras exactas, hay en el derecho muchas ocasiones como la citada, donde es viable la sustitución de términos por sinónimos correferentes sin alterar la verdad del enunciado. Que esto suceda puede deberse a dos causas. Una es que ambos términos tengan en el enunciado una función puramente extensional: se limitan a denotar algo (lo mismo en ambos casos). Otra es que ambos tengan la misma intensión relevante, además de la misma extensión. Como veremos, lo más probable es esto último, porque los contextos jurídicos típicos son intensionales y en ellos la descripción extensional no lo es todo.

La diferente intensión de los términos correferentes es lo que explica que estos no sean totalmente intercambiables en los contextos opacos indirectos u oblicuos. Este fenómeno interesa en el derecho porque pone de manifiesto contenidos de la intensión

4 Explica KELSEN (1960-1991): «La norma estatuida por el legislador [...], y el enunciado formulado por la ciencia del derecho describiendo esa norma [...] tienen características lógicas diferentes. De ahí que sea conveniente distinguir, aun terminológicamente, como "norma jurídica” y "enunciado jurídico", ambas expresiones» (p. 87). Si el enunciado jurídico doctrinal describe normas, el jurisdiccional también las avala: «La función del tribunal no es mero descubrimiento y formulación del derecho, y en este sentido, declaratoria [...]. El tribunal [...] debe decidir la cuestión de si la norma que aplicará fue producida constitucionalmente [...]. Esta formulación del enunciado jurídico dilucida la posición que el denominado derecho constitucional —es decir, las normas que regulan la producción de normas generales - tiene en el marco de un orden jurídico» (pp. 246-247). 
jurídica difíciles de diseccionar. ¿Cuál es la intensión peculiar que aporta el derecho a las expresiones que usa, y por la cual no son sustituibles por otras expresiones correferentes salva veritate? A mi juicio, en la intensión jurídica que se pone de manifiesto al comprobar la opacidad referencial del derecho destacan dos contenidos. Hablaré al respecto de dos modos de intensión jurídica, o simplemente de dos intensiones jurídicas. Ambas son previsibles y nada sorprendentes, pero es interesante (e infrecuente) observarlas en acción desprovistas de velos. Estos modos o aspectos de la intensión jurídica son, en primer lugar, la eficacia de la comunicación, que requiere sencillez y precisión en el lenguaje que hace públicas las normas; y en segundo lugar la generalidad, que demanda un lenguaje abstracto y de perfiles borrosos. Como se aprecia, ambas intensiones pueden empujar en sentidos opuestos y ser contradictorias, pero ambas conviven en el derecho.

Para empezar, ¿qué intensión peculiar tiene «18 años» frente a «216 meses», la cual hace que (5) y (6) sean diferentes? Probablemente la voluntad de eficacia del derecho, que recomienda claridad y sencillez en las formulaciones normativas; hasta el punto de que respetar mínimamente estas y otras propiedades asociadas, como la publicidad, puede llegar a ser un requisito de juridicidad. No se justifica nombrar la edad con «216 meses» si «18 años» es más sencillo y más claro. Ambas expresiones denotan lo mismo, pero solo la segunda connota el propósito comunicativo característico del lenguaje coloquial que emplean los destinatarios de la disposición. En cualquier caso, la opción no es trivial: una vez usada en el derecho, la expresión «18 años» genera implicaciones distintas a las de sus alternativas. Por ejemplo, nos invita a pensar las edades en años y no en meses, de manera que si algún día hubiese que pensar en un principio jurídico relativo a la edad (como - digamos - la edad en que un menor puede decidir sobre los tratamientos médicos que le conciernen o sobre sus derechos de imagen), debería plantearse en años y no en meses. Precisamente, la relevancia de la intensión jurídica estriba, sobre todo, en sus implicaciones normativas.

Ahora bien, la comunicación y la sencillez del mensaje no lo son todo en el lenguaje jurídico, como podremos ver en el siguiente ejemplo, también tomado de la CE:

Disposición Transitoria Segunda: «Los territorios que en el pasado hubiesen plebiscitado afirmativamente proyectos de Estatuto de autonomía y cuenten, al tiempo de promulgarse esta Constitución, con regímenes provisionales de autonomía, podrán [ampliar sus competencias autonómicas sin esperar cuatro años]».

Como se sabe y se sabía, estos territorios eran únicamente Cataluña, Galicia y el País Vasco. Considérense ahora estos enunciados jurídicos:

(9) La disposición dice que los territorios que en el pasado bubiesen plebiscitado afirmativamente proyectos de Estatuto de autonomía y cuenten, al tiempo de promulgarse la Constitución, con regimenes provisionales de autonomía, pueden...

(10) La disposición dice que Cataluña, Galicia y el País Vasco pueden...

En este ejemplo hemos sustituido una larga expresión de (9) por otra expresión correferente más precisa y el resultado (10) es una oración que ningún jurista consideraría equivalente a la primera. Porque el sentido de la descripción normativa en (9) no es solo designar unos territorios, sino sobre todo dar a entender por qué se designan. La disposición transitoria 2. ${ }^{a} \mathrm{CE}$ dice lo que afirma (9), pero no dice lo que afirma (10), aunque extensionalmente sea lo mismo. Lo que cambia entre (9) y (10) es la intensión. 
Pero, al contrario de lo que ocurría entre (6) y (7), ahora la diferencia no está en la mayor claridad y sencillez de la expresión jurídica (9), porque ocurre al revés; por tanto, la intensión jurídica ha de ser otra. De hecho estamos posiblemente ante la genuina intensión jurídica: la generalidad.

Nótese que si el enunciado de (10) parece falso, al contrario que (9), no es porque (10) se aparta del texto literal de la Constitución y como consecuencia el verbo «dice» es inapropiado. Tampoco (8) respetaba el texto literal del art. 49 CE y allí «dice» no parecía inapropiado. En realidad (10) seguirá pareciendo falso aunque cambiemos «dice» por un verbo que connote más el mensaje que su forma, por ejemplo «dispone», «comunica», «informa» o «transmite». Para hacer (10) verdadero tendríamos que neutralizar la intensión, por ejemplo sustituyendo «dice» por «viene a decir» (o incluso «significa», dando por sabido que a menudo el significado rebasa lo que se dice). El problema, por tanto, no es la fidelidad al texto. Si (10) parece falso es únicamente porque «Cataluña, Galicia y el País Vasco» carecen de la nota de generalidad que tiene «quienes...», y que es característica distintiva del derecho. Es esta intensión jurídica peculiar la que permite hacer implicaciones normativas y la que, en su caso, hará posible proyectar la disposición hacia el futuro ${ }^{5}$.

Reparar en la opacidad referencial nos desvela que cuando la disposición describe el supuesto de hecho regulado informa sobre su extensión, pero también aporta una intensión. Dicho de otro modo, la intensión es parte del mensaje del texto legal, y para tenerla en cuenta no es necesario recurrir a una finalidad o espíritu ajenos a su letra. Esto deberían tenerlo presente quienes critican las doctrinas interpretativas apegadas al texto reprochándoles, un tanto alegremente, que el significado literal de las disposiciones debe ceder ante su propósito o su justificación ${ }^{6}$. Lo cierto es que una interpretación del texto legal que verdaderamente haga honor al texto no ha de tener en cuenta solo su significado convencional estrictamente lingüistico, independiente del contexto de habla, sino también - y sobre todo- el significado efectivamente comunicado, en el cual participan activamente los componentes pragmáticos que aportan la intensión y las implicaciones del texto interpretado. Las cuales, por cierto, tienen mucho que ver con las intenciones, los fines y las razones justificativas que subyacen a dicho texto.

\subsection{Modalidades}

La opacidad referencial presente en los contextos indirectos de cita o mención se da también típicamente en los contextos modales, caracterizados por el uso de operadores como necesariamente o posiblemente; y esto repercute con fuerza en el derecho a

5 Tendría interés aprovechar el fenómeno de la opacidad referencial para investigar el enfrentamiento práctico entre las dos intensiones jurídicas identificadas - la generalizadora y la comunicativa -, y para discutir el peso respectivo que cada una de ellas tiene y debe tener en la legislación. Pero esto ha de quedar para otro trabajo.

${ }^{6}$ La tesis de la primacía del espíritu sobre la letra en la interpretación legal ha florecido en la jurisprudencia y en la doctrina españolas al amparo del art. 3.1 del CC. Ahora bien, el contenido y los efectos de esta tesis dependen de qué se entienda por letra o significado literal de las leyes, un concepto muy discutido, como se sabe. Véase un estudio en ITURRALDE (2014), quien defiende una acepción amplia como «significado convencional», el cual tiene en cuenta «los usos consolidados del lenguaje de los juristas» (p. 64). 
través de operadores deónticos como obligatorio o permitido. Los contextos opacos modales tienen su ilustración canónica en el siguiente ejemplo de QuiNE (1961: 143-144):

(11) El número de los planetas $=9$.

(12) 9 es necesariamente mayor que 7.

(13) El número de los planetas es necesariamente mayor que 7.

Aunque los enunciados (11) y (12) sean verdaderos ${ }^{7}$, no se sigue que lo sea (13). El ejemplo enseña que si en (12) sustituimos «9» por «el número de los planetas» cambia el valor de verdad de la oración, aunque ambas expresiones sean idénticas en su referencia. La explicación de QuINE es que «9» no es puramente referencial en el contexto modal ${ }^{8}$.

Este fenómeno se reproduce en el lenguaje normativo jurídico.

(14) El castellano = el idioma oficial de Colombia9.

(15) Conocer el castellano es obligatorio para todos los españoles ${ }^{10}$.

(16) Conocer el idioma oficial de Colombia es obligatorio para todos los españoles.

Está claro que (16) no se sigue de (14) y (15), como tampoco (13) se seguía de (11) y (12). La razón, de nuevo, es que «el castellano» en (15) no tiene una función puramente referencial. El operador modal «obligatorio» crea un contexto opaco en el que el significado extensional de «el castellano» no juega un papel determinante. Esta circunstancia se visibiliza al formalizar el enunciado (15), porque fuerza a situar la variable existencial fuera del operador deóntico «obligatorio» $(\mathbf{O})^{11}$.

(15') $\mathbf{O} \exists x(\mathrm{C} x)[\forall y(\mathrm{E} y) \rightarrow \mathrm{S} y x]$;

En lugar de:

$\left({ }^{* 15}\right) \quad \exists x(\mathrm{C} x) \mathbf{O}[\forall y(\mathrm{E} y)] \rightarrow \mathrm{S} y x$

Como veremos, esta misma diferencia en el alcance del operador o inductor modal es lo que explica la ambigüedad de dicto/de re.

\subsection{Actitudes}

La formación de contextos opacos es más notable todavía por efecto de verbos como «creer», «saber», «querer», «pretender» y varios otros, que expresan lo que se ha dado en llamar «actitudes proposicionales» ${ }^{12}$. El ejemplo clásico es aquí de RUSSELL (1905: 485):

7 El ejemplo es anterior a la devaluación de Plutón como planeta, por lo que asume (11) como verdad.

8 QUINE (1961: 144; 1960: 196).

9 «El castellano es el idioma oficial de Colombia» (art. 10 de la Constitución Política de Colombia).

10 «El castellano es la lengua española oficial del Estado. Todos los españoles tienen el deber de conocerla y el derecho a usarla» (art. 3.1 de la Constitución Española).

11 Tomemos que «C $»=\langle$ el castellano», «E» = «es español» $\mathrm{y}$ «S $\gg=\langle$ conocer». La fórmula adecuada (15') sería algo así: «Es obligatorio que dado un elemento $x$ que es el castellano, cualquier sujeto $y$ que es español ha de conocer $x$ ». La formulación alternativa errónea ( $\left.{ }^{*} 15^{`}\right)$ diría: «Dado un elemento $x$ que es el castellano, es obligatorio que cualquier sujeto $y$ que es español ha de conocer $x \gg$.

${ }_{12}$ Las actitudes proposicionales son estados mentales y disposiciones psicológicas acerca de algo afirmado en una proposición. RuSSELL acuñó la noción tomando como caso paradigmático creer, pero es común extenderla a disposiciones no epistémicas, como los deseos o las intenciones. Adoptó esta aplicación extensiva, aun- 
(16) Jorge IV quería saber si Scott era el autor de Waverley.

(17) Scott era el autor de Waverley.

(18) Jorge IV quería saber si Scott era Scott.

Según RuSSELL, la clave de la ambigüedad de la oración (16) está en que en ella la expresión «el autor de Waverley» puede aparecer de dos modos. En el primario, una y solo una persona escribió Waverley y Jorge IV quería saber si Scott era esa persona. En el secundario, Jorge IV quería saber si una y solo una persona escribió Waverley y Scott era esa persona. La distinción se puede hacer visible formalizando (16) con las dos interpretaciones alternativas; pero también, como pronto veremos, recurriendo a la distinción lingüística entre las modalidades de dicto (sobre lo dicho) y de re (sobre la cosa). Compárese (simbolizamos Waverley como «W» y Scott como «S»):

(16a) Jorge IV quería saber si $\exists x(\mathrm{~W} x \wedge \mathrm{S} x) \quad$ (modo secundario; lectura de dicto)

(16b) $\exists x(\mathrm{~W} x)$ y Jorge IV quería saber si $\mathrm{S} x$ (modo primario; lectura de re)

El ejemplo puede reproducirse sin dificultad para un entorno jurídico:

(19) El tribunal quería saber si Cataluña, Galicia y el País Vasco eran los territorios que en el pasado plebiscitaron afirmativamente proyectos de Estatuto de autonomia y contaban, al tiempo de promulgarse la Constitución, con regímenes provisionales de autonomía.

(20) Cataluña, Galicia y el País Vasco eran los territorios que en el pasado plebiscitaron afirmativamente proyectos de Estatuto de autonomia y contaban, al tiempo de promulgarse la Constitución, con regimenes provisionales de autonomía.

(21) El tribunal quería saber si Cataluña, Galicia y el País Vasco eran Cataluña, Galicia y el País Vasco.

De hecho, el modelo del ejemplo se reproduce constantemente al aplicar el derecho en los casos que cuentan con una única respuesta correcta. Tal vez no sean muchos, pero los hay. Pensemos, por ejemplo, que una disposición habla de «los ministros del Gobierno» y un juez debe identificar qué miembros forman esa clase.

(22) El juez quería saber si $\{a, b, \ldots n\}$ son la clase $\mathrm{C}$.

(23) La clase $\mathrm{C}=\{a, b, \ldots n\}$.

(24) El juez quería saber si $\{a, b, \ldots n\}$ son $\{a, b, \ldots n\}$.

¿Qué nos enseña esto? Nos enseña que las expresiones y descripciones con contenido referencial del lenguaje jurídico — como «los territorios que...»— no cumplen únicamente la función de identificar las realidades que refieren. A veces el derecho no es una norma superpuesta a una realidad (unos elementos $\{a, b, \ldots n\}$ que existen de hecho), sino una norma que construye una realidad (una clase $\mathrm{C}$ que existe como posibilidad). Esto es importante percibirlo cuando se interpretan las leyes. Para entender cabalmente las leyes hay que comprender qué papel desempeñan en ellas los términos referenciales, lo cual requiere procesar adecuadamente la información pragmática para dar la forma lógica correcta a los enunciados jurídicos. Ha de asumirse que en ciertos contextos opacos las descripciones legales no están ahí para referirse a algo, sino para hablar de algo. Por decirlo así, los entes o clases nombrados por las leyes no son meros objetos afectados por la prescripción y externos a ella, sino que son creaciones de la

que no es pacífica. Cfr. en LAMARQUE, ed. (1997) las entradas «Propositional Attitudes» (que incluye lamentar o desear) e «Intensionality» (que excluye buscar o desear). GARCíA SuÁREZ (1997: 278) hace un uso aún más amplio, que incluye decir y afirmar, y por tanto estudia los problemas referenciales causados por las citas en el contexto de las actitudes proposicionales. 
propia ley e internos a la prescripción. Esta se pone de manifiesto también en la distinción entre interpretaciones de dicto y de re, como veremos.

La opacidad referencial crea una ambigüedad pragmática en las expresiones nominales, por cuanto cabe dudar de si la intención de quien las usa - el legislador, digamos - es designar una realidad (uso extensional o referencial) o aludir a unas propiedades (uso intensional o atributivo). En el primer caso es indiferente cómo se nombre o describa la realidad si con ello queda identificada. En el segundo caso la denominación o descripción es lo que connota las diferencias intensionales, y por tanto es distintiva e insustituible. Como es la intensión, más que la extensión, lo que fundamenta la posibilidad de proyectar una descripción normativa a otros casos análogos, es decisivo comprender si un nombre o descripción legal tiene función referencial o atributiva. Y por eso la ambigüedad creada por los contextos opacos puede llegar a ser un problema jurídico.

Continuemos con otro famoso ejemplo de opacidad referencial propuesto por QUINE (1956). Supongamos que Ralph ve un hombre con sombrero marrón y cree que es un espía.

\section{(25) Ralph cree que el hombre del sombrero marrón es un espía.}

La expresión «el hombre con el sombrero marrón» tiene la ambigüedad pragmática que comentamos, porque no sabemos con certeza si tiene la función de referir la persona real que llevaba el sombrero (Orcutt, por seguir a QUINE) o de comunicar las características de la persona que el sujeto cree un espía, a saber: ser un hombre con sombrero marrón. Porque puede ocurrir, como dice QuINE, que Ralph vea en la playa a un hombre que cree de fiar, sin saber que es la misma persona (Ortcutt) que había visto con sombrero.

\section{(26) Ralph no cree que el hombre que vio en la playa sea un espia.}

La oraciones (25) y (26) son compatibles, pese a que designan la misma persona con mensajes contradictorios, porque estas oraciones no son acerca de esa persona (Orcutt), sino acerca de las hipotéticas personas descritas. Esta situación la provoca la construcción «cree que», la cual expresa una actitud proposicional y es «referencialmente opaca» (QUINE, 1956: 179). Como no podemos estar seguros de que «el hombre con sombrero marrón» en (25) tenga función referencial, no podemos saber cómo entender correctamente la oración. Esto se demuestra al intentar formalizar el enunciado, como enseña QuiNE.

(25a) Ralph cree que $(\exists x)$ ( $x$ es un espía).

(25b) $\quad(\exists x)$ (Ralph cree que $x$ es un espía).

La primera versión (25a) es la lectura de dicto (según lo dicho) de la misma oración (25): Ralph cree que hay alguien (un hombre con sombrero marrón) que es un espía. La segunda versión (25b) es la lectura de re (según la cosa) de la oración (25): hay alguien (un hombre con sombrero marrón) que Ralph cree que es un espía. Ambas lecturas son posibles, pero evidentemente no significan lo mismo. La segunda lectura (y formalización) no es posible en el caso relatado por QuINE. Ni tampoco en los casos de ambigüedad como:

(27) Ralph cree que alguien es un espía [Ralph believes that someone is a spy]. 
El derecho es un entorno fecundo para esta ambigüedad pragmática, porque se nutre de actitudes proposicionales. En realidad, todo el derecho puede reconstruirse como expresión de una actitud proposicional, y por tanto como contexto referencialmente opaco. Pensemos, por ejemplo, en el art. 5 CE ( «La capital del Estado es la villa de Madrid»):

\section{(28) El constituyente español quiso que la capital del Estado fuese la villa de Madrid.}

Esta oración (28) es referencialmente opaca, por cuanto cabría dudar si la expresión «la villa de Madrid» es extensional y se limita a designar la ciudad, de manera que es sustituible salva veritate por «Madrid» o por «la ciudad donde nació Carlos III»; o, por el contrario, aporta un significado adicional, una intensión, que no recogen otras fórmulas aparentemente sinónimas como esas.

Por lo demás, así como las normas jurídicas pueden reconstruirse como actitudes proposicionales del legislador, también puede reportase como citas en estilo indirecto:

(29) Según el derecho español, los españoles son mayores de edad a los 18 años.

Así las cosas, no sorprende que el derecho manifieste fenómenos causados por la opacidad referencial, como la ambigüedad de dicto/de re, de la que se ocupa el resto de este trabajo.

\section{LA AMBIGÜEDAD DE DICTO/DE RE}

ARISTÓTELES, en sus Refutaciones sofísticas ( $\$ 166 .{ }^{2} 20-30$ ), enumera lo que llama «composición» entre los argumentos con que se puede refutar a otro en función de su expresión. Son ejemplos de «composición» —escribe- «cosas tales como: es posible que el que está sentado camine y que uno que no escribe escriba» ${ }^{13}$. Los ejemplos de Aristóteles presentan varias capas de ambigüedad (necesidad/contingencia, potencia/ acto y otras); pero la que nos interesa aquí fue puesta de manifiesto en el siglo XII por Pedro ABELARDO, al notar que una oración como «Es posible que quien está de pie esté sentado» (possibile est stantem sedere) es susceptible de dos interpretaciones. Entendida per compositionem o de sensu (hoy se prefiere de dicto) afirma que es posible que alguien esté a la vez de pie y sentado, lo cual es falso. En cambio, entendida per divisionem o de re afirma que quien está de pie puede estar sentado en algún momento, lo cual puede ser verdadero ${ }^{14}$.

La posibilidad de interpretaciones de dicto y de re se explica por la diferente relación que se establece en cada una de ellas entre el nombre o la expresión nominal («quien está de pie») y el verbo o la estructura modal que crea la ambigüedad («es posible que»); y repercute en el grado de especificidad con que se entiende el propio nombre. La «estructura modal» causante de la ambigüedad se forma por circunstan-

13 La cita sigue así: «(pues no significa lo mismo que uno siga dividiendo o diga componiendo que es posible que el que está sentado camine; de la misma manera si uno establece por composición que el que no escribe escriba: pues significa que tiene capacidad de escribir mientras no escribe; en cambio, si no compone, significa que, cuando no escribe, tiene capacidad de escribir)» (ARISTÓTELES, ed. 1982, \$166. ${ }^{a} 20-30$ ).

14 Abelardo (ed. 1958: 13). Vid., al respecto, entre otros: KnEAle (1962: 624-625) y PINZANi (2003: 106 y ss.) 
cias diversas, pero entre ellas destacan las que ya vimos en el origen de los contextos intensionales: las menciones indirectas, las modalidades y las actitudes subjetivas o proposicionales. En la interpretación de dicto, el nombre se ve afectado o alcanzado por el verbo y forma parte de la estructura modal creada: es posible que alguien de pie esté sentado. El resultado es una versión inespecífica de «quien está de pie» (no es nadie en concreto) y una proposición falsa. En la interpretación de re, el nombre queda fuera del alcance del verbo y de la estructura modal: hay alguien de pie y es posible que esté sentado. El resultado es ahora una versión específica de «quien está de pie» (es una persona que está efectivamente de pie), y una proposición que puede ser verdadera.

La ambigüedad creada por la posibilidad de lecturas alternativas de dicto y de re se da en una gran cantidad de casos, también en el derecho. Estas situaciones tienen un claro aire de familia con los contextos opacos que hemos examinado en el apartado anterior, por cuanto en aquellas también hay oscuridad sobre la referencia. Además, las mismas condiciones que crean los contextos opacos crean también la ambigüedad de dicto/de re. Pero mientras que en la opacidad referencial genuina la incertidumbre se produce ante la posibilidad de términos con la misma extensión y distinta intensión, en cambio la ambigüedad de dicto/de re tiene lugar porque un mismo término puede tener al menos dos extensiones distintas, una más específica que la otra. Esta ambigüedad no se debe a la homonimia ni a la polisemia de las palabras, aunque puede manifestarse como ambigüedad léxica, sino a razones sintácticas y pragmáticas que solo pueden captarse con precisión con ayuda de la lógica ${ }^{15}$.

Como quedó apuntado, la ambigüedad de dicto/de re guarda estrecha relación con la ambigüedad inespecífico/específico, y no es fácil deslindarlas. La Nueva gramática de la lengua española (REAL ACADEMIA ESPAÑOLA, 2009, \$\$ 15.9 y 15.10) las trata conjuntamente y presenta a la primera ambigüedad como una variante de la segunda, provocada por un «inductor modal» externo al grupo nominal. Por su concisión y relevancia para nuestro tema, merecen cita estos fragmentos:

La ambigüedad que se da en los contextos de inducción modal entre la interpretación específica, denominada LECTURA DE RE en la tradición lógica, y la inespecífica, llamada generalmente LECTURA DE DICTO en esa misma tradición, tiende a vincularse al distinto ÁMBITO O ALCANCE que en cada caso tiene el inductor contenido en la oración con respecto al grupo nominal. Así, los dos enunciados siguientes contienen un inductor modal, el condicional [...]: Me gustaría ver una película; Hay una película que me gustaría ver. Como se puede comprobar, frente a las dos interpretaciones que admite una película en el primero (es decir «una película concreta de un género concreto», o bien «una película cualquiera»), en el segundo tan solo es posible la lectura específica («una película cualquiera») (\$15.10b, vol. I: 1140).

En general, la interpretación específica de un grupo nominal indefinido se obtiene cuando este no se ve afectado por la presencia del operador modal, de modo que se dice

15 Las referencias a la ambigüedad de dicto/de re abundan en los estudios de lógica y de filosofía de lenguaje, entre ellos varios de los ya citados, como KnEALE (1960), LAMARQue, ed. (1997: 316-319, passim) o GARCíA SuÁREZ (1997: 279). También la lingüística se ha ocupado de esta ambigüedad, así GuTIÉRREZ ORDÓÑEZ (1995). En cambio, la doctrina jurídica apenas la ha tratado, por lo que me consta. Entre las escasas excepciones: YAFFE (2011) y ANDERSON (2014). Pero estos autores tratan también como ambigüedad de dicto/ de re algunos problemas de indeterminación semántica sin causa lógico-sintáctica, tales como la ambigüedad específico/inespecífico de los nombres de cargos, como «el gobernador de California» (YAFFE, 2011: 194): vid. infra $\$ 2.2 .1$. 
que - en la lectura de re- el grupo nominal indefinido queda fuera de su ámbito. En la interpretación inespecífica o de dicto, la relación entre ambas unidades es la contraria: el operador toma dentro de su ámbito al grupo nominal, por lo que la referencia de este se ve condicionada o determinada por aquel ( $\$ 15.10$ c, vol. I: 1140).

Los entornos modales que inducen a la interpretación inespecífica de los grupos nominales indefinidos se denominan en la tradición lógica CONTEXTOS OPACOS O INTENSIONALES. Estos entornos, muy a menudo prospectivos, permiten dejar en suspenso la existencia del referente de alguno de los argumentos de la predicación. Focalizan, pues, su mera INTENSIÓN, es decir, su significado, por tanto las propiedades que caracterizan a los elementos que dicho argumento designa. Este fenómeno se conoce como OPACIDAD REFERENCIAL. Así, el complemento directo de la oración Busco un taxi que me lleve al aeropuerto no se refiere a ningún taxi en particular, e incluso podría ser que en el momento en que se emite el enunciado no hubiera vehículo alguno que pudiera satisfacer tal descripción. La interpretación semántica obtenida está, pues, inducida por la naturaleza prospectiva del verbo buscar [...] y también [...] por la presencia del subjuntivo, ya que la oración Busco un taxi que tiene un vidrio quebrado se referiría a un taxi en particular (\$15.10d, vol. I: 1140).

La Nueva gramática advierte también que «existen muchas diferencias entre los especialistas en cuanto a si la (in)especificidad es un fenómeno semántico o más bien pragmático» ( $\$ 15.9 \mathrm{~d}$, vol. I: 1135$)$. No es de extrañar, porque las situaciones que crean especificidad o inespecificidad son muy variadas. En cualquier caso, el resultado es una ambigüedad semántica cuya raíz es pragmática, porque tiene que ver con las intenciones del hablante y con el modo en que el oyente las capta dado el conocimiento del entorno que cada uno de ellos tiene y que en alguna medida comparten. Por otro lado, esta ambigüedad también es sintáctica, ya que tiene que ver con la estructura de las oraciones y con la función que en ella desempeñan sus componentes.

Observemos esta oración, inspirada en (27):

(30) Raúl cree que un vecino es un espía.

Aquí hay tres posibles lecturas (simbolizo «ser un vecino» como «v») ${ }^{16}$ :

$\left(30 a_{1}\right)$ Raúl cree que todo posible vecino es un espía, que quien sea vecino es un espía. Raúl cree que $(\forall v)$ ( $v$ es un espía). Lectura de dicto, inespecífica y universal.

$\left(30 a_{2}\right)$ Raúl cree que algún vecino suyo es un espía; sospecha que hay un vecino espía. Raúl cree que $(\exists v)$ ( $v$ es un espía). Lectura de dicto, inespecífica pero singular.

(30b) Raúl cree que cierto vecino suyo es un espía; hay un vecino de quien sospecha. $(\exists v)$ (Raúl cree que $v$ es un espía). Lectura de re, específica.

Todo indica que confluyen aquí factores léxicos, sintácticos y pragmáticos para crear la ambigüedad. Lo mismo ocurre en muchas oraciones del lenguaje jurídico. A continuación pondré algunos ejemplos tomados del Código Penal español (CP), cuya especial relevancia es innecesario subrayar. Mostraré primero un grupo de ejemplos donde es ambigua la construcción «un + grupo nominal»; y en segundo lugar ejemplos donde la ambigüedad de dicto/de re se solapa con otras modalidades de la ambigüedad específico/inespecífico, en las que ya se reconocen causas léxicas.

16 Descarto una cuarta lectura, según la cual Raúl cree que todos los vecinos que hay son espías [ $\forall v$ (Raúl cree que $v$ es un espía)], porque la oración (30) no la admite. Para expresar esa idea habría que decir algo así: Raúl cree que los vecinos son espías. Lo cual también podría leerse de dicto [Raúl cree que $\forall x$ ( $x$ es un espía)]. 


\subsection{Indefinición referencial}

\subsection{1. «Un preso»}

Art. 470.1 CP: «El particular que proporcionare la evasión a un condenado, preso o detenido, bien del lugar en que esté recluido, bien durante su conducción, será castigado con la pena de prisión de seis meses a un año y multa de doce a veinticuatro meses».

Del art. 470.1 CP podemos extraer el siguiente enunciado jurídico:

(31) Es delito proporcionar la evasión a un preso del lugar en que esté recluido.

Este enunciado es ambiguo, porque admite dos interpretaciones:

(31a) De dicto: proporcionar la evasión a un posible preso (hipotético).

(31b) De re: proporcionar la evasión a un preso concreto (real).

Con la primera interpretación sería delito abrir las puertas de una prisión o difundir sus claves de seguridad sin saber si hay o no presos dentro, sin que los haya o sin que, de haberlos, ninguno se evada. Con la segunda interpretación, para que haya delito ha de haber al menos un preso al que se presta ayuda; e incluso (aunque esto es asunto aparte) que consiga evadirse. La lectura de re es la que viene primero a la mente, sin duda incitada por «que esté recluido»: nos imaginamos una persona real presa a quien el autor del delito ayuda a fugarse. La jurisprudencia y la doctrina ni se plantean otra $\cos a^{17}$. Pero la lengua española, dada la estructura sintáctica del artículo, sí permite otra lectura alternativa. Recordemos el ejemplo de la Nueva gramática: «Busco un taxi que me lleve al aeropuerto» ${ }^{18}$.

17 Vid., entre la jurisprudencia, la SAP Castellón 67/2003, de 12 de marzo (FD 2..$^{\circ}$ : «La simple lectura del precepto pone de manifiesto que el tipo penal no menciona solo el proporcionar o favorecer la evasión, sino que exige también como requisito integrante del mismo que se favorezca la evasión del lugar donde se esté recluido o durante su conducción. [...] Esta y no otra es la interpretación literal que debe hacerse del artículo 470.1 del Código Penal en cuanto existe como requisito del tipo no solo que se proporcione la evasión a un condenado, preso o detenido, sino también que lo sea del lugar en que esté recluido o durante su conducción desde ese lugar». En la doctrina, por ejemplo, QUERALT (2015: 1293): «Se trata de un delito de favorecimiento del hecho de otro, aquí del privado de libertad; [...]. Se trata, en fin, de connivencia con el fugado». También García AlbERO (en QuiNTERO OLIVARES, 2011, II: 1428): «Se contempla en este precepto la conducta del tercero que proporciona la violación de una situación de guarda o custodia del condenado, preso o detenido». Esto es, del preso, no de un preso. Además GARCía AlBERO asume que el delito se comete únicamente si alguien de hecho se evade, pues consiste en realizar «actos sin los cuales la evasión no se hubiese realizado» (ibid., 1430). Si así fuera, quedaría excluida una interpretación de dicto extensible al supuesto de que ningún preso reciba efectivamente la acción del autor del delito. Sin embargo, el artículo nada dice acerca del resultado del acto (doloso) de proporcionar los medios para una evasión. La acción de una evasión que el agente cree probable basta para integrar el tipo, al menos cuando se interpreta de dicto, sin necesidad de que se evada preso alguno; e incluso sin que haya preso alguno susceptible de evadirse y sea imposible lo que el agente creía probable.

18 Adviértase que la diferencia entre las interpretaciones de dicto y de re del art. 470.1 CP no estriba propiamente en negar o afirmar que la evasión es una condición del delito. Por un lado, la lectura de re es compatible con entender que el delito es la actividad de proporcionar la evasión de un preso aunque no se produzca ese resultado. Cabría objetar que «proporcionar» una evasión no es simplemente facilitarla, sino que la ayuda ha de ser determinante para que la evasión se produzca, y esto solo puede comprobarse si se produce. Así parece entenderlo la mayoría de la doctrina. Sin embargo, «proporcionar» no es conseguir u obtener, sino «poner a disposición de alguien lo que necesita o le conviene» (dice el Diccionario de la Real Academia Española). En los términos del artículo, proporciona la evasión de un preso quien pone a disposición de este los medios para evadirse, y esta conducta es anterior a la eventual evasión e independiente de ella. Por otro lado, la lectura de dicto es compatible con entender que proporcionar la evasión de un preso es un delito de resultado. La clave de la lectura de dicto es que no hay ningún preso específico cuya evasión se proporciona. Esto sucede 
Una explicación verosímil de la predisposición de los juristas a la lectura de re, que es a menudo la única que se acepta, puede ser el efecto de heurísticos, prejuicios o sesgos cognitivos como la disponibilidad o la representatividad (vid. ANDERSON, 2014). Todos, incluidos jueces y demás juristas, al interpretar una situación o al resolver un problema tendemos a sobredimensionar los casos que nos vienen a la mente y los que nos parecen representativos, y a infravalorar otras posibilidades aunque estas sean más probables. Esto ha sido comprobado experimentalmente, con resultados a menudo sorprendentes ${ }^{19}$. Dada nuestra condición psicológica, es natural que en los planteamientos ambiguos, a falta de indicadores que sugieran lo contrario, prefiramos las interpretaciones asociadas a personas y situaciones reales que nos imaginamos fácilmente, en vez de las hipótesis y los supuestos imaginarios.

\subsection{2. «Un menor de edad»}

Considérese ahora el art. 188.1 CP y las posibles interpretaciones de un enunciado jurídico que describe parte de su contenido:

Art. 188.1 CP: «El que induzca, promueva, favorezca o facilite la prostitución de un menor de edad o una persona con discapacidad necesitada de especial protección, o se lucre con ello, o explote de algún otro modo a un menor o a una persona con discapacidad para estos fines, será castigado con las penas de prisión de dos a cinco años y multa de doce a veinticuatro meses».

(32) Es delito promover la prostitución de un menor de edad.

(32a) De dicto: promover que algún posible menor sea víctima de prostitución.

(32b) De re: promover que un menor concreto (real) sea víctima de prostitución.

En la lectura de dicto es delito alentar la prostitución infantil en publicaciones o películas aunque no las vea ningún menor. No así en la lectura de re, que exige que haya al menos un menor que sea víctima de la actuación delictiva. Nótese que la diferencia de interpretaciones no depende de si ha de haber o no un menor que efectivamente sufra prostitución. En ninguna de las dos lecturas se requiere (es un asunto aparte) que la actividad de promover la prostitución tenga el resultado que busca. La diferencia estriba en si ha de haber o no un menor que sea víctima de la actividad promocional, aunque esta no logre su propósito. En este punto, como cabría esperar, la tónica es la lectura de re ${ }^{20}$.

claramente cuando no hay ningún preso que se evade, pero puede suceder también cuando un preso se evade como consecuencia de la actuación de un «particular» que no sabe de su existencia. Por lo demás la exigencia de dolo tampoco es inconveniente para la lectura de dicto, porque bastaría con la voluntad de que se produzca la evasión de algún preso. Nada en el artículo exige que el agente quiera que se evada una persona específica. Ni siquiera hay que acudir a la noción de dolo eventual, entendido como la aceptación de un daño que no se buscaba, porque cabe exigir que el agente quiera la evasión que proporciona. La peculiaridad de la lectura de dicto es, simplemente, que el agente no tiene que dirigir su acción intencional hacia nadie en concreto.

${ }_{19}$ En uno de los experimentos más famosos (KAHEMANN y TVERSKY, 1974) se preguntaba por la profesión más probable de un hombre con esta descripción (traduzco aproximadamente): «Es muy tímido y retraído, siempre dispuesto a ayudar, pero con escaso interés en la gente, o en el mundo real. Un personalidad dócil y organizada, necesita orden y estructura, y tiene pasión por el detalle». Las respuestas sistemáticamente asignaban mayor probabilidad a «bibliotecario», cuyo estereotipo estaba representado en la descripción, que a otras profesiones mucho más abundantes, y por tanto, mucho más probables, como «granjero».

${ }_{20}$ En la jurisprudencia se admite la posibilidad de que haya delito sin que ningún menor llegue a prostituirse, pero (hasta donde sé), no sin que haya un menor involucrado. Dice la STS (Penal) 152/2008, de 8 de 
La lectura de dicto de la expresión «un menor de edad» en el Código Penal no ha de verse como una interpretación extensiva ajena a lo que dice expresamente (y por tanto vetada por su art. 4.1), porque puede formar parte del sentido propio del texto. Por ejemplo, el art. 189.1 CP precisa así lo que se considera pornografía infantil:

a) Todo material que represente de manera visual a un menor o una persona con discapacidad necesitada de especial protección participando en una conducta sexualmente explícita, real o simulada. [...]

d) Imágenes realistas de un menor participando en una conducta sexualmente explícita o imágenes realistas de los órganos sexuales de un menor, con fines principalmente sexuales.

La referencia a «un menor» en el primer inciso es ambigua, por cuanto puede designar a un menor específico (lectura de re) o a algún menor inespecífico e incluso inexistente (lectura de dicto). Pero en el otro inciso $d$ ) la referencia a «un menor» es claramente de dicto, porque al hablar de «imágenes realistas» incluye expresamente la posibilidad de que el menor no sea una persona real sino una mera imagen virtual.

\subsection{3. «Una mujer»}

Art. 144 CP: «El que produzca el aborto de una mujer, sin su consentimiento, será castigado con la pena de prisión de cuatro a ocho años e inhabilitación especial para ejercer cualquier profesión sanitaria, o para prestar servicios de toda índole en clínicas, establecimientos o consultorios ginecológicos, públicos o privados, por tiempo de tres a diez años.

Las mismas penas se impondrán al que practique el aborto habiendo obtenido la anuencia de la mujer mediante violencia, amenaza o engaño».

(33) Es delito producir el aborto de una mujer sin su consentimiento.

(33a) De dicto: producir que una mujer cualquiera (inespecífica) aborte.

(33b) De re: producir que una mujer determinada (específica) aborte.

En este supuesto ambas lecturas requieren que haya una mujer real y existente, pues el aborto ha de producirse (no basta con facilitarlo o provocarlo). Pero es ambi-

abril (FD 6. ${ }^{\circ}$ ): «Inducir, promover, favorecer y facilitar son conductas que, aun estando orientadas a la consecución de un determinado propósito, agotan su propia entidad aunque el mismo no se alcance, por lo que cabe entender que su contenido del injusto es independiente de que se produzca o no el resultado querido por el sujeto activo». En el mismo sentido, STS (Penal) 809/2006, de 18 de julio (FD 2. ${ }^{\circ}$ ), STS (Penal) 510/2010, de 21 de mayo (FD 1. ${ }^{\circ}$ ) y Auto del TS (Penal) 1317/2014, de 4 de septiembre. En la doctrina, puede verse QUERALT (2014: 280): «Lo decisivo es, pues, un eficaz influjo psicológico, que haga nacer o desarrolle el deseo de prostituirse del menor». Además, el dolo requiere que haya una víctima real: «Se trata de un delito doloso; ha de abarcar el conocimiento de la menor edad o discapacidad de la misma» (ibid., 281). Las modalidades comisivas son amplias, pero no tanto como para abstraer la víctima. Al respecto dice CUGAT (en ÁLVAREZ GARCÍA, 2010, I: 491): «Los términos en los que se describe la conducta delictiva permite incluir cualquier tipo de contribución a la prostitución del menor o incapaz». Porque «la víctima del delito es el menor o incapaz» (ibid.). Nótese: el menor. Una interpretación más extensiva del tipo la defienden MORALES PRATS y GARCÍA Albero (en QuinTERO, 2011, I: 1207): «Trata pues el Código de incriminar, indiferenciadamente, conductas que inciden, con mayor o menor intensidad, en la conformación de un mercado de prostitución de menores». Además - añaden - «el tipo se configura como infracción de mera actividad que no exige de un resultado separable o añadido a la acción de inducir, promover, favorecer o facilitar»; de modo que «no es preciso que el menor llegue materialmente a prostituirse, bastando el peligro o riesgo de que subsiga tal resultado (STS 21 mayo 2010)» (ibid., 1208). 
guo si el tipo penal exige o no que el autor trate directamente con la víctima ${ }^{21}$. La lectura de dicto calificaría dentro del tipo, por ejemplo, diseminar una sustancia abortiva en un comedor universitario para causar el aborto de alguna mujer embarazada que pudiese consumirla inadvertidamente, siempre que la acción resulte efectivamente en un aborto. En la lectura de re, en cambio, el autor ha de conocer a la mujer que aborta y actuar sobre ella. Los casos que se plantean en la jurisprudencia y en la doctrina son de esta segunda lectura ${ }^{22}$.

\subsection{4. «Una persona»}

La expresión «una persona» abunda en el Código Penal y normalmente hace clara referencia a una persona real que es víctima del delito. Muchos delitos requieren para existir que el perjuicio o la acción se concreten en una víctima específica, que la redacción legal nombra de manera genérica o inespecífica como «una persona» ${ }^{23}$. En tales casos el contexto semántico y pragmático determina que la interpretación de re de la fórmula «una persona» sea la única posible y la única admitida en la práctica por los juristas. Pero esta lectura de re tiene otras veces alternativas y en ocasiones ni siquiera es admisible. Por ejemplo, el Código Penal español emplea la expresión de dicto en el art. 127 quater, al autorizar el decomiso de efectos y ganancias transferidos a terceros «cuando una persona diligente habría tenido motivos para sospechar, en las circunstancias del caso, de su origen ilícito». Claramente, el artículo no alude a ninguna persona diligente específica pero todavía desconocida, sino a una clase de personas que incluso puede ser hipotética: el artículo es inteligible aunque no haya en el mundo ninguna persona diligente. Es decir, el Código Penal normalmente se refiere a personas reales y efectivas, pero a veces no; y puede ser un problema determinar cuál es el caso. La posibilidad de lecturas de dicto de expresiones como «una persona» en el Código Penal debe alertar a quienes preferirían adoptar una actitud de incredulidad o escepticismo hacia la ambigüedad de dicto/de re. Las lecturas de dicto son posibles y vigentes en el derecho, y en ocasiones son posibles simultáneamente (ambiguamente) con las lecturas de re.

21 En ambas interpretaciones el delito requiere una mujer real que aborta, pero en la lectura de re la mujer ya está identificada antes del aborto, mientras que en la lectura de dicto la concreción no es necesaria antes del aborto. La diferencia se ve quizás más claramente aplicando la teoría del dolo eventual. Con esta doctrina, el agente comete el delito del art. $144 \mathrm{CP}$ aunque no quiera producir el aborto de ninguna mujer: basta con que quiera los actos que llevan a ese resultado. En tal caso, «una mujer» se refiere a una persona real, pero inespecífica.

22 VAlle MuÑIZ y Quintero (en Quintero, 2004, 94) subrayan que «se prohíbe la producción de un aborto sin más especificaciones» y que el resultado «puede ser alcanzado de cualquier forma». Sin embargo, para Cugat (en Álvarez García, 2010, I, 131) esto «no significa que cualquier conducta que de algún modo contribuya al aborto, realice el tipo». En cualquier caso, ninguno plantea supuestos de dolo dirigido a una víctima abstracta.

23 El Código Penal se refiere a víctimas reales de actos o de hechos, por ejemplo, cuando habla de «la muerte de una persona» (arts. 131.3 o 133.2), el acoso a «una persona» (art. 172 ter), el atentado «contra la integridad moral de una persona» (art. 175), no socorrer a «una persona que se halle desamparada y en peligro manifiesto y grave» (art. 195), etc. El art. 510 CP es un caso especial, pues habla de incitar al odio y de otras actuaciones «contra una persona determinada», con lo cual subraya que en este delito ha de haber una víctima específica; pero suscita la pregunta de si han de recibir una interpretación distinta, a contrario sensu, los delitos donde el tipo se refiere genéricamente a «una persona» sin cualificarla como determinada. 
Así las cosas, la dificultad estriba en detectar y resolver los casos de ambigüe$\mathrm{dad}^{24}$. Por ejemplo, hay ambigüedad en la expresión «una persona con discapacidad» empleada en el art. 188.1 CP, idéntica a la examinada en la expresión «un menor de edad» que le precede; y también en el art. 189.1, también citado, al precisar lo que se considera pornografía infantil. Asimismo, cabe apreciar ambigüedad en la fórmula «alguna persona» del art. $313 \mathrm{CP}:$ «El que determinare o favoreciere la emigración de alguna persona a otro país simulando contrato o colocación, o usando de otro engaño semejante». Aunque la conducta de determinar la emigración parece requerir una persona concreta que emigre, no así la de favorecer la emigración, pues la acción puede realizarse aunque nadie emigre. Por eso el delito de favorecer la emigración de alguna persona simulando contrato o colocación admite tanto lecturas de re (según la cual ha de haber un emigrante involucrado) como de dicto (según la cual puede haber delito sin emigrantes involucrados); y la primera es la normal ${ }^{25}$.

La concordancia de los arts. 164 y $168 \mathrm{CP}$ nos ofrece otro ejemplo de ambigüedad en la expresión «una persona». El art. $164 \mathrm{CP}$ castiga «el secuestro de una persona exigiendo alguna condición para ponerla en libertad»; lo cual solo puede leerse de re, pues para que haya secuestro ha de haber una víctima real secuestrada. Pero el art. $168 \mathrm{CP}$ castiga «la provocación, la conspiración y la proposición para cometer los delitos previstos en este Capítulo», entre los cuales está «el secuestro de una persona» castigado en el art. 164 CP. Por tanto, es delito la proposición para cometer el secuestro de una persona. Lo cual puede interpretarse de dicto (proponer el secuestro de alguien, sin concretar la víctima) o de re (proponer el secuestro de alguien en particular) ${ }^{26}$.

24 Algunos supuestos de potencial ambigüedad son tan insólitos que difícilmente serían tomados en serio si se planteasen en la práctica. Son casos donde el lenguaje crea la ambigüedad pero los usos jurídicos la despejan, y se resolverían eventualmente con una reducción al absurdo. Por ejemplo el art. 456.1 CP sanciona a: «Los que, con conocimiento de su falsedad o temerario desprecio hacia la verdad, imputaren a alguna persona hechos que, de ser ciertos, constituirían infracción penal, si esta imputación se hiciera ante funcionario judicial o administrativo que tenga el deber de proceder a su averiguación». La lectura obvia y natural del artículo toma de re la expresión «alguna persona», entendiendo que hay alguien concreto víctima de la calumnia. Pero desde un punto de vista puramente lingüístico la redacción legal admite también una lectura de dicto, según la cual habría delito si se denuncia falsamente una infracción penal ante un funcionario que deba investigarla diciendo que hubo de cometerla alguna persona, pero sin especificar quién. El bien protegido ya no sería aquí el honor de nadie, sino el mismo interés público que protege el art. 457 CP (que castiga a quien denuncia una infracción legal inexistente, provocando actuaciones procesales). De hecho, la lectura de dicto del art. 456.1 CP hace redundante esa parte del art. $457 \mathrm{CP}$; lo cual es, sin duda, un argumento para rechazarla, añadido a su propia extravagancia. Pero ni la extravagancia ni la redundancia eliminan completamente la ambigüedad.

${ }^{25}$ Así, Villacampa Estiarte (en Quintero Olivares, 2014, II: 595) alude repetidamente al «sujeto pasivo del delito», dando a entender que no contempla la posibilidad de que este delito carezca de un sujeto pasivo. Es verdad que el requisito de que la conducta de favorecer la emigración se haga «simulando contrato o colocación» invita a pensar en una persona concreta contratada ficticiamente. Pero no hay razón lingüística para excluir la posibilidad de cometer el delito favoreciendo la emigración con falsas ofertas de contratación innominadas, dirigidas a potenciales emigrantes, incluso antes de que esas ofertas lleguen a atraer de hecho a nadie.

26 Quintero (en Quintero Olivares, 2011, I: 1032) relaciona este artículo con «los responsables de los actos preparatorios» de los delitos de detención ilegal y secuestro; y destaca que, a efectos de determinar la pena, «la duración del secuestro» puede ser desconocida con anticipación. Con esto da a entender que el delito consiste en haber preparado un secuestro o una detención efectivamente producidos, por tanto de una persona real. El modo en que QUINTERO se expresa excluye la posibilidad de aplicar el tipo a quien propone un secuestro en abstracto, sin víctima prefijada, pero con intención clara y plan suficiente para que se lleve a cabo. 


\subsection{Doble inespecificidad}

Una oración puede poseer ambigüedad específico/inespecífico por razones sintácticas o semánticas que se combinan o se solapan con la distinción lógica de dicto/de re. En tales casos esta distinción ayuda a interpretar la oración y a reconocer las alternativas disponibles. Veamos algún ejemplo.

\subsection{1. «El Rey»}

Los nombres de cargos y posiciones tienen una característica ambigüedad inespecífico/específico, porque puede entenderse que designan al cargo (interpretación atributiva, inespecífica) o a quien lo desempeña (interpretación individual o referencial, específica). Por ejemplo, «el rey» puede referirse a la institución («El rey puede ser menor de edad») o a la persona («El rey tiene dos hijas»). Cuando esta ambivalencia se combina con la ambigüedad de dicto/de re, el resultado es una doble ambigüedad.

Art. 490.2 CP: «Con la pena de prisión de tres a seis años será castigado el que amenazare gravemente a cualquiera de las personas mencionadas en el apartado anterior [entre ellas: $e l$ Rey], y con la pena de prisión de uno a tres años si la amenaza fuera leve».

(34) Es delito amenazar gravemente al Rey.

$\left(34 a_{1}\right)$ De dicto atributiva: amenazar a la Casa Real.

$\left(34 a_{2}\right)$ De dicto individual: amenazar a la persona que sea rey (ahora o en el futuro)

$\left(34 b_{1}\right)$ De re atributiva: amenazar a la persona que es rey por serlo.

$\left(34 b_{2}\right)$ De re individual: amenazar a la persona que es rey sin tener en cuenta que lo es.

En la lectura de dicto el sustantivo «Rey» no se refiere a ninguna persona concreta. En la versión atributiva no se refiere a ninguna persona, sino a la institución. Se castigaría a quien amenazase de muerte a la «Casa Real» o a la «Monarquía»; y en general a la institución real como tal institución ${ }^{27}$. En la versión de dicto individual, «rey» refiere a una persona posible; y sería delito, digamos, amenazar con matar dentro de veinte años a quien sea entonces rey, si alguien lo es. La lectura de re, que invoca una persona física y actual con título de rey, también tiene dos interpretaciones. En la atributiva solo sería delito amenazar a quien se sabe que es rey y porque lo es. En la versión individual sería delito amenazar de muerte a un motorista con casco que resulta ser el rey. La lectura de re atributiva es la más próxima a los juristas, pero no la única posible ${ }^{28}$.

27 Esta interpretación es extraña, pero sorprendentemente posible. Al parecer (no he podido localizar la sentencia), la Audiencia Nacional condenó el 17 de marzo de 2015, tras un acuerdo de conformidad, a una persona que escribió en Twitter (junto a otras amenazas): «Algún día asesinaré a la Casa Real» (noticia publicada el 18 de marzo de 2015 por Europa Press: http://www.europapress.es/nacional/noticia-condenadospagar-380-desear-muerte-rey-twitter-20150318133658. btml. Enlace comprobado el 21 de julio de 2016). Con todo, una interpretación así fuerza el significado de «Rey» y choca con el tenor del art. 490.2 CP, que habla de amenazar a «las personas». Para castigar las amenazas a instituciones la redacción debería ser otra, en el estilo del art. 504.1 CP, se refiere a «los que calumnien, injurien o amenacen gravemente al Gobierno de la Nación, al Consejo General del Poder Judicial, al Tribunal Constitucional», etc. Estas son fórmulas que designan las instituciones y no sus miembros.

28 Téngase en cuenta que el apartado 3 del mismo art. $490 \mathrm{CP}$ castiga al que «calumniare o injuriare al Rey [...] en el ejercicio de sus funciones o con motivo u ocasión de estas», con lo cual sugiere a contrario que el apartado 2 no requiere que la amenaza se dirija al rey en ejercicio de sus funciones. TAMARIT SUMALLA y Rodríguez Puerta (en Quintero Olivares, 2011, II: 1470) consideran — con Córdoba Roda- que 


\subsection{2. «Otro»}

Muchos artículos del Código Penal utilizan la palabra «otro» en su acepción pronominal, para referir a una persona indeterminada pero específica. Así, se castiga al que «matare a otro» (art. 138), «causare a otro una lesión» (art. 147), «encerrare o detuviere a otro» (art. 164), etc. En estos casos no hay ninguna ambigüedad, porque la lectura de re es la única posible. Esos artículos tratan sobre personas reales víctimas del delito. Pero a veces la redacción legal suscita la duda de si el artículo se refiere a una persona concreta y real o a una persona en abstracto $^{29}$. Es el caso del art. $248.1 \mathrm{CP}$ que abre este trabajo.

Art. 248.1 CP: «Cometen estafa los que, con ánimo de lucro, utilizaren engaño bastante para producir error en otro, induciéndolo a realizar un acto de disposición en perjuicio propio o ajeno».

Es delito utilizar engaño bastante para producir error en otro induciéndole...

En la lectura inespecífica (35a) sería delito crear una apariencia de empresa eficaz para captar dinero ajeno sin dar contraprestación alguna, aunque nadie llegue a caer en el engaño. En la lectura específica $(35$ b), por supuesto la habitual, no hay estafa sin una víctima concreta ${ }^{30}$. Esta ambigüedad entre versiones inespecíficas y específicas de «otro» es análoga a la ambigüedad de dicto/de re que veíamos en «una persona»; y de hecho en la mayoría de los casos «otro» podría sustituirse por «una persona» con resultado jurídicamente idéntico (son expresiones correferentes y tienen la misma intensión).

«debe exigirse que la amenaza llegue a conocimiento del sujeto pasivo». Esta condición es incompatible con la interpretación de dicto que incluye en el tipo la amenaza a un eventual rey futuro. Personalmente creo que es una condición sensata, pero, no obstante, la lectura de dicto cabe en la letra del artículo. También es sensato exigir que el autor conozca la identidad real (valga el juego de palabras) de la persona amenazada. En su comentario del supuesto análogo contenido en el art. 485.1 CP («El que matare al Rey...»), dicen Tamarit Sumalla y Rodríguez Puerta (en Quintero Olivares, 2011, II: 1466): «El dolo debe abarcar el conocimiento de la identidad y la condición de las personas especialmente protegidas». Por tanto, se prefiere (con exclusión de otras) la lectura de re inespecífica, donde la víctima del delito es una persona concreta (existente), pero no la persona por sí misma (como individuo específico), sino por su estatus (como titular de una institución).

${ }^{29}$ Incluso las leyes penales claramente orientadas de re pueden tener lecturas de dicto en caso de tentativa. El delito de «matar a otro» exige sin duda una víctima, pero la tentativa de matar a «otro» podría ser punible aunque no vaya contra nadie en particular o nadie estuviese realmente en peligro de muerte (por ejemplo, si un individuo entra en un colegio con un fusil, abre la puerta de un aula y dispara repetidamente, pero no hay nadie dentro).

${ }^{30}$ Dicen Valle MuÑIZ y Quintero (en Quintero, 2004, 631): «Si algo caracteriza al delito de estafa con respecto al resto de delitos de enriquecimiento es la necesidad, en el iter comisivo, de la cooperación del sujeto víctima del engaño, lo que se formaliza a través del requisito del acto de disposición». La interpretación ortodoxa no ve delito cuando hay una víctima potencial, pero no actual. Dice QUINTERO (en QUINTERO, 2011, II: 81): «El engaño es idóneo si realmente ha producido un error»; y «culmina con el acto de disposición, que por ser algo que realiza el "engañado" exige la identidad personal entre disponente y engañado». Por otra parte, no hay estafa sin daño real, no basta con crear un riesgo por grave que sea: «La estafa es un delito de resultado material que exige la lesión del bien jurídico protegido que es el patrimonio ajeno, en el que ha de provocar una mengua» (ibid., 82). Crear un riesgo sería a lo sumo tentativa: «La tentativa solo cabría en casos de engaño idóneo pero en los que la víctima no llega a realizar el acto de disposición por causas sobrevenidas» (ibid.). 
Como se apuntó en la Introducción, la palabra «otro» se usa en español para referirse a personas concretas («Pedro acusó a otro») o abstractas («Pedro fingió ser otro»); y a veces de modo ambiguo («Pedro se hizo pasar por otro»). No hay ambigüedad cuando la información contextual o semántica la despeja, y esto ocurre a menudo. Por ejemplo, el art. $401 \mathrm{CP}$ dice: «El que usurpare el estado civil de otro será castigado con la pena de prisión de seis meses a tres años». Simular el estado civil de «otro» puede entenderse de re, referido a una persona concreta y real a la que se suplanta; o de dicto, referido a una identidad distinta del sujeto, aunque sea ficticia. Pero el artículo no habla de «simular» ni de «adoptar», sino de «usurpar», y la semántica de este verbo exige una víctima concreta y real (no se puede «usurpar» una identidad ficticia). Si el legislador quiere evitar la ambigüedad cuando la detecta en el proceso de redacción legislativa, hará bien introducir marcadores semánticos como este para dirigir la interpretación en un solo sentido.

Un problema especialmente difícil en el tema que tratamos es interpretar el castigo de la inducción del delito. El art. $28 \mathrm{CP}$ considera autores del delito a «los que inducen directamente a otro u otros a ejecutarlo». En teoría, «otro» puede leerse de dicto, según lo cual es autor quien induce a cometer delitos aunque nadie en concreto sea inducido. Sin embargo la tesis doctrinal más extendida es que la inducción penada en el art. 28 $\mathrm{CP}$ requiere que el hecho delictivo que se induce se cometa efectivamente, lo cual implica naturalmente que el sujeto inducido ha de ser una persona real y existente y no una mera posibilidad teórica. Pero esta doctrina es frágil y sus implicaciones no son del todo claras. Por ejemplo, no está claro cómo afecta al delito de inducción al suicidio (art. $143 \mathrm{CP}$ ) o al de inducción de menores a la prostitución (art. 188.1 CP); porque la doctrina da respuestas diferentes a cada caso. «El que induzca al suicidio de otro será castigado con la pena de prisión de cuatro a ocho años», dice el art. 143.1 CP. En teoría este tipo penal podría entenderse como un delito de actividad (la inducción) que no requiere la producción efectiva del resultado buscado (el suicidio); en cuyo caso por «otro» cabría entender no solo una persona actual a quien el autor insta a suicidarse (lectura de re), sino también un suicida potencial cualquiera, que podría no llegar a existir o ser desconocido para el autor. Pero esta interpretación teórica es inviable por cuanto la jurisprudencia y la doctrina condicionan el castigo penal de la inducción a que sea exitosa. Ha de haber un suicida, y el «otro» que menciona el artículo es ese suicida, por tanto una persona real y no una mera posibilidad ${ }^{31}$. De esta manera, la potencial ambigüedad de la palabra «otro» en el art. 143.1 CP, donde puede referirse a alguien concreto e identificado o a alguien abstracto y meramente posible, se despeja de derecho, porque no hay inducción al delito sin delito, ni inducción al suicidio sin suicida $^{32}$. En cambio, como ya vimos, no ocurre lo mismo al interpretar el art. 188.1 CP

31 Como indica Quintero en su comentario del art. 143 CP (en Quintero Olivares, 2011, I: 899): «La interpretación de lo que ha de entenderse por inducción se ha hecho siempre en sintonía con la interpretación que a su vez se dé a la inducción al delito; [...], incluyendo, lógicamente, la necesidad de que el suicidio se produzca». En este sentido, el propio QUINTERO al comentar el art. 28 CP (ibid., I: 342) explica que «de acuerdo con larga tradición jurisprudencial y doctrinal, la inducción ha de ser a persona determinada, a delito concreto y ha de ser eficaz» (cursivas en el original).

32 Esta misma argumentación es aplicable al sintagma «una persona» del art. 143.3 CP: «Se impondrá la pena de prisión de dos a cinco años al que coopere con actos necesarios al suicidio de una persona». En una primera impresión cabría apreciar aquí la ambigüedad de dicto/de re. Leído de dicto castiga cooperar para que alguna persona pueda eventualmente suicidarse (por ejemplo publicando cómo conseguir y utilizar un produc- 
(«El que induzca, promueva, favorezca o facilite la prostitución de un menor de edad o una persona con discapacidad necesitada de especial protección...»). En este caso la jurisprudencia aclara que para que haya delito no es necesario que ningún menor se prostituya (vid. nota 17 supra). Por tanto, la tensión de dicto/de re al interpretar la inducción del delito es un problema que no está del todo resuelto. La solución puede consistir en diferenciar entre la inducción general del art. 28 CP y la inducción especial de los arts. 143.1 o $188.1 \mathrm{CP}$, o en diferenciar entre inducción y provocación ${ }^{33}$; pero las preguntas siguen abiertas. Por ejemplo, ¿cómo interpretar el art. $224 \mathrm{CP}$, que castiga a «el que indujere a un menor de edad o a una persona con discapacidad necesitada de especial protección a que abandone el domicilio familiar»?

\subsection{Retos interpretativos}

La ambigüedad de dicto/de re es un fenómeno lógico y lingüístico que merece atención por los juristas y que puede pasar fácilmente desapercibido. La inclinación de los juristas por la lectura de re cuando el texto la permite se explica seguramente por los heurísticos que el cerebro emplea para procesar la información, los cuales determinan sesgos cognitivos bien documentados. Pero todo esto pertenece al contexto de descubrimiento, y al jurista le interesa no solo conocer y entender cómo y por qué razona como lo hace, sino también —y quizá sobre todo— justificar sus razonamientos. La pregunta clave, entonces, es qué interpretación está justificada, o tiene mejor justificación, en los casos de ambigüedad.

No sostengo que los juristas se equivoquen al adoptar únicamente las versiones de $r e$ en los enunciados legales ambiguos. Sí sostengo que se equivocan cuando no tienen en cuenta otras posibilidades, cuando no piensan en ellas, aunque sea para rechazarlas. Muchos casos de ambigüedad de dicto/de re tendrán una solución jurídica clara, sea cual sea la doctrina interpretativa que sigamos. La intención del legislador, los fines objetivos de la norma y el significado público del texto son los tres intereses fundamentales de la interpretación jurídica; y aunque pueden ser antagónicos, a menudo confluirán en la misma respuesta, probablemente la versión de re por cuanto el redactor del texto y sus destinatarios comparten los mismos sesgos cognitivos. Pero habrá casos de divergencia entre los enfoques interpretativos; casos, por ejemplo, donde cualquiera que preste atención puede percibir y dar sentido a la lectura de dicto, pero una tesis finalista o la indagación intencionalista la descartan. En mi opinión, en estos casos no estaría justificado prescindir de la lectura de dicto sin ulteriores argumentos.

En los asuntos penales, por ejemplo, podrían invocarse tres argumentos importantes para inclinar la balanza interpretativa. El primero es el requisito de dolo, que podría exigir alguna figuración y conocimiento de la víctima (por ejemplo, de su edad o de su embarazo). Pero la exigencia de dolo ha de desprenderse de la lectura del Código

to letal e indoloro «idóneo para suicidarse»). Leído de re, en cambio, castiga cooperar para que una persona concreta llegue a suicidarse. Pero esta teórica ambigüedad de «una persona» en el art. $143.3 \mathrm{CP}$ se despeja igual que la de «otro» en el apartado 1, porque se entiende unívocamente que para que haya cooperación necesaria al suicidio ha de haber suicidio, y, por tanto, un suicida real y no meramente hipotético.

33 Al respecto, Quintero Olivares, 2011, I: 342. 
Penal y no esta de aquella; y por otra parte el dolo puede consistir en la intención de causar el daño descrito de dicto en el artículo (por ejemplo, provocar abortos a mujeres desconocidas). Un segundo argumento es que la seguridad jurídica y el principio de legalidad penal imponen respetar las expectativas, porque si siempre se ha entendido un artículo únicamente de re, podría ser arbitrario aplicarlo de dicto sin previo aviso. Pero, previo aviso, la posibilidad de ampliar la interpretación para el futuro está abierta. Alguien podría discrepar y sostener que ampliar la interpretación del Código Penal con lecturas de dicto en las que nadie había reparado es una forma de interpretación extensiva que contraviene la legalidad penal estricta. La objeción no es menor, pero a mi juicio no hay interpretación extensiva cuando no se abandona el significado del texto tal como cualquier hablante competente puede entenderlo, aunque sea en una segunda lectura más atenta. El tercer argumento es el principio In dubio pro reo, cuya fuerza se dirige sobre todo a la valoración de la prueba, pero que también se proyecta sobre la interpretación como un canon hermenéutico. Aplicando este principio, si un artículo es ambiguo y no está claro si todas las opciones son viables a la vez o, de no serlo, cuáles son inadmisibles, cabría defender que debe optarse por la interpretación más favorable al reo, que normalmente será la lectura de re. Pero este principio - circunscrito en todo caso al ámbito penal - no prevalece frente a otras razones interpretativas más poderosas, como la obligación de guiarse por la Constitución y sus valores, los cuales pueden justificar en algún caso la penalidad de conductas que el Código Penal solo nombra de dicto.

\section{BIBLIOGRAFÍA}

ABelardo, ed. 1958: «Glosse Super Periermenias, capp. XII-XIV», en L. Minio-Paluello, Twelfth Century Logic. Texts and Studies. II. Abaelardiana Inedita: 1. Super Periermenenias XII-XIV. 2. Sententie Secudum M. Petrum, Roma: Edizione di Storia e Letteratura, 13-14.

Álvarez García (dir.), 2010: Derecho penal español. Parte especial, vols. I y II, Valencia: Tirant lo Blanch.

ANDERSON, 2014: «Misreading Like a Lawyer. Cognitive Bias in Statutory Interpretation», Harvard Law Review, 127: 6, 1521-1592.

Aristóteles, ed. 1982: Tratados de Lógica, trad. de M. Candel SANMARtín, Madrid: Gredos.

FREGE, 1892/2005: «Über Sinn und Bedeutung», Zeitschrift für Philosophie und philosophische Kritik, 100, 25-50. Se cita por la trad. esp. de U. MouLINES: «Sobre sentido y referencia», repr. en L. M. ValdÉs VilLanUeva (ed.), La búsqueda del significado, Madrid: Tecnos, 2005 (4. ${ }^{a}$ ed.), 29-49.

GARCíA SUÁREZ, 1997: Modos de significar. Una introducción temática a la filosofía del lenguaje, Madrid: Tecnos (hay 2. ${ }^{a}$ ed. 2011).

GUTIÉRREZ ORDÓÑEZ, 1995: «Referencia y pronominalización "de dicto"», LEA (Lingüistica española actual), 17: 1, 49-68.

ITURRALDE, 2011: Interpretación literal y significado convencional. Una reflexión sobre los límites de la interpretación jurídica, Madrid: Marcial Pons.

KAHNEMAN y TVERSKY, 1974: «Judgement under Uncertainty: Heuristics and Biases», Science, 185, núm. 4157, 1124-1131. Hay trad. esp. de J. CHAMORRO: «El juicio bajo incertidumbre: Heurísticas y sesgos», en D. Kahneman, Pensar rápido, pensar despacio, Madrid: Debate, 2012 (apéndice). 
KELSEN, 1960-1991: Reine Rechtslehre, Viena: Franz Deuticke, 1960 (2. ${ }^{\text {a ed. }}$.). Se cita por la trad. esp. de R. Vernengo: Teoría Pura del Derecho, México: Porrúa-UNAM, 1991.

KNeale, 1960: «Modality De Dicto and De Re», en E. NAgel, P. SuppeS y A. TARSKI, Logic, Methodology and Philosophy of Science, Stanford: Stanford University Press, 622-633.

LAmarque (ed.), 1997: Concise Encyclopedia of Philosophy of Language, Oxford: Pergamon.

PINZANI, 2003: The Logical Grammar of Abelard, Dordrecht: Kluwer.

Queralt Jiménez, 2015: Derecho penal español. Parte especial, 7. a ed., Valencia: Tirant lo Blanch. QuiNe, 1956: «Quantifiers and Propositional Attitudes», Journal of Philosophy, 53: 5, 177-187. Hay trad. esp. de L. M. VALDÉS: «Cuantificadores y actitudes proposicionales», en L. M. ValdÉs Villanueva (comp.), La búsqueda del significado, Madrid: Tecnos, 1999 (4. a ed.), 171-182.

- 1960: Word and Object, Cambridge (Mass.): MIT Press, 1960. Hay trad. esp. de M. SACRISTÁN: Palabra y objeto, Barcelona: Labor, 1968.

- 1961: From a Logical Point of View, 2. ${ }^{a}$ ed., Cambridge (Mass.): Harvard University Press (1. a ed. 1953). Se cita por la reimpr. de New York: Harper \& Row, 1963. Hay trad. esp. de M. SACRISTÁn: Desde un punto de vista lógico, Barcelona: Ariel, 1962; reed. en Barcelona: Paidós, 2002.

Quintero Olivares (dir.), 2004: Comentarios a la Parte Especial del Derecho Penal, Madrid: Thomson-Aranzadi.

- 2011: Comentarios al Código Penal Español, 2 vols., Madrid: Aranzadi/Thomson Reuters, 6. ${ }^{a}$ ed. (primera con este título).

LEIBNIZ, ed. 1890: «Specimen Calculi universalis», en Die philosophische Schriften (ed. C. I. GERHARDT), vol. VII, Berlin: Weidmann.

ReAl ACADEMIa Española, 2009: Nueva gramática de la lengua española, 2 vols. (I: Morfología. Sintaxis I; II: Sintaxis II), Madrid: Real Academia Española y Asociación de Academias de la Lengua Española/Espasa.

RuSSELL, 1905: «On Denoting», Mind, 14: 56, 489-493.

Whitehead y Russell, 1927: Principia Mathematica, 2. ${ }^{a}$ ed., vol. I, Cambridge: Cambridge University Press (1. ${ }^{\text {a }}$ ed. 1910); reimpr. de 1963.

YAfFe, 2011: «De Dicto and De Re Intention in Attempted Crimes», en A. Marmor y S. SoAMES (eds.), Oxford: Oxford University Press, 184-216. 



\section{PERSPECTIVAS HISTÓRICAS DE LA FILOSOFÍA DEL DERECHO}





\title{
EL EXILIO IUSFILOSÓFICO ESPAÑOL $(1936-1977 / 1981)^{*}$
}

\author{
Benjamín Rivaya \\ Universidad de Oviedo \\ rivaya@uniovi.es
}

RESUMEN. La Guerra civil española (1936-1939) trajo consigo el exilio de cinco filósofos del Derecho españoles: Alfredo Mendizábal, Blas Ramos Sobrino, Felipe González Vicén, Luis Recaséns Siches y José Medina Echevarría. Se analiza el exilio de todos ellos así como el pensamiento que elaboraron durante el mismo.

Palabras clave: Filosofía del Derecho española, sociología española, exilio, Alfredo Mendizábal, Blas Ramos Sobrino, Felipe González Vicén, Luis Recaséns Siches, José Medina Echevarría.

\section{The Spanish lusphilosophical Exile}

ABSTRACT. The Spanish Civil War (1936-1939) made that five Spanish legal philosophers went to exile: Alfredo Mendizábal, Blas Ramos Sobrino, Felipe González Vicén, Luis Recaséns Siches y José Medina Echevarría. The exile of all of them is studied as well as the thought that they developed during that period.

Keywords: Spanish Philosophy of Law, spanish sociology, exile, Alfredo Mendizábal, Blas Ramos Sobrino, Felipe González Vicén, Luis Recaséns Siches, José Medina Echevarría.

* Fecha de recepción: 8 de enero de 2017. Fecha de aceptación: 16 de marzo de 2017. 


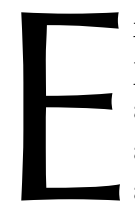

n lo referente a la filosofía jurídica, al tiempo de la Segunda República se le puede denominar edad de plata; o quizás mejor al periodo que va de 1929 al inicio de la Guerra civil ${ }^{1}$. Desde luego, la edad de plata iusfilosófica no abarca de 1902 a 1939, periodo del canon de Mainer (1999), pero referida a la filosofía jurídica, la expresión resulta afortunada para designar los años, en cualquier caso menos de una década, inmediatamente anteriores a la guerra (GIL CREMADES, 1987: 564; RIVAYA, 2010: 107). Este tiempo de esplendor está vinculado a la figura de Luis Recaséns Siches, «la cabeza dirigente de la filosofía del derecho española moderna» (GÓMEZ ARBOLEYA, 1982: 688), que en el veintinueve publicó sus Direcciones contemporáneas del pensamiento jurídico, especie de programa orientador para la filosofía del Derecho española. Si a ello unimos que Recaséns se convirtió en uno de los más destacados discípulos de José Ortega y Gasset y que aplicó el raciovitalismo al estudio del Derecho (además de convertirse en un político reputado que trató de poner en práctica la teoría que enseñaba en la cátedra), resulta que, desde nuestra perspectiva, su figura será la que marque la época. Sus Estudios de Filosofía del Derecho (1936), publicados al borde de la guerra, así lo prueban.

No puedo detenerme a apuntar las vinculaciones entre Recaséns y quienes iban a seguirle en la misión renovadora (aunque estoy persuadido de la ascendencia en todos los casos), pero sí referir quiénes eran estos y su afán transformador. Me refiero a José Medina Echevarría, Felipe González Vicén y Luis Legaz Lacambra. Medina escribió otro panorama de la filosofía jurídica presente entonces, dejando claro su amplio conocimiento de las corrientes contemporáneas, así como su vocación por la moderna ciencia social. González Vicén se dio a conocer con la tesis doctoral, titulada Teoría de la revolución, aunque con un sentido que iba más allá de lo coyuntural, en la que ahondaba en ese concepto y en la que también dejaba claro su amplio conocimiento de la filosofía contemporánea. Por fin, Legaz Lacambra, tras estudiar con Kelsen en Viena, nada menos, recomendado precisamente por Recaséns, hará la tesis sobre la teoría pura del Derecho. Eso sí, aunque orientado a lo nuevo (y con una ingente capacidad de trabajo), Legaz provenía de un mundo tradicional al que parecían ajenos Medina y González Vicén.

Por otra parte, seguía habiendo una corriente precisamente tradicional, católica, habitualmente de tendencia tomista o neotomista, habitualmente conservadora y hasta reaccionaria en lo político, en la que se integraban los ya mayores (Eduardo Callejo de la Cuesta, Mariano Puigdollers, Wenceslao González Oliveros, Miguel Sancho Izquierdo), pero en la que también se iban incorporando jóvenes pensadores (Alfredo Mendizábal, Enrique Luño Peña, José Corts Grau).

Además habría que apuntar algún otro filósofo del Derecho al que el calificativo que mejor le vendría sería el de «raro», caso de Blas Ramos Sobrino; aunque quizás habría que citarlo entre los otros, los reformadores, porque nada tenía que ver con esta corriente tradicional, si bien era ágrafo y sus escasas obras no se publicarán hasta mucho más adelante.

$$
* * *
$$

\footnotetext{
${ }^{1}$ Para conocer ese periodo, RIVAYA, 2010: 70-112.
} 
Visto el estado de la filosofía del Derecho española a la altura de 1936, la historia que aquí se narra comienza al poco del inicio de la guerra porque, ante el cariz que tomaron los acontecimientos tras el 18 de julio, el gobierno del Frente Popular decidió enviar una comisión de notables a París para recabar el apoyo del Estado francés. La composición de la delegación fue heterogénea. Parece que en principio la integraban Dolores Ibarruri (Partido Comunista), Marcelino Domingo (Izquierda Republicana), José Salmerón y Luis Recaséns (Unión Republicana), además de Wenceslao Roces (Partido Comunista), a quien no siempre se cita, y que en Francia se les unieron, Antonio de Lara (Unión Republicana) y Jiménez de Asúa (PSOE).

Fueron de Madrid a Valencia y luego a Barcelona. Allí se entrevistaron con Companys, tras lo cual parece que se produjo un incidente (téngase en cuenta que la información proviene de Dolores Ibarruri y, por tanto, por ser enemiga de los anarquistas, tiene que ser tomada con cautela, si bien es congruente con la circunstancia), un incidente que serviría para darse cuenta del ambiente que se vivía aquellos días y para comprender la posterior opción de Recaséns. Al llegar la comisión citada a la frontera no fueron los policías correspondientes sino los anarquistas de la FAI quienes les exigieron sus pasaportes y, por fin, tras muchas pegas, les autorizaron a seguir viaje. «[V]amos a París a decir al mundo que en España hay un gobierno legítimo en pleno ejercicio de sus prerrogativas — dice la Pasionaria — y la negación de esto lo hacemos nosotros mismos, llevando en nuestro pasaporte la autorización de salida de las milicias de la FAI». Si Dolores Ibarruri, que en sus memorias se muestra especialmente crítica con los otros miembros de la comisión ( $\ll \mathrm{A}$ mis compañeros de viaje no les llegaba la camisa al cuerpo», por ejemplo), si la Pasionaria — digo- se escandalizó, ¿qué pensaría Recaséns?

Ya en París, entre otras gestiones, llegaron a entrevistarse con Léon Blum, pero nada lograron de él, que siguió negándose a intervenir en los que consideraba asuntos internos de España. Luego viajaron a Bruselas a continuar con los actos a favor de la República. Parece que la mayor parte de los miembros de aquella comisión no quería regresar a España. «Por fin una mañana — cuenta la líder comunista- me despedí de ellos y volví a Madrid sola. Salmerón volvió unos días después. Lara se quedó en París, y Marcelino Domingo y Recaséns Siches se fueron a América» (IBARRURI, 1992: 414-427). Realmente, tras la infructuosa gestión, Recaséns optó por quedarse en la capital francesa y no volver a España, y solo pasado un tiempo decidiría irse a América.

Por más que a Pasionaria le escandalizara aquello, vista desde aquí la decisión de Recaséns parece razonable o, en todo caso, no resulta absurda, cuando ni se encontraba radicalmente ideologizado ni podía sentirse cómodo, ni siquiera seguro, con ninguno de los contendientes. Es cierto que en Francia el filósofo expresó públicamente su lealtad a la República. En un número de 1937 de Cabiers du Cercle Descartes dedicado a Le Problème Espagnol se publicó la intervención de Recaséns en el acto del Círculo Descartes (aunque el artículo venía firmado por M. Riscasers Siches, sin duda era él: «Professeur de Philosophie du Droit á l'Université de Madrid, Député aux Cortés»), una intervención en la que mostraba su opción por la «España nueva», como llamaba a la republicana, frente a la otra «España fosilizada» que querían imponer los rebeldes. Realmente la República tenía tras de sí la legitimidad de la voluntad popular, que se 
había expresado en las urnas en febrero del '36, y contra ella se habían levantado los militares. Por lo demás — seguía-, el Frente Popular no había dejado el poder en manos de la extrema izquierda, sino que había formado un gobierno propiamente liberal, lo que — venía a decir — no justificaba la sublevación. No hacía Recaséns un análisis completo de la situación, pero aprovechaba para arremeter contra la Iglesia oficial, con la que siempre se había mostrado tan respetuoso, por carecer de un verdadero espíritu cristiano (1937b).

Así todo, Recaséns no era un hombre de armas y supongo que no podía sentirse cómodo con ninguno de los bandos, decía. Ni con los alzados, pues había sido y continuaba siendo un republicano significado y seguro que convencido; ni con el Frente Popular, cada vez más controlado por sectores extremistas. Ni para unos, que lo tenían por un rojo, ni para otros, para quienes probablemente era un derechista y un señorito, resultaba de fiar. Realmente él no dejaba de ser lo que siempre había sido, un moderado (formaba parte del Frente Popular, sí, pero en su ala más moderada, la Unión Republicana, de Martínez Barrio), lo que menos convenía en aquellos momentos, y quizás ya entonces, aunque este carácter se acentuaría con los años, un ferviente anticomunista (RIVAYA, 2001). Vale la distinción de Bobbio: cuanto más se elogian las virtudes guerreras, como el heroísmo, el coraje y el riesgo, más se tienen por defectos las de «la prudencia, la tolerancia, la calculadora razón» (1995: 81). El caso de Luis Recaséns serviría para verificar la tesis de Julián MARÍAS, para quien la mayoría de los intelectuales que se fueron de España no lo hicieron al fin de la guerra, en el '39, sino a su principio, al considerar que, ocurriera lo que ocurriera, «la libertad estaba perdida en todo caso, que no se podía trabajar — acaso simplemente vivir — con algún decoro» (1988: 200).

El otro filósofo del Derecho (del grupo de los que tuvieron que exiliarse) que se encontraba en España cuando estalló la sublevación era José Medina Echevarría, pero su caso, aunque inevitablemente azaroso como todos los de aquel tiempo, no fue tan rocambolesco. Aunque parezca minúscula, quiero dejar noticia de que el estallido bélico también impidió que disfrutara de una beca que le había concedido la Junta para la Ampliación de Estudios con el fin de que estudiara Sociología en Estados Unidos. Hombre fiel al proyecto republicano, en febrero de 1937 el gobierno le asignó un puesto en un lugar apropiado para un profesor, la legación diplomática de Varsovia, legación cuya dirección acababa de ser puesta en manos de Mariano Ruiz Funes, catedrático de Derecho penal de la Universidad de Murcia que había sido ministro de justicia en el gobierno de Largo Caballero. Al poco, Ruiz Funes sería destinado a Bruselas, quedándose Medina en Polonia, donde pasó el tiempo de la guerra civil ${ }^{2}$, yéndose luego para México al acabar esta, privado ya de su condición de catedrático de la Universidad española, conforme a la solicitud de sanción hecha por la Comisión depuradora, que le acusó de estar «al servicio del gobierno rojo de Valencia» (MARTÍNEZ CHÁvEZ, 2016a).

$* * *$

2 Vid. Archivo General del Ministerio de Asuntos Exteriores Serie/Grupo: Personal. Legajo: 312. Expediente: 22514. 
Los otros tres filósofos del Derecho exiliados, Blas Ramos Sobrino, Alfredo Mendizábal y Felipe González Vicén, el 18 de julio de 1936, se encontraban en el extranjero. Ante las dramáticas noticias, los dos primeros no regresarían a España, pero González Vicén sí lo hizo. Mas comencemos con los que se hallaban en Francia.

$\mathrm{Al}$ acabar el curso en la Universidad de Valladolid, Blas Ramos se fue a París a pasar el verano, lo que debía de ser algo usual en él, y allí le encontró el levantamiento militar que se produjo en España. Por lo que se ve, no volvió al conocer la noticia de la sublevación, por lo que fue sancionado por los luego vencedores con la exclusión de la cátedra ${ }^{3}$. Es difícil seguir su trayectoria, aunque sea fácil imaginar que durante aquellos años terribles tuvo que malvivir en Francia.

$* * *$

El caso de Alfredo Mendizábal, tanto por lo complicado que fue como por la postura pacifista que asumió, reviste especial interés. Además, tenemos el testimonio del mismo Mendizábal, cuyas memorias (2009) tuve la suerte de poder editar ${ }^{4}$. También el catedrático de la Universidad de Oviedo había pedido permiso para salir al extranjero durante el verano. De hecho, la semana anterior al golpe de Estado estaba en Londres, en representación del Grupo español de la Unión de Friburgo, en un congreso internacional organizado por la Catholic Council for International Relations, hablando, qué curioso, sobre la obligación de los católicos de hacer todo lo posible para evitar la guerra. De regreso a España, el día 19 de julio estaba en Amberes, donde se enteró de la rebelión. Corrió a París para alcanzar un vuelo que le llevara a Madrid, pero las comunicaciones estaban cortadas y entonces se fue a Hendaya, por si encontraba forma de entrar en España. No lo consiguió, así que tras el verano volvió a la capital francesa, donde se estableció (2009: 138-147). Allí, a comienzos del '37, tuvo noticia de que Leopoldo Alas, el hijo de Clarín, rector de la Universidad de Oviedo, había sido condenado a muerte y comenzó a dirigir una campaña para evitar el fusilamiento. Consiguió que se enviaran dos telegramas a las autoridades de los alzados en armas: uno de los profesores de la Facultad de Derecho de París; otro del profesorado del Instituto Católico de París. Entonces creyó que sus esfuerzos habían dado resultado (2009: 148-149), pero no fue así. Quizás en esa acción se encuentra el germen que poco más tarde fructificaría en el Comité Español por la Paz Civil, organismo creado por nuestro protagonista y que propugnó todo tipo de medidas para lograr una solución pacífica al conflicto; sin éxito, como es obvio (MENDIZÁBAL, 2009: 235-317; GONZÁLEZ LÓPEZ, 2009).

El resultado de su atrevimiento, ni con unos ni con otros, fue que ambos bandos lo condenarían apartándole de su cátedra. Conocemos con detalle la condena de la Comisión Depuradora del Profesorado Universitario, del bando alzado en armas, que se basó en los siguientes «argumentos»: ser «discípulo predilecto» de Ángel Ossorio y Gallardo; ser católico pero «de carácter terco y tenaz, de los que discuten hasta al

3 Archivo General de la Administración, Sección de Educación y Ciencia, legajo núm. 92059-27. Vid. también MARTíNEZ CHÁVEZ, 2016b.

${ }^{4}$ Hace no mucho tiempo apareció traducido al castellano Los orígenes de una tragedia (2012), libro en el que Mendizábal interpretaba la reciente historia de España, desde la dictadura de Primo de Rivera hasta la Guerra civil. 
Sumo Pontífice»; haber trabajado para conseguir el indulto de Teodomiro Menéndez (quien, por cierto, le salvó la vida durante los sucesos de octubre del '34 en Asturias) y González Peña; ser «[p]oco aficionado a la función docente» (i!); no haberse presentado en su Universidad ni saberse de su paradero (RIvaYa, 2009; PetiT, 2016c). Por la otra parte, el ministerio de Instrucción Pública también lo destituyó de la cátedra.

$$
* * *
$$

En cuanto al caso de Felipe González Vicén, quizás el más extraño de todos, merece cierto detenimiento. El 18 de julio de 1936, González Vicén se encontraba en Berlín, donde ampliaba sus estudios. Unos meses más tarde, a fines de noviembre, volverá a España, presentándose en Sevilla ante las autoridades universitarias, lo que no valió para evitar que se le abriera un expediente. Mientras se tramitaba, Felipe González Vicén dejará Andalucía, refugiándose en Valladolid, donde se encontraba su hermano Luis, un importante jefe de Falange, y donde coincidió con y se hizo amigo de Dionisio Ridruejo, que lo describió de la siguiente manera:

por fortuna apareció por allí un personaje nuevo con el que pronto hice buenas migas. Era el hermano «intelectual» —y profesor- que tenía González Vicén. Felipe González Vicén tenía una figura maciza y un espíritu agilísimo que se le salía por los ojos. Era irónico. Procedía de la izquierda [...] Vicén, que se aburría bastante, viajaba conmigo frecuentemente, pues mi oído era liberal aunque mis convicciones del momento fueran fascistas (2007: 191).

El expediente se resolvería con la separación definitiva del servicio y la inhabilitación para cargos directivos y de confianza, es decir, con la privación de la cátedra, dados por buenos los cargos que se le imputaron: significado izquierdista; gran propagandista y profesor «de ideas extremísimas, para cuya difusión — decía el pliegopensaba emplear la cátedra, según declaraba en las oposiciones» (j!) (RIVAYA, 1994; PETIT, 2016b). La influencia de su hermano le evitó males mayores —explicó Ridruejo--, pero no fue bastante para impedir «que el fanático don Enrique Suñer», que dirigía la Comisión de Educación, le privase de su cátedra. Entre quienes trataron de ayudarle estuvieron Valdecasas y, quizás, Vegas Latapié (RiDRUEJO, 2007: 191).

El González Vicén universitario tendrá que marcharse, probablemente a toda prisa, y buscar acomodo, que encontrará en Berlín.

En 1937, y gracias a amigos fraternales, pude escapar de España. Luego, la vida del emigrado: Francia, Inglaterra, Holanda. La lucha interminable por el permiso de residencia y el de trabajo. Finalmente en Alemania, en casa de la familia de mi mujer donde me sorprendió el estallido de la guerra (ATIENZA y RuIZ MANERO, 1986: 317 ).

La siguiente noticia que tenemos remite a enero de 1938, cuando el Instituto Iberoamericano de Berlín solicita la edición de una revista escrita en español y que parece que estaba previsto que dirigiera Felipe González Vicén, pero «su pasado republicano y socialista» suscitó recelos, por lo que se pidieron informes a las autoridades españolas, que respondieron desaconsejando el nombramiento: «El ministro de Educación Nacional, Pedro Sainz Rodríguez, contestó a esta solicitud diciendo que los antecedentes que obraban en su Ministerio eran poco favorables a González Vicén, lo que hizo que su aprobación se retrasara indefinidamente» (DE LA HERA, 2002: 396). 
Tras formar parte de la comisión que se había trasladado a Francia para recabar el apoyo para la causa republicana, Wenceslao Roces, subsecretario de Instrucción Pública y compañero de Recaséns en la comisión referida ${ }^{5}$, autorizó a este para residir en el extranjero. El iusfilósofo se quedará en París ocupando un puesto en representación de la República. Bastará poco tiempo, sin embargo, para que ambos bandos condenen sus actuaciones.

En 1937, por medio de Daniel Cosío Villegas (MARTínez ChÁVEZ, 2015a: 207), el Instituto Hispano-Mexicano de Intercambio Universitario, en colaboración con la UNAM, lo invitarán a irse a México (CAUDET, 1997: 175); una oferta que, en aquella circunstancia, Recaséns no podía rechazar. Lo cuenta él mismo: «A pesar de haber cumplido honestamente con la misión, llevé entonces a cabo la resolución que con anterioridad a mi salida de España ya me había forjado: no volver a regresar. De entre todas las ofertas que recibí resolví, por último, escoger la que México me concedió. El 2 de junio de 1937 dejé el continente europeo» (GONZÁLEZ DíAZ-Llanos, 1967-1968: 351). Supongo que no dio cuenta a las autoridades republicanas o que estas le negaron el permiso, porque el mismo Wenceslao Roces pediría al embajador de España ante el país hermano que le comunique a Luis Recaséns que ha incurrido en abandono de destino y que «tiene un mes de plazo para incorporarse a su cátedra en la Universidad de Valencia» $(\text { sic })^{6}$. Recaséns desobedecerá la orden, claro.

México recibirá, seguro que con todos los honores, a quien la ficha de emigración describía como un «[h]ombre de treinta y cuatro años, blanco y delgado, de cabello castaño y ojos azules, 1,68 metros de estatura y nariz recta» (MARTínEZ CHÁVEZ, 2015a: 199). No podía decir que se trataba de un pensador excepcional ni que, aunque siguiera dedicado intensamente al estudio y la reflexión, «el ánimo se le había mellado», que había perdido «un entusiasmo vital, un arresto juvenil, que seguramente tenía antes de la guerra» y del que en México apenas quedarán restos (REYES NEVARES, 1982: 578).

Como otros, Recaséns se beneficiaría de la recepción que el presidente Cárdenas dispensó a los exiliados españoles, que fue magnífica. En 1938 creó la Casa de España en México, hecha en cierta forma a imagen y semejanza de la madrileña Residencia de Estudiantes (LLERA ESTEBAN, 1996: 577, n.), que recibirá a un buen número de intelectuales exiliados, antes de convertirse en el Colegio de México. Realmente fueron muchas las personalidades que colaboraron en la creación de la Casa de España. A resultas de la guerra civil española el

ministro mexicano en Portugal, Daniel Cosío Villegas, promovió, por medio del director del Banco de México, Luis Montes de Oca, el traslado [a México] de intelectuales y hombres de ciencia. A esta propuesta se unieron otros personajes de la cultura y la política en México, como el escritor y diplomático Alfonso Reyes, el historiador Jesús Silva Herzog, el escritor y abogado internacionalista Genaro Estrada y el político y abogado Antonio Martínez Báez. Cárdenas apoyó el proyecto y así se invitó por medio de Cosío Villegas a connotados españoles a formar la Casa de España en México (SERRANO Migallón, 2002: 52).

5 Al viaje de la delegación republicana a París se refirió Wenceslao Roces en la entrevista que le hizo Asunción H. de León Portilla muchos años más tarde. Sus palabras, probablemente, encerraban el reproche (a Recaséns y otros): «La gira, para algunos delegados, termino allí [en París], pero para otros siguió adelante» (DE LEÓN PORTILLA, 1978: 358).

${ }^{6}$ Archivo General de la Administración, Educación y Ciencia, legajo núm. 92060. 
De esta forma, México se adelantaba a otros países, algunas de cuyas instituciones también se plantearon recibir los cerebros en fuga provocada por la guerra española, como las Universidades de Harvard, de Columbia o de Buenos Aires. Así, tanto España como México se beneficiaban, pues se recibió a un buen número de desterrados que se encontraban en una circunstancia penosa (o que preveían que en breve tiempo su circunstancia se convertiría en penosa) y, a la vez, se importaba una docencia y una investigación de extraordinaria calidad (LIDA Y MATESANZ, 1987: 124-125).

El acuerdo presidencial que constituyó la Casa de España, de julio de 1938, disponía que se invitara a un grupo de profesores e intelectuales españoles para que fueran a México a continuar con sus trabajos docentes e investigadores que la guerra había interrumpido. Lo que no puede dejar de llamar la atención es que el referido acuerdo presidencial citaba muy pocos nombres propios, siendo el primero de ellos el de Recaséns, que ya se encontraba allí:

El señor Presidente ha acordado que se cree la Casa de España en México, para que sirva de centro de reunión y de trabajo a los hasta ahora invitados, a otros a quienes más tarde se invite y a tres españoles ya residentes en México: Luis Recaséns Siches, profesor de la Facultad de Derecho de Madrid, y los escritores José Moreno Villa y León Felipe Camino (CAUDET, 1997: 171-172).

La Casa actuará como centro que irradiaba cultura por toda la nación: en 1938, por ejemplo, encontramos a Recaséns en la Universidad de Morelia impartiendo diez conferencias sobre La sociedad y el Derecho en la vida bumana (LLERA ESTEBAN, 1996: 573 y 578). Así, mientras el iusfilósofo triunfaba en México, en España la guerra tocaba a su fin, pero antes de que se acabe, los que serán vencedores le privarán de su cátedra, por poseer «antecedentes completamente desfavorables» y estar en radical «oposición con el espíritu de la Nueva España» ${ }^{7}$. Para ese entonces Recaséns ya era un transterrado.

$$
* * *
$$

Recapitulemos. A la altura de 1939, antes de que se pusiera fin a la guerra, Recaséns ya se encontraba en México, exiliado por decisión propia y dedicado a la docencia y la investigación de sus especialidades; Mendizábal, que intentó pero no consiguió volver a España, lo que resultó providencial, se encontraba en París tratando de sobrevivir; lo mismo que en la capital francesa estaría Blas Ramos Sobrino, creo. Medina Echevarría ocupaba un puesto diplomático, representando a la República en Varsovia; y Felipe González Vicén se hallaba en Berlín, adonde había tenido que huir.

Viendo la composición del grupo que se fue al exilio (o tuvo que irse o quedarse en el exilio), creo que se pueden observar ciertos rasgos comunes, tanto políticos como filosóficos, por más que haya peculiaridades y excepciones. Se puede decir que eran jóvenes o, al menos, que no se encontraban entre los mayores de la asignatura. Salvo Blas Ramos, de 1891, y Alfredo Mendizábal, de 1897, los demás ya habían nacido en el siglo Xx, lo que quiere decir que, a la altura del 1939, la mayoría no tenía cuarenta años. En lo político eran republicanos; algunos de ellos especialmente significados; sobre todo Recaséns, pero también Medina y Mendizábal. También en lo político eran

7 Archivo General de la Administración, Educación y Ciencia, legajo núm. 92060. Vid. también MARTíNEZ CHÁvEZ, 2016c. 
«liberales», término difuso que los describe mejor que el de «conservadores» o «socialistas», aunque quizás hoy días les encajase bien el de «socialdemócratas», por lo que luego veremos. En cualquier caso, se trataba de moderados que se encontraban alejados de posturas extremistas, ya fuera a un lado o al otro del arco político. En lo filosófico eran renovadores sin duda: Recaséns había sido, aún hacía pocos años, el gran reformador de la filosofía del Derecho española, empeño en el que le habían seguido Medina y González Vicén. Es cierto que Mendizábal hacía profesión de filosofía tomista, pero dentro de este pensamiento era otro renovador, en la línea que en Francia marcaba Maritain, y estaba al tanto de la filosofía más moderna. Salvo Mendizábal, por tanto, los demás no eran escolásticos, estimaran más o menos el pensamiento de estos, sino seguidores de las últimas tendencias del pensamiento europeo. Todos, por cierto, habían estudiado en el extranjero, en Alemania, en concreto; muchos de ellos becados por la Junta para la Ampliación de Estudios. Por lo demás, estos cinco profesores fueron sancionados por el bando vencedor privándoles de sus cátedras, sanción que el gobierno republicano también aplicó a alguno de ellos. Por cierto, uno de nuestros protagonistas, Alfredo Mendizábal, es — a mi juicio- el mejor representante de lo que se ha dado en llamar tercera España.

Aun con matices, si en la academia de la Filosofía del Derecho había una corriente reformista, tanto en lo filosófico como en lo político, y otra defensora de la tradición, de nuevo en uno y en otro sentido, la primera tuvo que irse. Así, el 1 de abril de 1939, cautivo y desarmado el ejército rojo, comenzó o se hizo definitivo un exilio que iba a durar mucho más de lo que sus protagonistas pudieran imaginarse.

Tras un viaje que tuvo que resultar penoso y que, dada la circunstancia europea, no pudo ser como estaba previsto, José Medina llegó con su familia a México el 10 de mayo de 1939 (MOYA LÓPEZ, 2007: 772). Otra vez Daniel Cosío Villegas había hecho la gestión para que, perdida la guerra la República, se le invitara a incorporarse a La Casa de España, como así sería ${ }^{8}$. De esta manera, la insigne institución acogió a los dos filósofos del Derecho españoles que optaron por establecerse en México: a Luis Recaséns Siches, como ya sabemos, y un poco después a José Medina Echevarría, llegado de Polonia tras la derrota. Incluso cuando luego hubo restricciones presupuestarias y solo quedaron doce miembros vinculados al Colegio, entre ellos siguieron estando Recaséns y Medina (LÓPEZ SÁnCHEZ, 2013: 126). Además sus anfitriones, Daniel Cosío Villegas y Alfonso Reyes, gestionaron ante el rector de la UNAM, Gustavo Baz, la creación de dos plazas en esa Universidad, una para Recaséns y otra para Medina, que les fueron concedidas el mismo 1939 (MOYA LóPEZ, 2007: 773). Años más tarde, en 1943, Medina pedirá una licencia para dirigir el Centro de Estudios Sociales, sección del ya Colegio de México (LÓPEZ SÁNCHEZ, 2013: 126-127), lo que constituiría el punto culminante de su trayectoria académica en México (MOYA LÓPEZ, 2007: 781). Aunque también había diferencias entre ellos, ambos exiliados tenían tantas cosas en común, además del año de nacimiento y el de fallecimiento, y de que el exilio de los dos fuera

8 Cuando en 1940 Cárdenas ponga fin a su mandato, un buen número de intelectuales españoles acogidos por La Casa de España, estando entre ellos Medina Echevarría, le agradecieron su iniciativa y su generosidad. Vid. la carta en CAUDET, 2005: 144. 
un «transterrarse fecundo», como dijo Medina (1943b: 248) utilizando la definición de su amigo Gaos; tenían tantas cosas en común que constituyeron una buena pareja intelectual. Un poco más adelante, sin embargo, las circunstancias les separarían de nuevo.

Mientras Recaséns y Medina se encontraban en México rehaciendo sus vidas, Mendizábal luchaba en Francia por salvar la suya. En el país vecino, los meses posteriores al fin de la guerra civil tuvieron que resultar terribles. Alfredo, que estaba en París y que, al igual que le ocurrió a los demás refugiados españoles en la capital francesa, que no eran pocos, ante la inminente caída de la ciudad bajo el poder nazi, lo que ocurriría en junio de 1940, decidió huir (junto con Ramon Sugranyes, quien falleció hace aún no mucho tiempo', y José María Semprún, sus dos grandes amigos; el último dedicado también a la filosofía del Derecho). Eligió Burdeos como destino, a quinientos cincuenta kilómetros que habría de recorrer, en principio, andando. Ya en Burdeos tendrá noticia del resultado de las gestiones que Jacques Maritain y otros amigos estaban realizando en Nueva York: la New School for Social Research, con el apoyo de la Fundación Rockefeller, le contrataba como profesor de Ciencia Política. A partir de aquí, todas las peripecias que vivirá Alfredo tendrán como objetivo embarcar en Lisboa con destino a Norteamérica. No las contaré porque ya lo hizo él en sus Memorias de un utopista (2009: 161-199), pero bien pudieran servir de argumento para una película de Michael Curtiz (GArCía MANRiQUe, 2010). Al fin, en Casablanca, logró embarcar con destino a Nueva York, adonde llegó en el verano de 1942 tras un viaje que le cambió la vida. Allí le esperaba la familia Maritain, la docencia en la New School, organismo que acogió a muchos intelectuales franceses y belgas emigrados de una Europa terrible, y en L'Ecole Libre, centro de enseñanza superior que trataba de preservar la cultura francesa e impartía la docencia en su lengua. En la primera hay constancia de que impartió un curso semestral sobre la ideología de los modernos estados totalitarios, un tema muy mendizabaliano, y en la segundo, Teoría General del Derecho (2009: 209-215).

Pero antes de llegar a Estados Unidos, Mendizábal había tenido tiempo de poner en marcha una (otra) interesante iniciativa, como todas las suyas. Hay que volver atrás, por tanto, otra vez a Francia, donde surgió un nuevo proyecto de la cabeza de Mendizábal en el que coincidirían los tres exiliados iusfilósofos que se establecieron en América. Al acabar la guerra civil Alfredo, bien relacionado con gran parte del exilio republicano y encontrándose todavía en suelo francés, se había entregado a la tarea de crear e impulsar la Unión de Profesores Universitarios Españoles en el Extranjero (UPUEE), grupo que tenía por finalidad proteger y ayudar a los docentes exiliados para que se reintegrasen a su trabajo, y del que formarán parte la mayoría de los profesores exiliados de la Universidad española, ya se encontraran en América o en Europa. Por lo que a la filosofía del Derecho se refiere, hay constancia de que pertenecieron a la UPUEE, como ya he dicho, además de Mendizábal, Medina y Recaséns.

\footnotetext{
9 Sugranyes nos ha dejado una descripción de Mendizábal: «De nombre vasco pero hijo de Alcañiz, era bajo y grueso, con un espíritu indomable en la defensa de lo que creía justo, sobre todo de los derechos humanos. Tenía la profesión más adecuada a su temperamento: era catedrático de Derecho natural y filosofía del Derecho en la Universidad de Oviedo. Católico y liberal, era uno de los que "no cabía en ninguna de los dos Españas”» (1998: 70).
} 
Fue en el verano de 1939 cuando comenzaron a establecerse contactos y realizarse gestiones con el fin de crear la nueva organización, hasta que se constituyó definitivamente en enero de 1940, siendo nombrado presidente, Gustavo Pittaluga, y secretario, Alfredo Mendizábal, que eran quienes venían ejerciendo los cargos interinamente antes de la constitución. La situación de la UPUEE y de muchos que en ella se integraban se convirtió en trágica una vez que el ejército alemán ocupó París. Se lo contaba Mendizábal a Alfredo Matilla, delegado de la UPUEE en la República Dominicana. Le decía que se sentían «en la ratonera»:

La Directiva de nuestra Unión, que tenía sus reuniones y había instalado sus servicios de Secretariado en el «Instituto Internacional de Cooperación Intelectual», hubo de salir de París (al mismo tiempo que dicho Instituto) para poder conservar su libertad de acción y su comunicación con el Mundo, ahora imposible para quienes se encuentran en zona invadida. La mayor parte de nuestros compañeros se han visto obligados, por esas mismas razones, a trasladarse al mediodía de Francia; y este Secretariado, instalado primeramente en Burdeos y ahora en Toulouse (desde la ocupación de aquella ciudad), ha logrado restablecer la comunicación con los compañeros refugiados en Toulouse (donde existe un numeroso grupo), en Lyon, Marsella, Niza, Montpellier, Pau, Montauban, Caracassonne y otras poblaciones de la zona libre; y se ocupa de la situación de los que quedaron en París y otros lugares de la zona ocupada, de muchos de los cuales pudo tener noticias en los primeros días de la ocupación. Tanto unos como otros tienen, en general, puesta la mirada en la solución que para el problema de cada uno y del conjunto no es otra que el viaje a América (LÓPEZ SÁNCHEZ, 2006: 205-206).

Como los demás que pudieron, Pittaluga y Mendizábal se fueron para América: el presidente a Cuba; el secretario, a Estados Unidos, como ya sabemos. Aunque el mayor número de miembros de la Unión se hallaba en México, el hecho de que Pittaluga se hubiera establecido en La Habana hizo que fuera en esta ciudad donde se celebrara la Primera Reunión de Profesores Universitarios Españoles Emigrados, en 1943. Se organizó el congreso en torno a tres secciones: «Problemas de educación y cultura», «Problemas sociales» $\mathrm{y}$ «Problemas jurídicos y económicos». En esta última participaría Alfredo con una ponencia sobre «La libertad religiosa y las relaciones del Estado con la Iglesia». A la reunión se puso fin con la Declaración de La Habana de la Primera Reunión de Profesores Universitarios Españoles, cuyos considerandos decían:

Que, como españoles libres sienten el deber imperioso de alzar su voz en nombre propio y en el de los españoles obligados por la tiranía a guardar silencio.

Que, al hacerlo no les inspira otro deseo que mantener la dignidad histórica de España, reclamar su liberación y proclamar sus derechos esenciales en este trance capital de la vida del mundo.

Después, en los once puntos de que constaba la Declaración, se condenaba la dictadura de Franco y se pedía la vuelta a un régimen de libertades, a la vez que se solicitaba la solidaridad de las naciones democráticas (COBOS, PULGARÍn y CARAPETO, 2004). A fines de 1943, tendrá «lugar en México, en el Palacio de Bellas Artes, un gran acto público para informar y difundir la Reunión de La Habana. La asistencia de exiliados es multitudinaria [...] La Reunión de La Habana se convierte así en un llamado desesperado al mundo para que no se olvide de España en la coyuntura que vive» (RUIZ FunES, 1999: 443). A partir del acontecimiento de La Habana, tanto Pittaluga como Mendizábal presentarían su dimisión con el fin de dejar que fuera la Sección de México, la mayoritaria, la que se hiciera cargo de la reorganización de la Unión, que 
seguirá desarrollando sus actividades, incluida la publicación de un Boletín, aunque de corta vida, hasta fines de los años cincuenta, cuando desaparece «por muerte natural» (RUIZ FunES, 1999: 448).

$* * *$

Pero volvamos de nuevo a Europa, a Berlín, donde Felipe González Vicén había encontrado acomodo. Allí, en 1940, volverá a encontrarse con Dionisio Ridruejo, quien acompañaba a Ramón Serrano Suñer, que había viajado a Alemania con la misión de diseñar la política española con ese país. Al hilo del nuevo encuentro, el jefe de la propaganda falangista volverá a describirnos, aunque muy resumidamente, las vicisitudes del iusfilósofo:

Era el profesor Felipe González Vicén, de origen republicano, que en el año 37 me había acompañado con frecuencia en Valladolid donde esperaba, al amparo de un hermano falangista, que le «depuraran» en la Comisión de Educación Nacional. No le valió el apellido ni le valieron mis reiteradas gestiones y fue despojado de su cátedra, con lo que se fue a enseñar a la Universidad de Berlín, donde le sorprendió la nueva guerra (2007: 379-380).

Con el exiliado español y otros amigos, trotarán por Berlín (el verbo trotar es Ridruejo quien lo usa). Interesa el caso de Krausser, filólogo que Felipe presentaría a Dionisio, también por lo que nos dice del iusfilósofo español:

Conducido por Vicens (sic), conozco a algunos profesores de Universidad y los corresponsales me ponen en contacto con políticos menores, diplomáticos, militares y gente de sociedad. Una noche he cenado con Vicens y el profesor Krausser, un hombre extraordinariamente inteligente, profesor en lenguas románicas y eslavas. Es antinazi sin cautela alguna y desprecia bastante al común de sus compatriotas. «Espero — me dice- que las masas eslavas acaben con este pueblo usando de su superioridad». Admira a España de un modo un poco confuso. Es un imprudente sublime y esto me resulta simpático (1978: 262).

Que yo sepa, Ridruejo no hará más referencias en sus libros a su amigo «Vicens». La otra noticia que ahora interesa de González Vicén se contiene en la correspondencia que mantuvo con Carl Schmitt, nada menos, con quien tuvo que coincidir en Berlín. De las pocas cartas que se conservan de ellos, la primera está fechada en la ciudad alemana, el 2 de marzo de 1943, pero las dos siguientes, de 11 de diciembre de 1943 y de 14 de septiembre de 1944, están fechadas en Madrid. En la primera de estas dos expresa su intención de volver a Berlín aunque, dadas las circunstancias y la suspensión de clases, no quisiera «emprender un viaje en vano», le dice. En la segunda, vuelve a comentarle a Schmitt que piensa volver a Alemania, pero todo está «un tanto en el aire» debido a «estos tiempos tan difíciles» que se viven (GARCÍA GÓMEZ Del Valle y Marzán TRujILlo, 2010: 147-148). El exilio de González Vicén ya había acabado en 1943, aunque todavía necesitará algunos años para recobrar la cátedra, si bien no la de Sevilla sino que le será asignada, en 1946, la de la Universidad de La Laguna, dejándole así apartado de los centros de poder iusfilosófico. En las Canarias y manteniendo una dirección de pensamiento filosófico jurídico única en España, será el suyo un exilio interior.

En cuanto a la producción de González Vicén durante estos años, hasta 1946, no fue filosófico jurídica sino de estudios que podríamos denominar hispanistas (Don Quijote, Donoso, Unamuno, la decadencia de España) y, como siempre, sobre todo a partir de aquí, interesantes traducciones de obras que en esta etapa tampoco versa- 
rán sobre filosofía del Derecho (de Vossler, Guardini, Freyer, Rassow); quizás porque González Vicén preveía una posibilidad, que no llegase a recupera su cátedra.

$$
\text { *** }
$$

En cuanto a nuestros tres protagonistas exiliados en América, Recaséns, Medina y Mendizábal, compartían muchos rasgos, pero como los dos primeros se encontraban juntos en México, conviene referirse a ellos y luego a Mendizábal. Para empezar, Medina y Recaséns compartían una ideología política. Es difícil precisar pero si las ideas políticas forman una línea continua, ambos se encontrarían en puntos muy próximos. Además, aunque no la vivieran directamente, la experiencia de la guerra civil tuvo que resultar traumática para los dos. Ya he dicho que el calificativo que mejor les describiría es el de «liberales» pero también he dicho que quizás hoy se les podría llamar «socialdemócratas» sin miedo a equivocarse. En esa línea continua, se encontrarían en puntos cercanos, en la zona más templada, entre el liberalismo y la socialdemocracia.

En 1942, Recaséns publicaría un artículo que trataba la debatida cuestión de la relación entre «Libertad y planificación» (a partir del comentario de una obra de Mannheim que publicaba el Fondo de Cultura Económica). Importa mucho porque en este texto Recaséns mostraba, tras la guerra civil y en medio de la mundial, sus opciones políticas, que no diferían de las de Medina, como veremos. Aunque en este punto hay que decir que Recaséns, probablemente escaldado y desencantado con el trágico fin de la experiencia republicana, no volvió a la política activa, siendo su perspectiva la de un mero teórico. Atacó sin contemplaciones a los fascismos, que negaban completamente la dignidad humana y destruían todo margen de libertad individual (1942: 103), y con alguna contemplación al comunismo, cuya doctrina proclamaba los ideales humanistas — decía—, aunque en la práctica soviética utilizaba medios totalitarios (1942: 104). No sé si en un futuro Recaséns seguirá siendo tan condescendiente con el comunismo, creo que no, pero en cualquier caso él ya se reconocía un anti-radical, porque no se podía reformar la sociedad «de raíz y totalmente» (1942: 111), y un liberal que decía sentir repugnancia ante la opresión (1942: 115), pero también «graves dudas» ante la defensa a ultranza del libre mercado, que necesitaba ser corregido para que no produjera injusticias obvias, y más en los momentos tan críticos que vivía la humanidad (1942: 120).

En cuanto a Medina, no dejará de proclamar sus ideas. En Responsabilidad de la inteligencia, no solo defenderá la ciencia social sino también el liberalismo, si bien «en su sustancia permanente más que en sus formas temporales y caducas» (1943b: 149), advirtió, y la democracia, que implica «una sociedad de hombres libres y responsables, unidos por la cooperación en tareas comunes» (1943b: 263). Su defensa moral de la democracia era inequívoca: porque implica fe en la naturaleza humana, porque exige reconocer su personalidad y porque es inseparable de una imprescindible cultura humanista (1943b: 257). Quizás hoy pueda parecer obvio, pero no lo era tanto a principios de los cuarenta. Expresamente repudió el fascismo y el comunismo cuando calificó de sandeces tanto una ciencia racial como otra proletaria (1943b: 59). Con John Dewey, rechazó el marxismo con la crítica del economicismo, que niega que un solo factor, el económico, valga como causa explicativa de los fenómenos socioculturales. Advirtió también de que esa unilateralidad explicativa solía acabar en «absolutismo ideológico», como demostraba — dijo- el experimento soviético (1943b: 264-265). Por otra 
parte, Medina y Recaséns compartieron el interés y la dedicación por la sociología ${ }^{10}$, aunque Medina, en régimen de monopolio. En la nueva patria, primero ocupó una cátedra de Sociología en la Escuela Nacional de Jurisprudencia y luego en la UNAM, hasta que en 1943 se entregue completamente a la dirección del recién creado Centro de Estudios Sociales de El Colegio de México. La orientación de Medina estaba clara y ya la había puesto de manifiesto al poco de llegar a aquella tierra de promisión: ¡la sociología! En efecto, al poco de arribar a México, precisamente La Casa de España le publicó un libro que ya tenía preparado sobre historia de la ciencia social, Panorama de la sociología contemporánea (2008), que explica algunos de los estudios y traducciones que se llevarán a cabo próximamente en América Latina; libro en cuyas palabras previas lo dijo claro:

«La necesidad de superar el estado de una tradición académica y científica que cada vez me parecía más empobrecida y estéril, me fue llevando, con interés creciente, del campo de la filosofía jurídica — materia de mi profesión oficial— al de la Sociología». Y explicaba sus primeros pasos en la nueva ciencia y las vicisitudes de la obra que ahora se editaba en México: «Ya en el año 1934, por invitación de don Adolfo Posada —quede aquí este recuerdo agradecido- di un Curso de Sociología en la Facultad de Derecho de la Universidad de Madrid. Y su contenido fue cristalizando luego en una Introducción a la sociología, totalmente dispuesta para su publicación en julio de 1936. Por obra de los acontecimientos iniciados en ese mes, perdí, con otras cosas, la mayor parte del manuscrito; pero el azar salvó una parte de la obra, que era la que con carácter histórico abría e iniciaba la Introducción» (MEDINA ECHEVARRÍA, 2008: 78).

$\mathrm{Al}$ año siguiente, en 1941, publicará otra obra sobre cuestiones metodológicas y principales problemas de este tipo de conocimiento, Sociología: teoría y técnica (1946). Poco después, en 1943, el Fondo de Cultura Económica le editará un libro recopilatorio de artículos diversos, bajo el significativo título de Responsabilidad de la inteligencia (1943b). En sus páginas no se encontraba casi ninguna referencia explícita a la filosofía del Derecho, si bien hay dos citas que parecían dedicarse, para censurarla, a la teoría pura del Derecho, de Kelsen: «En el momento en que se estaba gestando la actual tragedia, se entretenían quizá algunos profesores en discutir con toda seriedad el inocente problema de la posición del derecho internacional en la jerarquía escalonada de las normas que nos da una teoría calificada de pura. Se comprende el fracaso inmediato de semejantes purezas» (1943b: 45). En otra ocasión arremeterá contra la pretendida pureza de la ciencia, pureza que sería la mejor demostración de su acientificidad — dijo—, pues toda ciencia es, por principio, impura, «es decir, penetrada de experiencia por todos sus poros y por eso mismo operando en la realidad» (1943b: 68). Parece cierto, por tanto, que Medina hacía la crítica a Kelsen «desde una trinchera sociológica» (ALARCÓN, 1997: 191). La misma desde la que se quejaba del formalismo jurídico que imperaba en España (1943b: 75).

Pero Responsabilidad de la inteligencia era, sobre todo, un llamamiento a favor de las ciencias sociales. Podría parecer entonces, dada la circunstancia que vivía el mundo, una cuestión menor, incidental, pero no lo era: se trataba de saber si los gravísimos

10 Fue Recaséns quien expresamente se comparó con Medina, cuando comentó un libro de este: «A quien escribe estas líneas le ha ocurrido algo similar: se despertó en mí de manera auténtica el interés por los temas sociológicos fundamentales, a virtud de una íntima necesidad, surgida en el desarrollo de las meditaciones filosófico-jurídicas», citado por MOYA LÓPEZ y MORALES MARTín, 2008: 25 n. 
problemas con que se encontraba la civilización podrían enfrentarse racionalmente; si así era, la ciencia social resultaría imprescindible (1943b: 29-30). Por supuesto que se habían lanzado muchas críticas contra un mundo dominado por la ciencia, como la del automatismo, la negación de la libertad, etc., pero la ciencia solo trataba de buscar la verdad, «aquello con que necesariamente hay que contar» a la hora de decidir (1943b: 33); por supuesto que la ciencia podría ponerse incluso al servicio de la guerra (1943b: 170) y, en este sentido, no era garantía absoluta de nada; pero la alternativa, la renuncia a la ciencia, sí era garantía de «la irrupción de lo irracional» (1943b: 52), del fin de «nuestra civilización» (1943b: 62). Además, aunque la cuestión de la relación entre los valores y la ciencia era problemática, el conocimiento científico no solo era conocimiento sino que también parecía unido a ciertos valores: racionalidad, seguridad, libertad, tolerancia, mesura, cooperación (1943b: 34).

A la vez, Recaséns publicará su Wiese en 1943 y a partir de ahí aparecerán artículos suyos sobre Weber, Tarde, Durkheim y otros, hasta que en 1956 se publique su Tratado General de Sociología, reeditado y reimpreso en muchas ocasiones (1976). También Recaséns tenía interés y fe en la nueva ciencia social:

los estudios necesarios para podernos orientar en la situación presente e inquirir las orientaciones para la acción adecuada son muy complejos. Es preciso que lleguemos a entender de qué manera el desarrollo psicológico, el intelectual y el moral están relacionados con los procesos sociales: cómo cada edad histórica produce tipos humanos enteramente diversos (1942: 111).

¿Cuál era la situación presente? De profunda crisis, una «crisis total del mundo contemporáneo», como ya había dicho Medina en 1935 (2008b: 16). Pues esa crisis, o la conciencia de esa crisis, era la que dotaba de más sentido a la sociología, el estudio científico de la sociedad y sus transformaciones, que podría satisfacer — decía Recaséns- «el vehemente deseo de entender lo que está pasando hoy en día» (1976: 3).

Por cierto, si bien hasta hace no mucho se podía decir que la aportación de uno y otro, en este ámbito, no habían sido suficientemente estudiadas; a estas alturas creo que ya han sido investigadas; tanto la sociología de Medina ${ }^{11}$, como la de Recaséns ${ }^{12}$

Pero si ambos hacían profesión de fe liberal y coincidían en el interés por la sociología, creo que discrepaban, en cambio, en lo tocante a la filosofía del Derecho. El último artículo de la etapa española de Recaséns, aunque publicado en revista alemana, lo había dedicado a esclarecer lo que era una verdadera filosofía del Derecho (1937a). El primer libro que publicaría en México, en 1939, en el que se encuentra el origen del que será su magnífico Tratado, Vida bumana, sociedad y Derecho, se subtitulaba Fundamentación de la Filosofía del Derecho, una fundamentación que sería orteguiana, como ya podía imaginar el lector al leer el título. La jurisprudencia, la ciencia jurídica, no

${ }^{11}$ La sociología de Medina ha merecido la atención de dos tesis doctorales: MOYA LóPEZ, 2013, y MORALES MARTÍN, 2012a; esta última de próxima publicación. Además de un buen número de artículos y referencias en las obras generales sobre la historia de la sociología española; entre otros, por ejemplo, RODRíGUEZ CAAMAÑO, 2004.

12 Sobre la sociología de Recaséns, vid. Ribes LeIVA, 2006, que ya al comienzo de su trabajo dice que pretende ser «una primera aproximación a la obra de Recaséns, prácticamente inexplorada desde la sociología» (2006: 9); en el mismo sentido, GONZÁlez RADÍo, 2005. 
bastaba; se requería una filosofía del Derecho, que sería la que podría «decir la verdad plenaria y fundamental sobre lo jurídico, o por lo menos plantearse este problema» (1945: 20).

Medina, sin embargo, ya en España había mostrado su desapego por la filosofía del Derecho y ahora lo diría más claramente aún. Lo había anunciado en su Panorama de 1940, como acabamos de ver, pero en 1943 dedicará un artículo (pequeño, de apenas nueve páginas) a explicar su alejamiento de la filosofía jurídica. Lo tituló precisamente así: «¿Filosofía del Derecho?», entre interrogantes, y la respuesta bien pudiera ser: «No, gracias». En principio se trataba de un comentario del libro de BoDENHEIMER, Teoría del Derecho, cuya traducción acababa de publicar el Fondo de Cultura Económica, pero así como juzgaba elogiosamente esa obra, condenaba la inmensa mayoría de la filosofía del Derecho de los últimos años, que solo le producía «insatisfacción y desgana» (1943a: 111). La verdad es que la censura de Medina resultaba incluso excesiva; hasta se permitía aconsejar una receta «para uso de aspirantes a pomposos títulos»: «acéptense los ingredientes de la herencia neokantiana, añádase un poco de iusnaturalismo, agréguense fuertes dosis de teoría pura y fenomenología y que no falten, si se quiere estar al día, unas gotas de existencialismo» (1943a: 115). «iQué serie interminable de bla-bla-bla!», llegaba a manifestar (1943a: 113). Dicho por otro tal vez pudiera parecer un reproche fácil, pero puesto en boca de Medina era algo más, pues conocía perfectamente las corrientes de la filosofía jurídica contemporánea, que ya había expuesto en un magnífico libro, como sabemos. Tal vez la crítica fuera excesiva, pero ¿qué había ofrecido la filosofía jurídica a un mundo que se desmoronaba y que, yendo a lo personal, le había expulsado de su patria y le había convertido en un exiliado? Parece que nada.

La dedicación de Medina a la filosofía del Derecho (AlARCón, 1997), por tanto, se redujo a dos libros: uno propio, La situación presente de la filosofía jurídica, de 1935 (2008b), y otro ajeno, la Filosofía del Derecho (1933), de Radbruch, que tradujo.

$* * *$

Llama la atención la orientación a la sociología que se encuentra entre nuestros exiliados. Para Medina a partir de entonces ya constituyó su dedicación, apartado completamente de la filosofía del Derecho; Recaséns compartió ambas disciplinas; Ayala también se orientó a la sociología, combinándola tanto con la literatura como con el pensamiento político. Cito a Ayala, y así creo un trío, porque se trata, al decir de Enrique Gómez Arboleya en su clásico «Sociología en España», de los tres pensadores españoles más destacados dedicados a la nueva ciencia social en América. De ellos afirmó que eran «sociólogos sin sociedad propia» (1982: 686-687), afortunada expresión que alcanzaría éxito para referirse a la sociología del exilio. Efectivamente, Medina, Recaséns y Ayala serían los principales juristas pasados a la sociología, pero habría que citar otros nombres, como el de Manuel García Pelayo, discípulo de Recaséns en Madrid antes de la guerra civil que no pudo exiliarse al acabar esta (cuando se le encerró en un campo de concentración) pero que lo haría en 1951. También a Alfredo Mendizábal, por su articulito sobre «La sociología española» (1965) e, incluso, ya en el interior, a Felipe González Vicén por la traducción que llevó a cabo de la Introducción a la sociología (1945), de Hans Freyer. 
Parece que la pregunta no resulta impertinente: ¿transformó el exilio a los teóricos del Derecho en sociólogos? Porque «se ha llegado a pensar que nuestro trío de autores, dedicados antes a la filosofía jurídica y a la ciencia política, hubieran sufrido una catarsis en el exilio, que habría arrumbado buena parte de sus creencias académicas anteriores» (GIL CREMADES, 2006: 38). Pero la respuesta es negativa: tanto en el caso de Medina como en el de Recaséns y Ayala, el acercamiento a la sociología ya se había producido en España en los años treinta. Realmente, la pregunta pertinente es distinta de la que antes nos hicimos; la cuestión es por qué desde la filosofía del Derecho se ha trabajado tanto por la implantación de la Sociología; porque parece que hay una relación muy estrecha, aunque no evidente, entre ambos conocimientos.

Realmente en este punto no hay demasiada diferencia entre el exilio y el interior, salvo que la guerra hizo que dentro de España se retrasara algo más la implantación de la Sociología. Pero también en la España franquista hubo juristas que hicieron su aportación a la ciencia social, como Luis Legaz Lacambra, Francisco Javier Conde, Enrique Gómez Arboleya, Salvador Lissarrague o Enrique Tierno Galván, además de instituciones receptivas a ese nuevo tipo de conocimiento, como el Instituto de Estudios Políticos y la Revista de Estudios Políticos, el Instituto León XIII, la Revista Internacional de Sociología o los Estudios geográficos (RIvAYA, 1993).

Realmente, entre el Derecho y la sociología había habido vínculos desde fines del siglo XIX, pues tanto juristas como, específicamente, filósofos del Derecho colaboraron no solo en la constitución de una sociología jurídica sino también en la recepción y el desarrollo de la sociología general: Francisco Giner de los Ríos, Manuel Sales y Ferré, Joaquín Costa, Pedro Dorado Montero, Severino Aznar, entre otros (MendizÁbal, 1965: 344; GÓMEZ ARBOLEYA, 1982: 660-677; DíAZ, 1974: 171). Antes de la guerra dos nombres resultarán fundamentales: el de Adolfo Posada y el de José Ortega y Gasset. Con más o menos intensidad, ambos influirán en el trío de sociólogos exiliados antes referido. Por lo demás, si hubiera que buscar la clave de la relación entre el Derecho y la sociedad, es decir, entre la filosofía jurídica y la sociología, habría que citar a Ortega:

Sin que yo pretenda resolver ahora con gesto dogmático, de paso y al vuelo, las cuestiones más intrincadas de la filosofía del Derecho y de la sociología, me atrevo a insinuar que caminará seguro quien exija, cuando alguien le hable de un derecho jurídico, que le indique la sociedad portadora de ese derecho y previa a él. En el vacío social no hay ni nace Derecho. Este requiere como substrato una unidad de convivencia humana, lo mismo que el uso y la costumbre, de quienes el derecho es el hermano menor pero más enérgico. Hasta el punto es así que no existe síntoma más seguro que la existencia de un hecho jurídico. Enturbia la evidencia de esto la confusión habitual que padecemos al creer que toda auténtica sociedad tiene por fuerza que poseer un Estado auténtico. Pero es bien claro que el aparato estatal no se produce dentro de una sociedad, sino en un estado muy avanzado de su evolución. Tal vez el Estado proporciona al derecho ciertas perfecciones, pero es innecesario enunciar ante lectores ingleses que el derecho existe sin el Estado y su actividad estatutaria (1947: 222-223).

$$
* * *
$$

Por su parte Alfredo Mendizábal, en su exilio estadounidense, escribió al menos cuatro obras, capítulos de libros de gran interés (ambos, los capítulos y los libros) a los que tuvo que ser invitado a participar. Los trabajos versaban sobre el pensamiento español, la sociología y las filosofías política y jurídica, y servían para que el autor 
expusiera sus perspectivas, siempre prudentes y moderadas (aunque seguro que había quien las veía como inaceptables y radicales). El que tituló «España», en un volumen colectivo sobre el pensamiento político del tiempo transcurrido del siglo XX, era una presentación de las ideologías políticas en España durante ese periodo. Interesa apuntar la importancia que, a su juicio, tuvieron las ideas (y la falta de ideas) en el colapso español:

La crisis del pensamiento político en España es el resultado del limitado número o de la limitada fortaleza de las ideas liberales. Muchos de los que se llaman liberales solo lo son mientras se encuentran ellos mismos oprimidos, y dejan de serlo tan pronto como llegan al poder. Extremistas de la derecha y de la izquierda combaten por conquistar el poder y sus beneficios más por el triunfo de sus tesis, que utilizan como arma de lucha. Y falta siempre un grupo numeroso de hombres que conciba el servicio a la libertad de una manera generosa y que sea capaz del difícil heroísmo que la causa de la justicia requiere (1946: 616-617).

Mendizábal seguía siendo un pensador católico, lo que explica otro estudio sobre Francisco de Vitoria (1947) ${ }^{13}$, de quien tenía que hallarse muy cercano, tanto por ser en cierta forma el creador del Derecho internacional como por sus tendencias pacifistas. También el que dedicó a estudiar las obligaciones y los límites que la fe impone a los cristianos en la vida política (MENDIZÁBAL, 1948), si bien había dos tendencias evidentes: una tendencia conservadora, autoritaria, incluso reaccionaria, y otra liberal, tolerante y democrática. La opción de Alfredo por la segunda resulta obvia: contra el fascismo, contra la dictadura, por el Estado de Derecho y la democracia. De después ya no conozco publicaciones de Mendizábal (aunque supongo que las habrá dispersas), dedicado a labores de traducción en organismos internacionales.

$$
* * *
$$

Entre las labores que desempeñaron los profesores exiliados españoles en América Latina destaca la de traducción. Por una parte, nuestros protagonistas cumplían con el requisito sin el cual no podrían llevar a cabo el trabajo, sabían idiomas; por otra, les podía reportar algunos ingresos y, además, de esta forma colaboraban en lo que les resultaba más propio: alumbrar y difundir ideas. Así, Medina Echevarría (MOYA LÓPEZ, 2007) coordinó el proyecto de trasladar al castellano los cuatro volúmenes de Economía y sociedad (FCE, 1944), de Max Weber, y tradujo el primero (los otros traductores serían Juan Roura Parella, Eduardo García Máynez, Eugenio Imaz y José Ferrater Mora). Tradujo también, de Karl Mannheim, Diagnóstico de nuestro tiempo (FCE, 1944); de Harry Alpert, su biografía de Durkheim (FCE, 1945); de Henry Patt Fairchild, tradujo Medina en colaboración con Julián Calvo y T. Muñoz, el Diccionario de sociología (FCE, 1949). Luis Recaséns también traslado al castellano obras fundamentales (MARTínez CHÁveZ, 2015a), como la Historia de la cultura (FCE, 1941), de Alfred Weber; La filosofía del Derecho latinoamericana en el siglo XX (LOSADA, 1951),

13 Ahora que cito el estudio de Alfredo Mendizábal sobre Vitoria, conviene llamar la atención en que es Ángel Ossorio y GALLARDO quien presenta en Argentina el libro El pensamiento vivo de fray Francisco de Vitoria (1943). La coincidencia hace que recordemos al maestro político de Mendizábal, Ossorio, que se exilió en Argentina tras la Guerra civil, donde no solo publicó un buen número de libros, como Los derechos del hombre, del ciudadano y del Estado (1946), sino que asesoró a diversos gobiernos latinoamericanos; por ejemplo al boliviano, para el que elaboró un Anteproyecto de Código Civil (1943). Resulta sorprendente que no exista una biografía crítica de Ángel Ossorio, que además de político activo durante décadas fue un filósofo de notable interés de la política y del Derecho. 
de Josef Laurenz Kunz; La justicia (UNAM, 1961), de Emil Brunner. En cambio, Alfredo Mendizábal no se dedicaría a la traducción, pero haría una excepción con $\mathrm{Hu}$ manismo integral, la conocida obra de su amigo Jacques Maritain, que aparecería en Santiago de Chile, en 1940, publicada por la editorial Ercilla.

Pero en aquellos años, en Latinoamérica, en lo relativo a la labor de traducción no pueden dejar de citarse otros nombres, casi siempre cercanos a la filosofía del Derecho, como el de Francisco Ayala, que en Argentina, «sobre todo en la década de los cuarenta, se dedicó a la edición y la traducción» (GIL CREMADES, 2006: 36) de, entre otros, Jeremy Bentham, Benjamin Constant, Herbert Spencer, Hans Freyer, Georges Gurvitch o Karl Mannheim (LoEdel RoIs, 2012: 371-372). Pero sobre todo no puede dejar de citarse a quien llevó a cabo una labor traductora ciclópea, Wenceslao Roces, el controvertido dirigente comunista ${ }^{14}$, catedrático de Derecho romano, que ya ha aparecido en esta narración. Se trata del «marxista español del siglo XX a quien más debe la difusión en castellano de la obra de Marx y Engels» (RIBAS, 1990: 134) y de otros clásicos del socialismo (entre otros muchos, de Lenin, Stalin y hasta de Trotsky), pero no únicamente porque también tradujo a autores que nada tenían que ver con el movimiento obrero, como Hegel, Humboldt, Dilthey, Cassirer, Jaeger, Radbruch o Kelsen. Resulta imposible citar ahora toda su impresionante producción (RIVAYA, 2000) ${ }^{15}$. También en este momento hay que citar a otro socialista, pero anarquista, Diego Abad de Santillán, que llevó a cabo una importante labor traductora en Argentina; sobre todo por la versión castellana de El fin en el Derecho, de Ihering, que apareció en 1961, editada por Cajica.

La labor traductora estuvo unida al desarrollo editorial en América Latina: Porrua, Losada, Grijalbo, la UNAM y, sobre todo, el Fondo de Cultura Económica; desarrollo en el que también colaboraron nuestros protagonistas; así por ejemplo José Medina participó en la fundación de la Sección de Sociología del Fondo de Cultura Económica, que coordinó (SOLARI, 1977: 7; MOYA LÓPEZ, 2007: 775); como Wenceslao Roces impulsó la sección de Historia de la misma editorial y José Gaos la de Filosofía. Por motivos obvios, no extraña esa relación entre los exiliados españoles y el mundo editorial, que en el caso del FCE fue todavía mayor, dado el liderazgo de Daniel Cosío Villegas en ambas empresas (la de la incorporación de los pensadores españoles en México y la del Fondo, del que era director, además de ser secretario, en su momento, de la Casa de España); Daniel Cosío Villegas, que fue quien puso en contacto a los intelectuales exiliados con el Fondo de Cultura Económica (MARTínez CHÁveZ, 2015a: 207).

$$
* * *
$$

Volvamos a mirar lanzar una mirada de conjunto para darnos cuenta de que no existió un «exilio filosófico» entendido como unidad.

El de Felipe González Vicén fue corto; ya quedó dicho que fue el suyo un exilio interior, una vez recuperada su cátedra pero apartado en la Universidad de La Laguna,

${ }_{14}$ Wenceslao Roces siempre actuó al servicio del Partido Comunista, defendiendo las tesis de este, ya fuera en actos públicos o privados (CAUDET, 1997: 419-421). También participó en sus publicaciones, por ejemplo en Nuestro Tiempo. Revista Española de Cultura, órgano del Partido Comunista de España, dirigida por Juan Vicens entre 1949 y 1953 (LLERA EsTEBAN, 1996: 461).

${ }^{15}$ Hay que dejar noticia, además, de un dato en el que yo no había reparado: «Roces, cuando tenía que traducir algo que no le parecía de su gusto, optaba por firmar con seudónimo» (DíAz ARCINIEGA, 1994: 99). 
en las Canarias. Blas Ramos trató de volver a España pero no lo consiguió (MARTínEZ CHÁveZ, 2016b). Tuvo que malvivir en Francia, dedicándose (por lo menos) a la enseñanza de idiomas. Murió en Auch, el 27 de noviembre de 1955 (RAmos, 1969: 15). Durante parte de la década de los cuarenta, en Estados Unidos, Alfredo Mendizábal pudo dedicarse a la docencia y el estudio, pero creo que avanzado ese decenio, o quizás en los cincuenta, pasó a trabajar al servicio de las Naciones Unidas en labores de traducción y ya no retomaría nunca la especulación jurídica o, al menos — creo-, nunca volvió a dedicarse a la enseñanza y la publicación de aquella reflexión. José Medina Echevarría sí dedicó toda su vida al pensamiento, si bien desde que comenzó su exilio, al acabar la guerra civil, no se ocupó con la filosofía del Derecho, por la que manifestó expresamente su desinterés, como vimos, sino con la sociología, alcanzando reconocimiento como sociólogo en toda América Latina (VVAA, 1982). Será Luis Recaséns Siches el único de nuestros protagonistas exiliados cuya dedicación a la filosofía del Derecho constituyó su profesión; con gran éxito, además, pues se trata de uno de los grandes filósofos del Derecho del siglo XX, no solo en lengua española sino en cualquier lengua, siendo su pensamiento radicalmente moderno; encontramos en él, muchas veces, innovadoras ideas y sugestiones que solo más tarde se popularizarían o alcanzarían reconocimiento.

$* * *$

Aunque Medina se encontraba integrado en el país de acogida, en México, donde estaba desempeñando un relevante papel para las ciencias sociales, importando a la lengua española el último pensamiento social y creándolo él mismo, el cierre del Centro de Estudios Sociales y un enfrentamiento con Daniel Cosío Villegas hicieron que lo abandonara en 1945 y se fuera como profesor visitante a Bogotá, a la Universidad Nacional de Colombia. Al año siguiente se irá para Puerto Rico ${ }^{16}$, donde permanecerá en su Universidad ocupándose de las clases de Sociología hasta $1952^{17}$, cuando se vaya a Santiago de Chile, donde residirá, salvo un breve paréntesis en España, hasta su fallecimiento. A partir de su establecimiento en Chile, Medina Echevarría comenzará a trabajar para la Comisión Económica para América Latina y el Caribe (CEPAL), a la que dedicará casi todo el resto de su vida profesional, así como seguirá colaborando en la implantación de la sociología en Latinoamérica; por ejemplo dirigiendo la Escuela de Sociología de la Facultad Latinoamericana de Ciencias Sociales, o desde el Instituto Latinoamericano de Planificación Económica y Social, además de publicando diversos trabajos, entre los que destaca, con carácter póstumo, La sociología como ciencia social concreta (1980), «su obra probablemente más completa, comprensiva y sistemática» (MOya López y MORAles MarTín, 2008: 69).

$$
* * *
$$

Ya quedó dicho que Recaséns fue el único de los exiliados que, aunque también tiene una importante obra sociológica, siguió dedicando toda su vida a la filosofía del

16 En Puerto Rico sufrirá «una intensa campaña falangista clerical contra los "elementos subversivos" de la Universidad de Puerto Rico, entre los cuales por supuesto Medina era identificado así» (MoyA LÓPEZ, 2007: 788).

17 Viene al caso el recuerdo de Francisco Ayala: «En la Universidad de Puerto Rico, la gran figura, cortejada y displicente, de la Facultad de Ciencias Sociales era Pepe — don Pepe-, pues por si fuera poco el respeto que inspiraba su estatura intelectual, su prudencia y la reserva distante de su carácter, Medina era de esas personas que, en lo físico, representan bastante más edad de la que en realidad tienen» (1988: 376). 
Derecho, alcanzando reconocimiento en España y Latinoamérica; incluso internacional, lo que no suele suceder entre los filósofos que elaboran su especulación en español. En México se le quiso y se le admiró ${ }^{18}$, y Recaséns, a la recíproca, ofreció al país hermano una docencia y una investigación magistral, además de participar en acontecimientos relevantes para el mundo jurídico de allá, como el viaje que en 1960 Kelsen realizó a México, cuando ya estaba establecido en Estados Unidos (MARTínEZ CHÁveZ, 2015: 248-249) ${ }^{19}$.

Como sabemos, Recaséns tenía una impresionante preparación filosófico jurídica: partiendo de una formación clásica, había estudiado con los más relevantes pensadores europeos del Derecho y, a eso, añadió el raciovitalismo orteguiano. La suya era una novedosa perspectiva sobre el Derecho que, a mediados de siglo, dio un fruto que merece expreso reconocimiento: la teoría del logos de lo razonable (CABRA APALATEGUI, 2011). Así, resulta que Recaséns fue uno de los autores del selecto grupo que revolucionó la metodología propia del Derecho con una de las modernas teorías de la argumentación jurídica que

vendrán a buscar una vía media entre el irracionalismo metodológico de los unos y el optimismo cientifista de los otros. Desde los años cincuenta, la situación de crisis de la metodología jurídica va a motivar una serie de respuestas estrechamente emparentadas por compartir una idea fundamental: que la demostración meramente lógica y la prueba empírica no son ciertamente aplicables al trabajo valorativo con el derecho, pero que ello no implica que la aplicación del Derecho sea una operación perfectamente arbitraria y aleatoria, pues poseería su propia racionalidad. Pero esta racionalidad que el derecho compartiría con otras disciplinas pertenecientes al ámbito de la acción o la razón práctica sería de un género especial: sería racionalidad práctica. Se anticipa así, en estrecha referencia al derecho y su problemática metodológica, lo que la filosofía general celebrará años más tarde como «rehabilitación de la razón práctica (GARCíA AMADO, 1999: 136).

En efecto, en 1956 aparecerá su Nueva filosofía de la interpretación del Derecho donde, por una parte, repudiaba el uso «de la lógica tradicional en materia de los contenidos jurídicos», a la vez que se proponía hallar solución a la cuestión del razonamiento que se ha de utilizar para trasladar y adaptar la norma general al caso particular (1980: 29). ¿Qué ocurre cuando al aplicar la norma a un caso concreto sucede una obvia injusticia? ¿Cómo se puede resolver ese patente problema? A juicio de Recaséns, «ponderando, comprendiendo y estimando» los efectos que provocaría la aplicación de la norma en esa circunstancia. Si ese uso de la norma entra en contradicción rotundamente con las valoraciones que sirven de sustento al orden jurídico, entonces esa norma no es aplicable, o no es aplicable de esa forma, al caso concreto (1980: 265-266). Ese es un uso razonable del Derecho. «Creo que esta palabra, lo razonable - decía Recaséns-, es muy expresiva para designar el ámbito y la índole de lo que podríamos denominar también el logos de lo bumano» (1986: 646); se trata de lo opuesto a lo disparatado, lo evidentemente injusto, lo indebido a todas luces. Mucho antes de

18 Para darse cuenta del afecto y el predicamento que tuvo Recaséns en México, baste con citar un homenaje que se le tributó en 2002 y 2003, a los veinticinco años de su fallecimiento: un curso de doctorado sobre «El pensamiento filosófico-jurídico y político en Luis Recaséns Siches» que dio lugar a un libro en el que colaboraron catorce relevantes intelectuales que escribieron sobre la obra de aquel (MOLINA PIÑEIRO, OJESTO MARTínEZ y SERRANO MigALlÓN, 2003).

19 Sobre la visita de Kelsen a México: Flores, 2014. 
que se popularizaran, en Recaséns ya encontramos la razonabilidad, los principios, las valoraciones, la ponderación, enfrente de la razón formal, las normas al pie de la letra, la asepsia, la aplicación mecánica de las reglas (1986: 627-665).

Al fin, desde México nos legó Recaséns un manual de Filosofía del Derecho (1986) y una historia de la filosofía jurídica en el siglo XX (1963) que siguen siendo de necesaria lectura para quienes se dediquen a esta disciplina, no solo porque (salvo en lo tocante a la expresión, magnífica pero demasiado ampulosa) sigan estando en vigor sino porque Recaséns ya es un clásico.

$$
* * *
$$

Al comienzo de la década de los sesenta, algunos de nuestros protagonistas pudieron retornar a España; no para establecerse sino a pasar temporadas. Evidentemente, otros ya habían muerto y nunca pudieron volver a la patria; o por ser significados comunistas, como por ejemplo Wenceslao Roces, tuvieron que esperar a la muerte de Franco. Quienes estaban menos marcados, al menos algunos, pudieron regresar. Así, Francisco Ayala volvió por vez primera en 1960 y luego retornaría todos los veranos; lo cuenta en sus bellas pero a veces maledicentes memorias (1988: 484-489). Para visitar a su familia, en Almería, sin ningún reconocimiento ${ }^{20}$, desde la costa francesa comenzó a venir Alfredo Mendizábal, probablemente antes de la muerte de Franco, aunque resulte difícil determinar las fechas. También en visita privada para reunirse con su familia, también sin ningún reconocimiento, José Medina Echevarría volvería por vez primera en 1963 y una vez más en 1969, antes de ensayar quedarse de forma definitiva. Que yo sepa, Medina fue el único de nuestros protagonistas que regresó a España con la intención de quedarse pero, como en el caso de otros exiliados de la guerra y el franquismo vueltos a España, fracasó en el empeño (luego diría que había sido un doloroso intento) y, tras año y medio de permanencia en Madrid, antes de la muerte de Franco, regresó para Santiago de Chile. Entre quienes lo recibieron en España, por cierto, hubo profesores de Sociología pero creo que no de Filosofía del Derecho (MORALES MARTín, 2010: 138; 2012a: 819-848; 2012b: 121-123) ${ }^{21}$.

Por el cariñoso recibimiento que se le tributó, el caso más llamativo fue el de Luis Recaséns Siches. El mismo protagonista contó cómo había sido su primer regreso ${ }^{22}$ :

Mi primer regreso a España fue en noviembre de 1964. A comienzos de 1964 el profesor Ruiz Jiménez me invitó para dar un cursillo en la Facultad de Derecho de Madrid. Me sentí conmovido y entusiasmado; acepté, pero le dije que no podía ser en el 64 por haber sido ya invitado con anterioridad por el gobierno de la República Federal alemana y, por tanto, le pedía que se aplazase hasta el próximo año. Estuvo de acuerdo. Pero al enterarse muchos y entrañables amigos españoles de que yo iba a estar en Europa, cariñosa y vehementemente me instaron a que diese un salto a Madrid, aunque fuese por unos pocos días.

${ }^{20}$ Que yo sepa, el único reconocimiento que se le tributó se debió, en 1974, a Gil Cremades, quien le invitó a intervenir en la Universidad de Zaragoza cuando este ganó la cátedra, aunque Mendizábal se disculparía; vid. Gil Cremades, 2016: 289-290.

21 En el recibimiento académico que se le hizo a José Medina intervinieron al menos Salustiano del Campo y Manuel Lizcano (MORAles MarTín, 2012a: 842). Este último también participó en el recibimiento de la Sociología española a Luis Recaséns (LizCANO, 1967).

22 No concuerda con los recuerdos de Manuel FragA (1979: 124), que cita como anfitriones a Lissarrague, Muñoz Alonso y Truyol Serra. Así todo, seguro que estos también participaron en el reencuentro con Recaséns, al igual que Legaz Lacambra. 
Me convencieron y llegué a Madrid en la fecha indicada. Pude permanecer aquí solo catorce días. No venía a dar conferencias y di nueve. Además, mis buenos amigos y colegas de Madrid, como Muñoz Alonso, Legaz y Lacambra, y el decano de la Facultad de Derecho, Hernández Tejero, me propusieron «institucionalizar» mi visita académica a Madrid. Y, efectivamente, en años posteriores, por lo menos de noviembre a diciembre suelo encontrarme en tierras españolas (GONZÁLEZ DíAZ-LLANOS, 19671968: 354).

Manuel Fraga, ministro de Información y Turismo en el gobierno de la época, se reunió con Recaséns y manifestó haberse sentido impresionado por «su firme anticomunismo y lo engolado de su retórica, anticuada en muchos temas sin perjuicio de un conjunto de brillantez intelectual» (1979: 124). Ambos rasgos eran reales. Por cierto, ¿se dejó utilizar Recaséns por el franquismo?, como vino a afirmar Francisco Ayala (1988: 501-502). Por una parte, probablemente sea cierto que el régimen, y quizás su por entonces ministro de Información y Turismo, quisieron aprovecharse de sus regresos para presentarse como liberales ( $i$ !), aunque estoy seguro de que no era esa la intención de sus colegas universitarios, que así veían la manera de cicatrizar una herida sin duda muy dolorosa; por otra, algo más adelante el Ministerio de Trabajo publicó un texto del mismo Recaséns bajo el título de El impacto de la emigración española de 1939, en el que el autor no mostraba ninguna beligerancia hacia el régimen de Franco, sino incluso —-se vino a decir- acercamiento (RIBES LeIVA, 2006: 24).

Detengámonos en ese texto, que muestra — creo- el carácter y la postura de Recaséns en ese momento, porque tiene interés. Por una parte, hacía referencia y daba una interpretación de aquel trauma que tuvo que ser decisivo en su biografía:

yo no pertenezco a la emigración de 1939 [...] yo fui, en 1936, un fugitivo. Y confieso que esa calidad de fugitivo no tiene ninguna dimensión heroica. Todo lo contrario [...] Abrumado por el incendio que había cundido en España me sucedió algo contrario a mi propio temperamento: verme inundado por una ola de pesimismo. Y traté de buscar (si ustedes quieren, triste egoísmo, lo reconozco humildemente) una solución de autosalvación personal, de rescate de mí mismo (1967: 14).

Por otra parte, Recaséns se mostraba crítico con parte del exilio republicano, que había «creado — dijo- un mundo fantasmagórico» (1967: 23), y reconocía su colaboración con el Instituto Cultural Hispano-Mexicano, en el que tanto participaban «miembros de la Representación diplomática oficiosa de España en México» como representantes del exilio ${ }^{23}$, a la vez que abogaba por la reconciliación entre todos los españoles (1967: 24-26).

Aquella actitud le valdría la crítica de compañeros y compatriotas en el exilio. Pero en España también se alzaron algunas voces contra el filósofo; la extrema derecha se quejó del retorno de quien había formado parte del gobierno del Frente Popular, al que ahora se le permitía dirigirse a los estudiantes españoles. «Creo que huelgan los comentarios porque es muy difícil explicar una Cruzada contra españoles de una absoluta integridad política que después son invitados oficialmente a aleccionar a la juventud universitaria española», dijo Blas Piñar (2000: 225).

23 México no mantuvo relaciones diplomáticas con la España de Franco sino con el gobierno de la República en el exilio, de ahí que Recaséns se refiera a esa diplomacia «oficiosa». 
Pero más allá de esas polémicas, en las que no quiero entrar, nuestros protagonistas ya habían envejecido. Ahora, avanzados los setenta y a principios de los ochenta, después de la muerte de Franco en todo caso, se irían los concretos pensadores que tuvieron que escapar de la guerra y de lo que vino tras ella. Luis Recaséns Siches fallecía en Ciudad de México el 4 de julio de 1977. José Medina Echevarría fallecía en Santiago de Chile poco después, el 13 de noviembre de 1977. Alfredo Mendizábal Villalba sería el único que fallecería en España, en Almería, el 5 de abril de 1981.

\section{BIBLIOGRAFÍA}

AlarCón, V., 1997: «José Medina Echevarría y la filosofía jurídica», Isonomía, 7, 179-204.

Atienza, M., y Ruiz Manero, J., 1986: «Entrevista con Felipe González Vicén», Doxa, 3, 317 325.

Ayala, F., 1988: Recuerdos y olvidos, Madrid: Alianza Editorial, 574 pp.

BobBio, N., 1995: Derecha e izquierda. Razones y significados de una distinción política (trad. por A. PiCOnE), Madrid: Taurus, $187 \mathrm{pp}$.

Cabra Apalategui, J. M., 2011: «Claves de la argumentación jurídica en Luis Recaséns Siches: estimativa jurídica y logos de lo razonable», Anuario de Filosofía del Derecho, XXVII, 37-61.

CAMPO, S. DEL, 2001: Historia de la sociología española, Barcelona: Ariel, 326 pp.

CAUdeT, F., 1997: Hipótesis sobre el exilio republicano de 1939, Madrid: Fundación Universitaria Española, $541 \mathrm{pp}$.

- 2005: El exilio republicano de 1939, Madrid: Cátedra, 453 pp.

Cobos Bueno, J.; Pulgarín Guerrero, A., y Carapeto Sierra, C., 2004: «Reunión de la Unión de Profesores en el Extranjero UPUEE. La Habana, 22 de septiembre a 3 de octubre, 1942», Ábaco, 42, 61-74.

De Castro Cid, B., 1974: La filosofía jurídica de Luis Recaséns Siches, Salamanca: Universidad de Salamanca, 283 pp.

De la HeRA, J., 2002: La política cultural de Alemania en España en el periodo de entreguerras, Madrid: CSIC, 485 pp.

- 2014: «Ciencia y propaganda (El Instituto Alemán de Cultura de Madrid y sus antecedentes: 1924-1945)», Iurisprudentia Elegans: Revista de Derecho Político e Historia Constitucional, $1,57-75$.

De León Portila, A. H., 1978: España desde México. Vida y testimonio de transterrados, México: UNAM, 465 pp.

DíAz, E., 1974: Sociología y filosofía del Derecho, Madrid: Taurus, 449 pp.

DíAz ArciniegA, V., 1994: Historia de la casa. Fondo de Cultura Económica: 1934-1994, México: FCE, 412 pp.

FERNÁNDEZ GARCÍA, E., 2016: «Felipe González Vicén: La soledad de la conciencia ética individual y la obediencia al Derecho», inédito.

Flores, I. B., 2014: «Una visita a Hans Kelsen en México», Problema. Anuario de Filosofía y Teoría del Derecho 8, 53-94.

Fraga Iribarne, M., 1979: Memoria breve de una vida pública, Barcelona: Planeta, 393 pp.

GARCía AmAdO, J. A., 1999: «Retórica, argumentación y Derecho», Isegoría, 21, 131-147.

García Gómez del Valle, J. M. ${ }^{a}$, y MARZÁn Trujillo, C., 2010: «Notas sobre la correspondencia entre Felipe González Vicén y Carl Schmitt», Empresas Políticas, 14/15, 143-150. 
García Manrique, R., 2010: Recensión de A. Mendizábal Villalba, Pretérito imperfecto. Memorias de un utopista, Anuario de Filosofía del Derecho, XXVI, 606-611.

GIL CREMADES, J. J., 1987: «Filosofía del Derecho y compromiso político: Alfredo Mendizábal (1897-1981)», Anuario de Filosofía del Derecho, 4, 563-590.

— 2006: «Francisco Ayala. El intelectual en la crisis», Siglo XXI, 4, 17-46.

- 2016: «Benjamín Rivaya. Entrevista a Juan José Gil Cremades», Diálogos Jurídicos, 1, 271 291.

Gómez Arboleya, E., 1982: «Sociología en España» (1. ${ }^{\text {a }}$ ed., 1958), en Estudios de teoría de la sociedad y del Estado, Madrid: Centro de Estudios Constitucionales, 656-705.

GonZÁlez DíAZ-Llanos, A. E., 1967-1968: «Don Luis Recaséns Siches», Anuario de Filosofía del Derecho, XIII, 345-354.

GonzÁlez López, E., 2009: «El Comité por la Paz Civil en España», en Mendizábal, 259-317.

GonZÁlez RAdío, V., 2005: «Recaséns Siches: Filosofía del Derecho y Sociología», Revista Galego-Portuguesa de Psicoloxía e Eduación, 10, 141-161.

GONZÁLEZ ViCÉN, F., 2009: Escritos (1931-1949) (Con ocasión de su centenario), edición a cargo de C. Marzán Trujillo y J. M. ${ }^{a}$ García Gómez del Valle, Santa Cruz de Tenerife: Universidad de La Laguna, 188 pp.

IBARRURI, D., 1992: El único camino, Madrid: Castalia, 627 pp.

LiDA, C. E., y MATESAnZ, J. A., 1987: «Un refugio en el exilio: La casa de España en México y los intelectuales españoles», Revista de Occidente, 78, 118-129.

LizCANO, M., 1967: «La mayoría de edad de la sociología (Curso del profesor Recaséns Siches en el Instituto de Estudios Sindicales, Sociales y Cooperativos)», Revista de Estudios Políticos, 156, 213-216.

LOEDEL Rois, G., 2012: Los traductores del exilio republicano español en Argentina, tesis doctoral. Dirección URL: http://www.tdx.cat/bitstream/handle/10803/108338/tglr.pdf? sequence=1 (consulta: 25 de abril de 2016).

LÓPEZ SÁNCHEZ, J. M. ${ }^{a}$, 2006: «El exilio científico republicano en México: la respuesta a la depuración», en L. E. Otero Carvajal (dir.), La destrucción de la ciencia en España. Depuración universitaria en el franquismo, Madrid: Universidad Complutense, 177-239.

- 2013: Los refugios de la derrota. El exilio cientifico e intelectual republicano de 1939, Madrid: Consejo Superior de Investigaciones Científicas, 286 pp.

Llera Esteban, L. DE, 1996: El último exilio español en América, Madrid: Mapfre, 1996, 780 pp.

MAINER, J. C., 1999: La Edad de Plata (1902-1939). Ensayo de interpretación de un proceso cultural, Madrid: Cátedra, 466 pp.

MARÍAS, J., 1988: Una vida presente. Memorias I, Madrid: Alianza Editorial, 389 pp.

MartíneZ ChÁveZ, E. E., 2015a: «Luis Recaséns Siches, un puente entre culturas», en A. VALERO PIE (ed.), Los empeños de una casa. Actores y redes en los inicios de El Colegio de México. 1940-1950, México: El Colegio de México, 199-214.

- 2015b: «Rutas científicas y académicas. Juristas republicanos españoles exiliados en México durante el régimen de Franco», en M. MECARELli y P. PALCHETTI (eds.), Derecho en movimiento. Personas, derechos y derecho en la dinámica global, Madrid: Dykinson, 231-249.

— 2016a: «Medina Echevarría, José (1903-1977)», en PeTiT, $2016 a$.

— 2016b: «Ramos Sobrino, Blas (1891-1955)», en PETIT, $2016 a$.

— 2016c: «Recaséns Siches, Luis (1903-1977)», en PETIT, 2016a.

Medina EChevarRíA, J., 1943a: «¿Filosofía del Derecho?», Cuadernos Americanos, I/II, 111117.

- 1943b: Responsabilidad de la inteligencia, México: Fondo de Cultura Económica, 271 pp. 
- 1946: Sociología: Teoría y técnica (1. ${ }^{\text {a }}$ ed., 1941), México: FCE, 196 pp.

- 1980a: La obra de José Medina Echevarría (selección y estudio preliminar por A. GURRIERI), Madrid: Ediciones de Cultura Hispánica del Instituto de Cooperación Iberoamericano, $676 \mathrm{pp}$.

- 1980b: La sociología como ciencia social concreta, Madrid: Ediciones de Cultura Hispánica, $197 \mathrm{pp}$.

- 2008a: Panorama de la sociología contemporánea (1. a ed., 1940), México: El Colegio de México, 286 pp.

- 2008b: Situación presente de la filosofía jurídica. Esquema de una interpretación (1. ed., 1935), Zaragoza: Reus, $151 \mathrm{pp}$.

MendizÁbal Villalba, A., 1946: «Spain», en Twentieb Century Political Thought, New York: Philosophical Library, 593-618.

- 1947: «On Everlasting Values of the Spanish School of Natural Law (F. de Vitoria)», en P. SAYRE (ed.), Interpretations of Modern Legal Philosophies. Essays in Honor of Roscoe Pound, New York: Oxford University Press, 498-520.

- 1948: «Catholicism and Politics», en F. Gross (ed.), European Ideologies: A Survey of 20th Century Political Ideas, New York: Philosphical Library, 486-537.

- 1963: «Hacia una auténtica democracia. Punto de partida», en VVAA, Pensamiento y acción. Serie de artículos escogidos sobre el problema español, México: Ediciones de España en América, 27-33.

- 1965: «La sociología española», en G. Gurvitch y W. E. MoOrE (eds.), Sociología del siglo XX (1. a ed., 1945), vol. 2, Barcelona: El Ateneo, 343-357.

- 2009: Pretérito imperfecto. Memorias de un utopista, Oviedo: RIDEA, 335 pp.

- 2012: Los orígenes de una tragedia, edición, introducción y traducción de X. ITURRALDE, Madrid: Centro de Estudios Políticos y Constitucionales, 213 pp.

Molina Piñeiro, L. J., Ojesto Martínez, F., y Serrano Migallón, F. (coords.), 2003: El pensamiento filosófico jurídico y político en Luis Recaséns Siches, Mexico: Porrúa y Facultad de Derecho de la UNAM, 293 pp.

Morales Martín, J. J., 2010: «José Medina Echevarría y la sociología del desarrollo», Íconos. Revista de Ciencias Sociales, 36, 2010, 133-146.

- 2012a: José Medina Echevarría: vida y sociología, Tesis Doctoral inédita, Madrid, 994 pp.

- 2012b: «Exilio y sociología. Aproximación a José Medina Echevarría», Laberintos 14, 90 106.

Moya LóPez, L. A., 2007: «José Medina Echevarría y la colección de Sociología del Fondo de Cultura Económica, 1939-1959», Estudios Sociológicos, vol. 25, núm. 75, 765-803.

- 2013: José Medina Echevarría y la sociología como ciencia social concreta (1939-1980), México: El Colegio de México: 500 pp.

Moya López, L. A., y Morales Martín, J. J., 2008: «Estudio introductorio», Medina EcheVARRÍA, 2008: 11-76.

ORTEGA y GASSET, J., 1947: La rebelión de las masas (1. a ed., 1929), Buenos Aires: Espasa-Calpe, $241 \mathrm{pp}$.

Petit, C., 2016a: Diccionario de catedráticos españoles de Derecho (1847-1943), Madrid: Universidad Carlos III de Madrid. Dirección URL: http://portal.uc3m.es/portal/page/portal/instituto_figuerola/programas/phu/diccionariodecatedraticos (consulta: 4 de mayo de 2016).

— 2016b: «González Vicén, Felipe (1908-1991)», en PeTiT, 2016a.

— 2016c: «Mendizábal Villalba, Alfredo (1897-1981)», en PETIT, 2016a. 
PIÑAR, B., 2000: Escrito para la bistoria (I), Madrid: Fuerza Nueva, 608 pp.

Ramos, B., 1969: El Derecho y el hombre actual. Filosofía. El hombre y la máquina. Decadencia de los principios jurídicos de la burguesía, con prólogo de L. GONZÁlEz RAMOS, Madrid: Gráficas Halar, 146 pp.

ReCASÉns SiCHes, L., 1936: Estudios de Filosofía del Derecho, Barcelona: Bosch, 550 pp.

- 1937a: «Los interrogantes filosóficos del Derecho. Misión de una auténtica filosofía del Derecho», Archiv für Rechts-und Sozialphilosophie, Band XXIX Heft 2, 287-294.

- 1937b: «Intervention de M. Riscasers Siches», Cahiers du Cercle Descartes. Le Probleme Espagnol, 4, février, 26-29.

- 1942: «Libertad y planificación (El tema central de nuestra época)», Cuadernos Americanos, 4, 100-120.

- 1945: Vida bumana, sociedad y Derecho. Fundamentación de la Filosofía del Derecho (1. a ed., 1939), México: FCE, 615 pp.

- 1963: Panorama del pensamiento jurídico en el siglo XX, México: Porrúa, 2 vols.

- 1967: El impacto de la emigración española de 1939, Madrid: Ministerio de Trabajo, Instituto Español de Emigración, 26 pp.

- 1976: Tratado de Sociología (1. a ed., 1976), México: Porrúa, 682 pp.

- 1980: Nueva filosofía de la interpretación del Derecho, México: Porrúa, 320 pp.

- 1986: Tratado General de Filosofía del Derecho, México: Porrua, 717 pp.

Reyes Nevares, S., 1982: «Juristas, economistas, sociológos», en VVAA, El exilio español en México, 1939-1982, México: FCE, 567-598.

RiBAS, P., 1990: Aproximación a la bistoria del marxismo español, Madrid: Ediciones Endymion, $319 \mathrm{pp}$.

RiBES LeIVA, A. J., 2006: «Luis Recaséns Siches (1903-1977): La sociología como respuesta a la crisis, defensa del individuo y fundamentación de la convivencia», Anduli. Revista Andaluza de Ciencias Sociales, 5, 9-31.

Ridruejo, D., 1978: Los cuadernos de Rusia, Barcelona: Planeta, 297 pp.

- 2007: Casi unas memorias (edición al cuidado de J. АмAT), Barcelona: Ediciones Península, $619 \mathrm{pp}$.

RivaYA, B., 1993: «Alguna notas referidas, en el marco iusfilosófico, a la "presunta" inexistencia de sociología en la década que siguió a la guerra civil», Revista de Estudios Políticos, 82, 229-247.

- 1994: «En torno a la Universidad y la guerra: el caso González Vicén», Sistema, 121, 97-112.

- 2000: «Comunismo y compromiso intelectual: Wenceslao Roces», Papeles de la FIM, 14, $149-187 ; 15,160-165$.

- 2001: «Biografía política de Luis Recaséns Siches (1930-1936)», Revista de las Cortes Generales, 52, 193-225.

— 2009: «Estudio (biográfico) preliminar: Alfredo Mendizábal Villalba (1897-1981)», en MENDIZÁBAL, 2009, 11-49.

- 2010: Una historia de la filosofía del Derecho española del siglo XX, Madrid: Iustel, 238 pp.

Rodrígez CaAmaño, M. J., 2004: «José Medina Echevarría (1903-1977): La sociología como ciencia social concreta», Política y Sociedad, 41, 11-29.

RuIZ-Funes, C., 1999: «La Unión de Profesores Universitarios españoles en el exilio. Motivos y razones», en VVAA, Los refugiados españoles y la cultura mexicana, México: Colegio de México, 435-449.

SerRano Migallón, F., 2002: «...Duras las tierras ajenas...» Un asilo, tres exilios, México: FCE, $440 \mathrm{pp}$. 
SOlari, A. E., ed. 1977: Poder y desarrollo. América Latina. Estudios sociológicos en homenaje a José Medina Echevarría, México: Fondo de Cultura Económica, 425 pp.

SugRAnYes DE FranCH, R., 1998: Militant per la justícia. Memòries dialogades amb el pare Hilari Raguer, Barcelona: Proa Perfils, 270 pp.

VÁzquez Montalbán, J., 2004: Galíndez (1.a ed., 1991), Barcelona: Plaza Janés Editores, $426 \mathrm{pp}$.

VVAA, 1982: Medina Echevarría y la sociología latinoamericana, Madrid: Ediciones Cultura Hispánica del Instituto de Cooperación Iberoamericana, 157 pp. 


\title{
LA FILOSOFÍA DEL DERECHO DE ALEXANDRE KOJËVE*
}

\author{
Oriol Farrés Juste ** \\ Universidad Autónoma de Barcelona \\ Oriol.Farres@uab.es
}

RESUMEN. Este artículo es una presentación de la filosofía del derecho de Alexandre KOJÈVE contenida en su Esquisse d'une phénoménologie du droit (1981). La poca atención que dicha obra ha recibido es un vacío que debiera llenarse con una reflexión crítica de sus puntos fuertes. Entre ellos destaca una concepción de la justicia internacional que proyecta una luz muy singular sobre los actuales debates en torno a la globalización y el cosmopolitismo. A ojos de este autor, la ciudadanía es el elemento clave para aquilatar la expansión global de lo jurídico. En suma, KOJÈVE aparece como un valioso referente en la labor de pensar la contraposición entre lo jurídico y lo político que está en la base de toda filosofía del derecho, con la aspiración al logro de la justicia internacional y la paz mundial en el horizonte.

Palabras clave: fenomenología del derecho, cosmopolitismo, ciudadanía, derecho, política, paz.

\section{Alexandre Kojève's Philosophy of Law}

ABSTRACT. This article is a presentation of Alexandre KOJĖVE's philosophy of law, exposed in his Esquisse d'une phénoménologie du droit (1981). Little attention has been paid to this work. So there is a gap that has to be filled with a critical reflection of its strengths. Among them, undoubtedly, we count the fact that KOJĖVE is introducing a conception of international justice that casts a singular light on current debates about cosmopolitanism and globalization. According to this author, citizenship is the key element of the process of global expansion of the juridical sphere. In sum, KoJèVE's philosophy is useful to reflect upon the contrast between the juridical and the political, which is the basis for all philosophy of law, in order to achieve world peace and international justice.

Keywords: phenomenology of right, cosmopolitanism, citizenship, right, politics, peace.

\footnotetext{
* Fecha de recepción: 1 de junio de 2016. Fecha de aceptación: 13 de febrero de 2017.

Este artículo es resultado del proyecto de investigación FFI2015-64858-P, titulado: Justicia y democracia: hacia un nuevo modelo de solidaridad, y financiado por el Ministerio de Economía y Competitividad (España).

** Investigador Postdoctoral Docente. Departamento de Filosofía.
} 


\section{INTRODUCCIÓN}

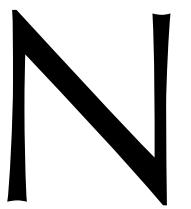

os proponemos abordar en lo que sigue las tesis más relevantes de la filosofía del derecho contenida en Esquisse d'une phénoménologie du droit (1981) de Alexandre KoJÈVE, autor más conocido por su Introduction à la lecture de Hegel (1968). Esta última es una recopilación, llevada a cabo por Raymond QUENEAU, de los apuntes correspondientes a las clases dictadas por KoJÈVE en l'École Pratique des Hautes Études de París, durante el que fue un celebérrimo seminario que marcó generaciones enteras en Francia y en el mundo entero por lo que respecta a la interpretación de la hegeliana Fenomenología del Espíritu. A raíz de ello y tras ingresar en la administración De Gaulle, KojèvE se convirtió en una enigmática eminencia gris que influyó sin ostentación en autores de la talla de Leo STRAUSS ${ }^{1}$, Georges BATAILlE o Jacques LACAN. La teoría del fin de la historia relanzada más tarde por Francis FuKUYAMA ${ }^{2}$ representó, sin lugar a dudas, la puesta al día de KOJÈvE en los debates políticos posteriores al término de la guerra fría y la implosión de la Unión Soviética. Sin embargo, aunque menos difundido más importante resulta, según acreditadas voces, su Esquisse d'une phénoménologie du droit $^{3}$. En este libro argumenta KOJÈvE sobre la plausibilidad del «Estado universal y homogéneo», que sería su propia versión acerca de una integración jurídica mundial de la que se seguiría la imposibilidad tanto de las guerras como de las revoluciones, de tal modo que el proyecto kantiano de la paz perpetua recibiría en dicha obra una validación no menor in bipothesi que in thesi $i^{4}$.

En el fondo se trata, en Esquisse d'une phénoménologie du droit, de desarrollar los temas del derecho, la justicia y el Estado universal y homogéneo que se encuentran ya en la Introduction à la lecture de Hegel, si bien todavía demasiado sujetos a la interpretación de HEGEL. En cambio, en el Esquisse el autor se muestra «satisfecho» con los resultados obtenidos hablando ya en primera persona, esto es, sin limitarse a glosar a Hegel (AufFret, 1990: 280). Enuncia además una serie de problemas y consideraciones muy pertinentes en el ámbito de la filosofía del derecho por sus consecuencias políticas y filosóficas de primer orden. Aun así, sorprendentemente ha sido muy escasa la atención que se le ha prestado si se exceptúa su reciente interpretación por François TERRÉ, Bryan-Paul Frost y Robert Howse. Pero aún queda mucho por extraer de dicha obra. Por lo pronto, en este artículo vamos a trasladar sus análisis, en la medi-

1 Especialmente importante es el debate entre KojÈve y Strauss en L. STRAuss, On Tyranny, Chicago, Chicago University Press, 2000 (hay traducción castellana: Sobre la tiranía, Madrid, Ediciones Encuentro, 2005).

2 F. FunuYama, The End of History and the Last Man, New York, Free Press, 1992 (hay traducción castellana: El fin de la Historia y el último bombre, Barcelona: Planeta, 1992).

3 P. Anderson, «The Ends of History», en A Zone of Engagement, New York, Verso, 1992, 320-321, especialmente nota 102 .

4 «Los Estados con relaciones recíprocas entre sí no tienen otro medio, según la razón, para salir de la situación sin leyes, que conduce a la guerra, que el de consentir leyes públicas coactivas, de la misma manera que los individuos entregan su libertad salvaje (sin leyes), y formar un Estado de pueblos (civitas gentium) que (siempre, por supuesto, en aumento) abarcaría finalmente a todos los pueblos de la tierra. Pero si por su idea del derecho de gentes no quieren esta solución, con lo que resulta que lo que es correcto in thesi lo rechazan in hipothesi, en este caso, el raudal de los instintos de injusticia y enemistad solo podrá ser detenido, en vez de por la idea positiva de una república mundial, por el sucedáneo negativo de una federación permanente y en continua expansión, si bien con la amenaza constante de que aquellos instintos estallen» (KANT, 2003: 25-26). 
da de lo posible, al problemático contexto actual de la globalización y las relaciones internacionales; es decir, trataremos de exponer el planteamiento kojeviano de la integración jurídica mundial como realización paulatina de la idea de justicia y clausura de su evolución histórica. Cabe reconocer que la obra se ha granjeado escasa atención incluso en Francia; existe, empero, una traducción al inglés ${ }^{5}$. Con nuestra presentación nos gustaría suplir un tanto la ausencia de su traducción al castellano, cuando menos hasta que esta se produzca, y en el mejor de los casos, como un incentivo para ello.

A pesar del título, Esquisse, el autor va más allá de un mero bosquejo de la cuestión y ofrece un desarrollo sistemático en tres secciones: el derecho como tal, su origen y evolución, y por último, el sistema del derecho; 588 páginas en total de la edición francesa (1981). KoJĖvE parte de una fenomenología del derecho, esto es, de una descripción de las condiciones a partir de las cuales tiene o no sentido hablar de «derecho». Como primer elemento destaca el trasfondo social de toda relación jurídica. En este contexto está absolutamente injustificado hablar con propiedad de «derechos individuales». La relación jurídica siempre es, por un lado, una relación plural e implica, por el otro, al conjunto de una sociedad; dicho de otro modo, los derechos son siempre colectivos y su razón de ser está en la interacción de los individuos, nunca en una propiedad individualizada (KoJÈve, 1981: 112-15, 155-56 y 367 ).

En este contexto «fenomenología» significa descripción a partir de características visibles o, como establece el propio autor, en términos de un paradigma bebaviorista. Se basará, pues, en la observación: «Para llegar a tal definición "behaviorista" del derecho, veamos cómo actúan los hombres cuando se hallan en una relación típica de derecho» (KOJÈVE, 1981: 19) ${ }^{6}$. La tipología que KOJÈvE expone se inspira en PlaTÓN (ideas), WEBER (tipos ideales) y HuSSERL (descripción eidética) ${ }^{7}$, si bien difiere de sus tres antecesores por mantener una perspectiva histórica según la cual la comprensión y realización del derecho evolucionaría hasta llegar al punto, término final de la evolución, en que su esencia coincidiría con su existencia. Obviamente en el trasfondo de esta perspectiva está HEGEL —aunque interpretado y reelaborado por KOJÈvE (JARCZYK y LABARRIÈRE, 1996)—. Pero, asimismo, la descripción fenomenológica ha de permitir una crítica de los usos inadecuados del término «derecho». El objeto de tal descripción es dar con un criterio que sirva para discriminar caso por caso si existe o no propiamente una relación jurídica. Ahora bien, el Esquisse d’une phénoménologie du droit no puede ser más que un boceto. No nos da ninguna explicación ontológica o metafísica del derecho - sino solo fenomenológica - por tratarse de una reflexión todavía imperfecta, y sobre todo porque el Estado universal y homogéneo, único criterio - no transhistórico, sino inmanente a la historia— que permitiría juzgar (hegeliana-

5 A. KoJève, Outline of a Phenomenology of Right; translated, with and introductory essay and notes, by B.-P. Frost and R. Howse, edited by B.-P. Frost, Lanham: Rowman \& Littlefield Publishers [2000] 2007.

6 «Pour arriver à une telle définition "béhavioriste" du phénomène juridique, voyons comment agissent les bommes lorsqu'ils se trouvent dans un rapport typique de droit».

7 «Il s'agit de trouver l' "Idée" (PLATON), l'Idealtypus" (Max WEBER), le "Phénomène” (HuSSERL), etc., de l'entité étudiée, en analysant un cas concret particulièrement net, typique, spécifique, pur. Il faut découvrir en d'autres termes le contenu qui fait que le cas donné est un cas de droit par exemple, et non de religion ou d'art, etc. Et l'ayant découvert, c'est-à-dire ayant trouvé l' "essence" (WESEN) du phénomène, il faut le décrire d'une façon correcte et complète, cette description de l'essence n'étant rien d'autre que la définition du phénomène en question» (KOJÈVE, 1981: 10). 
mente) el desarrollo del derecho aún no se habría realizado completamente (KoJÈve, 1981: 11, 13 y 17).

Ante todo, KoJÈve subraya el logro fundamental del derecho europeo moderno: «Porque el derecho europeo moderno tiene como principio que el ser humano (a saber, el homo sapiens) por el mero hecho de su existencia es un sujeto de derecho» (KoJÈvE, 1981: 41-2) ${ }^{8}$. Este principio reviste una enorme importancia, y no es nada difícil sacarlo a la luz de los fundamentos de la filosofía del derecho del que es su máximo referente (HEGEL, 1993). Paralelamente a dicha realización del derecho, el proceso histórico antropogénico da como resultado la figura del «ciudadano» del Estado universal y homogéneo (la ciudadanía cosmopolita), que desde la Introduction à la lecture de Hegel ve KOJĖvE como ya acontecido, al menos formal y potencialmente. En su argumentación, la universalización del derecho es una pieza clave de esa evolución histórica. Por otra parte, los derechos carecen de sentido fuera del mundo humano: animales o cosas solo son objeto de derecho en la medida de sus relaciones con los seres humanos, esto es, en la medida en que se encuentran bajo su cuidado y protección (KoJÈVE, 1981:34). Todo ello se apoya en una antropología filosófica de raíz hegeliana: el derecho avanza en paralelo con la historia de la emancipación, a saber, la historia del esclavo que, según HEGEL, se emancipa del amo para llegar a ser ciudadano.

Tres son las formas que adopta la relación jurídica9 : a) tener el derecho; $b$ ) no tener el derecho, y $c$ ) tener el deber de hacer u omitir determinada acción. Como $b$ y $c$ en realidad son equivalentes (puesto que, por un lado, no tener el derecho a hacer $x$ equivale a tener el deber de no hacer $x$; $y$ por el otro, no tener el derecho de no hacer $x$ equivale a tener el deber de hacer $x$ ) y tener el deber de hacer algo implica por necesidad tener también el derecho (si bien no se identifican), en realidad solo $a$ es pertinente. $Y$ es que donde haya alguien que tenga el derecho de hacer u omitir $x$, habrá derecho. Lo aclara perfectamente una serie de ejemplos (o casos prototípicos a la manera de paradigmas) que muestran la relación jurídica como resultado de la interacción entre tres elementos [como reza el adagio romano, tres faciunt collegium (KoJÈvE, 1981: 75)]: por un lado, dos agentes, A y B, que interactúan, y por el otro lado, $\mathrm{C}$, que dirime si existe o no el derecho a determinada acción a raíz de su intervención en el conflicto entre A y B. Antes de adentrarnos en los detalles de la formación del derecho es importante destacar que, desde un punto de vista metodológico, la descripción kojeviana del derecho no es ni una definición a priori del derecho ni una recolección a posteriori de todas las instancias denominadas «derecho».

Sería fácil dar una definición arbitraria del Derecho, aun con el riesgo de negarse a llamar «jurídico» a todo cuanto, por lo demás, así se denomina pero no se ajusta a la definición elegida. Solo que tal definición tendrá poco interés, pues es imposible hacer remilgos a las enseñanzas contenidas en el lenguaje y la historia. Si algo es —o fue— llamado «derecho», lo más probable es que no haya sido por azar. Pero, por otra parte, es materialmente imposible el reunir en una sola definición todo lo que se ha llamado «derecho» en todo momento y lugar: este contenido sería disparatado (KoJĖve, 1981: 9-10) ${ }^{10}$.

\footnotetext{
8 «[C]ar le droit européen moderne a pour principe que par le fait seul de son existence, l'être bumain (s'entend l'Homo sapiens) est un sujet de droit».

9 La explicación detallada se encuentra en las $\$ \$ 5-19$ del Esquisse d'une phénoménologie du droit.

10 «Il serait facile de donner du Droit une défnition arbitraire, quitte à refuser d'appeler "juridique" tout ce qui est appelé ainsi par ailleurs, mais ne cadre pas avec la définition choisie. Mais une telle définition aurait peu d'intérêt, car il est impossible de faire simplement fi des enseignements impliqués dans le langage et dans l'bistoire.
} 
Cabe una «vía intermedia» entre ambos métodos, que KoJÈvE se propone mediante el uso de paradigmas para definir y describir el derecho en cuanto derecho, autónomo y distinto de otras instancias tales como la religión, la moral o la política. Esta «vía intermedia» pondría de manifiesto la «autonomía del derecho», de modo semejante a cómo Carl ScHMiTT en El concepto de lo político había sostenido la autonomía de la política. En segundo lugar, KoJÈvE repasa el nacimiento del derecho a partir de la hegeliana lucha por el reconocimiento. Al mismo tiempo estudia su evolución histórica con relación a dos formaciones históricas de la justicia: la justicia de la igualdad (aristocrática) y la justicia de la equivalencia (burguesa), cuya síntesis sería la justicia de la equidad del ciudadano (propia del Estado universal y homogéneo). En tercer y último lugar, brinda una clasificación de los fenómenos jurídicos y una descripción, poco ortodoxa pero de gran interés filosófico, del derecho internacional, el derecho privado y el derecho público. Su objetivo es describir la esencia del derecho en su realización última (en el Imperio socialista o Estado universal y homogéneo) que satisfaría el deseo humano de reconocimiento, con lo cual se daría por finalizada la evolución histórica de la humanidad ${ }^{11}$.

\section{LA NOCIÓN KOJEVIANA DE DERECHO}

Por supuesto se debe a su obra anterior, Introduction à la lecture de Hegel cuyo hilo conductor es la dialéctica del amo y el esclavo, la importante función que esta última desempeña en la formación e historia del derecho desarrollada en la segunda parte del Esquisse. Ahora bien, ante todo es preciso atender a un elemento esencial de la kojeviana filosofía del derecho, cuyo mero planteo ya entraña por sí solo una original heterogeneidad con respecto a las posiciones más extendidas en dicha filosofía. Como ha defendido François TERRÉ (2011: 422), KoJÈVE aporta una luz singular que, siendo algo periférica, se demuestra de la mayor utilidad para reflexionar filosóficamente sobre el derecho. En efecto, resulta muy importante la intuición de que, para que se dé propiamente una «situación jurídica» o «relación de derecho», hace falta la presencia de una terceridad o tercero. La relación de derecho implica, pues, tres miembros: A y $\mathrm{B}$ son dos agentes que interactúan, lo que motiva - pero no determina- la intervención de un tercero, $\mathrm{C}$.

En resumen, el tercero $C$ no interviene sino en la medida en que la conducta (acción) de B (voluntad, acto o fin) tienda a suprimir la conducta (acción) de B (voluntad, acto o fin), esto es, en la medida en que la acción de B sea una verdadera «reacción», esto es, en la medida en que haya una «interacción» entre A y B (KoJève, 1981: 67) ${ }^{12}$.

Una acción se compone de tres elementos: 1) la «voluntad» (resolución interna o declaración expresa de hacer o no hacer algo); 2) el «acto» en sí u objeto de la volun-

Si quelque chose est —ou a été- appelé "Droit", il est plus probable que ceci n'a pas été fait par hasard. Mais d'autre part il est matériellement impossible de réunir en une seule définition tout ce qui est appelé "Droit" à un moment quelconque et quelque part: ce contenu serait trop disparate».

${ }_{11}$ Esta es una de las tesis rectoras de la Introduction à la lecture de Hegel (1968) de KojÈvE.

12 «En bref, le tiers $C$ n'intervient que dans la mesure où le comportement (l'action) de B (volonté, acte ou but) tend à supprimer le comportement (l'action) de A (volonté, acte ou but), c'est-à-dire dans la mesure où l'action de B est une véritable "réaction", c'est-à-dire dans la mesure où il y a une "interaction" entre A et B». 
tad, y 3) la meta o finalidad del acto en cuestión (FrOsT, 1999: 603). Estos tres elementos pueden darse por separado. Si, por el contrario, se dan conjuntamente se podrá hablar con propiedad de una «acción voluntaria», que es justo la materia sobre la que opera el derecho. KoJÈvE sostiene que la situación jurídica se revela cuando, a raíz de la interacción entre $\mathrm{A}$ y $\mathrm{B}$, interviene $\mathrm{C}$ para impedir la reacción de $\mathrm{B}$ a la acción de $\mathrm{A}$ (KoJÈVE, 1981: 28); y, por tanto, garantiza el derecho de A de hacer o de no hacer algo. Es en este punto, en $\$ 7$ (KoJÈVE, 1981: 22 y ss.), donde KoJĖVE describe las situaciones paradigmáticas que hacen comprensible a partir de ejemplos típicos la relación jurídica. El primero de tales ejemplos tiene que ver con el dinero. Supongamos que A quiere recibir una determinada cantidad de dinero de B. Esta acción de A tiene como consecuencia una reacción de B. Pueden abrirse entonces dos escenarios: 1) que B impida a A obtener esta suma de dinero, o 2) que A, que es más fuerte, obtenga el dinero de B por coacción. En ninguno de ambos casos, por lo dicho, se tratará propiamente de una relación de derecho. Tampoco lo será si al cabo se produce un robo o una donación voluntaria. Nada de todo ello pone de manifiesto el derecho como tal. Pero la situación cambiará radicalmente si aparece un $\mathrm{C}$ para garantizar a $\mathrm{A}$ la obtención de la suma. Ahora bien, la aparición de $\mathrm{C}$ deberá tener la siguiente forma:

A actúa con el fin de obtener el dinero; B reacciona para no soltarlo; pero una tercera persona $\mathrm{C}$ interviene y anula la reacción de $\mathrm{B}$ de modo que $\mathrm{A}$ recibe el dinero sin haber tenido que hacer esfuerzo alguno para obtenerlo, ya que la reacción de $\mathrm{B}$ que $\mathrm{A}$ hubiera debido anular ha sido anulada por la intervención de C. Hay que añadir que A y B son indiferentes, esto es, unos desconocidos para $\mathrm{C}$, y que $\mathrm{C}$ no está personalmente interesado en que el dinero quede en manos de $\mathrm{B}$ o pase a $\mathrm{A}$. En este caso puede decirse con certeza que asistía a A el derecho de tomarlo. Cabe suponer, por ejemplo, que A quería recuperar el dinero que había dejado en poder de $\mathrm{B}$ y que $\mathrm{C}$ es el agente judicial que ha efectuado la operación por cuenta de A al no querer B llevarla a cabo espontáneamente (KoJĖve, 1981: 22-23) ${ }^{13}$.

KoJÈvE añade cuatro ejemplos más: A y B están sentados en el banco de un parque de manera que $B$ proyecta su sombra sobre $A$, y $A$ le ruega que se aparte; $B$ es un vecino de $A$ que hace ruido por las noches y $A$ actúa para que $B$ cese de hacerlo; $B$, madre de un niño que se ha caído en el río y está ahogándose, pide ayuda a $A$, que sabe nadar, para salvarlo; y por último, $\mathrm{A}$ ataca a $\mathrm{B}$ y $\mathrm{B}$ reacciona para detener los golpes. «Es inútil alargar esta lista de ejemplos» (KoJĖVE, 1981: 23). En todos ellos aparece la figura de $\mathrm{C}$ como garante de que $\mathrm{A}$ tiene o no tiene el derecho de hacer o no hacer determinada acción. Lo más relevante, empero, es que $\mathrm{C}$ actúa desinteresadamente. Así que $\mathrm{C}$ tenga de antemano una preferencia por A o por B podrá afirmarse que no se da el fenómeno del «derecho». Para que el fenómeno jurídico aparezca resulta absolutamente necesario que la intervención de $\mathrm{C}$ sea «imparcial» y «desinteresada». Imparcial: $\mathrm{C}$ no siente ninguna preferencia ni por A ni por B; luego su intervención tendría exactamente las mismas características incluso si A y B se intercambiaran los papeles, de manera que A fuese B y B fuese A. Desinteresado: C modifica objetivamente el estado de A y B, pero

13 «A agit en vue d'obtenir l'argent; B réagit de façon à le garder; mais une troisième personne $C$ intervient, annule la réaction de $B$ de sorte que $A$ reçoit l'argent sans avoir eu à faire d'effort pour l'avoir, la réaction de $B$ que $A$ aurait dî annuler ayant été annulée par l'intervention de $C$; ajoutons que $A$ et $B$ sont indifférents, voir inconnus à $C$ et que $C$ n'est pas intéressé personnellement à ce que l'argent reste chez $B$ ou passe à $A$. Dans ce cas on peut dire avec certitude que $A$ avait droit de le lui prendre. On peut supposer par exemple que $A$ voulait reprendre à $B$ l'argent qu'il avait déposé chez lui et que C était l'buissier qui a fait l'opération pour le compte de $A, B$ ne voulant pas s'exécuter spontanément». 
no modifica el suyo propio (KoJÈvE, 1981: 77). Puesto que la idea de «desinterés» no queda lo bastante explicada con ese rasgo, KOJÈvE añade que $\mathrm{C}$ es desinteresado en tanto que $\mathrm{C}$ podría ser cualquiera y aun así no se modificaría su tipo de intervención; es decir, que cualquier otro intervendría de forma idéntica a la de $C$. En suma, la razón de ello es que la intervención de $\mathrm{C}$ no tiene otro objeto o interés que la Justicia. De ahí que se la califique de «desinteresada» y, por extensión, también de «imparcial».

Además la intervención de $\mathrm{C}$ debe ser «consciente y libre». La conciencia se revela fenomenológicamente en el hecho de que, sin la interacción de A y B, la intervención de $\mathrm{C}$ no hubiera tenido lugar. La libertad se revela en el hecho de que la intervención de $\mathrm{C}$ no se deriva mecánicamente de la interacción de $\mathrm{A}$ y $\mathrm{B}$, ya que tal intervención podría no haberse dado (es contingente). La intervención de $\mathrm{C}$ está condicionada por la interacción de A y B, pero no está determinada por ella. Esto es fundamental porque el criterio de intervención del tercero no se ciñe a los simples elementos que se ponen en juego en la interacción entre $\mathrm{A}$ y $\mathrm{B}$, sino que $\mathrm{C}$ tiene, por decirlo así, sus propias razones para intervenir entre A y $\mathrm{B}$. Pues bien, es la intervención y no la interacción per se lo que pone de manifiesto el fenómeno jurídico (KoJÈVE, 1981: 69-73). Aplíquese al contexto político (el Estado) en que aparece la relación de derecho:

Para que exista una situación jurídica hace falta (1) que el Estado se relacione con amigos políticos, que A y B, que interaccionan, sean ciudadanos, y (2) que A y B estén en interacción no política entre sí, de modo que el Estado pueda desinteresarse de la naturaleza de su interacción y no ser parte al dejar de ser juez (KoJÈve, 1981: 147) ${ }^{14}$.

Todo ello solo es posible si se comprende que $\mathrm{C}$ tiene su propio criterio a la hora de intervenir. Este criterio es lo que KoJĖve llama «la idea o ideal de Justicia». Por tanto, la motivación de $\mathrm{C}$ se basa en algo que podríamos llamar un «sentido de la justicia» ${ }^{15} \mathrm{y}$ un deseo de realización de un determinado ideal de justicia. El contenido de esta idea o ideal de justicia no es transhistórico, sino que está siempre ubicado históricamente. La fenomenología del derecho, por tanto, está también incardinada y contextualizada históricamente. KoJÈvE no duda en aclarar que la idea o ideal de justicia varía con el tiempo y que depende de la sociedad y del grupo que en ella ejerce el liderazgo: es su idea de justicia la que rige. Así pues, en realidad, el tercero $\mathrm{C}$ a lo largo de la historia no pudo ser cualquiera, o mejor dicho, solo un cualquiera de una época determinada y de un grupo exclusivo concreto (la élite dirigente) en una sociedad particular. No sería hasta el advenimiento de un Estado universal y homogéneo que, de hecho, $\mathrm{C}$ podría ser realmente cualquiera. Solo en estas circunstancias la existencia y la esencia del derecho se recubrirían totalmente.

La expresión «Estado universal y homogéneo» puede parecer algo extraña y contraintuitiva, pero de hecho capta a la perfección dos rasgos fundamentales de la rea-

14 «Pour qu'il y ait une situation juridique, il faut donc (1) que l'État se rapporte à des amis politiques, que $A$ et $B$, qui sont en interaction, soient des citoyens, et (2) que $A$ et $B$ soient en interaction non politique entre eux, de sorte que l'État puisse se désintéresser de la nature de leur interaction et ne pas être partie là où il est cessé d'être Juge».

${ }_{15}$ Para una versión normativa y no histórica de la idea o sentido de la justicia, vid. J. RAWLS, $A$ Theory of Justice, Oxford: Oxford University Press, especialmente cap. 8, sec. 69-77, 1980. Aunque se trata de dos contextos diferentes, tanto la «idea o ideal» de la justicia kojeviana como el «sentido» de la justicia rawlsiano dan contenido a principios formales. La fundamentación de la «idea o ideal» de la justicia es en KojÈve muy deudora de la filosofía de la historia hegeliana, con lo cual obviamente dista mucho de la posición de RAWLS. 
lización de la idea o ideal de la justicia. Primero, la universalidad: si una sociedad es realmente universal y engloba a la humanidad entera, se puede eliminar de la definición de derecho la circunstancia de que $\mathrm{C}$ forma parte de una sociedad particular. Solo entonces el desinterés de $\mathrm{C}$ será auténtico, porque no se basará en su pertenencia a una sociedad concreta. Segundo, la homogeneidad: este rasgo del estado final es de una relevancia capital. Significa que no hay un «grupo exclusivo» que detente el poder en una sociedad determinada, esto es, no hay un cúmulo de intereses particulares que obren en contra del resto de la sociedad, a saber, de aquellos que no forman parte del «grupo exclusivo» siendo miembros del «grupo excluido». Por tanto, «homogeneidad» no tiene el sentido de negación de toda diversidad. El propio KoJÈvE indica que, sin duda, en el Estado universal y homogéneo persistirá un montón de diferencias individuales insuperables. «[P]ues, de hecho, la homogeneidad nunca es absoluta: hay diferencias de edad, sexo, carácter, etc., y por consiguiente agrupaciones subestatales» (KoJÈVE, 1981: 152 ${ }^{16}$. Universalidad y homogeneidad combinadas garantizan la ausencia de enemigos exteriores (universalidad) y enemigos interiores (homogeneidad), con lo que el estado final logra una estabilidad suficiente como para que se dé por supuesta su continuidad e inmutabilidad en el tiempo. Justo en este momento podrá ser $\mathrm{C}$ cualquiera, imparcial y desinteresado.

Aunque Kojève no reflexione lo suficiente sobre las implicaciones de esta afirmación, dichas implicaciones son extraordinarias. Si solamente en el final de la historia $\mathrm{C}$ podría ser realmente cualquiera, entonces todos y cada uno de los individuos estarán de acuerdo con los principios jurídicos que determinan qué opciones específicas se consideran criminales, y el estado final y solo el estado final dará expresión a un sistema de derecho universalmente aceptado y plenamente satisfactorio (FrOST, 1999: 608) ${ }^{17}$.

Todas las concepciones del derecho anteriores en la historia serían todavía incompletas, no habrían conseguido realizar la esencia del derecho. Y ello debido a que serían relativas a los intereses de las élites gobernantes en una sociedad y estarían en función de una época determinada. A diferencia de las concepciones más formalistas del derecho, KoJÈVE apunta a la necesidad de considerar el derecho como un producto histórico, relativo a las sociedades formadas en momentos históricos definidos y regidas además por intereses de los grupos gobernantes. El ideal de justicia, pues, no es neutro en la historia, sino que se ha visto siempre teñido por su entorno. El único modo de romper con el horizonte histórico consiste precisamente en culminar la evolución histórica, siendo su culminación el estado final o universal y homogéneo. El Esquisse es deudor de la Introduction en este punto crucial.

Por último, debe advertirse que la relación jurídica, al implicar por fuerza una terceridad, elimina de antemano como situaciones de derecho todas las intervenciones en que el Estado es juez y parte al mismo tiempo, esto es, el derecho público como tal. «En cuanto al "Derecho" público, no es un Derecho ni en tiempos de guerra ni

\footnotetext{
${ }^{16}$ «[C]ar en fait l'homogénéité n'est jamais absolue: il y a différences d'âge, de sexe, de caractère, etc., et par conséquent des groupements cis-étatiques».

17 «Although Kojève only briefly elaborates upon the implication of this claim, these implications are nothing less than extraordinary. If $C$ could be anyone at all only at the end of history, then each and every individual would agree with the juridical principles which determined what specific options were considered criminal, and the end state and the end state alone would give expression to a universally accepted and fully satisfying system of right».
} 
en tiempos de paz» (KOJÈVE, 1981: 152, nota al pie). François TERRÉ se ha demorado en este punto, que llama mucho la atención ciertamente. El argumento kojeviano no deja lugar a dudas: solo hay derecho cuando un $\mathrm{C}$ imparcial y desinteresado interviene entre A y B. Si el Estado como tal es juez y parte afectada al mismo tiempo, entonces la relación es política, pero no jurídica. Afirma TERRÉ:

Así, pues, en el análisis que efectúa KoJÈve «allí donde se trata de relaciones de interacción con el propio Estado, no hay elemento jurídico en absoluto». Con más razón resulta ser así cuando se pasa del Derecho administrativo al Derecho constitucional: «En la medida en que la Constitución fija el estatus del Estado y de los ciudadanos, esta no tiene nada de jurídica. Es una ley puramente política del Estado, es decir, una ley que el gobierno crea como quiere y que este puede cambiar como quiera [...]. Si el ciudadano actúa como ciudadano entonces, por definición, este no puede entrar en conflicto con el Estado». Pese a la concurrencia de tantas fórmulas — a simple vista paradójicas, excesivas y radicales- el jurista de nuestra época debe especialmente interrogarse, no obstante, acerca de los excesos del todo jurídico, sobre todo ante el espectáculo de zonas intermedias respecto a las que el modo de operar del filósofo resultaría ser particularmente esclarecedor y operacional (TERRÉ, 2011: 421-22).

El tipo ideal kojeviano de relación de derecho o situación jurídica no encaja en el derecho administrativo y aun menos en el derecho constitucional. ¿Significa esto que deben abandonarse tales denominaciones? Es decir, ¿significa esto que el derecho administrativo y el constitucional no son propiamente «derecho»? No exactamente. Lo interesante del análisis de KOJÈVE consiste, precisamente, en cuestionar esas zonas intermedias del derecho en que la imparcialidad y el desinterés, criterios ambos de lo jurídico, pueden estar bajo sospecha por cuanto la relación que el Estado establece con el ciudadano no se basa en un tercero imparcial, sino en la unilateralidad de uno de los dos agentes, en este caso el Estado como juez y parte al mismo tiempo. En definitiva, lo interesante de KoJÈvE es que nunca cruza el umbral, que hace visible, de la relación entre derecho y política. Siempre tiene presente el elemento político en el derecho, pero sin reducir este a la política.

\section{EL SUPUESTO DERECHO INTERNACIONAL}

Una de las distinciones que KoJÈvE aplica al derecho es la de «derecho en potencia» y «derecho en acto», de evidente cuño aristotélico. La potencialidad del derecho implica que este se halla en proceso de devenir mientras que la actualidad del derecho implica, en cambio, que ya ha devenido. Semejante distinción resulta fundamental para comprender la relación jurídica entre Estados; tiene, pues, consecuencias en el ámbito del derecho internacional.

La diferencia entre potencialidad y actualidad se da en función de lo irresistible que sea la intervención de $\mathrm{C}$ en el conflicto entre $\mathrm{A}$ y $\mathrm{B}$. Si la intervención de $\mathrm{C}$ es realmente irresistible, puede anular la reacción de $\mathrm{B}$ contra el derecho de $\mathrm{A}$ de hacer u omitir $x$. En la medida en que la intervención de $\mathrm{C}$ no sea irresistible y $\mathrm{B}$ tenga la posibilidad de reaccionar contra A, se dirá que el derecho solo existe en potencia. Por el contrario, si la acción de $\mathrm{C}$ es irresistible, entonces el derecho se habrá actualizado. Conviene remarcar que dicho criterio es estrictamente formal: no da cuenta de los 
contenidos y objetos del derecho, sino de la forma en que una terceridad efectiva puede intervenir de manera irresistible (sin tropezar con una resistencia insuperable) en la interacción de A y B. Los contenidos del derecho dependen de la idea o ideal de Justicia; se trata de un contenido histórico que responde a la interpretación kojeviana de la hegeliana dialéctica del amo y el esclavo a lo largo de la historia. Nos detendremos más adelante sobre ello. Por de pronto lo decisivo es que el derecho internacional siempre se halla en potencia a menos que exista un organismo internacional que pueda actuar como tercero o C de forma irresistible; léase un Estado mundial, que KOJÈVE vincula al Estado universal y homogéneo. La universalización del derecho implica, por tanto, la desaparición de las soberanías estatales y, justamente por ello, cuestiona el ser mismo de lo político entendido como potencial relación de enemistad en un cuadro de inspiración hobbesiana y schmittiana. KoJève ilumina el derecho con una nueva luz al ponerlo en relación con su potencial de despolitización. En donde exista una relación jurídica se desvanecerá la relación propiamente política, que está basada en los opuestos amigo y enemigo. «Pero doy por supuestas estas dos categorías fundamentales, específicamente políticas» (KoJÈVE, 1981: 144 y en la nota al pie cita «Karl Schmidt» [sic], Der Begriff des Politischen). La influencia de Carl ScHMITT en el planteamiento kojeviano es manifiesta.

Se trata de entender que el Estado es una asociación política autónoma. En lo sucesivo, al existir una pluralidad de estados existe también una pluralidad de derechos. Pero el derecho está solo en potencia en tanto que cualquiera puede huir a un Estado donde la ley no le alcance; por ende, esta ley no es «irresistible». Con la kojeviana definición del derecho en mano es fácil reparar en que hasta los tratados de extradición y otras fórmulas de cooperación interestatal, en la medida en que dependen de la voluntad política de los Estados firmantes, seguirán siendo «derecho en potencia». Luego su relación no será jurídica sino política, sin menoscabo de que pueda suponer -y supone de hecho- algunos avances en el proceso de juridificación mundial. Ahora bien, tal proceso solo podrá darse por culminado con el advenimiento del Estado universal y homogéneo. Muchos y plausibles son los argumentos contra la existencia de un estado mundial (en terminología kojeviana, un «estado final»). Entre los mismos destaca algo que ya KANT había señalado: el peligro de una tiranía mundial sin contrapeso u oposición política algunos. El estado mundial pudiera traducirse en una efectiva liquidación de la ciudadanía, entendida esta según el modelo liberal y republicano.

Ahora bien, si el Estado es realmente universal y bomogéneo, entonces la ciudadanía será realmente universal y homogénea. No se trata de una simple tautología. Antes bien, logra evitarse el potencial bélico de los conflictos entre Estados, siempre dentro del esquema schmittiano amigo-enemigo, con lo cual la guerra pasa a ser imposible al universalizarse el Estado. La homogeneidad no debe entenderse como uniformización social, sino como supresión de la diferencia entre el grupo exclusivo de gobernantes y el grupo excluido de gobernados (esto es, como supresión de la diferencia entre clases). Entonces, lo reiteramos, cualquiera podrá ejercer de C desinteresado e imparcial que juzgue sobre la interacción de distintos agentes. Tampoco significa ello que todo C juzgará del mismo modo; así como las peculiaridades individuales de los ciudadanos del Estado universal y homogéneo persistirán (de ahí la insistencia de KOJÈvE en el fe- 
nómeno del esnobismo en varios pasajes de su obra) ${ }^{18}$, persistirá también la aplicación prudencial, contextual y en cada caso particular de C. Los dictámenes de C, por tanto, no serían idénticos para cada caso, pero sí las reglas de justicia en que se inspiraría. En suma, no habrá en el Estado universal y homogéneo distintas reglas de justicia en función de cada Estado, sino que las reglas de la justicia se habrán universalizado y actualizado. Si en la primera definición de derecho $\mathrm{C}$ puede ser cualquiera dentro de un grupo exclusivo en una sociedad dada en un momento determinado, según la definición final de derecho ocurre todo lo contrario:

Si una sociedad es homogénea, podremos suprimir las palabras «de un grupo exclusivo». Si es universal, podremos suprimir las palabras «de una sociedad dada». Si es homogénea y universal, podremos eliminar todo el paréntesis, es decir, todas las restricciones introducidas en este párrafo. Entonces la definición de la esencia del derecho se aplicará también a la existencia del derecho, precisamente porque existencia y esencia serán una: la esencia de la ley estará plenamente realizada y la existencia estará enteramente penetrada por la plenitud de la esencia jurídica. La justicia se realizará plenamente en y por el derecho, porque la Justicia determinará a toda existencia humana (KoJÈvE, 1981: 94) ${ }^{19}$.

En puridad, no cabe admitir fácilmente que el Estado universal y homogéneo sea de veras un Estado. Más bien parece tratarse de una sociedad organizada mediante un aparato jurídico. Si por «Estado» entendemos una administración (evidentemente la administración de la justicia inclusive), entonces el Estado universal y homogéneo es de hecho un «Estado» — en la medida en que todos los ciudadanos serán «administrados» por él一. Lo será en términos weberianos, por así decir. No obstante, al desaparecer lo político por saturación, en otro sentido el Estado (a partir de su significado histórico) está condenado a desaparecer. El Estado universal y homogéneo rompe con la existencia de Estados como expresión de lo político porque precisamente acaba con lo político concebido en el marco de la relación «amigo-enemigo». Al no haber una pluralidad de Estados (el «pluriverso» de Sснмітт) tampoco hay la posibilidad de enemistarse, de forma que se llega a una situación de «universalidad» despolitizada. Y no cabe hablar de «neutralidad» ya que ni siquiera existiría la posibilidad de un conflicto; más bien se trata de neutralización. Lo interesante en KoJÈvE es que la despolitización corre pareja a la juridificación: la autonomía y especificidad (es decir, la irreductibilidad a otros ámbitos) de lo jurídico se muestra análoga a la autonomía y especificidad de lo político en SCHMITT. De hecho, KOJÈvE la concibe como alternativa a la resolución de los conflictos humanos que, en SСНMiтT, lleva en casos extremos a la guerra para medir las diferencias ${ }^{20}$. Ahora, por el contrario, es el arbitraje del tercero lo que resuelve los conflictos entre miembros de la especie bomo sapiens sin tener que

18 Sobre todo en la famosa nota al pie añadida en la segunda edición de la Introduction à la lecture de Hegel (KoJÈve, 1968: 436-437).

19 «Si une Société est homogène, on pourra supprimer les mots: "d'un group exclusif". Si elle est universelle, on pourra supprimer les mots "d'une Société donnée". Si elle est homogène et universelle, on pourra supprimer toute la parenthèse, c'est-à-dire toute la restriction introduite dans ce paragraphe. La définition de l'essence du droit s'appliquera alors aussi à l'existence du Droit, précisément parce que l'existence et l'essence ne feront plus qu'un: l'essence du droit sera pleinement réalisée et l'existence sera entièrement pénétrée par la plénitude de l'essence juridique. La justice sera pleinement réalisée dans et par le Droit parce que toute l'existence humaine sera déterminée par la Justice».

${ }_{20}$ Para una contraposición y debate entre los planteamientos de Kojève y SCHMiTT, vid. A. Kojève, 2001: «Alexandre Kojève-Carl Schmitt Correspondence and Alexandre Kojève, Colonialism from a European Perspective», Interpretation, vol. 29, n. 1, 91-130. 
recurrir a las armas. La juridificación, por tanto, es algo así como una pacificación. Sin duda parten ambos autores de una tendencia al conflicto de orden antropológico, pero KoJĖVE la supera con un giro hegeliano desde el potencial irénico del derecho ${ }^{21}$.

KoJÈVE brinda una concepción del derecho internacional público como potencialidad pacificadora que superaría la beligerancia entre Estados. Pero el derecho internacional público no es más que un derecho facultativo (facultatif), esto es, en lenguaje de nuestro autor, un derecho en potencia. $\mathrm{O}$ en sus propias palabras:

Cuando dos Estados se someten al arbitraje de un tercero (o - lo que es lo mismo- al arbitraje de un tribunal internacional, de una SDN [Sociedad de las Naciones], o incluso de la «opinión mundial»), se da una situación jurídica real, ya que todos sus elementos (el juez y las partes) son reales. Pero desde el momento en que el arbitraje es facultativo, este derecho real solo existe en potencia. Los dos Estados-parte y el Estado-árbitro forman así una «Sociedad» que implica un derecho real. Sin embargo, cada miembro puede abandonar esta Sociedad y formar una sociedad «afuera». El derecho real de esta Sociedad no se actualiza pues necesariamente. Es un derecho real en potencia. Y es por eso que el derecho internacional contemporáneo debe modificarse para llegar a ser real y en acto (KOJÈVE, 1981: $131-132)^{22}$.

Esta modificación del derecho internacional público que plantea KoJÈVE no es otra cosa que la realización efectiva de una Sociedad mundial que no permita el abandono. $\mathrm{O}$ dicho de otro modo: se alcanza una situación en que las resoluciones de $\mathrm{C}$ (como árbitro entre A y B) son realmente irresistibles. Una de las fórmulas que KoJÈVE sugiere en su concepción de la expansión jurídica es su paso por una «federación» de Estados y un cosmopolitismo cívico (MURPHY, 2011). Su federalismo es pues un medio para alcanzar la universalidad y homogeneidad en la administración de la justicia:

Como entidad política, el Estado tiende a expandirse por conquista; lisa y llanamente, trata de absorber a los estados extranjeros. Pero como entidad jurídica, el Estado se conforma con imponer en el extranjero su derecho interno. En otras palabras, tiende a crear una Federación de Estados o un Estado federal, transformándose él mismo en uno de los Estados federados. Tal Federación tiene como base y resultado la existencia de un derecho único, común a todos los Estados federados, e implica —en su aspecto de «Derecho público»— un elemento de «derecho federal» que regula las relaciones de los Estados Federados entre sí; en particular, la organización federal de la justicia. Si la Federación no es universal, y si tiene Estados-enemigos en el exterior, deberá organizarse como Estado propiamente dicho (federal). Sus elementos integrantes - los Estados federados - también tendrán enemigos; por consiguiente, serán Estados. Pero tendrán siempre enemigos comunes y deberán reconciliarse con ellos en común: no serán, por tanto, Estados soberanos, sino Estados federados. Solo la Federación tenderá a expandirse tanto como le sea posible. En última

21 «En fait un État national ne réussit jamais ni à absorber tous ces ennemis, ni à s'isoler complètement d'eux. La limite n'est atteinte que par l'État universel ou l'Empire. Mais alors il n'y a plus d' "ennemis", c'est-à-dire plus de domaine politique. L'Empire, en actualisant complètement la relation politique fondamentale d'amis-ennemis, épuise la "puissance" politique. Or l'acte s'annule au moment où il épuise sa puissance. L'Empire n'est donc plus une entité politique au sens propre du mot : il n'a pas d'bistoire politique» (KOJÈve, 1981: 147).

${ }_{22}$ «Quand deux États se soumettent à l'arbitrage d'un troisième (ou —ce qui est la même chose-à l'arbitrage d'un Tribunal international, d'une S.D.N. [Société des Nations], ou même de l'"opinion mondiale”), il y a une situation juridique réelle, puisque tous les éléments (le Juge et les Parties) sont réels. Mais, du moment que cet arbitrage est facultatif, ce Droit réel n'existe qu'en puissance. Les deux États-parties et l'État-arbitre forment bien une "Sociétê" impliquant un droit réel. Mais chaque membre peut quitter cette Société et former une Société "en debors". Le Droit réel de cette Société ne s'actualise donc pas nécessairement. C'est un Droit réel en puissance. Et c'est pourquoi le Droit international contemporain doit se modifier pour devenir réel et en acte». 
instancia, abarcará toda la humanidad. Entonces dejará de ser un Estado en el sentido propio de la palabra al no tener enemigo exterior. Y los Estados Federados también dejarán de ser verdaderos Estados. La Federación se convertirá entonces en una simple unión jurídica mundial (al menos en su aspecto jurídico, que no es el único) (KOJÈVE, 1981:391) ${ }^{23}$.

Lo interesante y verdaderamente actual de la filosofía del derecho de KoJÈVE es que el Estado universal se convierte en una exigencia normativa para lograr el irénico objetivo de la paz entre naciones. La universalidad de tal sociedad imposibilitaría de facto su abandono. En cuanto a la homogeneidad, la exigencia de la misma es resultado de la base sociológica de raíz hegelomarxista en que se apoya nuestro autor. Su punto de partida es la constatación de que la posibilidad de conflictos no solo se da en un pluriverso de sociedades nacionales que denota su estado de naturaleza, sino que en el propio interior de las sociedades se produce necesariamente una separación entre grupos antagónicos en la forma de lo que KoJĖve llama «grupo exclusivo» y «grupo excluido». Aun concediendo la existencia de posibles fricciones en el seno de los grupos antagónicos, de ordinario el grupo excluido opondrá resistencia al poder - $\mathrm{o}$ incluso cabe desencadenar una revolución contra el orden establecido por y para el grupo exclusivo- - La homogeneidad social, en cambio, eliminaría la formación de estos dos grupos antagónicos, con lo que se alcanzaría entonces la paz social en el interior de la sociedad en cuestión. El Estado universal y homogéneo, por tanto, es la superación efectiva del recurso a la guerra o la revolución, de modo que las disputas entre los miembros de la sociedad pueden ser resueltas en función del ideal de Justicia universal y homogéneamente compartido.

\section{LA HISTORICIDAD DE LA JUSTICIA}

Una de las cuestiones que queda indudablemente por resolver es la de la formación de un ideal de justicia universalmente compartido. Esta idea o ideal de justicia (o este «sentido de la justicia») no se puede dar por supuesto como existiendo por sí mismo en un Estado universal y homogéneo. Le falta una garantía última, un fundamento. Se nos plantea, pues, una cuestión filosófica de gran calado. KoJÈve se apresta a solucionarla mediante el esquema hegeliano de su Introduction à la lecture de Hegel; más concretamente, sirviéndose de la mencionada lectura del cuarto capítulo, sección A, de la Fenomenología del espíritu de HEGEL. No es el presente artículo el lugar ade-

23 «En tant qu'entité politique, l'État tend à se propager par la conquête, il essaye d'absorber purement et simplement les États étrangers. Mais en tant qu'entité juridique l'État se contente d'imposer à l'étranger son Droit interne. Autrement dit, il tend à créer une Fédération d'États ou un État fédéral, en devenant lui-même un des États fédérés, la Fédération ayant pour base et pour résultat l'existence d'un Droit unique, commun à tous les États fédérés, et impliquant —dans son aspecte de "Droit Public" - un élément de "Droit fédéral", réglant les rapports des États fédérés entre eux, en particulier l'organisation fédérale de la justice. Si la Fédération n'est pas universelle, si elle a des États-ennemis à l'extérieur, elle devra s'organiser elle-même en État proprement dit (fédéral). Ses éléments intégrants - les États fédérés-auront eux aussi des ennemis; ils seront donc des États. Mais ils auront toujours des ennemis communs et ne pourront se réconcilier avec eux qu'en commun: ils seront donc non pas des États souverains, mais des États fédérés. Seulement la Fédération aura tendance à se propager le plus possible. À la limite elle englobera l'ensemble de l'bumanité. Alors elle cessera d'être un État au sens propre du mot, n'ayant plus d'ennemi au-dehors. Et les États fédérés cesseront par suite, eux aussi, d'être des États véritables. La Fédération deviendra alors une simple Union juridique mondiale (du moins dans son aspect juridique, qui n'est pas le seul)». 
cuado para entrar en el asunto de si la lectura hegeliana que KojÈve lleva a cabo es demasiado unilateral o de si, por el contrario, interpreta del mejor modo «lo que Hegel quiso decir». A juzgar por alguna alusión que le dedica, su propia filosofía residiría justamente en su peculiar interpretación de HEGEL ${ }^{24}$. Por ello nos parece del mayor interés la recuperación del Esquisse d'une phénoménologie du droit considerando que, según lo dicho más arriba, el autor habla en esa obra con voz propia, sin escudarse en el comentario de otra «autoridad» (a saber, HEGEL o lo que es más, HEGEL reelaborado con ingredientes marxistas y heideggerianos).

La base para la formación de la idea o ideal de justicia la pone la lucha antropogénica por el reconocimiento, esto es, la constitución de la humanidad a partir del afán de cada sujeto por ser reconocido por el otro. Huelga el insistir en el sumo interés de averiguar cómo se ha formado la idea o ideal de justicia, teniendo en cuenta que el contenido del derecho depende de tal idea. Pues bien, la respuesta empieza por abordar la lucha a muerte en aras del reconocimiento entre dos sujetos que arriesgan su propia vida a fin de ser reconocidos por el otro «en una franja de la ultrahistoria». En principio, las figuras hegelianas de la libertad y la dependencia de la conciencia (amo y esclavo) no responden a un hecho histórico fechable cronológicamente. Son más bien el resultado de un modelo «fenomenológico» (Fenomenología del Espíritu) de las relaciones entre los hombres como seres conscientes que luchan por el reconocimiento. En el híbrido filosófico, si se nos permite la expresión, de HeGEL y KoJÈve, se trata del desarrollo mismo de la historia de la humanidad.

Nos hallamos ahora mismo en la segunda sección del Esquisse d'une phénoménologie du droit, enfrentados a una lucha entre dos consciencias que pretenden el reconocimiento mutuo, y esta lucha afecta a la mera supervivencia animal. Cierto que, en busca del humano que está por acontecer, el animal se verá trascendido. Solo que en la lucha habrá un vencedor, el amo, y un perdedor, el esclavo. En términos de la idea o ideal de la justicia, ocurre que habrá una concepción de la justicia propia del amo reconocido como tal y una concepción de la justicia del esclavo. A la concepción de la justicia del amo la llamará KOJĖVE «justicia como igualdad» y, a la concepción de la justicia del esclavo, «justicia como equivalencia».

La justicia como igualdad surge de la perspectiva del amo, del sujeto vencedor en la lucha por el reconocimiento. Es una justicia de estatus. El amo solo reconocerá como iguales a otros amos, esto es, a aquellos que también han visto reconocida su humanidad por haber arriesgado su vida, negándola y trascendiéndola con vistas a un fin propiamente humano. La justicia de la igualdad es, paradójicamente, una justicia aristocrática. Ello significa, claro está, que el esclavo no merece siquiera consideración: que es lo otro, no reconocido en absoluto, al servicio del amo y poseído por él (su propiedad). En rigor, no hay desigualdad entre el amo y el esclavo, al existir entre ambos una diferencia cualitativa esencial que excluye toda noción de desigualdad. La justicia aristocrática es una justicia de la igualdad, pero no se asemeja en nada a la equivalencia porque nada tiene que ver con los contratos o las relaciones entre individuos. Es justo, ni más ni menos, que quienes han arriesgado su vida por un ideal humano y han salido

24 KOJÈvE habría manifestado en más de una ocasión que su lectura y comentario de HEGEL era una «obra de propaganda política», por ejemplo en una carta al fenomenólogo vietnamita TRAN DuC THAO, y que tras su interpretación de HEGEL se escondía su propia filosofía (ESQUIROL, 2006: 141-142). 
victoriosos sean reconocidos como iguales. KoJÈve busca un ejemplo de esta igualdad en las antiguas sociedades aristocráticas, como Esparta, donde los miembros de la clase dominante se llamaban a sí mismos hómoioi, los iguales. Así, es justo que los amos, en cuanto iguales, se traten en régimen de igualdad.

La justicia de la equivalencia, por contra, nace de la perspectiva del esclavo. Siendo este, propiamente, el sujeto que se ha rendido en la lucha por el reconocimiento, es decir, el que ha preferido conservar su vida a afrontar la lucha a muerte con todas sus consecuencias, sucede que la condena a servir a un amo (del que reconoce la humanidad aun no siendo reconocido) equivale a gozar de la gracia por él concedida de poder mantenerse con vida. Se trata de un germen de contrato cuyos elementos dispares (conservación de la vida y servicio en régimen de esclavitud) son vistos como equivalentes de manera que cabe una transacción. Se trata, pues, de una justicia protoburguesa, dicho en términos kojevianos. La justicia, en tal caso, nada tiene que ver con la igualdad, sino con la compensación entre dos valores, y residirá justo en el intercambio de un valor - al principio de la lucha, la conservación de la vida animal todavía no humana - por otro valor — los servicios que el esclavo deberá rendir al amo-.

Esta equivalencia constituye la nueva idea de Justicia. Esta justicia de equivalencia se manifiesta en y por el consentimiento mutuo que pone fin a la Lucha entablada por un consentimiento mutuo que ponía de manifiesto la Justicia de igualdad. A la Justicia de la igualdad, se ha añadido así una Justicia de la equivalencia (KoJĖve, 1981: 255) ${ }^{25}$.

Reparemos en el hecho de que, pese a las enormes diferencias implicadas, la situación final en que desemboca la lucha primordial es justa desde un doble punto de vista. En primer lugar lo es porque los contendientes han iniciado la lucha de mutuo consentimiento; nadie ha obligado al otro a luchar, sino que se han batido por propia voluntad, desde la igualdad. Claro está que el resultado final es dispar, pero esta disparidad cualitativa entre amo y esclavo no puede ser vista como injusta por el amo ya que las condiciones iniciales eran perfectamente iguales. En segundo lugar, tampoco el esclavo, por su parte, ve propiamente injusticia en su situación de esclavitud; pero su percepción no obedece a la consciencia de una igualdad primera, sino a la consciencia de una equivalencia entre el conservar la vida (como seguridad) y el mantener una relación de trabajo para pagar (como servicio) la seguridad vital que, por así decirlo, le garantiza el amo. Por ello puede KOJÈvE afirmar que el hombre en la historia no es nunca uno, sino dos: amo y esclavo. No existen, por lo demás, sociedades puramente basadas en la justicia como igualdad o sociedades exclusivamente basadas en la justicia como equivalencia. Lo que existe siempre es un compromiso o combinación entre ambos ideales de la justicia, que sirven de referencia para la formación del derecho realmente existente en las sociedades. Así, pues, la idea o ideal de la Justicia que pone en práctica un $\mathrm{C}$ desinteresado e imparcial en el conflicto entre un $\mathrm{A}$ y un $\mathrm{B}$ en una sociedad histórica particular estará siempre inspirado en una mezcla entre los componentes de la justicia de la equivalencia y de la justicia de la igualdad, mezcla en la cual uno de los componentes tendrá prioridad sobre el otro.

25 «C'est cette équivalence qui constitue la nouvelle idée de Justice. Et c'est cette justice d'équivalence qui se manifeste dans et par le consentement mutuel qui met fin à la Lutte engagée par un consentement mutuel qui manifestait la Justice d'égalité. À la Justice égalitaire vient s'ajouter ainsi une Justice de l'équivalence». 
Se hace evidente que la justicia como igualdad (aristocrática y de estatus) se halla en relación antitética con la justicia como equidad (burguesa y de contrato). Esto es, la justicia del amo y la justicia del esclavo se mantienen en una oposición no resuelta. KOJÈvE acude de nuevo a HEGEL para explicar que la síntesis entre la justicia aristocrática y la justicia de raigambre burguesa no es más que la reconciliación de estas dos instancias en la justicia absoluta o del ciudadano, que no es ni la justicia de la igualdad ni la justicia de la equivalencia, sino que es la justicia de la equidad. La justicia como equidad representa la combinación perfecta entre las dos figuras de la justicia en la historia (la oposición histórica entre amo y esclavo), y lógicamente solo podrá darse con el fin de la historia, como resolución final de la tensión existente entre los dos ideales en pugna. En suma, para KoJÈve la ciudadanía, en cuanto superación de la antítesis entre amo y esclavo, implica el fin del proceso histórico o, lo que viene a ser lo mismo, este desemboca en la realización de la humanidad como ciudadanía, algo que solo puede tener lugar en el Estado universal y homogéneo.

Para explicar el funcionamiento del principio de la equidad en la justicia, KoJÈvE se sirve de un ejemplo que ilustra a la perfección cómo se unen en un solo criterio los elementos de la igualdad y la equivalencia:

Tomemos el ejemplo del reparto de alimentos para la comida. El principio de igualdad exigirá una distribución a partes iguales entre los titulares de derechos, y no se ocupará de nada más. Pero el principio de equivalencia se preguntará si las partes iguales son verdaderamente equivalentes. Si se comprueba que algunos están más hambrientos que otros, entonces no será así en absoluto. Se distribuirá pues de otra manera, haciendo partes proporcionales a la necesidad de alimento de cada cual. Una vez satisfecho el principio de equivalencia, ya no se irá más lejos. Pero el otro principio se verá lesionado por la desigualdad del reparto y tratará de eliminarla. Solo que, para no lesionar el principio de equivalencia, hará falta eliminar la desigualdad de los participantes. Luego se preguntará por qué unos están más hambrientos que otros. Y si se comprueba que esta diferencia se debe a que unos han desayunado y otros no, se velará por que, en adelante, todos puedan desayunar. El principio de equivalencia, por tanto, habrá impulsado una realización más perfecta del principio de igualdad, llevando a que el principio de igualdad se realice con mayor perfección. $\mathrm{Y}$ al volverse perfecta, la igualdad coincide con la equivalencia. Pues si los poseedores de derechos son realmente iguales, la igualdad de sus partes ya no diferirá de su equivalencia y su equivalencia no será sino su igualdad (KoJÈVE, 1981:315) ${ }^{26}$.

En el planteamiento expuesto, la equidad implica una transformación de la igualdad desde la equivalencia y una transformación de la equivalencia desde la igualdad. Esta síntesis conlleva una modificación de las condiciones de partida de forma que la igualdad se torna equivalente y la equivalencia igualitaria. Con dicha modificación se

26 «Reprenons l'exemple du partage d'une nourriture pour le dîner. Le principe d'égalité exigera un partage en parts égales entre les ayants droit, et il ne se préoccupera plus de rien. Mais le principe de l'équivalence se demandera si les parts égales son vraiment équivalentes. Si l'on constate que les uns ont plus faim que les autres, on verra qu'il n'est est rien. On partagera alors autrement, rendant les parts proportionnelles au besoin de la nourriture de chacun. Le principe étant ainsi satisfait on s'en tiendra là. Mais l'autre principe sera choqué par l'inégalité du partage et il essayera de l'éliminer. Seulement, pour ne pas choquer le principe de l'équivalence il faudra éliminer l'inégalité des participants. On se demandera donc pourquoi les uns ont plus faim que les autres. Et si l'on constate que cette différence résulte du fait que les uns ont déjeuné et les autres non, on veillera à ce que dorénavant tous puissent déjeuner. Le principe de l'équivalence aura donc incité celui de l'égalité à se réaliser plus parfaitement. Et en devenant parfaite l'égalité coïncide avec l'équivalence. Car si les ayants droit son vraiment égaux, l'égalité de leurs parts ne diffère plus de leur équivalence, leur équivalence n'est autre chose que leur égalité». 
realiza propiamente la justicia ciudadana: universalización del derecho y homogeneización social a la par. Es por ello que fin de la historia, realización de la justicia en el derecho ciudadano y Estado universal y homogéneo coinciden en un mismo movimiento evolutivo. Según KoJÈve, este estado final aún no ha llegado, pero se están dando ya sus potencialidades en base a los principios revolucionarios de la libertad, la igualdad y la fraternidad. Como manifestó de forma claramente polémica en la Introduction à la lecture de Hegel, desde la batalla de Jena (1806) los cimientos del Estado universal y homogéneo ya estarían asentados. La expansión del código civil napoleónico equivaldría, pues, a la expansión del estadio final de la civilización, y su globalización consistiría nada menos que en la actualización de lo que ya estaría en potencia desde la Revolución Francesa (Robespierre) y la batalla de Jena (Napoleón) (KoJève, 1968: 436).

\section{CONCLUSIONES}

La filosofía del derecho de KoJève es un ímprobo esfuerzo con vistas a dotar de fundamento histórico la realización de la justicia. Vuelve para ello sobre la filosofía hegeliana partiendo de su lectura en términos marxistas, de forma que no concibe el derecho como algo estático, sino en permanente transformación histórica. Ahora bien, el criterio de materialización de la justicia o, lo que viene a ser lo mismo, de la realización del derecho en cuanto Idea o concepto realizado (según HEGEL) es inmanente al proceso histórico enfocado a la luz de la dialéctica entre el amo y el esclavo, que es la clave hermenéutica de la Lucha y el Trabajo en la Historia. De este modo, la kojeviana filosofía del derecho es una aplicación de la filosofía del mismo autor contenida en la Introduction à la lecture de Hegel.

Reviste suma importancia su descripción fenomenológica del Derecho en cuanto intervención de un tercero, $\mathrm{C}$, en la interacción de A y B. Ese tercero o C deberá ser imparcial y desinteresado al aplicar la idea o el ideal de la justicia resultante del proceso histórico formulado hegelianamente. Se trata, pues, de una filosofía del derecho que oscila entre el iusnaturalismo y el positivismo jurídico. Del derecho natural conserva el principio de que no todas las formas de interacción que reciben el nombre de «derecho» lo son propiamente; de ahí su insistencia en esclarecer lingüística y fenomenológicamente a qué llamamos «derecho», operando dicha clarificación a tenor de los paradigmas de intervención de terceros como árbitros en los conflictos sociales. Habría, en consecuencia, un marco supralegal a la luz del cual se podría dirimir qué es y qué no es «derecho». Ahora bien, la diferencia (esta vez de origen aristotélico) entre el derecho en potencia o facultativo, que no es, por tanto, «derecho» en sentido propio, y el derecho en acto, esto es, irresistible y realmente eficaz, acerca esta filosofía al iuspositivismo. KOJĖVE retiene este doble aspecto aparentemente contradictorio en un movimiento dialéctico en el cual el criterio supralegal (iusnaturalista) y el criterio de la eficacia (positivista) se sintetizan de tal modo que solo el derecho positivo del Estado universal y homogéneo puede realizar los principios verdaderos y esenciales del derecho. En suma, la naturalización de la legalidad se corresponde con la positivización de la Justicia.

Puede decirse que el Derecho «positivo» del Estado universal y homogéneo realiza el Derecho «natural», que no es sino el Derecho como tal, es decir, la «esencia» del Derecho. 
En el Estado universal y homogéneo, la teoría «racionalista» del Derecho coincide así con la teoría «histórica o sociológica». En ello reside el propio fondo del hegelianismo o, si se prefiere, de la comprensión dialéctica de la historia (KoJÈve, 1981: 91)27.

Lo más valioso que podría aportarnos una recuperación de la filosofía del derecho kojeviana sería su concepción de lo jurídico en términos de pacificación. A nuestro juicio, constituye una alternativa superadora del concepto schmittiano de lo político. Quizá resida su grandeza en el ideal regulativo (KERVEGAN, 2007b) que inspira la existencia de un Estado universal y homogéneo (o «Imperio socialista», como también lo llama KOJÈve), y que es el término final de la lucha histórica del esclavo por emanciparse del amo. La enorme distancia que actualmente nos separa de tal desenlace no representa una objeción concluyente a la teoría de KoJÈve dado que, en la medida en que prosigamos en la historia, habrá la posibilidad de realizar el ideal de una paz mundial que sea justa, o de perseverar al menos para acercarnos asintóticamente a la misma. Luego, según dicha interpretación, KOJÈvE propondría no tanto un final definitivo de la historia como una línea hermenéutica apta para juzgar los progresos jurídico-políticos con respecto a una pacificación e internacionalización siempre en marcha de las relaciones jurídicas.

Debe destacarse que el federalismo es una pieza clave en semejante expansión de lo jurídico, puesto que neutraliza la primacía de lo político en el Derecho. O dicho de otro modo, a la luz del proyecto kojeviano de un Estado global (universal) e igualitario (homogéneo) desaparece el problema de la fundamentación política del derecho. En efecto, las relaciones federales fusionan las soberanías de los distintos Estados federados, con lo cual ya no puede hablarse de los mismos como «Estados». Y por idéntica razón, la soberanía en su concepto clásico también estaría llamada a desaparecer al «final de la historia», en cuanto actualización del Estado universal y homogéneo. Soberano, en términos schmittanos, es quien decide. Pues bien, en el Estado universal y homogéneo podría decidir cualquiera posicionado como el tercero C. Desde luego, la consumación del referido estadio final solo resulta concebible en el supuesto de una perfecta mezcla (síntesis) de la justicia de la igualdad con la justicia de la equivalencia, mezcla que produciría una justicia de la equidad. De esta suerte, en un marco teórico en que lo jurídico iría ganando cada vez más terreno a lo político, los conflictos políticos de soberanía se transformarían en conflictos residuales.

Tiende a considerarse la filosofía de la historia que da pie a las mencionadas tesis en filosofía del derecho como una lectura creativa —o versión muy original — de las posibles consecuencias teóricas de la filosofía hegeliana. Ciertamente el hegelianismo de KoJève es sui generis; capta, no obstante, un elemento esencial: la dialéctica histórica o sucesión racional de las diversas épocas que HEGEL entendió como el desarrollo del «espíritu» (Geist). Pese a todo, la concepción kojeviana de la historia debe a KANT mucho más de lo que cabe admitir a primera vista. Así lo plantea Bryan-Paul Frost: «Kojève está mucho más cerca de la idea de Kant de lograr la paz a través de una federación de repúblicas que de la afirmación de Hegel de que la guerra es necesaria

27 «Nous pouvons donc dire que le Droit "positif" de l'État universel et homogène réalise le Droit "naturel", qui n'est rien d'autre que le Droit en tant que tel, c'est à dire l'"essence" du Droit. Dans l'État universel et bomogène, la théorie "rationaliste" du Droit coïncide donc avec la théorie "bistorique ou sociologique". C'est là le fond même du bégélianisme, ou, si l'on préfère, de la comprébension dialectique de l'bistoire». 
para la salud ética de las naciones» (Frost, 1999: 614) ${ }^{28}$. Diríase que KoJÈvE adapta el instrumental hegeliano a la defensa del irenismo kantiano atendiendo a la expansión transnacional de las relaciones jurídicas ${ }^{29}$.

La evolución jurídica hacia el ideal cosmopolita pasa necesariamente por las grandes federaciones. El propio KoJĖVE habría ofrecido una descripción de estos grandes poderes federales en su «Esquisse d'une doctrine de la politique française» de 1945, texto que iba destinado, según AufFret (1990: 288), a Charles De Gaulle y que diseñaba el papel de Francia en un mundo multipolar:

Los Estados-nación aún todopoderosos en el siglo XIX dejan de ser realidades políticas, esto es, Estados en el pleno sentido del término, igual que dejaron de serlo las baronías, las ciudades y los arzobispados medievales. El Estado moderno, la realidad política actual, requiere bases más amplias que las representadas por las Naciones propiamente dichas. Para ser políticamente viable, el Estado moderno debe descansar en una vasta unión «imperial» de naciones afines. El Estado moderno solo es un verdadero Estado siendo un Imperio (KoJÈVE, 2003: 88) ${ }^{30}$.

Del Imperio regional al Imperio mundial (Estado universal y homogéneo) hay evidentemente un largo trecho. Pero la lucidez de KoJÈve y su sentido histórico resultan apabullantes a la luz de la construcción de la Unión Europea en clave federal y del advenimiento de los grandes poderes regionales del planeta. Desde luego, la fundamentación hegeliana de su obra puede ponerse en tela de juicio. Sin embargo, no es nada fácil ignorar sus conclusiones jurídico-políticas, máxime si se entienden en función de los acontecimientos geopolíticos que han marcado la historia humana desde el final de la Segunda Guerra Mundial hasta nuestros días. La filosofía del derecho de KojÈvE es un especulativo banco de pruebas para dar con un posible sentido de las relaciones jurídico-políticas internacionales en el marco de una globalización que no descuide el sueño cosmopolita de raíces ilustradas.

\section{BIBLIOGRAFIA}

AufFret, D., 1990: Alexandre Kojève: La philosophie, l'État, la fin de l'Histoire, Paris: Grasset. EsquiROL, J. M., 2006: «Alexandre Kojève, o com es distreu un hegelià al segle XX», en J. VeRGÉs (ed.), Cons i neocons: El referons filosòfic, Girona: Documenta.

28 «Kojève is much closer to Kant's idea about achieving peace through a federation of republics than to Hegel's claim that war is necessary for the ethical health of nations».

${ }_{29}$ Hay un cierto kantismo en esta posición, pero es de lamentar que KojÈve no parezca ahondar demasiado en ello, lo cual ya ha sido subrayado por FrOST (1999) y KERVEGAN (2007b). Ni siquiera en su libro sobre KANT (KoJĖVE, 1973) menciona KojÈVE los escritos políticos del filósofo de Königsberg. Aun así, es obvia la filiación kantiana del constructo de la «unión jurídica mundial» en el Esquisse, alejado de la teoría del derecho internacional de Hegel ( $v . g r$. $\$ 331$ de la Rechtsphilosophie). KANT, al final de la sección segunda de la Paz perpetua, por citar un paso señalado, habla del «Derecho de ciudadanía mundial» como de algo más que una «fantasía jurídica». Será necesario profundizar más adelante, en otra ocasión, en este aspecto kantiano de la filosofía del derecho kojeviana.

30 «Les États-nations tout-puissants encore au XIXe siècle, cessent d'être des réalités politiques, des États au sens fort du mot, tout comme cessaient d'être des États les baronnies, les villes et les archevêchés médiévaux. L'État moderne, la réalité politique actuelle, exigent des bases plus larges que celles que représentent les Nations proprement dites. Pour être politiquement viable, l'État moderne doit reposer sur une vaste union "impériale" de nations apparentées. L'État moderne n'est vraiment un État que s'il est un Empire». 
Frost, B.-P., 1999: «A critical introduction to Alexandre Kojève's Esquisse d'une phénoménologie du droit», The Review of Metaphysics (52), 3: 595-640.

Hegel, G. W. F., 1993: Fundamentos de la filosofía del derecho, Madrid: Prodhufi.

- 2010: Fenomenología del espiritu, Madrid: Abada Editores.

Howse, R., 2006: «Europe and the New World Order: Lessons from Alexandre Kojève's engagement with Schmitt's “Nomos der Erde”», en Leiden Journal of International Law, 19.

Howse, R., y Frost, B.-P., 2007: «The Plausibility of the Universal and Homogeneous State», en A. KoJÈve, Outline of a Phenomenology of Right; translated, with and introductory essay and notes, by Bryan-Paul Frost and Robert Howse, edited by Bryan-Paul Frost, Lanham: Rowman \& Littlefield Publishers.

Jarczyc, G., y Labarrière, P.-J., 1996: De Kojève à Hegel. 150 ans de pensée hegelienne en France, Paris: Albin Michel.

KANT, I., 2003: Sobre la paz perpetua, Madrid: Tecnos.

Kervegan, J.-F., 2007a: Hegel, Carl Schmitt. Lo politico: entre especulación y positividad, Madrid: Escolar y Mayo.

— 2007b: «Kojève. Le temps du sage», en Hommage à Alexandre Kojève. Actes de la «Journée A. Kojève» du 28 janvier 2003, Paris: BnF, 16-27.

KoJÈve, A., [1947] 1968: Introduction à la lecture de Hegel, Paris: Gallimard.

- 1973: Kant, Paris: Gallimard.

- 1981: Esquisse d'une phénoménologie du droit, Paris: Gallimard.

- 2003: «Esquisse d'une doctrine de la politique française», Hommage à Alexandre Kojève. Actes de la «Journée A. Kojève» du 28 janvier 2003, Paris: BnF, 86-98.

Murphy, G., 2011: «Alexandre Kojève: Cosmpolitanism at the End of History», en L. TREPANIER y K. M. HABIB (eds.), Cosmopolitanism in the Age of Globalization: Citizens without States, Lexington: University Press of Kentucky.

Roth, M. S., 1983: «A note on Kojève's phenomenology of right», Political Theory (11), 3 : 447-450.

SChmitT, C., 1991: El concepto de lo político: texto de 1932 con un prólogo y tres corolarios, Madrid: Alianza.

TERRÉ, F., 2011: «La legitimidad de lo político», Anuario de Derechos Humanos (12), 1: 415-438. 


\title{
LA SOBERANÍA EN VITORIA EN EL CONTEXTO DEL NACIMIENTO DEL ESTADO MODERNO: ALGUNAS CONSIDERACIONES SOBRE EL DE POTESTATE CIVILI DE VITORIA*
}

\author{
Leopoldo José Prieto López \\ Universidad Francisco de Vitoria \\ lprieto7@gmail.com
}

RESUMEN. El artículo estudia algunas de las ideas políticas fundamentales presentes en el origen del Estado moderno, y especialmente la noción de soberanía política, que, inspirada tanto en la maiestas del Derecho romano imperial como en la interpretación averroísta de la idea aristotélica de comunidad perfecta, es recibida por Francisco DE VITORIA en el De potestate civili. VITORIA caracteriza la soberanía con las notas de supremacía en la actividad interna del Estado e independencia en relación con los demás Estados.

Palabras clave: soberanía, Estado, Iglesia, conciliarismo, Derecho romano imperial, averroísmo político, Marsilio de PADUA, Guillermo dE OCKHAM, Francisco DE VITORIA.

\section{The Sovereignty in Vitoria in the Birth of the Modern State: some Considerations on the De potestate civili of Vitoria}

ABSTRACT. The article studies some of the most important political ideas present in the origins of the modern State, especially the notion of political sovereignty, which, borne and developed in the maiestas of the imperial roman law and in the averroistic interpretation of the aristotelian idea of the perfect community, is accepted and developed by Francisco DE VITORIA in the De potestate civili. VITORIA characterizes sovereignty with the features of supremacy in the domestic activity of the State and independence with regard to other States.

Keywords: sovereignty, State, Church, conciliarism, imperial roman law, political averroism, Marsilius OF PADUA, William OF OCKHAM, Francisco DE VITORIA.

* Fecha de recepción: 23 de enero de 2016. Fecha de aceptación: 20 de enero de 2017.

El artículo aquí presentado se corresponde en parte con la ponencia La noción de soberanía política en Vitoria y Suárez en el contexto del nacimiento del Estado moderno. Algunas consideraciones sobre el De potestate civili de Vitoria y la Defensio fidei de Suárez, presentada en el «I Seminario del Instituto de Historia-CSIC y la Universidad Francisco de Vitoria», titulado «Francisco de Vitoria (1483-1546), su tiempo y su proyección», el 2 de diciembre de 2015 en el Centro de Ciencias humanas y sociales del CSIC. 


\section{ALGUNAS IDEAS SOBRE EL ORIGEN DEL ESTADO MODERNO}

A ntes de abordar el estudio del De potestate civili de Francisco DE VITORIA y de su recepción de la noción de soberanía política, presentamos preliminarmente algunos hechos e ideas que poco a poco han ido surgiendo en la filosofía política de la Baja Edad Media y que consideramos fundamentales tanto en relación con el origen del Estado moderno como con el desarrollo de la noción de soberanía política, tal como aparece esta idea, ya en el siglo XVI, en la obra de VITORIA. Los hechos e ideas a los que nos referimos son: algunos conceptos nuevos en el campo del pensamiento político; el nacimiento del espíritu nacional y laico ${ }^{1}$; la recepción del Derecho romano y del aristotelismo político; dos disputas paradigmáticas en el siglo XIV entre príncipes y papas; el surgimiento del conciliarismo como una nueva eclesiología de signo democrático.

La Baja Edad Media es, en efecto, de crucial importancia para comprender el espíritu de la filosofía política moderna. Como ha dicho A. BLACK, el periodo comprendido entre 1250 y 1450 es de capital importancia para los valores y la política del mundo moderno, porque en él fueron formuladas por primera vez en su forma moderna ideas tales como «la soberanía del Estado, la separación de Iglesia y Estado, la representación y el origen popular del gobierno»².

\subsection{Nuevos conceptos en el campo de las ideas políticas}

Si el Medievo, desde el punto de vista político, fue el tiempo del universalismo político, del objetivismo y del clericalismo, la Época Moderna se caracteriza por el surgimiento de la subjetividad (expresada políticamente en el auge del nacionalismo en la forja de los Estados modernos), la fragmentación de un orden político universal y el nacimiento del espíritu laico ${ }^{3}$.

Naturalmente, la transición de la Edad Media a la Moderna se realiza lenta y gradualmente en un proceso histórico que dura varios siglos, más o menos desde el siglo XIV al siglo XVII. Por eso, para comprender mejor algunas de las ideas fundamentales que dominan el horizonte de la filosofía política de la Modernidad, a la que pertenece de pleno derecho ya Francisco DE VITORIA, es necesario retroceder hasta el siglo XIV.

Pues bien, en este proceso histórico que va del siglo XIV al XVII se advierte, ante todo, la aparición de dos grandes novedades en el campo de las ideas políticas: $a$ ) una nueva concepción del poder político, a saber, la soberanía, acompañada de una natural tendencia hacia el absolutismo político ${ }^{4}$, y $b$ ) un modelo de relación entre la Iglesia y el

\footnotetext{
1 Se toma la expresión laico en el sentido de no clerical, no ciertamente en el de aconfesional.

2 A. Black, El pensamiento político en Europa (1250-1450), Madrid, Akal, 2003, ix. Cfr. M. J. WiLKs, The problem of sovereignty in later Middle Ages, Cambridge, Cambridge University Press, 1963, especialmente el capítulo «The Sovereign Prince», 151-183.

3 Cfr. J. LoRTZ, Historia de la Iglesia, II, Madrid, Ediciones Cristiandad, 2008, 5.

4 A propósito de la relación entre Estado moderno, soberanía y absolutismo, cfr. P. TOUBERT, «Eglise et Etat au XI ${ }^{\mathrm{e}}$ siècle: la signification du moment grégorien por la genèse de l'État moderne», en J. Ph. GENET y
} 
nuevo actor político que es el Estado, que, sugerido por el naciente laicismo inspirado en el Derecho romano, es corroborado por ciertas ideas eclesiológicas que favorecen tanto la tendencia a la formación de las iglesias nacionales (anglicanismo, galicanismo, etc.) como una nueva interpretación de la naturaleza de la potestad eclesiástica realizada por el conciliarismo.

Como no podía ser de otro modo, encontramos estas dos nuevas ideas en el pensamiento de Francisco DE VITORIA (1486-1546), especialmente en las siguientes obras: De potestate civili (1528), De potestate Ecclesiae prior (1532), De potestate Ecclesiae posterior (1533) y De potestate Papae et Concilii (1534). La noción de soberanía, como veremos más adelante, aunque presente solo de un modo implícito antes de su formulación canónica por BODIN, se halla en la concepción de VITORIA del Estado (o de la república, como lo suele llamar) como una sociedad perfecta. En cuanto tal, como veremos, el Estado no puede ser más que una comunidad política en la que el príncipe ejerce un poder supremo (desde el punto de vista interno) e independiente (desde el punto de vista externo). A su vez, las cuestiones relativas a la delimitación y armonización del poder civil y eclesiástico, y dentro de este a la delimitación del poder del papa y del concilio, revisten una notabilísima importancia en su obra. En efecto, las relecciones De potestate Ecclesiae (prior y posterior) y De potestate Papae et Concilii manifiestan el vivo interés que VITORIA siente por esta materia. La formación recibida por VITORIA en una Francia fuertemente inclinada al conciliarismo y galicanismo ya desde

B. VINCENT, Etat et Eglise dans la genèse de l'Etat moderne, Madrid, Casa de Velázquez, 1986, 9-22. Según TOUBERT es necesario retroceder hasta la reforma gregoriana del siglo XI para comprender el origen de algunas ideas importantes sobre la relación de la Iglesia y Estado tal como se desarrollarán posteriormente en la Época Moderna. En su opinión, en el contexto de la reforma gregoriana el papado hizo suyos no pocos elementos del modelo político-imperial, como ya indicaron en su momento H. W. KLAUWITZ (Reformpapstum und Kardinalkolleg, Darmstadt, Wissenschaftliche Buchgesellschaft, 1957) y G. ALBERIGO (Cardinalato e collegialità: Studi sull'ecclesiologia tra l'XI e il XIV secolo, Firenze, Vallecchi, 1969), tales como una administración financiera centralizada de la Iglesia, una cancillería pontificia y, sobre todo, la creación de un espacio geográfico de poder en el centro de Italia constituido como base territorial de su acción de gobierno. Todas estas realizaciones hicieron posible la concepción de una Christianitas, promovida por la reforma gregoriana, que desembocó en el siglo XII en la idea de institutio, cargada de implicaciones políticas y eclesiásticas, que anticipa la idea de soberanía que tiempo después reclamará para sí el naciente Estado moderno. Así, «en el cisma irreparable que se da entre Regnum y Sacerdotium, la concurrencia de los dos protagonistas a un poder supremo [sobre la Christianitas] ha permitido la elaboración, por vía de intercambios y transferencias de prerrogativas, de una ideología bastante uniforme de la soberanía» (21). Hace tiempo que P. E. SCHRAmm puso de manifiesto las convergencias ideológicas en el ámbito de los símbolos de Estado, mostrando por medio de qué transferencias de prerrogativas y derechos honoríficos el Regnum ha querido manifestarse como Sacerdotium, e inversamente, el Sacerdotium ha querido convertirse en Regnum, responsable de un proyecto histórico que va más allá del destino de los regna individuales [cfr. P. E. ScHRAMm, «Sacerdotium und Regnum im Austausch ihrer Vorrechte: eine Skizze der Entwicklung zur Beleuchtung des Dictatus Papae Gregors VII», en Studi gregoriani, 2 (1947), 403-457]. Por su parte, E. KANTOROwICZ prolongó la investigación de SCHRAmm focalizando en el final de la Edad Media y el inicio de la Edad Moderna esta dinámica de transferencias entre papas coronados y reyes mitrados [cfr. E. KANTOROWICZ, «Mysteries of State. An absolutist Concept and its late Mediaeval Origins», en Harvard Theological Review, 48 (1955) 65-91]. En palabras de KANTOROWICZ, es claro que «bajo un Papa convertido en princeps et verus imperator el aparato jerárquico de la iglesia romana [...] manifestaba la tendencia a convertirse en el prototipo perfecto de una monarquía absoluta y racional fundada sobre una base mística, a la vez que el Estado tenía cada vez más la tendencia a convertirse en una cuasi-iglesia, o de otra manera, en una monarquía mística fundada sobre una base racional» (79). De este modo, KANTOROWICZ llamaba la atención sobre determinados conceptos políticos, en virtud de los cuales los misterios de la Iglesia, los arcana Ecclesiae, eran transferidos al Estado, que elaboró así sus propios misterios del Estado, los nuevos arcana imperii seculares, que se encuentran en la raíz misma del absolutismo moderno. 
los siglos XIV y XV [con D’AILLY (1350-1420) y GERSON (1363-1429), ambos rectores de la Universidad de París, el alma mater de VITORIA], así como el fuerte influjo de sus maestros MAIR (1467-1550) y ALMAIN (1480-1515), los principales sostenedores del conciliarismo en la Universidad de París en el siglo XVI, explican la presencia en el dominico español de algunas ideas que pueden denotar un moderado conciliarismo ${ }^{5}$.

\subsection{Estado moderno, sentimiento nacional y esprit lä̈que}

El ideal de una Cristiandad que unía a todos los pueblos cristianos bajo la autoridad temporal del emperador y la espiritual del romano pontífice, que parecía haberse logrado en el siglo XIII, se reveló ya desde inicios del siglo XIV un proyecto fracasado. Los dos poderes que unificaban la Europa cristiana, el imperio y el papado, comienzan a perder autoridad y prestigio. Se entabla entonces una pugna en la que resultarán vencedores el sentimiento nacional y el Estado moderno, que terminan ocupando las parcelas de poder que el imperio y el papado pierden progresivamente. Como ha expuesto lúcidamente LAGARDE, se asiste en esta época al nacimiento del espíritu laico,

5 Sobre un posible conciliarismo, de seguro moderado, de Francisco DE VITORIA, cfr. R. GARCía ViLLOSLADA, La universidad de París durante los estudios de Francisco de Vitoria O.P. (1507-1522), Romae, Apud aedes Universitatis Gregorianae, 1938, 157: «Lo verdaderamente extraño es que un dominico español como VITORIA, tan poderosamente influido por las doctrinas teológicas de Cayetano y Torquemada, los grandes adalides del Primado romano contra galicanos y conciliaristas, se exprese con tanta reserva y cercene lamentablemente la plenitudo potestatis del sucesor de san Pedro frente a la autoridad de los Concilios». Más adelante, prosigue GarCía Villoslada, «Francisco DE Vitoria [...] se contagió un poco — fuerza es decirlo- de las ideas conciliaristas que se respiraban en la atmósfera universitaria y política de Francia» (172), como resultaría de la afirmación del De potestate Ecclesiae posterior, n. 6, donde si bien no defiende la superioridad del concilio sobre el papa, tampoco se atreve a defender lo contrario. Dice en efecto, VITORIA, a propósito de cuál de las dos potestades es superior en la Iglesia, el concilio o el papa: «Responderé en primer lugar que ahora no intento discutir de aquella odiosa comparación entre el Papa y el Concilio», para rematar inmediatamente después que «se puede sostener que es mayor la potestad del Concilio que la del Papa» (172). También J. GoÑI ha sostenido la tesis de un conciliarismo moderado de Francisco DE VITORIA. Afirma este autor: «En Francisco DE VITORIA, formado en la universidad de París, uno de los últimos reductos del conciliarismo, se detectan algunos resabios de conciliarismo sin ser personalmente conciliarista» [J. GOÑI GAZTAMBIDE, «El conciliarismo en España», en Scripta theologica, 10/3 (1978), 893-928, 924]. En concreto, prosigue GoÑI, «el concilio puede convocarse y reunirse contra la voluntad del papa para oponerse a él y contrarrestar su insolencia, si con mandatos insolentes y dispensas injustas causa grave daño a la Iglesia. La autoridad del papa puede ser limitada cuando existe una necesidad apremiante. ¿Por quién? Por el concilio» (924). De manera que, aunque VITORIA quiso oponerse al conciliarismo, «no logró superar, sin embargo, totalmente el error y en última instancia sometió el papa al concilio en determinados casos excepcionales» (925). En este mismo sentido, «en sus lecturas sobre la Secunda Secundae de 1526-1527 encontramos esta chocante frase: "Si el papa quisiese definir por sí mismo una proposición de fe sin un concilio y sin examinar la Escritura, podría errar" [...] El concilio es así el medio supremo de hallar la verdad, necesario en los casos difíciles» (925). Por el contrario, la tesis sobre un posible conciliarismo moderado de VITORIA fue atacada tanto por T. URDÁNOZ como por el carmelita J. DE JESÚs MARíA. Dice, en efecto, URDÁNOZ: «En ninguna de las dos relecciones [De Potestate Ecclesiae, prior y posterior, y De potestate concilii et Papae] ha querido resolver directamente la cuestión central de la superioridad entre ambas potestades del Papa y del concilio, por lo que no puede esperarse de él una refutación completa y sistemática del conciliarismo. Esa cuestión básica ha sido soslayada en esta relección por nuestro teólogo, que la llama odiosa comparación [...]. Más bien adopta en torno a ella una actitud de imparcial y aparente indecisión [...] Pero, en realidad, VITORIA rechaza de plano en ambas relecciones toda la teología conciliarista. Solo que su verdadero propósito es hacer una labor teológica constructiva y no simplemente de negativa repulsa de los excesos conciliaristas» (T. URDÁNOZ, Obras de Francisco de Vitoria, Madrid, BAC, 1960, 335). URDÁNOZ recurre a la autoridad de J. DE JESÚS MARÍA, en cuyo artículo «¿Francisco DE VITORIA conciliarista?», «se sostiene con decisión y se demuestra bien claramente que VITORIA rechaza abiertamente la teología conciliarista» (335). Cfr. J. DE JESÚS MARÍA, «¿Francisco DE VITORIA conciliarista?», en Ephemerides Carmeliticae, 1 (1947), 103-148. 
que da origen al Estado moderno ${ }^{6}$. El historiador del pensamiento medieval F. VAN STEENBERGHEN, preguntándose qué debe entenderse por espíritu laico, responde al respecto: «La expresión significa en primer lugar, de una manera general, la reacción de los simples fieles contra la hegemonía del clero en el seno de la Iglesia, o el esfuerzo de emancipación del laicado [...]. Pero en un sentido más preciso, el espíritu laico se refiere a las luchas por el poder espiritual y el poder temporal entre la Iglesia y el Estado y en tal sentido designa la tendencia a reivindicar, en pugna con la Iglesia, la integridad de los derechos soberanos de las sociedades civiles» ${ }^{7}$. El espíritu laico rechaza la idea misma de Cristiandad y con ella, la pretensión del clero de influir en la vida social de Europa. Sentimiento nacional y espíritu laico van de la mano en las reivindicaciones contra el papado en la construcción del Estado moderno.

\subsection{El retorno a las fuentes antiguas: aristotelismo político y Derecho romano}

Las nuevas ideas y sentimientos políticos recurren a dos fuentes intelectuales procedentes de la Antigüedad clásica, cuya contribución será decisiva en la transformación del panorama jurídico-político en los albores de la Modernidad: la recepción del Derecho romano y el aristotelismo político, especialmente en su concepción averroísta. Paradójicamente, como en otros campos del saber, la evolución en la historia de las ideas políticas ha ido acompañada de un retorno a las fuentes antiguas. Así, en la lucha sostenida contra el papado y el imperio, el Estado y la monarquía modernos recurrieron a la inspiración que la Antigüedad clásica les ofrecía en dichas fuentes.

El Derecho romano era un arma eficaz para combatir la concepción feudal del poder político. A la atomización del poder político, característica del feudalismo, y a su igualmente característica confusión del ámbito del derecho privado con el derecho público, el Derecho romano oponía una idea clara y nítida del poder público, el imperium, y del Estado o res publica. El imperium era entendido como el poder pleno, indiviso y absoluto entregado a quien personifica y rige el Estado, el princeps. Tal poder pleno es la maiestas o soberanía. El Derecho romano, especialmente en época imperial, no admitía la doctrina, típicamente cristiano-medieval, de los límites del poder político. En este sentido había dicho UlPIANO: Quod principi placuit, legis habet vigorem ${ }^{8}$. Se entiende así que la ley emana de la voluntad del princeps. Así también en la Baja Edad Media y Renacimiento se usará frecuentemente la expresión conclusiva en leyes y decretos dictados por el rey de que «tal es el beneplácito del rey», «porque así plugo al rey», etc. El rey ahora se presenta como el princeps, el primero del Estado. En este mismo sentido, A. MARONGiU ha visto en el uso del título de Majestad, del que

\footnotetext{
${ }^{6}$ Cfr. G. De Lagarde, La naissance de l'esprit lä̈que au déclin du moyen âge, 5 vols., Louvain-Paris, Nauwelaerts, 1956-1963. La expresión espíritu laico la tomamos aquí exactamente en el mismo sentido que tiene en la obra de G. DE LAGARDE, no pretendiendo en modo alguno extrapolar su sentido anacrónicamente a cuestiones sobre la aconfesionalidad del Estado, que no tienen cabida en los autores de la Baja Edad Media e inicios de la Época Moderna. Cfr. supra, nota 1.

7 F. van STEENBERGHEN, recensión de G. DE LAGARDE, «La naissance de l'esprit laïque au déclin du moyen âge», I, en Revue philosophique de Louvain, 68 (1962), 688-691, 688. Trad. propia.

8 UlPIANO, Institutiones, I, D. 1,4,1. A propósito de la recepción y práctica en la monarquía española de estas ideas procedentes del Derecho romano, $c f r$. S. DE Dios, El poder del monarca en la obra de los juristas castellanos (1480-1680), Cuenca, Ediciones Universidad Castilla-La Mancha, 2014, 24 y ss.
} 
los monarcas modernos se apropian ahora resueltamente, un indicio inequívoco de lo que ha llamado el proceso de imperialización de la figura del rey, característico de las monarquías del Renacimiento ${ }^{9}$. Es indicativo a este respecto que la correspondencia dirigida a Carlos V, por ejemplo, de quien Francisco DE VITORIA era coetáneo, fuera frecuentemente encabezada con la fórmula «a la sacra, cesárea y católica Majestad» ${ }^{10}$.

A su vez, el aristotelismo político contribuía en esta misma dirección. Si el Estado era concebido como algo natural y racional, ¿qué necesidad tenía entonces de una justificación y una sanción sobrenatural? Más aún, si el Estado perseguía fines no simplemente materiales, sino también morales, como favorecer la virtud de sus miembros, y si los hombres tendían naturalmente hacia una forma de vida social autosuficiente, como era la sociedad perfecta, ¿por qué la vida política debía someterse a la jurisdicción espiritual de un poder exterior a ella misma como era la Iglesia, cuyos derechos se basaban en la verdad revelada y en la vida sobrenatural, instancias que excedían con mucho lo que la sociedad requería? Si estos problemas no habían incomodado a fines del siglo XIII a Tomás DE AQUINO ello se debía al ideal que dominaba su pensamiento: la armonía entre fe y razón, teología y filosofía. Pero precisamente era este ideal el que se estaba desvaneciendo a inicios del siglo XIV en otros pensadores, particularmente los pertenecientes a aquella corriente llamada aristotelismo averroísta o averroísmo latino (a la que Juan DE JANDÚN y Marsilio DE PADUA pertenecen de pleno derecho), cuyo pensamiento se caracterizaba por una neta separación de fe y razón, hasta llegar al extremo de sostener la teoría de la doble verdad ${ }^{11}$. En realidad, la relación entre Iglesia y Estado no era sino la aplicación al campo del derecho y la política del tema general de la relación entre fe y razón, que el averroísmo latino consideraba inexistente.

\subsection{Dos disputas tardomedievales en los albores de la Modernidad}

La transición de la política medieval a la moderna se expresa, además de en el surgimiento de nuevos conceptos y nuevas fuentes (paradójicamente antiguas), en dos

9 Cfr. A. Marongiu, Lo Stato moderno. Lezioni di storia delle istituzioni politiche, Roma, Edizioni Ricerche, 1967. No se olvide que esta es la época de ViTORIA.

10 Cfr. V. DE Cadenas, Carlos de Habsburgo en Yuste, Madrid, Hidalguía, 2000, 79-83. En el uso de estos títulos vemos un ejemplo concreto de la transferencia de prerrogativas y honores de la Iglesia (sacra y católica) al Estado (cesárea Majestad) referida antes. Cfr. supra, nota 4.

11 Cfr. P. Mandonnet, Siger de Brabant et l'averroïsme latin au XIII siècle, Louvain, Institut Supérieur de Philosophie de l'Université, 1911, 142-195, donde en particular se dice: «No hay que olvidar que el reino de Felipe el hermoso fue testigo de un renovado vigor del averroísmo en París. Juan DE JANDún y Marsilio DE PADUA, los defensores de las pretensiones reales, eran averroístas notorios» (188, nota 4). Trad. propia. Sobre la teoría de la doble verdad, $c f r$. N. ABBagnano, Storia della filosofía, I, $\$ 286$ (Sigieri: L'eternità del mondo e la doppia verità), 590-593. Cfr. también J. FERRATER MORA, voz «Verdad doble», en Diccionario de filosofía, III, Madrid, Alianza, 1990, 3408-3409; A. MAIER, «Das Prinzip der doppelten Wahrheiten», en A. MAIER, Metaphysische Hintergründe der spätscholastischen Naturphilosophie, Roma, Edizioni di storia e letteratura, 1955 , 3-44; T. DoDD, The Life and Thought of Siger of Brabant, Thirteenth-Century Parisian Philosopher: An Examination of His Views on the Relationship of Philosopby and Theology, Lewiston, Edwin Mellen Press, 1998. En un sentido general puede decirse que la teoría de la doble verdad, mantenida más o menos explícitamente por un cierto número de filósofos y teólogos medievales y renacentistas relacionados por lo general con el averroísmo (entre los que se cuentan especialmente Siger DE BRABANTE, Juan DE JANDÚn, Marsilio DE PADUA y Pietro POMPONAZZI), consiste en afirmar la existencia de un contraste entre la verdad filosófica y la verdad revelada, de manera que lo verdadero en filosofía puede no serlo en teología y viceversa. 
polémicas, que trascienden el carácter de meros hechos históricos y alcanzan el valor de símbolos de lo que está por venir. En efecto, dos polémicas, cronológicamente muy próximas entre sí, a inicios del siglo XIV, harán visible el espíritu del tiempo y de la nueva filosofía política. Se trata de las disputas entre dos príncipes y dos papas: Felipe IV de Francia, llamado el hermoso, con Bonifacio VIII, de un lado; y Luis IV de Baviera con Juan XXII, de otro. El motivo inmediato de las mismas no podía ser otro que el replanteamiento de la relación entre potestad temporal y espiritual en el contexto de las relaciones entre papado, imperio y los nacientes Estados modernos.

a) La polémica de Felipe el hermoso y sus caballeros en leyes y Bonifacio VIII simboliza el violento contraste que, a inicios del siglo XIV, se da entre la Edad Media, representada por el romano pontífice (que, en la bula Unam sanctam de 1302, seguía amparándose en los viejos principios del agustinismo político), y la Edad Moderna, que, personificada en Felipe IV de Francia, se levanta con aspiraciones laicas y absolutistas $^{12}$.

El elemento doctrinal más sobresaliente en esta disputa es la influencia del Derecho romano en la mentalidad de los legistas de la corte francesa (Pedro FLOTTE, Guillermo DE Nogaret, Pedro DubOIS, etc.). Con una lógica abstracta, tan distinta del pensamiento medieval, los legistas de Felipe el hermoso combatieron teóricamente la organización feudal y la constitución jerárquica de la sociedad, que reverenciaba al emperador y atendía las directrices del romano pontífice, fomentando en cambio, el absolutismo regio ${ }^{13}$. Por influjo de estos teóricos del Derecho, el rey se creyó investido de un poder absoluto, cual ley viviente de la nación, y, en calidad de tal, empezó a considerarse superior a toda autoridad humana, no tolerando a partir de entonces injerencia alguna o intromisión de la Iglesia en los asuntos temporales e, incluso, en los espirituales. Es el origen del galicanismo y de las distintas formas de predominio del poder político sobre el espiritual. Estos legistas modificaron profundamente la figura y la función del rey, proclamándolo soberano y princeps, monarca absoluto, o lo que es igual, absuelto o libre de todo vínculo y restricción. Atribuyeron también a este príncipe y rey soberano, como sabemos, la función de fuente y origen de la ley. Por otro lado, el interés del príncipe en los asuntos de la Iglesia situada en el territorio de su jurisdicción nacional (lo que recibe propiamente el nombre de regalismo) era una tentación difícil de vencer. Paradigma de este espíritu fue la asamblea del clero francés, reunida en Bourges por el rey Carlos VII, que promulgó la Pragmática Sanción de 1438, por la que se otorgaba al rey de Francia un amplio derecho de vigilancia sobre la Iglesia de Francia ${ }^{14}$. Así, absolutismo y regalismo nacen de un mismo espíritu.

12 Cfr. G. DE LAGARDE, La naissance de l'esprit läque, I, 1956, 208-210. Según LAGARDE la querella bonifaciana puede ser considerada justamente como «la introducción a la política religiosa de los tiempos modernos». En tal sentido, esta querella no solo abre las puertas al galicanismo, sino que tiene una dimensión más profunda, porque «los abogados del príncipe, expresan con rara fortuna, las reivindicaciones fundamentales del Estado moderno frente a la sociedad religiosa: soberanía sobre los bienes y las personas, ejercicio exclusivo de la justicia, autonomía absoluta de la legislación, control de la vida espiritual de la nación» (G. DE LAGARDE, La naissance de l'esprit laïque, I, 210). Trad. propia.

13 Cfr. R. García Villoslada, Historia de la Iglesia católica, II, Madrid, BAC, 1988, 571.

14 La Pragmática Sanción de Bourges proclamada por el rey Carlos VII de Francia, el día 7 de julio de 1438, con el acuerdo del clero francés reunido en Bourges exigía que un concilio general de la Iglesia, cuya autoridad se consideraba superior a la del papa, había de celebrarse cada diez años. Así, el rey de Francia se proclamaba protector de la fe en territorio francés. Esta ordenanza constituía de algún modo una alianza 
Desde el punto de vista internacional, estos legistas y juristas de la corte consideraban que el príncipe no estaba sujeto a ninguna autoridad superior, fuera política (el emperador) o religiosa (el papa). Consecuencia necesaria de ello debía ser el fin del universalismo político medieval con la consiguiente fragmentación de la Cristiandad y el inicio del nacimiento de los nuevos Estados nacionales. El Estado y en él el príncipe eran considerados ante todo soberanos, es decir, entidades políticas supremas, no sometidas, por tanto, a ninguna otra instancia superior. El emperador perdía el poder de coerción sobre los reyes y pasaba a ser un príncipe más. Al papa no se le reconocía potestad de intervención sino en aquellos asuntos de naturaleza estrictamente espiritual. Resultaba así que el príncipe era el gran vencedor en el reparto de poder al que se asiste en los albores de la Edad Moderna.

b) La segunda polémica tiene lugar también en el siglo XIV, a pocos años de distancia de la anterior, esta vez entre Luis IV de Baviera, elegido emperador por los electores alemanes (de cuyo lado se pondrán Marsilio DE PADUA y Guillermo DE OCKHAM), y el papa Juan XXII. En la doctrina de Marsilio DE PADUA el elemento doctrinal prevalente es el aristotelismo averroísta; en la de OСКHAM, en cambio, una eclesiología conciliarista, reforzada por una metafísica del individuo, alimentadas ambas por la cuestión de fondo de la reivindicación franciscana de la pobreza, el rechazo del fasto de la corte papal de Aviñón y la revuelta de los fratricelli y espirituales contra un papado prisionero del monarca francés en la que entonces se llamó la cautividad babilónica.

Escrito contra el perturbador de la paz, Juan XXII, el Defensor pacis de Marsilio DE PADUA representa una poderosa máquina de guerra política e ideológica: una obra en la que se exponían las ideas conciliaristas más radicales contra la autoridad del pontífice y contra la constitución jerárquica de la Iglesia, exaltando hasta límites sorprendentes, propios ya del absolutismo, la potestad del príncipe secular ${ }^{15}$. La doctrina del Defensor pacis es la creación más notable del pensamiento político tardomedieval. Aparece en ella claramente, por primera vez, a qué extremas consecuencias podía conducir una interpretación política de ARISTÓTELES en términos puramente naturalistas. Marsilio DE PADUA acentuaba la idea del carácter natural del orden social, de su absoluta necesidad y del primado del bien común sobre el individual. Como era de esperar, dicha interpretación favorecía la independencia del orden humano respecto del espiritual. De este modo, la teoría aristotélica de la autosuficiencia de la ciudad, a la luz de la

entre el rey de Francia y el clero, limitaba las prerrogativas del papa y reafirmaba la idea de la supremacía de los concilios frente al papado. En su primer artículo, declaraba la supremacía de los concilios generales sobre el papado y limitaba los poderes del papa. De este modo, la Iglesia de Francia adquirió una gran autonomía respecto de Roma y el rey se aseguró la lealtad del clero francés.

${ }_{15}$ Que el elemento predominante en la teoría política de Marsilio DE PADUA sea el aristotelismo político no significa que no tuviera también una eclesiología. Al respecto, $c f r$. J. A. CASTELLO DuBRA, «La eclesiología de Marsilio DE PADUA», en Bulletin du centre d'études médiévales d'Auxerre, Hors-série, núm. 7, 2013, bttp:// cem.revues.org/12781. Sobre fuentes en general del pensamiento político de Marsilio DE PADUA, cfr. R. SCHOLZ, «Marsilius von Padua und die Genesis des modernes Staatsbewusstseins», en Historische Zeitsschrift, 156 (1937), 88-103; A. GEWIRTH, Marsilius of Padua. The Defensor Pacis, I: «Marsilius of Padua and the Medieval Political Philosophy», London, McMillan, 1951. También J. Quillet, La Philosophie politique de Marsile de Padoue, Paris, Vrin, 1970. Para una valoración de conjunto del Defensor pacis, cfr. B. BAYONA, «El poder y el Papa. Aproximación a la filosofía política de Marsilio DE PADUA», en Isegoría. Revista de Filosofía Moral y Política, 36 (2007), 197-218. También L. MARTínEZ GÓMEZ, «Estudio preliminar», en Marsilio DE PADUA, El defensor de la paz, Madrid, Tecnos, 2009, xv-xliv. 
nueva interpretación, abría perspectivas desconocidas hasta entonces por los juristas a la soberanía de la comunidad política.

En Guillermo DE OCKHAM, el otro teórico al flanco de Luis de Baviera en la disputa con Juan XXII, sobresalen fundamentalmente una eclesiología y una política dependientes de los presupuestos de una metafísica nominalista y una ética voluntarista. La principal obra de OCKHAM suscitada por esta polémica era Ocho cuestiones sobre el poder del papa ${ }^{16}$. OCKHAM critica acerbamente algunos aspectos característicos de la Iglesia medieval, como son la bierocracia totalitaria y la clericalización de la Iglesia.

En referencia al primer aspecto piensa OСКНАM que oponer el poder espiritual al poder temporal es una sutileza sin sentido, semejante a las que gustan de realizar los metafísicos, como igualmente lo es contraponer la naturaleza a la gracia y la política de los intereses temporales a la economía de la salvación. Todas estas realidades no son más que expresión de una única fuente: Dios creador y conservador de todos los seres. ¿Por qué, pues, distribuir arbitrariamente en géneros distintos las manifestaciones de la actividad humana que no se distinguen por ninguna diferencia fundamental? Conocemos bien con qué minucia ha mostrado OCKHAM, siguiendo el principio de economía del pensamiento, la inutilidad de las distinciones que los filósofos se han complacido en establecer en sus sistemas. Por ello, la distinción entre lo espiritual y lo temporal no es admisible, tanto menos si se utiliza para aplicarla a los poderes civil y eclesiástico de una misma comunidad política. ¿Por qué el poder del rey no puede ser considerado espiritual, al menos en algunas ocasiones? La atribución de poderes religiosos al poder civil y la protesta dirigida contra los canonistas, que han prohibido a los príncipes toda intervención en el campo espiritual, son la lógica consecuencia de la supresión de la distinción entre lo temporal y espiritual llevada a cabo por Guillermo DE OCKHAM ${ }^{17}$.

Por otro lado, la eclesiología de OCKHAM no admite en la Iglesia más estructuras que las que se derivan de la Escritura. OСКНАM critica la excesiva clericalización de la Iglesia. La Iglesia no es el clero, ni el episcopado, ni el colegio de cardenales, ni el papa, sino el conjunto de los cristianos. En una palabra, en coherencia con su eclesiología y su filosofía, la Iglesia es el conjunto de individuos cuya propiedad común es compartir la misma fe. A partir de ahí, hace pasar a un segundo plano todo lo que en la Iglesia es institucional o transciende a la realidad de los individuos cristianos. Además, una comunidad no deja de ser la misma porque se la considere desde un punto de vista religioso (la Iglesia) o político (el Estado). Es la misma comunidad, vista bien como sociedad que participa de una misma fe, bien como sociedad organizada en el plano civil. La Iglesia es así asimilada al Estado cristiano. Estado e Iglesia, en virtud de una filosofía que rechaza las distinciones metafísicas, han de identificarse. En consecuencia,

16 G. DE OcKHAM, «Octo quaestiones de potestate Papae», en H. S. OfFler, Guillelmi de Ockham Opera Politica, I, Manchester, Manchester University Press, 1974, 6-217. Cfr. también G. DE OCKHAM, «De imperatorum et pontificum potestate», en H. S. OfFleR, Guillelmi de Ockham Opera Politica, IV, Oxford, Oxford University Press, 1997, 261-355 (trad. esp. Sobre el poder de los emperadores y los papas, Madrid, Marcial Pons, 2007, con «Estudio preliminar» de J. C. UTRERA); G. DE OCKHAM, «Breviloquium de principatu tyrannico», en H. S. OfFler, Guillelmi de Ockham Opera Politica, IV, 79-260 (trad. esp. Sobre el gobierno tiránico del Papa, Madrid, Tecnos, 1992).

17 Las consecuencias últimas de dicha supresión las sacará Thomas HoBBES, para quien el soberano cristiano es simultáneamente cabeza de la Iglesia y del Estado, que son una y la misma cosa: el Estado cristiano, cuya exposición se realiza en el tercer libro del Leviathan. 
las autoridades laicas son invitadas a ejercer la potestad que, tanto en el plano civil como en el religioso, un clero ambicioso ha pretendido arrebatarle ${ }^{18}$. He aquí un inequívoco rasgo del nacimiento del espíritu laico ${ }^{19}$.

\subsection{El conciliarismo y la exigencia democratizadora en la Iglesia}

Finalmente, se ha aludido en varias ocasiones al conciliarismo, pero no se ha determinado aún qué es. El conciliarismo es una doctrina eclesiológica sobre la naturaleza de la potestad eclesiástica, según la cual la autoridad suprema de la Iglesia no reside en el papa, sino en el concilio o asamblea universal de los cristianos, que agrupa no solo a los eclesiásticos, sino también a los laicos, e incluso a la naciones tomadas como sujetos de derecho. En tal sentido, como hace tiempo observó FIGGIS, el movimiento conciliarista es la culminación del constitucionalismo medieval en el ámbito eclesiástico ${ }^{20}$. De otro lado es importante advertir que el conciliarismo guarda innegables vínculos con la corriente intelectual dominante en el siglo XIV: el nominalismo ${ }^{21}$.

Los orígenes del conciliarismo parecen encontrarse en dos fuentes de la Edad Media. La primera fuente es de naturaleza filosófica, y consiste en una corriente que postula la democratización de la Iglesia, amparándose para ello en la doctrina de Aristóteles según la cual el origen del poder público radica en la comunidad, de la que el príncipe recibe inmediatamente su potestad. En este sentido, la doctrina de Marsilio DE PADUA es un exponente claro del conciliarismo, dado que aplica esta doctrina al régimen de gobierno de la Iglesia. En opinión de Marsilio, recibiendo el papa su poder del conjunto de los fieles (como ocurre en el caso del gobernante secular), y solo remotamente de Dios, se entiende que la potestad papal debe estar sujeta al concilio universal (que representa a toda la Iglesia), como el rey lo está al parlamento. La segunda fuente es de naturaleza teológica. Se trata de la doctrina medieval del papa hereje. En el contexto de

18 Cfr. G. DE LAGARDE, La naissance de l'esprit lä̈que, V, 1963, 280.

19 A propósito de Guillermo DE OCKHAm y Marsilio DE PADUA, M. HARDT y A. NEGRi han realizado una sugerente interpretación de la obra de dichos pensadores en el contexto de la transición tardomedieval a la filosofía política moderna no tanto como las figuras más representativas del nominalismo y averroísmo latino, que son las coordenadas interpretativas clásicas en las que se suele encuadrar a estos pensadores, sino como representantes cualificados del «acontecimiento principal de la modernidad: la afirmación de los poderes de este mundo, el descubrimiento del plano de la inmanencia». Al respecto, $c f r$. M. HARDT y A. NEGRI, Imperio, Barcelona, Paidós, 2016, 91.

${ }^{20}$ Cfr. J. N. Figgis, From Gerson to Grotius (1414-1625), Cambridge, Cambridge University Press, 1907, 35. De esta obra reviste una peculiar importancia el capítulo segundo, «The Conciliar Movement and the papalist reaction», 35-61. Además de esta obra, sobre el conciliarismo desde una perspectiva predominantemente politica, cfr. B. TIERnEY, Foundations of the Conciliar Theory: The Contribution of the Medieval Canonists from Gratian to the Great Schism, Cambridge, Cambridge University Press, 1955; F. OAKLEY, The Conciliarist Tradition: Constitutionalism in the Catholic Church 1300-1870, Oxford, Oxford University Press, 2004.

${ }_{21} \mathrm{Cfr}$. J. VERGER, «Le transfert de modèles d'organisation de l'Église à l'État à la fin du Moyen Age», en J. Ph. Genet y B. Vincent, Etat et Eglise dans la genèse de l'État moderne, 31-39. Este autor ha expresado con claridad encomiable la relación histórica cierta que se da entre conciliarismo y nominalismo. En su opinión, «el conciliarismo, lejos de designar solamente una doctrina y unas prácticas eclesiásticas precisas, representa una suerte de estado de espíritu largamente extendido [...] entre las personas letradas de una concepción nominalista de la sociedad y del mundo, que, constatando la universalidad de la crisis y la urgencia de la reforma en todos los sentidos de la palabra [...] concluye que el remedio reside en el recurso a asambleas y consejos en los que, frente a los detentadores desviados de la autoridad, pueda expresarse la voluntad general [de todos los cristianos]» (38). Trad. propia. 
Aviñón, OcKHAM dio particular relevancia a esta teoría. Era opinión que se remontaba al Decreto de Graciano que un papa podía ser depuesto en caso de herejía por un concilio general. Pero si el papa podía ser depuesto por un concilio era inevitable admitir que la autoridad del concilio es superior al papa. Guillermo DE NOGARET había apelado a la doctrina del papa hereje en sus ataques a Bonifacio VIII y en idéntica doctrina amparaba Guillermo DE OCKHAM las acusaciones lanzadas contra Juan XXII.

\section{LA SOBERANÍA POLÍTICA EN EL DE POTESTATE CIVILI DE FRANCISCO DE VITORIA}

\subsection{Las relecciones de Vitoria}

Las relecciones (relectiones) constituyen la obra principal de Francisco DE VITORIA. A ellas debe este autor en gran parte su celebridad. En la Universidad de Salamanca se llamaban relecciones (o repeticiones) a unas conferencias revestidas de especial solemnidad pronunciadas por los graduandos o los catedráticos ante sus respectivas facultades o ante la Universidad. Se trataba de una reminiscencia de las famosas disputas medievales, las quaestiones disputatae y las quaestiones quodlibetales. Las constituciones de la Universidad de Salamanca, otorgadas por el papa Martín V en 1422, sancionaban esta práctica e imponían a los catedráticos la obligación de impartir una relección cada año, por primavera, que correspondiese de algún modo a la materia expuesta ese curso 22 .

Se conservan también algunas relecciones impresas de otros autores, como Pedro DE Osma, Domingo de Soto, Melchor CAno, Domingo BÁÑEz, etc. Pero con nadie alcanzó este género científico-literario la altura y brillantez que tuvo en Francisco DE VITORIA, que supo presentar bajo este género cuestiones vivas y originales que por su importancia y actualidad atrajeron poderosamente la atención del público universitario de su tiempo. En opinión de URDÁNOZ, «VITORIA ha pasado a la historia como el verdadero y propio autor de las relecciones teológicas, el único de nuestros autores clásicos que se ha inmortalizado con la publicación de estas sus solemnes lecciones universitarias, la obra científico-literaria cumbre de su vida» ${ }^{23}$.

Bastará echar una rápida ojeada a algunas temáticas tratadas por la relecciones de VITORIA para comprender el interés que despertaron en su tiempo: la potestad soberana del Estado, la potestad espiritual de la Iglesia, la potestad del papa y del concilio en la Iglesia, la legitimidad de la intervención de la Corona española en América, las cuestiones relativas al derecho de guerra, la cuestión del divorcio de Enrique VIII, el interés renacentista por la magia, etc. El conjunto de las relecciones de VITORIA, cronológicamente presentado, es el siguiente: De potestate civili (1528), De homicidio (1530), De matrimonio (1531), De potestae Ecclesiae prior (1532), De potestate Ecclesiae posterior (1533), De potestate Papae et concilii (1534), De augmento caritatis (1535), De eo ad quod tenetur veniens ad usum rationis (1535), De simonia (1536), De temperantia (1537), De indis prior (1539), De indis posterior seu de iure belli (1539), De

\footnotetext{
${ }^{22}$ Cfr. T. URDÁNOZ, «Introducción biográfica», en Obras de Francisco de Vitoria, 78.

23 T. URDÁNOZ, «Introducción biográfica», 82.
} 
magia $(1540)^{24}$. Pero desde la primera edición de las mismas (la edición de Boyer, Lyon 1557) ${ }^{25}$, todos sus editores las presentaron siguiendo un orden lógico, agrupando unas temáticas tan dispares, que correspondían a la actividad académica de VITORIA, según criterios de unidad lógica.

\subsection{La relección De potestate civili}

El De potestate civili es la primera relección escrita por VITORIA. Fue compuesta en su segundo año de docencia en la Universidad de Salamanca, cuya cátedra de teología le fue asignada en 1526. Fue pronunciada en la Navidad de 1528 y contiene la materia impartida en el curso de 1527-1528.

Vitoria había concebido el plan de estudiar conjuntamente las cuestiones, de tanta actualidad en sus días, de la potestad civil y eclesiástica. Prueba de ello son las referencias cruzadas entre el De potestate civili y el De potestate Ecclesiae prior. En tal sentido el De potestate civili se refiere al De potestate Ecclesiae prior en lo relativo a la subordinación del fin temporal al espiritual ${ }^{26}$, del mismo modo que el De potestate Ecclesiae prior da por sentada la noción de potestad civil tal como se trata en el De potestate civili ${ }^{27}$. Se puede por ello decir que el De potestate civili constituye la base de la serie de relecciones dedicadas a la cuestión de la potestad. En el momento mismo del nacimiento y consolidación del Estado moderno, dado el tipo de relaciones que este establece con la Iglesia, la oportunidad de la temática no podía ser mayor ${ }^{28}$.

Por otro lado, el De potestate civili es no solo una de las mejores y más conocidas relecciones de VITORIA, sino que en ella se exponen, además de las ideas fundamentales del gran renovador salmantino sobre el poder político y el Estado, algunas nociones importantes sobre la sociedad internacional [la «república de todo el orbe» (totus orbis, qui aliquo modo est una respublica), resultante de las recíprocas relaciones jurídicas entabladas en su seno por los diversos Estados] y el derecho de gentes (es decir, el derecho internacional). En efecto, según VITORIA, el derecho internacional, que regula las relaciones entre Estados, obliga a estos no solo en virtud de pactos y convenciones suscritos, sino en virtud de la misma «autoridad de todo el orbe» (totius orbis auctoritate). En este sentido afirma VITORIA en la parte conclusiva del De potestate civili: «De todo lo dicho se infiere un corolario: que el derecho de gentes no solo tiene fuerza por el pacto y convenio de los hombres, sino que tiene verdadera fuerza de ley. Y es que el orbe todo, que en cierta manera forma una república, tiene la potestad de emanar leyes justas y a

24 El orden cronológico ha sido establecido por Beltrán DE HeREDIA. Cfr. V. BELTRÁn DE HeREDIA, Los manuscritos del maestro Francisco de Vitoria OP, Madrid-Valencia, Biblioteca de tomistas españoles, IV, 1928, 132-153.

25 Reverendi Patris F. Francisci de Victoria ordinis Praedicatorum Sacrae Theologiae in Salmanticensi Academia quondam primarii Professoris Relectiones theologicae XII in duos tomos divisae, Lugduni, apud Iacobum Boyerium, 1557.

${ }^{26}$ Cfr. F. DE Vitoria, De potestate civili, n. 14. La cursiva es del propio Vitoria. Las citas de las diversas relecciones de VITORIA las tomamos siempre de la edición de T. URDÁNOZ, Obras de Francisco de Vitoria, Madrid, BAC, 1960.

27 Cfr. F. DE VitORIA, De potestate Ecclesiae prior, q. 1, n. 8; q. 3, n. 2.

28 Para una visión de conjunto del pensamiento político de Francisco DE VITORIA, $c f r$. J. CORDERO PANDO (ed.), Francisco de Vitoria, Relectio de potestate civili. Estudios sobre su filosofía politica, Madrid, CSIC, 2008. 
todos convenientes, como son las del derecho de gentes [...] y ninguna nación puede darse por no obligada ante el derecho de gentes, porque está dado por la autoridad de todo el orbe» ${ }^{29}$. Es clara, pues, la analogía que VITORIA establece entre Estado y sociedad internacional, de manera que lo que es la potestad civil del Estado frente a los súbditos, es la autoridad de todo el orbe frente a los Estados que integran la sociedad internacional, bien sabido que solo en virtud del ius naturale la autoridad de todo el orbe es capaz de obligar a los Estados en cuestión. En tal sentido, según C. GARCÍA PASCUAL, la inescindible relación en VITORIA entre ius naturale e ius gentium confiere una universalidad al derecho internacional de VITORIA de la que carece el pensamiento de $\mathrm{GROTIO}^{30}$. De este modo, queda bien establecida la estrecha relación que une el $D e$ potestate civili y las dos relecciones de ámbito internacional, el De indis prior y el $D e$ indis posterior seu de iure belli. Por todo ello FERRAJOLI ha podido decir que «Francisco DE VITORIA, cuyo papel preeminente en la fundación del derecho internacional es actualmente admitido por toda la crítica historiográfica, es autor de extraordinaria modernidad, en muchos aspectos más avanzado que muchos de sus sucesores, incluido Grotio» ${ }^{31}$, siendo sus dos grandes méritos al respecto, de nuevo con FERRAJOLI, el haber puesto los fundamentos tanto del Derecho internacional (en la elaboración de los títulos legítimos de conquista) como de la concepción moderna del Estado como sujeto soberano ${ }^{32}$.

En lo referente al contenido, la materia de esta relección se agrupa en dos grandes cuestiones: a) el origen y la naturaleza de la potestad o poder civil, y b) la obligación en conciencia del cumplimiento de las leyes que emanan de dicha potestad. Para facilitar su lectura ViTORIA introduce un sumario que divide la obra en veinticuatro números y un sucinto proemio en el que se enuncia la tesis general de la obra, como después veremos.

\subsection{Algunas fuentes del De potestate civili}

Como teólogo dominico, VITORIA encuentra su primera fuente de inspiración en la obra de Tomás DE AQUINO, ante todo en la Summa theologiae, especialmente en la I-II ${ }^{\text {ae }}$, q. 96, titulada De potestate legis humanae, en cuyos arts. 4-6 se plantea el Aquinate, exactamente como hará VITORIA en la segunda parte del De postestate civili, si la ley humana se impone ante el foro de la conciencia (a. 4), si todos los hombres le están sometidos (a. 5) y si a los que están bajo su jurisdicción les está permitido actuar más allá de las palabras de la ley (a. 6). De todas estas cuestiones trata, en efecto, la segunda parte del De potestate civili (nn. 14-24).

29 F. DE Vitoria, De potestate civili, n. 21, in fine. La cursiva es del propio Vitoria.

30 Cfr. C. GarCía PASCuAl, Norma mundi: la lucha por el derecho internacional, Madrid, Trotta, 2015, 22-23. De modo semejante opina A. PÉREZ LuÑo, según el cual el dominico español aboga por un derecho común de la humanidad, cuyos principios alcancen validez universal al reconocer como sujetos del mismo a los Estados y a los individuos (cfr. A. PÉREZ LuÑo, La polémica sobre el Nuevo Mundo. Los clásicos españoles de la filosofía del derecho, Madrid, Trotta, 1992, 78).

31 L. FERRAJOLI, «L'America, la conquista, il diritto. L’idea di sovranità nel mondo moderno», en Meridiana, 15 (1992) 21. Trad. propia.

32 Cfr. ibid., 22. 
Pero, además de a la teología moral de Tomás DE AQUino, las relecciones de VITORIA sobre la potestad (civil, eclesiástica y del papa y del concilio) deben no poco a la literatura teológica y canónica de los siglos XIV y XV, especialmente francesa, que había estudiado tanto el conciliarismo como las disputas sostenidas por príncipes y papas a lo largo del siglo XIV. El conciliarismo requería discernir la naturaleza y límites del poder del papa frente al concilio. Era una cuestión intraeclesiástica. Las disputas entre príncipes y papas exigían, por su parte, clarificar los límites entre la potestad eclesiástica y la estatal, así como explicar previamente en qué consistía la naturaleza espiritual y temporal, respectivamente, de ambas potestades, que OCKHAM y sus seguidores habían discutido. Como puede verse, se trata de buena parte de las cuestiones que dan nacimiento a la filosofía política moderna.

Debido a su larga estancia en la Universidad de París, VITORIA estaba bien informado sobre todo ello. En ningún lugar como en Francia urgía tanto clarificar las cuestiones del conciliarismo y de las relaciones del Estado con la Iglesia. No es casual, por ello, que en marzo de 1512 se celebrara un acto solemne en la Universidad de París en el que el maestro Luis BER comparaba las dos potestades, eclesiástica y civil, y el profesor del Colegio de Monteagudo, Jacobo Almain, intervenía exponiendo la doctrina conciliarista y la idea democrática aplicada a la potestad de la Iglesia a partir de la teoría de la transmisión del poder civil, que reside en la comunidad, a los príncipes. Es más que probable que VITORIA asistiera a aquella sesión académica ${ }^{33}$.

No está de más decir que así como los grandes teólogos del conciliarismo del siglo XV habían sido Pedro D’AILLY y Juan GERSON, sus defensores a inicios del siglo XVI habían sido precisamente Juan MAIR y Jacobo Almain, ambos maestros de ViTORIA. Esos cuatro nombres forman lo que ha sido llamado la cuadriga del conciliarismo galicano $^{34}$. El influjo de los dos últimos sobre VITORIA es considerable. BELTRÁN DE HEREDIA, por su parte, asegura que VITORIA debe a ALMAIN muchos elementos de sus relecciones ${ }^{35}$.

El discurso de ALMAIN en el referido acto académico de 1512 dio origen posteriormente a tres escritos: una Quaestio resumptiva agitata in Vesperiis de dominio naturali, civili et ecclesiastico (que contiene un análisis del origen y transmisión del poder civil como fundamento de las cuestiones posteriores sobre el poder del papa y del concilio general); el Tractatus de auctoritate Ecclesiae et Conciliorum generalium, escrito posteriormente por encargo de la Universidad de París, en polémica con el cardenal Cayetano; y, finalmente, una última obra sobre estas cuestiones, titulada Expositio circa decisiones M. Guillermi de Occam de potestate ecclesiastica et laica. Es manifiesto que una fuente de primera relevancia de la teología conciliarista de ALMAIN es OCKHAM, cuya obra Octo quaestiones de potestate Summi Pontificis analiza y estudia pormenorizadamente. Como puede verse, estas tres obras de ALMAIN contienen en su integridad

33 Cfr. T. URDÁNOZ, «Introducción biográfica», 111-112.

34 Cfr. R. García Villoslada, La Universidad de París durante los estudios de Francisco de Vitoria OP (1507-1522), 165.

35 Cfr. V. Beltrán de Heredia, Comentarios a la Secunda secundae, III-IV (De iustitia), Salamanca, Introducción, 1934, xxx. Cfr. también R. GaRcía VillosladA, La Universidad de París durante los estudios de Francisco de Vitoria OP (1507-1522), caps. VI y VII, sobre Juan MAIR y Jacobo ALMAIN. Cfr. también R. GARCÍA VILlosLADA, «Jacobo Almain y Francisco de Vitoria», en Estudios eclesiásticos, 59 (1936), 311-325. 
la temática que VITORIA desarrollará, aunque no del mismo modo, en la serie de sus relecciones sobre la potestad civil, eclesiástica y del papa y el concilio. Así pues, es ajustado a la realidad decir que después de Tomás DE AQUINO, Jacobo ALMAIN representa una de las primeras fuentes del pensamiento de VITORIA sobre la potestad civil y eclesiástica.

Aunque en el De potestate civili VITORIA no informa sobre los autores en que se ha inspirado para su elaboración, se hace eco al menos de la vastedad de la literatura al respecto ${ }^{36}$. En cualquier caso, en esta relección se percibe claramente que VITORIA sigue paso a paso la marcha de las ideas de los citados opúsculos de Almain, de quien, según URDÁNOZ, toma muchos elementos doctrinales y documentales para su concepción del poder político ${ }^{37}$.

\subsection{El contenido y las nociones fundamentales del De potestate civili}

Como se ha dicho ya, el De potestate civili estudia dos grandes cuestiones: el origen y naturaleza del poder público (nn. 1-14) y la obligatoriedad moral de las leyes (nn. 1524). En el proemio comienza VITORIA centrando su teoría del poder político en el marco más amplio de una teoría del Estado (o de la república, como lo llama inspirándose en el Derecho romano). Ya desde el comienzo se caracteriza la potestad política como el poder para el gobierno de la república. En efecto, se trata de aquel «poder público por el que se gobiernan los Estados» ${ }^{38}$. Se diferencia así este poder de otras formas de poder cuyo estudio no afronta ahora VITORIA. En cuanto pública, esta potestad se diferencia de la potestad privada, a la que se refiere VITORIA en el último número de esta relección (donde estudia la obligación de los mandatos impuestos en virtud de potestad privada por el padre a los hijos y el marido a la mujer) ${ }^{39}$. En cuanto temporal o civil, se diferencia también de la potestad eclesiástica, cuyo estudio reserva VITORIA a las futuras relecciones eclesiásticas. Así pues, el De potestate civili acota como objeto de sus consideraciones el estudio de la potestad pública secular y civil.

Pues bien, la tesis general que se sostiene a lo largo de toda esta relección es que no hay poder, o lo que es igual, no hay potestad pública secular y civil que no derive de Dios. Dice, en efecto, VitORIA: «El texto que se ha de releer y tratar es el que toma el Maestro de las Sentencias en 2 d. 44 de San Pablo en su epístola a los Romanos: No hay poder que no emane de Dios» ${ }^{40}$. En otros términos, el poder público, secular y civil es de origen divino. Ganada esta idea en el proemio, se reitera posteriormente en el n. 1 de nuestra relección: «Todo poder público [...] por el cual se administra la república secular, no solo es justo y legítimo, sino que tiene a Dios por autor, de tal suerte que ni por el consentimiento de todo el mundo se puede suprimir» ${ }^{41}$.

36 Cfr. F. DE VitORIA, De potestate civili, proemio.

37 Cfr. T. URDÁNOZ, «Introducción biográfica», 112.

38 F. DE VITORIA, De potestate civili, proemio: «de potestate publica [...] qua respublicae gubernantur».

39 Cfr. F. DE VITORIA, De potestate civili, n. 24.

40 F. DE Vitoria, De potestate civili, proemio. El «Maestro de las Sentencias» referido aquí por VitoRIA es Pedro Lombardo, autor del Liber sententiarum, una obra comentada por multitud de autores tanto de la primera como de la segunda escolástica.

41 F. DE VitORIA, De potestate civili, n. 1. 
Siendo el hecho a analizar la potestad pública, secular y civil, su estudio científico prescribe el análisis etiológico del mismo a partir de las diversas causas que concurren en su constitución, que según el método escolástico (que VITORIA hace plenamente suyo) son cuatro. En este sentido ViTORIA analiza el hecho de la potestad pública y secular desde la múltiple perspectiva de la causalidad final, eficiente (autor), material (sujeto) y formal (naturaleza).

\subsubsection{El fin de la potestad civil}

Resulta curioso que en una obra de teoría moral y política como el De potestate civili las primeras citas sean tomadas de la Metafísica y de la Física de ARISTÓTELES, en lugar de la Ética o de la Política del Estagirita ${ }^{42}$. Se puede ver en ello una prevención frente al nominalismo predominante en la Universidad de París, donde recibió su formación inicial ${ }^{43}$. Según los nominalistas, el mundo de las criaturas naturales, careciendo de suficiente densidad y estabilidad ontológicas, no es capaz de garantizar desde el punto de vista lógico las afirmaciones necesarias y, en consecuencia, propiamente científicas. En opinión de VITORIA, en cambio, las cosas, incluidas también las entidades políticas como son la sociedad y el Estado, poseen una esencia que las orienta establemente hacia un fin y que las dota de un cierto grado de necesidad ${ }^{44}$.

Tras esta justificación, más metafísica que política, del fin en general, procede VITORIA a aplicar la noción de fin al poder político ${ }^{45}$. VITORIA hace suyo a este propósito el razonamiento sobre la naturaleza humana que en nuestros días se ha dado en llamar antropología biológica. Dice nuestro autor así: «Conviene pensar que así como el hombre sobrepasa a los animales por la razón, por la sabiduría y por la palabra, así a este eterno, inmortal y sabio animal muchas cosas le fueron negadas por la providencia que fueron atribuidas y concedidas a los restantes animales» ${ }^{46}$. A diferencia de los demás animales, a los que la providencia dotó de los medios necesarios para su supervivencia, «al hombre, concediéndole la razón y la virtud, dejo frágil, débil, pobre, enfermo, destituido de todos los auxilios, indigente, desnudo e implume, como arrojado de un naufragio» ${ }^{47}$. De manera que para subvenir a la multitud de necesidades que hacen $\tan$

42 Cfr. ibid., n. 2.

43 Cfr. J. A. Maravall, «I pensatori spagnoli del "secolo d'oro"», en L. FiRPo (a cura di), Storia delle idee politiche, economiche e sociali, Torino, Utet, 1989, 611-693, 654. Sobre el trasfondo nominalista al que Vitoria pretende responder, $c f r$. R. GARCía VillosladA, La Universidad de París durante los estudios de Francisco de Vitoria OP (1507-1522), 128; A. DE LA HERA, «El magisterio de Vitoria en el contexto universitario de su época», en Estudios de historia social y económica de América, 13 (1996), 547-562, 550; K. MiCHALSKI, Les courants philosophiques à Oxford et à Paris pendant le XIV siècle, Cracovie, Imprimerie de l'Université, 1921, y también del mismo autor Les sources du criticisme et du scepticisme dans la philosophie du XIVe siècle, Cracovie, Imprimerie de l'Université, 1924. Sobre la relación entre nominalismo y la nueva física de la Universidad de París, cfr. P. DuHem, Etudes sur Leonard da Vinci, III, Paris, A. Hermann, 1911, 263-583: «Dominique Soto et la Scolastique parisienne». fine».

${ }_{44}$ Cfr. F. DE VitoRIA, De potestate Ecclesiae, I, q. 3,a. 3, n. 8: «Necessitas et ratio rerum sumenda est ex

${ }^{45}$ Cfr. F. DE Vitoria, De potestate civili, n. 3.

46 Ibid. Las cursivas son mías.

47 Ibid., n. 4. A propósito de la antropología biológica, cfr. L. PRIETO LÓPEZ, El hombre y el animal: nuevas fronteras de la antropología, Madrid, BAC, 2008, 533-543. 
onerosa la vida humana, «fue necesario que los hombres no anduviesen vagos y errantes $[\ldots]$ sino que viviesen en sociedad $[\ldots]$ y se ayudasen mutuamente» ${ }^{48}$.

De otro lado, la sociedad satisface no solo las necesidades naturales del hombre, sino también, y sobre todo, las espirituales. En efecto, «la palabra es nuncio del entendimiento» ${ }^{49}$, por medio del cual se eleva el hombre por encima de los animales. Pero el hombre la tendría inútilmente si viviera en soledad ${ }^{50}$. Además, la voluntad, cuyo ornamento es la justicia, «quedaría deforme y defectuosa, alejada del consorcio humano» ${ }^{51}$. En breve, «el hombre es naturalmente civil y social» ${ }^{52}$, como igualmente naturales son las ciudades y repúblicas, dice VITORIA, que nacieron con el fin de la defensa de la vida humana y la satisfacción de sus necesidades, tanto físicas como espirituales. Ahora bien, el fin de las ciudades es el mismo que el del poder público, «porque si para la guarda de los mortales son necesarias las congregaciones y asociaciones de hombres, ninguna sociedad puede persistir sin alguna fuerza y potestad que gobierne y provea» ${ }^{53}$. VITORIA llama a tal fin la utilidad, o incluso la comodidad, de los hombres ${ }^{54}$.

$\mathrm{Si}$, por un lado, la concepción de VITORIA de la sociedad puede decirse natural, en el sentido de que, como sociedad perfecta, es independiente y autónoma de la Iglesia (en virtud de sus propios fines de naturaleza temporal), su insistencia, por otro lado, en que el fin tanto de la sociedad como de la potestad pública es la utilidad (o comodidad) de los hombres, nos indica que el pensamiento del teólogo burgalés está dando pasos decididos hacia una discreta secularización de la vida política. En efecto, si la comunidad política, dada su esencia y fines peculiares, pertenece al orden natural, y el poder político se le ha dado para su conservación, se sigue de ahí que tal poder es legítimo con independencia de consideraciones de carácter espiritual; y que, por tanto, el poder que ejercitan los príncipes infieles, como es el caso de los indios americanos, es legítimo. El Estado, que desciende del derecho natural y no de ratificación espiritual alguna, es legítimo a condición de conformarse con el orden de la naturaleza ${ }^{55}$.

\subsubsection{El autor de la potestad civil}

El poder público viene de Dios, ha sentado ViTORia en la tesis general. Esto es tanto como decir que Dios es el autor o artífice del poder político, pues como creador del hombre, ha puesto en su naturaleza la necesidad de asociarse en comunidad y esta necesita el poder político para su gobierno. Dice, en efecto, VitORIA: «Habiendo mostrado que la potestad pública está constituida por derecho natural, y teniendo el derecho natural a Dios por su autor, es manifiesto que el poder público viene de Dios» ${ }^{56}$, porque «si las repúblicas y las sociedades están constituidas por derecho divi-

\footnotetext{
${ }^{48}$ F. DE Vitoria, De potestate civili, n. 4.

49 Ibid.

${ }^{50}$ Cfr. ibid.

51 Ibid.

52 Ibid.

53 Ibid., n. 5

${ }^{54}$ Cfr. ibid. Cfr. también De matrimonio.

$55 C f r$. F. DE VITORIA, De indis prior, en general.

56 F. DE Vitoria, De potestate civili, n. 6.
} 
no o natural, con el mismo derecho lo están las potestades, sin las cuales las repúblicas no pueden subsistir» ${ }^{57}$.

Ahora bien, para evitar malentendidos es necesario aclarar que el poder es de origen divino solo en un sentido general, es decir, en cuanto que pertenece naturalmente a la sociedad, y en tal sentido con independencia de la voluntad humana, por cuanto es indispensable para el gobierno, del que ninguna sociedad puede carecer. Sin embargo, la forma del poder político en que se concreta la necesaria acción de gobierno depende por completo de la voluntad de los hombres. En breve, el poder público procede de Dios en el sentido de tener en Él su origen, pero la forma de su ejercicio es de origen humano. No es, pues, en virtud del derecho natural y divino, sino solo en virtud del derecho bumano (es decir, del pacto de los hombres) como puede poseer un hombre cualquiera título legítimo para el gobierno de la nación. Veremos, enseguida, cómo VITORIA tropieza, o eso al menos creemos, en este aspecto.

De manera que la institución genérica de la potestad pública, sin la que la sociedad es inviable, procede del derecho natural y es de origen divino, mientras que la determinación particular de la modalidad de ejercicio de dicha potestad y de la forma de gobierno corresponde a la libre determinación humana.

\subsubsection{El sujeto de la potestad civil}

Por sujeto de la potestad civil debe entenderse no tanto quien ejerce dicha potestad, sino aquel a quien pertenece o en quien reside antes de cualquier determinación positiva. Pues bien, según ViTORIA, el sujeto de la potestad civil es la misma república. Con expresión propia de la escuela dice: «La causa material [es decir, el sujeto] en la que dicho poder reside es por derecho natural y divino la misma república» ${ }^{58}$. A ella compete «gobernarse a sí misma, administrar y dirigir al bien común todos sus poderes» ${ }^{59}$. Así pues, el sujeto último y principal de la potestad pública es la misma comunidad política. VITORIA razona al respecto certeramente: «Como por derecho natural y divino hay un poder de gobernar la república y, quitado el derecho positivo y humano, no haya razón especial para que aquel poder esté más en uno que en otro, es menester que la misma sociedad se baste a sí misma y tenga poder de gobernarse» ${ }^{60}$. Así pues, la potestad pública reside originalmente en la sociedad.

Ahora bien, no pudiendo la potestad pública ser ejercitada por una multitud de hombres, «fue necesario que la administración se confiase a alguno o algunos que llevasen este cuidado y nada importa que se encomendase a uno o a varios» ${ }^{61}$. La idea es clara: la delegación de la potestad pública es imprescindible para el gobierno. Esta delegación, a su vez, puede realizarse a favor de una persona (el rey o príncipe) o de varias (la aristocracia o la democracia), según las formas de gobierno establecidas por ARISTÓTELES. Luego la constitución concreta de la forma del Estado no es determinada

\footnotetext{
57 Ibid.

58 Ibid., n. 7.

59 Ibid.

60 Ibid.

61 Ibid., n. 8.
} 
por la naturaleza, sino por la voluntad de los hombres. Por tanto, solo en virtud de un pacto o acuerdo se realiza la delegación del poder y nadie podrá alegar ser titular de la potestad pública por derecho divino ${ }^{62}$.

Sin embargo, algo más adelante afirma VITORIA en sentido contrario: «Parece, pues, que la potestad regia no viene de la república, sino del mismo Dios, como sienten los doctores católicos» ${ }^{63}$. Como es natural, la mayor parte de los comentaristas ven en este texto una inconsecuencia con lo anteriormente sentado por VITORIA. Es, pues, necesario reconocer que cuando VITORIA intenta determinar en concreto cuál es el sujeto del poder político no se expresa claramente. Por un lado afirma que la comunidad política, en quien reside originalmente el poder, lo delega o encomienda al príncipe; pero por otro lado afirma que este no lo recibe de la república, sino de Dios mismo. Es necesario estudiar esta cuestión más detenidamente.

De un lado, la idea de la delegación o encomienda del poder político está claramente expuesta en varios pasos del De potestate civili. Afirma, por ejemplo, nuestro autor que «puesto que esta potestad está principalmente en los reyes, a los cuales la república encomendó sus veces, debe disputarse del principado regio y potestad» ${ }^{64}$. Ello supone, aceptada la tesis general sobre el origen divino del poder, que Dios entrega a la comunidad el poder de gobernarse a sí misma y que esta, por la necesidad de administrar la república, lo delega a su vez al gobernante. En efecto, «teniendo la república poder sobre todos los grupos de ella y no pudiendo ser ejercitado este poder por la misma multitud [...], fue necesario que la administración se confiase a alguno o algunos que llevasen este cuidado, y nada importa que se encomendase a uno o a varios» ${ }^{65}$. Pero, de otro lado, la idea contraria del inmediato origen divino del poder político aparece en varias ocasiones. En efecto, al inicio del n. 8 dice VitORia: «La monarquía o regia potestad no solo es legítima y justa, sino que los reyes, por derecho divino y natural, tienen el poder y no lo reciben de la misma república ni absolutamente de los hombres» ${ }^{66}$. En el mismo sentido, algo más adelante en el mismo n. 8, vuelve a insistir VITORIA: «Parece, pues, que la potestad regia viene no de la república, sino del mismo Dios, como sienten los doctores católicos» ${ }^{67}$, por lo que «la sagrada Escritura [...] llama a los príncipes ministros de Dios y no de la república» ${ }^{68}$. De nuevo, finalmente: «Parece, pues, que están en un error aquellos que defienden que el poder de la república es de derecho divino, mas no el poder del rey» ${ }^{69}$.

62 Cfr. ibid., nn. 8 y 14.

63 Ibid., n. 8.

${ }^{64}$ Ibid., n. 7.

65 Ibid., n. 8. Esto mismo afirma ViTORIA, y de manera más contundente si cabe, en el Comentario de la Secunda secundae. En él se sienta inequívocamente que la potestad del príncipe depende de la república. En efecto, «los magistrados civiles, los gobernadores y los príncipes tienen solo aquella autoridad y poder que les concede la comunidad. De ello se sigue el siguiente corolario: que los súbditos están obligados a obedecer a los superiores en aquellas cosas para las que la nación ha concedido a ellos el poder y en la forma en que esta lo ha establecido. Por ello, si la nación elige al rey a condición de que exija solamente determinados tributos e impuestos y este exige otros, los súbditos no están en modo alguno obligados a obedecerlo, ya que todo su poder depende de la comunidad» (cit. por E. NASZALYI, El estado según Francisco de Vitoria, Madrid, Ediciones Cultura Hispánica, 1948, 241).

66 F. DE VitORIA, De potestate civili, n. 8.

67 Ibid.

68 Ibid. Las cursivas son mías.

69 Ibid. 
Ha habido diversos intentos para salvar esta ambigüedad —así la llama URDÁNOZ— en el pensamiento de VITORIA ${ }^{70}$. Este autor, por ejemplo, cree que VITORIA quiere expresar solo que el poder político viene de Dios no solamente en abstracto, sino en todos los príncipes y poseedores legítimos del mismo, «pues es de derecho natural no solo que exista la autoridad civil en la república, sino también que esta potestad sea comunicada a alguno o algunos gobernantes» ${ }^{71}$. NASZALYI, por su parte, tras reconocer la existencia de esta ambigüedad, intenta explicar la mente de VITORIA sobre este asunto afirmando que, según VITORIA, aunque la traslación de la potestad se realiza cuando la comunidad designa a la persona en quien delega el ejercicio de la potestad, con esta designación y delegación la comunidad política no crea la potestad pública, sino que solo la concede a quien elige. Por tanto, la potestad viene de Dios, de él procede la potestad del Estado, que aquí se transfiere y la comunidad política solamente designa la persona ${ }^{72}$. MARAVALL, finalmente, en un nuevo intento de clarificar la cuestión del sujeto propio del poder político, afirma que según VITORIA «la república transfiere al príncipe su autoridad, es decir, según nuestra interpretación, su capacidad de mandar legítimamente, pero la sustancia o el contenido de esta función, es decir, el mando, la potestad, la asume el príncipe en el momento en que le es conferida la autoridad; y esta potestad es la misma que Dios, a través de la naturaleza, ha transmitido a la comunidad» ${ }^{73}$. Para esta interpretación MARAVALL se apoya, fundamentalmente, en el paso del De potestate civili n. 8 en el que VITORIA distingue la potestad (de origen divino) y la autoridad (de origen humano), según el cual la comunidad política autoriza el ejercicio de la potestad. Dice, en efecto, VITORIA: «Porque aunque el rey sea constituido por la misma república (ya que ella crea al rey), no transfiere al rey la potestad, sino la propia autoridad» ${ }^{74}$.

Ahora bien, más allá de la ambigüedad o contradicción de VITORIA, cuesta trabajo pensar que un autor de su talla no haya podido expresar su pensamiento al respecto con la debida precisión. La claridad con la que un siglo después SuÁREZ determina inequívocamente el origen humano de las formas del poder político, nos hace pensar que la ambivalencia de VITORIA sobre el origen del poder político puede deberse a una cierta justificación del absolutismo de su tiempo. En efecto, SUÁREZ afirma claramente en el De legibus: «Formalmente considerado, aunque este poder de gobierno procede sin duda de Dios, su transmisión a una persona concreta resulta de la concesión del propio pueblo, y en tal sentido es de derecho humano [...] Luego, hablando sencillamente, el poder proviene de los hombres» ${ }^{75}$. MARAVALL apunta a un posible deslizamiento de ViTORIA hacia las tesis del absolutismo $^{76}$. En efecto, VITORIA se estaría

70 Cfr. T. URDÁNOZ, «Introducción biográfica», 119. TRUYOL, en cambio, prefiere llamarla una contradicción. Cfr. A. Truyol SerRA, Los principios de Derecho público en Francisco de Vitoria, Madrid, Cultura Hispánica, 1946, 43-44.

71 T. URDÁNOZ, «Introducción biográfica», 120.

72 Cfr. E. Naszalyi, El Estado según Francisco de Vitoria, 241.

73 J. A. MARAVALL, «I pensatori spagnoli del "secolo d'oro"», 656. Trad. propia.

74 F. DE Vitoria, De potestate civili, n. 8.

75 F. SuÁREZ, De legibus, 3,4,5.

76 Sostienen esta idea S. Lisarrague, P. Mesnard, C. Barcia, A. Dempf, etc. Cfr. S. Lissarrague, La teoría del poder en Francisco de Vitoria, Madrid, Instituto de Estudios Políticos, 1947, 78 y ss. En sentido contrario, T. URDÁNOZ, «Introducción biográfica», 141. Cfr. también H. BEUVE-MERY, La théorie des pouvoirs publics d'après F. de Vitoria, Paris, Spes, 1928; A. TRuYOL SERRA, Los principios de Derecho público en Francisco de Vitoria, Madrid, Cultura Hispánica, 1946, 43-44, quien, para salvar la aparente contradicción, insiste en que «ViTORIA quiere destacar que el rey no es un simple mandatario de la república [...] sino un órgano de la 
convirtiendo en un defensor del absolutismo, como un siglo después lo juzga el jesuita RODRIGO DE ARRIAGA ${ }^{77}$. Con todo, la cuestión no es suficientemente clara ni se puede dar por cerrada.

Proponemos, por ello, dos textos de ViTORIA, tomados del Comentario de la Summa theologiae de sentido contrario, para poner de manifiesto esta ambigüedad. El primero se expresa en un sentido contrario a la tesis absolutista, afirmando que la potestad del príncipe depende en todo de la república. En efecto, «los magistrados civiles, los gobernadores y los príncipes tienen solo aquella autoridad y poder que les concede la comunidad. De ello se sigue el siguiente corolario: que los súbditos están obligados a obedecer a los superiores en aquellas cosas para las que la nación ha concedido a ellos el poder y en la forma en que esta lo ha establecido. Por ello, si la nación elige al rey a condición de que exija solamente determinados tributos e impuestos y este exige otros, los súbditos no están en modo alguno obligados a obedecerlo, ya que todo su poder depende de la comunidad» ${ }^{78}$. En cambio, en sentido favorable a la tesis absolutista se expresa VITORIA cuando afirma que la delegación de la potestad al monarca, a diferencia de la que se realiza en el régimen democrático y aristocrático (en la que la potestad se concede con limitaciones y con la posibilidad de revocarla), es realizada sin condiciones y a perpetuidad, de modo que no puede ser retirada, si fue concedida en estas condiciones. En concreto, «la república, una vez concedido el poder al rey, no puede reivindicarlo después si lo concedió al rey y sus herederos sin condiciones y perpetuamente» (respublica dedit auctoritatem regi, quam non potest repetere, si sine conditione dedit in perpetuum illi et eius successoribus ${ }^{79}$. El uso de la fórmula condicional no deja de tener un sentido retórico, pues ¿de qué otro modo sino incondicional y perpetuamente se entregaba la potestad al rey en el siglo Xvi? Sorprende, por otro lado, la semejanza de la fórmula de VITORIA con las palabras de BODIN, que vamos a ver al final de este artículo.

VITORIA es un autor del siglo XVI, la época en que España evolucionaba de las formas políticas medievales a la constitución del Estado monárquico moderno. Su época es la de los Reyes Católicos y de Carlos V. La supremacía, la majestad encarnada por el nuevo Estado moderno y su soberano era un hecho y las teorías políticas, como dice Jellinek, tienden de ordinario a plegarse y justificar los hechos ${ }^{80}$. Quizás a este estado de cosas se deban las vacilaciones de VITORIA en la determinación del sujeto del poder político. En cualquier caso la idea de que la delegación del poder es irrevocable, incondicional, perpetua, y en tal sentido dinástica, tal como lo expresan las palabras de la cuestión 105 del Comentario de la II-II ${ }^{a e}$ de VITORIA que acabamos de ver, parece una concesión de Vitoria al absolutismo.

La idea vitoriana de soberanía es bastante próxima a la de Bodin. Ahora bien, como vamos a ver enseguida, conviene tener presente que en BoDin la soberanía es la característica fundamental del poder político de la monarquía absolutista.

república, el cual, una vez constituido como tal, no puede ser revocado su poder mientras lo ejerza a favor del bien común» (44).

77 Cfr. J. A. MARAVALL, «I pensatori spagnoli del "secolo d'oro"», 656.

${ }^{78}$ F. DE Vitoria, Comentario de la II-IIae, cit. por E. NASZALYI, El Estado según Francisco de Vitoria, 241.

79 F. DE Vitoria, Comentario a la I-IIae, q. 105, a. 2, ed. BeltrÁn DE Heredia, t. 6, Salamanca, 1952, 482.

${ }^{80}$ Cfr. G. JellineK, Allgemeine Staatslehre, Berlin, Verlag von O. Häring, 1914, 452. 


\subsubsection{La naturaleza de la potestad civil}

Recapitulemos. Ya sabemos que, según VITORIA, el poder político es de origen divino. Procede inmediatamente de la naturaleza humana, de la que Dios es autor. Los hombres, en efecto, no pueden vivir más que socialmente. Pero ninguna sociedad humana puede subsistir sin una potestad que la gobierne. Por eso la potestad es esencial a la comunidad política, que es su sujeto titular último. Pero aún no hemos definido qué es la potestad política. Es, pues, el momento de preguntarnos qué es o en qué consiste formalmente la potestad.

VITORIA cree necesario distinguir entre poder (potentia) y potestad (potestas). El poder es una fuerza, una energía, una capacidad de obrar. Pero la potestad es un tipo de poder que añade algunas propiedades nuevas. En efecto, «la potestad, además de la potencia para la operación, comprende una cierta preeminencia y autoridad» ${ }^{81}$. Así pues, además del poder, la potestad conlleva la superioridad o preeminencia (o soberanía) y el carácter ético. No es mera fuerza coercitiva, según VITORIA. Se puede decir, por tanto, que la potestad pública representa en VITORIA un poder supremo de naturaleza moral de obligar a los hombres. Precisamente en virtud de su carácter moral, las leyes emanadas de dicha potestad obligan en conciencia, como afirma la segunda parte del De potestate civili. Esto supuesto, VITORIA define la potestad pública como «la facultad, autoridad o derecho de gobernar la sociedad civil» ${ }^{82}$. De donde se sigue que la potestad pública es un poder supremo de naturaleza moral cuyo fin es el gobierno del Estado.

Por otro lado, como sabemos, la potestad del Estado es temporal o civil, no espiritual. Es, por su propia esencia, independiente del orden espiritual o de la gracia, por lo cual, correspondiendo a la naturaleza humana, se da de igual modo entre paganos que cristianos. De ahí que tanto los Estados de los paganos como las autoridades que los gobiernan están revestidos de una potestad igualmente legítima. Por ello, en cuanto dotado de potestad temporal, el Estado es independiente de la Iglesia. En otras palabras, en lo tocante a asuntos temporales o civiles no tiene obligación alguna de obedecer a la Iglesia ${ }^{83}$. Además, la potestad del Estado es, por definición, pública. Mira al bien común, que es el que compete al Estado. El carácter público de la potestad del Estado se manifiesta ante todo en la potestad de legislar ${ }^{84}$. Pues bien, en el ámbito público y temporal o civil la potestad de la república es suprema (o soberana). VITORIA no acepta, sin embargo, que esta potestad sea suprema en el sentido de eximir al rey del respeto y obediencia de las leyes por él mismo dictadas. En este sentido, no acepta el carácter de legibus solutus del rey, que no pocos legistas y juristas de la corte, inspirándose en el derecho imperial romano, venían reivindicando, como veremos que hace BODIN $^{85}$.

81 F. DE ViTORIA, De potestate Ecclesiae, q. 1, n. 2: «Videtur potestas praeter potentiam ad actionem dicere preeminentiam quandam et auctoritatem».

82 F. DE VITORIA, De potestate civili, n. 10: «Potestas publica est facultas, auctoritas, sive ius gubernandi rempublicam civilem».

83 Cfr. F. DE VITORIA, De potestate Ecclesiae, I.

${ }^{84}$ Cfr. F. DE Vitoria, Comentario a la I-IIae, q. 90, a. 3.

85 En efecto, en el De potestate civili, n. 21, se expresa VITORIA abiertamente contra esta condición del soberano como absuelto de la ley. 
La supremacía de esta potestad se sigue de que el Estado es una comunidad política perfecta, que no carece de nada, y en tal sentido no puede tener potestad alguna por encima de ella ${ }^{86}$. Conviene aclarar que la idea de comunidad perfecta es una noción jurídica, no moral ${ }^{87}$. En efecto, el Estado de los indios, aunque no ha alcanzado la perfección ética, es, sin embargo, una sociedad perfecta. En tal sentido, una sociedad es perfecta cuando posee supremacía interior e independencia exterior. Ambas propiedades son las dos caras de la soberanía política. La potestad política es suma, o lo que es lo mismo, puede gobernar todos sus asuntos con autoridad y poder propios. Esta supremacía interior de la potestad política se da, ante todo, según VITORIA, en la potestad de legislar, que conlleva también, además de la capacidad administrativa, la potestad punitiva ${ }^{88}$. A su vez, la potestad es independiente, porque el Estado, a cuyo gobierno sirve, es una unidad autónoma o independiente de cualquier otro Estado. Dicha independencia exterior capacita al Estado a proceder contra los enemigos externos, juzgándolos y castigándolos si son particulares o declarándoles la guerra sin son Estados ${ }^{89}$.

Es claro que la idea de soberanía no podía hacerse explícita más que cuando el Estado moderno se desligó o independizó de otras entidades políticas. En efecto, como ya sabemos, en las luchas ocurridas al final de la Edad Media por la independencia del Estado, las monarquías nacionales son las portadoras de la idea del Estado moderno. Por eso, las monarquías modernas nacen bajo el signo laico y nacional de la lucha con el papa y el emperador, respectivamente, y es a ellas a quien se atribuye el poder soberano ${ }^{90}$. En este sentido también VITORIA establece y separa al Estado naciente tanto de la Iglesia (y de la potestad eclesiástica) como del imperio. Ya conocemos la afirmación de ViTORIA respecto de la superioridad (o soberanía) del Estado sobre la Iglesia en lo concerniente a asuntos civiles. Respecto del emperador afirma rotundamente «que no es señor de todo el orbe» ${ }^{91}$. Nunca se ha demostrado, afirma, ni por derecho divino ni natural ni humano, que el emperador tenga este dominio sobre todo el mundo ${ }^{92}$.

\subsection{Excursus sobre la soberanía en Bodin}

Este trabajo trata sobre la soberanía política en VITORIA. Pero la idea de soberanía tiene en BoDIN su madurez y su forma canónica. Por ello es necesario dedicar unas líneas a la soberanía en este autor, que la expone sistemáticamente por primera vez en la obra Los seis libros de la República (1576), casi cincuenta años después del De potestate civili de VITORIA. El propósito de BODIN, además de elaborar una ciencia política

${ }^{86}$ Cfr. F. DE Vitoria, De Indis, II, n. 7, a propósito de la comunidad perfecta.

87 Cfr. E. Naszalyi, El Estado según Francisco de Vitoria, 139.

s8 Cfr. F. DE Vitoria, De matrimonio, II, n. 1.

89 Cfr. F. DE ViTORIA, Comentario a la II-IIae, q. 40, a. 1.

90 Cfr. G. JelLineK, Allgemeine Staatslebre, 456: «In den mittelalterlichen Kämpfen um die Unabhängigkeit des Staates und seiner Gewalt ist es überall die Monarchie, welche als Träger des Staatsgedankens auftritt. Daher erscheint dem politischen Denken der Kampf um den Staat wesentlich als Kampf des weltlichen Herrschers mit dem Papste, des Königs mit dem Kaiser [...] Es ist daber fast selbstverständlich, daß die Souveränität zuvörderst auf den Monarchen bezogen wird». Las redondas son mías.

91 F. DE Vitoria, De Indis, I.

92 Cfr. F. DE VitORIA, De potestate Ecclesiae, I. 
moderna que sustituya la vieja Política de ARISTÓTELes, es elaborar un concepto de poder político suficientemente fuerte para poner al Estado a salvo de las turbulencias internas del momento (sobre todo, político-religiosas), así como de las guerras frente a otros Estados.

De otro lado, Bodin representa la conclusión y síntesis del proceso de imperialización de la figura del príncipe, de quien la soberanía (sowveraineté) es un atributo esencial. Profesor de Derecho romano en la Universidad de Toulouse y abogado de la corte, la figura de Jean BoDIN (1530-1596) se inscribe plenamente en la tradición de los juristas y publicistas en los que se apoyan las monarquías modernas para rodear de prestigio intelectual el impulso ascendente que está experimentando el Estado en los albores de la Época Moderna y para legitimar sus pretensiones absolutistas. No es necesario por evidente insistir en la semejanza de BODIN con los legistas de la corte de Felipe el Hermoso, de los que ya hemos hablado.

El Estado (o República, como lo llama Bodin, al igual que VitORIA) dispone de una potestad suprema y perpetua para su gobierno. En efecto, «la república es el recto gobierno de varias familias, y de lo que les es común, con poder perpetuo y supremo» ${ }^{93}$. Como dicho poder no ha sido definido todavía por ningún filósofo ni jurisconsulto, dice BoDiN ${ }^{94}$, es necesario determinar en qué consiste. Así pues, «la soberanía es el poder absoluto y perpetuo de una República, que los latinos llaman majestad ${ }^{95}$. El carácter absoluto del poder consiste en ser otorgado simplemente, sin condiciones ni límites para su ejercicio, fuera de los que impone la ley de Dios y la ley natural ${ }^{96}$. A su vez, la perpetuidad de dicho poder implica que, una vez otorgado, se ejerce en nombre propio «en el modo y por el tiempo que le [al soberano] plazca (tant et si longuement qu'il lui plaira) ${ }^{97}$. De las propiedades de absoluto y perpetuo se sigue que el soberano puede dictar y derogar leyes con completa libertad. En tal sentido, dice BoDin, es habitual incluir en la conclusión de las leyes y decretos la fórmula car tel est notre bon plaisir $^{98}$. Por otro lado, aunque las leyes no deben chocar con razones morales, «no dependen más que de la sola y pura voluntad del soberano» ${ }^{99}$. La soberanía, pues, se expresa, ante todo, en la potestad de promulgar leyes, de cuya obediencia, según BoDIN, el propio príncipe está absuelto.

En cualquier caso, el fundamento de la relación entre soberanía y absolutismo presente en el pensamiento de BoDIN estriba más en el carácter perpetuo del poder que en el de absoluto, pues en virtud de la perpetuidad el soberano ejerce el poder en nombre propio, no como concedido o delegado por la comunidad, en el modo y por el tiempo que desee. ¿No es quizás esta misma lógica de ideas la razón de las vacilaciones de VITORIA en la cuestión del sujeto de la potestad política a propósito del absolutismo? ¿Es simple casualidad que, como hemos visto, VITORIA emplee exactamente los mismos términos que BoDIN, a saber, incondicional, perpetuo e irrevocable, para referirse al poder

93 J. Bodin, Les six livres de la République, I, 1.

${ }_{94}$ Cfr. ibid., I, 8.

95 Ibid: «La souveraineté est la puissance absolue et perpétuelle d'une République, que les Latins appellent majestatem».

${ }_{96}$ Cfr. J. Bodin, Les six livres de la République, I, 8.

97 Ibid.

98 Ibid.

99 Ibid. 
soberano? ${ }^{100}$ ¿No es quizás esta la clave de solución de la ambigüedad de VITORIA en la determinación del sujeto del poder político?

\section{A MODO DE CONCLUSIÓN}

Aunque la idea de soberanía está presente en el De potestate civili solo de un modo implícito, contiene ya todos los elementos de la definición de soberanía de Los seis libros de la República de BODIN. Sin embargo, el hecho de que VITORIA rechace la condición de legibus solutus del principe, a diferencia de aquel, y dedique la segunda parte del De potestate civili a estudiar la obligatoriedad moral de cumplir en conciencia las leyes, pone en el pensamiento del pensador dominico una nota de bumanismo ético que, en el caso de que se admita la antes mencionada tendencia absolutista en su teoría del Estado y del poder político, circunscribe y matiza dicha propensión.

VITORIA fue llamado el Sócrates cristiano. No fue, en efecto, un metafísico. Orientó su filosofía hacia los argumentos morales y jurídicos, subordinando el interés especulativo a las grandes cuestiones candentes que los nuevos tiempos estaban planteando. Entre dichas cuestiones dedicó especial atención a las relacionadas con el nacimiento del Estado moderno, a saber: la naturaleza del poder soberano del Estado (tanto en sí mismo como en su relación con la Iglesia) y la índole de las fuentes del derecho internacional, que regula la relación entre los diversos Estados, cuyo conjunto, como sociedad de Estados, constituye la respublica totius orbis. De esta respublica afirma vigorosamente, con el mismo espíritu humanista y ético, «habet [...] potestatem ferendi leges aequas et convenientes omnibus, quales sunt in iure gentium» ${ }^{101}$.

100 Cfr. supra, nota 79.

101 F. DE VITORIA, De potestate civili, n. 21, in fine: «Tiene la potestad de emanar leyes justas y convenientes a todos, como son las del derecho de gentes». Las cursivas son mías. Cfr. supra, notas 30 y 32 . 



\title{
MUERTES Y RESURRECCIONES DEL POSITIVISMO JURÍDICO: UNA CRISIS DE DOSCIENTOS ÂNOS DE DURACIÓN*
}

\author{
Luis Lloredo Alix ** \\ Universidad Autónoma de Chile \\ luislloredo@gmail.com
}

RESUMEN. El objetivo de este artículo es mostrar que el positivismo jurídico ha vivido en crisis desde su mismo nacimiento, a principios del siglo XIX, y no solo desde la oleada neoconstitucionalista. En primer lugar se examinarán los problemas de las aproximaciones conceptuales al problema del positivismo y se defenderá la necesidad de un acercamiento histórico para comprender la cuestión de si el iuspositivismo se encuentra verdaderamente obsoleto. En segundo lugar se pasará revista a las sucesivas crisis que ha experimentado esta corriente a lo largo de sus doscientos años de historia, y se verá cómo ha ido adaptándose a todos esos embates. Por último se argumentará que, desde ese punto de vista, el ataque post-positivista no representa una impugnación radical de sus planteamientos, sino una reorientación que corre pareja con transformaciones ideológicas profundas del orden global.

Palabras clave: positivismo jurídico, post-positivismo, crítica ideológica, crisis del positivismo jurídico, historia del positivismo jurídico.

\section{Deaths and Resurrections of Legal Positivism: a Two Hundred Years' Crisis}

ABSTRACT. The aim of this essay is to demonstrate that legal positivism has been submitted to criticism from its very beginning, at early $19^{\text {th }}$ century, and not only from the neoconstitutionalist wave. Firstly we will examine the inconveniences of the conceptual approach to the problem of legal positivism and we will sustain that a historical approach is needed to properly undertake the question regarding the alleged obsolescence of legal positivism. Secondly we will go over the continuous crisis that legal positivism has endured along its two-hundred years' history, and it will be shown how this current has adapted to all its purported refutations. Lastly we will argue that, from the above mentioned perspective, the criticism of post-positivism does not involve a radical rejection to legal positivism, but a re-orientation which goes parallel with profound ideological transformations in the global order.

\footnotetext{
* Fecha de recepción: 1 de agosto de 2016. Fecha de aceptación: 16 de febrero de 2017.

Este trabajo ha sido posible gracias al Proyecto Fondecyt 11140660 de la Comisión Nacional de Investigación Científica y Tecnológica (CONICYT). Agradezco a la Sociedad Chilena de Filosofía Jurídica y Social por darme la oportunidad de pronunciar una conferencia sobre el tema, y a los miembros del Área de Filosofía del Derecho de la Universidad Autónoma de Madrid por permitirme presentar un borrador de este artículo en su seminario. Asimismo, estoy en deuda con la Sala Regional del Tribunal Electoral de Monterrey (México), que también me invitó a impartir una ponencia sobre el tema.

*** Doctor en filosofía del derecho por la Universidad Carlos III de Madrid y académico docente investigador en la Universidad Autónoma de Chile.
} 
Keywords: legal positivism, post-positivism, ideological criticism, crisis of legal positivism, history of legal positivism.

\section{INTRODUCCIÓN}

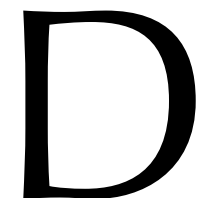

igámoslo sin dilación: el debate sobre el positivismo jurídico ha llegado a ser enormemente tedioso. Quizá se trate de uno de los ámbitos donde mayor virulencia teórica se ha desplegado en las últimas décadas, y es probable que estemos ante una de las polémicas más trilladas de la filosofía jurídica del siglo Xx. Como se intentará defender en las páginas siguientes, los motivos que me llevan a replantear el tema son de orden historiográfico y filosófico-político. Concretamente, se sostendrá que la presunta crisis del positivismo jurídico no es tan reciente como solemos pensar, ya que esta corriente ha estado recibiendo acusaciones de caducidad desde su mismo nacimiento. Creo que esta constatación historiográfica debería llevarnos a sospechar, por razones prudenciales, de aquelos planteamientos que se reclaman como sus superadores inapelables. Me parece que una afirmación semejante solo puede hacerse con suma cautela y teniendo en cuenta factores ideológicos distintos a los que habitualmente se han puesto sobre la mesa. En particular, se propondrá que los aprietos del positivismo jurídico no tienen que ver con la incorporación de la moral en los ordenamientos constitucionales contemporáneos, sino con un redimensionamiento de las relaciones entre derecho y política y con una transición profunda del orden global, que se ha traducido en la erosión irreversible de la soberanía estatal.

Dividiré la exposición en los siguientes apartados: primero se trazará una panorámica de la discusión en torno al positivismo, poniendo de manifiesto la logomaquia existente y la diversidad de tesis que se esconden bajo la misma rúbrica $(\$ 2)$; a continuación se hará una crítica de dos propuestas especialmente célebres e influyentes en este debate, las de Norberto BOBBIO y Herbert HART, para señalar sus deficiencias y justificar la necesidad de una aproximación genealógica (\$3); en tercer lugar se llevará a cabo una reconstrucción histórica de las impugnaciones sufridas por el positivismo a lo largo de los dos últimos siglos $(\$ 4)$; en cuarto lugar se defenderá la necesidad de una aproximación ideológica al problema, como único modo de explicar las causas de la crisis permanente del iuspositivismo $(\$ 5)$; por último se valorará la magnitud de los ataques (neo) constitucionalistas, para terminar proponiendo una forma alternativa de concebir la crisis del paradigma positivista $(\$ 6)$.

\section{LOS MIL ROSTROS DEL POSITIVISMO: LA BATALLA DE LAS ETIQUETAS}

Adentrarse por vez primera en el tema del positivismo jurídico es un quebradero de cabeza asegurado. Para empezar, la mayoría de los juristas profesionales utiliza la etiqueta de iuspositivismo a modo de sambenito: positivista sería ese jurista obtuso que vive ofuscado por el texto literal de la norma vigente, que jamás manifiesta preocupación por la ética, la justicia o el interés social, y que probablemente sacrificaría la lec- 
tura de un buen poema por el análisis ramplón del Boletín Oficial del Estado. Pero este prejuicio no solo proviene de los abogados «prácticos». De hecho, Norbert HOERSTER llegó a decir que en la filosofía del derecho alemana se consideraba «de buen tono» rechazar y condenar al positivismo jurídico (HOERSTER, 2000: 9). Esta afirmación debe ser cuidadosamente matizada, porque las cosas no siempre han sido así en todos los contextos geográficos y culturales. Por ejemplo, el enfoque positivista fue percibido como un soplo de aire fresco en la España post-franquista, dado que la ideología oficial del régimen había sido el nacionalcatolicismo y, por ende, la ortodoxia en las facultades de derecho fue el iusnaturalismo de corte religioso (RIVAYA, 2009). Algo similar podría decirse de muchos países latinoamericanos en los que la orientación positivista fue asociada con ideas más bien liberales o socialdemócratas, en clara oposición con las diversas dictaduras militares que azotaron la región (ATIENZA y RUIZ MANERO, 2007: 8-9). En estos casos, cabría afirmar que el iuspositivismo gozó de buena prensa durante al menos algunas décadas. Sin embargo, tengo la impresión de que las cosas han ido cambiando y que la penetración de la retórica neoconstitucionalista ha llegado a generar un nuevo sentido común, de acuerdo con el cual solo la testarudez, la inercia o la nostalgia podrían explicar el mantenimiento de las tesis positivistas tradicionales. Como irónicamente ha escrito Fernando ATRIA, «un nuevo fantasma recorre Europa: el fantasma del neo-constitucionalismo. Los poderes de la cultura jurídica europea han entrado en una santa alianza no para exorcizarlo sino para defenderlo e incluso exportarlo» (ATRIA, 2004: 118).

Así pues, las primeras incursiones en la polémica sobre el iuspositivismo resultan desconcertantes. Pero superado ese primer momento de estupor, y arrinconados los prejuicios que acabo de señalar, las cosas siguen siendo enormemente complejas. La logomaquia salta a primera vista: se ha hablado de positivismo legalista, normativista, historicista, analítico, formalista, institucionalista, realista, metodológico, teórico, ideológico, ético, normativo, corregido, sofisticado, incluyente, excluyente, incorporacionista, presuntivo, moderado, positivo, negativo, sociologista o psicologista, entre otras etiquetas que cabe encontrar en la literatura especializada (OTT, 1992: 32-103; ESCUDERO, 2004: 150-198; GONZÁLEZ VICÉN, 1979: 47-140). En algunas ocasiones estos calificativos son intercambiables, como sucede con los de incluyente e incorporacionista. En otras ocasiones, tales epítetos se dirigen a aspectos diversos de una teoría - aunque eventualmente complementarios- y, en ese sentido, pueden acumularse en un mismo autor sin estridencias. Sin embargo, lo que ocurre más a menudo es que existen discrepancias profundas entre los representantes del positivismo jurídico. Esta logomaquia, producto de dichas desavenencias, ha dado pie a numerosos propósitos de clarificación del canon positivista. Dado lo profuso de la discusión, no me parece posible realizar una panorámica exhaustiva en este momento, pero creo que sí conviene señalar algunos hitos relevantes.

Probablemente el pistoletazo de salida para este proceso de autodefinición tuvo lugar en 1958, como consecuencia de un artículo publicado por Herbert HART, en el que este propuso distinguir cinco significados distintos de la locución «positivismo jurídico». El positivismo sería así una corriente que sostiene cosas muy distintas, no necesariamente compatibles entre sí: 1) que el derecho está compuesto por mandatos humanos; 2) que no existe una conexión necesaria entre el derecho y la moral; 3) que el análisis de los conceptos jurídicos es la tarea principal de la teoría jurídica, y que 
dicha actividad debe desvincularse de otras investigaciones de naturaleza histórica o sociológica; 4) que el ordenamiento jurídico es un sistema cerrado, del que pueden extraerse decisiones correctas para los casos concretos con el mero auxilio del razonamiento lógico, y sin necesidad de apoyarse en consideraciones éticas, políticas o sociales, y 5) que no es posible establecer juicios morales mediante pruebas empíricas o argumentaciones racionales (HART, 1958: 601-602). Se trata de tesis que, en efecto, han sido defendidas por muchos iuspositivistas a lo largo de la historia: el imperativismo es reconocible en la primera; casi cualquier variante del positivismo es identificable en la segunda; la jurisprudencia analítica, las teorías de los conceptos jurídicos fundamentales o el realismo genovés son manifestaciones de la tercera; la jurisprudencia de conceptos o la escuela de la exégesis son un reflejo de la cuarta; y el no cognitivismo se deja ver en la quinta. En algunas ocasiones, como el mismo HART señalaba, varias de estas tesis se dan simultáneamente en un autor, mientras que otras veces las encontramos de forma independiente.

Ahora bien, en ese mismo artículo, HART nos advertía sobre la posibilidad de añadir otros significados. Y tenía razón, porque solo dos años más tarde, en 1960, Norberto BOBBIO y Alessandro PASSÉRIN D'ENTREVES organizaron un célebre congreso acerca del positivismo jurídico en la ciudad de BELLAGIO. El propósito de este encuentro era trazar un mapa de la cuestión, involucrando a iusfilósofos continentales y anglosajones, con el ánimo de identificar los diversos sentidos con los que se manejaba la expresión. De acuerdo con SHUMAN y FALK, en el evento se pusieron de manifiesto ocho formas distintas de emplearla: 1) el iuspositivismo es una teoría que entiende el derecho como un conjunto de reglas dictadas por el Estado, y la totalidad de dichas reglas debe ser coherente; 2) el iuspositivismo es una teoría que atribuye al Estado la exclusividad en la formulación de normas jurídicas, insistiendo así en la fuente humana —no trascendental — del derecho; 3 ) el iuspositivismo es una rúbrica que comprende a la jurisprudencia analítica inglesa, la jurisprudencia de conceptos alemana, la escuela de la exégesis francesa, la teoría kelseniana, el realismo jurídico norteamericano y el escandinavo; 4) el iuspositivismo es el trasunto jurídico de dos grandes movimientos filosóficos: la teoría de August COMTE y el positivismo lógico del Círculo de Viena; 5) el iuspositivismo es una teoría que incorpora las siguientes ideas: el derecho y la moral son órdenes normativos independientes, el derecho es un conjunto de mandatos estructurados de forma autoritativa, la validez de las normas jurídicas depende de criterios procedimentales, el derecho natural no existe, los valores morales no son cognoscibles; 6) el iuspositivismo es una teoría que ciñe su objeto de estudio a las normas jurídicas formales y que, por tanto, se distingue de la jurisprudencia sociológica; 7) el positivismo jurídico es una doctrina que separa el derecho de la moral, y 8) el positivismo jurídico no es una teoría formal (SHUMAN y FALK, 1961).

Como puede intuirse a tenor de este abigarrado elenco, lo que SHUMAN y FALK hicieron fue dejar constancia de los múltiples significados que los participantes del congreso habían utilizado, pero no elaboraron la información de manera sistemática. Si lo observamos con mirada crítica, nos damos cuenta de que en esas ocho acepciones se entremezclan tesis que quizá no deberían ir juntas, que algunas se repiten en varios puntos, que unas son descriptivas y otras prescriptivas, que algunas son contradictorias entre sí, o que algunas simplemente se refieren a aspectos accidentales del paradigma. En definitiva, se trata más bien de un totum revolutum que de una propuesta 
de definición del iuspositivismo. Ahora bien, lo importante de BeLlagio no fue el contenido de lo que allí se discutió o los eventuales acuerdos a los que llegaron sus participantes, sino la toma de consciencia respecto a la variedad de posiciones que se englobaban bajo la misma etiqueta. En ese sentido, el congreso fue un hito para el proceso de desbroce y clasificación que se dio a partir de entonces. En efecto, como ha señalado Genaro CARRIó, al «espíritu de Bellagio» se pueden retrotraer las siguientes publicaciones: Aspetti del positivismo giuridico de BoBBIO (1961), The Concept of Law de HART (1961), El concepto de validez y el conflicto entre el positivismo jurídico y el derecho natural de Alf Ross (1961) y Che cos'è il positivismo giuridico de Uberto SCARPELLI (1965) (CARRIÓ, 1981: 22). A continuación analizaré dos de las más célebres definiciones del positivismo que se hicieron a partir de entonces.

\section{UNA CRÍTICA A LAS PROPUESTAS DE BOBBIO Y HART: LA DIFICULTAD DE HALLAR UN CONCEPTO UNITARIO DE POSITIVISMO}

De todas las propuestas surgidas tras el congreso de BELLAGIO, conviene que nos detengamos primero en la de BOBBIO, porque se trata de uno de los intentos de clarificación que más éxito han cosechado. Me refiero a la celebérrima distinción entre el positivismo como «modo de aproximarse al estudio del derecho», como una «determinada teoría o concepción del derecho» o como una «ideología de la justicia», de donde se desprende la habitual tripartición entre positivismo metodológico, teórico e ideológico (Воввіо, 1977: 101-126). De acuerdo con BоввіO, el positivismo metodológico entrañaría una aproximación al fenómeno jurídico que diferencia con nitidez entre el derecho que es y el derecho que debe ser, entre el derecho como hecho y el derecho como valor, o entre el derecho real y el derecho ideal. Se trata, por tanto, de una actitud de neutralidad valorativa respecto al objeto de estudio. El positivismo teórico implicaría un posicionamiento más sustantivo, ya que identifica al derecho con una serie de rasgos, que grosso modo pueden reconducirse a la idea del Estado como agente monopolizador de la fuerza: la teoría de la coacción, la concepción del ordenamiento como un sistema pleno y coherente, la visión de la interpretación jurídica como un proceso mecánico y la descripción de las normas como mandatos o imperativos. El positivismo ideológico, en fin, sostendría algo mucho más fuerte aún: que todo orden jurídico positivo es justo per se. Ya se ha escrito mucho sobre esta diferenciación y no es momento de entrar en todos sus pormenores, pero sí estimo necesario hacer dos apuntes críticos.

El primero de ellos tiene que ver con el excesivo grado de abstracción que implica, cosa que se logra al precio de deformar drásticamente los perfiles de las teorías y los autores reales. Es muy difícil encontrar, por ejemplo, un filósofo que quepa dentro de lo que BOBBIO denominaba positivismo como ideología, al menos en la variante extrema de dicha corriente, que supuestamente identificaba al derecho positivo con la justicia (BoBBIO, 2005: 27) ${ }^{1}$. También es ficticia la pretensión de hallar autores que

1 BobBio aludió a las teorías del derecho del más fuerte como ejemplo de este reduccionismo tan brutal, pero basándose para ello en el retrato que Platón nos legó del sofista TrasímaCO (BOBBIO, 1996: 238). Sin em- 
asuman el positivismo en su aspecto metodológico, sin a la vez suscribir uno o varios de los elementos que el turinés asociaba al positivismo como teoría. En efecto, las distinciones entre el derecho que es y el derecho que debe ser casi siempre se llevan a cabo identificando al derecho «real» con el derecho estatal, por lo que el positivismo metodológico coincide en la mayoría de las ocasiones con alguna modalidad de positivismo teórico. Por otra parte, los rasgos que BOBBIO atribuía al positivismo teórico casi nunca se dan de forma conjunta en autores concretos, salvo quizá en algún representante de la escuela de la exégesis. De hecho, se suele decir que el positivismo teórico equivale a lo que normalmente llamamos formalismo, pero el formalismo así definido resulta inservible para aprehender las ideas de la jurisprudencia de conceptos, ya que esta no aceptaba la tesis de la coactividad o la supremacía de la ley como fuente de derecho. Resultaría de ello que uno de los momentos estelares del formalismo jurídico queda fuera de los criterios de formalismo à la $\mathrm{BOBBIO}^{2}$. A su vez, por poner un último ejemplo, las características del positivismo metodológico hacen que tanto un realista como un formalista quepan dentro de dicha definición, porque ambos tienden a demarcar con precisión el derecho como hecho del derecho como valor; la diferencia radicaría en qué entiende cada uno de ellos por «hecho» y por «valor». En suma, creo que la tripartición de BOBBIO no sirve para abrazar las teorías realmente existentes, que genera equívocos y que no resulta clarificadora para entender divisiones significativas dentro del paradigma positivista.

El segundo reproche que se le podría hacer a esta clasificación tiene que ver con la cuestión de la ideología. El tema de la ideología es uno de los más espinosos de la filosofía y las ciencias sociales, pero también uno de los campos de debate más interesantes que hoy existen en el mundo de las ideas. Hay muchas definiciones de ideología, desde las que tienen un cariz fundamentalmente epistemológico, en la estela de la doctrina de los idola de Francis BACON o de aquellos que Napoleón denominó con desprecio «ideologues», hasta las que se ubican con más decisión en el terreno filosófico-político (LENK, 2000: 9-46). Ambas dimensiones, no obstante, están entretejidas en la mayoría de las teorías contemporáneas. Tanto la noción de paradigma científico de KuHN, como la idea de episteme de Foucault (WEINERT, 1982), tanto el concepto de inconsciente de FrEUD como el sentido de lo fantasmático en ŽižEK (ŽIŽEK, 1992) —entre otros ejemplos- son reverberaciones de la cuestión de la ideología. Pese al tradicional aislamiento de la cultura jurídica, estas reverberaciones también han alcanzado a la filosofía del derecho, donde este asunto ha tenido episodios notables. El realismo

\footnotetext{
bargo, sabemos que PLATÓN deformó pro domo sua las ideas de los sofistas y los filósofos presocráticos, por lo que su interpretación de TRASíMACO no resulta del todo fiable (MENZEL, 1922). El otro ejemplo de positivismo ideológico aducido por BOBBIO es HoBBES. Este caso es más escurridizo, pero tampoco me parece adecuado considerarlo como positivista. De hecho, a juicio de HoBBEs, el deber absoluto de obediencia al orden legal era un precepto del derecho natural. En consecuencia, el presunto positivismo ideológico que BoBBIO le achacaba no era sino una manifestación de su concepción iusnaturalista (MURPHY, 1995).

${ }^{2}$ Las ideas de la jurisprudencia de conceptos son variables en función de los autores y de la época. En lo que se refiere a la teoría de las fuentes, SAVIGNY sostenía que la primacía debía recaer en la doctrina como intérprete privilegiada de la costumbre. Más adelante, JHERING criticaría a SAVIGNY por haber minusvalorado el papel de la legislación, pero ese era ya el segundo JHERING (WILHELM, 1958). Respecto a la teoría de la coactividad, tampoco me parece que se acomode a la jurisprudencia de conceptos: la metafísica idealista de PUCHTA o el primer JHERING desembocaba en una visión de los conceptos como entidades productivas de normas jurídicas, con independencia del apoyo que estas recibieran de la autoridad (JHERING, 2013: 234-275).
} 
jurídico escandinavo, por ejemplo, desplegó una crítica demoledora a la naturaleza ideológica de numerosas instituciones del derecho occidental —el derecho subjetivo, la autonomía de la voluntad, el deber jurídico, etc.- con base en una aproximación epistemológica que hunde sus raíces en el pensamiento de Axel HÄGERSTROM (HIERRO, 2008). La teoría jurídica soviética, por su parte, desarrolló un sólido acercamiento político a la cuestión de la ideología, pero no solo denunciando el contenido burgués de las normas — esta es la óptica de Piotr STUčKA—, sino también poniendo al descubierto el sesgo ideológico de las formas jurídicas, de los conceptos, las clasificaciones o las construcciones dogmáticas pretendidamente generales: este era el objetivo de Eugeni PAŠUKANIS (PAŠUKANIS, 1976). También los Critical Legal Studies pusieron sobre la mesa el tema de la ideología, haciendo hincapié en la construcción clasista, racial o patriarcal del derecho, y desvelando el trasfondo conservador de las teorías jurídicas tradicionales (PÉREZ LLEDÓ, 1996). Toda esta problemática es fundamental en relación con el iuspositivismo, pues se trata de una corriente que ha evolucionado conforme a las derivas ideológicas de los últimos dos siglos. En particular, me parece imprescindible incorporar la mirada epistemológico-política para desenmascarar los sesgos implícitos de la filosofía positivista o el currículum oculto que esta ha contribuido a imponer inconscientemente en la enseñanza de la teoría del derecho (LLOREDO, 2015: 209-227). Sin embargo, la noción bobbiana del positivismo ideológico ignora por completo este acercamiento a la cuestión de la ideología y, en ese sentido, emborrona y empobrece un debate que debería afrontarse con mayor profundidad.

Ahora bien, la de BOBBIO es solo una de las tentativas que se han sugerido para intentar poner orden en la miríada de significaciones que se asocian al positivismo jurídico. Probablemente, la propuesta de HART sea la más difundida en la filosofía del derecho contemporánea. Según el filósofo inglés, el iuspositivismo incorpora tres tesis básicas que todo autor debería mantener para ser considerado como un representante legítimo del paradigma: la tesis de las fuentes sociales, la tesis de la separabilidad entre derecho y moral y la tesis de la discrecionalidad judicial (HART, 1990). La primera afirma que las fuentes del derecho no son de naturaleza ideal, y que el sustento de la validez de las normas jurídicas puede identificarse en un hecho social: el legislador, el juez o, en general, una convención social. La segunda afirma que derecho y moral son órdenes conceptualmente separables, puesto que la validez jurídica no depende de la satisfacción de un determinado estándar de moralidad, sino de su conformidad con una regla de reconocimiento que, en última instancia, reenvía a la mencionada convención. La tercera, en fin, sostiene que los jueces tienen un determinado margen de discrecionalidad a la hora de decidir sobre los casos denominados difíciles. De acuerdo con HART, cualquier teoría positivista debería estar comprometida con estas tres tesis para poder ser concebida como tal. De hecho, fueron estas ideas las que DwORKIN eligió como blanco de sus ataques contra el paradigma iuspositivista en su conjunto.

La popularidad de esta aproximación al asunto del positivismo es enorme. Sin embargo, creo que volvemos a estar ante una definición discutible, sobre todo en lo que atañe a la tesis de la discrecionalidad. En efecto, si bien es cierto que las principales teorías positivistas del siglo XX se acomodan sin aprietos a la horma propuesta por HART, no sucede lo mismo con el iuspositivismo decimonónico. Tanto la escuela de la exégesis como la jurisprudencia de conceptos habrían rechazado dicha tesis, porque ambas mantuvieron una concepción cerrada del sistema jurídico, a saber: la idea de 
un ordenamiento pleno y coherente, que se integra a sí mismo sin necesidad de recurrir a intromisiones extrajurídicas y que prevé una única respuesta correcta para cada situación (LOSANO, 2002: 167 y ss.). En el caso de la escuela de la exégesis, esto era una consecuencia del espíritu cesarista con que se impuso el código napoleónico, cuyo propósito político era erigir un derecho pretendidamente infalible. Para ello se promocionó una ciencia jurídica basada en el comentario literal del código y la interpretación estrictamente silogística de sus disposiciones. En línea con tales pretensiones, se eliminaron también los estudios filosóficos e históricos de las facultades de derecho (FAssò, 2006: 17-21). En el caso de la jurisprudencia de conceptos, el resultado al que arribaron fue similar, aunque partiendo de presupuestos filosóficos distintos. De lo que se trataba era de construir una ciencia jurídica tan sofisticada que ni siquiera fuese necesario el legislador, merced a la identificación de una serie de supra-conceptos jurídicos obtenidos mediante inducción a partir de las prescripciones inferiores del derecho vigente. Estos supra-conceptos permitirían deducir nuevas normas para resolver cualquier desafío imaginable. El sistema así configurado quedaba estructurado a través de una férrea trabazón lógico-deductiva, de modo que era impensable la existencia de lagunas, antinomias o discrepancias interpretativas. La discrecionalidad, por tanto, tampoco cabía en los esquemas de la jurisprudencia de conceptos. Así las cosas, resulta que dos de las variantes más señeras del positivismo decimonónico quedan fuera de la definición de HART. Esto plantea una aporía frente a la que solo se me ocurren tres posibles salidas, todas ellas insatisfactorias.

La primera posibilidad consistiría en rebajar las exigencias establecidas por HART y descartar la característica de la discrecionalidad judicial como definitoria del positivismo. Esto nos llevaría a una concepción mínima del paradigma, que quedaría identificado por la tesis de la separabilidad entre derecho y moral y por la teoría de las fuentes sociales. Pero esto sigue siendo problemático porque, para empezar, es dudoso que las teorías positivistas del siglo XIX tuvieran una visión tan estricta de la separación entre lo ético y lo jurídico. Al menos en el caso de la escuela alemana, el estatus de los conceptos jurídicos resultaba muy ambivalente: estos eran obtenidos mediante inferencia a partir de las prescripciones particulares del ordenamiento - es decir, arrancando del derecho positivo- pero terminaban quintaesenciándose en entidades conceptuales de naturaleza ética que poseían validez con independencia del derecho vigente (R. DREIER, 1993). Podríamos entonces prescindir del rasgo de la separabilidad, pero entonces llegaríamos a una definición aún más raquítica del positivismo, según la cual positivistas serían todas aquellas teorías que reconozcan el origen «social» del derecho. Existen varias formas de entender el significado de «fuentes sociales»y, como ha mostrado Juan Carlos BAYÓN, no se trata en absoluto de una idea trivial (BAYÓN, 2002). Sin embargo, es una tesis que apenas dice nada y que, por tanto, condena al iuspositivismo a la irrelevancia teórica (ATIENZA y RUIZ MANERO, 2007: 21).

La segunda posibilidad consistiría en restringir las tesis de HART al positivismo jurídico del siglo XX, pero esta tampoco me parece una salida airosa. Primero, porque ello nos obligaría a trazar una diferencia entre un positivismo «en sentido pleno» y uno «primitivo», con lo que incurriríamos en el clásico prejuicio de ver la historia como un proceso tendente siempre a mayores grados de depuración. Además, si tenemos en cuenta que Luigi FERRAJOLI ya ha apostado por distinguir entre un positivismo constitucionalista y un «paleo-positivismo» del Estado legislativo de derecho 
(FERRAJOLI, 2011: 16), creo que una diferenciación ulterior no haría sino arrojar mayor confusión a un debate por sí mismo enrevesado. Por otra parte, discriminar entre un positivismo del siglo XIX y otro del XX levantaría una frontera artificiosa sobre la base de las cuestiones de la separabilidad y la discrecionalidad judicial, encubriendo lazos de continuidad fundamentales y estableciendo barreras que en realidad son enormemente porosas. Pensemos, por ejemplo, en cómo las ideas del segundo JHERING se encuentran desarrolladas en los diversos antiformalismos del siglo XX, entre ellos el realismo jurídico. Por último, una compartimentación semejante traería problemas a la hora de clasificar a la jurisprudencia analítica inglesa, que sí defendió la separación entre derecho y moral y que, en consecuencia, tiene una prolongación evidente en los positivismos del siglo XX. Desde luego, se puede optar por una definición estipulativa, restringiendo el positivismo a sus modalidades contemporáneas y a la jurisprudencia analítica, pero esto tiene un sesgo anglosajón que conllevaría dejar fuera a corrientes que siempre fueron concebidas como positivistas en la cultura continental.

La tercera posibilidad consistiría en dictaminar el carácter espurio de algunas teorías que solo serían positivistas en apariencia, ya que en realidad incorporan un planteamiento metafísico idealista. Esta estrategia ha sido utilizada por muchos autores para sostener que la escuela histórica no fue sino un epígono del iusnaturalismo: NINO, por ejemplo, llegó a hablar de iusnaturalismo historicista (NINO, 2003: 29). No obstante, creo que esta apreciación se asienta en varios equívocos. El primero es que los conceptualistas alemanes no se propusieron la tarea de edificar un catálogo de conceptos jurídicos universales, válidos para todo tiempo y lugar, sino que aspiraron más bien al momento de la generalidad, es decir, a diseñar un elenco de nociones jurídicas básicas para un sistema jurídico determinado (FALZEA, 1992: 62 y ss.). En la traducción española de El sistema de derecho romano de SAVIGNY, auspiciada por un iusnaturalista como Manuel DURÁN Y BAS, se comete a menudo el error de traducir «general» por «universal», lo que probablemente haya contribuido a generar dicha confusión (LLOREDO, 2014: 257-258). El segundo equívoco tiene que ver con el modo en que se obtienen dichas nociones. Para la escuela histórica se trata de una tarea artificial: los conceptos no se descubren y la ciencia jurídica no procede deductivamente desde arriba hacia abajo, como en la tradición del derecho natural, sino que estos se construyen mediante operaciones de inducción escalonada. El tercer equívoco tiene que ver con la supuesta equivalencia entre la idea de «espíritu del pueblo» y las típicas instancias trascendentales que el iusnaturalismo identificaba como fuentes del derecho. Se trata de un error, porque SAVIGNY no empleó la expresión «espíritu del pueblo» de la forma en que se le achaca: solo la encontramos en su obra a partir de 1840 —antes solía usar las locuciones de «convicción común» o «conciencia común» del pueblo (SAVIGNY, 1814: 8; CONTRERAS, 2005: 72) —, y nunca lo hizo con la pretensión de designar a una especie de agente que dictaba el contenido del derecho a modo de deidad, sino con ánimo metafórico.

En suma, ninguna de estas alternativas me parece convincente para soslayar las aporías a las que nos abocaba el enfoque de HART. Al igual que en el caso de BOBBIO, el propósito de encontrar una serie de tesis definitorias del positivismo se ve condenado al fracaso, ya que ninguna consigue reducir a una unidad coherente y precisa la multiplicidad de posiciones que se han desplegado en los dos últimos siglos. Por eso, como se proponía en la introducción, considero imprescindible recurrir a una mirada 
historicista que explique las características de este paradigma en clave evolutiva, en la línea de los clásicos trabajos de Felipe GonZález VicÉn (GONZÁlez VicÉN, 1979; 1984). A continuación optaré por este tipo de aproximación, con el objetivo de resaltar las sucesivas crisis experimentadas por dicha corriente.

\section{CRISIS Y REINVENCIONES DEL IUSPOSITIVISMO: UNA APROXIMACIÓN COMPREHENSIVA E HISTORICISTA}

La historia del positivismo es un reguero de disputas, impugnaciones, caídas y reconstrucciones. A continuación pretendo mostrar que, desde el mismo inicio del siglo XIX, se ha diagnosticado la obsolescencia del positivismo y se ha pronosticado su inmediata superación. A veces estas acusaciones se han producido desde plataformas que han pretendido situarse fuera de la órbita del paradigma, aun cuando hoy las percibimos como manifestaciones consustanciales del mismo. Otras veces, en cambio, las críticas se han elevado desde el mismo interior del positivismo jurídico, por parte de autores o corrientes que han reprochado a sus predecesores el no ser suficientemente positivistas o el ser prolongaciones encubiertas del iusnaturalismo. Tendríamos, entonces, una larga retahíla de críticas desde dentro y desde fuera del paradigma. Lo interesante es que, en todos los casos, el positivismo logró rehabilitarse mediante una sorprendente capacidad de adaptación. No en vano, Horst DREIER ha sostenido que, al igual que se suele decir del iusnaturalismo, podría hablarse de un «eterno retorno del positivismo» (H. DREIER, 2007).

El primer embate externo contra el positivismo lo encontramos indirectamente en el propio SAVIGNY, que desplegó una crítica demoledora contra el legalismo francés en su célebre escrito de 1814, De la vocación de nuestro siglo para la legislación y la ciencia jurídica. Pese a que SAVIGNY no utilizaba la locución «iuspositivismo», en su escrito existen múltiples alusiones al peligro de reducir la ciencia jurídica al derecho positivo de impronta legislativa, ya que, a su juicio, el origen de las normas jurídicas se encontraba en el sentimiento y la historia de los pueblos (SAVIGNY, 1814: 8-17): de ahí su crítica contra el Code de Napoleón y contra la propuesta de codificación para Alemania. Años atrás, en los trabajos preparatorios de su Metodología jurídica, SAVIGNY también había descargado su ira contra el formalismo, refiriéndose con ello a las teorías que pretendían construir la ciencia jurídica sin apoyarse en la historia del derecho y que, por ende, configuraban un sistema cuya realidad era «puramente formal o lógica» (SAVIGNY, 1993: 101). Tanto el antilegalismo como el antiformalismo deben entenderse como pilares del proyecto filosófico de SAVIGNY, que consistía en ofrecer una suerte de tercera vía frente al iusnaturalismo racionalista del siglo XVIII y frente al positivismo ramplón de los primeros compases del siglo XIX. Esto se confirma cuando leemos un célebre discurso pronunciado por Otto VON GIERKE en 1882, en el que presentaba a la escuela histórica como alternativa frente al «positivismo obtuso» y frente al «apriorismo» del derecho natural (GIERKE, 1883: 11). Hoy solemos considerar a SAVIGNY como representante del positivismo jurídico, dado que su escuela fue responsable de introducir la idea de la historicidad del derecho en la conciencia jurídica occidental. Sin embargo, esto no se veía así a principios y mediados del siglo XIX, y menos en Alemania, donde no es extraño encontrar a SAVIGNY catalogado dentro de la doctrina 
de la «naturaleza de las cosas». Así lo interpretó Gustav RADBRUCH en pleno siglo XX (RADBRUCH, 1960; FOLJANTY, 2013: 196 y ss.).

El tópico de la tercera vía es una constante en la historia que nos ocupa. Este es el caso del realismo jurídico, especialmente el escandinavo, que también se planteó como una forma de superar la dicotomía entre iusnaturalismo y positivismo. Podemos apreciarlo en el pensamiento de Karl OliveCronA, para quien la disyuntiva fundamental era otra: la que enfrentaba al realismo con el idealismo. De acuerdo con esta nueva bipartición, tanto las teorías del derecho natural como las concepciones positivistas debían ser agrupadas dentro del idealismo. En efecto, en opinión de OliveCrOnA, el positivismo surgió con la aspiración de demoler las falsas especulaciones del derecho natural, pero terminó incurriendo en posiciones igualmente metafísicas. Y ello por dos razones. Por un lado, porque una de las orientaciones más características que asumió el positivismo, la teoría general del derecho, cayó en el viejo anhelo iusnaturalista de buscar un breviario de principios jurídicos universales. Con ello, a su juicio, el positivismo se deslizó inconscientemente hacia el idealismo. Por otro lado, porque los positivistas trataron de reducir el derecho al Estado o, en casos más sofisticados, a la voluntad de una autoridad efectivamente hegemónica en una comunidad dada. Pero eso, pensaba OLIVECRONA, implicaba quintaesenciar la noción de autoridad, cayendo en una especie de esencialismo de la voluntad, como si hubiera un poder preexistente a toda relación político-jurídica. A juicio del pensador sueco, la única respuesta realista al problema de la existencia del derecho pasaba por concebir a este como un fenómeno que se alza sobre un «conjunto de regularidades psicológicas» o «de hechos sociales», y no como el fruto de una voluntad exterior que sostiene la eficacia del derecho desde fuera del derecho (OliveCronA, 2013: 248-263). La cuestión de si el realismo es o no una manifestación del positivismo es ciertamente problemática en la literatura especializada. Acabamos de ver que, para muchos de sus representantes, el realismo jurídico era una manera de esquivar la dualidad de las dos escuelas tradicionales. Sin embargo, para muchos iusfilósofos actuales no es sino una profundización de la crítica al derecho natural que ya había iniciado el positivismo decimonónico (GONZÁLEZ VICÉN, 1979: 190 y ss.). Nos volvemos a encontrar así con otro caso de impugnación externa del positivismo, que sin embargo hoy tendemos a percibir como ejemplo de evolución interna del paradigma.

A la vez que se desarrollaba el realismo jurídico, en diversas partes del mundo surgieron numerosos movimientos que solemos calificar con la etiqueta de antiformalistas. Me refiero a la jurisprudencia sociológica, a la escuela del derecho libre de los países germánicos, a la libre investigación científica de François GÉNY o al solidarismo de Duguit en Francia y, en general, a las teorías sociologistas que florecieron en las primeras décadas del siglo XX. Al igual que el realismo, muchas de estas corrientes nacieron con la voluntad de subvertir la disyuntiva entre iusnaturalismo y positivismo jurídico. Sin embargo, en algunos casos los exponentes de esta oleada se vieron a sí mismos como rehabilitadores del derecho natural. Un caso llamativo es el de Hermann KANTOROWICZ, buque insignia del movimiento del derecho libre, que trató de presentar a la nueva escuela como un resurgir del iusnaturalismo. A su modo de ver, la hornada de teóricos que, a inicios del siglo XX, estaban criticando el dogma del estatalismo de las fuentes del derecho, la concepción mecanicista de la interpretación judicial o el exceso de logicismo de la ciencia jurídica, se caracterizaba por una censura del legalis- 
mo y por una correlativa resurrección de la aproximación ética al fenómeno jurídico, cosa que él equiparaba a las teorías del derecho natural. En realidad, KANTOROWICZ estaba agrupando bajo un mismo paraguas a autores muy dispares: tardo-iusnaturalistas como Rudolf STAMMLER, pioneros de la sociología jurídica como Eugen EHRLICH, partidarios de la jurisprudencia de intereses como Max RüMELIN y exponentes del derecho libre stricto sensu como Ernst STAMPE (KanTOROWICZ, 1906: 10-12). Pero se trata de una mezcolanza injustificada (RÜCKERT, 2011) que poco tiene que ver con un rebrote del derecho natural. Obviando la incomodidad que la mayoría de estos autores habría sentido al verse catalogados de dicha manera, es que ni siquiera el pensamiento de KANTOROWICZ se deja alinear en una cosmovisión iusnaturalista: su objetivo no era restablecer la creencia en una serie de valores superiores al ordenamiento jurídico que determinan su validez, sino criticar la reducción del derecho al derecho estatal, promocionar un papel más creativo del juez y reconectar el derecho con la experiencia social. Todas estas son ideas que, como bien vio Guido FAssò, no deben entenderse como un renacimiento del derecho natural, sino como una tentativa de sociologizar el pensamiento jurídico, una operación característica de muchas concepciones de la primera mitad del siglo XX (FASSÒ, 2006: 199). He aquí, por tanto, otro caso de refutación pretendidamente externa del positivismo, que sería más prudente considerar como ejemplo de adaptación interna.

La mención de Rudolf STAMMLER es interesante, porque la siguiente parada de nuestro recorrido son aquellas teorías que pretendieron restaurar el credo iusnaturalista e impugnar las «unilateralidades» del positivismo jurídico en diversos momentos del siglo XX. Se trata de un tema complejo que no puede abordarse ahora con exhaustividad, pero me parece que deben hacerse al menos dos apreciaciones.

La primera es que, en realidad, las rehabilitaciones del iusnaturalismo del siglo XX no lo fueron en un sentido estricto. Es significativo que la mayoría de las apuestas que se dieron en esa línea adoptasen una estrategia formalista o procedimental, puesto que con ello renunciaban a la idea de un derecho natural supra-positivo, con contenidos sustanciales cognoscibles y vinculantes. Aquí se encuadra, por ejemplo, el proyecto filosófico de STAMMLER, que diseñó su teoría sobre la base del armazón epistemológico neokantiano, identificando un conjunto de «formas» jurídicas «universales» que debían presuponerse como «condición de posibilidad» del contenido de los ordenamientos vigentes. Ahora bien, esas formas jurídicas no eran más que eso, categorías conceptuales que, en su opinión, debían existir en cualquier experiencia jurídica imaginable, porque son un a priori de nuestra conciencia: objeto y sujeto de derecho, causa y relación jurídica, supremacía y subordinación, juridicidad y antijuridicidad. De la combinación de estas, a su vez, podía extraerse un catálogo aún más nutrido de conceptos jurídicos fundamentales: obligación, prestación, culpa, deber, daño, prohibición, validez, potestad, etc. (STAMMLER, 1911: 109 y ss.). Se trata de una estrategia que, como ha explicado Angelo FALZEA, se asemeja mucho a la que venían cultivando las teorías generales del derecho de cuño positivista (FALZEA, 1992: 57 y ss.). También en este apartado podría señalarse el caso de Lon L. FULLER que, con base en presupuestos diferentes, trató de resucitar al iusnaturalismo mediante una aproximación formal, es decir, desistiendo de postular un conjunto de contenidos «materiales» de derecho natural. En efecto, lo que FULLER denominó «moral interna del derecho» era el resultado de una serie de características procedimentales del derecho que, grosso 
modo, pueden reconducirse a la noción de seguridad jurídica. Esto hizo que muchos autores - entre ellos HART - percibieran como incorrecto calificar a tales elementos de morales, y que muchos positivistas estén de acuerdo con las tesis de FULLER, una vez que las desprendemos de su aura pretendidamente iusnaturalista (EsCUDERO, 2002). En resumidas cuentas, las recuperaciones del derecho natural en clave formal o procedimental no son más que retornos espurios del iusnaturalismo y se dejan aprehender mucho mejor como manifestaciones del paradigma iuspositivista en sentido amplio (GONZÁLEZ VICÉN, 1979: 134-140).

La segunda apreciación que cabe hacer respecto a la resurrección del derecho natural en el siglo XX se refiere a otras propuestas que sí intentaron transitar por la vía iusnaturalista clásica, es decir, que afirmaron la existencia de valores materiales superiores a los ordenamientos jurídico-positivos, ante los que estos debían quedar subordinados. Se trata, en general, de todos aquellos autores que se aferraron a la existencia del derecho natural después de la Segunda Guerra Mundial, como reacción desesperada ante el horror o a modo de antídoto contra una posible reedición de la barbarie nazi. El caso paradigmático es el del segundo RADBRUCH, que llegó a hablar de un «derecho supralegal» (RADBRUCH, 1946). Pero también aquí se encierran varios equívocos. En primer lugar, se trata de una postura que no tuvo una continuidad significativa en la segunda mitad del siglo XX: pasado el estupor de la inmediata posguerra, las posiciones críticas con el positivismo adoptaron otras formas de impugnación menos rotundas, en el entendido de que afirmar la existencia de valores de derecho natural por encima del derecho positivo era más bien una suerte de fideísmo que una posibilidad científica razonable. Desde este punto de vista, podría afirmarse que las teorías del derecho natural de la edad contemporánea son algo así como «frutos fuera de temporada» (BOBBIO, 1989: 377) o «plantas exóticas» (GONZÁLEZ VICÉN, 1986: 324). En segundo lugar, las teorías del derecho natural de posguerra deben entenderse más como un grito éticopolítico que como un verdadero proyecto iusfilosófico. De lo que se trataba era de rehabilitar la profesión del jurista, que había quedado en entredicho tras la divulgación del ignominioso papel que jueces y abogados habían desempeñado en la administración del Tercer Reich. En ese contexto, el recurso al derecho natural hizo las veces de aparato propagandístico para defender el valor de la ética profesional y redignificar un estamento profundamente desacreditado (FOLJANTY, 2013: 298 y ss.).

La que sí ha tenido un eco perdurable es la última de las impugnaciones externas que me gustaría traer a colación: la ofensiva «postpositivista» orquestada en torno a la crítica que DwORKIN realizó a la teoría de HART. Los términos del debate son sobradamente conocidos y sería improcedente entrar en todos sus pormenores. Pero sí me parece necesario destacar dos aspectos relevantes para la presente argumentación. El primero es que el ataque inaugurado por DWORKIN, más tarde proseguido por ALEXY y toda la oleada (neo) constitucionalista, arrancaba del propio derecho positivo. En efecto, el andamiaje sobre el que se asientan todos ellos depende de la constatación —más bien la postulación- de que el derecho positivo tiene una complejidad mayor de la que suponía HART. Según esta propuesta, existiría un tipo de normas, los principios, caracterizados por una densidad moral superior a la de las reglas, lo cual violentaría la pulcra delimitación entre lo ético y lo jurídico que el positivismo había trazado con tesón. Pero creo que la estrategia principialista resulta problemática como ariete para desarbolar al iuspositivismo en su conjunto. En particular, me parece que la jurispru- 
dencia de conceptos se asemeja mucho a la visión del derecho como integridad que propone DWORKIN, y que la naturaleza ambiguamente ética de los conceptos jurídicos en la doctrina de SAVIGNY es muy similar al carácter moral que hoy se suele adjudicar a los principios (GARCÍA AMADO, 2012). Dicho de otro modo, el enfoque dworkiniano serviría para rechazar el iuspositivismo en la versión desarrollada por HART, pero no necesariamente ha de verse como un ataque al paradigma en su totalidad. Además, resulta revelador que la crítica de DwORKIN partiera de una complejización del concepto de derecho positivo, ya que nos coloca ante un planteamiento presuntamente antipositivista que, no obstante, se eleva sobre uno de los legados más firmes de la corriente criticada: la irrenunciable positividad e historicidad del derecho. Esto me lleva a pensar que, si de veras estamos ante una disolución del positivismo, se trata de una disolución mucho menos tajante de lo que suele afirmarse.

El segundo aspecto al que aludía tiene que ver con la forma en que se está empezando a releer la historia de la filosofía jurídica de los últimos dos siglos. Me refiero a la noción de pragmatismo de Manuel ATIENZA, que él atribuye a autores como Ronald DWORKIN y Robert ALEXY, pero que retrotrae a juristas del siglo XIX o principios del XX como Holmes o JHERING (ATIENZA, 2013: 806 y ss.). Se trata de una reconstrucción del pasado interesante, que busca trazar una línea de continuidad entre los enfoques postpositivistas y algunas personalidades del antiformalismo clásico, pero que suscita muchos inconvenientes. Para empezar, el uso de la etiqueta «pragmatismo» resulta discutible, porque pragmatistas en el sentido de ATIENZA serían casi todos los autores y las escuelas positivistas que se han desplegado desde el siglo XIX hasta la fecha. Incluso la jurisprudencia de conceptos se constituyó con una clara vocación política, que consistía en adaptar el viejo derecho romano a las necesidades de la revolución industrial, pero controlando el proceso de cambio desde las élites académicas, y evitando así la democratización que implicaba entregar la batuta del cambio social a un legislador secundado por la legitimidad parlamentaria. Lo que el primer JHERING denominaba ciencia jurídica «productiva» (JHERING, 2013: 251 y ss.) es una manifestación de ese «pragmatismo» que aspira a una ciencia del derecho destinada a solucionar problemas y no a la mera especulación abstracta. Además, la genealogía propuesta por ATIENZA conduce a una paradoja difícil de sortear: si JHERING y HOLMES son exponentes de una tradición pragmatista que desemboca en el postpositivismo, ¿en qué medida pueden seguir siendo considerados positivistas? ¿Se trataría de postpositivistas avant la lettre? $\mathrm{Y}$ en caso de que no lleguemos a afirmar tanto: ¿qué justifica que hablemos de antiformalismo positivista para referirnos a JHERING o HOLMES, mientras que hablamos de antiformalismo postpositivista para aludir a DwORKIN? Creo que al final nos veríamos forzados a reconocer que esta pretendida superación del positivismo no es sino una vuelta de tuerca más en el zozobrante recorrido de este paradigma. Así lo percibió GonZÁLEZ VicÉn cuando ATIENZA y RUIZ MANERo le preguntaron acerca de DworKIN y la extinción del iuspositivismo (GONZÁLEZ VICÉN, 1986: 322-325).

Hasta aquí se ha hecho un repaso de las múltiples críticas externas que ha recibido el positivismo jurídico desde sus inicios, sugiriendo que sería más sensato percibir tales ataques como evoluciones de una corriente heterogénea, en la que caben alternativas teóricas diversas. Pero las cosas son aún más llamativas, puesto que también se han producido numerosas invectivas desde dentro. El primer episodio que he podido encontrar se encuentra en JHERING, que en 1868 pronunció una conferencia en la 
que caracterizó al positivismo como «enemigo mortal de la ciencia jurídica» (JHERING, 1998: 55). En realidad, el jurista alemán estaba pensando en la variante legalista y en el logicismo exacerbado de la jurisprudencia de conceptos. Pero resulta curioso que un autor hoy percibido como arquetipo del positivismo se expresase en esos términos tan contundentes. Más sorprendente aún es el hecho de que, medio siglo más tarde, otro de los representantes típicos del paradigma, KELSEN, se refiriese a JHERING como un remedo enmascarado del iusnaturalismo. En opinión de austriaco, su colega alemán había incurrido en la tentación de incluir un elemento material en su teoría del derecho subjetivo: la idea del interés jurídicamente protegido era para KELSEN un vestigio del derecho natural porque, al tratar de dar una definición de los derechos subjetivos, JHERING no se contentó con señalar sus características formales, sino que introdujo un contenido sustancial, el interés, que inmediatamente reenviaba el problema a consideraciones morales (KELSEN, 1984: 567-618). Las cosas pueden seguir complicándose, porque el mismo KELSEN fue después censurado por Ross por haber erigido una teoría que únicamente podía considerarse «cuasi-positivista» (Ross, 1994: 375 y ss.), una opinión derivada del enfoque naturalista del realismo, según el cual solo una metodología empirista podía ostentar el apelativo de positivista. El último ejemplo de esta batalla interna lo encontramos en la polémica que hoy enfrenta al positivismo incluyente con el excluyente. Al igual que en los casos anteriores, los positivistas excluyentes censuran a sus colegas incluyentes por no ser suficientemente positivistas o, incluso, por tropezar de nuevo en las redes del iusnaturalismo.

Si los ejemplos que he esgrimido hasta ahora son adecuados, me parece evidente que no cabe hablar de la crisis del positivismo como un proceso reciente. Al contrario, podemos afirmar que el paradigma lleva en crisis dos siglos. Son muchos los embates recibidos por parte de oponentes que en su momento pretendieron superar los planteamientos positivistas, y son muchas las diatribas internas que, desde dentro del paradigma, se produjeron en aras de una concepción más «pura» o «auténtica» del positivismo. Teniendo en cuenta todo esto, creo que sería más prudente hablar de una evolución permanente de la concepción positivista, que ha ido adaptándose a los desafíos de cada momento histórico, y que ha ido perfilándose en versiones aparentemente enfrentadas, pero enraizadas en un mismo suelo y dependientes de unos mismos presupuestos. La clave, entonces, estaría en discriminar cuál es ese suelo y cuáles son los cambios históricos que han movido al positivismo a evolucionar en uno u otro sentido. Para responder a esta pregunta, me temo que la única salida es adoptar una perspectiva ideológica, parcialmente coincidente con la de SCARPELLI, y comprender el positivismo como un paradigma que ha ido forjándose como reflejo de las transformaciones del Estado en la Edad contemporánea. Desarrollaré esta idea en el siguiente epígrafe.

\section{LA TRASTIENDA DEL POSITIVISMO JURÍDICO. UN ANÁLISIS IDEOLÓGICO DE LA EVOLUCIÓN DEL PARADIGMA}

Hasta ahora he procedido de la siguiente forma: en primer lugar se rechazó la aproximación conceptual al positivismo, dado que ninguna de las propuestas al uso servía para aprehender en toda su complejidad las múltiples variantes del paradigma; en segundo lugar se procedió a un acercamiento historicista, con el ánimo de incluir en 
una misma horma al positivismo decimonónico y al contemporáneo. El problema de la aproximación conceptual es que circunscribe con tanta precisión el ámbito de lo que debe considerarse positivista, que muchas teorías tradicionalmente concebidas como tales se quedan fuera del mapa. El problema de la aproximación historicista es que, salvada la dificultad anterior, ofrece una visión poco informativa: positivista es toda teoría que entiende el derecho como un producto humano, firmemente enraizado en la historia y dependiente de esta.

La pregunta ahora es: ¿más allá de esta débil afinidad epistemológica, que nos reenvía al hecho sociocultural de la secularización, existe algún rasgo que nos permita identificar el núcleo del positivismo, y que a la vez nos suministre alguna información relevante para comprender su evolución? Aquí es donde se ubica la aportación de SCARPELLI, que me sigue pareciendo la más certera para abordar este problema. De acuerdo con el italiano, hay tres tipos de definiciones, las lexicales, las estipulativas y las explicativas (SCARPELLI, 1997: 52-55). Las primeras tratan de abarcar todos los usos del concepto que se dan en el lenguaje; las segundas tratan de cortar el nudo gordiano estableciendo una definición prescriptiva, pese a que ello implique dejar fuera algunos empleos del concepto que se quiere delimitar; las terceras se sitúan en un terreno intermedio, ya que le dan importancia a la base empírica, pero tratan de buscar un núcleo común que proporcione claves explicativas para comprender el fenómeno. Casándose con esta última perspectiva, SCARPELLI propuso abandonar el enfoque puramente epistemológico y adoptar una mirada política para abordar la cuestión del positivismo. La posición de SCARPELLI es compleja y rica en matices, pero aquí solo me quedaré con uno de los elementos de su argumentación, a saber, el que hace depender el positivismo del Estado de derecho.

Antes de continuar, conviene aclarar que utilizo la expresión Estado de derecho en un sentido débil, asimilable a lo que se denomina Rechtstaat en la tradición alemana, es decir, ese periodo de desarrollo del Estado en el que este logró monopolizar la producción del derecho y empezó a utilizarlo como cauce fundamental de la acción política, que quedaba así sometida al yugo jurídico (COSTA, 2002: 111 y ss.). Se trata de un momento en el que el derecho adquirió un puesto de centralidad en la vida colectiva que anteriormente había sido ocupado por otras esferas de regulación como la religión o la costumbre, y que corrió parejo con un auge formidable de la profesión del jurista, reconvertido en peón al servicio del Estado y en agente principal de la política. Este protagonismo de los juristas dio pie a que el francés Édouard LABOULAYE se mostrase irónico respecto al papel que desempeñaban sus colegas en la vida pública: «unos cuantos abogados son la sal de una Asamblea; pero que se componga de ellos en sus tres cuartas partes, francamente, es demasiado» (ORTEGA, 1989:319). Ese mismo puesto de centralidad del derecho es el que aparece descrito en buena parte de la obra de Max WEBER, y que en alguna ocasión definió como proceso de «burocratización universal» (WEBER, 2008: 112). Con ello se refería a un fenómeno generalizado de juridificación y funcionarización, que provocó el derrame del derecho del Estado en todos los intersticios de la vida social. Como se explicitará en las siguientes páginas, el iuspositivismo fue el correlato intelectual de esta transformación estructural de la política contemporánea.

Así visto, el problema del positivismo jurídico, con todas sus variantes, sus críticas, sus evoluciones, etc., adquiere una enorme nitidez. Incluso el surgimiento de la filoso- 
fía del derecho como disciplina, que GONZÁLEZ VICÉN databa a finales del siglo XVIII y principios del XIX (GONZÁLEZ VICÉN, 1979: 207-257) podría interpretarse desde ese enfoque: la filosofía del derecho sería una nueva rama de los estudios jurídicos que se instaló en la Academia y se configuró como una suerte de portavocía de las necesidades del Estado de derecho. Esta vinculación entre filosofía jurídica y iuspositivismo dio lugar a un modo de teorizar sobre el derecho que debía partir del ordenamiento positivo, no de elucubraciones metafísicas o religiosas, ni de planteamientos éticos extrínsecos, y es la que explica la célebre preferencia de BoBBiO por los juristas-filósofos frente a los filósofos-juristas (BOBBIO, 1977: 43-44). Al contrario de lo que probablemente pensaba el intelectual turinés, esta no era una predilección científica o metodológica, sino claramente política.

Lo que ocurre es que no existe un único modelo de Estado de derecho, ni el Estado se ha mantenido incólume desde el siglo XIX hasta la fecha. Por eso, tanto el positivismo como la filosofía del derecho han ido evolucionando de forma significativa a lo largo de los dos últimos siglos, lo cual justifica las polémicas, la logomaquia y las discrepancias internas ya vistas. A continuación trataré de ofrecer una interpretación de los virajes del paradigma en clave ideológica, tomando en consideración las escuelas que ya se mencionaron en el apartado precedente. Pero es necesaria una advertencia preliminar: esta reconstrucción historiográfica no pretende hacer una lectura política del positivismo en un sentido idéntico al de SCARPELLI o de otras teorías contemporáneas como la de Tom CAMPBELl (CAMPBELL, 2002), que han propuesto la idea de un positivismo ético, normativo o prescriptivo con el ánimo de defender las ventajas morales y políticas de adherirse a una concepción positivista. El punto de vista que aquí manejo es externo y, si se quiere, podría caracterizarse como una crítica de la ideología subyacente — casi siempre inconsciente - a las diversas formas que ha ido asumiendo el paradigma con el paso de las décadas.

La primera variante de positivismo que podemos contemplar es la legalista - positivismo súper estricto, en terminología de Walter Отт (Отт, 1992: 39 y ss.) —, que se asocia paradigmáticamente a la escuela de la exégesis francesa, pero que encontramos en muchos otros contextos. En general, se trata de un tipo de positivismo que fue de la mano con el Estado fuerte característico de principios del siglo XIX, es decir, con ese Estado que logró monopolizar plenamente el uso de la fuerza, que se dotó a sí mismo de un denso aparato burocrático y que pretendió ratificar su dominio mediante la teoría de la ley como única fuente de derecho. El ejemplo de la Francia napoleónica es claro, pero hay otros: la transformación de la escuela histórica del derecho, que a partir del segundo JHERING y de WINDSCHEID comenzó a minusvalorar la costumbre y a reivindicar el papel de la legislación, para llegar hasta el ultra-legalismo de Karl Bergbohm (BergBOHM, 1892: 454-456), se explica en el marco de la Alemania bismarckiana. Ahora bien, esta modalidad de positivismo no solo encontró apoyo en el marco de regímenes cesaristas o autoritarios. De hecho, también los movimientos democráticos que, desde mediados del siglo XIX, pugnaban por la universalización del sufragio, apostaron por esta clase de positivismo, mientras que las fuerzas conservadoras se aferraron a posicionamientos antiformalistas. Este último es el caso de Raymond SALEILLES, maestro de François GÉNY y padre intelectual del derecho comparado, que diferenciaba entre derecho y ley con la voluntad de reservar una esfera de influencia a las élites: por mucho que el parlamento haga la ley, son los juristas quienes se ocupan 
de interpretar, recortar, ampliar o reformar esta en función de criterios casi siempre inconfesables (ARAGONESES, 2009: 120 y ss.). Esto explica el éxito histórico del positivismo legalista, que logró concitar el apoyo de fuerzas aparentemente contradictorias — tanto por la izquierda como por la derecha— y que le procuró una vida más larga de lo esperable.

La siguiente modalidad de positivismo que cabe identificar es la escuela histórica del derecho, opuesta en muchos sentidos a la anterior. Sin embargo, desde el punto de vista ideológico existen lazos significativos entre ambas corrientes. Tanto la una como la otra diseñaron teorías fuertes del sistema jurídico, que concebían a este como un orden cerrado y autosuficiente, muy en la línea de las necesidades de un Estado que exigía para sí el monopolio en el control del derecho, y que no podía permitir fisuras e intromisiones. La diferencia más notable entre ambas direcciones estriba en el aparato filosófico subyacente, y que en el caso de la escuela alemana nos remite al romanticismo y al nacionalismo. De acuerdo con tales ideas, el derecho es el precipitado de la historia de los pueblos, se debe a un espíritu o convicción popular del que no puede prescindir, y se convierte así en un elemento cultural inextirpable de la nación, equiparable a otras manifestaciones de esta como la lengua o la literatura. No por casualidad Jakob GRIMM, el famoso recopilador de cuentos de la tradición germánica, fue discípulo aventajado de SAVIGNY. A él se debe, entre otras cosas, la analogía entre derecho y lengua que tanto usaron los miembros de la escuela histórica (WYSs, 1979). Lo que me interesa destacar ahora es que el positivismo historicista se convirtió en una plataforma inestimable como aparato justificativo del Estado-nación, es decir, de esa fórmula jurídico-política que se convirtió en hegemónica desde entonces hasta bien entrado el siglo XX, y que trata de establecer una ligazón orgánica entre el derecho y la identidad del pueblo. Esto hizo que, desde mediados del siglo XIX, SAVIGNY fuera recibido en España por la escuela jurídica catalana, que trató de parapetar su reivindicación del derecho foral tras las ideas de la corriente historicista (FIGUERAS, 1978), o que en el ámbito anglosajón sus ideas fueran acogidas por el abogado escocés John REDDIE, a modo de escudo contra las intromisiones «legislativas» de la corona inglesa (VOGENAUER, 2015). Hace no muchos años, por cierto, las ideas de SAVIGNY volvieron a ser esgrimidas en la península ibérica por José Ignacio LACASTA, en el marco del problema del nacionalismo vasco (LACASTA, 1998: 94-98).

La introducción del elemento historicista-nacionalista en el núcleo del positivismo generó muchísimas controversias desde el primer momento. En la misma época de SAVIGNY se produjo una sonada escisión de la escuela histórica entre los romanistas y los germanistas, pues estos entendían que la auténtica esencia nacional se encontraba en el antiguo derecho germánico, y no en las pandectas justinianeas que se dedicaban a comentar y reinterpretar los discípulos directos de SAVIGNY. Esta división desencadenó, a finales del siglo XIX, la aparición de un subparadigma pluralista dentro del iuspositivismo, que comenzaría a cosechar sus frutos en el contexto del problema de las nacionalidades de principios del siglo Xx. Un pionero de esta orientación fue Otto VON GIERKE — con su concepción de la comunidad como sujeto de derecho—, pero su promotor más destacado sería Eugen EHRLICH, nacido en una de las regiones más multiculturales del imperio austrohúngaro, la Bucovina, y conocedor de las dificultades derivadas de la coexistencia de diversas tradiciones, lenguas, religiones y experiencias jurídicas en un mismo Estado (ROBLEs MORCHÓN, 2002). De esta problemática se 
hicieron conscientes, en general, casi todas las variantes de antiformalismo sociológico de la primera mitad del siglo XX, que tendieron puentes directos entre derecho, sociedad y cultura, y que facilitaron la adaptación del positivismo a un contexto donde empezaba a hacerse visible la complejidad que se escondía bajo la apariencia de uniformidad de los Estados cristalizados a lo largo del siglo XIX. En este sentido, no es casual que uno de los representantes más destacados del realismo jurídico estadounidense, Karl LLEWELLYN, se asociara con el antropólogo Edward E. HOEBEL para confeccionar un libro acerca del derecho tradicional de los indios cheyennes: The Cheyenne Way (LLEWELLYN y HOEBEL, 1941).

Ahora bien, antes de que se produjera esta reorientación del positivismo, se desarrolló una de las variantes más exitosas del paradigma, y en un sentido ideológico muy distinto al anterior. Me refiero a la teoría general del derecho, tal y como esta fue propuesta por John Austin en Inglaterra. El objetivo de la General Jurisprudence fue responder al dilema que se le había presentado a la ciencia jurídica tras el derrumbe del iusnaturalismo: ¿cómo es posible erigir una ciencia en torno a un objeto tan mudable como el derecho? Si no existe un corpus de normas o principios fijos esperando a ser descubiertos y revelados, ¿qué papel le queda a los juristas científicos? Una de las respuestas que se le dio a este interrogante fue la brindada por la sociología y la antropología jurídicas: ante la irreductible heterogeneidad de experiencias jurídicas del globo, la única salida posible es sociologizar la ciencia del derecho, es decir, contentarse con el estudio y la exposición de las culturas jurídicas existentes, esbozando la trabazón que hay entre el derecho formal y la sociedad en la que este se proyecta, y analizando las brechas que se producen entre ambos niveles. También el derecho comparado en la versión de SALEILLES, con una óptica socio-antropológica y no como mera legislación comparada, sirvió como método para reinventar la investigación jurídica. Pero la otra gran respuesta a este dilema fue la teoría general del derecho, que se elevó sobre la base del siguiente supuesto: pese a que los ordenamientos jurídicos del mundo son tremendamente distintos, y pese a que el contenido del derecho cambia de forma irremediable - tanto en el tiempo como en el espacio- debe de baber algún rasgo formal o estructural compartido por cualquier cultura jurídica. A la búsqueda de dichas características formales es a la que se encaminó la teoría general del derecho (GONZÁLEZ VICÉN, 1981: 5-22).

Tomando como prisma la aproximación ideológica que estoy proponiendo aquí, me parece que la teoría general del derecho debería verse como la derivada que asumió el positivismo en el marco del Estado colonial e imperialista característico del siglo XIX, pero todavía activo en nuestros días. En efecto, si echamos un vistazo a los conceptos generales seleccionados por AUSTIN como presuntamente universales, veremos que se trata, en realidad, de nociones propias del derecho occidental: la distinción entre derecho objetivo y subjetivo, entre propiedad y posesión, entre derecho público y privado, entre objeto y sujeto de derecho, etc. (AUSTIN, 1981: 26 y ss.). Esa universalización de una experiencia particular sirvió para consagrar un canon de lo que puede y no puede concebirse como derecho y, por extensión, terminó generando demarcaciones entre culturas superiores e inferiores. Se trata de una tendencia que sigue vigente en la actualidad, aunque evidentemente bajo diferentes ropajes. Es el caso, por ejemplo, de Mauro BARBERIS, que en su Europa del diritto ha propuesto reservar la etiqueta «derecho» para aquellas culturas, como la occidental, que deslindan con claridad el ámbito jurídico del 
político o el religioso (BARBERIS, 2008). Pero es una conclusión que circula implícitamente incluso en aquellos textos legales más sensibles a la problemática del pluralismo jurídico: en las constituciones de Bolivia, Venezuela, Colombia o Ecuador se habla siempre de «usos y costumbres» $\mathrm{O}$ «tradiciones» para referirse al derecho propio de sus pueblos originarios. Solamente en la constitución mexicana se habla en un momento de los «sistemas normativos» de los pueblos indígenas, aunque en el resto del articulado se vuelve a recurrir a la expresión «usos y costumbres» ${ }^{3}$. Esta tendencia constitutivamente eurocéntrica de la teoría general del derecho ha sido denunciada por William TwINING, que desde hace años viene proclamando la necesidad de rebajar las aspiraciones de generalidad de la teoría del derecho, para hacerla más consciente de la heterogeneidad jurídica del mundo, máxime en la época de la globalización (Twining, 2009).

El último caso de evolución política del positivismo que me gustaría traer a colación tiene que ver con las tendencias sociológicas de la primera mitad del siglo Xx, de las que ya se ha hablado antes. Creo que hay buenas razones para interpretar el giro sociologizante del antiformalismo como una respuesta a la cuestión social que ya se puso de manifiesto en los últimos compases del siglo XIX. El propio JHERING, a quien muchas de estas corrientes vieron como pionero o inspirador, desarrolló su obra tardía con el propósito de acompasar a la ciencia jurídica con las necesidades derivadas de la industrialización, en una orientación teórica que él veía paralela al reformismo social emprendido por Bismarck en la década de los ochenta. Evidentemente, este correlato no debe verse de forma mecánica, ya que no existe en todos los autores, ni puede percibirse con la misma intensidad en todas las escuelas, pero creo que sí es útil establecer un paralelismo entre la socialización del derecho de la primera mitad del siglo XX —constitucionalismo social, génesis del derecho laboral, doctrina de la función social de la propiedad, teoría de la responsabilidad objetiva, etc.- y sociologización del pensamiento jurídico. Es significativo, por ejemplo, que varios representantes del realismo jurídico estadounidense desempeñaran cargos en la administración del New Deal diseñado por el presidente Roosevelt (HoRwITZ, 1992), o que las teorías solidaristas de Léon DUGUIT sirvieran como acicate para algunas políticas sociales que después se verían sistemáticamente consagradas en los Estados sociales de posguerra (LOSANO, 2011). En el mismo sentido - aunque esta vez en clave conservadora - estaría el caso de Philipp HECK, padre de la jurisprudencia de intereses, que estableció una ligazón entre su enfoque antiformalista y los requerimientos de la política social del régimen nacionalsocialista (HECK, 1936). En líneas generales, lo que tuvo lugar fue una adaptación del paradigma positivista a una realidad política compleja, en la que el Estado se estaba viendo asediado por nuevos poderes económicos y por las correspondientes reivindicaciones sociales que, ya desde principios del siglo XX, trataron de hacer sombra a la hegemonía que había ostentado durante la centuria anterior. Para ello, fue necesario abandonar las rigideces del formalismo decimonónico y diseñar una teoría más sensible a la problemática social.

Llegados a este punto, podría decirse que el positivismo ha asumido formas muy diversas y que, en líneas generales, hay una continuidad entre sus propuestas episte-

3 Vid. el art. 2 de la Constitución mexicana, el art. 191 de la Constitución ecuatoriana, los arts. 119 y 186 de la Constitución venezolana, el art. 130 de la Constitución colombiana y el art. 374 de la Constitución boliviana. 
mológicas y la evolución del Estado. Huelga decir que en la mayoría de las ocasiones se trata de una continuidad inconsciente, es decir, que no hay ningún proceso intencional subyacente. De ahí la relevancia del concepto de ideología en el sentido de cosmovisión, episteme o imaginario colectivo: el positivismo tiene ideología, desde luego, pero esta es mucho más compleja y entreverada de lo que daba a entender la clasificación de BoвBIO. Las crisis experimentadas desde principios del siglo XIX hasta la fecha se explican, entonces, como evoluciones internas del paradigma, que ha ido respondiendo a las transformaciones ideológicas del Estado en la Edad contemporánea. Por recapitular, podríamos concluir que el positivismo transitó de la variante legalista a la historicista en el contexto del Estado de derecho decimonónico y del desarrollo de los Estados nación. Posteriormente se desplegó la teoría general del derecho en todas sus manifestaciones - aquí me he referido a AUSTIN, pero también podría haber hablado de BIERLING o de MERKEL, entre otros-y el arco ciertamente heterogéneo de las corrientes pluralistas, en ambos casos como formas de adaptación a la realidad del Estado colonial, que a su vez era una derivada del Estado nación. En última instancia, me he referido a las variantes sociológicas del paradigma como un reflejo del Estado social. En el último apartado trataré de analizar someramente la situación actual y propondré una forma alternativa de comprender la presunta crisis del positivismo.

\section{LA CRÍTICA (NEO) CONSTITUCIONALISTA. ¿ESTAMOS HOY ANTE LA CRISIS DEFINITIVA?}

¿En qué situación nos hallamos ahora? Como se deriva de lo dicho hasta aquí, me parece extremadamente difícil hacer diagnósticos acerca del momento presente, y creo que la historia expuesta nos da motivos prudenciales para no incurrir en planteamientos categóricos. De algún modo, me sucede algo parecido a lo que se relata en la fábula del lobo y las ovejas: de tanto anunciar la crisis del positivismo, sin que esta haya llegado de manera definitiva, tiendo a desconfiar de las voces que hoy en día proclaman su superación. Sin embargo, también creo que nos encontramos en un momento de cambio indiscutible, que tiene que ver con las transformaciones copernicanas que la globalización está provocando en nuestra forma de comprender el derecho. No es el momento de entrar en un análisis pormenorizado de todos estos cambios, pero sí me parece necesario destacar que el denominador común de estas mutaciones es la erosión irrevocable de la autoridad del Estado y el surgimiento de un ordenamiento global en el que este ya no es el agente principal de la política. Fenómenos como la denominada lex mercatoria o el soft law - con todo lo ambiguo de estas expresiones (LAPORTA, 2007: 243 y ss.) - , el constitucionalismo multinivel, el estallido y visibilización del pluralismo jurídico o la profunda penetración del campo económico en la esfera política y jurídica son algunas de las manifestaciones de este fenómeno generalizado.

En parte, la filosofía jurídica ha reaccionado a este estado de cosas. En una primera fase, de entre las mismas filas del positivismo surgió la teoría del derecho internacional, con el viejo debate entre el monismo y el dualismo que enfrentó a KELSEN con las doctrinas de TRIEPEL o ANZILOTTI, y que pugnaba por dotar de juridicidad al derecho internacional, algo que había sido cuestionado en el siglo XIX por filósofos positivistas como John Austin (WALZ, 1930). Ahora bien, en una segunda fase, la teoría jurídica 
ha adquirido una consciencia mucho más profunda de la trascendencia de la globalización y, si se me permite el tropo, está transitando de la clásica teoría del derecho internacional a una teoría internacional del derecho. Con esto me refiero a una concepción del derecho que desborda los límites del Estado-nación y que se hace cargo de la irremediable degradación de la soberanía en el mundo contemporáneo, reivindicando una teoría jurídica menos «pura» y más cercana a la sociología, la antropología o el derecho comparado. Aquí podríamos incluir — cada una con sus peculiaridades - a la teoría del droit global de Benoît FRYDMAN (FRYDMAN, 2012), a la Global Jurisprudence de Twining (Twining, 2009), a las consideraciones filosófico-jurídicas del Imperio de HARDT y NEgRI (HARDT y NEGRI, 2005: 21-42) o, entre nosotros, a la teoría comunicacional del derecho de Gregorio RoBLES (ROBLES, 2007). Todas ellas apuestan por un paradigma pluralista — superador del rígido debate entre monismo y dualismo-y comparten la convicción de que la teoría jurídica no puede seguir obcecándose en encajar los conceptos fraguados al amparo del derecho estatal del siglo XIX en un contexto de relaciones globales que desbordan con creces dicho marco. En este sentido, la teoría del derecho debería hacerse cargo de la variedad de experiencias jurídicas que coexisten en el globo y, sobre todo, del mestizaje permanente que se produce entre todas ellas.

Creo que el giro ético promovido en la filosofía a partir de los años setenta del siglo XX, e implícitamente presente en las propuestas teóricas de DwORKIN o ALEXY, forma parte de este conjunto de transformaciones que vivimos, y que podrían interpretarse como un tránsito de la modernidad a la posmodernidad. El tema de la posmodernidad es por sí mismo complejo y genera virulentas adhesiones a favor y en contra. Aclaro desde el primer momento que estoy asumiendo la noción de posmodernidad como un descriptor de las mutaciones generalizadas que se han producido en todos los órdenes del saber a partir de los años setenta y que, en ese sentido, nos afecta a todos, incluso a aquellos que reniegan de ella. Por eso, como propone Boaventura DE SOUSA SANTOS, conviene diferenciar entre un posmodernismo celebratorio - conservadory un posmodernismo de oposición — progresista— (SANTOS, 2009: 29 y ss.). Se trata de un proceso cultural que no cabe explicar aquí con toda la exhaustividad deseable, pero que, en general, ha implicado una crisis radical de la noción de sujeto, tal y como esta se había forjado al calor de la modernidad. Hay que tener en cuenta que la teoría del sujeto fue uno de los ámbitos de reflexión filosófica más complejos y a la vez más representativos de la Edad moderna: desde el cogito ergo sum cartesiano, pasando por las doctrinas del self del empirismo anglosajón, hasta la idea de la alienación marxista, el mundo moderno elevó todos sus proyectos filosóficos sobre dicha noción, a veces de forma expresa y a veces de forma implícita. En efecto, por muy problematizada que estuviera, la idea de un sujeto estable es la piedra angular que explica el surgimiento de la biografía como género literario, el a priori de la conciencia en la epistemología kantiana, el método del psicoanálisis freudiano y hasta el solipsismo del primer WITTGENSTEIN, entre muchísimos otros ejemplos que podrían argüirse.

Es verdad que el concepto fue mutando en función de las épocas y las escuelas, pero en cualquiera de sus variantes se mantuvo una idea relativamente fija del sujeto (BRONCANO, 2013), como un pilar incuestionable sobre el que levantar cualquier entramado de proposiciones teóricas o de proyectos prácticos imaginables. Esta suerte de pacto metafísico tácito se plasmó políticamente en las teorías del pacto social y en el 
nacimiento correlativo de una mentalidad individualista que, a su vez, se transfirió al ámbito jurídico mediante la doctrina de los derechos subjetivos. Lo que me interesa destacar ahora es que el trasunto de esta lógica del sujeto en el plano colectivo fue la teoría de la soberanía, o sea, la concepción de un sujeto político autónomo e investido de autoridad que no reconoce superior. Es significativo que tanto la noción de autonomía como la de autoridad - ambas marcadas por el prefijo auto- sean definitorias de la soberanía, porque reenvían la cuestión a la idea del sí mismo, de la identidad. En definitiva, el problema de la soberanía no es sino el problema del sujeto en la órbita política y social. Tanto las teorías mecanicistas, características del siglo XVIII, como las doctrinas organicistas del siglo XIX, coinciden en una percepción del Estado como sujeto soberano: en el primer caso el Estado es un artefacto cultural que engrana las subjetividades individuales en una maquinaria política superior —el Estado como persona jurídica - mientras que en el segundo caso el Estado es un organismo natural que hipostasia las subjetividades individuales en un cuerpo político totalizador (STOLLEIS, 1992: 123-125). En ambos casos, no obstante, subyace la metafísica moderna del sujeto.

Esta equivalencia entre la doctrina del sujeto y la doctrina de la soberanía ya fue vista con acierto por Léon DUGUIT en su clásico Las transformaciones del derecho público de 1913, cuando apostó por abandonar ambas ideas como ejes del derecho público contemporáneo: a su modo de ver, se trataba de nociones obsoletas en el marco de los Estados industrializados, que deberían ser reemplazadas por el concepto de servicio público (Duguit, 1913: IX-XIX). Pese a que Duguit no llegó a conocer el brutal desgaste de la soberanía en el contexto de la globalización, es significativo que ya a principios del siglo XX se hiciera una observación semejante. Y es particularmente interesante para la presente argumentación, porque pone de relieve que ya en aquel entonces había comenzado a deteriorarse la soberanía tal y como esta fue definida en la época moderna. De hecho, como ha observado Ugo MATTEI, «la teoría y la praxis de la soberanía solo coincidieron en algunas raras hipótesis - geográficamente delimitadas - en las que un aparato estatal moderno fue capaz de dotarse de una burocracia, de una policía y de un sistema capilar de tribunales de justicia. Esto ocurrió en Europa solo en casos relativamente excepcionales y tardíos, como la Francia napoleónica, la Alemania bismarckiana o la Inglaterra victoriana» (MATTEI, 2013: 30). Desde esta perspectiva, la evolución del iuspositivismo analizada en los acápites anteriores podría verse como un intento desesperado por rezurcir la teoría a una realidad que poco a poco iba revelando la imposibilidad de mantener incólume el sueño estatal de la modernidad. La apreciación visionaria de DuguiT no fue sino uno de esos episodios de rehabilitación, que en su caso se enmarca bajo la rúbrica del positivismo sociológico.

Con todo, es solo en la posmodernidad cuando este proceso ha llegado a umbrales verdaderamente palpables y las concepciones tradicionales han estallado por los aires. La reflexión filosófica se ha dedicado a tematizar la crisis del sujeto a través de múltiples estrategias, que a menudo se han centrado en observar la aparición de identidades fragmentarias, móviles, fluidas, o bien en el rechazo de las dicotomías que habían servido para apuntalar la noción fija del sujeto en la modernidad: naturaleza y cultura, hombre y mujer, alma y cuerpo, razón y sentimiento, etc. La filósofa feminista Donna HARAWAY ha utilizado la metáfora del ciborg para referirse a este fenómeno de hibridación entre cultura y naturaleza, entre animalidad y tecnología que caracteriza a 
lo humano, y que nos lleva a vivir siempre en la frontera, borrando límites y trazando nuevas lindes provisionales (HARAWAY, 1995: 251 y ss.). Ahora bien, también en el mundo del derecho existen ciborgs, especies jurídicas híbridas surgidas al calor de la globalización, que no encajan en los moldes de la teoría decimonónica. Esto explica el resquebrajamiento de la noción de sujeto de derecho, que poco a poco ha ido asumiendo formas aberrantes para la cosmovisión moderna: desde la idea de derechos colectivos hasta la reciente atribución de personalidad jurídica a un río —esto ha sucedido en algunas comunidades maoríes de Nueva Zelanda-, pasando por la extraña locución de «derechos de la pacha-mama», el sujeto de derecho de la modernidad parece haber entrado en un frenesí de metamorfosis permanente (MíGUEZ, 2014). Este tipo de fenómenos de transfiguración, típicamente posmodernos, se vienen dando desde hace décadas y se proyectan en multitud de ámbitos. En particular, es notorio el cruce de culturas jurídicas que se está produciendo como consecuencia de la globalización, y que han llevado a Benoît FRYDMAN a utilizar el concepto de OJNIS (Objetos Jurídicos No Identificados) para describir esa clase de instituciones extrañas para las concepciones tradicionales (FrYDMAN, 2012: 20 y ss.).

Al igual que el sujeto de derecho, la noción de soberanía se ha problematizado desde hace décadas y existe la percepción generalizada de que el mundo ha entrado en una fase post-estatal que está dando lugar a un nuevo statu quo global. Sin embargo, la incertidumbre es poderosa y hay una inercia difícil de resistir, que tiende a seguir interpretando el derecho a la luz de las categorías tradicionales. No es el momento de entrar en todas las derivadas que se desprenden de este fenómeno, pero sí me gustaría subrayar la concomitancia entre la posmodernidad como hecho cultural y el desmantelamiento de la soberanía como hecho político. Como han mostrado HARDT y NEGRI en Imperio, no se trata de un paralelismo casual, sino que son dos caras de la misma moneda, dos facetas de un proceso que nos está conduciendo a un nuevo orden imperial en el que ya no existe una única potencia hegemónica, en el que los poderes son múltiples, lábiles y fragmentarios, y donde el dominio no se ejerce de manera vertical, sino reticular. Es imposible abordar todo esto en esta sede, pero sí me interesaría ligar esta dinámica con la idea de deconstrucción, que no por casualidad es uno de los emblemas de la posmodernidad. Interpretándola en clave de la presente argumentación, podría decirse que el derecho ha sufrido un proceso de deconstrucción en diferentes ámbitos: la descodificación y la correlativa proliferación de legislación especial (IRTI, 1992), la aparición de normas difícilmente clasificables, cuyos efectos oscilan entre lo político y lo jurídico — pensemos en las recomendaciones del derecho internacional-, un constitucionalismo que ha dinamitado la visión piramidal del ordenamiento para adoptar constituciones de múltiples vértices (TROPER, 2001) o el auge de formas alternativas de resolución de conflictos como la mediación o la conciliación (AGUILÓ, 2015) son solo algunas de las manifestaciones de esta transformación global.

Pero conviene hacer una advertencia: la clave de este recorrido deconstructivo no es la «fragmentación», la «descomposición» en partes o la «desestructuración» del derecho. Todos esos pueden ser síntomas o etapas de un proceso general más profundo e incisivo, que podría describirse mejor con las etiquetas de «difuminación», «disolución» o «conmixtión» del derecho con otras esferas. Si se me permite una analogía, algo parecido sucede con las artes plásticas: la esencia de la deconstrucción en pintura no se encuentra en el largo itinerario de descomposición de las formas que condujo desde 
el impresionismo hasta el suprematismo abstracto de MALÉviCH, sino en el fenómeno por el cual la pintura perdió la vanguardia de los movimientos artísticos y le cedió el testigo a la performance, o en el hecho de salir de los museos e instalarse en las calles a través del grafiti, o en el proceso por el cual se hibridó con la literatura dando lugar al cómic. Todos estos son fenómenos típicamente posmodernos que ya se produjeron hace varias décadas y que no tienen que ver con la descomposición de las formas pictóricas, sino más bien con la misma «disolución» de la pintura y de su papel en el mundo de las artes. Creo que la deconstrucción del derecho debe interpretarse en esa clave y que, por tanto, la posmodernidad jurídica consiste en el fenómeno de disolución y desaparición del derecho. Por utilizar una expresión que ya se empleó antes, en su pérdida de centralidad. En este sentido, me parece que las tesis marxistas que defendieron la superación del derecho y el Estado han adquirido una actualidad inesperada en el contexto de la globalización, solo que no como se pensó en su momento: no es que el derecho deba desaparecer, sino que el derecho está desapareciendo de facto. Obviamente, esto no quiere decir que desaparezcan las normas y la regulación. Al contrario, los poderes que nos gobiernan, el control biopolítico al que estamos sometidos y los focos de producción de normas globales parecen ser cada vez más opresivos y numerosos (HARDT y NEGRI, 2005). Pero estos poderes ya no son los del Estado, ni sus agentes principales son los juristas, sino una pléyade de instituciones, entidades y profesionales de índole económica, financiera o política que, eventualmente, utilizan el derecho, pero que han reemplazado a los juristas en el puesto de primacía que tuvieron en la modernidad.

Este proceso de disolución ha sufrido varias fases y consiste, esencialmente, en el desvanecimiento de los límites del derecho, que está perdiendo el estatus de aislamiento o autonomía con el que se había revestido a lo largo de la historia moderna (RÜCKERT, 1988) y que está dando lugar a una confusa amalgama de la esfera jurídica con la moral, la economía o la política. Aquí es donde entra el giro ético de la filosofía posmoderna y, en lo que nos afecta, el giro argumentativo de la filosofía jurídica contemporánea. La conceptualización del derecho como una ramificación más de la razón práctica y su correlativa equiparación con la ética o la política, la transfiguración de la teoría de la ciencia jurídica en las teorías de la argumentación (GARCÍA AMADO, 1986), el reemplazo de la racionalidad por la razonabilidad o muchos otros rasgos del paradigma postpositivista son ideas característicamente posmodernas, que apuntan hacia la disolución de las barreras del derecho como un ámbito profesional y científico aislado. Además, si prestamos atención, todos los ejemplos que acabo de citar nos reenvían a una concepción del derecho como discurso, algo en lo que las teorías postpositivistas coinciden, paradójicamente, con un arquetipo de la filosofía posmoderna como Richard RORTY, cuando este nos proponía abandonar el paradigma de la fundamentación racional de los derechos, para sustituirlo por el de la narración «de historias tristes y sensibles» (RORTY, 1998).

Ahora bien, lo relevante es la concomitancia de todas estas transformaciones con la era de la post-soberanía. Nótese que la crítica principialista de DwORKIN tiene lugar en los años setenta, es decir, en un momento en el que se empiezan a poner en cuestión las políticas sociales de los Estados del bienestar, coincidiendo prácticamente con la publicación de Law, Legislation and Liberty de Friedrich HAYEK o con la Teoría de la justicia de John RAWLS, y con el florecimiento de la crítica al paternalismo estatal, una tendencia académica que no cabe interpretar como algo puramente azaroso. Creo que 
la apelación a la moral de la oleada neoconstitucionalista, que también nos encontramos en el auge de las deontologías profesionales o en la retórica de las virtudes promovida por cierta clase de republicanismo moralizante, debe interpretarse como un síntoma de la crisis del Estado, como una suerte de refugio en la ética ante el desplome de las instituciones tradicionales. Y es que, como pensaba María ZAMBRANO, la moral florece en tiempos de crisis, mientras que la política lo hace en tiempos de esplendor (ZAMBRANO, 1992: 21 y ss.). Obviamente, todas estas derivas no están conectadas entre sí de forma causal, directa e intencional, sino que constituyen una trama compleja cuyas costuras se han ido trenzando de manera silenciosa e inconsciente, pero cuyo dibujo puede hoy apreciarse con algo de nitidez.

Así las cosas, no creo que el embate neoconstitucionalista signifique por sí mismo una demolición del paradigma positivista, pero sí me parece que debe ser interpretado como otra de las crisis que ha vivido esta corriente. Lo particular de esta crisis es que quizá sea más severa que las anteriores, porque afecta a los mismos cimientos del Estado. Hoy, más de treinta años después de que DwORKIN pusiera sus cartas sobre la mesa, el desmantelamiento de las estructuras estatales —o más bien la disipación de las fronteras entre la esfera del Estado y la del mercado mundial— está tremendamente avanzado. Si hacemos caso de la argumentación precedente y suscribimos la tesis de que el positivismo jurídico nació y evolucionó conforme a las derivas que el Estado experimentó en los dos últimos siglos, entonces quizá sí quepa diagnosticar la existencia de una crisis paradigmática desconocida hasta ahora. Lo que ocurre es que esta crisis no tendría que ver con la desaparición de los lindes entre el derecho y la moral, como parece decírsenos desde las filas neoconstitucionalistas, sino con un cambio trascendental en la esfera global, que se explica mejor a través de la tensión entre derecho y política o entre derecho y economía, y en el marco de las teorías internacionales del derecho. Este cambio está dando lugar a lo que antes caractericé como pérdida de centralidad del derecho, en la medida en que la regulación de la vida se encomienda a otras esferas, fundamentalmente económicas. A veces, esto se manifiesta de manera indirecta, cuando el derecho público asume el discurso de la economía global y adopta las formas del derecho corporativo o comercial —la «huida» del derecho administrativo- o cuando el ejercicio de la abogacía se pliega a los usos y la estética empresarial.

En paralelo a este proceso, que por sí mismo no tiene nada de halagüeño —más bien lo contrario - se está produciendo, no obstante, un reverdecer de la política. De hecho, pese a que se escucha a menudo el lema de la «juridificación de la política», creo que lo que se está produciendo es el fenómeno inverso: una profunda politización del derecho. Desde este punto de vista, me parece que la tensión fundamental a la que debería prestar atención la teoría jurídica no es la de derecho y moral, sino la de derecho y política. De hecho, ya hay signos reveladores en esta línea: la aparición del denominado constitucionalismo popular estadounidense (NIEMBRO, 2013), del llamado nuevo constitucionalismo latinoamericano (VICIANO y MARTínEZ DALMAU, 2012: 11-49) o de la justicia dialógica (GARGARELLA, 2014), con todas sus diferencias, son manifestaciones de una cultura que pretende aminorar la brecha entre la esfera del derecho - fuertemente tecnificado- y la ciudadanía, haciendo hincapié en la dimensión participativa que ha de asumir el derecho de nuestros días. Todas estas corrientes, en efecto, pugnan por re-politizar la Constitución o el ámbito jurisdiccional en general, en el entendido de que también el derecho y su práctica deben ser objeto de deliberación 
democrática. Evidentemente, todas estas expresiones pueden interpretarse desde la base del positivismo en su versión mínima - positivismo metodológico, tesis de las fuentes sociales, convencionalismo-, pero eso no quiere decir que el paradigma siga vivo. Las teorías pueden fracasar por dos razones: o bien porque no logran abarcar semánticamente el fenómeno o el conjunto de fenómenos que se proponen describir, o bien porque dejan de plantear las preguntas relevantes. Tengo la impresión de que, si esta vez el positivismo ha fracasado, lo habrá hecho por esta segunda razón.

\section{BIBLIOGRAFÍA}

Aguiló, J., 2015: El arte de la mediación: argumentación, negociación y mediación, Madrid: Trotta.

ARAgOneSES, A., 2009: Un jurista del modernismo. Raymond Saleilles y los orígenes del derecho comparado, Madrid: Dykinson.

ATIENZA, M., 2013: Curso de argumentación jurídica, Madrid: Trotta.

AtienZA, M., y Ruiz MANERo, J., 2007: «Dejemos atrás el positivismo jurídico», Isonomía, 27: $7-28$.

ATRIA, F., 2004: «La ironía del positivismo jurídico», Doxa, 27: 81-139.

Austin, J., 1981: Sobre la utilidad del estudio de la jurisprudencia, F. GONZÁlez VicÉN (trad. y estudio preliminar), Madrid: Centro de Estudios Políticos y Constitucionales.

BARBERIS, M., 2008: Europa del diritto, Bologna: Il Mulino.

BAYÓN, J. C., 2002: «El contenido mínimo del positivismo jurídico», en V. ZAPATERO, Horizontes de la filosofía del derecho. Homenaje a Luis García San Miguel, Alcalá de Henares: Servicio de Publicaciones de la Universidad de Alcalá, 33-54.

Bergbohm, C., 1892: Jurisprudenz und Rechtsphilosophie. Kritische Abhandlungen, vol. 1, Lepzig: Duncker \& Humblot.

BobBIO, N., 1977: Giusnaturalismo e positivismo giuridico, Milano: Edizioni di Comunità.

- 1989: «Hegel y el iusnaturalismo», en G. AmENGUAL (ed.), Estudios sobre la Filosofía del Derecho de Hegel, Madrid: Centro de Estudios Constitucionales, 377-406.

- 1996: Il positivismo giuridico. Lezioni di filosofia del diritto raccolte dal dott. Nello Morra, Torino: Giapichelli.

- 2005: Teoría general del derecho, 2. ${ }^{a}$ ed., J. GuERRERO (trad.), Bogotá: Temis.

BRONCANO, F., 2013: Sujetos en la niebla. Narrativas sobre la identidad, Barcelona: Herder.

CAMPBELl, T., 2002: «El sentido del positivismo jurídico», Doxa, 25, 303-331.

CARRIÓ, G., 1981: Dworkin y el positivismo jurídico, México: UNAM.

Contreras Peláez, F., 2005: Savigny y el historicismo jurídico, en A. E. Pérez LuÑo (pról.), Madrid: Tecnos.

COSTA, P., 2002: «Lo Stato di diritto: un'introduzione storica», en P. CosTA y D. ZOLO (eds.), Lo Stato di diritto. Storia, teoria, critica, Milano: Feltrinelli, 89-170.

DrEIER, H., 2007: «Naturrecht und Rechtspositivismus. Pauschalurteile, Vorurteile, Fehlurteile», en W. Härle y B. Vogel, Vom Rechte, das mit uns geboren ist. Aktuelle Probleme des Naturrechts, Freiburg: Herder, 127-169.

DREIER, R., 1993: «Jherings Rechtstheorie - eine Theorie evolutionärer Rechtsvernunft», en O. BeHRENDS, Privatrecht heute und Jherings evolutionäres Rechtsdenken, Köln: Dr. Otto Schmidt, 111-129.

Duguit, L., 1913: Les transformations du droit public, Paris: Librairie Armand Colin. 
Escudero Alday, R., 2002: «Argumentos para la recuperación de la teoría de Lon L. Fuller», Anuario de Filosofía del Derecho, XIX, 309-331.

- 2004: Los calificativos del positivismo jurídico. El debate sobre la incorporación de la moral, Madrid: Thomson-Civitas.

Falk, R. A., y Shuman, S. I., 1961-1962: «The Bellagio Conference on Legal Positivism», Journal of Legal Education, 14, 213-228.

FALZEA, A., 1992: Introduzione alle scienze giuridiche (I). Il concetto del diritto, Milano: Giuffré.

FAssò, G., 2006: Storia della filosofia del diritto, vol. III. Ottocento e Novecento, 9. ${ }^{a}$ ed. aggiornata, C. FARAlli (a cura di), Roma-Bari: Laterza.

Ferrajoli, L., 2011: Principia Iuris. Teoría del derecho y de la democracia (vol. 1), en P. Andrés, J. C. Bayón, M. Gascón, L. Prieto y A. Ruiz Miguel (trads.), Madrid: Trotta.

Figueras, M., 1978-1979: «Notas sobre la introducción de la Escuela Histórica de Savigny en España», Anales de la Cátedra Francisco Suárez, 18-19, 371-393.

FolJANTY, L., 2013: Recht oder Gesetz: Juristische Identität und Autorität in den Naturrechtsdebatten der Nachkriegszeit, Tübingen: Mohr Siebeck.

Frydman, B., 2012: «Comment penser le droit global?», en J.-Y. CHÉROT y B. FrYdMAN (dirs.), La science du droit dans la globalisation, Bruxelles: Bruylant, 17-48.

GARCía Amado, J. A., 1986: «Del método jurídico a las teorías de la argumentación», Anuario de Filosofía del Derecho, 3, 151-182.

- 2012: «Sobre formalismos y antiformalismos en la teoría del derecho», Eunomía. Revista en cultura de la legalidad, 3, 13-43.

Gargarella, R. (ed.), 2014: Por una justicia dialógica. El Poder Judicial como promotor de la deliberación democrática, Buenos Aires: Siglo XXI.

GIERKE, O. VON, 1883: Naturrecht und Deutsches Recht. Rede zum Antritt des Rektorats der Universität Breslau, Frankfurt am Main: Literarische Anstalt Rutten \& Loening.

GonZÁlez VicÉn, F., 1979: Estudios de filosofía del derecho, Santa Cruz de Tenerife: Universidad de La Laguna.

- 1981: «Estudio preliminar», en J. Austin, Sobre la utilidad del estudio de la jurisprudencia, Madrid: Centro de Estudios Políticos y Constitucionales, 5-22.

- 1984: «Del Derecho natural al positivismo jurídico», De Kant a Marx (Estudios de historia de las ideas), Valencia: Fernando Torres, 206-221.

- 1986: «Entrevista con Felipe González Vicén», en M. AtienZa y J. Ruiz Manero (eds.), Doxa, 3, 317-325.

HARAWAY, D., 1995: Ciencia, cyborgs y mujeres. La reinvención de la naturaleza, en M. TALENS (trad.), Madrid: Cátedra.

Hardt, M., y Negri, A., 2005: Imperio, en A. Brixio (trad.), Barcelona: Paidós.

Hart, H. L. A., 1958: «Positivism and the Separation of Law and Morals», Harvard Law Review, 71 (4), 593-629.

- 1990: «El nuevo desafío del positivismo jurídico», en F. LAPORTA, L. Hierro y J. R. DE PÁRAMO (trads.), Sistema, 36, 3-19.

HecK, P., 1936: Rechtserneuerung und juristische Methodenlebre, Tübingen: J. C. B. Mohr.

HiERro, L., 2008: El realismo jurídico escandinavo. Una teoría empirista del derecho, 2. ed., Madrid: Iustel.

Hoerster, N., 2000: En defensa del positivismo jurídico, J. MALEm (trad.), 2. ${ }^{\text {a }}$ ed., Barcelona: Gedisa.

HoRwITZ, M. J., 1992: The Transformation of American Law, 1870-1960: The Crisis of Legal Orthodoxy, Oxford: Oxford University Press. 
IRTI, N., 1992: La edad de la descodificación, en L. ROJO AJURIA (trad.), Barcelona: Bosch.

JHERING, R. VON, 1998: Ist die Jurisprudenz eine Wissenschaft? Jherings Wiener Antrittsvorlesung vom 16. Oktober 1868, en O. BEHRENDS (Hrsg.), Göttingen: Wallstein.

- 2013: «Nuestra tarea», en L. LLOREDO ALIX (trad. y estudio preliminar), Eunomía. Revista en cultura de la legalidad, 4, 234-275.

Kantorowicz, H., 1906: Die Kampf um die Rechtswissenschaft, Heidelberg: Carl Winter's.

KELSEN, H., 1984: Hauptprobleme der Staatsrechtslebre (Entwickelt aus der Lebre vom Rechtssatze), 2. ${ }^{a}$ ed., Darmstadt: Scientia.

LACASTA, J. A., 1998: «Savigny eta Iheringen artean (ez duzu Savignyren izena ahotan alferrik hartuko», Euskal Herriko legelarien aldizkaria, 3, 94-98.

LAPORTA, F., 2007: El imperio de la ley. Una visión actual, Madrid: Trotta.

LENK, K., 2000: «Las etapas esenciales en la concepción de la ideología», en K. LENK, El concepto de ideología. Comentario crítico y selección sistemática de textos, 2. ${ }^{a}$ ed., J. L. ETCHEVERRY (trad.), Buenos Aires: Amorrortu, 9-46.

Llewellyn, K., y Hoebel, E. A., 1941: The Cheyenne Way: Conflict and Case Law in Primitive Jurisprudence, Oklahoma: University of Oklahoma Press.

LlOREDO Alix, L., 2014: «La recepción de Savigny en España. Un episodio en la historia de la circulación de las ideas», Derechos y Libertades, 30, 227-268.

- 2015: «Una propuesta de redefinición de la teoría jurídica a la luz del movimiento de los indignados», en J. A. GARCía SÁEZ y R. VAÑó (eds.), Educar la mirada. Documentales para una enseñanza crítica de los derechos bumanos, Valencia: Tirant lo Blanch, 209-227.

LosAno, M. G., 2002: Sistema e struttura del diritto (I): Dalle origini alla Scuola storica, Milano: Giuffré.

— 2011: «Las teorías del solidarismo y su influencia en la formulación de los derechos fundamentales económicos», en M. G. LosAno (ed.), Solidaridad y derechos bumanos en tiempos de crisis, C. LEMA y L. LlOREDO (trad.), Madrid: Dykinson.

MENZEL, A., 1922: Kallikles. Eine Studie zur Geschichte der Lebre vom Rechte des Stärkeren, Wien/Leipzig: Franz Deuticke.

Míguez, R., 2014: «De las cosas comunes a todos los hombres. Notas para un debate», Revista Chilena de Derecho, 41 (1), 7-36.

Murphy, M. C., 1995: «Was Hobbes a Legal Positivist?», Ethics, 105, 846-873.

Niembro, R., 2013: «Una mirada al constitucionalismo popular», Isonomía, 38, 191-224.

NiNO, C. S., 2003: Introducción al análisis del derecho, 2. ${ }^{a}$ ed. ampliada y revisada, Buenos Aires: Astrea.

OliveCrOnA, K., 2013: «Realismo e idealismo. Algunas reflexiones sobre la cuestión capital de la filosofía del derecho», en O. VERGARA (trad. y ed.), Eunomía. Revista en cultura de la legalidad, 5, 248-263.

Ortega y Gasset, J., 1989: «España», en P. GARRAgOrRi (ed.), Obras completas. Vol. X (Ideas políticas), Madrid: Alianza.

OTT, W., 1992: Der Rechtspositivismus. Kritische Würdigung auf der Grundlage eines juristischen Pragmatismus, 2. ${ }^{a}$ ed., Berlin: Duncker \& Humblot.

PAŠUKANIS, E., 1976: Marxismo y teoría general del derecho, en V. ZAPATERO (trad. y presentación), Barcelona: Ediciones Labor.

Pérez Lledó, J. A., 1996: El movimiento Critical Legal Studies, Madrid: Tecnos.

RADBRUCH, G., 1946: «Gesetzliches Unrecht und übergesetzliches Recht», Süddeutschen Juristen-Zeitung, 5 (August), 105-108.

- 1960: Die Natur der Sache als juristische Denkform, Darmstadt: Wissenschaftliche Buchgesellschaft. 
RIVAYA, B., 2009: «Historia política de la filosofía del derecho española del siglo XX», Doxa, 32 : 541-582.

Robles Morchón, G., 2002: Ley y derecho vivo. Método jurídico y sociología del derecho en Eugen Ehrlich, Madrid: Centro de Estudios Políticos y Constitucionales.

RORTY, R., 1998: «Derechos humanos, racionalidad y sentimentalidad», en S. SHUTE y S. HuRLEY (eds.), De los derechos humanos. Las conferencias Oxford Amnesty de 1993, Madrid: Trotta, 117-136.

Ross, A., 1994: «El concepto de validez y el conflicto entre el positivismo jurídico y el derecho natural», en P. CASANOvaS y J. J. MORESO (eds.), El ámbito de lo jurídico. Lecturas de pensamiento jurídico contemporáneo, Barcelona: Crítica, 361-382.

RÜCKERT, J., 1988: Autonomie des Rechts in rechts historischer Perspektive, Hannover: Juristische Studiengesellschaft.

- 2011: «Freirechtsbewegung», en Handwörterbuch zur deutschen Rechtsgeschichte, Berlin: Erich Schmidt Verlag.

SAnTOS, B. DE, 2009: Sociología jurídica crítica. Para un nuevo sentido común en el derecho, en C. LEMA (nota introductoria y revisión de la trad.), Madrid: Trotta.

SAVIGnY, F. K. VON, 1814: Vom Beruf unsrer Zeit für Gesetzgebung und Rechtswissenschaft, Heidelberg, Mohr und Zimmer.

- 1993: Vorlesungen über juristische Methodologie 1802-1842, A. MAZZACANE (Hrsg.), Frankfurt am Main: Vittorio Klostermann.

SCARPELli, U., 1997: Cos'è il positivismo giuridico, en A. CATANIA y M. Jori (introduzione e cura), Napoli: Edizioni Scientifiche Italiane.

STAMmLER, R., 1911: Theorie der Rechtswissenschaft, Halle: Waisenhaus.

STOLLeIS, M., 1992: Geschichte des öffentlichen Rechts in Deutschland, II. Band (1800-1914), München: C. H. Beck.

Troper, M., 2001: Por una teoría jurídica del Estado, en M. Venegas (trad.), G. PeCes-BArbA (pról.), Madrid: Dykinson.

TwinING, W., 2009: General Jurisprudence. Understanding Law from a Global Perspective, Cambridge: Cambridge University Press.

Viciano Pastor, R., y Martínez Dalmau, R., 2012: «Fundamento teórico del nuevo constitucionalismo latinoamericano», en R. VICIANO PASTOR (ed.), Estudios sobre el nuevo constitucionalismo latinoamericano, Valencia: Tirant lo Blanch, 11-49.

VOGENAUER, S., 2015: «Schlüsselwörter in englischen Savigny-Übersetzungen», en J. RÜCKERT y T. Duve (Hrsg.), Savigny, international?, Frankfurt am Main: Vittorio Klostermann, 251-343.

Walz, G. A., 1930: Wesen des Völkerrechts und Kritik der Völkerrechtsleugner, Stuttgart: Kohlhammer.

WeINERT, F., 1982: «Die Arbeit der Geschichte: Ein Vergleich der Analysemodelle von Kuhn und Foucault», Zeitschrift für allgemeine Wissenschaftstheorie, XIII (2), 337-358.

WILHELM, W., 1958: Zum juristischen Methodenlebre im 19. Jahrhundert. Die Herkunft der Methode Paul Labands aus der Privatrechtswissenschaft, Frankfurt am Main: Vittorio Klostermann.

Wyss, U., 1979: Die Wilde Philologie: Jacob Grimm und der Historismus, München: C. H. Beck. Zambrano, M., 1992: El pensamiento vivo de Séneca, 2. ed., Madrid: Cátedra.

ŽižEK, S., El sublime objeto de la ideología, en I. VericAT (trad.), México: Siglo XXI.

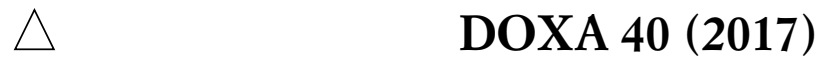


NOTAS 



\title{
DECIDIR, ARGUMENTAR Y ENGROSAR: EL CASO MARTÍN DEL CAMPO*
}

\author{
Roberto Lara Chagoyán*** \\ roberto.larac@gmail.com
}

RESUMEN. El proceso de decisión en la Suprema Corte mexicana consiste en discutir un proyecto de resolución, llevar a cabo una deliberación y tomar una votación. Posteriormente, se encarga a uno de los ministros la elaboración de un documento que, en teoría, debe contener los argumentos que fundamentan el acuerdo alcanzado en la deliberación. Sin embargo, algunas veces el documento no coincide con lo acordado. El propósito de este trabajo es analizar en profundidad uno de estos casos y sus implicaciones en el sistema jurídico mexicano. También se aborda el tema de la falta de un pronunciamiento sobre uno de los temas centrales de la decisión: la obligatoriedad de los informes de la Comisión Interamericana de Derechos Humanos.

Palabras clave: tortura, decisión, formalismo, obligatoriedad, deber, obligación, Informe de Fondo, Comisión Interamericana de Derechos Humanos, reconocimiento de inocencia, juicio de amparo.

\section{Voting, Arguing and Drafting: Producing a Judgment to the Martín del Campo Case}

ABSTRACT. The decision-making in the Mexican Supreme Court consists of a process that encompasses the distribution of a draft judgment, deliberation and voting. Once justices reached an agreement, one of them becomes in charge of preparing a final judgement that, in theory, must resemble such agreement. In practice, however, some judgments do not reflect neither the arguments nor the agreement made by justices. The purpose of this article is to analyze in depth one of this cases in order to provide some remarks about the implications of the Court's decision-making process for Mexico's legal system. Also, the paper debates about one of the case's major topics: the lack of providing an analysis regarding the obligatory status of the Inter-American Commission on Human Rights' Reports on merits.

Keywords: torture, decision-making, compulsoriness, Inter-American Human Rights Commission, reports on cases, amparo.

* Fecha de recepción: 4 de mayo de 2017. Fecha de aceptación: 30 de mayo de 2017.

** Director General del Centro de Estudios Constitucionales de la Suprema Corte de Justicia de la Nación México.

Agradezco a Camilo SaAvedra, Alejandra Martínez Verástegui, Diana Beatriz GonZÁlez Carballo, Karla Quintana Osuna, Fernanda Aguilar Cortés y Grizel Robles CÁRDEnAS, sus valiosos comentarios a las diferentes versiones de este trabajo. 


\section{INTRODUCCIÓN}

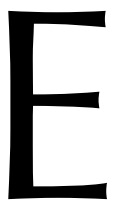

118 de marzo de 2015, la Primera Sala de la Suprema Corte de Justicia de la Nación de México (SCJN) decidió ordenar la libertad inmediata de Alfonso Martín del Campo Dodd, quien había permanecido en prisión durante veintitrés años por un doble homicidio, mediante una confesión obtenida por tortura, como única prueba (amparo en revisión 631/2013). En esa sesión, se determinó que uno de los ministros (magistrados) se hiciera cargo del «engrose», el cual se publicó hasta el 9 de febrero de 2016, es decir, casi once meses después. En la Corte mexicana llamamos «engrose» al escrito final de una sentencia que se emite luego de haberse decidido el caso en una sesión pública mediante la deliberación correspondiente a partir de un proyecto inicial a cargo del ministro ponente ${ }^{1}$. El proyecto original y el engrose pocas veces coinciden, y los ministros que suscriben tales documentos tampoco suelen ser los mismos. Ello no tendría nada de particular si entre estas tres acciones (proyectar, decidir y engrosar) existiera una línea coherente en la que los posibles cambios reflejaran los avances en la decisión.

En este caso en particular, se discutió un primer proyecto a cargo del ministro José Ramón Cossío Díaz el 2 de julio de 2014, en el cual se proponía conceder el amparo «liso y llano» ${ }^{2}$ al quejoso, con lo cual se habría ordenado su libertad inmediata; sin embargo, el proyecto fue desechado, esencialmente, porque la mayoría de los ministros consideró que no convenía «comprometer el criterio ${ }^{3}$ de la Sala con relación a la obligatoriedad de los Informes de la Comisión Interamericana de Derechos Humanos (CIDH), en los cuales se tenía por probada la tortura. Conviene aclarar que la obligatoriedad de esos informes era uno de los temas planteados en el recurso de revisión que la Corte resolvió, esto es, se trataba de un tema cuya resolución no era optativa sino obligatoria.

Siete meses después, el 18 de marzo de 2015, se presentó un segundo proyecto de resolución a cargo del ministro Jorge Mario Pardo Rebolledo a quien, por cuestión de turno, le había correspondido tal encomienda. Esta vez el proyecto no tomó en cuenta los informes de la CIDH y propuso conceder el amparo «para efectos», es decir, propuso emitir una orden al tribunal de segunda instancia (autoridad responsable) para que analizara algunas pruebas ofrecidas por el quejoso. No obstante lo anterior, la propuesta no convenció al resto de los integrantes de la Sala por razones de las que luego me ocuparé. Lo cierto es que consideraron que con esa resolución era improbable que el quejoso obtuviera su libertad.

El dilema continuaba en el aire. Sin embargo, habiendo analizado pormenorizadamente todo el expediente de reconocimiento de inocencia y también la causa penal, la mayoría de los ministros quedó convencida de que no había duda alguna de que Alfonso Martín del Campo había sido torturado, y que el amparo debía concederse de

${ }^{1} \mathrm{El}$ engrose, por lo regular, es el proyecto inicial modificado que acoge las sugerencias surgidas en la discusión que se lleva a cabo el día de la sesión; sin embargo, existen casos en los que, prácticamente, se elabora un nuevo documento a partir de lo acordado por los ministros.

2 «Liso y llano» en la jerga judicial significa que el amparo se concede de manera inmediata o directa, sin que tenga que regresar el expediente a la autoridad responsable para que dicte otra resolución en la que cumpla con lo ordenado por el tribunal de amparo. Lo contrario es el «amparo para efectos».

3 Esta frase se utiliza normalmente para defender una postura silenciosa de la Suprema Corte ante un determinado problema. 
manera lisa y llana, es decir, como lo había propuesto el ministro José Ramón Cossío Díaz en el primer proyecto, pero sin atender los informes de la CIDH. De este modo, se determinó que el ministro Alfredo Gutiérrez Ortiz Mena quedara como encargado de la redacción del engrose y que se ordenara la inmediata libertad de Alfonso Martín del Campo Dodd. Este acuerdo permitió que el caso fuera «decidido» ese 18 de marzo de 2015. Pero lo que la mayoría no acordó fue qué vía o vías argumentativas debían seguirse para alcanzar esa decisión.

En este trabajo haré una crítica al modelo de toma de decisiones en México a partir de este caso. Busco responder a la pregunta sobre cuál es el valor de un proyecto de resolución a cargo de una de las ponencias y cuál el de los llamados «engroses». Desde mi punto de vista, si la Corte decide un caso mediante la deliberación sin tomar en cuenta necesariamente el proyecto y, después, elabora un engrose sin tomar en cuenta necesariamente la decisión, entonces tenemos un problema.

Por lo demás, el caso elegido es uno de los más controvertidos en los últimos años en México, puesto que versa sobre tortura. La tortura es un fenómeno cultural asociado a la administración y procuración de justicia que, por desgracia, desde hace mucho tiempo forma parte del quehacer cotidiano de las autoridades dedicadas a la investigación de los delitos y a la seguridad pública. Pero este caso en particular, además, tiene aristas que lo distinguen de otros casos de tortura por varias razones: 1) porque se trata de un asunto relacionado con el homicidio de una pareja, en su propio domicilio, con utensilios de cocina y que, aparentemente, lo había perpetrado un miembro de la familia: Alfonso Martín del Campo Dodd, hermano de la mujer asesinada (así fue difundido por la autoridad y por los medios de comunicación); 2) porque —-como ya adelanté- la única prueba que se utilizó para fincar su responsabilidad penal fue una confesión (así lo aceptó el tribunal de segunda instancia); 3) porque esa confesión fue obtenida - como se comprobó después- mediante el empleo de la tortura; 4) porque, una vez que el caso fue cerrado en México por haberse agotado las instancias jurisdiccionales internas, incluyendo el amparo, se abrió un litigio internacional que, por circunstancias de competencia temporal, no pudo ser resuelto por la Corte Interamericana de Derechos Humanos (CorteIDH) - los hechos ocurrieron en 1992 y México reconoció la competencia contenciosa de ese organismo hasta 1998- aunque fue atendido con importantes resultados en la $\mathrm{CIDH}$; 5) porque el caso despertó el interés en el ámbito legislativo del entonces Distrito Federal y del Senado de la República, lo que se tradujo en importantes reformas legales y pronunciamientos políticos; 6) porque el caso, el litigio y la resolución final estimularon el interés en la academia y la sociedad en general; 7) porque el caso ha servido como acicate para despertar la polémica en torno al binomio tortura-impunidad; y 8) porque, a la hora de resolver de manera definitiva el problema, la SCJN evadió de forma deliberada una de las cuestiones centrales: la pregunta por la obligatoriedad de los informes de la CIDH. Este último punto es particularmente delicado, pues a partir de la reforma constitucional en materia de derechos humanos de 2011, el Constituyente Permanente estableció un mandato según el cual ninguna autoridad podrá desconocer el papel de los instrumentos internacionales en la materia en la resolución de los conflictos sociales y menos que nadie, la Suprema Corte. ¿Qué razones están detrás de esta omisión? ¿Qué sucede en el seno de un Tribunal Constitucional cuando va a resolver un asunto de este tipo? 
Procederé de la siguiente forma: en primer lugar, narraré la historia del caso (I); posteriormente, distinguiré entre la decisión y el engrose (II); más adelante exploraré las razones «políticas» que, a mi juicio, están detrás del silencio de la Corte con relación a la obligatoriedad de los informes de la CIDH (III); enseguida, diré por qué y de qué manera pudieron haberse tomado en cuenta tales informes (IV); y finalmente, presentaré algunas conclusiones $(\mathrm{V})$.

\section{LOS HECHOS DEL CASO Y LA SECUELA PROCESAL}

Existen dos versiones de los hechos, como suele ocurrir en todos los asuntos criminales. La del Ministerio Público es la siguiente: Alfonso Martín del Campo Dodd confesó que asesinó a su hermana y a su cuñado de «forma despiadada», utilizando guantes de plástico y utensilios de cocina, y que perpetró el ataque mientras estaban dormidos. El ataque habría derivado de una discusión sostenida horas antes entre las víctimas y el victimario por cuestiones de dinero. En la confesión se detalla que Alfonso Martín del Campo huyó a bordo del coche de su cuñado, que se dirigió hacia Cuernavaca pero que tuvo un accidente en la carretera y regresó a la ciudad de México, donde acudió a la oficina de la entonces Policía Federal de Caminos para informar falsamente que había sido secuestrado en su domicilio por dos personas, y que necesitaba comunicarse con su familia para asegurarse que se encontraban a salvo.

La segunda versión es la de Alfonso Martín del Campo. Él sostuvo que la confesión que firmó, y que fue la única prueba en la que se basó todo el juicio, fue arrancada mediante actos de tortura a cargo de oficiales de la policía judicial. Aseguró que lo que en realidad sucedió el 29 de mayo de 1992 fue lo siguiente: aproximadamente a las 22:30 horas, llegó a su domicilio y se dirigió a su habitación donde, poco tiempo después, se quedó dormido sin percatarse de la hora a la que llegaron sus familiares. Horas después despertó al oír los gritos de su hermana que lo llamaba, por lo que de inmediato se levantó de la cama y se dirigió hacia donde ella se encontraba. Al abrir la puerta de su habitación, se percató de la presencia de un sujeto que tenía la cabeza cubierta por una media quien, al verlo, se lanzó hacia él, comenzó a golpearlo y lo obligó violentamente a recostarse sobre su cama. Una segunda persona entró a su habitación portando un cuchillo en la mano derecha y, entre los dos, continuaron golpeándolo. Momentos después, lo amordazaron con un pedazo de toalla, lo subieron al maletero del automóvil de su cuñado y condujeron por varios minutos. De pronto, escuchó un fuerte golpe y sintió que el vehículo se había detenido. Una vez que se las arregló para abrir la cajuela del coche y, después de pedir auxilio sin resultado alguno, caminó por la carretera hasta que logró encontrar un camión que lo llevó hasta la caseta de cobro, donde llamó a la policía para decirles que lo habían secuestrado. Afirmó, finalmente, que durante la diligencia de reconstrucción de hechos, los agentes de la entonces Policía Judicial lo corrigieron todo el tiempo y, mediante amenazas, lo obligaron a decir lo que ellos quisieron.

La versión que se tomó en cuenta en el proceso judicial fue la de la autoridad. Así, en la sentencia de primera instancia, dictada el 28 de mayo de 1993, el juez determinó que Alfonso Martín del Campo Dodd era responsable del doble homicidio calificado, 
por lo que le impuso una pena de cincuenta años de prisión ${ }^{4}$. El 17 de agosto de 1993, la segunda instancia confirmó la decisión ${ }^{5}$.

En febrero de 1994, luego de una denuncia a cargo de la defensa del sentenciado, la Procuraduría de Justicia del Distrito Federal formó el procedimiento administrativo de responsabilidad núm. QC/0011/FEB-94, mediante el que se determinó que el señor Sotero Galván Gutiérrez, agente de la Policía Judicial del Distrito Federal, era administrativamente responsable por la detención arbitraria, incomunicación y tortura en contra de Alfonso Martín del Campo Dodd. Este procedimiento administrativo, sin embargo, no tuvo ninguna injerencia en el juicio; sería hasta 1999 cuando el interesado ofrecería esta resolución como prueba en un primer reconocimiento de inocencia.

Volviendo a la determinación de la segunda instancia, el sentenciado promovió un juicio de amparo directo contra la misma, que fue resuelto por el Cuarto Tribunal Colegiado en Materia Penal del Primer Circuito, el 2 de diciembre de 1997, en el sentido de negar el amparo ${ }^{6}$. Esta determinación fue recurrida por el quejoso ante la Primera Sala de la SCJN, la cual desechó por improcedente el recurso, el 9 de febrero de 1998, al considerar que no existía planteamiento de constitucionalidad.

Tendrían que transcurrir trece años ${ }^{7}$ para que el caso volviera a la SCJN. La vía fue un segundo incidente de reconocimiento de inocencia (el RI-5/2010) que fue resuelto por la Séptima Sala Penal del Tribunal Superior de Justicia del Distrito Federal, el 25 de octubre de 2011, en sentido igualmente desfavorable para Alfonso Martín del Campo ${ }^{8}$. Esta resolución fue utilizada como acto reclamado de un juicio de amparo (expediente 1183/2011), que fue resuelto por el juez Sexto de Distrito de Amparo en Materia Penal en el Distrito Federal, el 30 de abril de 2013, en el sentido de conceder el amparo, por falta de motivación, para el efecto de que se volviera a dictar el reconocimiento de inocencia ${ }^{9}$.

A pesar de ese resultado, tanto el quejoso (en un recurso principal y otro adhesivo) como el Ministerio Público impugnaron la sentencia. El Cuarto Tribunal Colegiado en Materia Penal del Primer Circuito integró el expediente 109/2013, para resolver todos los recursos; pero sería la Primera Sala de la SCJN quien terminaría haciéndolo vía el ejercicio de la facultad de atracción (SEFA-189/2013), mediante la intercesión del ministro Arturo Zaldívar Lelo de Larrea.

Como adelanté, la Primera Sala de la SCJN resolvió el caso en la sesión celebrada el 18 de marzo de 2015 mediante una sentencia que concedió el amparo y, por ende, la

${ }^{4}$ La sentencia fue dictada por el Juzgado Quincuagésimo Quinto Penal en el Distrito Federal en la causa penal 57/1992.

5 El recurso de apelación interpuesto por el sentenciado, lo resolvió la Octava Sala Penal del Tribunal Superior de Justicia del Distrito Federal.

${ }^{6}$ Se trata del juicio de amparo directo núm. 2004/97-475.

7 El caso siguió durante todo ese tiempo otros caminos derivados, precisamente, de la forma en la que Martín del Campo había sido condenado: litigio internacional ante el sistema interamericano, recomendaciones de organismos de derechos humanos, intervenciones procedentes del ámbito legislativo, entre otras.

${ }_{8}$ Anteriormente, Alfonso Martín del Campo había intentado un primer reconocimiento de inocencia: el RI-1/99, resuelto por la Décima Séptima Sala Penal del Tribunal Superior de Justicia del Distrito Federal, el 29 de abril de 1999 en forma adversa, aun cuando había presentado como prueba la mencionada resolución del procedimiento administrativo de responsabilidad núm. QC/0011/FEB-94, en el que se determinó que el policía judicial Sotero Galván Gutiérrez era administrativamente responsable por la detención arbitraria, incomunicación y tortura del señor Martín del Campo.

9 Cuaderno del juicio de amparo 1183/2011, páginas de la 971 a la 991. 
libertad inmediata del quejoso. En engrose se cerró hasta el 9 de febrero de 2016 y se publicó al día siguiente, casi once meses después.

A continuación se presentan dos esquemas: el primero contiene las principales etapas procesales por las que atravesó el caso (figura 1). En la primera columna se nombra la etapa correspondiente, en la segunda su contenido y en la tercera una línea de tiempo con el nombre de la autoridad que emitió el acto. El segundo esquema (figura 2) representa las etapas procesales posteriores al cierre del procedimiento ordinario y al correspondiente juicio de amparo, con las mismas variables: nombre, contenido, línea de tiempo y autoridades. El propósito de dividir en dos grandes partes el esquema es mostrar que lo que sucedió en la segunda parte del proceso es lo que se relaciona con las fuentes del Derecho Internacional de los Derechos Humanos y que, por tanto, la Corte habría podido resolver el caso, sencillamente, atendiendo al reconocimiento de inocencia sin necesidad de complicar más la resolución.

\section{Figura 1}

Hechos:

Investigación:

Causa penal:

Segunda instancia:

Primer juicio de amparo:

Recurso de revisión:
Hechos violentos en el domicilio, huida y captura del presunto responsable.

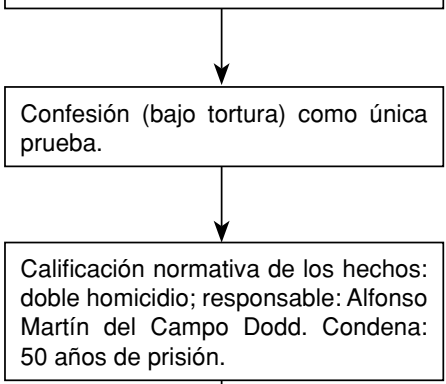

50 años de prisión.

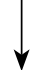

Recurso de apelación: confirmación de la sentencia de primera instancia: se afirma que la confesión es la única prueba en la que se basa la condena.

Primer juicio de amparo directo: se revisa la constitucionalidad de la sentencia de segunda instancia, y se niega el amparo.

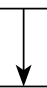

Se revisa la procedencia y se determina que el recurso no procede porque no existe un planteamiento de constitucionalidad.

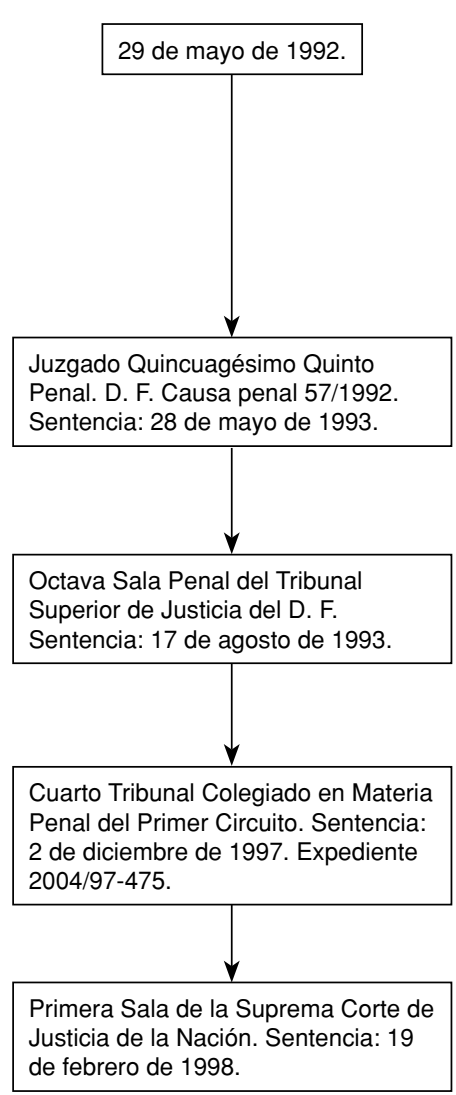


Figura 2

Primer incidente de reconocimiento de inocencia:

Juicio de amparo:

Recurso

de Revisión:

Facultad

de atracción

Decisión-acto

Decisión-documento (engrose):
Se presentó como prueba el expediente QC/0011/FEB.94, por la cual se determinó que el señor Sotero Galván Gutiérrez, agente de la entonces Policía Judicial del Distrito Federal, era administrativamente responsable por la detención arbitraria, incomunicación y tortura en su contra.

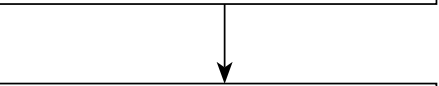

Se niega el reconocimiento de inocencia.
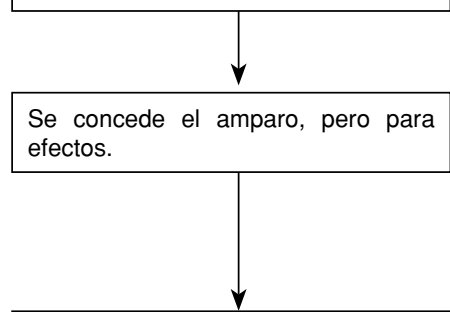

Se admite el recurso, pero no es resuelto por el Tribunal Colegiado.

Se determina atraer el recurso.

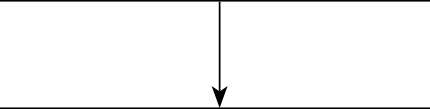

Se decide no tomar en cuenta los informes de la $\mathrm{CIDH}$; se concede el amparo; y se ordena la libertad inmediata del reo.

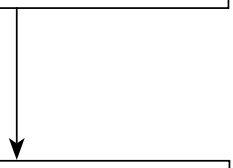

Se hace un análisis conjunto de la causa penal y los reconocimientos de inocencia; se mencionan las pruebas contenidas en los informes de la $\mathrm{CIDH}$; y no se hace pronunciamiento alguno sobre su obligatoriedad.
RI-1/99. Décima Séptima Sala Penal el TSJDF. 29 de abril de 1999.

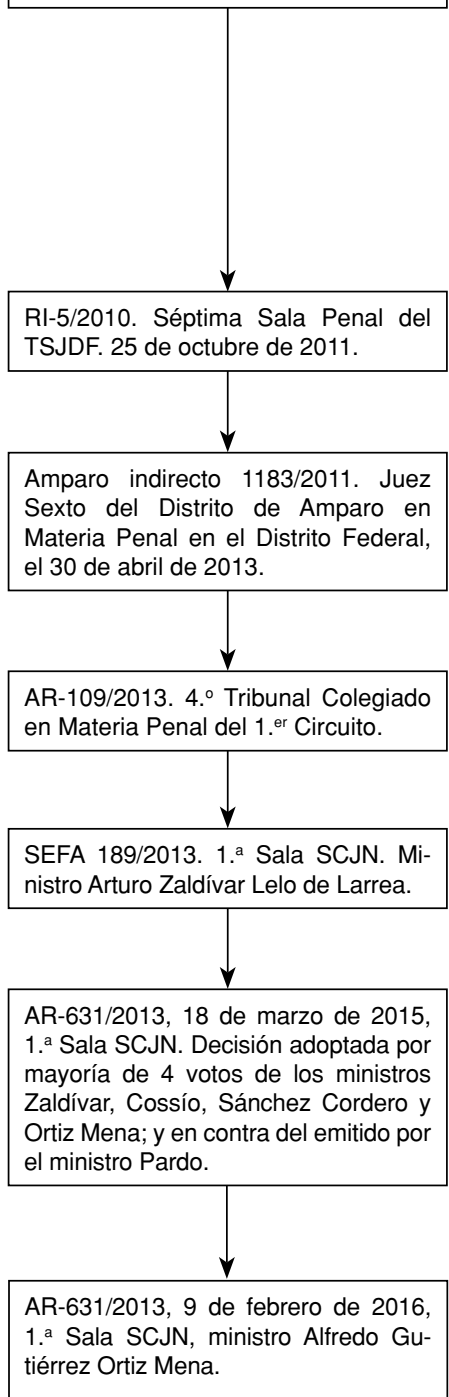




\section{DECISIÓN ACTO Y DECISIÓN DOCUMENTO}

\subsection{La decisión-acto}

En este caso — como en muchos otros- primero se toma la decisión colegiada y posteriormente se busca su justificación mediante un proceso de argumentación que satisfaga, en primer lugar, a quienes la tomaron y, en segundo lugar, al resto del mundo. Así, es posible distinguir entre la decisión-acto y la decisión-documento. La primera constituye un acuerdo (algunas veces de tipo político), donde la retórica y la dialéctica determinan el resultado, mientras que la segunda es un proceso de justificación en el que la lógica deductiva juega un papel fundamental, aunque no decisivo. Sin embargo, ambas acciones se encuentran estrechamente vinculadas porque la primera determina la segunda, lo cual no tiene nada de particular. El problema viene cuando la decisión del caso implica la evasión de una cuestión políticamente controvertida - como el no pronunciarse por la obligatoriedad de un informe de la CIDH - que constituye uno de los cuestionamientos centrales de una de las partes. Cuando esto sucede, la elaboración de la sentencia suele ser más difícil, porque se hace necesario maquillar esa omisión mediante procesos argumentativos dirigidos a justificar o validar la omisión. Una vez que emitido el engrose es posible develar el maquillaje porque el proceso argumentativo deja entrever algunas huellas de la omisión.

¿Qué y cómo se decidió el caso en la Primera Sala? Como ya señalé, la primera discusión se llevó a cabo el 2 de julio de 2014, a partir de un proyecto de resolución presentado por el Ministro José Ramón Cossío Díaz, en el que se proponía conceder el amparo liso y llano, tomando en cuenta el valor probatorio y normativo de los Informes 33/09 y 117/09 de la CIDH. La propuesta se traducía en la libertad inmediata de Alfonso Martín del Campo y agotaba completamente todos los temas planteados en el recurso. Ese día, sin embargo, no solo se desechó el proyecto de resolución, sino que también se tomó conciencia de la envergadura del problema, y se plantearon los extremos y los riesgos del mismo. Se trataba de un verdadero dilema: o se daba algún tipo de valor a los informes de la CIDH o se buscaban pruebas de la tortura en el expediente. En el primer caso, se presentaba la «desventaja» de dar valor a los Informes de fondo de la Comisión, lo que supondría que en casos futuros tendría que otorgárseles ese mismo valor; en el segundo caso, es decir, si se buscaban pruebas de la tortura, la Corte se enfrentaba ante el problema de no encontrar pruebas «fehacientes» de la misma ${ }^{10}$, tal y como se había concluido ya por la primera y segunda instancia y por los tribunales de amparo cuando resolvieron el doble homicidio. Pero los ministros ya no estaban frente al caso de homicidio, sino frente a un incidente de reconocimiento de inocencia; más concretamente,

10 Hasta ese momento, el único medio de prueba de la tortura legalmente admisible habría sido una sentencia en la que se condenara a alguien por la comisión de ese delito; no fue sino hasta el 6 de noviembre de 2013, que la Primera Sala de la SCJN determinó que, para actuar en consecuencia ante una denuncia de tortura, no era necesario contar con una sentencia condenatoria. Cfr. Amparo en revisión 703/2012, 6 de noviembre de 2013. Cinco votos por la concesión del amparo de los ministros Arturo Zaldívar Lelo de Larrea, José Ramón Cossío Díaz, Alfredo Gutiérrez Ortiz Mena, Olga Sánchez Cordero de García Villegas y Jorge Mario Pardo Rebolledo. Mayoría de tres votos por el amparo liso y llano de los ministros Arturo Zaldívar Lelo de Larrea, Alfredo Gutiérrez Ortiz Mena y Olga Sánchez Cordero de García Villegas. Disidentes: José Ramón Cossío Díaz y Jorge Mario Pardo Rebolledo. Ponente: Jorge Mario Pardo Rebolledo. Encargado del engrose: Alfredo Gutiérrez Ortiz Mena. Secretario: José Alberto Mosqueda Velázquez. 
estaban frente a un amparo concedido para efectos y frente a dos recursos de revisión (uno del quejoso y otro del Ministerio Público) que, por distintas razones, cuestionaban esa concesión de amparo (el primero buscaba un amparo liso y llano, mientras que el segundo, pedía que se negara el amparo). Consecuentemente, la Corte tenía que decidirse por alguna de estas dos alternativas y hacerse cargo de las consecuencias. Los ministros se decantaron por buscar pruebas de tortura en la causa penal.

En este punto conviene preguntarnos: cla Corte iba a buscar pruebas de tortura en un caso en el que los tribunales del D. F. y de la Federación en su momento concluyeron en que Alfonso Martín del Campo era el responsable del homicidio? ¿Encontrar pruebas de tortura en donde nunca se admitió siquiera la posibilidad de consignar a los policías acusados de llevarla a cabo? ¿Pruebas de tortura ante un caso cerrado en la que la propia Corte había intervenido confirmando las determinaciones judiciales ordinarias? ¿No habría sido más fácil atenerse al expediente relativo al reconocimiento de inocencia, donde los informes de la CIDH podían ser tomados como pruebas de tortura?

Como señalé, la decisión-acto se llevó a cabo en la sesión celebrada el 18 de marzo de 2015 sin tomar en cuenta ni el proyecto del ministro Cossío ni tampoco el del ministro Pardo. No hubo, pues, un tercer proyecto. De este modo los ministros llegaron a un acuerdo por mayoría de votos, según el cual: 1) debía concederse el amparo liso y llano y, en consecuencia, ordenar la libertad inmediata de Martín del Campo; y 2) las pruebas de tortura debían recogerse no del expediente de reconocimiento de inocencia (donde estaban integrados los informes de la CIDH), sino del expediente penal.

La decisión no se basó en un proyecto escrito o en una propuesta concreta. No se fueron revisadas líneas de argumentación en positivo, sino que la decisión se tomó a partir del conocimiento de un hecho por todos asumido: el quejoso había sido torturado. Con o sin informes de la CIDH, la mayoría de los ministros asumieron una postura política. La argumentación necesaria para justificarla llegaría once meses después y no podría variar el resultado: Martín del Campo estaba fuera de la cárcel.

Ahora bien: ¿cómo quedó la decisión-documento? ¿Se ajustó al acuerdo tomado en la decisión-acto? El expediente era por todos conocido, pero el engrose no. Como veremos, el engrose no respetó del todo el acuerdo tomado en la decisión-acto, pero realmente ya no importaba, porque nadie lo discutiría en serio nunca más ${ }^{11}$. ¿Qué relevancia tiene esta variación?

\subsection{La decisión-documento}

El engrose está estructurado de tal forma que no se distingue claramente entre la causa penal, los reconocimientos de inocencia y los distintos juicios de amparo; tampo-

11 Existe una normatividad interna en la Corte según la cual los engroses se circulan por cinco días hábiles a fin de que los ministros que votaron la decisión-acto verifiquen si se tomaron en cuenta o no sus opiniones. La mayoría de las veces no se revisan los engroses, con lo cual es posible «colar» argumentos, datos o pruebas que no estaban en el acuerdo inicial. Alguna vez algún ministro protestó con relación a la variación de los engroses. Ocurrió el 28 de agosto 2008, al resolverse las acciones de inconstitucionalidad 146/2008 y 147/2008. La protesta no tuvo repercusión alguna. La suerte ya estaba echada. Esto muestra que las variaciones entre la decisiónacto y la decisión documento dan cuenta de un problema de no poca importancia en la toma de decisiones. 
co deja fuera algunas pruebas contenidas en los informes de la CIDH, contrariamente a lo acordado en la decisión-acto. Lo que más llama la atención, sin embargo, es que no existe un adecuado planteamiento de la cuestión a resolver en el recurso de revisión al que obedeció, sino que el caso se resuelve mezclando las distintas cuestiones surgidas en las diferentes etapas procesales.

Así, se empieza haciendo un recuento sobre los distintos y recientes avances jurisprudenciales en materia de tortura, especialmente a partir del caso Arzate ${ }^{12}$, a finales del 2013. Enseguida, se aclara que, a lo largo de la secuela procesal, las autoridades tuvieron la noticia de los hechos de tortura, y que omitieron los deberes constitucionales y de orden internacional de investigar los hechos denunciados, no solo como delito, sino también como violación de los derechos humanos. Posteriormente, se traza la distinción de la tortura como hecho delictivo y como práctica violatoria de derechos humanos, y se hace hincapié en que la prohibición de la tortura constituye un derecho absoluto que pertenece al dominio del ius cogens. Asimismo, se precisa cuáles son los deberes del Estado que generan ese reconocimiento, tales como la obligación de investigar cuando exista evidencia razonable y otros matices relacionados con el tema.

En otro punto del engrose la Sala se plantea que lo que debe resolverse es si se acredita o no el supuesto del art. 614, fracción VI, del Código de Procedimientos Penales para el Distrito Federal. Para ello, sin embargo, opta por analizar, no las pruebas del expediente del reconocimiento de inocencia, sino las contenidas en la causa penal del homicidio. El resultado de este análisis es que Alfonso Martín del Campo fue detenido arbitrariamente, retenido y torturado y, en consecuencia, se violaron sus derechos de libertad personal; además, que no fue puesto a disposición del Ministerio Público de forma inmediata y que no se acreditó la flagrancia. A partir de ello, la Sala concluye que todas las pruebas derivadas de tales violaciones - solo existía la confesión mediante tortura - resultan inválidas, por ser violatorias de la Constitución, de la Convención Americana sobre Derechos Humanos, así como de la Convención Interamericana para Prevenir y Sancionar la Tortura.

En seguida, se concluye que la Séptima Sala Penal del Tribunal Superior de Justicia del Distrito Federal —autoridad responsable en el amparo relativo al reconocimiento de inocencia - no debió excluir las pruebas ofrecidas por el quejoso, entre otras, los informes de la $\mathrm{CIDH}$, que habían sido excluidos en la decisión-acto y que, de conformidad con el acuerdo político al que habían llegado los ministros, no debían ser tomadas en cuenta. La Sala concluye que no existen dudas de que Alfonso Martín del Campo fue torturado ${ }^{13}$.

Finalmente, la Sala regresa a contrastar esta última valoración con las pruebas de cargo del doble homicidio, y concluye que ninguna de ellas acredita genuinamente la participación del quejoso en esos hechos, esto es, se concluye que Martín del Campo no cometió el doble homicidio que se le imputó.

Así, luego de todo este serpenteo argumental, la Sala concluye dos cosas: a) que, debido que se acreditó la tortura, quedó desvanecida la única prueba en la que se

${ }_{12}$ Cfr. Amparo en revisión 703/2012.

13 Ibid., párrafos 205, 206 y 207 de la sentencia. 
sustentó la condena de homicidio: la confesión; y b) que debe declararse fundado el incidente de reconocimiento de inocencia.

Con todo, el engrose es omiso en cuanto a la pregunta acerca de la obligatoriedad de los informes de la CIDH. No responde en modo alguno la cuestión, sino que se esfuerza por acreditar la tortura apenas mencionando los referidos informes como pruebas, pero sin señalar con alguna precisión qué papel jugaron en el razonamiento judicial.

\subsection{Lo que dicen estas variaciones}

¿Qué supone el hecho de variar una decisión-acto a la hora de redactar la decisióndocumento? A mi juicio, una falta de seriedad y una suerte de preferencia por las decisiones-acto. Dado que las variaciones no suelen ser radicales, pareciera que los ministros de la Corte las consienten, porque, por un lado, no tienen mucho tiempo para controlarlas y, por otro, los costos no son graves. Sin embargo, las variaciones demuestran que pesa más la deliberación que el documento que, se supone, las refleja. Si uno piensa en que la deliberación se lleva a cabo mediante el cumplimiento de ciertas reglas y pautas propias de la argumentación oral en los cuerpos colegiados, entonces el resultado debe ser respetado. Para ello, debería vigilarse muy de cerca el engrose, para que fuera un fiel reflejo de los acuerdos derivados del ejercicio de la deliberación racional; sin embargo, en la Corte mexicana no siempre se hace.

En lo personal, considero que este es un signo de politización de la Corte que supone un alejamiento de los argumentos por escrito, lo cual no es un asunto menor, si se piensa en que la decisión-documento será utilizada en el futuro a manera de precedente. La distorsión acaba afectando a la propia Corte cuando los ministros se dan cuenta de que el precedente que se cita no se ajusta a lo que ellos votaron en la decisión-acto. La célebre CT-293/2011 es un caso que ejemplifica esta situación, ya que cuando el engrose estuvo listo, nadie o casi nadie estaba dispuesto a admitir los términos del engrose.

La forma de resolver esta situación es la emisión de votos particulares y concurrentes que suelen acompañar a las ya de por sí voluminosas sentencias, con lo cual se complica todavía más la imagen (al menos escrita) de la Corte mexicana. Los documentos resultantes acaban siendo ininteligibles; lo cual obedece, muchas veces, a la dificultad de ensamblar cada una de las posiciones de los ministros o magistrados; ingrata tarea que corresponde a los sufridos letrados.

En suma, las variaciones, profundas o superficiales, que se dan entre las decisiones-acto y las decisiones-documento dicen mucho de la Corte Suprema. Hablan de un sistema de decisión que: no es eficiente (se invierte una gran cantidad de energía entre el proyecto inicial y la elaboración del engrose); no es transparente; no es fiel con las posiciones genuinas de los ministros y no permite que los justiciables y el público en general tengan claro cual es la postura genuina de la Corte en un determinado tema. 


\section{LAS RAZONES DE UN OLVIDO: SOBRE LA EVASIÓN DE LA CUESTIÓN}

¿Por qué la mayoría de los ministros integrantes de la Primera Sala de la SCJN prefirieron no pronunciarse (ni en la decisión-acto ni en la decisión-documento), sobre la obligatoriedad el Informe 117/09 de la CIDH? Bien pudieron argumentar que no es vinculante por no ser una sentencia internacional, o que no es una fuente formal del Derecho, o que la Corte no es la destinataria de ese tipo de informes. Sin embargo, optaron por el silencio. En la decisión-documento se hace mención de los informes de forma un tanto subrepticia.

Como sea, la resolución (acto y documento) es incompleta porque, al no responder si los informes de la CIDH son o no obligatorios, el quejoso, en primer lugar, y la comunidad jurídica, en segundo, se quedan esperando la respuesta de la Corte y, con ello, una buena cantidad de implicaciones relevantes, tales como la importancia del trabajo de la CIDH, la utilidad del compromiso internacional del Estado mexicano con relación a la Comisión, las respuestas dadas por México al interactuar con ese órgano y, en general, el valor mismo del Derecho internacional de los derechos humanos.

Entiendo que cualquier respuesta conlleva riesgos: si se opta por un sí (los Informes sí son obligatorios), entonces en el futuro cualquier Informe de la Comisión — que es un organismo cuasi-jurisdiccional— que mandatara al Poder Judicial de la Federación alterar el curso de un juicio, tendría que ser acatado con el consecuente menoscabo de la autonomía; si se opta por un no (los Informes no son obligatorios), entonces podría decirse que esas investigaciones que no terminan en la Corte de Costa Rica son papel mojado. Como sea, la pregunta no puede ser evadida sin un razonamiento, tal como se presenta en el engrose. Incluso la vía del no pronunciamiento demandaba la expresión de razones: el silencio no es una razón.

¿Cuáles son las razones de fondo? Una primera razón que encuentro es el formalismo jurídico, porque si se hubiera tratado de una sentencia de la CorteIDH no habría habido ningún problema. Es decir, pienso que la Corte supo que lo que decía el Informe, con respecto a la tortura, era cierto desde la decisión-acto, pero no podía atenderse por ser un simple informe. Sin embargo, en el engrose, la Sala parece olvidarse de esta formalidad y lo toma en cuenta aunque de forma casi residual en un obiter dicta. En estas condiciones no puede decirse que el informe haya sido realmente integrado al engrose, con lo cual la Primera Sala evadió la cuestión planteada con un costo apenas perceptible para el caso concreto, pero no así para casos futuros. En efecto, para el caso concreto, esta omisión no representó mayores problemas porque, con todo, se concedió el amparo y Alfonso Martín del Campo Dodd fue liberado, pero para otros casos la pregunta acerca de la relevancia de los pronunciamientos de la CIDH sigue en el aire.

Una segunda razón es de tipo político: hay resquemor por atender los pronunciamientos de la CIDH, quizás porque se trata de un órgano más político que jurídico con una vocación de denuncia y señalamiento de las violaciones a los derechos humanos, y a ningún Estado le gusta que le digan que sus instituciones violan derechos o que sus acciones dirigidas a prevenir o reparar esas violaciones son insuficientes. La SCJN, como parte del Estado, prefiere resolver estas cuestiones de forma doméstica, aunque ello suponga no responder a alguna de las cuestiones planteadas en el juicio de amparo. 
Este comportamiento evasivo no es aislado. Existe una marcada resistencia de la SCJN para hacerse cargo en serio del llamado nuevo paradigma ${ }^{14}$. En efecto, el caso Martín del Campo se olvidará pronto gracias a una sentencia esencialmente satisfactoria, pero al mismo tiempo se suma a otros casos relevantes relacionados con esa falta de apertura: las contradicciones de tesis 21/2011, 293/2011 (en las que se estableció que el parámetro de regularidad constitucional se compone por los derechos humanos contenidos en la Constitución y en los tratados internacionales, aunque con prevalencia de las restricciones a los derechos contenidas en el texto constitucional); y el expediente varios 1396/2011 «Inés y Valentina» (en el que se reiteró el criterio de la CT 293 en el sentido de que las restricciones a los derechos deben prevalecer incluso en contra de una sentencia internacional que condene al Estado mexicano). En todos estos casos, la Corte mexicana no ha estado a la altura de los mandatos de la reforma Constitucional de junio de 2011, porque la interpretación del texto constitucional y el cumplimiento de las sentencias de la CorteIDH han dejado mucho que desear.

El mensaje que la Corte envía con este tipo de decisiones es que las normas, pronunciamientos y resoluciones en materia de derechos humanos a cargo de organismos internacionales no tienen la fuerza obligatoria que dicen tener, porque no pueden incidir decisivamente en los casos resueltos por los tribunales nacionales. Consecuentemente, la eliminación de prácticas deleznables como la tortura y, en general, la lucha por los derechos humanos son anhelos de los que parece estar celoso el Poder Judicial de la Federación. En efecto, cuando instancias internacionales actúan en ejercicio de sus competencias y se pronuncian sobre violaciones a los derechos humanos, las respuestas de nuestra Corte no son del todo receptivas, quizás porque ve la esfera de los derechos humanos como un territorio en disputa. La sociedad mexicana es, sin duda, la gran perdedora en este jaloneo.

\section{EL INFORME 117/09 DE LA CIDH COMO INGREDIENTE DE LA DECISIÓN}

Como se ha visto, nunca se despejaron las dudas sobre si el Informe 117/09 de la CIDH resultaba o no vinculante para el Estado mexicano y, por ende, si podía ser considerado para integrarlo en el razonamiento judicial. A mi juicio, habría sido adecuado

14 La expresión «nuevo paradigma» suele aplicarse al cambio de perspectiva surgido en México, a partir de las reformas constitucionales y legales en materia de Derechos Humanos y juicio de amparo de 2011 y 2013, pero especialmente a partir de la interpretación que la Suprema Corte de Justicia de la Nación llevó a cabo al respecto, al resolver el expediente varios 912/2010 (cumplimiento de la sentencia de la CorteIDH en el Caso Rosendo Radilla Pacheco), el 12 de julio de 2011. Como se sabe, a partir de esos cambios, se entiende que todas las autoridades del país, dentro del ámbito de sus competencias, tienen la obligación de velar no solo por los derechos humanos contenidos en la Constitución Federal, sino también por aquellos contenidos en los instrumentos internacionales celebrados por el Estado mexicano, adoptando la interpretación más favorable al derecho humano de que se trate, lo que se conoce en la doctrina como principio pro persona. Estos mandatos - dijo el Tribunal Pleno_- deben interpretarse junto con lo establecido en el art. 133 constitucional; así, se obtiene que, aun cuando existieren disposiciones en contrario, los jueces están obligados a preferir los derechos humanos contenidos en la Constitución y en los tratados internacionales; consecuentemente, dejarán de aplicar esas normas inferiores dando preferencia a las contenidas en la Constitución y en los tratados en la materia. Cfr. R. Lara Chagoyán, Argumentación jurídica. Estudios prácticos, 2. ${ }^{a}$ ed., México, Porrúa, 2015, 57-59. 
responder esta cuestión distinguiendo entre obligatoriedad del instrumento y utilidad de su contenido, como a continuación mostraré.

\subsection{Respondiendo el planteamiento del quejoso}

Como se sabe, la obligación de cumplir lo dispuesto en las resoluciones emitidas por órganos internacionales en materia de derechos humanos corresponde a un principio básico del derecho sobre la responsabilidad internacional del Estado, respaldado por la jurisprudencia internacional, llamado pacta sunt servanda, según el cual los Estados deben cumplir el tratado internacional de buena fe ${ }^{15}$. Al respecto, el art. 26 de la Convención de Viena sobre el Derecho de los Tratados de 1969, ratificada por México el 5 de julio de 1974, por el presidente Luis Echeverría Álvarez ${ }^{16}$, establece que: «[t] odo tratado en vigor obliga a las partes y debe ser cumplido por ellas de buena fe». Por otra parte, el art. 27 del mismo tratado establece que los Estados no pueden «invocar las disposiciones de su derecho interno como justificación del incumplimiento de un tratado». Así, las obligaciones de los Estados parte vinculan a todos los poderes y órganos del Estado, los cuales tienen el deber de cumplir de buena fe con el derecho internacional ${ }^{17}$.

En específico, en relación con el Sistema Interamericano de Derechos Humanos, de conformidad con el art. 2 de la Convención Americana sobre Derechos Humanos, los Estados tienen la obligación de «adoptar, con arreglo a sus procedimientos constitucionales y a las disposiciones de (dicha) Convención, las medidas legislativas o de otro carácter que fueren necesarias para hacer efectivos (los) derechos y libertades» reconocidos en dicho tratado. Ello podría implicar, dependiendo de la situación concreta, dos cosas: i) la supresión de las normas y prácticas de cualquier naturaleza que signifiquen una violación a la Convención, o ii) la expedición de normas y el desarrollo de prácticas conducentes a la efectiva observancia de dicho instrumento ${ }^{18}$.

15 Cfr. Responsabilidad internacional por expedición y aplicación de leyes violatorias de la Convención (arts. 1 y 2 de la Convención Americana sobre Derechos Humanos). Opinión Consultiva OC-14/94 de 9 de diciembre de 1994. Serie A No. 14, párr. 35, y Caso Barrios Altos vs. Perú. Supervisión de cumplimiento de Sentencia. Resolución de la CorteIDH de 7 de septiembre de 2012, considerando cuarto. Lo anterior ha sido recogido en «Resolución aprobada por la Asamblea General [sobre la base del Informe de la Sexta Comisión (A/56/589 y Corr.1)] 56/83, Responsabilidad del Estado por hechos internacionalmente ilícitos, 85. ${ }^{a}$ sesión plenaria, de 12 de diciembre de 2001, Documentos Oficiales de la Asamblea General, quincuagésimo sexto periodo de sesiones, Suplemento No. 10 y correcciones (A/56/10 y Corr.1 y 2). Corte IDH. Resolución de cumplimiento de sentencia de 20 de marzo de 2013 en el caso Gelman vs. Uruguay, párr. 59».

16 Conviene tener presente que la Cámara de Senadores aprobó la Convención de Viena el 29 de diciembre de 1972, y fue publicada en el Diario Oficial de la Federación el 14 de febrero de 1975.

${ }_{17} \mathrm{Cfr}$. Corte IDH. Resolución de cumplimiento de sentencia de 20 de marzo de 2013 en el caso Gelman vs. Uruguay, párr. 59. Caso Castillo Petruzzi y otros vs. Perú. Supervisión de Cumplimiento de Sentencia. Resolución de la CorteIDH de 17 de noviembre de 1999, considerando cuarto, y Caso Barrios Altos vs. Perú. Supervisión de cumplimiento de Sentencia. Resolución de la CorteIDH de 7 de septiembre de 2012, considerando cuarto.

${ }_{18}$ Cfr. Corte IDH. Resolución de cumplimiento de sentencia de 20 de marzo de 2013 en el caso Gelman vs. Uruguay, párr. 60. Caso Almonacid Arellano y otros vs. Chile. Excepciones Preliminares, Fondo, Reparaciones y Costas. Sentencia de 26 de septiembre de 2006. Serie C No. 154, párr. 118; Caso Ximenes Lopes vs. Brasil.Fondo, Reparaciones y Costas. Sentencia de 4 de julio de 2006. Serie C No. 149, párr. 83, y Caso «La Última Tentación de Cristo» (Olmedo Bustos y otros). Sentencia de 5 de febrero de 2001. Serie C No. 73, párr. 85. La Corte ha 
Con base en lo anterior, podemos concluir que los Estados deben garantizar tanto el cumplimiento de lo que se han obligado al ratificar los diferentes tratados en materia de derechos humanos, como su efecto útil en el plano de sus respectivos derechos internos. Es importante destacar que este principio se aplica tanto a las normas sustantivas de los tratados de derechos humanos (las que contienen disposiciones sobre los derechos reconocidos), como a las normas procesales ${ }^{19}$.

Conviene precisar que en el sistema interamericano de derechos humanos existen diferencias conceptuales entre las sentencias emitidas por tribunales internacionales (vgr. Corte IDH $)^{20}$ y las decisiones - informes, resoluciones y opiniones- emitidas por otros órganos internacionales de derechos humanos, cuya naturaleza puede variar entre sí (vgr. $\mathrm{CIDH}^{21}$, el Comité de Derechos Humanos de Naciones Unidas ${ }^{22}$, los diferentes Grupos de Trabajo de la ONU) ${ }^{23}$.

afirmado en relación con ello que, [e]n el derecho de gentes, una norma consuetudinaria prescribe que un Estado que ha celebrado un convenio internacional, debe introducir en su derecho interno las modificaciones necesarias para asegurar la ejecución de las obligaciones asumidas. Esta norma aparece como válida universalmente y ha sido calificada por la jurisprudencia como un principio evidente («príncipe allant de soi»; Echange des populations grecques et turques, avis consultatif, 1925, C.P.J.I., série B, no. 10, p. 20). Cfr. Caso Almonacid Arellano y otros vs. Chile, párr. 117; Caso «Instituto de Reeducación del Menor» vs. Paraguay. Excepciones Preliminares, Fondo, Reparaciones y Costas. Sentencia de 2 de septiembre de 2004. Serie C No. 112, párr. 205, y Caso Bulacio Vs. Argentina. Fondo, Reparaciones y Costas. Sentencia de 18 de septiembre de 2003. Serie C No. 100, párr. 140.

19 Cfr. Corte IDH. Resolución de cumplimiento de sentencia de 20 de marzo de 2013 en el caso Gelman vs. Uruguay, párr. 63. Caso Ivcher Bronstein vs. Perú. Competencia. Sentencia de 24 de septiembre de 1999. Serie C No. 54, párr. 37, y Caso Barrios Altos vs. Perú. Supervisión de cumplimiento de Sentencia. Resolución de la CorteIDH de 7 de septiembre de 2012, considerando quinto.

${ }^{20}$ De conformidad con lo establecido en el art. 67 de la Convención Americana, «[e]l fallo de la Corte será definitivo e inapelable», el cual produce los efectos de autoridad de cosa juzgada. Asimismo, el art. 68.1 de la Convención Americana estipula que «[1] os Estados Partes en la Convención se comprometen a cumplir la decisión de la Corte en todo caso en que sean partes». En el mismo sentido, la SCJN, al resolver el expediente Varios 912/2010, estableció que «las resoluciones pronunciadas por (la Corte Interamericana) son obligatorias para todos los órganos del Estado mexicano al haber figurado como parte en un litigio concreto». Vid. la Tesis Aislada P. LXV/2011 (9. ${ }^{a}$.

${ }^{21} \mathrm{El}$ art. 50 de la Convención Americana sobre Derechos Humanos establece:

1. De no llegarse a una solución, y dentro del plazo que fije el Estatuto de la Comisión, esta redactará un Informe en el que expondrá los hechos y sus conclusiones. Si el Informe no representa, en todo o en parte, la opinión unánime de los miembros de la Comisión, cualquiera de ellos podrá agregar a dicho Informe su opinión por separado. También se agregarán al Informe las exposiciones verbales o escritas que hayan hecho los interesados en virtud del inciso 1.e. del art. 48.

2. El Informe será transmitido a los Estados interesados, quienes no estarán facultados para publicarlo.

3. Al transmitir el Informe, la Comisión puede formular las proposiciones y recomendaciones que juzgue adecuadas.

El art. 51, por su parte, establece lo siguiente:

1. Si en el plazo de tres meses, a partir de la remisión a los Estados interesados del Informe de la Comisión, el asunto no ha sido solucionado o sometido a la decisión de la Corte por la Comisión o por el Estado interesado, aceptando su competencia, la Comisión podrá emitir, por mayoría absoluta de votos de sus miembros, su opinión y conclusiones sobre la cuestión sometida a su consideración.

2. La Comisión hará las recomendaciones pertinentes y fijará un plazo dentro del cual el Estado debe tomar las medidas que le competan para remediar la situación examinada.

3. Transcurrido el periodo fijado, la Comisión decidirá, por la mayoría absoluta de votos de sus miembros, si el Estado ha tomado o no medidas adecuadas y si publica o no su Informe.

${ }^{22}$ De conformidad con el Pacto de Derechos Civiles y Políticos, el Comité de Derechos Humanos podrá presentar Informes sobre los Estados Parte. Vid. art. 28 y ss.

${ }^{23}$ Existen tres tipos: a) grupos de trabajo; $b$ ) grupo de trabajo especial; c) grupos de trabajo especial de composición abierta; y d) grupos de trabajo de composición abierta, vid. bttp://www.un.org/es/ga/about/ subsidiary/other.shtml. 
No obstante lo anterior, es claro que existe la obligación internacional de cumplir de buena fe con los tratados (pacta sunt servanda) y que, si bien no todos los instrumentos obligan de la misma forma o con la misma intensidad, ello no implica que aquellos que no son sentencias no tengan ningún valor.

Lo anterior nos lleva a afirmar que unos y otros instrumentos obligan de manera distinta o en distinto grado. Para poder distinguir entre uno y otro tipo de obligaciones, me voy a permitir introducir, de manera estipulativa, la distinción entre «deber» y «obligación». Al respecto, Juan Carlos Bayón ha señalado que estos términos se han usado la mayoría de las veces como equivalentes, pero que hay quienes han encontrado una diferencia notable entre ellos. Sucintamente, viene a decir que por «deber» habría que entender la modalidad o posición normativa más elemental, es decir, una conducta calificada deónticamente como no opcional; «tener un deber» es, simplemente, ser destinatario de una norma de ese tipo. Por «obligación», en cambio, se podría entender alguna clase de modalidad o posición normativa compleja que podría estar determinada por la conexión entre una norma N1 que prescribe una conducta a un agente A1 y otra norma N2 que prescribe a cierto órgano aplicar una sanción a A1 si transgrede N1, de manera que una obligación implicaría la combinación de dos «deberes». Otra manera de entender a la obligación jurídica es verla como «una posición normativa compleja integrada, según los casos, por diferentes combinaciones de «deberes» $\mathrm{y}$ - suponiendo que no sean a su vez reductibles a «deberes»— situaciones de poder normativo - y correlativa sujeción-o ausencia del mismo ${ }^{24}$.

Pues bien, podemos convenir en que las sentencias internacionales son obligatorias en el sentido apuntado, mientras que las decisiones - Informes, resoluciones y opiniones- son debidas, es decir, no opcionales. La consecuencia de cada una de ellas es distinta: en el primer caso, el Estado mexicano es responsable del incumplimiento y podría ser sancionado internacionalmente por ello; mientras que en el segundo caso, la consecuencia sería simbólica - incluso política - y podría suponer un desprestigio internacional.

Con el objeto de hacer más sencillo el uso de la distinción, podemos convenir en que las sentencias son obligatorias en sentido estricto, mientras que las decisiones son obligaciones en sentido amplio. De este modo, podemos concluir que el Informe 117/09 es obligatorio en sentido amplio, lo cual implica que el Estado mexicano, en este caso la SCJN, no puede obviar su existencia, sino que debe tomarlo en cuenta, debe usarlo en algún sentido que resulte justificado.

\section{2. ¿Qué utilidad tiene el Informe 117/09 de la CIDH?}

La autoridad responsable del amparo, el Juez de Distrito y también la Primera Sala de la SCJN fueron conscientes, cada uno en su momento, de que la única prueba por la que se había condenado a Alfonso Martín del Campo era la confesión, porque así lo había reconocido el Tribunal de apelación de la causa penal — la Octava Sala del

${ }^{24}$ Cfr. J. C. BAYÓN, «Deber Jurídico», en Enciclopedia Iberoamericana de Filosofía. El Derecho y la Justicia, edición de E. GARZÓN VALDÉS y F. LAPORTA, Madrid, Trotta, 1996, 325. 
Tribunal Superior de Justicia del Distrito Federal— en el expediente toca 454/93, de 17 de agosto de 1993, en cuya página 29 se afirma:

La declaración confesoria aludida, rendida por el ahora procesado, resulta ser el único indicio de prueba relevante en cuanto al esclarecimiento de los derechos que nos ocupa, pues el precitado inculpado es el único que establece un panorama respecto a la forma en que acaecieron los hechos.

Sin embargo, lo que no resultaba claro era que la confesión hubiera sido obtenida mediante actos de tortura, porque, desde el punto de vista jurídico, la tortura no estaba probada ni en la causa penal, ni el primer juicio de amparo, ni en el primer reconocimiento de inocencia. Por ello, resultaba imprescindible acreditar la tortura en el reconocimiento de inocencia. Pues bien, el Informe 117/09 de la CIDH habría valido para este propósito. Veamos.

A lo largo de las discusiones de este caso, nunca quedó clara cuál era la relevancia de determinar la obligatoriedad del Informe 117/09 de la CIDH. El Informe está dirigido al Estado mexicano a través de una serie de recomendaciones que se traducen en el impulso de una serie de medidas orientadas a la anulación de la confesión de Alfonso Martín del Campo, así como de todas las pruebas derivadas de la misma; a la revisión de todo el proceso judicial; a su liberación inmediata; a la investigación de los hechos de tortura y sanción de los responsables; y a la reparación de las violaciones ${ }^{25}$.

Siendo así las cosas, ni la autoridad responsable, ni el juez de Distrito, ni la Primera Sala de la SCJN eran destinatarias de esas recomendaciones; por ello, ninguna de ellas podría haber ordenado, por ejemplo, la liberación de Alfonso Martín del Campo.

Lo anterior es así, porque el reconocimiento de inocencia no es un mecanismo para atender las indicaciones del Informe de fondo, ya que ninguna de las autoridades mencionadas resultaba competente para ello. Por ello, resulta extraño que el juez de Distrito, en una clara desviación de la cuestión, resolviera el juicio de amparo como si se le hubiere preguntado por la soberanía del Estado o por las especificaciones técnicas de un informe de la CIDH frente a una sentencia de la CorteIDH.

El Informe 117/09 debió haberse tomado en cuenta como una prueba, tal como lo ofreció Alfonso Martín del Campo, y que arroja información sobre hechos que no fueron controvertidos por el Estado mexicano, es decir, que este los da por ciertos y que además cuentan con un respaldo probatorio e institucional que así lo demuestra. En efecto, las conclusiones del Informe 117/09 son las siguientes:

\section{CONCLUSIONES}

126. Con base en las consideraciones de hecho y de derecho que anteceden, la Comisión Interamericana ratifica su conclusión respecto a que Alfonso Martín del Campo Dodd fue detenido arbitrariamente el 30 de mayo de 1992 y sometido a torturas y otros tratos crueles, inhumanos y degradantes por policías judiciales de la Ciudad de México, con el objeto de hacerle confesar el homicidio de su hermana Juana Patricia Martín del Campo Dodd, y su cuñado Gerardo Zamudio Aldaba, cometido la noche anterior.

127. Igualmente, la CIDH reitera que no se respetaron las garantías del debido proceso de Alfonso Martín del Campo Dodd, en particular el derecho a la presunción de

25 Cfr. Informe 117/09 de la CIDH, párrafos del 129 al 132. 
inocencia, en virtud del valor otorgado por distintos magistrados a su supuesta confesión obtenida bajo tortura. Tampoco se garantizó a la víctima en el presente caso la protección de sus derechos fundamentales.

128. Asimismo, reitera que los hechos establecidos en el presente informe constituyen violaciones de los artículos 5, 7, 8(1), 8(2), 8(3) y 25 de la Convención Americana, así como de los artículos 6, 8, y 10 de la Convención Interamericana para Prevenir y Sancionar la Tortura; todo ello en violación al deber de respeto y garantía consagrado en el artículo 1(1) de la Convención Americana.

Por lo anterior, si al resolver el recurso de revisión en el juicio de amparo, la Primera Sala de la SCJN hubiera atendido la cuestión efectivamente planteada, entonces habría tenido que rectificar la valoración del juez de Distrito señalando que el Informe 117/09 de la CIDH resultaba obligatorio en el sentido de «no opcional» (supra $\$ 4.1$ ) y, en consecuencia, habría podido valorar de primera mano las afirmaciones sobre los hechos de tortura ahí contenidas, sin necesidad de haber complicado tanto las cosas.

\section{A MANERA DE CONCLUSIÓN}

La Corte mexicana, como cualquier tribunal de máxima instancia, resuelve conflictos mediante una decisión basada en argumentos. La forma de decidir, sin embargo, es peculiar en el caso mexicano porque el acto de decisión no siempre se corresponde con el documento (engrose) que contiene las razones de la decisión. Esta variación es relevante porque impacta al funcionamiento de la Corte y a su legitimidad de cara a la sociedad. He buscado exponer esta situación mediante el análisis de un caso controvertido: Martín del Campo, en el que uno de los temas centrales era pronunciarse sobre la obligatoriedad de los informes de la CIDH. En la decisión-acto se excluyen, pero en la decisión-documento no queda clara la exclusión. Con todo, en ninguna de las dos decisiones se responde realmente un planteamiento central: la obligatoriedad de dichos informes.

A mi juicio, era perfectamente posible hacerse cargo del tema de la obligatoriedad, mediante una adecuada integración de algunos materiales probatorios provenientes del Derecho Internacional de los derechos humanos al razonamiento judicial. De este modo, la solución del caso habría sido mucho más simple: se habría podido declarar fundado el recurso de revisión del quejoso y, por ende, se habría podido convertir la concesión del amparo «para efectos» en una concesión «lisa y llana».

Sin duda, la deliberada evasión de la cuestión relativa a la obligatoriedad el Informe 117/09 de la CIDH es una cuestión preocupante. Pareciera como si un fantasma vagara por el edificio de Pino Suárez núm. 2, del Centro Histórico de la Ciudad de México (locación del edificio sede de la SCJN) y dejase cierto influjo formalista entre sus muros. Este influjo parece tener un efecto de rechazo hacia los pronunciamientos de la CIDH, quizás por no ser un órgano plenamente jurisdiccional, aunque lo que diga sea cierto. Formalismo y política se funden en ese rechazo. Es una lástima que lo que se rechace sean denuncias y señalamientos de violaciones a los derechos humanos.

El presente caso se suma a otros en los que se nota una suerte de resistencia de la SCJN para hacerse cargo del nuevo paradigma. Se trata, al menos, de las contradiccio- 
nes de tesis 21/2011, 293/2011 (en las que se estableció que el parámetro de regularidad constitucional se compone por los derechos humanos contenidos en la Constitución y en los tratados internacionales, aunque con prevalencia de las restricciones a los derechos contenidas en el texto constitucional); y el expediente varios 1396/2011 «Inés y Valentina» (en el que se reiteró el criterio de la CT 293 en el sentido de que las restricciones a los derechos deben prevalecer incluso en contra de una sentencia internacional que condene al Estado mexicano). Esta colección de casos muestra que la Corte no parece ir en la dirección marcada por el Constituyente en la reforma Constitucional de junio de 2011, porque la interpretación llevada a cabo por la Corte no ha estado a la altura de esos mandatos, ya que se ha inclinado la balanza hacia los valores de la autoridad y de la ley, que a los derechos humanos y los límites al ejercicio del poder. Por ello, parece que vale más una restricción al ejercicio de un derecho humano que el derecho humano mismo.

Nuestra Corte no parece apreciar y aceptar libremente las normas, pronunciamientos y resoluciones en materia de derechos humanos a cargo de organismos internacionales. No se trata de que los «acepte sin más», sino de que sepa abrir el razonamiento judicial para incorporar racionalmente algunos contenidos provenientes del Derecho internacional. Sin embrago, con sus últimas resoluciones, la Corte parece estar celosa de ese territorio en disputa que constituyen las violaciones a los derechos humanos. Pareciera que quisiera resolverlos sin ayuda del exterior, sin la colaboración de instancias que parece considerar de dudosa autoridad, como el Sistema Interamericano de Derechos Humanos. Mientras eso sucede, las prácticas deleznables como la tortura y, en general, las violaciones a los derechos humanos no disminuyen, sino que aumentan de manera preocupante. Ante este panorama desolador, ¿será correcta una actitud anti-aperturista?

En suma, con este trabajo he buscado mostrar que el proceso argumentativo de una sentencia es tan importante como el producto del mismo. Por ello, la selección de las estrategias metodológicas para abordar un caso como este no es cosa menor. Pensando en ello, he tratado de hacer una evaluación tanto del proceso decisorio como del engrose elaborado. El balance final nos habla de una buena decisión en general, aunque accidentada y complicada en su proceso y con una cuestión no resuelta: la obligatoriedad de los informes de la CIDH. 



\title{
HASTA QUE LA MUERTE LOS SEPARA. LEGÍTIMA, DERECHO DE PROPIEDAD Y PROHIBICIÓN DE DISPOSICIÓN DEL TITULAR DE LOS BIENES: UN EJEMPLO PRÁCTICO DE INCONSISTENCIA NORMATIVA*
}

\author{
Alberto Carrio Sampedro \\ Universitat Pompeu Fabra \\ alberto.carrio@upf.edu
}

RESUMEN. La institución de la legítima ha generado un interesante debate entre la doctrina iusprivatista que atañe a dos cuestiones estrechamente emparentadas con la teoría del Derecho, como son la función y estructura del ordenamiento jurídico.

En el presente artículo examino cuáles y de qué tipo son las razones que se ofrecen a favor y en contra de la legítima. Esto me permite distinguir las razones justificativas de las identificativas del Derecho. Es decir, las que se refieren al porqué de la legítima de las que informan de qué es la legítima, o lo que es lo mismo, cuál es la configuración de este instituto en el ordenamiento jurídico. A continuación examino la compatibilidad de la legítima con los derechos de herencia y de propiedad tal como vienen enunciados en la Constitución española. Propondré entonces dos posibles interpretaciones del enunciado constitucional que vincula ambos derechos y mostraré qué argumentos sustentan una y otra.

Finalmente pongo de manifiesto la incoherencia de la legítima con una de las dos posibles interpretaciones del art. 33.1 de la Constitución española y la dudosa compatibilidad con la otra al situar en una posición de privilegio a ciertos parientes del causante, o si se prefiere, en una posición de no derecho al propietario de los bienes. Es decir al titular de un derecho que goza de garantía institucional.

El artículo concluye con un apéndice en el que i) identifico el tipo de inconsistencia que introduce la legítima en el ordenamiento jurídico español, y ii) propongo reconducir el debate a partir de una distinción adecuada entre el ámbito de justificación e identificación del Derecho.

Palabras clave: legítima, propiedad, herencia, coherencia del ordenamiento jurídico, inconsistencia, identificación y justificación del Derecho.

* Fecha de recepción: 20 de julio de 2016. Fecha de aceptación: 16 de febrero de 2017.

Agradezco a Sebastián AgüEro, José Luis Pérez TriviÑo, Lorena RAmíreZ y Josep Maria Vilajosana haberse tomado la molestia de leer las versiones previas de este artículo y la generosidad de sus comentarios y sugerencias que me han permitido mejorarlo formal y sustancialmente. Asimismo quiero agradecer a los revisores anónimos de Doxa sus acertadas observaciones y comentarios. 


\section{Until Death do Them Part. Legitimate Portion, Ownership and the Ban on the Disposal of Goods by the Property Holder: a Practical Example of Normative Inconsistency}

ABSTRACT. Forced heirship has raised an interesting disagreement among academics, which is linked with two key questions of Legal theory: the function and structure of Legal systems.

In this article I examine what are the pro and cons of forced heirship and what kind of reasons support each of them. This allows me to distinguish between justificatory and identifying reasons of the Law. This is, the reasons that answer the question of why should or should not exist forced hiership from the reasons that explain what forced heirship is. Next I examine the compatibility of forced heirship with both, the rights of inheritance and property as they are enounced by the Spanish Constitution. Then, I will propose two ways of interpretation of the constitutional text in which both rights are linked, and I will try to show what their grounds are.

Finally, I show the incoherence of forced hiership with one of the two possible interpretations of the Spanish Constitution, and the hard compatibility with the other one. Certainly, forced hiership puts into a position of privilege some relatives of the holder of the right of property while places the proper holder in a position of no right.

The article ends with an appendix in which I identify what kind of inconsistency introduces force hiership in the Spanish legal system and a way to bring fruitful the academic debate from the proper distinction between the justificatory and identifying domains of the Law.

Keywords: forced hiership, property, inheritance, coherence of Legal system, inconsistency, identifying and justification of the Law.

\section{INTRODUCCIÓN}

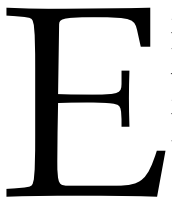

n el presente artículo me propongo examinar la institución jurídica de la legítima tal y como se encuentra actualmente configurada en nuestro ordenamiento jurídico. Dos son las razones que me mueven a ello. De una parte, participar modestamente en el debate generado entre la doctrina más autorizada en relación con este instituto jurídico. En este sentido, analizaré las razones que se ofrecen a favor y en contra del mismo, que son, como veremos en el apartado segundo, razones justificativas de su permanencia, modificación o derogación. La segunda razón, aunque emparentada con lo anterior, tiene que ver con una cuestión menos coyuntural. La de comprobar el encaje constitucional de la legítima y, en suma, la coherencia interna del ordenamiento jurídico, que analizaré en el apartado tercero. En el cuarto apartado examino la relación entre los derechos de propiedad y de herencia que establece el art. 33.1 de la Constitución española. Sostendré que el tenor literal de este artículo permite dos lecturas contrapuestas y enunciaré dos tesis interpretativas que se desprenden de cada una de estas lecturas del texto constitucional. Denominaré tesis de la conjunción de la titularidad (TCT) a la primera y tesis de la disyunción de la titularidad (TDT) a la segunda. En el siguiente apartado, el quinto, examinaré las razones que avalan cada una de estas tesis y la relación que guarda con ellas el instituto de la legítima. Mostraré entonces que la legítima tan solo es compatible con la segunda de estas tesis si se prueba que la garantía institucional de la herencia se extiende también al derecho de los legitimarios. Con la intención de enfocar adecuadamente el debate y comprobar cuáles son las vías de solución del aparente dilema al que conduce, el artículo concluye con un apéndice en el que identifico el tipo de inconsistencia que genera la legítima en el ordenamiento jurídico. Con todo ello trato 
de poner de manifiesto que el debate, para ser fructífero, debe deslindar claramente los argumentos que se ofrecen en el ámbito de identificación y en el de justificación del Derecho dado que no siempre son intercambiables entre sí.

\section{EL DEBATE EN TORNO A LA INSTITUCIÓN DE LA LEGÍTIMA}

La institución jurídica de la legítima y en particular el alcance que esta deba tener, ha generado una interesante controversia entre juristas. Así, hay quien sostiene que la legítima debería desaparecer dado que se ha diluido la función que estaba llamada a desempeñar tiempo atrás. Esta posición, ciertamente minoritaria, centra la crítica en la pérdida de eficacia del instituto jurídico, que justificaría su derogación ${ }^{1}$.

La gran mayoría de la dogmática se inclina, sin embargo, por reconocer cierta función a la institución legitimaria, aun cuando existen importantes discrepancias en relación con cuál deba ser su alcance ${ }^{2}$.

De este modo, defensores y detractores coinciden en señalar el impacto que el derecho de legítima tiene en el de propiedad. Pero mientras que para los primeros la pérdida de eficacia del instituto jurídico justificaría su desaparición, que conllevaría, a su vez, una adecuada protección del derecho de propiedad ${ }^{3}$; para los segundos tal pérdida de eficacia es, en todo caso, relativa y, a lo sumo, lo que el instituto jurídico requiere es alguna modificación que permita atemperar ambos derechos ${ }^{4}$. De este modo, las razones que alegan los defensores y detractores de la legítima tienen en común que se basan en algún cálculo de utilidad, o lo que es lo mismo, de eficiencia del Derecho.

No deja de ser curioso que el debate, así planteado, se centre en una cuestión valorativa o, si se prefiere, externa al ordenamiento jurídico, antes que en la descriptiva o interna. La cual es, por otra parte, la que se espera que los juristas aborden en primer lugar.

Ciertamente, la doctrina es unánime a la hora de reconocer la plena vigencia de la institución de la legítima allí donde existe. Y justamente ocurre lo contrario en los ordenamientos jurídicos que no la contemplan o que, como es el caso del español, admiten una variedad de regímenes que transitan de uno a otro extremo. Pero esto no permite avanzar demasiado. A lo sumo, se puede concluir que existe un reconocimiento generalizado de los operadores jurídicos que dota de estabilidad a cada ordenamiento jurídico de referencia, lo cual permite, a su vez, abordar una discusión coherente sobre las razones internas y externas que justifican la existencia o inexistencia de la legítima en cada uno de ellos 5 . Ahora bien, esto exige deslindar adecuadamente unas y otras razones. Es decir, analizar en primer lugar si existen razones internas que justifiquen la existencia o inexistencia de la legítima y, con independencia de cuál sea la respuesta,

\footnotetext{
1 Calatayud (1995), Valladares (2004) y Magariños (2005).

DíEZ-PiCAZo y Gullón (2006) y Delgado (2006).

VALladares (2004), Magariños (2005) y Cobas (2006).

4 LÓPEZ (2002), PARRA (2009) y DELGADO (2011) y (2012).

5 Una esmerada exposición de las diferentes regulaciones de la legítima en el derecho comparado se encuentra en ALCOY (2007) y PARRA (2009).
} 
esgrimir después las de utilidad ${ }^{6}$. De no hacerlo así, el debate jurídico se torna farragoso y tienden a confundirse dos planos diferentes, aunque relacionados, del Derecho.

Pero no adelantemos acontecimientos que no hacen más que entorpecer el hilo argumental. Veamos primero en qué consiste la institución de la legítima y de qué tipo son las razones que se ofrecen a favor y en contra de la misma.

\subsection{La institución de la legítima}

La legítima viene definida en el art. 806 del Código Civil español como

«... la porción de bienes de que el testador no puede disponer por haberla reservado la ley a determinados herederos, llamados por esto herederos forzosos» ${ }^{7}$.

La norma que se extrae de este enunciado es claramente imperativa: la prohibición de disposición $(P h \mathrm{~d})$ del testador de esa porción de bienes de la cual es titular. Así pues, a tenor de lo que dispone el art. 806 del CC, la legítima opera como un límite a la voluntad expresa del causante. O dicho de otro modo, el derecho de los legitimarios queda fuera de la capacidad de decisión del propietario testador ${ }^{8}$. Puede afirmarse en consecuencia que, en tanto que norma imperativa, una de las caras de la legítima resguarda el derecho de los legitimarios, mientras que la otra impone una restricción a la voluntad del causante. En suma, la obligatoriedad de la legítima $(O l)$ lleva aparejada la prohibición de disposición del titular del derecho de propiedad $(\mathrm{Phd}$ ) A continuación examinaré con un poco más de detalle cada una de estas vertientes de la legítima.

\subsubsection{La legítima como derecho de los legitimarios}

En tanto que derecho de los legitimarios $(\mathrm{Ol})$, la legítima protege el interés de los parientes más próximos del causante, generalmente descendientes y ascendientes, y en algunos casos al cónyuge. Las razones que avalan este derecho de los legitimarios son dispares. En algunas ocasiones se afirma que el derecho de legítima garantiza cierta igualdad entre los herederos, a los que el Código Civil denomina forzosos en desafortunada expresión. Otras que el instituto de la legítima asegura cierta función asistencial de la herencia y contribuye con ello a fortalecer la solidaridad intergeneracional ${ }^{9}$.

Sin perjuicio de la inapropiada expresión del Código Civil, que llama a la confusión entre herederos y legitimarios pese a la diferente posición jurídica que ostenta cada uno de ellos ${ }^{10}$; la institución de la legítima parece llamada a cumplir ciertas funciones básicas

\footnotetext{
6 Como afirma Vilajosana, la importancia del análisis conceptual radica en «ofrecer una concepción de nuestra red conceptual en un determinado campo que pueda explicar nuestras intuiciones conceptuales»; VILAJOSANA (2007).

7 Cfr. art. 806 del Código Civil.

8 La jurisprudencia no ofrece ninguna duda en relación con este extremo. Véanse al respecto SSTS de 5 de octubre de 1991, 6 de abril de 1998 y 9 de julio de 2002.

9 SChÖPflin (2006), DE WAal (2007) y LAMARCa (2014).

10 Ciertamente el heredero puede serlo por voluntad del causante o por previsión legal, mientras que el legitimario tan solo obedece a esta última. Por lo demás tanto herederos como legitimarios pueden renunciar a su derecho, por lo que el calificativo de forzoso tan solo opera contra la voluntad del causante.
} 
del Derecho. Proporciona seguridad jurídica a los parientes más próximos del causante dado que asegura sus expectativas frente a los actos de disposición de aquel, bien sean inter vivos o de última voluntad. Soluciona también un problema de coordinación entre los herederos del causante y entre este y aquellos. El derecho de los legitimarios condiciona ciertamente los actos de disposición del causante y, de este modo, permite acomodar las decisiones de uno y las expectativas de los otros ${ }^{11}$. A ello habría que añadir que este instituto jurídico vendría a evitar un problema de interacción estratégica entre los herederos de tal manera que evitaría la competencia desleal entre ellos ${ }^{12}$. La función de justicia social, en fin, porque si es discutible que una obligación jurídica como la que impone la institución de la legítima contribuya a fortalecer una razón moral como es la solidaridad intergeneracional, lo cierto es que garantiza al menos el derecho de los parientes más próximos a una porción de los bienes del causante ${ }^{13}$. Cuestión diferente es, si este es el concepto de solidaridad intergeneracional que debe proteger el Derecho.

Sea como fuere, lo cierto es que una vez examinada esta cara de la legítima parece innegable que posee cierta utilidad.

\subsubsection{Y como restricción de la voluntad del causante}

La cruz de la moneda es la restricción que la legítima impone a la voluntad del causante $(P h d)$. El grueso de la controversia radica aquí en la cuestionada utilidad de un instituto jurídico que en la actualidad difícilmente cumple las funciones que estuvo llamado a desempeñar. Con el fin de liberar o al menos disminuir el peso de esta carga legal a la que queda sujeto el testador se han hecho varias propuestas interesantes. También entre ellas se encuentran razones variadas que justifican la revisión de la legítima. Algunas se refieren a la conveniente adaptación del ordenamiento jurídico a un mundo cada vez más globalizado en el que la tendencia parece ser la erradicación o en todo caso disminución notable de las legítimas ${ }^{14}$. Otras señalan el progresivo envejecimiento de nuestras sociedades, con lo que pierde peso la función asistencial y de sustento que la legítima cumplió en otras épocas. Sin que falten las que señalan que el instituto de la legítima es actualmente un obstáculo para el desarrollo del sector empresarial ${ }^{15}$. Últimamente van cobrando importancia también las propuestas que se refieren a la necesidad de relajar las causas de privación de la legítima ${ }^{16}$. Todas estas razones hacen hincapié en la perdida de utilidad y, en definitiva, la ineficiencia de un instituto jurídico que ha devenido arcaico y que genera, además, problemas jurídicos relevantes como pueden ser los de determinación de la ley aplicable a los actos de última voluntad o declaraciones de nulidad ${ }^{17}$.

Como hemos visto hasta aquí, tanto las razones a favor como en contra de la legítima hacen referencia a su utilidad, es decir a lo que cabría denominar la justificación

\footnotetext{
11 Busto (2015).

12 Cainismo entre parientes, lo denomina LAMARCA (2014).

13 López (1994), CARrasco (2003), DE WAal (2007) y LAMARCa (2014).

14 Alcoy (2007) y FerRer (2011).

15 MAgariños (2005) y SÁEZ-SANTURTUN (2008).

16 Arroyo y Farnós (2015).

17 Álvarez (2011).
} 
externa del instituto jurídico. Ninguna de ellas atiende sin embargo a la justificación interna, que quizá resulte apropiado considerar por si arrojase alguna luz sobre el problema.

\section{EL ENCAJE CONSTITUCIONAL DE LA LEGÍTIMA}

En el caso del ordenamiento jurídico español, la institución de la legítima ha sobrevivido sin variación sustancial a la reforma constitucional. La doctrina se muestra por lo general unánime a la hora de reconocer el encaje de este instituto en el ordenamiento jurídico constitucional, sea cual sea la caracterización que haga de ella en el régimen general o en los diferentes derechos civiles regionales. Es decir, se asume que el reconocimiento expreso del derecho de herencia en el art. 33.1 de la Constitución española otorga carta de validez constitucional a la legítima. Nótese que aquí se encuentra la clave de la genuina controversia jurídica. Si el juicio de validez o justificación interna es positivo, el resto de consideraciones en relación con su mayor o menor utilidad tienen sentido, pero en caso contrario deben ser descartadas. No deja de ser curioso, sin embargo, que esta cuestión sea la que menos interés despierta entre los juristas ${ }^{18}$.

Como el art. 33.1 CE reconoce conjuntamente «el derecho a la propiedad privada y a la herencia», se colige que la protección de la primera conlleva el respeto de la segunda dado que se garantiza con ello una mínima vinculación familiar del patrimonio del causante. Incluso las escasas voces críticas al respecto coinciden en señalar que es posible compatibilizar la institución de la legítima, la vinculación de una parte del patrimonio del causante a los parientes más próximos, con la capacidad de decisión del causante sobre su patrimonio para después de su muerte ${ }^{19}$.

Seguramente debido a esta aceptación unánime de la legítima no se ha presentado la ocasión de que el Tribunal Constitucional español se pronuncie sobre esta cuestión. Sí lo ha hecho, sin embargo, el alemán. Este último, en Sentencia de 19 de abril de 2005, afirma sin ambages que si bien la libertad de disposición del causante es el corolario del derecho de propiedad y que no existe en consecuencia mandato constitucional alguno por el que el causante deba conceder un trato igual a sus descendientes, el mismo derecho de propiedad merece una participación mínima de los hijos en la herencia que se alcanza mediante la legítima. Las razones que ofrece el alto tribunal alemán son parecidas, sino idénticas, a las mencionadas anteriormente: la protección constitucional de las relaciones entre padres e hijos, la vinculación del patrimonio familiar y la solidaridad intergeneracional ${ }^{20}$. En definitiva, que el Derecho existente es también el que debe ser.

\footnotetext{
18 Como excepción, es encomiable el esfuerzo exegético que en este sentido realiza LópEz (1994).

19 LÓPEZ (2000: 279) y DELGADO (2011) y (2012).

20 VAquer (2007), Pintens \& Seyns (2009) y Delgado (2012).
} 


\section{EL PROBLEMA SUBYACENTE. LA TITULARIDAD DE LOS DERECHOS}

El problema que subyace al desacuerdo entre juristas, tal y como ha sido expuesto hasta aquí, parece radicar en una divergencia profunda a la hora de interpretar el art. 33.1 CE, que como hemos visto reconoce el derecho de propiedad y el de herencia por igual ${ }^{21}$. Ciertamente, con independencia de que colisionen entre sí, el contenido de ambos derechos viene delimitado por su función social (art. 33.2 CE). Así, el derecho de propiedad privada queda supeditado a la utilidad pública o interés social (art. 33.3 CE), al estado de necesidad de ciertos parientes, como ocurre con la obligación de alimentos (art. 143 CC). Por otra parte, los diversos impuestos que gravan la propiedad afectan sin duda al disfrute pleno de la misma con la finalidad de distribuir la riqueza. Por su parte, el derecho de herencia, además de por algunas de las anteriores, también se encuentra limitado individualmente por cuestiones de indignidad (art. 756 CC), maltrato o injurias (art. 853 CC). Así pues, dada la generalidad con la que el art. 33.1 CE enuncia ambos derechos, parece que es aquí donde se encuentra el problema antes que la solución. Es decir, dado que ambos derechos son enunciados de forma genérica o, si se prefiere, principialista, la cuestión que hay que resolver es cuál de ellos tiene prioridad cuando colisionan entre sí, como ocurre claramente en el caso de la legítima ${ }^{22}$.

Pero esta forma de plantear la cuestión no es del todo neutral. En realidad no denota una divergencia sino todo lo contrario. Nótese que con ello se asume que hay una única lectura del art. 33.1, a saber, la de la diferente titularidad del derecho de herencia y el de propiedad. Esta tesis que denominaré tesis de la disyunción de la titularidad (TDT), podría enunciarse del siguiente modo:

TDT: «se reconoce el derecho de disposición del propietario de los bienes excepto sobre una porción de ellos reservada a sus parientes más próximos».

Esta parece ser una manera adecuada de cohonestar ambos derechos. Ciertamente, de esta forma el ordenamiento jurídico protege el derecho de propiedad y el de herencia a la vez que deja en manos del legislador la cuantía máxima que puede detraerse del primero y la mínima con la que se dota al segundo. El ordenamiento jurídico adoptaría de este modo una posición de garante con respecto a la protección de los intereses del propietario y de sus herederos. Del primero porque no le impide disponer libremente de la mayor parte de sus bienes al tiempo que resguarda otra parte con la finalidad de dar continuidad al patrimonio familiar y proteger las expectativas de los segundos ${ }^{23}$. De acuerdo con esta lectura la garantía institucional de la que goza la herencia abarcaría también el derecho de legítima.

Sin embargo, también cabe otra lectura del art. 33.1 CE. De acuerdo con esta segunda interpretación, podría entenderse que el derecho de herencia no es sino el

21 Llama la atención sobre este problema interpretativo LÓPEZ al afirmar que «el verbo "reconocer" que se emplea en el art. 33.1 del texto constitucional, carece de preciso sentido»; LÓPEz (1994: 50).

${ }_{22}$ Lo cual conduce a un farragoso proceso ponderativo en el que se entremezclan, a decir de LÓPEZ, elementos valorativos, sociológicos, funcionales, etc.; LÓPEZ (1994: 51 y ss.).

${ }_{23}$ Que vendría justificado en virtud del denominado «principio de vinculación familiar del patrimonio a la hora de la sucesión mortis causa»; LóPEZ (1994: 54). 
corolario del carácter temporalmente ilimitado de la propiedad privada, también después de la muerte de su titular. Esta tesis, que llamaré de la conjunción de la titularidad (TCT), puede enunciarse del siguiente modo:

TCT: «se reconoce la propiedad privada y la disposición a cualquier título por parte de su titular».

De acuerdo con esta lectura alternativa, el ordenamiento jurídico adoptaría de nuevo una posición de garante, pero en este caso del disfrute y libre disposición de la propiedad privada por su titular, también para después de la muerte. Nótese que esta segunda lectura permite garantizar tanto la libertad de disposición del titular de los bienes cuanto el derecho de los herederos a mantener en manos privadas el patrimonio del causante para el caso de que este no haya dispuesto expresamente de él ${ }^{24}$.

Ambas lecturas son ciertamente posibles pero no pueden esgrimirse conjuntamente dado que son incompatibles entre $\mathrm{si}^{25}$. Por de pronto cabe preguntarse qué razones justifican la adopción de esta posición de garante del ordenamiento jurídico en uno y otro caso. Quien se acoja a la primera de ellas (TDT), se verá obligado justificar las razones, paternalistas o de otro tipo, que avalan el derecho de legítima, en tanto que opera contra la voluntad expresa del titular del derecho de propiedad. La segunda lectura (TCT) es, por el contrario, inmune a cualquiera de esas razones. Brevemente, para TCT las únicas razones que importan son internas y se atienen en consecuencia a los criterios que ofrece el propio ordenamiento jurídico.

Conviene evitar la confusión entre ambas tesis dado que puede dar lugar a equívocos importantes. Tal es el caso de lo que ocurre al tomar una parte de TCT para justificar la totalidad de TDT. Así sucede, por ejemplo, cuando el derecho del causante a disponer de sus bienes por título mortis causa pretende usarse como justificación de la situación de potestad o privilegio en la que se encuentran los parientes más próximos en relación con una porción de sus bienes. Nótese que lo que TCT defiende es la conjunción de la titularidad y, en consecuencia, el derecho del titular a disponer de la totalidad de sus bienes por título mortis causa o por cualquier otro. Es decir, el derecho de propiedad es visto desde TCT como un genuino derecho subjetivo en sentido kelseniano, en tanto que provee al titular de una potestad jurídica frente al resto ${ }^{26}$. Este derecho subjetivo sería también el que se transmitiría a los herederos en el caso de que el titular de los bienes no disponga de ellos. Justamente lo contrario es lo que ocurre con TDT dado que al invertir el derecho y su correlativa obligación sitúa a los parientes del causante en una posición de privilegio frente a este, o si se prefiere deja al titular de los bienes en una situación de no derecho ${ }^{27}$.

${ }^{24}$ A esto es a lo que parece referirse LÓPEZ cuando afirma que «la garantía institucional de la herencia lo que expresa de una manera primaria es la preservación de un ámbito de poder del individuo sobre sus bienes, más allá de su muerte, lo que por pura lógica no es otra cosa sino un círculo de disposición de bienes contemplatione mortis. Sin la existencia de este poder individual la garantía quedaría aniquilada», LóPEZ (1994: 50).

${ }^{25}$ LóPEZ realiza un encomiable esfuerzo por compatibilizar ambas tesis pero como el propio autor reconoce este «discurso deviene extraordinariamente resbaladizo», LÓPEZ (1994: 56).

26 KeLSEN (1960: 147).

27 De acuerdo con HOHFELD obligación y no derecho son los correlatos de derecho y privilegio. Cuando se afirma que $\mathrm{X}$ tiene el derecho de propiedad sobre algo se dice con ello que $\mathrm{Y}$ tiene la obligación de respetarla. En el mismo sentido puede afirmarse que $\mathrm{X}$ se encuentra en una posición de privilegio frente a $\mathrm{Y}$, o que $\mathrm{Y}$ está en una situación de no derecho frente a X. HoHFELD (1913: 38-9). 


\section{LOS CUERNOS DEL DILEMA}

Parece pues que nos encontramos ante un dilema interpretativo cuya solución pasa por tomar partido por uno de sus cuernos. De este modo, o bien se da plena protección al derecho de propiedad, como exige TCT; o bien se restringe la posibilidad de disposición de su titular en aras de la protección del patrimonio y los intereses de ciertos parientes del causante sobre él, como requiere TDT.

De acuerdo con el tenor en el que se expresa el art. 33.1 CE, para acogerse a la primera de las soluciones tan solo es necesario aferrarse a la dicción literal del artículo. Dado que el derecho de propiedad y el de herencia vienen unidos por el texto constitucional, no debe separarlos el legislador. Al fin y al cabo, una de las máximas más firmemente arraigadas entre los juristas es in claris no fit interpretatio.

Los críticos parecen ser más escépticos en relación con lo que exige el Derecho. Pero el escepticismo, aunque mayoritario, tiene diferentes grados.

\subsection{El cuerno interpretativo del derecho...}

Para desvirtuar el argumento literal, y en consecuencia el dilema, los defensores de la legítima afirman que dado que no está claro qué exige el art. 33.1 CE, la solución requiere estipular una respuesta, y esta pasa por equilibrar ambos derechos. La institución de la legítima, concluyen de este modo, no solo tiene perfecta cabida dentro del texto constitucional sino que es, además, la forma más coherente de compatibilizar el derecho de propiedad y el de herencia. Cuestión diferente es el alcance que a favor de uno u otro derecho se dé a dicha institución. Este sería, en consecuencia, el problema relevante en el que debe centrarse la discusión jurídica. Pero esta es una estrategia que no está exenta de complicaciones.

La primera y más obvia de las objeciones que cabe hacer a esta forma de presentar las cosas es que debe diferenciarse el proceso de decisión de la decisión como producto. En tanto que producto, la decisión bien puede ser el resultado de una estipulación que, por definición, está vinculada con preferencias, no con razones. Es decir, estipular que una, entre las varias posibles, es la solución de un caso, se debe a que las razones a favor de esta y las restantes soluciones colapsan entre sí y, en consecuencia, la opción por la que se inclina el decisor es aquella que satisface en mayor medida sus preferencias. Pero esto quiere decir que esa opción tiene el mismo peso que la que pueda tomar otro decisor con preferencias diferentes.

Pero que las decisiones estipulativas se basen en preferencias y no en razones no implica que el proceso de decisión jurídica deba atenerse a las preferencias del decisor $^{28}$. Dicho de otro modo, la decisión jurídica puede ser finalmente acorde con las intuiciones del decisor. Pero lo será no por razón de la intuición, sino por la validez

28 Denomino intuitivas a aquellas preferencias basadas en emociones o experiencias personales, como las que expresan López (1994: 53), LACRUZ (2004: 318) o LAMARCA (2014: 252 y 274), carentes, por tanto, de cualquier justificación basada en criterios constructivos. Sobre la debilidad justificativa del intuicionismo y las formas más comunes de perfeccionismo a las que conduce, véase RAWLS (1971: 34-40). 
de las razones que se esgriman en defensa de la intuición. Tales razones, por lo demás, podrán ser jurídicas o de otro tipo y devienen totalmente secundarias en el caso de que el resultado de la decisión sea finalmente una estipulación. Es aquí donde se encuentra la segunda de las objeciones que cabe hacer a TDT.

Como hemos visto la preferencia por TDT tiene que ver con la utilidad de la legítima, la protección de las expectativas de los familiares o la continuidad del patrimonio familiar. Aunque ciertamente dispares, todas ellas omiten cualquier análisis de la titularidad de los derechos de propiedad y herencia. Asumen, en consecuencia, que hay una lectura del art. 33.1 CE, que es sobre la que se sustenta TDT. Es decir, que hay una colisión entre ambos derechos y para deslindarlos tan solo cabe recurrir al ejercicio de ponderación.

\section{2. ... y del revés}

Para analizar el alcance de las razones que avalan la preferencia de TDT quizá sea conveniente plantear la cuestión a la inversa. Es decir, preguntarse si dado que los derechos de propiedad y herencia vienen unidos en el texto constitucional, las razones que permiten restringir uno y otro vienen también definidas en el ordenamiento jurídico. El propio texto constitucional supedita, como vimos, el derecho de propiedad a su función social. Existen, además, otras restricciones como las impuestas a los menores o incapaces, que tienen que ver con medidas paternalistas cuya finalidad es la protección del patrimonio del titular, bien sea por cuestiones de índole temporal o de capacidad intelectual. Hay también restricciones que, como antes dije, están relacionadas con ciertos estados de necesidad. Sin embargo, ninguna de estas razones sirve para justificar la legítima. Ciertamente, la institución de la legítima difícilmente puede relacionarse con el interés nacional, la redistribución de la riqueza, el estado de necesidad de los parientes o la incapacidad para decidir del titular de los bienes ${ }^{29}$. Más bien ocurre todo lo contrario: hay una decisión expresa del testador que, debemos suponer, se ha realizado haciendo uso de sus plenas facultades mentales, dado que de lo contrario lo que debería impugnarse es la validez jurídica del testamento. Y, si esto es así, tan solo cabe concluir que la preferencia por TDT se enroca en una suerte de perfeccionismo jurídico que se desentiende injustificadamente del derecho de propiedad y de la libertad de su titular de disponer de sus bienes ${ }^{30}$.

Pero TDT aun tiene que hacer frente a la objeción más demoledora, a saber, la de basarse en un argumento circular que pide el principio.

$\mathrm{El}$ argumento sobre el que se asienta TDT consta de tres pasos. El primero consiste en suponer que el derecho de propiedad y el de herencia tienen diferente titularidad. El siguiente paso sostiene que cuando ambos derechos colisionan entre sí, como es el caso de la legítima, hay que encontrar algún equilibrio entre el derecho del propietario a disponer de sus bienes y el de ciertos parientes a heredarlos. La conclusión, como es

29 Así pues, las razones en las que se basaba la justificación de TDT (vid. supra 4) desembocan en un paternalismo jurídico injustificado. Sobre la justificación del paternalismo jurídico GARZÓN (1988).

30 Como afirma RAWLS (1971: 325) en relación con el «principio de perfección»: «The requirments of perfection override the strong claims of liberty». 
obvio, es que esta es precisamente la finalidad a la que responde la legítima. Pero esta forma de presentar la cuestión no es del todo correcta.

Nótese que en la primera premisa se presupone la separabilidad de ambos derechos y, en consecuencia, que la garantía institucional de la que gozan el derecho de propiedad y el de herencia se extiende a la legítima; que es precisamente lo que TDT debe probar.

Veamos ahora de qué modo se construye el argumento sobre el que se sostiene TCT. Recuérdese que esta tesis defiende la conjunción de ambos derechos, por lo que en principio queda libre de toda pirueta argumental. Ahora bien, TCT aun tiene que probar las razones que avalan el argumento literal.

Para ello TCT tan solo necesita aferrarse al primero de los recursos interpretativos que contempla el propio ordenamiento jurídico, que no es otro que el de la interpretación literal o gramatical (art. 3.1 CC). Siempre cabe cuestionar la utilidad de este criterio dado que es precisamente el alcance de uno y otro derecho lo que se encuentra en discusión. Pero esta objeción tan solo tiene sentido a partir de algunos presupuestos:

i) que la interpretación literal es plenamente coherente con el ordenamiento jurídico desde el momento en el que este admite regímenes regionales en los que no rige la legítima y por lo tanto está permitida la plena disposición del titular $(P \mathrm{~d})$. Con ello decae en consecuencia el argumento de la extensión de la garantía institucional de la herencia a la legítima ${ }^{31}$.

ii) que, por muy vagos que sean los conceptos de herencia o propiedad, es indiscutible que ambos vienen unidos en el texto constitucional y no parece que sea apreciable en la conjunción algún defecto de vaguedad.

iii) que el resto de criterios interpretativos que señala el art. 3.1 CC, es decir, el sistemático, el histórico y el sociológico tampoco parecen servir de mucha ayuda en el contexto jurídico actual. El sistemático porque una lectura a cobaerentian del ordenamiento jurídico conduce justamente a la conclusión contraria. El histórico porque si bien es cierto que la legítima ha sido tradicionalmente un derecho reconocido a los parientes más próximos, no parece que esta sea una razón suficiente para su mantenimiento en contra del resto de criterios interpretativos que ofrece el ordenamiento jurídico actual. Y el sociológico, en fin, porque como manifiestan las voces críticas de la legítima y demuestran las encuestas disponibles ${ }^{32}$, este instituto jurídico ya no cumple con la función que estaba llamado a desempeñar tiempo atrás.

Llegados a este punto a TCT tan solo le cabe preguntar qué razón avala a la legítima dado que no se apoya en las que justifican el resto de restricciones al derecho de propiedad. Es decir, por qué se mantiene un instituto jurídico que no responde a razones de interés general, de redistribución de la riqueza, de protección del interés del titular de los bienes o, en fin, a algún estado de necesidad. De este modo, la conclusión a la que se llega desde TCT es que la legítima opera en todo caso como un instituto que restringe la voluntad expresa del titular de los bienes sin más razón aparente que la presuposición de que la garantía institucional que se otorga al derecho de herencia

\footnotetext{
31 PARRA (2004: 500).

32 VAquer (2007).
} 
abarca también al de legítima. Es decir, nos encontramos de nuevo en el punto de partida del argumento, que es también el de llegada, o lo que es lo mismo, ante un argumento circular que pide el principio.

\section{APÉNDICE PARA JURISTAS}

Una de las dificultades interpretativas de la práctica jurídica es que en ella convergen dos planos del Derecho, el de identificación y el de justificación, que conviene deslindar adecuadamente a la hora de realizar un análisis riguroso de ella. Es normal que ambos planos tiendan a confundirse en la práctica, no en vano, la jurídica, como cualquier otra práctica social, se asienta sobre ciertas convenciones que son las que, entre otras cosas, nos permiten reconocerla como tal ${ }^{33}$. Pero precisamente por ello conviene no confundir los argumentos que se esgrimen en uno y otro plano ya que no siempre son intercambiables entre sí. Entre otras cosas porque las razones justificativas del Derecho tan solo cobran sentido una vez que se ha superado con éxito la tarea de identificación. Ciertamente esta es la prioritaria para todo jurista y en principio también la más sencilla, siempre que se disponga del arsenal adecuado para interpretar ${ }^{34}$. Ahora bien, aun cuando se muestre cierto escepticismo ante lo que exige el Derecho en cada caso particular, lo más prudente es comenzar por la interpretación más sencilla, o si se prefiere, adoptar el nivel más bajo de interpretación, que es el que impone además el propio ordenamiento jurídico. Y en este sentido la legítima aparece como un elemento extraño o incoherente dentro del ordenamiento jurídico dado que la prohibición de disposición $(\mathrm{Phd}$ ) que se impone al derecho de propiedad carece de más argumento que la muy dudosa extensión de la garantía institucional de la herencia al derecho de ciertos parientes que, paradójicamente, sitúa en una posición de no derecho al titular del derecho de propiedad.

Así pues nos encontramos en este punto ante una inconsistencia entre normas que imputan consecuencias jurídicas incompatibles a la misma condición fáctica, a saber, la titularidad del derecho de propiedad y la prohibición de disposición. Para comprender mejor esta contradicción normativa puede servirnos de ayuda el esquema de inconsistencias lógicas entre normas ideado por Alf Ross ${ }^{35}$. De acuerdo con Ross, la inconsistencia entre normas puede darse de tres maneras diferentes, que denomina total-total, total-parcial y parcial-parcial ${ }^{36}$.

Existe una inconsistencia total-total cuando ninguna de las normas puede ser aplicada sin entrar en conflicto con la otra. Se produce por tanto una incompatibilidad absoluta entre normas. No es este el caso ante el que nos encontramos, se apresurará a decir quien se acoja a TDT, dado que el derecho de propiedad y el de herencia no colisionan totalmente entre sí, como ocurre cuando el titular de los bienes no dispone expresamente de ellos. En este caso, el derecho subjetivo del que goza el titular de la

\footnotetext{
33 Sobre hechos convencionales y regla de reconocimiento VILAJOSANA (2010: 153 y ss.).

34 Aunque ello exiga en ocasiones embarcarse en una tarea hercúlea de interpretación como muestra DWORKIN (1986: 313 y ss.).

35 Agradezco a Josep Maria VILAJOSANA haberme recordado lo pertinencia de aplicar en este punto la distinción entre las inconsistencias normativas posibles.

36 Ross (1958: 124).
} 
propiedad, como vimos anteriormente, pasa por el mero hecho de su fallecimiento a manos de los herederos. La conclusión es correcta, pero el razonamiento no. Aunque es cierto que el derecho de propiedad y el de legítima no son totalmente inconsistentes entre sí, la razón de ello no se encuentra en la ausencia de disposición del causante, dado que a esto afecta al derecho de herencia, no al de legítima. Y en todo caso, no puede haber incompatibilidad entre ambos derechos toda vez que el causante, en esta situación, no expresa su voluntad. La razón de que la legítima y el derecho de herencia no sean absolutamente incompatibles se encuentra en que el propio ordenamiento jurídico permite la plena disposición del titular de los bienes (Pd), como ocurre con algunos derechos civiles. Hay, en consecuencia, un campo de aplicación del derecho de propiedad que no entra en colisión con la legítima.

La inconsistencia total-parcial se produce cuando una de las normas no puede ser aplicada sin entrar en conflicto con la otra, mientras que esta tiene un campo de aplicación adicional en el cual no entra en conflicto con la anterior. Diremos, en este caso, que se produce una inconsistencia entre la norma general y la particular. Esta es el tipo de inconsistencia que interesa aquí. La legítima, en tanto que norma particular e imperativa para el testador, $(\mathrm{Ol})$, entra siempre en conflicto con la voluntad expresa del titular de los bienes $(\mathrm{Phd})$. Es cierto que esto ocurre también con otro tipo de restricciones, pero como antes vimos, todas ellas encuentran su justificación en razones de justicia distributiva, incapacidad temporal o cognitiva del titular o, en fin, estados de necesidad de los parientes. Razones que, como vimos también, no son aplicables a la previsión legal de la legítima.

Por último nos encontraríamos ante la inconsistencia parcial-parcial o mera superposición de normas, que ocurre cuando ambas tienen un campo de aplicación en el que colisionan entre ellas pero disponen además de un campo independiente de aplicación en el que no se produce conflicto. Tampoco este es el tipo de inconsistencia aplicable al caso de la legítima.

Con lo anterior pretendo decir que una vez superado el proceso de identificación de lo que requiere el Derecho podrán alegarse razones de peso a favor o en contra del resultado que arroje. Pero en todo caso tales razones operan como instancia crítica del Derecho existente al sustentarse en criterios valorativos adicionales (morales, políticos o económicos) a partir de los que se justificará la decisión de su permanencia o derogación. Pero como es obvio, valorar el mérito o demérito del Derecho es algo que tan solo se puede realizar después de haberlo identificado ${ }^{37}$.

\section{CONCLUSIÓN}

En el presente artículo he pasado revista al debate generado entre la doctrina iusprivatista en relación con la institución de la legítima. Para ello, he tratado de reconstruir, en el apartado segundo, los argumentos ofrecidos a favor y en contra de la misma. Todos ellos se sustentan, como se ha visto, en la mayor o menor eficacia que tiene la

37 En palabras de AUSTIN «la existencia del Derecho es una cosa; su mérito o demérito otra»; AUSTIN (1995: 157). 
legítima en la actualidad. Es decir, en un cálculo de utilidad o si se prefiere de eficiencia del Derecho. Así las cosas, el debate se plantea a partir de la asunción de que este instituto jurídico es plenamente coherente con la estructura del ordenamiento jurídico vigente $\mathrm{y}$, a partir de aquí, se ofrecen razones a favor su permanencia o modificación. En algunos casos, ciertamente los menos, se esgrimen también razones que avalan su derogación .

A mi modo de ver, esta forma de presentar la cuestión no es del todo correcta por dos razones. La primera se refiere a que con ello no se hace sino preterir un análisis que debe ser prioritario en el ámbito jurídico, cual es el de la identificación de aquello que requiere el Derecho. La segunda hace alusión a la objeción de circularidad del argumento en torno al cual gira el debate planteado de este modo. Ello permite omitir el análisis de coherencia interna del ordenamiento jurídico, el cual, como vimos, está estrechamente relacionado con lo anterior.

Para arrojar algo de luz sobre lo primero examiné en el tercer apartado la titularidad de los derechos de propiedad y de herencia que vienen conjuntamente enunciados en el art. 33.1 de la Constitución española. De acuerdo con la dicción literal de este artículo afirmé que se podían realizar dos lecturas completamente dispares entre sí. La primera, que denominé tesis de la disyunción de la titularidad (TDT), que asume acríticamente la doctrina mayoritaria, afirma que uno y otro derecho tienen distinta titularidad, sin ofrecer más razón que la garantía institucional que les otorga el texto constitucional. La segunda, que llamé tesis de la conjunción de la titularidad (TCT), sostiene por el contrario que hay argumentos para defender que el derecho de propiedad y el de herencia tienen idéntica titularidad. Las razones que avalan esta tesis se encuentran, como dije también, en que el propio tenor literal del texto constitucional permite afirmar que el derecho de propiedad se encuentra configurado como un genuino derecho subjetivo y, en tanto que tal, no admite más causas de restricción que las que vienen justificadas por los fines a los que atiende el ordenamiento jurídico.

En relación con la segunda de las razones, la que se refiere a la objeción de circularidad, afirmé que para que esté justificado apartarse de la interpretación literal, el argumento alternativo debe construirse sobre premisas más firmes que las que presuponen lo que se quiere probar, a saber, que ambos derechos colisionan entre sí porque tienen diferente titularidad. Para mostrar la debilidad de este argumento propuse, por último, analizar la cuestión desde la perspectiva inversa. Esto me permitió poner de manifiesto i) que la inexistencia de la legítima es plenamente coherente con nuestro ordenamiento jurídico y en consecuencia resulta inviable el argumento de la extensión de la garantía institucional, y ii) que las razones que se ofrecen a favor de la legítima se apartan en todo caso de las que el propio ordenamiento señala como justificativas del resto de restricciones que se imponen al titular del derecho de propiedad.

Finalmente, a partir de la tipología de incompatibilidades lógicas de Ross, identifiqué el tipo de inconsistencia que introduce la legítima en el ordenamiento jurídico. Con ello pretendo poner de manifiesto que si bien en la práctica jurídica aparecen generalmente entremezclados el plano identificativo y el justificativo del Derecho, conviene diferenciarlos adecuadamente cuando se pretende realizar un análisis escrupuloso de esta práctica con el fin de señalar los errores en los que recae y proponer vías de solución constructivas. 


\section{BIBLIOGRAFIA}

Alcoy, A., 2007: «Reflexiones sobre una eventual reforma de la legítima», en InDret. Revista para el análisis del Derecho, 3, bttp://www.indret.com/pdf/457_es.pdf.

ÁlvarEZ, S., 2011: «Las legítimas en el Reglamento sobre sucesiones y testamentos», en Anuario Español de Derecho Internacional Privado, XI, 369-406.

ARroYo, E., y FARNÓs, E., 2015: «Entre el testador abandonado y el legitimario desheredado ¿a quién prefieren los tribunales?», en InDret. Revista para el análisis del Derecho, http://www. indret.com/pdf/1132_es.pdf.

Austin, J. [1832], 1995: The Province of Jurisprudence determined, Cambridge: Cambridge University Press.

Busto, J. M., 2015: «Legítimas y reservas», en BerCovitz, R., Manual de Derecho Civil. Sucesiones, Madrid: Bercal, 3. ${ }^{a}$ ed., 207-248.

Calatayud SierRA, A., 1995: «Consideraciones acerca de la libertad de testar», Academia Sevillana del Notariado IX.

Carrasco Perera, A., 2003, «Acoso y derribo de la legítima hereditaria». Actualidad Jurídica Aranzadi, 580.

Cobas Cobiella, M. ${ }^{a}$ E., 2006: «Hacia un nuevo enfoque de las legítimas», Revista de Derecho Patrimonial, núm. 17.

DeLGADO, J., 2006: «Una propuesta de política legislativa en Derecho de sucesiones por causa de muerte. Segunda parte: objetivos de una reforma del Derecho de sucesiones. Presente y futuro», XII Jornadas de la Asociación de Profesores de Derecho civil, Murcia: Servicio de Publicaciones de la Universidad de Murcia.

- 2011: «El fundamento constitucional de la facultad de disponer para después de la muerte», en Diario La Ley, núm. 7675.

- 2012: «Autonomía privada y derecho de sucesiones», en Lorenzo PRATS AlBENTOSA (coord.), Autonomia de la voluntad en el derecho privado: Estudios en conmemoración del 150 aniversario de la Ley del Notariado, vol. 1 (Derecho de la persona, familia y sucesiones), 513-640.

De WaAl, M. J., 2007: «A Comparative Overview», en Reinhard ZimmermanN, Exploring the Law of Succession, Edinburgh: Edinburgh University Press, 1-26.

DíEz-Picazo, L., y Gullón, A., 2006: Sistema de Derecho civil, IV, 10 ed., Madrid.

Dworkin, R., 1986: Law's Empire, Cambridge, Massachusetts: The Belknap Press of Harvard University Press.

FERRER RibA, J., 2011: La successió per causa de mort: llibertat de disposar i interessos familiars, en C. E. Florensa i TOMÀs (dir.) y J. M. Fontanellas Morell (coord.), La codificación del derecho civil de Cataluña. Estudios con ocasión del cincuentenario de la Compilación. Madrid, Barcelona, Buenos Aires: Marcial Pons, 337-362.

GARZÓN, E., 1988: «¿Es éticamente justificable el paternalismo jurídico?», Doxa, 5, 155-73.

HoHFELD, W. N., 1923: Some fundamental legal conceptions as applied in judicial reasoning and other legal essays. New Haven: Yale University Press.

KELSEN, H., 1960: Teoría pura del Derecho, trad. esp., por la que se cita, de Reine Rechtslebre, zweite, vollständing neu bearbeitete und erweiterte Auflage, a cargo de VERNENGO, R., 11. ${ }^{a}$ ed., México: Porrúa, 2000.

Lacruz Berdejo, J. L., 2004: Elementos de Derecho civil V, Sucesiones, Madrid: Dykinson.

LamarcA, A., 2014: We Are Not Born Alone and We Do Not Die Alone: Protecting Intergenerational Solidarity and Refraining Cain-ism Through Forced Heirship. Oñati Socio-legal Series [online], 4 (2), 264-282. Available from, http://ssrn.com/abstract=243105. 
LóPEZ, A., 1994: «La garantía institucional de la herencia», en Derecho Privado y Constitución, 3 , 29-62.

— 2002: «El derecho a la propiedad privada y a la herencia. Función y límites», en J. L. Moreneo Pérez, Cristóbal Molina Navarrete y M. N. Moreno Vida (dir.), Comentario a la constitución socio-económica de España, Granada.

Magarinos, V., 2005: «La libertad de testar», Revista de Derecho Privado, septiembre/octubre.

PARRA, M. A., 2009: «Legítimas, libertad de testar y transmisión de un patrimonio», en Anuario de la Facultade de Dereito da Universidade da Coruña, 13, 481-554.

PInTENS, W., y SEYnS, S., 2009: «Perspective 5. Comparative Law - Germany. Compulsory Portion and Solidarity Between Generations in German Law», en C. Castelein, R. Foqué y A. VERBEKE (eds.), Imperative Inheritance Law in a Late-Modern Society. Five Perspectives. Antwerp, Oxford, Portland: Intersentia, 167-188.

RAWls, J., 1971: A Theory of Justice, Cambridge, Massachusetts, London: The Belknap Press of Harvard University Press, 2005.

Ross, A., 1958: El Derecho y la justicia. Traducción al español por la que se cita de On Law and Justice, a cargo de G. CARRIÓ, Buenos Aires: EUDEBA, 1994, 5. . ed.

SAEZ-SANTURTUN, J., «Intervención notarial en la estructuración de las pequeñas y medianas empresas», Revista Juridica del Notariado, núm. IX, extraordinario.

SCHÖPflin, M., 2006: «Economic Aspects of the Right to a Compulsory Portion in the (French and German) Law of Succession», German Working Papers in Law and Economics, 2006, paper 34, http://www.bepress.com/gwp, 2008.

VALLADARES, E., 2004: «Por una reforma del sistema sucesorio del Código civil», en Libro Homenaje al profesor M. Albaladejo, t. II, Murcia.

Vilajosana, J. M., 2010: El derecho en acción. La dimensión social de las normas jurídicas. Madrid, Barcelona: Marcial Pons.

- 2014: Identificación y justificación del Derecho. Madrid, Barcelona: Marcial Pons. 


\title{
SOBRE DERECHO Y LA AVERIGUACIÓN DE LA VERDAD*
}

\author{
Sebastián Reyes Molina ** \\ Universidad de Uppsala \\ sebastian.reyes@filosofi.uu.se
}

«The secret to keeping authority is to give only orders that you know will be obeyed»
Joe ABERCROMBIE, HaW

RESUMEN. En el ámbito del derecho probatorio la relación entre derecho y verdad ha sido un debate abandonado en los últimos treinta años. Se ha aceptado que existe una conexión entre ambos la cual se traduciría en que el derecho es un medio de averiguación de la verdad de los hechos alegados. La tesis reconstruida en este trabajo ha sido presentada por el profesor Jordi FERRER quien justifica la relación entre derecho y verdad en términos de necesidad para que el derecho pueda motivar la conducta de los ciudadanos. A esta tesis la denomino la teoría de la cláusula estructural de la verdad. En este trabajo se presenta una reconstrucción de esta teoría, dos objeciones a las que se debe enfrentar y cinco posibles interpretaciones de la relación entre derecho y verdad.

Palabras claves: teoría del derecho, proceso legal, verdad, hechos, derecho probatorio.

\section{On Law and the Ascertainment of Truth}

ABSTRACT. In the field of Evidence Law the relation between truth and law has been a somewhat nondebated topic in the past years. It is a given that such connection exists and, it is understood as the notion of the ascertainment of truth of disputed questions of fact through legal evidence. The thesis that I have reconstructed in this paper has been presented by the Prof. Jordi FERRER who grounds the connection between truth and law in the role of the legal system as a tool for guiding the behaviour of the governed. I call this thesis the theory of the structural clause of truth. In this paper I shall present a possible reconstruction of this theory, I shall raise two objections against it and I shall present five possible interpretations of the relation between truth and law.

Keywords: Legal Theory, Truth, Facts, Legal Process, Evidence Law.

* Fecha de recepción: 8 de junio de 2016. Fecha de aceptación: 8 de diciembre de 2016.

** PhD (c) por la Universidad de Uppsala. LL. M., por la Universidad de Génova. LCJS, por la Universidad Austral de Chile. Correo: sebastian.reyes@filosofi.un.se. Quiero agradecer al profesor Álvaro NúÑEZ VAQUERO (Universidad Austral de Chile) y a Donald Bello HutT (King's College London) por sus valiosos comentarios a versiones previas de este trabajo y a la profesora Patricia Mindus (Universidad de Uppsala) y al profesor Jordi FERRER (Universidad de Girona) por sus observaciones y recomendaciones. Una versión previa de este trabajo fue presentado en las I Jornadas de Filosofía del Derecho del Mundo Latino celebrado en Alicante el 26-29 de mayo de 2016. Los errores en los que se ha podido incurrir son de mi responsabilidad. 


\section{COMENTARIOS INTRODUCTORIOS}

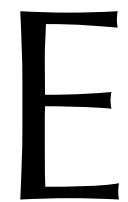

1 presente trabajo tiene por objeto analizar una de las tesis centrales (y hasta cierto punto indiscutidas ${ }^{1}$ del derecho probatorio contemporáneo: la relación necesaria entre derecho y verdad. Esta relación ha sido ampliamente tratada por la literatura especializada la cual entiende que para que el sistema esté orientado a decisiones justas es necesario entonces que las consecuencias jurídicas se apliquen a hechos que han ocurrido en el mundo².

La tesis analizada en este trabajo es la reconstrucción hecha por Jordi FERRER en su libro La valoración racional de la prueba ${ }^{3}$ de la relación existente entre derecho y verdad ${ }^{4}$. FERRER no argumenta a favor de dicha conexión en términos de la justicia de la decisión sino que le atribuye a la verdad un rol central para el derecho en tanto sistema que motiva la conducta de una determinada comunidad. La tesis de FERRER que denominaré como «la tesis de la cláusula estructural de la verdad» (TCEV) posiciona a la búsqueda de la verdad en un sitial preferente con respecto a los demás fines que el derecho promueve ${ }^{5}$. Lo anterior no supone que la búsqueda de la verdad sea el único fin a promover o que este sea absoluto respecto a otros fines. Por el contrario, hay consenso en la literatura especializada de que el derecho promueve diferentes objetivos y que en ocasiones dichos objetivos son contrapuestos ${ }^{6}$. Sin embargo, en «condiciones de normalidad» ${ }^{7}$ la búsqueda de la verdad tendría un lugar preferente sobre el resto de los objetivos protegidos por el derecho.

${ }^{1}$ «Hoy en día nadie minimamente informado puede poner en tela de juicio las ideas maestras de una concepción racionalista del juicio de hecho ni sus implicaciones más evidentes para la práctica jurisdiccional [...] Y todo eso a la luz de dos ideas auténticamente centrales. La primera, que el proceso se orienta a la búsqueda de la verdad, si bien la naturaleza inductiva de los razonamientos probatorios hace que el resultado de la prueba no garantice la certeza absoluta. La segunda, que, aunque el proceso se oriente a la búsqueda de la verdad, al derecho no le interesa solo la averiguación de la verdad, sino también la consecución o protección de otros fines que pueden justificar la introducción de normas sobre la actividad probatoria» (BAYÓN, 2008: 16-7). Las cursivas son mías.

2 Esta postura es defendida en la obra de BENTHAM quien sostenía que el fin del derecho adjetivo (adjective law) es la rectitud de la decisión (Bentham, 1843: 33-34). Por esta se entiende la aplicación de derecho sustantivo (substantive law) a hechos acaecidos en la realidad (ANDERSON, SCHUM y TwINING, 2005: 41) De forma general uno puede encontrar el mismo argumento, quizás mas refinado, en la doctrina contemporánea la que sostiene que la verdad es condición necesaria más no suficiente para alcanzar una decisión justa. A modo de ejemplo vid. TARUFFO, 2010; STEIN, 2005 y Ho, 2008.

3 J. FERRER, La valoración racional de la prueba, Marcial Pons, 2007. Si bien esta tesis ya fue esbozada en trabajos anteriores (FERRER, 2002: 80-1 y FERRER, 2003: 27) es en este libro en el cual la desarrolla de forma más extensa. También es mencionada en FERRER, 2010:3-20.

${ }^{4}$ De forma específica, y expresa, Ferrer sostiene la relación entre prueba y verdad. Sin embargo, como se verá más adelante, su argumento basal es que a través de la prueba jurídica el derecho debe perseguir la verdad si quiere ser útil como herramienta de motivación de la conducta de los gobernados. Es por esto que, en razón de la obra de FERRER, he decidido referirme al binomio derecho-verdad en vez de prueba-verdad. Cabe hacer presente que, en este sentido, la discusión general sobre esta materia ha sido formulada en los términos prueba-verdad.

5 Por sitial preferente me refiero a que la búsqueda de la verdad goza de mayor jerarquía con respecto a la consecución de otras metas promovidas por el derecho.

6 Vid. en este sentido GASCÓN, 2006: 52, FERRER, 2007: 36-40, LAUdAn, 2005: 95, BAYÓN, 2008 y REYes, 2012b.

7 Por condiciones de normalidad me refiero a casos en los cuales las tensiones entre valores opuestos o en competencia no existen o son mínimos. 
Como se explicará mas adelante, FERRER sostiene que la relación entre verdad y derecho es necesaria si este último va a ser un medio útil para determinar la conducta de los sujetos miembros de una comunidad ${ }^{8}$.

El objetivo de este artículo es cuestionar la tesis sostenida en el trabajo de FERRER arguyendo que en los términos en que esta es presentada no es posible sostener la conclusión de que la averiguación de la verdad de los hechos litigiosos es necesaria para que el derecho pueda motivar la conducta. Lo anterior debido a que esta no permite distinguir entre veracidad y verosimilitud en lo que se refiere a la creación del estado psicológico de «sentirse motivado» por el derecho, ni tampoco permite explicar cómo la averiguación de la verdad sortea los problemas del desconocimiento del contenido del derecho y de la indeterminación jurídica. Sin embargo, esto no supone abandonar la noción de relación entre verdad y derecho sino que se pone énfasis en que esta debiese ser objeto de revisión y redefinición para dar cuenta cómo esta noción permea nuestras concepciones sobre la prueba en el derecho. En este espíritu es que se presentan cinco propuestas de redefinición de la relación entre derecho y verdad desde una perspectiva de los usuarios del sistema, a saber: como una norma implícita, como un micro-derecho, como un macro-derecho, como parte de nuestro concepto de derecho y como un ideal regulativo extra-jurídico.

\section{EL MARCO DE LA DISCUSIÓN}

En los últimos treinta años, el derecho continental ha dado un vuelco cuasi-copernicano en el estudio de la prueba jurídica. El llamado «giro epistemológico» (DEI VECCHI, 2013: 235) ${ }^{9}$ experimentado en el estudio de esta disciplina fue de la mano con el cambio de metodología que tradicionalmente se había adscrito al estudio de las reglas que regulan la prueba jurídica ${ }^{10}$. Así, el clásico enfoque del análisis dogmático

${ }^{8}$ La reconstrucción de la relación entre derecho y verdad hecha por FERRER aporta luz desde la teoría del derecho a una de las asunciones preanalíticas quizás más importantes en el derecho probatorio. Su esfuerzo presenta una relación plausible entre dos dimensiones que se han entendido generalmente, tanto en la práctica como en la enseñanza del derecho, como separadas, a saber, lo relativo a la quaestio iuris y la quaestio facti abriendo de esta forma el debate hacia otros ámbitos que generalmente no entran en diálogo.

9 Esto se ve reflejado en un boom en la literatura tanto anglosajona como continental referente a aspectos generales y/o particulares del estudio de la prueba jurídica. Solo a modo de ejemplo vid.: D. SCHUM, A. TERENCE, y W. Twining (2005), Analysis of Evidence, Cambridge: Cambridge University Press; W. TwINING (2006), Rethinking Evidence: Exploratory Essays, Cambridge: Cambridge University Press; L. LAUDAN (2006), Truth, Error and Criminal Law: An Essay on Legal Epistemology, Cambridge: Cambridge University Press; FERRER (2002), Prueba y Verdad en el Derecho, Madrid: Marcial Pons; J. FERRER (2007), La valoración racional de la prueba, Madrid: Marcial Pons; M. TARUFFO (2002), La prueba de los hechos, Madrid: Trota; M. Gascon (1999), Los hechos en el derecho: bases argumentales de la prueba, Madrid: Marcial Pons; D. GonZÁLEZ (2011), Quaestio Facti: Ensayos sobre la prueba, causalidad y acción, México: Fontamara; A. STEIN (2005), Foundations of Evidence Law, Oxford: Oxford University Press; H. L. Ho (2009), A Philosophy of Evidence Law: Justice in the Search of Truth, Oxford: Oxford University Press; C. VÁZQuEz (2015), De la prueba científica a la prueba pericial, Madrid: Marcial Pons; A. KeAne y P. McKeown (2014), The Modern Law of Evidence (10. ${ }^{a}$ ed.), Oxford: Oxford University Press; J. ANDERSon y A. Hopkins (2014), Uniform Evidence Law Guidebook, Oxford: Oxford University Press; S. HAACK (2014), Evidence Matters, Cambridge: Cambridge University Press; B. GARRET (2011), Convicting the Innocent: Where Criminal Procedure Goes Wrong, Boston: Harvard University Press; P. Murphy (2003), Evidence, Proof and Facts, Oxford: Oxford University Press; P. Davis, W. TwinIng y M. VASILAKI (2011), Evidence, Inference and Inquiry, Oxford: Oxford University Press.

${ }_{10}$ Hasta finales del siglo Xx los estudios sobre la prueba en el derecho continental se enmarcaban dentro de la disciplina del derecho procesal. Así, los primeros estudios sobre la prueba fueron llevados a cabo 
de las normas que regulan la prueba jurídica ofrecido por los teóricos del derecho procesal, ha dado paso a una reflexión teórica y crítica con pretensiones normativas sobre qué modelos de admisión y valoración de la prueba son mejores o más aptos para alcanzar determinados fines del sistema, e. g., la verdad de los hechos discutidos, decisiones justas, etc. No es de extrañar entonces que sean los teóricos del derecho los que en la actualidad se han encargado de liderar la discusión en el ámbito del derecho probatorio ${ }^{11}$.

Si bien no existe una escuela o movimiento «oficial» de pensamiento en el derecho probatorio, hay un gran número de académicos que comparten o parecen compartir, explícita o implícitamente, determinados postulados nucleares los cuales permiten trazar líneas en común entre sus trabajos. De forma general, es posible sostener que estos autores se caracterizan por sostener una visión particular de la prueba jurídica: esta debe ser una actividad racional la cual debe ser guiada por reglas epistémicas y criterios de racionalidad general ${ }^{12}$. Los autores que comparten esta pretensión de racionalidad han sido considerados bajo la etiqueta de la tradición racionalista de la prueba $^{13}$.

El paradigma epistemológico adoptado por la generalidad de la tradición racionalista es el cognoscitivista ${ }^{14}$, el cual concibe la actividad probatoria como una actividad eminentemente epistemológica ${ }^{15}$.

El cognoscitivismo, sostiene Gascón, es el

modelo según el cual los procedimientos de fijación de los hechos se dirigen a la formulación de enunciados fácticos que serán verdaderos si los hechos que describen han sucedido y falsos en caso contrario [...] el objetivo que persigue un paradigma cognoscitivista de fijación judicial de los hechos es, pues, la formulación de enunciados fácticos y verdaderos [...] que sean 'fácticos' significa que son una descripción de los hechos acaecidos; es decir, que el juicio de hecho tiene naturaleza descriptiva [...] que sean «verdaderos» significa que los hechos descritos por tales enunciados han tenido lugar (GASCÓN, 1999: $51-53)$.

por profesores especialistas en derecho procesal (siendo el caso italiano quizás el más conocido). Vid. en este sentido Chiovenda, 1923; CARnelutti, 1915; CAlamandrei, 1943, y en Sudamérica, Couture, 1942 y Devis ECHANDÍA, 1974.

11 No solo los teóricos del derecho han demostrado interés en el ámbito probatorio sino que también, entre otros, epistemólogos y psicólogos por medio de la ciencia cognitiva. Los estudios de derecho probatorio contemporáneo han demostrado ser esfuerzos multidisciplinarios e interdisciplinarios.

12 Vid. en este sentido, GASCÓN, 1999 y LAUDAN, 2006. Cabe señalar, siguiendo a TARUFFO, que la elección de una concepción racionalista responde a una elección político-valorativa de un modelo de explicación y estudio de la prueba jurídica, así «cabe subrayar que la adopción de una concepción racionalista —o simplemente racional- de la decisión judiciaria no se puede considerar como una premisa pacífica, que se puede considerar como dada a priori. Al contrario, se trata de una elección evaluativa, de carácter esencialmente ideológico, que tiene profundas implicaciones culturales y políticas» (TARUFFO, 2013: 92).

${ }_{13}$ Quizá los orígenes de esta nomenclatura pueden ser trazados en los trabajos de William TwINING por medio de lo que él ha denominado la «tesis histórica» del derecho probatorio (TwINING, 2006: 75 y ss.) Como sea hoy parece ser una etiqueta aceptada, a veces de forma explícita, por los autores que trabajan estas materias. Esto no quiere decir que exista una «escuela oficial» conocida como «racionalista» en materia de derecho probatorio.

14 Sin embargo, este no es el único modelo. En el seno del debate se han presentado y elaborado concepciones alternativas al modelo cognoscitivista siendo el modelo coherentista el que generalmente se adopta como contrario a la corriente mayoritaria. Vid. (AMAYA, 2013 y 2015).

15 En este sentido, vid. GASCÓN, 2002. 
De acuerdo a esta postura, el procedimiento probatorio, en el contexto de un juicio, desempeña una función cognitiva por cuanto permite al juez conocer o descubrir los hechos a partir de las pruebas rendidas en el proceso por las partes. Es decir,

(e)l término «prueba», en el contexto jurídico, identifica los trámites o actividades que se orientan a acreditar o a determinar (en definitiva, a probar) la existencia o inexistencia de hechos relevantes para adoptar la decisión. Precisamente por eso, frente a la concepción retórica o argumentativa de la prueba [...] desde una perspectiva racional la concepción más adecuada (y no por casualidad la más extendida) es la cognoscitivista, según la cual la prueba se endereza a conocer o acreditar la verdad de (los enunciados sobre) los hechos litigiosos o controvertidos (GASCÓN, 2006: 47).

El modelo cognoscitivista presupone un vínculo entre prueba y verdad. La prueba puede, o al menos debería intentar, alcanzar la verdad de los hechos ${ }^{16}$, es decir, somos capaces de conocer hechos que han ocurrido en el pasado por medio de las pruebas rendidas en un juicio. Existe, entonces, una relación teleológica entre prueba y verdad, de este modo «la finalidad de la prueba como institución jurídica es la de permitir alcanzar el conocimiento acerca de la verdad de los enunciados fácticos del caso» (FERRER, 2006: 33).

Para esto, la tradición racionalista, aboga por un sistema de prueba libre ${ }^{17}$. El derecho no debe regular la actividad probatoria, al menos en lo concerniente a la valoración judicial de la prueba. Esta debe estar constreñida no por normas jurídicas sino por normas de la epistemología general. Así

se deja atrás la imagen subjetivista y puramente potestativa del principio de valoración de la prueba reconociéndose que el descarte de las reglas de tasación legal no implica la exclusión de toda regla, sino más bien la sujeción solo a los criterios de racionalidad de la epistemología general (ACCATINO, 2010: 119).

De este modo la noción de libertad de prueba se refiere a la eliminación de un sistema tasado de la misma. Lo anterior no significa que el juez no esté constreñido por regla alguna sino que las normas jurídicas no deben guiar la valoración de la prueba. Este rol es asignado a otro tipo de reglas: las reglas de la razón y epistemología general ${ }^{18}$.

Por medio de estas reglas la valoración racional de la prueba, apunta a disminuir al máximo la discrecionalidad del juez al momento de determinar los hechos. Es decir, se empeña en expulsar/contener/restringir elementos subjetivos (elementos de la personalidad del juez, criterios políticos, morales, y en general cualquier criterio que escape de las solas reglas epistémicas) que eventualmente puedan influenciar al juzgador al momento de decidir sobre las hipótesis discutidas por considerarlas como obstáculos para alcanzar la verdad.

16 Sin perjuicio de lo anterior, como el juicio se desarrolla en condiciones de incertidumbre, el objetivo de alcanzar la verdad se traduce en la minimización del riesgo de error en las decisiones sobre hechos. Vid., en este sentido, STEIN, 2005: 12.

17 Reconstruido como la «libre valoración de la prueba», esta tesis fue propuesta por BENTHAM en el siglo XIX. Vid. J. BENTHAM, «The Rationale of Evidence», The Works of Jeremy Bentham, vol. 6, London: Simpkin, Marshal \& Co.

18 En líneas generales, un sistema de valoración libre de la prueba viene aparejado con ciertos «límites». Estos son los previstos en el modelo denominado sana crítica: reglas de la lógica, máximas de las experiencias y conocimientos científicamente afianzados. De esta forma el juzgador no podría infringir estos límites al momento de valorar la prueba. 
Para FERRER una concepción racional de la prueba no es el resultado de una preferencia de un determinado modelo ideal de prueba por sobre otro. Al contrario, es lo que el ordenamiento jurídico demanda como garantía del derecho a la prueba:

Sostendré que es el propio sistema jurídico, a través del denominado «derecho a la prueba», el que exige la aplicación de esas reglas de la epistemología o la racionalidad generales [...] para la valoración de la prueba [...]. La idea fundamental es que el ciudadano tiene derecho a mostrar la verdad de los hechos en los que funda su pretensión [cita omitida]. En otras palabras el ciudadano tiene derecho a probar que se han producido, o no, los hechos a los que el derecho vincula consecuencias jurídicas. Solo de este modo puede garantizarse una correcta aplicación del derecho y, [...] una adecuada seguridad jurídica (FERRER, 2007: 53-4) ${ }^{19}$.

Para FERRER la averiguación de la verdad es un criterio de corrección de la decisión judicial. Esto presupone que por medio del proceso judicial es posible averiguar la verdad de los hechos discutidos. El juicio, bajo esta concepción, es una herramienta epistémica que permitiría al juez el conocimiento de hechos pasados, únicos e irrepetibles (REYES, 2012a: 234) ${ }^{20}$.

La TCEV propuesta por FERRER se inscribe dentro de una concepción racionalista de la prueba. De acuerdo a esta si la verdad de los hechos declarados probados es necesaria para validar las decisiones jurídicas entonces se requiere una vía para poder averiguar dicha verdad. Esa vía sería el juicio (o el proceso legal). Solo si se es posible averiguar la verdad de los hechos litigiosos por medio del proceso tiene sentido entender la verdad como un criterio de corrección de la decisión judicial. Ahora bien, que la verdad sea un criterio de corrección de la decisión no dependería, de acuerdo a FERRER, de una preferencia de un modelo sobre otro, sino que responde a una exigencia del sistema jurídico que al consagrar el derecho a la prueba prevería la necesidad de buscar la verdad de los hechos alegados dentro de un juicio.

La reconstrucción presentada permite identificar las bases de una relación entre derecho y verdad. Hasta ahora una de las razones por las cuales la verdad juega un rol, no menor, en el derecho es que permitiría justificar (junto con otras razones) el ejercicio de poder estatal ${ }^{21}$. Sin embargo, la tesis de FERRER pretende explorar las implicancias de la averiguación de la verdad desde el punto de vista de los fines del sistema jurídico.

FERRER identifica siete características definitorias del contexto de la prueba jurídica: 1) El objetivo institucional es la averiguación de la verdad, 2) se determina nor-

19 FERRER no es el único autor que apoya la concepción racional desde un punto de vista del sistema jurídico. Autores como GASCÓN argumentan que la concepción racionalista de la prueba (y el modelo cognoscitivista que pregona) responde a exigencias del sistema jurídico. Para GASCÓN es un criterio de corrección de la decisión judicial de acuerdo a lo dispuesto por el principio de legalidad. Sostiene que «en el modelo epistemológico el fin de la prueba es la averiguación de la verdad. Es cierto que se trata de un fin instrumental, constituye un requisito para que la solución pueda entenderse correcta, al menos en los sistemas regidos por el principio de legalidad. Ello es así porque la solución judicial a los conflictos exigida por el principio de legalidad es la que deriva de la aplicación de una regla jurídica que prevé una determinada consecuencia en presencia de ciertos hechos, de manera que si los hechos a los que se anuda esa consecuencia son falsos, la solución no será correcta: dentro del principio de legalidad» (GASCÓN, 2002: 492). Las cursivas son del autor.

20 Lo anterior no supone que, por medio del proceso, se pueda efectivamente alcanzar la verdad, sino que al menos este debiese estar configurado de tal forma que permita averiguarla.

21 En términos de una «decisión justa», aquí se reconduce a la idea original de BENTHAM sobre rectitude of adjudication. 
malmente la ocurrencia de hechos pasados, 3) el derecho incluye un buen número de reglas jurídicas sobre la prueba, 4) la toma de decisiones sobre la prueba en el proceso está sometida a estricta limitaciones temporales, 5) las partes intervienen en el proceso, 6) la justificación de la decisión adoptada es relativa a un conjunto determinado de elementos de juicio y 7) la decisión que se adopte está dotada de autoridad (FERRER, 2007: 29-40). Debido a que el presente trabajo busca analizar el enfoque que FERRER le da a la relación derecho-verdad, el objeto a estudiar en este trabajo corresponde a la primera característica mencionada en las lineas anteriores: el objetivo institucional es la averiguación de la verdad.

\section{LA TESIS DE LA CLÁUSULA ESTRUCTURAL DE LA VERDAD}

En su reconstrucción, FERRER vincula el fin de la actividad probatoria (alcanzar la verdad de los hechos alegados) con las funciones del derecho en tanto sistema motivador de conductas ${ }^{22}$.

\section{FERRER explica que}

el objetivo institucional del proceso es la averiguación de la verdad. Y ello no puede ser de otra manera, puesto que ese objetivo es estructuralmente necesario para que funcione el propio derecho como mecanismo de motivación de la conducta. Solo si las consecuencias jurídicas previstas por el derecho para acciones determinadas se aplican efectivamente a esas acciones [...] este podrá cumplir su función de mecanismo de resolución de conflictos (FERRER, 2010: 13-4). Las cursivas son mías.

De este modo,

para que ello resulte efectivo, los sistemas jurídicos desarrollados prevén la existencia de órganos específicos - jueces y tribunales - cuya función principal es la determinación de la ocurrencia de esos hechos a los que el derecho vincula consecuencias jurídicas y la imposición de esas consecuencias a los sujetos previsto por el propio derecho [...] solo si el proceso cumple la función de determinar la verdad de las proposiciones referidas a los hechos probados podrá el derecho tener éxito como mecanismo pensado para dirigir la conducta de sus destinatarios. Solo podrá influirse en la conducta de los hombres y mujeres para que no maten si, efectivamente, el proceso cumple la función de averiguar quién mató y le impone la sanción prevista por el derecho.

Por todo ello, la prueba como actividad tendría la función de comprobar la producción de los hechos condicionantes a los que el derecho vincula consecuencias jurídicas o, lo que es lo mismo, determinar el valor de verdad de las proposiciones que describen la ocurrencia de esos hechos condicionantes» (FERRER, 2007: 29-30). Las cursivas son mías.

FERRER reconstruye la relación entre derecho y verdad como necesaria y teleológi$\mathrm{ca}^{23}$. La prueba es un medio para alcanzar la verdad (relación teleológica entre derecho

22 FERRER señala que «seguramente no se discutirá que una de las funciones principales del derecho es dirigir la conducta de los ciudadanos. Se da por supuesto que lo que pretende el legislador al dictar normas jurídicas prescriptivas es que sus destinatarios realicen o se abstengan a realizar ciertas conductas» (FERRER, 2007: 29).

${ }_{23}$ La tesis teleológica supone el descarte de la relación conceptual entre derecho y verdad bajo la cual no es posible sostener que una proposición fáctica ha sido probada si esta no es verdadera. En líneas generales, la diferencia entre las dos tesis recae en que la última — relación conceptual — supone la vinculación entre la verdad y la prueba como resultado (i. e., solo se tendrá una prueba si lo que se declara probado es también verdad). En cambio, la primera plantea una relación entre la verdad y la prueba como actividad probatoria. Si 
y verdad) porque solo si es posible averiguar la verdad de los hechos alegados se podrá motivar la conducta en los términos dictados por las normas que integran un sistema jurídico (relación necesaria entre derecho y verdad).

A esta tesis la denomino la tesis de la cláusula estructural de la verdad (TCEV).

La ventaja del enfoque presentado por FERRER es que la averiguación de la verdad responde a una demanda del sistema jurídico y no a preferencias morales o ideológicas de las ventajas de un sistema por sobre otro. La TCEV ubica a la averiguación no tan solo en el centro de la actividad probatoria, posicionándola como un fin preferente frente a otros posibles fines, sino que, además, como condición necesaria para que el derecho sea efectivo en motivar la conducta de los gobernados.

Así

(s)ólo si las consecuencias jurídicas previstas por el derecho para acciones determinadas se aplican efectivamente a esas acciones (idealmente siempre a esas acciones y nunca a otras), los ciudadanos tendrán motivos para actuar conforme a lo prescrito por el derecho y este podrá cumplir su función de mecanismo de resolución de conflictos. Esta faceta estructural no es compartida por otros valores con los que la averiguación de la verdad puede entrar en conflicto (FERRER, 2007: 82). Las cursivas son mías.

FERRER es consciente que el derecho promueve distintos fines y que estos fines pueden colisionar entre sí,

(a)hora bien, si parece claro ya que la averiguación de la verdad es el objetivo fundamental de la actividad probatoria, también lo es que ese no es el único objetivo [...] decir que algo es la finalidad de una institución o actividad, no excluye que existan otras finalidades o propósitos. Y este es el caso de la regulación jurídica de la prueba, que en muchos casos puede ser entendida como la imposición de excepciones a las reglas de la epistemología general en aras de la protección de otros valores, que comparten protección jurídica con la averiguación de la verdad (FERRER, 2007: 31). Se han omitido las citas.

Sin embargo, la relación necesaria que existiría entre verdad y derecho posiciona a la primera en un sitial preferente con respecto a estos otros valores. Esta posición favorable se traduce en que no sería posible prescindir de la verdad si se quiere tener un sistema jurídico que funcione,

(u)n sistema jurídico puede funcionar perfectamente sin asumir el valor de la inviolabilidad del domicilio o las comunicaciones, por ejemplo. Sería un sistema jurídico indeseable por otros motivos, pero no hay nada que impida que un sistema así sea perfectamente efectivo y eficiente en el cumplimiento de su función motivadora de la conducta. En cambio, el sistema no puede prescindir de la averiguación de la verdad como objetivo institucional del proceso (y, por tanto de la aplicación del derecho) puesto que de otro modo el sistema colapsaría (FERRER, 2007: 82-83). Las cursivas son mías.

En resumen la TCEV sostiene que la relación entre derecho y verdad (averiguación de la verdad) es necesaria para que el derecho sea efectivo como sistema que dirige la conducta de los ciudadanos.

\footnotetext{
bien las dos concepciones coinciden en que para que una proposición se considere probada es necesario que existan elementos de juicio a favor de la misma, divergen en que la teoría de la relación conceptual le agrega un segundo requisito, que la proposición sea verdadera. Como la tesis teleológica no requiere de la verdad de la proposición para ser considerada como probada, perfectamente es posible que una hipótesis sobre los hechos pueda resultar probada, aun cuando sea falsa (FERRER, 2006: 30).
} 
Si bien la TCEV no es el argumento central del libro la valoración racional de la prueba sí es un presupuesto necesario para poder sostener el modelo racionalista que FERRER describe en su obra. Solo en la medida en que la verdad y el derecho estén conectados tiene sentido presentar un modelo racional de valoración de la prueba. Así, la TCEV es la espina dorsal en la cual la obra de FERRER se soporta. Lo cierto es que FERRER no ha desarrollado a fondo esta tesis en su obra y el hecho de que sea generalmente aceptada (o al menos no discutida) en el debate académico ${ }^{24}$ sobre materias de prueba no ayuda a la revisión de sus postulados e implicancias.

Es por esto que este trabajo pone bajo examen crítico la TCEV sosteniendo que en los términos en los que FERRER ha desarrollado esta tesis no es posible concluir que la relación entre derecho y verdad sea necesaria para que el derecho sea efectivo como sistema que dirige la conducta de los gobernados.

\section{EL DERECHO COMO HERRAMIENTA PARA MOTIVAR LA CONDUCTA}

El argumento central de este artículo es que la averiguación de la verdad no es necesaria para motivar la conducta de los agentes. En este sentido, la TCEV es superflua si lo que se quiere justificar es la motivación de la conducta por medio del derecho. Lo anterior no supone eliminar la búsqueda de la verdad de la «ecuación» solo que no ostentaría una posición privilegiada frente a los otros valores que el derecho buscaría promover y proteger. En definitiva no tendría un valor estructural.

Para desarrollar este argumento primero paso a presentar dos formas de entender la TCEV. Estas reconstrucciones giran en torno a dos posibles sentidos que la expresión motivar la conducta puede adoptar a la luz de la relación derecho y verdad.

La primera, es que la TCEV es una tesis que lidia con una noción central en la teoría del derecho: la noción de normatividad. Desde este punto de vista, motivar la conducta sería adscribirle al derecho una propiedad a nivel de conceptual: el derecho tiene fuerza obligatoria. De esta forma, solo sería posible sostener que el derecho guía la conducta si tiene capacidad para obligar a los dirigidos con independencia de las preferencias personales de estos ${ }^{25}$.

En virtud de esta supuesta fuerza obligatoria el derecho solo puede motivar la conducta, si y solo si, está orientado a la búsqueda de la verdad de los hechos discutidos en el proceso. En este sentido, la conexión teleológica entre prueba y verdad se justifica en términos de garantía de la fuerza vinculante del derecho para guiar la conducta de los participantes en una comunidad determinada: en orden de garantizar la fuerza vinculante del derecho es que se debe averiguar la verdad de los hechos discutidos en el proceso judicial ${ }^{26}$.

24 En DeI VeCCHI, 2013: 243 se puede ver una aceptación de la TCEV.

25 Para una revisión crítica de esta tesis vid. REYES, 2016.

26 Esta posibilidad de entender el planteamiento de FERRER abre la puerta al debate de que es lo que él entienda, a su vez, por normatividad del derecho. Lo cierto es que en La valoración racional de la prueba, al menos, no se encuentra explicada esta noción debido a que escapa del objetivo del libro. De esta forma 
La segunda forma de entender la TCEV es la siguiente: el derecho es un sistema de normas entendido como una herramienta para motivar la conducta. En este sentido, el derecho, como cualquier otro sistema de normas con pretensión de control o dirección de conductas (como la religión, códigos morales, etc.), necesita que sea posible la averiguación de la verdad de los hechos si quiere tener éxito en lograr su cometido. Luego, si se requiere averiguar la verdad, se debe disponer entonces mecanismos para su búsqueda y alcance. En este sentido por motivar la conducta se entendería un estado psicológico en los gobernados de conformar su comportamiento a lo dispuesto por el derecho.

Es esta segunda alternativa la que creo que FERRER tiene en mente al presentar la relación entre derecho y verdad en los términos de la TCEV y es en la que me enfocaré para sustentar la postura delineada en las primeras lineas de este apartado. De esta forma, la TCEV es presentada como un argumento instrumental en el sentido de que el derecho es una herramienta para un fin. Este fin es la dirección de las conductas de un grupo de personas. La averiguación de la verdad sirve como medio para lograr ese fin. De acuerdo a la TCEV pareciera ser que la averiguación de la verdad genera un incentivo psicológico en los gobernados, quienes estando al tanto de la posibilidad de que el derecho pueda comprobar sus acciones se sentirán motivados a seguir las prescripciones contenidas en las normas. Si se tiene en cuenta esta línea de argumentación, creo que la TCEV puede ser objeto de al menos dos críticas que debilitarían la relación necesaria entre derecho y verdad.

\subsection{Veracidad $\mathrm{v} / \mathrm{s}$ verosimilitud}

El término motivación utilizado por FERRER es ambiguo. Por una parte, puede ser entendido como la razón para hacer o no hacer algo, por otra, como la justificación de una acción. La diferencia entre ambos sentidos recae, entre otras cosas, en el factor temporal con las que estas suponen operar. El primero es previo a la realización o no de una acción, el segundo es posterior a esta. Si bien FERRER no aclara qué sentido adopta cuando utiliza la noción de motivación creo que él presupone la primera. Esto, debido a que solo se podría modificar o guiar la conducta si se es posible influir en el agente previo a la realización o a la abstención de la conducta objeto de regulación. De este modo, FERRER pareciera referirse, aunque no lo señala explícitamente, a una noción psicológica de motivación. Ya OlIVECRONA nos advertía la naturaleza psicológica de este vínculo «(l)os juristas y los filósofos están conscientes del hecho que la fuerza obligatoria del derecho no pertenece al mundo del tiempo y espacio, el mundo natural. $\mathrm{La}$ conclusión más obvia debe ser que la fuerza vinculante del derecho existe solamente en nuestra imaginación» (OlIVECRONA, 1930: 15) ${ }^{27}$.

\footnotetext{
plantear la discusión en estos términos me parece que excede los propósitos tanto del trabajo de FERRER como de este trabajo. Sin embargo, una cuenta sobre derecho y normatividad se puede encontrar en SPAAK, 2003: 469-485.

${ }_{27}$ En principio es posible sostener que el mundo de las instituciones sociales también se encuentra inserto en un contexto tiempo/espacio puesto que es comprobable empíricamente a la existencia de instituciones sociales que afectan nuestra realidad y vida. Sin embargo, lo que es posible encuadrar en este contexto no son las instituciones sociales per se sino que los comportamientos verificables de una determinada comunidad como
} 
HART sostiene que como generalmente los comportamientos regulados por normas jurídicas son deseables en la vida social, estas se encontrarán investidas de una fuerte presión social para que sean cumplidas. En razón de lo anterior es que los sistemas jurídicos contarían con un contingente de autoridades que velarán por el cumplimiento de lo prescrito por el derecho: «la presión social aparece como una cadena, atando a aquellos que tienen una obligación para que así no actúen libremente. El otro lado de la cadena es sostenida por un grupo de autoridades representativas, quienes insisten en la verificación de algún comportamiento o exigen el castigo» (HART, 2012: 87). En otras palabras, el derecho ejerce presión en los miembros de una comunidad. En este sentido, las normas son (entre otras cosas) elementos que componen el estado psicológico de motivación de las personas y que influencian su comportamiento ${ }^{28}$. Este estado, a su vez, responde a «expresiones imperativas las cuales son usadas en orden de inculcar un determinado comportamiento sobre la gente» (OLIVECRONA, 1930: 21).

En los términos de la TCEV la noción de motivación de la conducta pareciera suponer la creación de un estado psicológico en las personas a seguir las normas jurídicas que conforman un determinado ordenamiento ${ }^{29}$. De esta forma, si averiguar la verdad de los hechos litigiosos implica la creación de un estado psicológico en los gobernados, entonces, para influir en su conducta en la forma prescrita por las del derecho, pareciera ser que no se requiere la verdad para que el derecho tenga éxito en guiar el comportamiento. Bastaría, para lograr el fin propuesto, la apariencia de búsqueda de la verdad. De este modo, no sería necesario que las decisiones/veredictos/sentencias contengan enunciados fácticos verdaderos sino que solo se requeriría que el público (los gobernados) crea que son verdaderos o que parezcan serlos. Es decir, esta apariencia de verdad, i. e., una decisión ordenada de tal forma que parezca haber sido dictada como si hubiese sido el producto de la investigación de la verdad de los hechos discutidos, o lo que es lo mismo, que un observador externo como el usuario del sistema y los miembros de la comunidad, se forme la creencia de que el juicio busca averiguar la verdad, serviría para que los gobernados ajusten su conducta a lo prescrito por las normas (Ho, 2008: 57-59) ${ }^{30}$.

respuesta a lo previsto por lo que conocemos como institución social. Es a esto a lo que se refiere OLIVECRONA cuando sostiene que el derecho no es susceptible de ser entendido como un fenómeno físico del cual podamos dar cuenta con nuestros sentidos.

28 HART presenta una distinción entre sentirse obligado y tener una obligación: la primera corresponde a los motivos psicológicos (creencias) por las cuales se realiza una conducta (HART, 2012: 82-3). La segunda, es una afirmación independiente de los motivos o factores subjetivos de quien se le imputa el deber y «generalmente implica la existencia de una regla» (HART, 2012: 85). Sin embargo, no creo que FERRER sostenga que el derecho de becho crea un «sentimiento de obligación» en las personas sino más bien la motivación a la que hace referencia es una noción, si se quiere, más moderada, en la cual el papel del derecho (o las normas jurídicas) cumple un rol fundacional mas no excluyente con respecto a otras consideraciones de orden extra-jurídico que las personas puedan adoptar con el fin de adecuar su conducta.

29 No pareciera ser que cuando FERRER se refiere a la necesidad de alcanzar la verdad para motivar la conducta este describiendo la existencia de una regla y el comportamiento de los sistemas procesales cuando lidian con la prueba. La TCEV en este aspecto tiene un claro componente normativo, es por esto que adopto la versión psicológica en la cual por motivación se entiende la creación de un estado psicológico de conformar el comportamiento a lo dispuestos por las normas de un sistema jurídico.

${ }_{30} \mathrm{Si}$ bien Ho acepta que a mayor apariencia de que el sistema persigue la verdad existirá mayor conformidad de los gobernados con las normas jurídicas, también es cauto en señalar que el requisito que de becho sea alcance la verdad juega un rol en la justicia de la decisión (Ho, 2008: 60). 
Veracidad y verosimilitud colapsan no haciendo posible la distinción ex ante de algo que parece verdad con algo que es verdad ${ }^{31}$. En este sentido, la TCEV no permite explicar por qué una cuenta verosímil de los hechos no sería idónea para motivar a los gobernados. La búsqueda de la verdad no es necesaria puesto que se podría cumplir el mismo fin por medios distintos a esta en la medida que parezca como si fueran el producto de la investigación veraz ${ }^{32}$.

\subsection{Desconocimiento e indeterminación del derecho}

El segundo argumento que se puede esgrimir en contra de la relación necesaria entre derecho y verdad que postula la TCEV puede ser elaborado en dos partes:

Por una parte, si se requiere que los miembros de una comunidad se comporten acorde a lo prescrito por el derecho, estos debiesen, al menos, tener una idea o estar al tanto de que el proceso cumple la función de averiguar la verdad de los hechos descritos, es decir, al menos debiesen conocer, no a de forma acabada pero si a un nivel general, el funcionamiento del derecho, i. e., saber que el derecho puede alcanzar la verdad, y, al menos, por cuales medios se puede lograr este cometido ${ }^{33}$. Sin perjuicio de lo anterior, esto no parece ser una descripción adecuada de la realidad. La generalidad es que los miembros de una comunidad no posean dicho conocimiento y sin embargo, en su mayoría, se comporten en conformidad a las normas jurídicas (o al menos no en un quebrantamiento constante que pueda poner en jaque el ordenamiento social). En este sentido, no es necesario que los gobernados conozcan que el derecho es capaz de averiguar la verdad de los hechos para ajustar su conducta ${ }^{34}$ a lo previsto por este.

Por otra parte, para que el derecho pueda motivar la conducta se requeriría un mínimo de conocimiento sobre el contenido del derecho por parte de los dirigidos. Este conocimiento, de forma general, recaería tanto en los hechos (que el derecho buscaría tanto promover como desalentar) como en las consecuencias jurídicas que la realización o no realización de dichos hechos conllevarían. Solo de esta forma sería posible saber cómo la conducta de los miembros de la comunidad está o no ajustada a lo dispuesto por las normas jurídicas que la rigen. Vale decir, para planear nuestra conducta acorde al derecho debemos estar en la posibilidad de conocer mínimamente qué dice el derecho. Sostener esta postura es problemática si se reconoce que el dere-

31 Sin perjuicio de lo anterior, verdad y veracidad si bien son nociones estrechamente vinculadas no son sinónimas.

32 Por supuesto, esto no obsta a que si en algún momento se «descubriese» que el derecho solo aparenta la averiguación de la verdad, los gobernados dejaran de guiarse por este. Sin embargo, podría sostenerse que aquí ya no existiría un caso de verosimilitud. Los efectos del acto verosímil solo existen mientras la apariencia de verdad se mantenga.

33 Esto pareciera sugerir que los miembros de la comunidad tengan conocimiento de las reglas procesales de sus respectivos sistemas jurídicos. Lo cierto es que es perfectamente posible no tener conocimiento alguno de cómo funciona el derecho de una determinada comunidad y aun así tener una impresión (o pensar) que el derecho persiga la verdad. Esta actitud puede reconducirse a la primera crítica. Si lo que se requiere para que se ajuste la conducta a las normas es la creencia de que se pueden averiguar los hechos (que infrinjan o cumplan normas) entonces el requisito de que el derecho de hecho averigüe la verdad es superfluo al objetivo planteado.

34 Por ajustar la conducta me refiero en líneas generales a la situación en que los gobernados no infringen de forma sistemática y recurrente lo dispuesto por las normas de un sistema jurídico. 
cho es indeterminado (GUASTINI, 2005: 139-144; LeITER, 2007; DAGAN, 2013) ${ }^{35}$. Esto porque las normas derivadas de la interpretación de disposiciones normativas ${ }^{36}$ pueden arrojar resultados contrarios pero que sin embargo son legalmente válidos (NÚÑEZ VAQUERO, 2013: 15) ${ }^{37}$. Vale decir, ante un mismo caso sería posible concluir que un comportamiento está permitido y prohibido a la vez (GUASTINI, 2014: 91-2). Si bien se podría contra argumentar que la indeterminación del derecho apunta a las consecuencias jurídicas y no a los hechos, no es menos cierto que para determinar qué hechos serán utilizados como premisas del razonamiento jurídico se debe tener de antemano un conocimiento de la categoría deóntica (ordenado, permitido o prohibido) prevista por el derecho, sobre esos hechos. En este sentido, aun si aceptamos que 1) el derecho pueda efectivamente alcanzar la verdad de los hechos alegados y 2) esto sea de conocimiento de los gobernados, la tarea de motivar la conducta será difícil en la medida en que los gobernados, aun teniendo esta información, no estarán en una posición de saber si dichos comportamientos están prohibidos o permitidos ${ }^{38}$.

La TCEV no permite dar cuenta del desconocimiento general del funcionamiento del derecho por parte de los gobernados ni tampoco sortear el problema de la indeterminación jurídica y la imposibilidad de conocer de antemano (antes de una decisión judicial) si un determinado comportamiento está o no prohibido por el derecho ${ }^{39}$.

35 Tratar el fenómeno de la indeterminación del derecho excede los propósitos de este trabajo. Para un desarrollo del tema, vid., entre otros, IGLESIAS VILA, 2006: 55-82; LEITER, 1995: 482-495 y KRESS, 1989: 283337. Cabe hacer la observación de que la doctrina ha presentado diversos tipos de indeterminación. Sin embargo, para efectos de este articulo esta se entenderá de forma general como la imposibilidad general de conocer las consecuencias jurídicas de los actos. Lo anterior está íntimamente relacionada con una de las preocupaciones centrales del realismo jurídico estadounidense, la posibilidad de predecir las decisiones de los tribunales. Vid. a modo de ejemplo K. LLEWELlyn, «A Realistic Jurisprudence: The Next Step», Columbia Law Review, vol. XX, núm. 4 (1930): 448. Si bien puede ser tildado de proto-realista, el autor (quizá más reconocido) que impulsó esta inquietud fue O. W. Holmes en su discurso titulado «The Path of Law». Vid. O. W. HoLmes, The Path of Law and the Common Law (New York: Kaplan, 2008). Sin perjuicio de lo anterior, si bien desde una perspectiva general, no sería posible la predicción de las decisiones judiciales no es menos cierto que (y esto ya requiere de un análisis empírico) si un juez o grupo de jueces llegan a una decisión determinada, basado en estímulos similares para casos similares durante un periodo de tiempo determinado, entonces sí sería plausible sostener que al menos podríamos predecir la decisión que se adoptará, con respecto a ese juez o grupo de jueces en particular, en un caso con similares características.

36 Por interpretar entiendo la adscripción de significado a un texto (GUASTINI, 2011a: 133). En este sentido sostengo que la distinción disposición norma es relevante para entender la noción de indeterminación del derecho. Vid. en este sentido GUASTINI, 2011a:133-156.

37 NÚNEEZ VAQUERO adopta la reconstrucción presentada por LEITER de indeterminación jurídica.

38 En este sentido la noción de indeterminación tiene relación con la posibilidad de conocer de antemano (o no) las consecuencias jurídicas de las acciones realizadas en una determinada comunidad (COMANDUCCI, 1998: 101). Estoy consciente de que podría contra-argumentarse que en un escenario $i d e a l$, en el cual no existe controversia sobre la capacidad epistémica del derecho, como el presentado en la última parte de mi argumento, la averiguación de la verdad sería una condición necesaria más no suficiente para motivar la conducta. Sin embargo, no me detendré a desarrollar las posibles objeciones a este contra-argumento.

39 Una opción sería adoptar una postura cognoscitivista de la interpretación jurídica en la cual el ejercicio de interpretación de disposiciones normativas es un ejercicio de descubrimiento del significado único o correcto de esa disposición (DWORKIN, 1986). Si se sigue esta línea de argumentación entonces se concluye que el derecho está determinado y que es posible para el interprete conocer ese significado único aparejado a la disposición normativa. En este sentido se abre una puerta para que los gobernados puedan, de antemano, conocer el derecho y así conformar sus conductas con lo dispuesto en las normas jurídicas. Lo cierto es que esta postura no permite responder los retos planteados por la tesis de la indeterminación sino que niega de plano que la indeterminación del derecho sea posible. A modo de ejemplo, para ver un desarrollo sobre la discusión: ATIENZA, 2009: 13-26 y AARNIO, 1990: 23-38. 


\section{TCEV REVISITADA}

Las dos objeciones planteadas a la TCEV en el apartado anterior presentan un cuadro en el cual la búsqueda de la verdad no es necesaria para el derecho si lo que se quiere es argumentar a favor de la función motivadora de conductas de un sistema jurídico. En este sentido, el ajuste de comportamiento de los gobernados acorde a lo prescrito por el derecho no depende de la capacidad de este de averiguar la verdad de las conductas de los miembros de una comunidad. $\mathrm{O}$ al menos, como ya se señaló, la verdad no sería necesaria para esto. Lo anterior no supone negar una relación entre derecho y verdad sino que argumentar a favor de una re-examinación de sus presupuestos. Sin perjuicio de que redefinir la relación entre derecho y verdad escapa de los propósitos de este trabajo, en este apartado presentaré cinco reconstrucciones posibles de la TCEV, sin tomar partido por ninguna de estas, tomando como noción central la exigencia de averiguar la verdad.

\subsection{Norma implícita}

La exigencia de averiguar la verdad de los hechos alegados estaría contenida en una norma implícita del sistema. Vale decir, una norma que no es resultado de la interpretación de una disposición normativa ni es consecuencia lógica de una disposición normativa expresa (GUASTINI, 2004: 251) ${ }^{40}$. Estas normas, como su nombre lo indica, no están formuladas de forma expresa en el sistema sino que son el fruto de la interpretación creativa ${ }^{41}$ de una o varias normas explícitas por medio de diversos métodos no deductivos (GUASTINI, 2012:33).

Así

son principios no expresos los que carecen de disposición, es decir, los no explícitamente formulados en alguna disposición constitucional o legislativa, sino elaborados o «construidos» por los intérpretes. Se entiende que los intérpretes, cuando formulan un principio no expreso, no se convierten en legisladores, sino que asumen que tal principio está implícito, latente, en el discurso de las fuentes (GUASTINI, 2001: 138) ${ }^{42}$. Citas omitidas.

En este sentido, la averiguación de la verdad sería una norma implícita del sistema derivada de los derechos fundamentales de corte procesal (derecho a la prueba, debido proceso, defensa, etc.). Desde esta perspectiva se puede hablar de la verdad como valor estructural en la medida en que está implícita en el sistema siendo posible extraer una norma que prescriba la averiguación de la verdad de un conjunto de normas expresas, i. e., derechos fundamentales.

40 Para una cuenta de los tipos de normas implícitas vid. GUASTINI, 1995: 259.

41 No me detendré a analizar la distinción entre interpretación e interpretación como creación jurídica, para esto vid. GUASTINI, 2011b: 157-179. Sin embargo, sostengo que las normas implícitas son un ejercicio de creación jurídica.

42 Si bien la cita presentada habla solo de principios, esto no obsta a que distintos tipos de normas puedan encontrarse de forma implícita en un determinado sistema jurídico. 


\subsection{Micro-derecho a la averiguación de la verdad}

Una segunda forma de entender la TCEV es explorando el concepto de micro y macro derechos. Por micro-derechos entiendo situaciones favorables simples: libertades, inmunidades, potestades y pretensiones ${ }^{43}$, mientras que por macro-derecho entiendo situaciones favorables complejas, vale decir, combinaciones de situaciones favorables simples (BARBERIS, 2008: 14).

De acuerdo a esta interpretación, existiría un micro-derecho a averiguar la verdad de los hechos discutidos en juicio el cual corresponde a las partes litigantes y que se ejercería dentro del proceso. Si bien en este trabajo no analizaré cual posición jurídica favorable corresponde al micro derecho de averiguación de la verdad, una intuición posible es que corresponda a una pretensión cuya contraparte, quien carga con el $d e$ ber, sería el estado, i. e., el juez en tanto órgano estatal. En este esquema el juez debe propender a tratar la prueba, tanto en su admisión como en su valoración, de la forma más acorde para averiguar la verdad. Para lograr este objetivo es que la TCEV propone una concepción racionalista de la prueba.

Este micro-derecho se derivaría, siguiendo a FERRER, del macro-derecho a la prueba (y para el caso de que este no este positivado en un ordenamiento jurídico particular, entonces sería posible de derivar del derecho a defensa o debido proceso) el cual estaría formado por una serie de combinaciones de situaciones favorables simples (micro-derechos) los cuáles son, de acuerdo a FERRER, 1) el derecho a utilizar todas las pruebas de que se dispone para demostrar la verdad de los hechos que funda su pretensión (FERRER, 2007: 54), 2) el derecho a que las pruebas sean practicadas en el proceso (FERRER, 2007:55) y 3) el derecho a una valoración racional de las pruebas practicadas (FERRER, 2007: 56). La verdad sería parte estructural del proceso en su calidad de micro derecho derivado de macro-derechos consagrados en textos autoritativos.

\subsection{Macro-derecho a la verdad}

Una tercera interpretación posible corresponde a que existe un macro-derecho a la verdad. Este macro-derecho estaría compuesto por una serie de posiciones favorables simples de distintas naturaleza que se verán traducidas en las diversas acciones que las partes pueden adoptar en el transcurso del proceso. Así, determinar qué pruebas se presentarán y cómo se desarrollará el examen y contra examen de testigos podrían recaer en categorías de libertades, mientras que tener la opción de presentar prueba, de excluir prueba y de que la prueba presentada sea valorada racionalmente pueden ser pretensiones, a su vez estar dispensado de probar determinados hechos puede verse como inmunidades, etc. La interacción de estas posiciones favorables simples en el contexto del juicio configuraría el macro-derecho a la verdad que le asiste a las partes en el proceso. Este macro-derecho, que se traduce en la averiguación de la verdad por

43 Las llamadas categorías o incidentes bohfeldianos (HOHFELD, 1919). Analizar a fondo las nociones de micro y macro derechos junto con la de derechos-razones escapa del alcance de este trabajo. Para esto vid. BARBERIS, 2008. Una cuenta de esta postura y su relación con concepciones pragmatistas de los derechos se puede encontrar en TUZET, 2013: 11-36. 
medio del proceso, permea toda la instancia del litigio e informa el actuar tanto de las partes como del juez. En este sentido la averiguación de la verdad es estructural puesto que el proceso está orientado a buscar la verdad. Es estructural en relación al proceso que a su vez es la concretización de la posibilidad de defender nuestros derechos o intereses ante un juez.

\subsection{Verdad como parte de nuestro concepto de derecho}

Una cuarta forma de entender la TCEV es sostener que la verdad forma parte de nuestro concepto de derecho. Es decir, no sería posible concebir un ordenamiento jurídico que no tome en cuenta, en algún nivel, la verdad de los hechos a los que busca aplicar las consecuencias jurídicas. En otras palabras, no estaríamos dispuestos a calificar como derecho un conjunto de normas en los que la averiguación de la verdad no jugase ningún papel. Pareciera ser que FERRER implícitamente adhiere a esta postura cuando expresa que «el sistema no puede prescindir de la averiguación de la verdad como objetivo institucional del proceso, y, por tanto de la aplicación del derecho, «puesto que de otro modo el sistema colapsaría» (FERRER, 2007: 83) ${ }^{44}$. Esto refuerza, a su vez, la opción de un modelo racionalista de la prueba, si se asume que este modelo es el más apto para alcanzar la verdad, y la tesis de que la verdad ostenta un lugar de preferencias por sobre otros fines que el derecho promueve. Por otro lado, este enfoque colisiona con concepciones y prácticas clásicas del proceso civil las que generalmente no le otorgan un valor relevante a la persecución de la verdad para el fin del proceso civil, i. e., la resolución de conflictos (TARUFFO, 2013: 97 y ss.) ${ }^{45}$. La adopción de esta postura, también, abre el debate a varios tópicos que exceden el ámbito del derecho probatorio e inciden directamente en clásicas discusiones de la teoría del derecho como la validez material de las normas, la relación entre derecho y moral, predicción de las decisiones judiciales, etcétera.

\subsection{Ideal regulativo extra jurídico}

Por último otro significado posible es entender a la verdad como un ideal regulativo. Ahora bien, la expresión ideal regulativo es ambigua puesto que puede referirse a un principio jurídico o a valores extra jurídicos. Es esta segunda acepción a la que me refiero cuando utilizo la expresión ideal regulativo (KANT, 1781, Crítica de la razón pura, A569-B597; POPPER, 1963: 264 y ss.; HAACK, 1978: 134 y ss.). Que la verdad sea un ideal regulativo supone que es un fin deseable de perseguir pero que sin embargo

44 Las cursivas son mías.

45 De hecho en los países que han desarrollado un estándar de prueba civil se han preocupado no de la consecución de la verdad sino de la existencia de narraciones plausibles o más «convincentes» (e. g., estándar de probabilidad prevalente) excepcionalmente se exige un grado de corroboración mayor (e. $g$., estándar de prueba clara y convincente) sin embargo, dado que generalmente estos estándares están formulados en términos probabilísticos, la probabilidad asignada para determinar cuando un hecho ha sido probado es un reflejo de cuán importante en materia civil es la distribución del error. No analizaré la problemática de los estándares de prueba civil, para esto vid. Reyes, 2015; LARroucau, 2012 y PARDO, 2009. 
cabe la posibilidad de que nunca lo alcancemos. Esto no supone el abandono del ideal regulativo sino que tal es posible cumplir de forma gradual con la pretensión contenida en dicho ideal, $i$. e., averiguar o alcanzar la verdad de los hechos a los cuales se le aplicarán consecuencias jurídicas, i. e., poder estatal. En este sentido la verdad es un valor extrajurídico compartido por una comunidad. Es una pretensión o una expectativa de los usuarios del sistema a que las instituciones que los gobiernan actúen en base a hechos que han ocurrido en la realidad y no ejerzan el poder estatal de forma arbitraria. En este sentido la expectativa de verdad refuerza la confianza en el sistema ${ }^{46}$.

\section{COMENTARIOS FINALES}

La TCEV presentada por FERRER ha sido generalmente aceptada, implícita o explícitamente, por los estudiosos del derecho probatorio en el ámbito de habla hispana. Esta aceptación general ha llevado a una falta de discusión y análisis sobre cuál es el rol de la verdad en el proceso y qué entendemos cuando decimos que el derecho demanda averiguar la verdad de los hechos alegados en un juicio. Se da por sentado, consciente o inconscientemente, que existe una relación entre derecho y verdad y, al menos en el discurso contemporáneo, esto significaría la adopción de un determinado modelo de concepción de la prueba jurídica, i. e., concepción racionalista de la prueba. En líneas generales, este modelo es el reflejo de una agenda de política jurídica en el sentido de que busca cambiar el meta-discurso clásico de la prueba jurídica la cual ha sido estudiada tradicionalmente desde el derecho procesal (al menos en la tradición del Civil Law), a uno de reflexión teórica en el cual se proponen las mejores respuestas a los problemas probatorios que persisten en la práctica de hoy. Lo anterior requiere un arduo trabajo intelectual y bases sólidas de las cuales derivar estudios específicos en la amplia gama que el derecho a la pruebe provee. Una de estas bases es cómo interactúa el derecho y la verdad (si es que interactúan de algún modo).

En este trabajo se ha tratado de presentar una reconstrucción de los argumentos centrales de la tesis de la cláusula estructural de la verdad, dos objeciones posibles que plantean problemas a resolver si lo que se quiere sostener es que: 1) existe una relación entre derecho y verdad y 2) que esta es necesaria para el derecho si queremos que este cumpla su función de motivar la conducta. Por último, se presentaron cinco formas de entender esta relación enfocándome en el rol de averiguación de la verdad que, de acuerdo a quienes sostienen la TCEV, existiría.

Las cinco interpretaciones presentadas del rol estructural que ha sido adscrito por FERRER a la verdad dentro del derecho son de naturaleza distinta, e. g., no es lo mismo un principio o norma implícita que un macro derecho, o un micro derecho que un ideal regulativo extrajurídico o un elemento de nuestro concepto de derecho, y quizás a veces incompatible, $e$. g., si es un macro-derecho entonces no es un ideal regulativo en sentido extra-jurídico.

46 Sin embargo, cabe distinguir tener una expectativa de verdad que de hecho el derecho sea capaz de averiguar la verdad. 
En conclusión, el presente ensayo es simplemente una llamada a no abandonar el estudio de concepciones que, por muy persuasivas y deseables que parezcan a primera vista, son la base para entender cómo funciona el derecho.

\section{BIBLIOGRAFÍA}

AARNIO, A., 1990: «La tesis de la única respuesta correcta y el principio regulativo del razonamiento jurídico», Doxa, 8: 23-38.

ACCATINO, D., 2010: «El modelo legal de justificación de los enunciados probatorios en las sentencias penales y su control a través del recurso de nulidad», en D. ACCATINO, Formación y valoración de la prueba en el proceso penal, Santiago: Legal Publishing, 119-143.

AmayA A., 2013: «Coherence, Evidence and Legal Proof», Legal Theory, 19 (1): 1-43.

- 2015: The Tapestry of Reason: An Inquiry into the Nature of Coherence and its Role in Legal Argument, Oxford: Hart.

ANDERSON, J., y HopKINS, A., 2014: Uniform Evidence Law Guidebook, Oxford: Oxford University Press.

Anderson, T.; Schum, D., y TwInING, W., 2005: Analysis of evidence, UK: Cambridge University Press.

AtIENZA, M., 2009: «Sobre la única respuesta correcta», Jurídicas, 6 (2): 13-26.

BARBERIS, M., 2008: Ética para juristas, Madrid: Trotta.

BAYÓN, J. C., 2008: «Epistemología, Moral y prueba de los hechos: Hacia un enfoque no benthamiano», en Analisi e diritto, 15-34.

Bentham, J., 1843: «The Rationale of Evidence», The Works of Jeremy Bentham, vol. 6, Londres: Simpkin, Marshal \& Co.

CALAmANDReI, P., 1943: Istituzioni di diritto processuale civile secondo il nueovo codice, Milan: CEDAM.

CARNELUTTI, F., 1915: La prova civile: parte generale: il concetto giuridico della prova, Roma: Athenaeum.

Chiovenda, G., 1923: Principii di diritto processuale civile, Napoli: N. Jovene.

Comanducci, P., 1998: «Principios jurídicos e indeterminación del derecho», Doxa, 21 (2), 89-104.

Couture, E., 1943: Fundamentos del derecho procesal civil, Montevideo: B de F., Ltda.

Dagan, H., 2013: Reconstructing American Legal Realism E Rethinking Private Law Theory, Oxford: Oxford University Press.

Davis, P.; Twining, W., y Vasilaki, M., 2011: Evidence, Inference and Inquiry, Oxford: Oxford University Press.

Dei VeCCHI, D., 2013: «Tres discusiones acerca de la relación entre prueba y verdad», Discusiones, 13: 233-264.

Devis Echandía, H., 1976: Teoría general de la prueba judicial, Buenos Aires: Editorial Zabalía.

Dworkin, R., 1986: Law's Empire, Boston: Harvard University Press.

FERRER, J., 2002: Prueba y verdad en el derecho, Madrid: Marcial Pons.

- 2003: «Derecho a la prueba y racionalidad en las decisiones judiciales», Jueces para la democracia, 47: 27-34.

- 2006: «La valoración de la prueba: Verdad de los enunciados probatorios y justificación de la decisión», en M. CARBOnELl, J. OROZCO y R., VÁZQuez, Estudios sobre la prueba, México: UNAM: $1-41$. 
- 2007: Valoración racional de la prueba, Madrid: Marcial Pons.

- 2010: «La prueba es libertad, pero no tanto. Una teoría de la prueba cuasi-benthamiana», en D. Accatino, Formación y valoración de la prueba en el proceso penal, Santiago: Legal Publishing, 3-20.

GARRET, B., 2011: Convicting the Innocent: Where Criminal Procedure Goes Wrong, Boston: Harvard University Press.

GASCÓN, M., 1999: Los hechos en el derecho: bases argumentales de la prueba, Madrid: Marcial Pons.

- 2002: «Sobre el modelo cognoscitivista en la prueba judicial. A propósito de las observaciones de Mario Ruiz», Anuario de Filosofía del Derecho, 19: 489-496.

— 2006: «Freedom of Proof? El cuestionable debilitamiento de la regla de exclusión de la prueba ilícita», en M. CARBONELl, J. OROZCO y R. VÁZQUEZ, Estudios sobre la prueba, México: UNAM: 47-88.

GonZÁLEZ, D., 2011: Quaestio Facti: Ensayos sobre la prueba, causalidad y acción, México: Fontamara.

GUASTINI, R., 1995: «Normas supremas», Doxa, 17 (18): 257-270.

- 2001: Estudios de teoría constitucional, México: Fontamara.

— 2004: «Proyecto para la voz “ordenamiento jurídico" de un diccionario», Doxa, 27 (2): 247-282.

- 2005: «A Sceptical View on Legal Interpretation», en P. ComAnDUCCI y R. GuASTini, Analisi e diritto 2005. Ricerche di giurisprudenza analitica, Giappichelli: 139-144.

- 2011a: «Disposición vs norma», en R. Escudero y S. Pozzolo, Disposición vs Norma, Lima: Palestra: $133-156$.

— 2011b: «Introducción a la teoría de la interpretación. Una formula ambigua», en R. ESCUDERO y S. Pozzolo, Disposición vs Norma, Lima: Palestra, 157-179.

- 2012: «Escepticismo ante las reglas replanteado», Discusiones, 11: 27-57.

- 2014: «Realismo jurídico redefinido», en A. NúÑEZ, Modelando ciencia jurídica, Lima: Palestra: 87-114.

HAACK, S., 1978: Philosophy of Logics, Cambridge: Cambridge University Press.

- 2014: Evidence Matters, Cambridge: Cambridge University Press.

HaRT, H. L. A. (1994) 2012: The Concept of Law, 2. ${ }^{a}$ ed., Londres: Clarendon Law Series.

Ho, H. L., 2008: A Philosophy of Evidence Law: Justice in the Search of Truth, UK: Oxford University Press.

Holmes, O. W., 2008: The Path of Law and the Common Law, Nueva York: Kaplan.

Hohfeld, W. N., 1923: Fundamental Legal Conceptions as Applied in Judicial Reasoning: An Other Legal Essays, New Haven: Yale University Press.

Kant, I. (1781) 2007: Critique of Pure Reason, Reino Unido: Penguin.

Keane, A., y Mckeown, P., 2014: The Modern Law of Evidence (10. ${ }^{a}$ ed.), Oxford: Oxford University Press.

KRESS, K., 1989: «Legal Indeterminacy», California Law Review, 77: 283-337.

LAUDAN, L., 2005: «Por qué un estándar de prueba subjetivo y ambiguo no es un estándar», Doxa, 28: 95-113.

- 2006: Truth, Error and Criminal Law: An Essay on Legal Epistemology, Cambridge: Cambridge University Press.

Larroucau, J., 2012: «Hacia un estándar de prueba civil», Revista Chilena de Derecho, 39 (3): 783-808.

LEITER, B., 2007: Naturalizing Jurisprudence; Essays on American Legal Realism and Naturalism in Legal Theory, Oxford: Oxford University Press. 
Llewellyn, K., 1930: «A Realistic Jurisprudence: The Next Step», Columbia Law Review, vol. XX, núm. 4: 431-465.

Murphy, P., 2003: Evidence, Proof and Facts, Oxford: Oxford University Press.

NúÑEZ, A. 2013: «¿Deciden los jueces por razones políticas?», Jurídicas, 9 (2): 13-31.

Olivecrona, K. 1930: Law as Fact, 1. ${ }^{\text {a }}$ ed., UK: Oxford University Press.

PARDO, M., 2009: «Second Order Proof Rules», Florida Law Review, 61, 1083-1113.

Popper, K., 1963: Conjectures and Refutations: The Growth of Scientific Knowledge, Reino Unido: Routledge \& Kegan Paul.

REYES, S., 2012a: «Juicio como herramienta epistemológica: El rol de la verdad en el proceso», Anuario de Filosofía Jurídica y Social, Sociedad Chilena de Filosofía Jurídica y Social, 30: 221-235.

- 2012b: «Presunción de inocencia y estándares de prueba en el proceso penal: Reflexiones sobre el caso chileno», Revista de Derecho Universidad Austral de Chile, 25 (2), 229-247.

- 2015: «Estándares de prueba y Moral Hazard», Nuevo Derecho, 11 (16), 15-35.

- 2016: «Derecho, motivación de la conducta y quaestio facti» en M. A. NEIRA, Derecho constitucional en la encrucijada, Baja California: Universidad Autónoma de Baja California, Status: en prensa.

SpaAK, T., 2003: «Legal Positivism, Law's Normativity, and the Normative Force of Legal Justification», Ratio Juris, 16 (4): 469-485.

SteIn, A., 2005: Foundations of Evidence Law, Oxford: Oxford University Press.

TARufFo, M., 2002: La prueba de los hechos, Madrid: Trota.

- 2010: Simplemente la verdad, Madrid: Marcial Pons.

- 2013: Verdad, prueba y motivación en la decisión sobre los hechos, México: Cuadernos de divulgación de la Justicia Electoral.

Tuzet, G., 2013: «Una concepción pragmatista de los derechos», Isonomía, 39, 11-36.

TwINING, W., 2006: Rethinking Evidence: Exploratory Essays, Cambridge: Cambridge University Press.

VÁzQUEZ, C., 2015: De la prueba científica a la prueba pericial, Madrid: Marcial Pons.

VILA, M. I., 2006: «La fuente de indeterminación del derecho: una aproximación filosófica», Cuadernos de Derecho Público, 28: 55-82. 


\title{
¿ES NECESARIO UN GIRO ARETAICO DE LA TEORÍA DE LA ARGUMENTACIÓN JURÍDICA?*
}

\author{
Tasia Aránguez Sánchez \\ Universidad de Granada \\ tasia@ugr.es
}

RESUMEN. La actual teoría de la argumentación jurídica tiene como base epistemológica la ética discursiva de HABERMAS y, en última instancia, la noción kantiana de la racionalidad práctica. Dicho paradigma se basa en una razón fría, que aspira a ser neutral, imparcial, universal y descontextualizada. Este enfoque abandona cuestiones centrales para la argumentación, tales como el carácter de la persona oradora, las emociones del auditorio o la persuasión producida por los elementos estéticos. Por eso, frente al paradigma habermasiano, las llamadas «éticas de la virtud» podrían dar lugar a un nuevo punto de vista de la teoría de la argumentación que se preocupe por los auditorios reales desde una noción de la racionalidad más humana, hermanada con la emoción y la biografía.

Palabras clave: HABERMAS, ética discursiva, ética de la virtud, retórica de la virtud, argumentación jurídica, teoría estándar, dialéctica.

\section{Is it Necessary an «Aretaic Turn» in the Theory of Legal Argumentation?}

ABSTRACT. The epistemological basis of the current theory of legal argument is the discursive ethics of HABERMAS and, ultimately, the Kantian notion of practical rationality. This paradigm is based on a cold reason, which aspires to be neutral, impartial, universal and decontextualized. This approach leaves issues that are central to the argument theory, such as the character of the speaker person, the emotions of the audience or persuasion produced by the aesthetic elements. So, against the Habermasian paradigm, "virtue ethics» could lead to a new point of view of the theory of argumentation that cares about the actual audiences from a notion of the human rationality, coupled with emotion and biography.

Keywords: HABERMAS, discursive ethics, virtue ethics, rhetoric of virtue, legal arguments, standard theory, dialectic.

\footnotetext{
* Fecha de recepción: 4 de agosto de 2016. Fecha de aceptación: 16 de febrero de 2017.
} 


\section{INTRODUCCIÓN}

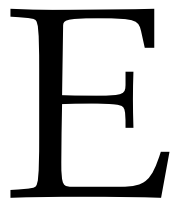

xiste una idea muy extendida de que para el punto de vista retórico una buena argumentación es aquella que logra persuadir, de modo que las reglas que rigen la retórica tienen un carácter puramente técnico: son los medios e instrumentos que pueden usarse para lograr la persuasión. Pero este punto de vista suscita serias dudas con respecto a la legitimidad de la retórica: ¿Qué ocurre si esas técnicas persuasivas se utilizan para fines injustos?, ¿un fin legítimo justifica medios como el engaño? Ante estos problemas, la llamada «teoría estándar de la argumentación» recurre al que podemos denominar «criterio de Perelman» (C. Perelman y L. Olbrechts-Tyteca, 1989: 72): lo importante no es si se persuade o no a un auditorio particular en un momento dado, sino más bien si se logra realizar una argumentación racional, que es la que sería capaz de persuadir a un auditorio ideal formado por personas racionales. Esta tesis de PERELMAN tiene una gran semejanza con la contraposición de HABERMAS (J. HABERMAS, 1981: 143) entre consenso fáctico y consenso ideal.

La teoría de la argumentación actual, cuyo corpus teórico fundamental es denominado «teoría estándar» ${ }^{1}$, aspira a un acercamiento entre la disciplina retórica y la argumentación dialéctica. En el ámbito de lengua hispana tanto VEGA REÑÓN (L. VEGA, 2003) como ATIENZA (M. AtiENZA, 2013: 365) expresan este desiderátum. En el caso de VEGA REÑÓN, la propuesta consiste en el surgimiento de una teoría integradora que reivindique lo mejor de las tres grandes perspectivas de la teoría de la argumentación (lógica, dialéctica y retórica). En el caso de ATIENZA, su propuesta consiste en unificar la dialéctica y a la retórica en la «dimensión pragmática» de la argumentación. Esta fusión podría tener la ventaja de aportar a la retórica la oportunidad de parecerse a la dialéctica, volviéndose más ética y más racional. La retórica devendría una «retórica buena», que intenta convencer a las personas juzgadoras mediante argumentos, y que dejaría de lado sus aspectos de «retórica mala», que es la que intenta persuadir mediante pasiones, imágenes o falacias.

Este desiderátum se corresponde con la preferencia que ARISTÓTELES manifestó por el logos, frente al ethos y al pathos. Como es sabido, ARISTÓTEles (ARISTÓTELES, 1990: RETS II-1357a 31-32) distinguió tres vías distintas de persuasión que forman parte del saber retórico: la que se basa en el carácter de la persona oradora (ethos), la que se basa en las emociones (pathos) y la que se basa en los aspectos internos del discurso (logos). Considero que la «teoría estándar» está intentando limpiar el nombre de la retórica de modo parecido al que empleó ARISTÓTELES; es decir, separando la retórica legítima de la ilegítima, y vinculando a esta última con la manipulación

1 Como señala ATIEnZA la llamada «teoría estándar» surgió como rechazo a entender el razonamiento jurídico en términos estrictamente lógico-formales. Los predecesores de la teoría estándar de la argumentación jurídica se opusieron a la reducción de la misma al razonamiento deductivo. Así, RECASÉNS SICHES defendió la idea del logos de lo razonable frente al logos de lo racional. VIEHWEG sostuvo que lo peculiar del razonamiento jurídico se encuentra en la noción tradicional de tópica, que no se refiere a las estructuras internas de los argumentos, sino a las nociones comúnmente aceptadas y consideradas razonables por parte de la comunidad. PERELMAN, por su parte, siguiendo a ARISTÓTELES, contrapuso los argumentos lógicos a los retóricos, estos últimos no buscarían establecer verdades evidentes, pruebas demostrativas, sino mostrar el carácter razonable de una determinada decisión. M. ATIEnZA, Curso de argumentación jurídica, Madrid: Trotta, 2013, 31. 
propagandística. ARISTÓTELES intentó trazar puentes entre la retórica legítima y la lógica, para dar a la retórica un barniz de credibilidad. La teoría estándar no apela ya a la lógica (de hecho la «teoría estándar» surgió frente a la hegemonía de la lógica formal en la teoría de la argumentación) ${ }^{2,3}$. La teoría estándar trata de purificar la retórica aproximándola a la ética discursiva (dialéctica) de autores como HABERMAS y ALEXY. He de aclarar que esto no es una mera especulación mía, sino que como señala AtienZa (M. AtienZA, 1991: 33), los tres enfoques de la «teoría estándar», a pesar de sus diferencias, comparten aspectos filosóficos comunes tales como la apuesta por una ética discursiva de raigambre kantiana y la preocupación de cuño aristotélico por la estructura de los argumentos.

En el presente trabajo voy a explicitar y criticar los fundamentos de la «teoría estándar» basados en las «éticas discursivas» y, al final de este artículo, voy a esbozar un modelo retórico alternativo, procedente de QuINTILIANO y compatible con las llamadas «éticas de la virtud» (por eso hablo de giro «aretaico») ${ }^{4}$. La razón por la cual considero necesario este cambio de paradigma es que las bases filosóficas de la teoría de la argumentación actual han provocado que la teoría estándar desconfíe y deje en la periferia analítica aspectos centrales como las emociones, el carácter del orador o de la oradora, el humor, la expresión no verbal, la arquitectura del edificio en el que se produce la comunicación y el estilo de los escritos. Mi tesis es que es posible construir una teoría de la retórica jurídica que incluya, sin recluirlos en la periferia, todos estos aspectos, y que dicha teoría puede basarse en una concepción ética. Reivindico esos aspectos a los que la «teoría estándar» mira con recelo. Aunque en este trabajo voy a

2 PeRElman sostiene que no hay que confundir la lógica con la lógica formal, pues ello implica tratar de reconducir los razonamientos habituales de las y los juristas a estructuras formales. El razonamiento jurídico tiene una lógica específica. Su tipo de razonamiento se centra en identificar semejanzas y diferencias, utilizando contraposiciones y analogías. No se trata de llegar a juicios verdaderos, sino a juicios razonables y justos. A diferencia del razonamiento deductivo, en el derecho no podemos hablar casi nunca de algo correcto o incorrecto de una manera impersonal.

Además de oponerse al lenguaje formal, PERELMAN niega la utilidad de la deducción, dado que las deducciones se basan sobre premisas, y en el Derecho lo dudoso son precisamente las premisas. PERELMAN trae la afirmación de S. MiLl de que nadie admitirá la tesis de que todos los hombres son mortales, si duda de que SÓCRATES es mortal, por tanto la conclusión de que SóCRATES es mortal le resultaría una petición de principio. Para convencer al auditorio la oradora o el orador tiene que conocerlo un poco y así sabrá qué tesis pueden tomarse como punto de partida de los razonamientos. Pero incluso aceptando los mismos valores y hechos como punto de partida, hay tal arsenal de estos que es posible llegar a conclusiones muy distintas e incluso opuestas. En el Derecho se producen confrontaciones entre pruebas y entre valores, de modo que la persona juzgadora debe ponderarlos y motivar una decisión. C. PERELMAn, La lógica jurídica y la nueva retórica, Madrid: Civitas, $1979,19,154$ y 176.

3 A pesar de esta tesis de Perelman y de la oposición a la deducción que manifestaron los pioneros de la teoría estándar, la mayoría de los autores que integran la concepción estándar no sostienen que el razonamiento jurídico se oponga a la deducción, sino que para comprender el razonamiento jurídico hemos de contar con más herramientas además de la lógica. Tendrían este punto de vista autores como PECZENIK, AARNIO, AlEXY o MACCORMiCK. Algo característico de este enfoque es la distinción entre la justificación interna (lógica-deductiva, paso de las premisas a la conclusión) y la justificación externa, que se refiere al establecimiento de las premisas y que requiere algo más que lógica deductiva. M. ATIENZA, op. cit., 2013, 31.

4 De «Areté», en griego «virtud» o «excelencia». Las éticas de la virtud que han inspirado este artículo son las de MACINTYRE, NuSSBAum y GADAMER; y la teoría aristotélica que los tres toman como punto de partida. H. Gadamer, Verdad y método (A. Y. Agud, Trans.), Salamanca: Sígueme, 1997. A. Macintyre, Tras la virtud, Barcelona: Austral, 2013. M. NussBAuM, Justicia poética (C. GARDINI, Trans.), Barcelona: Editorial Andrés Bello, 1995. M. Nussbaum, La fragilidad del bien, Madrid: Machado, 2004. Aristóteles, Ética a Nicómaco (M. Araujo y J. Marías, Trans.), Madrid: Instituto de Estudios Políticos, 1970. 
centrarme en las bases teóricas y no en el análisis de dichos elementos, la teoría que esbozaré al final de este artículo tiene la ventaja de que permite situar en el centro a todos esos elementos que tanto influyen sobre la persuasión real, sin caer por ello en la defensa de una retórica propagandística, carente de una base ética y preocupada únicamente por la persuasión.

La perspectiva propuesta en este artículo se integra dentro del resurgimiento, a partir de los años cincuenta, de las éticas de la virtud (giro aretaico) y, en concreto, el presente trabajo se enmarca en el incipiente corpus teórico denominado «jurisprudencia de la virtud» ${ }^{5}$, que está ganando especial relevancia en el ámbito de la argumentación jurídica ${ }^{6}$. Considero que incorporo relevantes elementos originales a esta innovadora corriente, dado que mis reflexiones parten de fuentes distintas a las que inspiran la mayoría de los estudios de la jurisprudencia de la virtud ${ }^{7}$. Parto del estudio de la retórica clásica y, en particular, de la obra de QuinTILIANO. Son esas fuentes las que me condujeron al cuestionamiento de la teoría estándar de la argumentación. Mi mirada se dirige hacia un tiempo en el que la abogacía era considerada la más elevada de las profesiones, que aunaba un conjunto de virtudes morales, intelectuales y cívicas que representaban el ideal de vida de una concepción del mundo a la que se puede denominar «cultura de la retórica». A través de la indagación en la retórica clásica he tratado de trasladar a la teoría de la argumentación aquel espíritu apasionado, de gran potencial humanista y democratizador.

\section{CRÍTICA AL PUNTO DE VISTA DIALÉCTICO DE LA TEORÍA ESTÁNDAR}

Perelman (C. Perelman, 1979) explica que la dialéctica es la dimensión de la argumentación que entra en juego cuando hay una diferencia de opinión que no puede resolverse mediante medición o demostración empírica, o cuando el objeto de debate no es la verdad, sino el valor de una decisión justa, razonable, oportuna o ética. En estos casos la solución más razonable será la que surja de un acuerdo. VEGA REÑón (L. VEGA, 2003) expone las características de la perspectiva dialéctica, que constituye el enfoque central de la teoría estándar, pues ocupa el lugar medio e irradia a las otras dos perspectivas (lógica y retórica). Para este punto de vista de la argumentación, sostiene, todo gira en torno a la existencia de una discusión. La discusión puede producirse en el marco de una deliberación, un debate o una negociación. En cada caso, las reglas serán distintas. Obviamente, no son iguales las reglas que rigen una negociación

5 Algunos trabajos que dan muestra de la jurisprudencia de la virtud son: A. AmAYA y H. HOCK LAI (eds.), Law, Virtue and Justice, Oxford: Hart Publishing, 2012. C. Farrelly y L. Solum, Virtue Jurisprudence, Basingstoke: Palgrave MacMillan, 2008. J. ChapMAn y W. GaLsTON, Virtue, NOMOS XXXIV, New York: New York University Press, 1992.

6 Algunos trabajos que ejemplifican la teoría aretaica de la argumentación son los siguientes: A. AmALIA, «Virtud y razón en el Derecho. Hacia una teoría neo-aristotélica de la argumentación jurídica», en R. GONZÁlez de la Vega y G. LaRiguet, Problemas de Filosofía del Derecho. Nuevas Perspectivas, Bogotá: Temis, 2013. J. SAlDAÑA, Ética judicial. Virtudes del juzgador, México: Suprema Corte de Justicia de la Nación, 2007. E. YANKAH, «Virtue's Domain», University of Illinois Law Review, 2009, vol. 2009, núm. 4.

7 Es sabido que el renacimiento presente de las éticas de la virtud tiene su origen en la relectura de ARISTÓTELES, y lo mismo ocurre con las jurisprudencias de la virtud. 
entre dos abogadas, que las reglas que seguirán estas mismas en su controversia ante los tribunales.

Aquí lo que importa no es si un argumento es bueno desde el punto de vista lógico, sino si la argumentación es adecuada a los fines y a las reglas del tipo de discusión en cuestión. La fuerza de un argumento se medirá, no en abstracto, sino frente a la fuerza de otro que se le oponga ${ }^{8}$, su mayor o menor aceptabilidad ${ }^{9}$, y también se medirá su fuerza en atención a su productividad para el curso del debate, es decir, en atención a si los argumentos promueven nuevos y mejores argumentos, si abren nuevos contextos o trazan nuevas líneas argumentativas. En opinión de VEGA REÑÓN ${ }^{10}$ (L. VEGA, 2003: 131), la perspectiva dialéctica, más que juzgar la estructura interna de un argumento, se plantea si ese argumento es adecuado a las reglas de la discusión. Lo que importa no es un argumento concreto, sino la actitud de argumentar correctamente, siguiendo unas normas que regulan la buena conducta argumentativa. La idea de fondo es la de que, cuando no es posible alcanzar certezas hay que tratar de llegar a un acuerdo sobre cuál es la solución más razonable, y para poder llegar a un acuerdo hay que debatir siguiendo unas reglas que permitan que se produzca un intercambio racional de argumentos, y no un intercambio de amenazas o chantajes.

VAn Eemeren y Grootendorst (F. van Eemeren y R. Grootendorst, 2004: 1) proponen unas reglas para que se desarrolle correctamente la argumentación que ellos denominan «pragma-dialéctica». Las reglas regulan aspectos de sentido común como argumentar la propia tesis o escuchar a las demás personas. En esencia, el principio central de sus reglas es el principio cooperativo: la disposición de las partes a cooperar para alcanzar la mejor solución posible. R. AlEXY (R. AleXY, 1989: 70) también ha formulado un código de reglas, muy parecidas a las de VAN EEMEREN y GROOTENDORST, que también pretenden dar lugar a un diálogo racional, en este caso en el ámbito del derecho.

Se ha objetado a la perspectiva dialéctica que en el derecho las partes no siempre quieren llegar a un acuerdo, y que cuando lo desean, no persiguen el bien común,

${ }^{8}$ La fuerza de las argumentaciones se basa, en gran medida, en la plausibilidad. Las cosas plausibles son aquellas que todo el mundo comparte, las que sostiene la mayoría o aquellas que comparten unas pocas personas pero que son dignas de crédito. La tradición tópica ha mostrado esta conexión entre la dialéctica y la plausibilidad. La analogía y la correlación se basan en la plausibilidad: si consideramos que algo es verdadero, también parecerá verdadero algo muy semejante. La plausibilidad no es un atributo interno de la argumentación, sino que está basada en lo que la gente cree, en lo que tiene respaldo social. Por tanto, es algo graduable, hay cosas más plausibles y otras menos plausibles, de modo que ha de valorarse comparando las opiniones enfrentadas para ver cuál es más plausible.

9 Aunque el presente trabajo no verse sobre el método tópico, considero de utilidad señalar brevemente sus características esenciales. La tópica, señala VIEHWEG, fue conceptualizada por ARISTÓTELES, es un modo de razonamiento consistente en partir de «topoi», puntos de vista utilizables y aceptables universalmente, que se emplean para apoyar la argumentación y que parecen conducir a la verdad. En el diálogo la tópica adquiere gran relevancia pues es necesario alcanzar el común entendimiento y los tópicos pueden facilitarlo. Estos puntos (tópicos) no son aceptados por mera autoridad, sino que entre personas cultas se acepta como razonable lo que tiene determinado peso, como es el caso de los juristas de reconocido prestigio. Depositar confianza en ellos no constituye una mera creencia. T. VIEHWEG, Tópica y jurisprudencia, Madrid: Taurus, 1964.

${ }_{10}$ En este artículo expongo las tesis más canónicas de VEGA REÑón, pero he de señalar que dicho autor se está alejando progresivamente del trasfondo de las tesis racionalistas que subyacen a la ética discursiva. Esto puede observarse en L. VEGA, Introducción a la teoría de la argumentación: Problemas y perspectivas, Lima: Palestra Editores, 2015. 
ni buscan la verdad, sino que persiguen sus propios fines o intereses que casi nunca serán compatibles con las reglas basadas en el principio cooperativo. ALEXY y VEGA REÑÓN defienden la perspectiva dialéctica argumentando que, incluso en el contexto más estratégico (pensemos en una negociación jurídica) es necesario que exista un mínimo de buena fe argumentativa. VEGA REÑÓN (L. VEGA, 2003: 289) pone un ejemplo clarificador de esta tesis: la comunicación se parece al comercio en el sentido de que nadie podría comprar ni vender si no existiera el principio de la buena fe mercantil, que parte de que los demás van a cumplir sus compromisos. Nadie podría argumentar si todas las personas presumieran que las demás mienten por sistema. Es necesario que exista un mínimo de sinceridad, un mínimo de confianza y un mínimo de buena fe para que exista un diálogo (o un proceso legal). Considero que los autores tienen razón: de no ser así, todos los asuntos se resolverían mediante la violencia privada dado que nadie confiaría en el derecho.

Este argumento de ALEXY y VEGA REÑÓN fue formulado, aunque de manera más compleja, por HABERMAS (J. HABERMAS, 1981) en su Teoría de la acción comunicativa. Nava Tovar (A. TOVAR, 2015: 242), discípulo de AleXY explica la idea alexyana de la pretensión de corrección que rige en el derecho y que implica que, para que la comunicación sea posible en el ámbito jurídico, es necesario que confiemos en que el derecho tiene la finalidad de servir a la justicia. AlEXY señala que en el derecho, la judicatura y el legislativo forman parte de un discurso oficial que, si no desea ser considerado simple fuerza bruta, debe procurar la aceptabilidad de la sociedad. La pretensión de justicia es, por tanto, un elemento totalmente necesario para la existencia de un sistema jurídico. AlEXY probará esto mediante el ejemplo de las contradicciones performativas ${ }^{11}$. La pretensión de corrección significa que el derecho intenta parecer moralmente correcto, lo que no implica necesariamente que lo sea ${ }^{12}$.

Estas explicaciones permiten comprender por qué la perspectiva dialéctica considera que las reglas del diálogo no son una mera convención, sino la condición de posibilidad de cualquier comunicación lingüística, incluyendo la comunicación que se produce en el ámbito del derecho ${ }^{13}$ (R. AlEXY, 1989: 183). Ahora bien, y aquí formulo una primera crítica al punto de vista dialéctico: aunque comparto que en el derecho existe una pretensión de corrección, considero que la etérea pretensión de corrección no logra demostrar que en el derecho existan o que deban existir las reglas tan específicas que formula ALEXY. No parece posible fundamentar la necesidad de que una abogada sea completamente sincera durante un litigio, por ejemplo. Más bien al contrario, parece que la judicatura es plenamente consciente de que

11 La contradicción performativa es la siguiente: imaginemos un Tribunal Superior que se llamase «Tribunal Supremo de Injusticia de la Nación»; ¿quién respetaría los fallos de semejante tribunal?, se pregunta ALEXY, ¿podría instaurarse un tribunal con semejante nombre sin que la sociedad hiciera algo al respecto? Ningún tribunal apela a la injusticia para dictar sentencias. Incluso aunque la judicatura no creyese en la justicia en su fuero interno, tendría que apelar a ella en términos institucionales. Cfr. R. AlEXY, Teoría de la argumentación jurídica (M. ATIENZA, Trans.), Madrid: Espejo CEC, 1989.

12 Es cierto que un tribunal puede llevar el sustantivo «justicia» en su nombre y dictar fallos injustos, pero eso tan solo confirma la necesidad de la pretensión institucional de justicia, incluso en los regímenes más injustos. Las leyes y fallos deben parecer justos aunque no lo sean, pues de lo contrario no serían considerados «derecho».

13 A esto se le llama «fundamentación pragmatico-transcendental». 
la abogacía por lo general no es, ni completamente mentirosa ni completamente sincera $^{14,15}$.

Sin embargo, mi discrepancia principal con el punto de vista dialéctico no proviene de su tesis de que el derecho sirve a la justicia. La idea con la que discrepo (lo que me conduce a formular una segunda crítica) es la que vincula dicha justicia con el acatamiento de unas reglas que se presentan como algo formal, prácticamente carente de contenido material. Es decir, las reglas se presentan como si estuvieran por encima de las consideraciones éticas particulares y de los puntos de vista en liza de la sociedad. Las reglas son vistas como algo apriorístico. El ideal de VAN EEMEREN y GROOTENDORST (F. VAN EEMEREN y R. GROOTENDORST, 2004: 73) se basa en la idea de que la argumentación debe intentar convencer a una persona razonable. Los autores asumen una noción de racionalidad que privilegia los elementos lingüísticos de la comunicación (frente a los no verbales) y las consideraciones intelectuales (frente a las emociones y las intenciones). Sin embargo, la noción de racionalidad contenida en las reglas propuestas por estos autores no es técnica o neutral, sino que tiene un contenido valorativo. El contenido valorativo recoge principios básicos como la igualdad de derechos, la ausencia de coerción y la búsqueda de la universalidad de las decisiones. Este contenido valorativo se defiende por la dialéctica como el más neutral posible, es decir, el contenido valorativo estrictamente imprescindible para posibilitar un debate racional en el que se pueda alcanzar la mejor solución posible.

Por tanto, considero que la propuesta dialéctica no debería presentarse a sí misma como si fuese algo incuestionable, algo que forma parte de la naturaleza de cualquier acto comunicativo. No debería presentarse como si no hubiera ninguna persona, ninguna ideología y ningunos intereses detrás de la misma. En definitiva, pienso que no debería autoproclamarse (sin humildad intelectual alguna) como «pragmática-transcendental», es decir, como concebida sin madre ni padre, en la fuente misma de la racionalidad. La visión de la racionalidad del punto de vista dialéctico (de raigambre habermasiana) es expresión del racionalismo europeo e ilustrado que privilegia una determinada visión de la verdad, la justicia y la racionalidad. Encontramos en la ética que sustenta a dicha perspectiva una determinada visión de la racionalidad «kantiana» que pretende ser transcendental, formal, desprovista de contenido material y basada

14 Las reglas del discurso racional que establece ALEXY no parecen aplicables fácilmente a los litigios jurídicos (y aún menos a las negociaciones). Su carácter necesario e inherente a todo acto comunicativo es dudoso. En el derecho las normas procesales garantizan cierta ética discursiva, aunque mucho más modesta que la postulada por ALEXY. Otro aspecto que no comparto con AlEXY es su tesis de que el derecho es un tipo de discurso especial que se diferencia de la comunicación general porque en el derecho hay que respetar, ante todo, el precedente y el principio de universalidad. Considero que el precedente representa, en su cara negativa, una dimensión autoritativa del derecho y en su cara positiva, representa un compromiso con el diálogo social y con el valor de la igualdad jurídica. Sin embargo, la deferencia al precedente no debería ser la piedra angular de la actuación judicial, pues esto daría lugar a una jurisprudencia muy conservadora. Considero que el respeto al precedente debe complementarse, en un sistema de enfoque dialéctico como este, con una marcada tendencia judicial hacia la promoción de la justicia y los derechos humanos.

15 WALTON considera que no todas las argumentaciones en el Derecho pueden reducirse a un diálogo racional, y esto puede criticársele a ALEXY. En el Derecho hay otros tipos de diálogos como la negociación, el interrogatorio de búsqueda de información, el diálogo educativo, el debate jurídico, etc. Y, por otra parte, la argumentación jurídica no tiene porqué girar en torno a la idea de consenso, tan propia del punto de vista dialéctico, pues hay otros valores en el Derecho como la justicia o la verdad. D. WALTON, Informal Logic. A Handbook for Critical Argumentation, Cambridge: CUP, 1989. 
en una universalidad de la razón imparcial, incorpórea y sin contexto ni biografía. Esa racionalidad casi divina decide con ayuda de un imperativo categórico de nuevo cuño, que toma forma en las reglas del discurso racional. Esta idea, aplicada al derecho, nos conduciría a una idea de persona juzgadora que se autoproclama «imparcial» y que intenta dejar a un lado sus emociones.

NusSBAum (M. NussBAuM, 2012) ha criticado esta visión kantiana de la racionalidad, que se concibe como algo idealizado y contrapuesto a la animalidad y también a las emociones. La racionalidad kantiana consiste en la capacidad de realizar juicios morales. El agente kantiano reflexiona de manera solitaria, es adulto, con una determinada capacidad intelectual, y no posee necesidades corporales, ni necesita asistencia para desenvolverse. La dignidad humana en KANT radica en la autonomía moral e ignora, por tanto, la naturaleza dependiente de muchos momentos de la existencia humana, así como la ubicación corporal y sociocultural de la razón. El problema de la concepción kantiana es que su concepto de racionalidad se basa en la capacidad de abstraerse de la propia identidad para alcanzar una suerte de mirada universal. El relativismo moral puede acusar a KANT, con razón, de enmascarar sus propias nociones éticas heredadas tras un manto de imparcialidad y objetividad.

Habermas (J. Habermas, 1989), principal exponente de este punto de vista, considera que no todos los juicios morales son iguales, sino que es posible considerar que algunos de ellos son más racionales que otros. Según HABERMAS, el criterio que nos permite diferenciar a los mejores juicios morales es el de que todas las personas con las que yo pudiera entablar un diálogo (incluyendo a todas las personas que han existido y existirán) pudieran estar de acuerdo conmigo. AleXY (R. AleXY, 1989: 120) explica que esta noción de acuerdo es criticable, ya que no se puede conseguir el acuerdo de todas las personas, porque las personas fallecidas no pueden dialogar y no sabemos en qué sentido se hubieran pronunciado. HABERMAS (J. HABERMAS, 1981) intenta salvar estas dificultades considerando que solo puede considerarse racional un consenso ideal basado en el principio de universalidad (o generalizabilidad). Nótense las semejanzas entre la propuesta habermasiana y la kantiana. Imaginar este hipotético consenso racional nos permite alcanzar soluciones éticas que todo el mundo pueda querer. El tipo de normas que todo el mundo pudiera querer es el de las que cumplen la característica de generalizabilidad, es decir, las que satisfagan necesidades que sean aceptables por todas las personas. El consenso racional sería aquel al que llegaríamos mediante la situación ideal de diálogo, en la que no se diesen coacciones que interfieran sobre la comunicación libre e igualitaria ${ }^{16}$.

Desde mi punto de vista, y aquí formulo una tercera crítica al punto de vista dialéctico, la propuesta de HABERMAS es más transcendental que intersubjetiva, en el sentido de que su criterio para elegir un buen juicio ético radica en una determinada noción de la razón (razón imparcial y abstracta) más que en la indagación de los valores compartidos con otras personas.

16 Habermas establece una serie de reglas del buen diálogo: 1. Todos los participantes, por igual, pueden iniciar un discurso, replicar, preguntar y responder. 2. Las opiniones anteriores pueden ser cuestionadas y criticadas. 3. Todos los hablantes pueden expresar sus opiniones, sentimientos e intenciones. 4. Todos los hablantes pueden, por igual, ordenar, oponerse, permitir, prometer, rendir y exigir cuentas. 
La concepción liberal de la persona (que está implícita en la teoría de KANT, de HABERMAS o de RAWLS) según MACInTYRe (A. MACINTYRe, 2013: 314), parte de una persona que se da a sí misma su propia ley. Es su aislamiento lo que le impone la carga de un intenso trabajo de deliberación moral, porque reniega de todo concepto de lo bueno que proceda de su contexto, reniega de las normas sociales y de las virtudes que admira la sociedad en la que vive, así como de los sentimientos compartidos de la comunidad que configuran la comprensión social de lo valioso y lo bueno. Este individuo del liberalismo se arranca a sí mismo del mundo, de la narrativa vital en la que aprendió desde la infancia interiorizando fines y propósitos, de un sentido de la vida al que aspiró con anhelo, desarrollado en el seno de la comunidad. La persona ilustrada se enfrenta a la comunidad social de la que forma parte y, de manera casi heroica, quiere inventar por sí misma la moral, transformándose si es necesario en una razón pura, al despojar a su propia identidad de todo cuanto esté contaminado por la tradición.

Otra tesis problemática del punto de vista dialéctico es la incidencia sobre autores dialécticos como ALEXY que sostienen además que, junto a las reglas comunicativas, es necesario que exista una autoridad que decida si se están siguiendo adecuadamente. Esto, como acertadamente señala VEGA REÑÓN (L. VEGA, 2003: 145), supone abandonar el paradigma intersubjetivo. El derecho, en el modelo dialéctico de ALEXY, como vemos, no es un debate intersubjetivo, sino más bien un debate mediado por un tercero (juez o jueza) que se conduce por el ideal de imparcialidad. Tal imparcialidad se supone que es lo que garantiza que en los litigios prime el intercambio racional de argumentos y que no se trate de una simple negociación de intereses. Me temo, y aquí presento una cuarta crítica al punto de vista dialéctico, que esta tesis de la autoridad imparcial aunada con el aura incorpórea y prístina de la racionalidad dialéctica, acaba legitimando a las instituciones (y en particular a las personas juzgadoras), concibiéndolas como las representantes de la racionalidad discursiva, como las bocas que pronuncian las palabras más cercanas a la verdad a las que se puede acceder en un mundo desencantado.

\section{PERELMAN Y LA NUEVA RETÓRICA}

Hablar del punto de vista retórico de la teoría estándar es hablar, fundamentalmente, de PERELMAN, el padre de la «Nueva Retórica» ${ }^{17}$. LÓPEZ EIRE (A. LÓPEZ EIRE, 1998) explica que esta «Nueva Retórica» se retroalimenta con los principios de la ética del discurso propugnados por HABERMAS. Es decir, el punto de vista retórico adopta, al igual que el punto de vista lógico, las mismas bases filosóficas que el punto de vista

17 Cuenta López EIRE que, junto con la Nueva Retórica de Perelman, que es la propuesta más avalada por la teoría estándar, también hemos de citar al grupo $\mu$ (o grupo de Lieja), que formula la Retórica General. Esta concepción, a diferencia de la de PERELMAN, no se centra en la argumentación sino en el estilo. Concibe la retórica como un instrumento de la poética, acogiéndose a la síntesis aristotélica entre retórica y poética en el área del estilo, y a la tradición humanista del renacimiento que vio en la retórica un arte creativo. La Retórica General se restringe al estilo y por eso se llama «grupo $\mu$ », en alusión a la primera letra de la palabra «metáfora» (metabolés) en griego. Este grupo centra su trabajo en la clasificación de figuras retóricas o literarias. A pesar de la aportación del grupo de Lieja, que es de tipo clasificatorio más que filosófico, la visión dominante del punto de vista retórico en el interior de la «Teoría Estándar» es la de PERELMAN. A. LÓPEZ EIRE, «La retórica clásica y la actualidad de la retórica», en VVAA, QuINTILIANO, Historia y actualidad de la retórica (vol. I, 203-315), Logroño: Instituto de Estudios Riojanos, 1998, 299. 
dialéctico. En efecto, PERELMAN se acerca a la dialéctica porque quiere restaurar la denostada imagen de la retórica. Es decir, PERELMAN intenta hacer lo que en su día hizo ARISTÓTELES: mostrar que la retórica no es una mera técnica para el logro de la persuasión, sino que en ella tiene lugar la ética. PERELMAN defiende que puede existir un marco ético que regule las relaciones entre la persona oradora y su público.

Cuenta LÓPEZ EIRE que ARISTÓTELES intentó, al igual que se intenta en nuestros días, mejorar la imagen denostada de la retórica, y que lo hizo destacando su carácter argumentativo y la proximidad de los argumentos retóricos con los silogismos, inaugurando el terreno de la verosimilitud, a medio camino entre la verdad y la creencia irracional. Lo que trataba de evitar ARISTÓTELES era que todas las cuestiones de la vida, de gran importancia, que no son susceptibles de demostración, quedasen en manos de la irracionalidad. La tesis aristotélica es que la razón tiene cabida en el lugar de la opinión y del consenso social. Pero, objeta LÓPEZ EIRE ${ }^{18}$, por mucho que ARISTÓTELES nos diga que la retórica guarda similitudes con la lógica, nos se nos escapa, ni tampoco al propio ARISTÓTELES, que en la retórica no solo se emplean argumentos que apelan a la sabiduría común, sino que hace gala del noble carácter del orador o la oradora (ethos), del estado de ánimo del auditorio (pathe) y de la emoción placentera que provocan la estética y la belleza de la palabra (estilo). En suma, la retórica es hechicera y cautivadora.

Como explica López Eire, Perelman, fundador de la «Nueva Retórica» se enfrentó también al dilema de si debían dejarse de lado todas las cuestiones no susceptibles de demostración científica. PERELMAN rehabilitó la retórica antigua indagando las relaciones del discurso retórico con el lógico y rebelándose contra la concepción de la retórica como arte de hablar y escribir bien haciendo caso omiso de la argumentación. PERELMAN se enfrentó al rechazo cartesiano a la retórica (pues el cartesianismo solo cree en la verdad científica) y a las retóricas estratégicas de moda; igual que ARISTÓTELES se enfrentó a PLATÓN y a la sofística. El modelo de la «Nueva Retórica» concibe a la retórica, ante todo, como teoría de la argumentación (y no como exaltación de las pasiones, del carácter o de la belleza estilística). La retórica, para PERELMAN es parte de la dialéctica, que se basa en el arte de razonar a partir de opiniones generalmente admitidas ${ }^{19}$.

La dialéctica de PERELMAN está asociada a la lógica informal, en la que no se pretende alcanzar verdades cartesianas, con deducciones que surgen de las premisas por la fuerza de los axiomas, sino que, mediante argumentos parecidos a los de la lógica formal podemos aspirar a mostrar el carácter razonable de una propuesta, sin pretender que esa propuesta sea universal, pues admitimos que caben tesis contrarias ${ }^{20}$. La parte de la tradición retórica que PERELMAN rescata es la que persuade por medio del

18 Ibid., 290.

19 Ibid., 293.

20 Esto que explica tan bien LóPEz EIRE lo dice también claramente el propio PERELMAN. Así, en La lógica jurídica y la nueva retórica, explica que su meta era encontrar una metodología que permitiera realizar razonamientos sobre cuestiones valorativas. Por eso, él y OLBRECHTS-TYTECA analizaron múltiples textos jurídicos tratando de estudiar cómo operaba la lógica en la argumentación jurídica y llegaron a la conclusión de que en el ámbito del derecho no había lógica formal, sino técnicas de argumentación propias de la tradición retórica, dialéctica y tópica, tal y como dicha tradición era concebida antes de que la retórica quedase reducida a una recopilación de recursos literarios. C. PERELMAN, La lógica jurídica y la nueva retórica, Madrid: Civitas, $1979,136$. 
discurso, excluyendo tanto la violencia como la seducción (es decir, excluyendo la parte más estética y emocional de la retórica, y quedándose con la más cercana al logos).

Perelman (C. Perelman, 1979) rescata un concepto relevante en la retórica (el de «auditorio») y lo reforma para dar a la retórica un giro hacia un modelo de ética discursiva muy semejante al habermasiano. Este es el modo que PERELMAN escoge para limpiar a la tradición retórica de impurezas. Como es sabido, ARISTÓTELES estudió los auditorios particulares, que se diferenciaban por la edad y por la posición social de las personas que los integraban. El Estagirita analizó la forma de ser propia de varios grupos de edad (juventud, madurez y vejez) y de distintos estratos socioeconómicos. El aspecto que ARISTÓTELES estudió fue la predisposición de esos grupos a experimentar determinadas emociones ante distintas situaciones (por ejemplo, la propensión de la juventud a apasionarse). Estas variaciones en el carácter de las personas que componen el auditorio condiciona la eficacia del discurso en ese público concreto. Frente a este auditorio de ARISTÓteles, PERELMAN imagina un auditorio universal, formado por cualquier persona razonable. Es decir, PERELMAN se centra en los aspectos discursivos que podrían convencer a cualquier interlocutor posible, sin importar su edad o condición social.

La persona razonable de PERELMAN, a la manera de la dialéctica, nace sin biografía, sin historia y sin emociones. Es incluso incorpórea, de modo que su presencia real no es necesaria. Es solo un artificio imaginativo en la imaginación de la persona orado$\mathrm{ra}$, que le sirve para calificar de eficaz a su propio discurso sin tener que someterse a los antojadizos auditorios formados por gente real. Por tanto, esta «Nueva Retórica», sostiene PERELMAN, nace unida a la dialéctica, e incluso a la lógica formal, que se considera algo complementario y útil para los momentos en los que sean necesarias las demostraciones.

Alexy (R. Alexy, 1989: 142) señala que, para Perelman, la retórica se legitima por remisión a la razonabilidad del auditorio al que persuade. Por eso, en el centro de la teoría de PERELman se encuentra la caracterización de un auditorio al que solo se persuade mediante argumentos racionales. Para PERELMAN este es el auditorio universal, que es el criterio para la racionalidad y objetividad de la argumentación. Sin embargo, ALEXY constata que PERELMAN encuentra algunas dificultades de fundamentación, que son semejantes a las dificultades a las que se enfrentó HABERMAS con su ética discursiva. La primera de ellas es que un acuerdo real de todas las personas es algo imposible. Quien se dirige al auditorio universal sabe que es imposible que todos los seres humanos escuchen sus argumentos, y no espera que el mundo entero concuerde con ellos, pero sí parte de que todas las personas, si tuvieran conocimiento de sus argumentos y los comprendieran, estarían de acuerdo con ellos.

Lo más complicado de la idea de Perelman, afirma Alexy, es su tesis de que la composición de este auditorio universal depende de cómo cada uno de nosotros, desde nuestra cultura y circunstancias, nos imaginamos tal auditorio universal. PERELMAN (C. Perelman, 1957) plantea, siguiendo el imperativo categórico de KANT (I. KanT, 1981), la exigencia de comportarnos como si fuésemos una persona juzgadora cuya decisión deba proporcionar un principio válido para todo el mundo ${ }^{21}$. En consecuencia,

${ }^{21}$ Esta tesis de AlEXY se parece a otra de VEGA REÑÓN. Sostiene dicho autor que podríamos considerar buena argumentadora a la persona que obra de acuerdo con esta máxima de corte kantiano: «Argumenta de 
la persuasión del auditorio universal es la persuasión de todos los seres racionales. El auditorio no es, según PERELMAN, el conjunto de todos los seres humanos reales. El auditorio universal es la humanidad ilustrada, el conjunto de seres humanos en tanto que seres racionales, que poseen información y tienen competencias para comprenderla (R. AlEXY, 1989: 162). El auditorio universal, por tanto, podría entenderse como la totalidad de las personas en el estado en el que se encontrarían si hubieran desarrollado sus capacidades argumentativas.

El auditorio universal de PERELMAn se corresponde con el consenso alcanzado bajo condiciones ideales en la filosofía de HABERMAS. La idea central en el planteamiento de ambos es el principio de universalidad: un juicio de valor solo puede considerarse argumentado si todas las personas racionales pudieran estar de acuerdo. En la «Nueva Retórica», continúa AleXY (R. AleXY, 1989: 165), lo que se busca no es la persuasión de un auditorio real, formado por personas de carne y hueso al que nos estamos dirigiendo en un momento concreto. El concepto de filosofía de PERELMAN no se orienta a persuadir, sino a convencer. No se busca realizar un discurso eficaz, sino un discurso válido, capaz de lograr el asentimiento de todos los seres racionales. Dado lo expuesto hasta aquí, puedo concluir que la perspectiva retórica de la teoría estándar, se encuentra más cerca del punto de vista dialéctico que de la propia tradición retórica.

Según Vega ReÑón, la pregunta ¿qué es una buena argumentación para la retórica? habría de responderse con la respuesta: la que logra persuadir; mientras que la pregunta ¿qué es una buena argumentación para la dialéctica? se respondería: la que cumple con las reglas del diálogo racional ${ }^{22}$. Si aceptásemos esta clasificación de VEGA REÑÓn observamos que con la tesis del auditorio universal de PERELMAN, nos hemos salido del punto de vista retórico y nos hemos adentrado en el dialéctico. La buena argumentación ya no es, como en la tradición retórica, la que consigue persuadir a un auditorio particular, sino que la buena argumentación es la que realizaría una persona racional (entendiendo por «racionalidad» una concepción kantiana como la que adopta HABERMAS).

manera que tus intervenciones discursivas sean contribuciones que respeten los valores de la argumentación y faciliten nuevas contribuciones a los fines de la argumentación en su marco y contexto». Los valores que aporta la buena argumentación son el entendimiento mutuo, el respeto de cada persona a sí misma y a sus interlocutoras como agentes discursivos autónomos y competentes, la asunción de las responsabilidades contraídas y el control efectivo de la información y del conocimiento compartido o público. L. VEGA, op. cit., 2003, 289.

22 Por supuesto, esta clasificación de VEGA REÑón es cuestionable (de hecho, yo la cuestiono dado que mi noción de retórica no se limita a verla como arte de persuasión, pues incorpora una ética), pero por el momento nos sirve a efectos filosóficos. Ahora bien, paradójicamente, otras propuestas históricas que se llaman a sí mismas «dialécticas», pertenecen al punto de vista retórico según la clasificación que tomo de VEGA REÑÓN basada en la pregunta ¿qué es una buena argumentación para el punto de vista retórico?; he señalado que la respuesta a esta pregunta es: aquella que logra persuadir. Pues bien, veamos lo que escribió SCHOPENHAUER en su célebre El arte de tener razón. Explica el filósofo que en la dialéctica hay que dejar de lado la verdad, o considerarla accidental. La dialéctica consiste en el arte de tener razón, en defenderse contra ataques de todo tipo. La dialéctica no se preocupa por quién tiene razón realmente, al igual que en la esgrima no se tiene en cuenta quién tenía razón en la discusión que originó el duelo. La dialéctica es una esgrima intelectual. Como vemos, la dialéctica erística de SCHOPENHAUER alude a una retórica que se despliega en el contexto de un debate, al igual que hicieron otros autores de la tradición retórica, pues dicha tradición siempre se ha preocupado por los debates rápidos y de intervenciones cortas, y no solo por los discursos unilaterales. A. SCHOPENHAUER, El arte de tener razón, expuesto en 38 estratagemas (F. VolPI, Ed., y J. AlborÉs, Trans.), Madrid: Alianza, 2002, 17. 
Pero las similitudes entre la «Nueva Retórica» y el punto de vista dialéctico no quedan aquí. ALEXY señala que, si adoptamos la tesis del auditorio universal estaremos aceptando algunas reglas discursivas implícitas: la persona que se dirige al auditorio universal se dirige también a sí misma, por lo que se excluye la mentira; además ha de ser imparcial, pues quien actúa con parcialidad solo convence a las personas que se encuentran en la misma situación. Perelman (R. AleXY, 1989: 171) sostiene que la persona oradora, cuando se dirige a un auditorio particular, debe apoyarse en lo que las y los oyentes le concedan en un principio. La diferencia es que, cuando se habla a un auditorio universal, la persona oradora trata de proponer tesis que todas las personas racionales puedan compartir.

PERELMAN, en su intento por rechazar la visión de la retórica como «persuasión a cualquier precio», pretende sustituir a la persuasión por un interés más elevado, que tienen aquellas personas que dirigen al auditorio universal: la convicción racional. Esta convicción racional, además, no se basa en la calidad de las inferencias argumentales, ni en su correspondencia con la verdad; sino que se basa en la capacidad de la persona oradora de imaginar a todas las personas racionales, según claro está, su propia noción de racionalidad (vemos cuanto recuerda esta noción de PERELMAN al «imperativo categórico» de KANT). Por tanto, vemos que PERELMAN llama «Nueva Retórica» a una propuesta que encaja perfectamente en la filosofía que adopta el punto de vista dialéctico de la teoría estándar. Realmente ese sustrato filosófico es precisamente lo que caracteriza a la llamada «teoría estándar de la argumentación».

\section{LA RETÓRICA DE LA VIRTUD}

Frente al sustrato filosófico de la «teoría estándar», la cultura romana nos ofrece una fundamentación distinta de la retórica y una original respuesta a la pregunta sobre la legitimidad moral de la retórica. El carácter romano era demasiado práctico para denostar elementos persuasivos como las emociones o la belleza. Por eso CiCERÓN desarrolla un ideal humanista que ilustra un giro hacia lo que podríamos llamar «retórica de la virtud», que constituye un aumento de la importancia de los elementos psicológicos y, especialmente, del ethos de la persona abogada, entendido como configuración de un carácter enriquecido por múltiples virtudes y conocimientos intelectuales y morales.

En el modelo ciceroniano, la legitimidad de la retórica no procede de su analogía con la lógica ni de su tratamiento de lo verosímil (es decir, de una verdad de segunda clase); sino que procede de la dignidad inherente al habla, como cualidad característica y distintiva del ser humano. El habla, unida al cultivo de la sabiduría y orientada hacia la acción en la esfera pública, da lugar a la retórica. La retórica es la fuente de la dignidad humana, pues dice CICERÓN, «aunque en mi opinión los hombres son en muchos aspectos inferiores y más débiles que los animales, los superan especialmente por la capacidad de hablar» (M. CICERÓN, 1997: 91). La retórica es, según CiCERÓN, un elemento definitorio de la actividad política ${ }^{23}$. CICERÓN desarrolla una noción de

23 Ibid., 93. 
retórica que explica bien el significado primigenio de la misma: la retórica expresa el ejercicio de la ciudadanía y el cultivo de las virtudes que permiten alcanzar una vida óptima en el seno de la sociedad. En esta filosofía ciceroniana la sabiduría se pone al servicio de la praxis y es un elemento necesario de la figura del «orador».

Quintiliano (M. Quintiliano, 2001), es el gran sucesor de Cicerón. Para él la retórica es la esencia de la educación humanista, de la persona de letras que además se conduce por un ideal de virtud moral. La retórica de la virtud que defiende QuiNTILIANO bebe del estoicismo romano y también de la retórica de ISÓCRATES (ISOCRATES, 1928) que había defendido el ideal republicano según el cual la retórica era la enseñanza central de la completa educación intelectual y moral que debía poseer cualquier ciudadano de la polis. GORGIAS ${ }^{24}$ también había sostenido que un orador debe comenzar por ser justo, de modo que, contra las acusaciones aristotélicas, la retórica sofística no era una mera técnica, sino que contenía una educación ética.

Siguiendo a LÓPEZ EIRE (A. LÓPEZ EIRE, 1998: 237), según QuiNTILIANO, para ser un orador se debe ser dos cosas: una persona buena y una persona experta en hablar de modo persuasivo. En el modelo de QuINTILIANO, por consiguiente, la retórica consiste en dos cualidades: en ser una persona que se conduce de modo ético y en ser capaz de persuadir mediante la palabra. Este aspecto de la filosofía de QuINTILIANO es central y no debería pasar desapercibido: para QuINTILIANO la retórica no es simplemente el arte de persuadir, sino el arte de persuadir ejercido por una persona que posee una determinada educación moral e intelectual. Es decir, ante la pregunta de VEGA REÑón (L. VEGA, 2003) ¿qué es una buena argumentación según este punto de vista?, QUINTILIANO respondería: la argumentación persuasiva realizada por una persona que ha construido un determinado carácter. No hay oratoria sin persona oradora. No hay retórica sin ethos.

LÓPEZ EIRE explica que el orador de QuiNTILIANO es alguien que ejemplifica el ideal ético e intelectual de su sociedad. La retórica requiere conocimiento de la poesía, la filosofía, la pedagogía, la ética, el derecho, la política, la teoría literaria y la gramática. La retórica es la asignatura fundamental de la formación humana total, provista de marcados perfiles morales. Es una retórica humanista que se estudia en la escuela romana. QUINTILIANO señala, en relación con este cuestión, que existe una diferencia entre opiniones que consiste en que «algunos pretenden que aun los hombres malos pueden llegar a ser oradores; otros, por el contrario (a cuya opinión me arrimo), dicen que el arte de que tratamos no puede convenir sino a los buenos». Y continúa diciendo «los que quitan a la elocuencia aquella principal alabanza de vida, que es la virtud, hacen consistir este arte en la persuasión, o en decir y hablar a propósito para persuadir, lo cual, dicen, lo puede lograr el hombre aunque no sea virtuoso» (M. QuinTILIANO, 2001: $\$ 2-17-1)$.

Sin embargo, opina QuinTILIANO, la persuasión no puede ser sin más el elemento distintivo de la retórica, ya que pueden persuadir el dinero, la autoridad, «la dignidad de la persona, y aun su sola presencia sin hablar palabra, [...] por la memoria de los méritos del sujeto, por verle miserable y aun por prendarnos de su hermosura» ${ }^{25}$. Y

24 Platón, 1983; Gorgias, Diálogos (J. Calonge, Trans.), Madrid: Gredos, $\$ 456$ d-e; 457 a; 460 c-e.

25 Ibid., \$2-16. 
cuenta, a propósito de esto último, la célebre anécdota de la hermosísima Phriné, que ganó un pleito porque se desabrochó la túnica, descubriendo parte de su cuerpo ${ }^{26}$. Por otra parte, QUINTILIANO señala que la definición aristotélica de la retórica, consistente en encontrar argumentos racionales adecuados para persuadir tiene el problema de que no tiene en cuenta aquello que no es argumentación, pero que es vital en la retórica, como el estilo ${ }^{27}$.

QUINTILIANO considera que «la retórica es el arte del bien hablar» ${ }^{28}$, recogiendo la opinión de GORGIAS de que no puede haber un verdadero orador que no se conduzca con justicia. A continuación QuiNTILIANO señala que las personas que consideran que lo distintivo de la retórica radica en la persuasión, no por ello deben condenarla, pues una técnica puede utilizarse para fines diversos, incluidos los moralmente buenos. Pero, señala QUINTILIANO, las personas que consideran, como él, que la retórica es el arte del bien hablar, vinculada al orador virtuoso; estas personas no tienen necesidad de justificar a la retórica de manera instrumental ${ }^{29}$. En mi opinión, esta teoría de QuINTILIANO tiene la gran ventaja de que no requiere situar a las emociones, al estilo y al carácter en un segundo plano para conservar la legitimidad moral de la retórica. No es necesario que los argumentos y una perspectiva reduccionista de la razón desnaturalicen a la apasionada y artística tradición retórica ${ }^{30}$.

Llegados a este punto podemos responder a la pregunta, ¿para QUINTILIANO la finalidad de la retórica es la persuasión? QuINTILIANO sostiene que la meta de la retórica no es persuadir, sino hablar bien (que es cosa distinta). La medicina pretende la cura de las personas enfermas, pero si no lo logra por causas no imputables al médico o la médica, aún así habrá cumplido con el fin de la medicina. El objetivo no es persuadir, sino el acto de hablar bien, pues existe una dignidad unida a ese hecho del bien hablar ${ }^{31}$. Por tanto, la retórica que QuiNTILIANO quiere enseñar no es una técnica, es decir, que su virtud no depende del uso que de ella se haga. La retórica que quiere enseñar es un modelo de vida intelectual y moral, es una retórica que no es instrumento sino virtud ${ }^{32}$. La ética de la virtud (presente en la base teórica de la retórica clásica) es una propuesta no instrumental. Esto implica que la retórica no se entiende como una relación entre medios (habilidades necesarias para persuadir) y un fin (la persuasión). Por el contrario, en la retórica de la virtud la finalidad (el bien hablar) es algo que se va haciendo mediante la praxis de las virtudes retóricas. No hay un fin que pueda entenderse al margen de una práctica de vida y, por eso, la retórica (el bien hablar) sería

26 Ibid., $\$ 2-1$.

27 Ibid., \$2-16.

28 Ibid., $\$ 2-15 ; 2-17-1,2$.

29 Ibid., $\$ 2-17-1,2$.

30 En efecto, frente al racionalismo ilustrado presente en la teoría estándar de la argumentación, las éticas de la virtud no desvinculan la razón de las emociones. Desde el punto de vista de las éticas de la virtud, para actuar correctamente es necesaria la implicación de las emociones. Esto conduce, según sostengo, a renegar de la idea de una judicatura imparcial y fría o de una abogacía técnica. Se defiende, desde la retórica de la virtud, que para emocionar es necesario que nos emocionemos primero y que desarrollemos la empatía (esta tesis es un tópico de la retórica clásica). Por eso, la empatía es imprescindible para la abogacía. Con respecto a la judicatura, la retórica de la virtud sostiene que, junto a la imparcialidad hay que situar a la virtud de la compasión como compañera inseparable.

31 Ibid., \$ 2-17-1,2.

32 Ibid., $\$ 2-17-1,2$. 
la virtud de virtudes, es decir, la praxis consistente en vivir de modo conforme con las virtudes que configuran este ideal de vida del mundo clásico. La retórica constituye un ideal político, moral y educativo, pero también constituye un ideal de realización humana y de vida óptima.

Como explica García Castillo (P. G. CAstillo, 1998) la definición del perfecto orador como vir bonus ${ }^{33}$, es uno de los temas recurrentes sobre QuINTILIANO, su gran aportación al saber retórico. La realización humana consiste en alcanzar la excelencia moral (vir bonus) por medio de la habilidad discursiva (dicendi peritus). La retórica no es solo una disciplina, sino una práctica vital, una virtud que se despliega en su vida. Según el modelo que QuiNTILIANO desarrolla en sus Instituciones oratoria, el ideal de virtud de la persona abogada está vinculado a la intelectualidad y a la ética (QUINTILIANO, 2001: $\mathbb{X}$ XII-I-I). A pesar de ser muy consciente de las características de la abogacía, como es lógico, dado que el propio QuiNTILIANO era un eminente abogado, este defendió que el motivo principal que ha de inspirar a la abogacía ideal debe ser el amor por la justicia.

Como afirma A. GEAREY (GEAREY, 2001), la persona abogada puede ser vista como héroe existencial cuya actividad le transforma a ella misma y a la sociedad. Esta visión supone apartarse de la visión de nuestros días de la persona abogada que provee un servicio a sus clientes. Podríamos denominar a dicho punto de vista «profesionalismo». GEAREY sostiene que el profesionalismo provee de una cortina de humo que oscurece las difíciles decisiones individuales que toma la persona abogada y también oculta el papel de la actividad jurídica para el cambio social. La profesión de la abogacía, vista como un trabajo técnico, continúa GEAREY ${ }^{34}$, construye apologetas del statu quo que creen aplicar objetivamente unas determinadas reglas a las disputas sociales. Esta visión ya no puede ser sostenida porque no se corresponde con el protagonismo actual de las personas abogadas. Elegir ser abogada o abogado no es simplemente elegir una profesión, sino que implica aceptar la responsabilidad de cambiar algunos aspectos de la sociedad y de la cultura. Los textos legales contienen conceptos vagos y son un lugar donde ocurren disputas ideológicas. Una aproximación retórica al derecho acepta que hay lugar para cambios e innovaciones que hagan a la sociedad más justa. Las éticas de la virtud, aunadas con un punto de vista retórico del derecho, pueden contribuir al desempeño de una labor profesional comprometida, intelectualmente rica y emocionalmente satisfecha.

\section{CONCLUSIÓN}

La noción «profesionalista» de la abogacía, muy extendida en nuestros días, concibe la abogacía como un trabajo técnico en el que los fines ya vienen determinados

33 La originalidad de este punto ha merecido estudios específicos de WinTERBOTTOM, MEADOR, BRINTON, KENNEDY. WINTERBOTTOM, «Quintilian and the vir bonus», The Journal of Roman Studies (LIV), 1964, 90-97. P. MEADOR, «Quintilian and the Good Orator», Western Speech (34), 1970, 162-169. A. BRINTON, «Quintilian, Plato and the Vir Bonus», Phylosophy and Rhetoric (16), 1983, 167-184. G. Kennedy, Quintilian, New York: Twayne Publishers, 1969.

${ }^{34}$ Ibid., 124. 
desde fuera (intereses de la clientela) y el objetivo, por tanto, consiste en persuadir a la persona juzgadora utilizando las herramientas más efectivas. La retórica sería el arte de persuadir a cualquier precio. Frente a este punto de vista, la teoría de la argumentación jurídica, reivindica una retórica racional, que es la que convencería mediante argumentos (y no mediante pasiones o imágenes) a un auditorio universal formado por personas críticas e inteligentes. En esto consiste la «Nueva Retórica» de PERELMAN.

Sin embargo, este punto de vista tiene el problema de que implica un prejuicio contra las emociones, las imágenes y lo biográfico, y se sostiene sobre una noción de la racionalidad demasiado abstracta y rupturista con la dimensión social y cultural del ser humano. Estas tensiones son particularmente notorias en el mundo del derecho, invadido hoy por una lógica instrumental. Por ello propongo el retorno a la «retórica de la virtud», un paradigma clásico que se preocupa por los elementos emocionales y estilísticos de la comunicación (además de por los argumentativos) dentro de un sistema ético que se configura como el cultivo de una serie de virtudes profesionales. Las virtudes expresan la preocupación por el lugar que ocupa el desarrollo de una profesión en el conjunto de la vida. La abogacía no se percibe como un mero trabajo técnico, sino como una vocación llena de dignidad y de retos intelectuales y morales. Considero que este punto de vista responde mejor que las éticas discursivas a la percepción de las personas abogadas sobre su trabajo y permite desarrollar las habilidades comunicativas necesarias en el derecho, haciendo que estas formen parte de un desarrollo profesional ético.

\section{BIBLIOGRAFÍA}

Alexy, R., 1989: Teoría de la argumentación jurídica (M. AtIENZA, Trad.), Madrid: Espejo CEC. Amalia, A., 2013: «Virtud y razón en el Derecho. Hacia una teoría neo-aristotélica de la argumentación jurídica», en R. GONZÁleZ DE LA Vega y G. LARigueT, Problemas de Filosofía del Derecho. Nuevas Perspectivas, Bogotá: Temis.

Amaya, A., y Hock Lai, H., 2012 (eds.): Law, Virtue and Justice, Oxford: Hart Publishing.

Aristóteles, 1970: Ética a Nicómaco (M. Araujo y J. Marías, Trans.), Madrid: Instituto de Estudios Políticos.

- 1990: Retórica (Q. Racionero, Trans.), Madrid: Gredos.

Atienza, M., 1991: Las razones del derecho. Teorías de la argumentación jurídica, Madrid: CEC.

- 2013: Curso de argumentación jurídica, Madrid: Trotta.

Castillo, P. G., 1998: «Influencias filosóficas en la definición del vir bonus de Quintiliano», en VVAA, T. Albadalejo, E. Del Río y J. CABAllero (eds.), Quintiliano: historia y cualidad de la retórica, Logroño: Instituto de Estudios Riojanos, 891-899.

Chapman, J., y GALSTON, W., 1992: Virtue, NOMOS XXXIV, New York: New York University Press.

CiCERÓN, M., 1997: La invención retórica (S. NúÑEZ, Trans.), Madrid: Gredos.

Farrelly, C., y Solum, L., 2008: Virtue Jurisprudence, Basingstoke: Palgrave MacMillan.

Gadamer, H., 1997: Verdad y método (A. Y. Agud, Trans.), Salamanca: Sígueme.

GEAREY, 2001: Law and Aesthetics, Oxford: Hart Publishing.

Habermas, J., 1981: Teoría de la acción comunicativa, Madrid: Taurus.

- 1989: «Teorías de la verdad», en Teoría de la acción comunicativa. Complementos y estudios previos, Madrid: Cátedra. 
IsOCRATES, 1928: «Antidosis», en Isocrates (G. Norlin, Trans., vol. I), Cambridge: Harvard University Press.

KANT, I., 1981: Crítica de la razón práctica (E. MiÑAnA y M. GARCía MoRENTE, Trans.), Madrid: Espasa-Calpe.

MaCInTYRE, A., 2013: Tras la virtud, Barcelona: Austral.

NussBaum, M., 1995: Justicia poética (C. GARDINI, Trans.), Barcelona: Editorial Andrés Bello.

- 2004: La fragilidad del bien, Madrid: Machado.

- 2012: Las fronteras de la justicia, Barcelona: Paidós.

Perelman, C., 1957: «Evidence et Preuve», Dialectica (11), 230-238.

- 1979: La lógica jurídica y la nueva retórica, Madrid: Civitas.

Perelman, C., y Olbrechts-Tyteca, L., 1989: Tratado de la argumentación: La nueva retórica, Madrid: Gredos.

Quintiliano, M., 2001: Sobre la formación del orador (Institutiones Oratoriae) (A. ORTEGA, Trans.), Salamanca: Universidad Pontificia de Salamanca.

SAldAÑA, J., 2007: Ética judicial. Virtudes del juzgador, México: Suprema Corte de Justicia de la Nación.

SCHOPENHAUER, A., 2002: El arte de tener razón, expuesto en 38 estratagemas (F. VOLPI, Ed., y J. AlBorés, Trans.), Madrid: Alianza.

Tovar, A., 2015: La institucionalización de la razón, Madrid: Instituto de Estudios Políticos.

VAn Eemeren, F., y GroOtendorst, R., 2004: A Systematic Theory of Argumentation. The pragma-dialectical approach, Cambridge: CUP, 1.

VEGA, L., 2003: Si de argumentar se trata, Montesinos: Ediciones de Intervención Cultural.

VIEHWEG, T., 1964: Tópica y jurisprudencia, Madrid: Taurus.

Walton, D., 1989: Informal Logic. A Handbook for Critical Argumentation, Cambridge: CUP.

YANKAH, E., 2009: «Virtue’s Domain», University of Illinois Law Review, vol. 2009, núm. 4. 


\title{
LA PONDERACIÓN: ANÁLISIS DE LA SITUACIÓN DEL DEBATE EN ESPAÑA*
}

\author{
Miguel Fernández Núñez \\ Universidad Autónoma de Madrid \\ mfernandez@outlook.it
}

RESUMEN. Desde la clásica enunciación del método ponderativo elaborada por ALEXY se han dirigido distintas críticas tanto a sus pasos y aspectos metodológicos como a las concepciones que presupone. Este artículo pretende dar cuenta de las visiones de distintos críticos españoles acerca del modelo ponderativo alexiano, poniendo de manifiesto diferencias y afinidades.

Tras una breve introducción, se examinan aspectos de la distinción entre principios y reglas en que descansan algunas de las razones para sostener o descartar la necesidad de ponderar, necesidad que es analizada en segundo lugar; en el tercer apartado se expone la ley de la ponderación vista por ALEXY y el cuarto punto presenta un panorama de algunas críticas planteadas recientemente por cuatro autores españoles (Atienza, García Amado, Martínez Zorrilla y Moreso). Por último, se proponen algunas consideraciones al hilo de lo expuesto.

Palabras clave: Ponderación judicial, principios, postpositivismo, Alexy, AtienZA, García Amado, Martínez ZorRilLa, Moreso.

\section{Balancing: Analysis of the State of the Debate in Spain}

ABSTRACT. Since the classic statement of the method of balancing developed by ALEXY, much criticism has been adressed to its steps and methodological issues as well as to its underlying conceptions. This article aims to present the visions of some Spanish critics of the Alexian model of balancing, by pointing out differences and similarities.

A brief introduction is followed by an explanation of some aspects of the distinction between principles and rules, whereupon lie some of the reasons to support or dismiss the necessity of balancing, a necessity that is analised in the second part; third, an explanation about the Law of Balancing as presented by ALEXY; fourth, a brief overview of some recent criticism exerted by four Spanish authors (Atienza, García Amado, Martínez Zorrilla and Moreso); and fifth, some considerations are proposed in the light of what has been explained.

Keywords: Judicial balancing, principles, Post-positivism, AleXY, AtienZA, GarcíA AmADo, MARTínez ZorRiLLA, MORESO.

* Fecha de recepción: 19 de julio de 2016. Fecha de aceptación: 16 de febrero de 2017. 


\section{INTRODUCCIÓN}

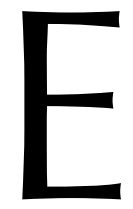

1 presente artículo aborda el estado del debate sobre la ponderación a la luz de distintas propuestas críticas elaboradas por teóricos españoles.

Robert ALEXY (1993) enunció la que se ha convertido en la versión estándar de la ponderación como modelo descriptivo y normativo de lo que los tribunales alemanes empezaron a aplicar a partir de la tradicional doctrina de la probibición de exceso (MONTEALEGRE, 2014: 13). Desde entonces, dicha versión ha sido objeto de muy distintas críticas, de mayor o menor calado.

$\mathrm{Si}$, en sus notas más sucintas, la ponderación consiste en el enjuiciamiento de un conflicto no previsto por una regla entre, generalmente, dos principios opuestos que se resuelve con la precedencia condicionada de uno de esos principios, resulta que cada uno de los elementos que la conforman es controvertido. La naturaleza del conflicto, la caracterización de las normas, la pertinencia de los instrumentos metodológicos y su relevancia normativa así como, una vez efectuada la operación, su alcance, son cuestiones sobre las que no media acuerdo.

De las distintas críticas que ha recibido el modelo alexiano acaso la de mayor envergadura sea que no ofrece criterios adecuados para una resolución sistemática y racional de los conflictos entre principios, abocando las decisiones al particularismo. El método alexiano es muy dúctil, de modo que no logra evitar —al menos no se lo propone seriamente- decisiones judiciales arbitrarias.

Las colisiones entre principios se producen con notable frecuencia y resulta crucial disponer de un instrumento adecuado para resolverlas. En un contexto de intenso debate como el actual, resulta obligado definir un panorama comparado de los distintos análisis y propuestas teóricas. Para ello, el artículo aborda las posiciones más interesantes de diferentes iusfilósofos españoles que en los últimos años han tratado la cuestión con mayor detalle: Manuel ATIENZA, José Juan MORESO, David MARTíNEZ ZORRILla y Juan Antonio GARCÍA AMADO. La circunscripción al panorama español es especialmente interesante pues, por una parte, refleja distintas posturas (universalismo, escepticismo, etc.) que cabe defender frente a la ponderación, mientras que, por otra, revela alternativas teóricas singularmente originales. En las críticas de este artículo el lector encontrará coincidencias con muy distintos autores del ámbito internacional; el corpus español quizás resulte relevante por esta peculiar combinación de visiones continuadoras, propias del clima general del debate y propuestas del todo originales y rupturistas.

Pero antes de alcanzar este punto, el artículo se detiene en distintos aspectos.

En primer lugar, se apuntan algunos términos de la distinción entre principios y reglas, a través de varias contribuciones significativas en el debate internacional. El examen de las normas prescriptivas permite comprender las situaciones que llevan a ponderar y arrojar luz sobre particularidades de los principios y de la ponderación que son únicamente cuantitativas, aparentes o comunes a toda interpretación judicial.

En segundo lugar, se realiza un breve bosquejo de los métodos tradicionales de resolución de antinomias y su posible capacidad para resolver conflictos entre principios. 
En tercer lugar, se describe la versión estándar de la ponderación enunciada por ALEXY en cuanto punto de partida del que arrancan los varios posicionamientos, ya se hallen próximos o alejados de aquella.

En cuarto lugar, se examinan las diferentes críticas y, en su caso, los modelos alternativos de los mencionados autores españoles.

En quinto lugar, se presenta una serie de consideraciones a raíz de lo dicho en los distintos apartados.

Finalmente, tras una recapitulación del contenido analizado, se extraen algunas conclusiones.

Este artículo pretende: 1. comprender el sentido de la distinción entre principios y reglas, 2. plantearse cómo conviene concebir el conflicto entre principios y si este justifica el recurso a la ponderación, 3. analizar los elementos de la operación ponderativa en las distintas visiones teóricas, 4 . decantarse por el modelo más idóneo para un tratamiento racional y, a ser posible, sistemático de los casos y, por último, 5. definir el carácter de los casos resueltos y el alcance de las reglas de precedencia condicionada.

\section{LOS PRINCIPIOS}

\subsection{Sobre la distinción entre principios y reglas}

En los actuales ordenamientos constitucionales conviven dos clases de normas prescriptivas o regulativas: reglas y principios. Tal afirmación a estas alturas no es discutida desde casi ninguna concepción estructural del derecho, pero a medida que se indaga el contenido de ambas categorías surgen los contrastes.

Tradicionalmente se ha asociado a los principios un amplio conjunto de rasgos: «la generalidad, la indeterminación (elasticidad, indefinición, vaguedad), la fundamentalidad, la alta jerarquía, el carácter reformulatorio respecto de normas del sistema, la vinculación a la idea del derecho, lo explícito de su contenido valorativo, la ubicuidad o la validez general, la dificultad de su conocimiento seguro, etc.» (GARCÍA FigUEROA, 1998: 132) ${ }^{1}$. Dicho esto, el reconocimiento de los principios suscita dos importantes dudas: si estamos ante una categoría unitaria y si su oposición a las reglas es ontológica, gradual o aparente.

En lo relativo a la primera duda, GUASTINI arguye que estimar que los principios conforman una categoría unitaria es un problema fundamental del que adolecen los planteamientos principialistas (GUASTINI, 1996: 519). Si todas las características que se acaban de enumerar son propias de una categoría denominada «principios», esta acoge una gran variedad de normas, explícitas e implícitas. Por el momento, la primera duda se puede zanjar con la afirmación de que la ponderación aplica fundamentalmente aquellos principios que establecen derechos contenidos en los textos constitu-

${ }^{1}$ Como apunta PRIETO SANCHÍs cabe construir idealmente escalas graduales cuyos extremos estén representados por lo más accesorio frente a lo más fundamental, por lo más particular frente a lo más general, por lo más preciso frente a lo más vago y tal vez pueda aceptarse que los principios son un género de normas tendente a situarse en los extremos citados en segundo lugar (1992: 63). 
cionales. Esta aserción es algo tosca y deberá ser completada más adelante, cuando se aborden las visiones de DwORKIN y de ATIENZA (infra 1.2 y 3.2.1) para ser revisada al final (infra 4).

En lo concerniente a la segunda duda —el carácter cualitativo o cuantitativo de la dicotomía - existen tres posiciones: la tesis fuerte de la separación, la tesis débil y la tesis de la conformidad. La tesis fuerte hace de la dicotomía entre principios y reglas una cuestión ontológica, cualitativa; la tesis débil estima la distinción como una simple cuestión de grado, cuantitativa y para la tesis de la conformidad no habría distinción alguna entre reglas y principios.

Pasemos a ver dos concepciones clásicas de la dicotomía para luego analizar tres características de los principios, recientemente reformuladas y en buena medida matizadas. En este artículo se defiende que las diferencias que median entre principios y reglas, aun justificando en buena medida el recurso a la ponderación, son exclusivamente graduales; otras, especialmente en el momento de la interpretación-aplicación, son sencillamente aparentes.

\subsection{Principios en Ronald DwOrkIN y Robert AleXY}

La discusión teórica acerca de los principios jurídicos parte fundamentalmente de la obra de Ronald DwORKIN. Dos notas caracterizan a los principios y a las reglas: 1. la dimensión del «peso» de los principios y 2 . la aplicabilidad «todo o nada» de las reglas (1978: 24-26).

Esta diferencia es crucial en la práctica: las reglas son aplicadas mediante subsunción, de modo que un supuesto de hecho o encaja o no encaja en el antecedente de una regla. Así, las reglas se identifican por su idoneidad para servir de premisa mayor en el silogismo judicial.

Por lo que se refiere a los principios, estos forman parte del ordenamiento jurídico en función de su contenido y, por ello, su distintivo es el peso en sentido axiológico (ibid.: 26). La operación ponderativa es vista como una comparación de pesos relativos de principios, los cuales, al carecer de una condición de aplicación cerrada, exigen la deliberación del intérprete-aplicador.

Conviene señalar de pasada que DwORKIN (ibid:: 82) defiende dos categorías de principios: 1. principles o principios en sentido estricto y 2 . policies o directrices.

AlEXY (ibid.: 81 y ss.) ahonda en la distinción trazada por DwORKIN y sostiene que los principios, mandatos de optimización en su terminología, deben ser realizados en «la mayor medida posible» según las oportunidades fácticas y legales. «Esta optimización se regula a partir de un deber ser ideal (Ideales sollen) al que ha de tender la aplicación del principio, que marca el horizonte de la "mayor medida posible" (GARCÍA FIGUEROA, ibid:: 187). Los principios tienen carácter prima facie, debiendo amoldarse a las circunstancias del caso y cediendo ante principios de mayor peso.

Como se verá a continuación, muchas de las concepciones acerca de la oposición entre principios y reglas presuponen estas visiones clásicas pero en gran medida se alejan de ellas o las diluyen significativamente. 


\subsection{Tres distinciones cuantitativas de los principios}

De cuantos aspectos se han reputado característicos de los principios frente a las reglas, en este artículo se abordarán únicamente tres considerados especialmente relevantes con vistas a comprender la operación ponderativa: 1. la apertura de las condiciones de aplicación, 2. la tendencia a la derrotabilidad, 3. la dimensión justificativa.

En lo relativo a las condiciones de aplicación de la norma, se ha dicho que estas se configuran de forma cerrada en las reglas, abierta en los principios. Las reglas presentarían un catálogo cerrado de las situaciones en que se aplican y sus excepciones mientras que en los principios las situaciones se encontrarían indeterminadas y sus posibles excepciones no serían enumerables (ATIENZA y RuIZ MANERO, 2004: 31-33)². Conviene mencionar que tal apertura es independiente del carácter categórico o hipotético de la norma y de concebir los principios como normas categóricas - aquellas que no tienen más condiciones de aplicación que la oportunidad de realizar su contenido (VON WRIGHT, 1989: 120) ${ }^{3}$.

La apertura sí se corresponde, por el contrario, con la idea de derrotabilidad; se trata del mismo aspecto bajo dos perspectivas: estructural en el primer caso y de razones para la acción en el segundo (ATIENZA, 2001: 80-81). Lo destacable no es únicamente que no queden determinados los rasgos ${ }^{4} \mathrm{o}$ las ocasiones del antecedente ${ }^{5}$, sino que, aun de cumplirse el antecedente, este no es condición suficiente para que se produzca el consecuente, sino condición meramente contribuyente —esto es, condición necesaria de una condición suficiente.

Los principios mostrarían una especial propensión a ser superados, derrotados por otras normas y consideraciones y, así, distintos autores han concebido los principios como normas esencialmente derrotables (GUASTINI, 2008: 119 y ss.; ALCHOURRÓN en MENDONCA, 2011: 70) ${ }^{6}$. Tomada tal cual, esta afirmación parecería desplazar la cues-

2 DwORKIN admite que las reglas tienen excepciones pero sostiene que estas pueden quedar incluidas en la propia regla, lo que preservaría su idea de la aplicabilidad disyuntiva (ibid.: 25). Si la derrotabilidad se encuentra condicionada en buena medida por el carácter exhaustivo de la enumeración de excepciones, ALEXY suscitó gran perplejidad al decir que debiéramos entender que toda regla incluye una cláusula de cierre del tenor «si no se ordena jurídicamente otra cosa por un principio», cláusula que conllevaría «un auténtico caballo de Troya» (BAYÓN, 1991a: 361) que eliminaría del todo la distinción fuerte entre principios y reglas.

3 En alguna ocasión (AGUILÓ, 2000: 136; ATIENZA, 2012: 168) se ha dicho que la apertura de las condiciones de aplicación de los principios sería tan grande como para poder calificarlos de normas categóricas. Como ha puesto de manifiesto MORESO (2002: 236 y ss.), el carácter condicional (hipotético/categórico) es distinto del derrotable (apertura/cierre) de una norma, pues una cosa es que un deber esté sometido a alguna condición y otra distinta que se vea superado por otro deber.

${ }_{4}^{4}$ Esta indeterminación por el carácter no monótono del razonamiento es distinta de los clásicos problemas de imprecisión lingüística (ALCHOURRÓN, 2000: 23). La «zona de penumbra» (HART, 1961) es generalmente más amplia en los pricipios que en las reglas pero es dudoso que esta distinción sea siquiera una cuestión de grado (vid. MARTíNEZ ZORRILLA, 2007: 71-72).

5 Esta afirmación asume que toda norma prescriptiva está compuesta por un antecedente —o prótasis, un caso- y un consecuente —o apódosis, una solución normativa. Que la estructura condicional es común a toda norma prescriptiva ya lo dejó sentado KELSEN, asimismo, toda norma tiene condiciones de aplicación pues de otro modo sería inaplicable, por lo menos en el sentido de «aplicabilidad interna», esto es, cuando regula el caso al que se aplica (MORESO y NAVARro, en MARTíNEZ ZORRILla, ibid: : 75).

6 Tanto GUASTINI (1999: 151) como AlCHOURRÓN (ibid:: 24) hablan de condicionales derrotables. Según el autor argentino, un condicional derrotable puede ser definido de dos maneras: 1. el antecedente es condición necesaria pero no suficiente - se unen otros presupuestos- para el consecuente, o bien 2 . se trata de un condicional sometido a condiciones implícitas. 
tión al plano ontológico; en cambio, resulta más adecuado reconocer solamente una tendencia más acentuada en los principios a ser derrotados y una mayor apertura de las condiciones de aplicación, lo que normalmente - se trataría, al fin y al cabo, de generalizaciones - nos lleva a hablar de principios cuando todas las condiciones de aplicación sean implícitas y de reglas cuando nos encontremos ante un catálogo determinado de condiciones explícitas (MORESO, 2002: 240).

Asimismo, la derrotabilidad de los principios significa que si las reglas suelen determinar un curso de acción, aquellos solo proporcionan razones prima facie ${ }^{7}$. Esto suele reflejarse en una dicotomía terminológica; se habla de que las reglas proveen de razones perentorias y los principios ofrecen tan solo razones no perentorias. Conviene explicar brevemente qué quiere decir esto a través del origen de la analogía: el concepto de «razón protegida» empleado en el razonamiento práctico.

Aunque RAz diste de equipararlos totalmente (1991: 53 y ss.), parece fundada la asociación de los principios a razones para la acción de primer orden, en pugna entre sí en un primer nivel de deliberación y cuyo balance de razones se zanja con el mayor peso de una de ellas, a favor de la realización o no de una determinada acción. En el caso de las reglas, tal balance ya se ha producido y tenemos una razón de segundo orden para actuar («positiva») o no actuar («negativa» o «razón excluyente») de acuerdo con una razón de primer orden. Una razón protegida es «una razón de primer orden para $\varnothing$ y una razón excluyente para abstenerse de actuar por otras razones de primer

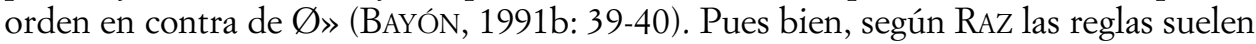
identificarse con razones protegidas para actuar, de modo que si disponemos de una regla «que ha decidido por adelantado qué hacer», podremos subsumir el caso en ella con el consiguiente ahorro de esfuerzo, incertidumbre y tiempo (ibid.: 238). ATIENZA y RUIZ MANERO (ibid.: 35) equiparan los conceptos de razón perentoria y razón protegida y aluden explícitamente al esquema raziano de deliberación del agente.

Es conveniente examinar ahora el tercer distintivo, el denominado por DwORKIN dimensión del «peso» de los principios y que, prescindiendo del tropo, puede llamarse dimensión justificativa (ATIENZA y RUIZ MANERO, 2000: 16-23). Los principios muestran una vinculación más estrecha con los valores del sistema jurídico y por esto la dimensión justificativa resulta más notoria en ellos que en las reglas, mientras que la dimensión directiva ( $\mathrm{ibid}$.) es en aquellos menos ostensible que en las reglas. En suma, si las reglas tienen como principal función guiar la conducta de los destinatarios, los principios hacen referencia de forma privilegiada a los valores de índole moral $^{8}$ que inspiran un determinado ordenamiento.

${ }^{7}$ El hecho de que los principios proporcionen únicamente razones prima facie lleva, según distintos autores, a que estas deban ser contrastadas con otras procedentes de otros principios y reglas (ATIENZA, 2012: 168) y los hace más idóneos para desempeñar el papel de justificación externa de la premisa mayor que el de genuinas premisas mayores de un silogismo judicial (GUASTINI, 1996: 141). En verdad, a pesar de su especial dificultad para «determinar una solución» (HART en MORESO, 2005: 112), los principios parecen tener mayores aptitudes que las estrictamente justificativas; lo que era una razón prima facie puede devenir una razón pro tanto o definitiva. ATIENZA no equipara totalmente razones no perentorias y meramente contribuyentes, de tal suerte que una «razón no perentoria puede, si no es derrotada, ser concluyente y determinar por completo el curso de acción» (ATIENZA, ibid:: 211).

${ }^{8}$ Dicha vinculación ha sido descrita de distintas formas; por ejemplo, afirmando que los valores constituyen el aspecto axiológico de las normas y los principios el deontológico (ALEXY, ibid.: 147; ÁvILA, 2011: 
La oposición entre las dimensiones justificativa/directiva es la más débil de las mencionadas en el momento en que tanto principios como reglas presentan siempre ambas dimensiones, y si en un sistema jurídico las reglas careciesen de dimensión justificativa tal sistema solo podría ser calificado de arbitrario. Podemos decir, con REGAN (1989), que las reglas pueden ser más transparentes o más opacas respecto a su justificación subyacente, pero en todo caso disponen de una y lo racional es que tenga prioridad sobre la directiva (RÓDENAS, 2015: 21).

En cuanto a lo expuesto hasta aquí se pueden formular varias observaciones. Por lo general, los principios tienen indeterminadas sus condiciones de aplicación, notablemente más abiertas que las de las reglas, tendentes a ser cerradas. Semejante apertura motiva la ponderación, que puede ser vista como una operación encaminada a «cerrar» las condiciones de aplicación de los principios.

Estos tienen una notable propensión a ser superados por otras normas. Justamente la ponderación es el supuesto más significativo y habitual en que un principio se ve derrotado; en concreto, por otro principio.

$\mathrm{El}$ «peso», que en primer lugar era una metáfora para denotar la dimensión justificativa, demuestra en los principios su capacidad para vehicular la directiva pues es el elemento - aunque habrá que ver cómo lo entiende cada autor- que permite determinar qué principio, habida cuenta de las circunstancias, va a prevalecer sobre el otro. Se puede decir que el elemento justificativo es especialmente relevante para determinar el resultado de la ponderación.

Dicho esto, la oposición entre principios y reglas solo puede ser entendida como una cuestión cualitativa. Muchas reglas - piénsese en las penales- muestran unas condiciones de aplicación muy abiertas y lo contrario puede decirse de muchos principios. Resulta expresivo que KELSEN no llegara a elaborar una «norma completa», esto es, una regla que incorporase todas sus excepciones relevantes dispersas en el ordenamiento (AlCHOURRÓN y BULYGIN, 1987: 98).

El caso de una norma inderrotable es extremadamente insólito; se ha señalado la prohibición de tortura como único deber incondicional e inderrotable del ordenamiento español (MORESO, ibid.: 238); que las reglas tiendan a «atrincherarse» (SCHAUER, 2004), que tengan «vocación» de no resultar derrotadas (ATIENZA, 2014b: 3), no quiere decir que no puedan ser derrotadas.

Por lo que se refiere a las dimensiones justificativa y directiva, baste añadir que el elemento directivo de los principios desempeña un papel crucial tanto en los supuestos de lagunas normativas y axiológicas como en aquellos en que sea «dudoso que exista una regla que regule de manera aceptable el caso» (ATIENZA en ATIENZA y GARCía AMADO, 2012: 28) y, naturalmente, en casos de colisión entre principios. En todos estos supuestos se presenta la necesidad de ponderar.

No cabe duda de que manejar principios es generalmente una tarea más compleja y más discrecional que la aplicación de reglas pero esta mayor dosis de complejidad y discrecionalidad solo puede ser concebida en un sentido comparado, cuantitativo. Los

130) o bien señalando que sirven «como justificación de las reglas, de las pautas específicas» (ATIENZA, 2014a: 302). 
principios no parecen estar hechos de una sustancia significativamente distinta de la de las reglas.

La necesidad de ponderar ha venido motivada por distintos rasgos de los principios pero resulta que si muchos de esos rasgos han sido atemperados lo mismo ocurrirá con el recurso a la ponderación.

\section{DISTINTA SOLUCIÓN DE LOS CONFLICTOS ENTRE REGLAS Y LOS CONFLICTOS ENTRE PRINCIPIOS}

Como es sabido, los llamados conflictos en concreto de reglas pueden ser resueltos de dos maneras: 1. mediante invalidez de una de las reglas, salvando la validez de la otra; 2 . mediante inaplicabilidad, al declarar que una regla no es aplicable al caso e introduciendo, por ejemplo, una cláusula de excepción.

La declaración de invalidez es inconcebible en el caso de los principios, al menos como método de resolución de conflictos. La declaración de inaplicabilidad se encuentra con el problema de asumir la aplicabilidad general de los principios, idea que no es pacífica habida cuenta de los rasgos que se acaban de predicar de los principios. Pese a ello, una concepción generalista de la ponderación no se encontraría muy lejos de la idea —ya se tome tan solo como ideal regulativo— de aplicabilidad/inaplicabilidad, al determinar casos genéricos ${ }^{9}$ en que un principio resulta aplicable y, a causa de ciertas propiedades, prevalece frente a otro y casos en que ocurre lo contrario. Esta vía será analizada infra 3.2.2, 3.2.3 y 4.3.

Por lo que concierne a los llamados conflictos en abstracto de reglas o antinomias (Alf Ross) ${ }^{10}$ existen tres criterios clásicos de resolución: cronológico, jerárquico y de especialidad. Los dos primeros difícilmente van a poder resolver un conflicto entre principios ya solo por razones empíricas y estructurales: los principios ponderados suelen pertenecer a un mismo texto de rango constitucional. Al margen de esto, también se dice que el carácter eminentemente formal de los tres criterios los haría inadecuados para resolver conflictos entre derechos.

En un sentido afín a lo señalado sobre la inaplicabilidad, ciertos autores consideran que el criterio de especialidad podría resolver antinomias entre principios, reformulando en sede interpretativa uno de ellos e introduciendo una cláusula de excepción (GuASTINI, 1999: 169). Ahora bien, poder emplear este criterio implica tres premisas

9 Es necesario referir la distinción entre caso individual y caso genérico tomando la perspectiva de ALCHOURRÓN. Caso individual es el litigio dirimido en un momento determinado y que puede ser visto como instanciación de un caso genérico, siendo este una categoría que aúna «acontecimientos que poseen una propiedad común» (ALCHOURRÓN, ibid.: 18). Para el autor, el postulado de completitud de un sistema jurídico se vincula con los casos genéricos. Las normas de un sistema jurídico seleccionan un conjunto de propiedades y según la ausencia o presencia de dichas propiedades se pueden construir casos genéricos elementales que debieran considerarse como clasificación exhaustiva y mutuamente excluyente de todos los casos individuales, de tal modo que «un sistema completo que brinda respuestas a todos los casos genéricos elementales provee indirectamente soluciones normativas para todos los casos individuales» (ibid.: 19).

${ }_{10}$ Se ha preferido mantener la distinción tradicional entre conflictos de reglas en concreto y en abstracto fundamentalmente por la utilidad de la misma. Esto no quiere decir que las antinomias no terminen también en una declaración de invalidez, en una pérdida de vigencia o en la inaplicabilidad de la norma. 
distintas: considerar que se pueda hablar en algún sentido de aplicabilidad de un principio; que no se trate simplemente de un conflicto en concreto sino de una auténtica inconsistencia lógica, y que se presente dicha inconsistencia como una antinomia totalparcial ${ }^{11}$. Conviene apuntar que numerosos autores - MARTínEZ ZORRILLA la califica de «posición doctrinal mayoritaria» (ibid.: 135) — mantienen una concepción de los conflictos entre principios que niega cada uno de los tres puntos.

Habiendo dicho algo sobre la primera premisa, se obviará la tercera para encarar a continuación la segunda, la fundamental.

Si bien es cierto que el criterio de inconsistencia lógica —un grupo de proposiciones es inconsistente si no es posible que sean simultáneamente verdaderas - no da cuenta, por demasiado exigente, de gran parte de las situaciones en que se presenta la necesidad de ponderar, no parece justificada la postura de quienes defienden que la colisión entre principios «solo se descubre, y se resuelve, en presencia de un caso concreto, y los casos en que ello ocurre resultan a priori imposibles de determinar» (PRIETO SANCHÍs, 2014: 114). No hay razones que nos lleven a excluir la posibilidad conceptual de conflictos entre principios, independientemente de que estos se produzcan o no. En ello hace especial hincapié MARTíNEZ ZORRILLA, quien propone tres categorías de conflictos en virtud de la relación entre acciones individuales y normas (ibid:: 135). Pero al margen de clasificaciones concretas, no hay duda de que se pueden concebir conflictos necesarios con independencia de que se den empíricamente y, del mismo modo, un caso puede reunir ciertas propiedades tales que puedan dar lugar a conflicto, al margen de que las circunstancias resulten previamente indeterminadas. Como ejemplo de conflicto necesario, GUASTINI menciona el conflicto prima facie entre el principio de presunción de inocencia del imputado ( $\$ 27$ Constitución italiana) y el principio que permite la prisión preventiva ( $\$ 13$ in fine Constitución italiana), los cuales regulan de forma incompatible el mismo supuesto de hecho (ibid.: 167).

Por otra parte, conviene recordar que la derrotabilidad es una propiedad disposicional, es decir, por oposición a las propiedades categóricas, no tiene que manifestarse para existir (GARCÍA FIGUEROA, 2010: 199).

Ni la regla lex specialis ni la noción de (in)aplicabilidad parecen criterios tan poco prometedores como para excluir de plano su extensión a las colisiones entre principios. Cierto es que dichos criterios tomados tal cual nada dicen acerca de la tarea de interpretación previa y que, sin mayores reservas, no han sido considerados métodos adecuados de resolución de conflictos entre principios.

En cuanto modo de aplicación de normas, tradicionalmente se ha opuesto la ponderación a la subsunción ${ }^{12}$. Si la subsunción consiste en la aplicación de una regla a un caso concreto que se puede inscribir en el supuesto de hecho, la ponderación se da precisamente a falta de regla que resuelva el caso ante un conflicto entre, al menos, dos

11 Considera GuAstini que la ponderación se plantea en casos de antinomias parcial-parcial: si fuesen total-total serían situaciones irresolubles, mientras que, precisamente, los casos de antinomias total-parcial pueden ser resueltos mediante el criterio de especialidad (ibid.: 170).

12 Este procedimiento constituye el silogismo judicial, alabado a lo largo de los siglos por su simplicidad y aparente objetividad. La deducibilidad y el carácter meramente cognoscitivo de la interpretación serían los paradigmas del positivismo formalista que encarna esta visión superada. 
principios jurídicos determinando cuál debe prevalecer sobre el otro, que se ve desplazado. El peso superior de cierto principio dadas determinadas circunstancias justifica su precedencia frente al principio concurrente. El último estadio de la ponderación puede entenderse como una regla, resultante de dicha precedencia condicionada, en la que se subsume el caso.

En verdad, ni la ponderación es privativa de los principios ni la subsunción de las reglas, como se dirá más adelante (infra 4.1) y, en cualquier caso, gran parte de los riesgos interpretativos son compartidos por ambas formas de aplicación (infra 4.3). Por el momento, no se pone en duda que una contradicción, lógica o empírica, entre principios no zanjada por una regla lleva a ponderar. Ahora bien, cómo se defina en concreto el proceso de la ponderación es cuestión bien distinta.

\section{LA PONDERACIÓN}

\subsection{El modelo de ALEXY}

Como se ha señalado antes, es ALEXY (ibid:: 89 y ss.) el teórico que con mayor detalle ha descrito y enunciado el método ponderativo y quien en mayor medida ha aportado una visión normalizada de la ponderación tanto en el ámbito de discusión teórica como en su recepción por parte de los tribunales.

Partiendo de la noción enunciada de principios como mandatos de optimización (supra 1.2), el conflicto entre ellos debe resolverse bajo la guía del principio de proporcionalidad en virtud, a su vez, de los principios de ubicuidad y optimización que informan todo moderno ordenamiento constitucional (ibid.).

El principio de proporcionalidad consta de tres subprincipios, tres requisitos que deben cumplirse en el siguiente orden: idoneidad, necesidad y proporcionalidad en sentido estricto o ponderación. Mientras que los de idoneidad y necesidad definen la optimización en términos de lo fácticamente posible, el principio de proporcionalidad en sentido estricto abordaría lo posible en términos normativos. Una medida que quiera limitar un principio debe ser idónea - debe proteger un principio constitucionalmente protegido—, necesaria — que no haya una medida alternativa igualmente eficaz con un coste menor para el principio sacrificado- y proporcional en sentido estricto - lo que es idéntico a la ley de ponderación. La ley de la ponderación consiste en que «cuanto mayor es el grado de no satisfacción o de afectación de un principio, mayor es la importancia de satisfacer el otro» (ibid.: 161).

La estructura de la ponderación, su «justificación externa» (ATIENZA, 2012: 172) estaría formada por tres elementos: la ley de la ponderación, la fórmula del peso y las cargas de la argumentación.

El primer elemento se desarrolla a través de tres etapas:

1. El establecimiento del grado de afectación de principios en un determinado caso, 2. el establecimiento de la necesidad de satisfacer la importancia del segundo principio, que juega en sentido contrario al primero y 3 . la determinación de si la importancia del segundo principio justifica el detrimento o no satisfacción del primero. 
La ley de ponderación se concreta mediante tres variables que conforman la fórmula del peso, que van a justificar la preferencia del primer principio respecto al segundo: 1. el grado de afectación de los principios en el caso, 2. el peso abstracto de cada principio en juego, 3. la seguridad de las afirmaciones empíricas.

Con el fin de comprender el grado de afectación y de importancia, ALEXY establece varias escalas triádicas: por un lado, las calificaciones de «leve, medio e intenso» para la posible afectación de los principios y su peso abstracto y las de «no evidentemente falsas, plausibles y seguras» en lo referente a la seguridad de las afirmaciones empíricas. De igual modo, considera que, como instrumento heurístico, tales escalas pueden ser representadas aritméticamente como 1, 2, 4. Esta formulación, advierte ALEXY, no hay que tomarla al pie de la letra, sino más bien como una analogía «instructiva» (ALEXY, 2002: 42).

En caso de que la aplicación de la fórmula del peso arrojase un empate numérico entre valores, habría que recurrir a fórmulas de desempate, las llamadas cargas de la argumentación: en el caso de la Teoría de los derechos fundamentales (1993) ALEXY estableció una carga argumentativa in dubio pro libertate mientras que, quince años después, en su Epílogo (2002) a la anterior obra, se inclina por la deferencia al legislador, un in dubio pro legislatore, como criterio de desempate (BERNAL PULIDO, 2003: 231).

\subsection{Críticas y modelos alternativos}

En este apartado se tratarán las críticas que algunos autores españoles han realizado al modelo de ALEXY y las propuestas que han defendido. Se abordarán los argumentos aducidos por los siguientes autores: Manuel ATIENZA, José Juan Moreso, Daniel Martínez Zorrilla y Juan Antonio García Amado.

MARTíNEZ ZORRILLA ha sintetizado una clasificación de distintas concepciones que cabe defender respecto de la ponderación que, a pesar de no ser exhaustiva ni excluyente $^{13}$, es sumamente esclarecedora, de modo que se remite la tabla (MARTínEZ ZORRILLA, ibid.: 157).

Concepciones de la ponderación:

\begin{tabular}{|ll|l|}
\hline \multicolumn{2}{|c|}{ Aceptación del conflicto } & \multirow{3}{*}{ Negación del conflicto } \\
\cline { 1 - 2 } Actividad discrecional: & a) Intuicionismo & \\
& b) Escepticismo & \\
\cline { 1 - 2 } Actividad racional: & c) Particularismo & \\
& d) & \\
\end{tabular}

Los autores que consideran que efectivamente se produce un conflicto pueden reputar que este se resuelve de forma discrecional (MARTínEZ ZORRILLA, ibid:: 155157): a) por medio de una suerte de intuición, b) de forma exclusivamente guiada por

13 MARTínez Zorrilla (ibid:: 157) así lo admite, declarando que su clasificación de las concepciones de la ponderación no es excluyente, sino que admite vinculaciones fuertes entre las posiciones «distintas e independientes entre sí» (ibid.). La única concepción ecléctica que será analizada en este artículo es, en cierta medida, la propuesta de GARCÍA AMADO (infra 3.2.4). 
las preferencias del juzgador. Asimismo, resulta posible que los autores que aceptan el conflicto contemplen la ponderación como un procedimiento susceptible de ser evaluado racionalmente. En esta categoría la principal distinción que señala MARTíNEZ ZORRILLA es: $c$ ) aquellos que consideran que los casos concretos que se enjuician son únicamente casos individuales, conque la solución es exclusivamente válida para ese caso, $d$ ) aquellos que conciben el caso concreto como instancia de un caso genérico, de tal modo que su respuesta puede generalizarse a otros casos que compartan idénticas propiedades.

Entremos a ver en detalle las concepciones de los cuatro autores.

\subsubsection{La visión de ATIENZA}

La postura de ATIENZA coincide sustancialmente con la de ALEXY, de quien adopta casi íntegramente su esquema ponderativo, aunque no tome sus aspiraciones literalmente sino «con miras a un uso más pragmático» (ATIENZA en ATIENZA y GARCía AmADO, ibid.: 21). El de ATIENZA es un planteamiento universalista.

Antes de entrar a ver la opinión que le merece a ATIENZA el modelo alexiano, conviene examinar la que, por otro lado, es la principal discrepancia del autor: su distinción taxonómica entre principios en sentido estricto y directrices o normas programáticas (ATIENZA y RuIZ MANERO, 2000: 18 y ss.), categorías que ya encontramos en DWORKIN (supra 1.2).

Las dos «especies» de principios configuran de forma abierta sus condiciones de aplicación —en ambos casos se trataría de normas categóricas (ATIENZA y RuIZ MANERO, 2004: 31$){ }^{14}{ }^{4}$, pero en lo que se refiere al consecuente, este se encuentra cerrado en los principios en sentido estricto y abierto en las directrices. El consecuente de los principios en sentido estricto exige la realización de una acción calificada deónticamente, siendo susceptibles tan solo de cumplimiento pleno o incumplimiento; en cuanto a las directrices, su consecuente exige la producción de un cierto estado de cosas «en la mayor medida posible», siendo susceptibles de cumplimiento gradual (ibid.). El disenso que surge a raíz de esta distinción estructural es el siguiente: mientras que las directrices sí coinciden con la noción alexiana de mandatos de optimización, al ser su consecuente susceptible de cumplimiento gradual, en opinión de ATIENZA son únicamente los principios en sentido estricto los aplicados en el modelo ponderativo. En la ponderación nos encontramos con dos principios, uno de los cuales es cumplido plenamente, debiendo ceder el de menor peso; si esto es así, la noción alexiana de mandato de optimización no se ajusta a la idea de principio en sentido estricto, ni antes ni después de la ponderación (ibid.: 34).

Por su parte, las directrices reclaman un proceso bien distinto, a cargo de legisladores y órganos administrativos, de concreción de objetivos y medios de realización, en virtud de los medios disponibles y los fines concurrentes (vid. ATIENZA, 2012: 174176). En este tipo de ponderación la discrecionalidad es notable y «el papel de los jue-

${ }_{14} \mathrm{El}$ análisis de la apertura del antecedente y el carácter prima facie y no perentorio de los principios que defiende ATIENZA ha sido acometido (infra 1.3) y a él se remite en esta ocasión. 
ces suele ser aquí el de controlar que ese proceso ha tenido lugar de manera adecuada» (ATIENZA, 2014a: 184).

La separación entre principios en sentido estricto y directrices tiene una doble ventaja argumentativa (en ATIENZA y GARCÍA AMADO, ibid.: 25): «1. la jerarquía que se establece a favor de los principios en sentido estricto (su prevalencia sobre las directrices) es lo que configura el elemento más importante del "orden débil" entre principios del que - con razón — habla ALEXY; y 2. la dualidad interna de los principios permite mostrar [...] que la racionalidad de los principios no es solo de tipo económico o instrumental, sino también político-moral».

La disensión entre los autores se atempera en aquellas ocasiones en que las razones provenientes de una directriz tengan una fuerza superior a aquellas provenientes de un principio. Y «por otro lado (por el de ALEXY), aunque niegue en principio la distinción, la misma juega un papel destacado a través de los elementos del peso abstracto de los principios (digamos, los principios en sentido estricto tienen también para ALEXY un mayor peso abstracto que las directrices) y de las reglas sobre la carga de la argumentación» (ibid.: 26).

Una precisión conceptual reveladora es que, si ALEXY considera su esquema de ponderación como «justificación interna», en opinión de ATIENZA este constituye la «justificación externa» de su segunda premisa (ibid.: 27). «Pero precisamente por ello, porque se trata de un esquema puramente formal (cuya base es una noción elemental de justicia o de racionalidad: los costes no deben superar a los beneficios), no puede usarse más que como una ayuda para resolver un problema, el de la ponderación, que es fundamentalmente material y, por así decirlo, interpretativo» (ibid.: 21). Este problema interpretativo precisamente «se encuentra en la segunda premisa, la que establece que, dadas determinadas circunstancias, un principio prevalece sobre otro» (AtiENZA, 2014a: 185). Para resolverlo, ATIENZA no considera necesario abandonar el esquema de ALEXY pues estima que la fórmula del peso como justificación externa y los demás factores alexianos (peso abstracto, certeza, carga de la argumentación) ${ }^{15}$ ofrecen respuesta a dicho problema (ibid.).

En pocas palabras, ATIENZA está fundamentalmente de acuerdo con el esquema de ALEXY pero advierte de que no se puede entender la fórmula del peso como un «algoritmo», pues no pasa de ser un «recurso heurístico», un «uso metafórico del lenguaje matemático, que no aporta nada en términos de rigor» (ATIENZA y GARCía AMADO, ibid:: 21). De hecho, la expresión en términos matemáticos de la fórmula del peso ha llevado a muchos juristas a incurrir en lo que VAZ FERREIRA denominó «paralogismo de falsa precisión», causando la falsa impresión de que los problemas ponderativos se pueden resolver mediante un algoritmo (ATIENZA, 2014b: 6).

Sin por ello restarle rigor conceptual, la sugerencia de ATIENZA es «la de no seguir a ALEXY en su excesivo afán sistematizador, sino hacer un uso más pragmático y, por así decirlo, oportunista de estas ideas» (ATIENZA y GARCíA AMADO, ibid.: 22).

15 ATIENZA sostiene que el esquema alexiano resulta interesante por mostrar «los lugares, los tópicos, a los que acudir para resolver conflictos entre derechos o entre bienes» (2014a: 258) y poner de manifiesto «cuáles son los diversos ingredientes que han de tomarse en cuenta para dar prioridad a un principio sobre otro, lo cual contribuye a racionalizar la operación» (2012: 173). 
Por último, ATIENZA concibe la ponderación como un procedimiento esencialmente dirigido a construir casos genéricos y determinar prevalencias condicionadas (ATIENZA y RuIZ MANERO, 2004: 37), creándose «una taxonomía en la que se van formando casos genéricos y las correspondientes reglas» distintas según la concurrencia de propiedades (ATIENZA, 2012: 171). Tales afirmaciones justifican una genuina adscripción del autor en las visiones generalistas de la ponderación.

\subsubsection{La estrategia especificacionista de MORESO}

La postura de MORESO es universalista y, de hecho, uno de sus principales objetivos es rehuir el particularismo. Con este fin, sugiere examinar las propiedades relevantes de los supuestos enjuiciados, instancias de casos genéricos, en aras de un tratamiento consistente y completo de los casos. Este tratamiento pasa por una revisión del alcance, de la «aplicabilidad» de los principios. En todo ello, MORESO se sirve del análisis de sistemas normativos de ALCHOURRÓN y BULYGIN.

En cuanto a las normas regulativas, MORESO no considera que haya que entender la diferencia en términos de derrotabilidad sino de grado de apertura de sus condiciones de aplicación, siendo la mayoría de los principios pautas derrotables con todas sus condiciones de aplicación implícitas (MORESO, 2002: 240) ${ }^{16}$.

Esto reviste gran importancia pues la posibilidad de explicitar las condiciones de aplicación implícitas ${ }^{17}$, reformulando idealmente todas las propiedades potencialmente relevantes, podría evitar el conflicto y la ponderación se llevaría a cabo como una forma de subsunción; de otro modo, sería fácil volver a caer en el particularismo (ibid.: 113-116).

Pero comencemos con las críticas que MORESO ha aducido contra los elementos del modelo alexiano.

Como se ha visto (supra 3.1) ALEXY incluye en la fórmula del peso la variable del peso abstracto de los principios —es decir, al margen de las circunstancias-, pero para concebir tal cosa, aclara MORESO, habría que construir una escala abstracta de ordenación de los derechos fundamentales, lo cual no parece ni posible ni deseable (en AleXY et al., 2007: 231-232).

La segunda crítica de MORESO se basa en la escala de afectación de los derechos como interferencias leve, moderada o grave. El autor considera que, en la medida en que tratamos con derechos, solo se van a poder generar conceptos clasificatorios pues no disponemos de conceptos métricos ni comparativos. El «test del rayado», que tan claramente clasifica en una escala de dureza los minerales según que rayen o sean rayados por otros, resulta improcedente, sostiene MORESO, en el caso de la afectación de los derechos pues en ellos no hay una propiedad claramente definida a la que hacer

${ }^{16}$ Esto quiere decir que el autor concibe los principios como normas categóricas en el sentido de VON WRIGHT pero, en lugar de ser condiciones suficientes, condicionales inderrotables o all the things considered son condiciones contribuyentes, deberes prima facie (MORESO, 2003: 109).

17 De cara a hacer explícitas las asunciones implícitas, MORESO (2002: 237) señala que ALCHOURRÓN proporciona un operador de revisión que se aplica al condicional como protección del deber ante defeaters. 
referencia (ibid.: 232-233). Aludir a una asignación de pesos solo puede entenderse como metáfora (MORESO, 2003: 105).

El tercer inconveniente es que la ponderación resultaría un método ad hoc pues, según ALEXY, esta operación «se refiere siempre a un caso individual» (ALEXY et al., 2007: 233). El hecho de que una característica individual conlleve una solución distinta de la ya tomada y que en cada ocasión haya que ponderar implica decantarse por un modelo particularista de toma de decisiones en lugar de uno generalista.

Estos tres problemas socavarían gravemente la propuesta de ALEXY y por ello MORESO plantea una alternativa desde una concepción universalista de la ponderación, con el fin de salvaguardar la previsibilidad y el control racional de las sentencias.

La ponderación para MORESO «consistiría estrictamente en la elaboración de un conjunto de reglas que correlacionan las propiedades del Universo de propiedades (ya sea aisladamente consideradas o en cierta combinación) con la correspondiente solución normativa, que sería consecuencia jurídica del principio [...] considerado como prioritario bajo esas circunstancias» (MARTÍNEZ ZORRILLA, 2010: 159).

Es necesario presentar la ponderación como paso previo a la subsunción, pasando de principios a reglas — es decir, de pautas de aplicación abiertas a cerradas, siguiendo la concepción de ATIENZA y RUIZ MANERO- y subsumir el caso. Para ello, el autor se vale de categorías y procedimientos enunciados por ALCHOURRÓN y BULYGIN en su clásico Normative Systems (1971). La estrategia especificacionista se estructura en cinco etapas.

La primera consiste en una delimitación clara del Universo del discurso, esto es, se acota de forma explícita el ámbito del problema jurídico.

En la segunda etapa se identifican las pautas prima facie aplicables, es decir, los principios concurrentes.

La tercera aborda la consideración de casos paradigmáticos, reales o hipotéticos, que constriñen el ámbito de las reconstrucciones admisibles. Solo serán admisibles aquellas reconstrucciones que den cuenta de los casos paradigmáticos adecuadamente. Los juicios del intérprete están constreñidos por la necesidad de dar cuenta adecuadamente de los casos paradigmáticos y de «sólidas intuiciones» (MORESO, 2003: 106). De esta manera, los casos paradigmáticos delimitan un «marco» de lo admisible para la solución del juez (ibid.).

Del mismo modo en que las reglas seleccionan en los casos genéricos propiedades relevantes, la cuarta etapa consiste en seleccionar las propiedades relevantes ${ }^{18} \mathrm{del}$ Universo del discurso.

La quinta etapa trata de la formulación de reglas que resuelvan de forma unívoca todos los casos del Universo del discurso. Un ejemplo de tales reglas sería el siguiente: «Las informaciones de relevancia pública, veraces y no injuriosas están permitidas» (en ALEXY et al., ibid.: 241).

De este modo, la estrategia de MORESO fija su atención en las propiedades relevantes para la resolución de los casos del Universo del discurso, cosa que de otro modo no

18 Conviene señalar que, al hablar de la relevancia de las propiedades, MORESO admite seguir a HuRLEY (en Moreso, ibid.), autora de la que parte MARTínEZ ZORRILLA para elaborar su matriz deliberativa. 
estaría determinada con anterioridad. De acuerdo con el autor, el no hacer explícitas las características relevantes haría de la ponderación un método por así decir de un solo uso (particularista), mermándose claramente la racionalidad de las sentencias (ibid.).

Su estrategia constituye un instrumento útil para la resolución de futuros casos, que serían subsumibles en reglas como las de la quinta etapa. El modelo queda abierto al distinguishing, a que se presente una nueva propiedad relevante no tenida en cuenta, lo que reflejaría los casos resueltos en el pasado pero ofrecería, con la introducción de un universo de casos más «fino» (ALCHOURRÓN y BULYGIN, 1971), un criterio de resolución de futuros conflictos (MORESO, 2003: 118).

Declara que su postura respecto de la reconstrucción de los derechos es especificacionista (cita a SHAFER-LANDAU): en caso de conflicto de principios la mejor forma de resolución es retener la máxima fuerza vinculante de los principios reduciendo su alcance mediante cláusulas de excepción (vid. supra 2). En términos aplicables a reglas, se preserva la validez pero se reduce la aplicabilidad. Por el contrario, alega MorEso, la estrategia de ALEXY es proporcionalista, conservando el alcance abstracto de los principios pero sacrificando su fuerza (en AlEXY et al., ibid.: 244).

Finalmente, MORESO reconoce que su estrategia: 1. nunca va a poder hacer una «reconstrucción completa y consistente del universo de los derechos fundamentales» y esto también por cuestiones conceptuales — si hay infinitos modos de describir las acciones individuales, será imposible delimitar las propiedades relevantes de un universo tan amplio-, 2. la estrategia especificacionista depende del contexto aunque mucho menos que la estrategia alexiana pues se trata del contexto del Universo del discurso escogido y de los principios considerados, lo que consiente tanto una aplicación subsuntiva como un control racional, 3. también en la estrategia especificacionista hay lugar para la indeterminación, por dos razones: por la vaguedad de los conceptos y porque con la colisión de dos principios pueden generarse dos o más reconstrucciones alternativas que, aun resolviendo de forma unívoca los casos paradigmáticos, representen diferencias relevantes en otros casos, sin que haya razones para elegir entre ellas (ibid.: 248).

Aunque esta exposición comenzó con el rechazo de Moreso hacia la escala de ordenación abstracta de derechos que parece presuponer el peso abstracto alexiano, el autor alienta a la elaboración de escalas de ordenación condicionada.

MORESO ve la Constitución en el nivel crítico como un «Sistema Maestro» —un sistema jurídico ideal caracterizado por completitud y consistencia (ALCHOURRÓN, ibid.) - para todos los casos genéricos. Si los Universos de casos son comparables entre sí entonces solo algunos casos quedarán indeterminados, mientras que otros estarán unívocamente determinados porque tendrán la misma solución en todas las «Master Constitutionis» admisibles (MORESO, 2003: 118-120).

\subsubsection{El modelo coherentista de MARTÍNEZ ZORRILLA}

La dirección tomada por MARTíNEZ ZORRILLA es muy cercana a la de MORESO, inscribiéndose en la concepción universalista de la ponderación, tanto en los resulta- 
dos como en el proceso. De manera semejante a MORESO, MARTínEZ ZORRILLA estima que «es necesario contar con criterios normativos o valorativos para seleccionar cuáles son esas circunstancias que tanta incidencia tienen en la determinación del peso de los elementos en conflicto. Y, lamentablemente, ALEXY pasa por alto esta cuestión» (MARTíneZ ZORRILla, ibid.: 171). Con este fin, propone el autor valerse de la teoría que Susan HuRLeY desarrolla en el ámbito moral para la toma de decisiones en caso de conflicto jurídico.

MARTÍNEZ ZORRILLA elabora una «matriz deliberativa», un esquema que ordena los elementos por filas y por columnas. En las filas se sitúan el caso en disputa y los casos paradigmáticos; en las columnas se ubican los principios en pugna y la solución derivada de las alternativas señaladas por cada norma (ibid.).

La primera etapa consiste en la especificación del problema: «Se identifican las alternativas que se plantean en el caso y se determinan las distintas razones (normas jurídicas) relevantes que se aplican a cada una de ellas y cómo ordenan las alternativas en conflicto» (ibid.). Una norma jurídica supondrá la prioridad de una alternativa (la prevalencia de un principio) y otra norma distinta, otra alternativa. Si hablamos de libertad de información [\$20.1.d) Constitución española], esta norma o «razón» favorecerá la prevalencia de este derecho (se decantará por una cierta alternativa) mientras que si hablamos del precepto que establece el derecho al honor ( $\$ 18.1$ Constitución española) hará lo propio en sentido contrario (ibid.: 172).

En la segunda etapa se enuncia el propósito de las normas, el valor último de la justificación subyacente, de cara a evaluar la importancia de cada razón en el caso. El fundamento de la libertad de información podría ser «la formación de una opinión pública libre» mientras que el derecho al honor respondería a la «dignidad» individual.

La tercera etapa se dedica al análisis de los casos paradigmáticos, ya sean situaciones reales (casos ya resueltos) o hipotéticas. Casos paradigmáticos son tanto aquellos «cuya solución es clara o evidente y sobre la cual exista un amplio consenso» como aquellos «cuya respuesta haya establecido una jurisprudencia consolidada o de seguimiento obligatorio» (ibid.: 174).

Los casos paradigmáticos se introducen en la matriz deliberativa proponiendo distintas alternativas para cada derecho.

La cuarta etapa consiste en elaborar hipótesis teóricas que determinen qué circunstancias resultaron relevantes en la atribución de un peso a cada principio en conflicto. En esta etapa se busca la hipótesis «que mejor reconstruya y sea más compatible con nuestras intuiciones plasmadas en los casos paradigmáticos» (ibid.: 175). Se comparan las hipótesis con los distintos casos paradigmáticos y se desecha aquella hipótesis que resulte insatisfactoria. Esta operación es crucial pues se dirige a seleccionar las circunstancias relevantes que tienen incidencia en los principios que se examinan. En este punto, la matriz deliberativa ofrecería un panorama de las distintas alternativas y circunstancias concurrentes en cada caso y, especialmente, de aquellas que han llevado a una determinada solución normativa. A modo de ejemplo, tendríamos que en favor de la prevalencia de la libertad de información es significativo que la información tenga relevancia pública pero esta no es condición suficiente para la prevalencia; por ejemplo, es necesario que no concurran expresiones vejatorias. Así, la prevalencia cam- 
biará ${ }^{19}$ según las circunstancias relevantes presentes en un caso individual y que hayan sido contempladas por anteriores casos paradigmáticos (ibid.: 177).

En esta etapa se manejan conceptos como «importancia» de los derechos, «grados» e «importancia de la afectación» del principio, que son comunes a la teoría de AleXY. Según MARTíneZ ZorRILla, esto es natural pues, aun pudiendo ser controvertidas, resulta difícil, en cualquier modelo de ponderación, prescindir de este tipo de consideraciones (ibid.).

En la quinta y última etapa se extraen las consecuencias de la que ha sido considerada la mejor hipótesis en la etapa precedente. Se aplica la hipótesis al caso que nos ocupa y la solución cambia según qué circunstancias estén presentes o ausentes en concreto.

Adoptar el modelo de HURLEY como estrategia ponderativa permite: acotar de forma explícita las circunstancias relevantes, siendo idóneo para seleccionar solo las propiedades verdaderamente significativas, y usar un método homogéneo, sin distinciones de ningún tipo entre casos de constitucionalidad de una ley y recursos de amparo, eludiendo de este modo el particularismo de otras teorías (ibid.: 178 y 179).

\subsubsection{El método interpretativo-subsuntivo de GARCíA AMADO}

La postura de GARCÍA AMADO supone una crítica singular al modelo alexiano pues puede inscribirse entre las categorías de escepticismo y de negación del conflicto de la clasificación de MARTínEZ ZORRILla (supra 3.2). GARCÍA AMADO sostiene al mismo tiempo que la ponderación consiste en un simple ejercicio discrecional de las preferencias del tribunal (escepticismo) y que los conflictos de principios son solo aparentes y suponen un pretexto para la arbitrariedad del juez (negación del conflicto). Al considerar esencialmente intercambiables ponderación y subsunción y principios y reglas, el autor defiende que, de existir algún conflicto, este habría de resolverse mediante la subsunción del caso en una regla (en ALEXY et al., 2007: 256 y ss.).

A la dualidad antes señalada respecto de la ponderación se acompaña una visión estructural de las normas regulativas que gravita entre el rechazo del carácter normativo de los principios y la tesis de la conformidad. La teoría de GARCÍA AMADO resulta coherente al otorgar mayor relevancia normativa a la negación o apariencia del conflicto y a la tesis de la conformidad frente a las otras dos concepciones. Tales concepciones (escepticismo y rechazo de los principios) se identificarían más bien con su reconstrucción crítica del modelo alexiano o jurisprudencial mientras que las dos anteriores conforman el núcleo de su propuesta teórica. En resumidas cuentas, se propugna una equiparación metodológica a favor de la subsunción.

En lo atinente a la propuesta alexiana, GARCíA AMADO sostiene que la proporcionalidad brinda un gran campo a la discrecionalidad del juzgador. Los tres principios de proporcionalidad «carecen de autonomía operativa», dependiendo el peso —lo que

19 Merece la pena señalar que el autor describe este cambio como un posible «cambio de polaridad» negativa/positiva, dejando parcialmente abierta la posibilidad de una descripción particularista del tratamiento del problema. 
es pesado y el resultado del pesaje- de las interpretaciones previas del tribunal, de su conciencia valorativa, sus preferencias y criterios contingentes, no de parámetros perfectamente racionales y controlables. El pesaje no va a ser más que un «sopesar»a raíz de una «impresión puramente subjetiva [...] que no es susceptible de ser justificada con más razones que razones personales» (GARCÍA AMADO en ATIENZA y GARCÍA AMADO, ibid.: 41).

Se dice del principio de idoneidad de AlEXY que «solo opera y opera bien cuando se ha predecidido entre qué dos derechos o principios tiene lugar el conflicto que en el caso se dirime» (en AlEXY et al., ibid.: 256). Lo que ocurre es que la decisión previa sobre los principios, una cuestión valorativa, ha predeterminado el resultado del juicio de idoneidad. Igualmente discutibles en relación con este principio son la interpretación teleológica y la determinación de la ratio de una regla por parte de los tribunales.

En cuanto al principio de necesidad, en muchas ocasiones sí existen alternativas menos lesivas pero el tribunal simplemente no las tiene en cuenta, de modo que «la regla de necesidad siempre queda al albur de la imaginación» del juzgador (ibid.: 284).

«El juicio de necesidad depende de la imaginación del Tribunal. El de proporcionalidad en sentido estricto de sus preferencias valorativas» (ibid.). Muchas aserciones que el tribunal estima evidentes lo son solo «para los que comparten determinados valores $[\ldots \mathrm{y}]$ en una sociedad libre y pluralista las evidencias compartidas son poquísimas, y en materia política y moral ninguna que no sea puramente formal o procedimental» (ibid:: 287). La ponderación presupone una concepción material de la Constitución marcada por el objetivismo ético, así que ponderar implica un compromiso con dicha concepción.

De todo ello, el autor extrae distintas conclusiones. La ponderación en sí carece de «autonomía» propia, dependiendo su decisión de la tarea argumentativa; los altos tribunales a menudo no realizan más que subsunciones vestidas de ponderaciones pero con un menor rigor argumentativo, de modo que cuando los tribunales dicen que ponderan o bien en realidad no lo hacen o lo hacen «con una mínima solvencia» (GARCÍA AMADO en ATIENZA, 2014a: 255).

Las distinciones entre principios y reglas y entre decisiones de legalidad ordinaria y constitucional se diluyen, de modo que cualquier cuestión de legalidad ordinaria podría ser tratada como un choque entre principios (en ALEXY et al., 2007: 256 y ss.), respondiendo el empleo de la ponderación o de la subsunción a un uso meramente estratégico, para fundamentar un fallo ya predeterminado (GARCÍA AMADO en ATIENZA, ibid.: 256). La ponderación, en pocas palabras, es terreno de la discrecionalidad en sentido amplio o, aun, de la arbitrariedad del juzgador.

Como alternativa, GARCÍA AMADO defiende que la ponderación es susceptible - $\mathrm{y}$ esto es, además, deseable - de ser representada como interpretación-subsunción, procedimiento «más comprensible y [que] aparenta mayor racionalidad» (en AlEXY et al., ibid.: 293). El caso «Titanic» ${ }^{20}$, analizado por AlEXY, permite al autor español

20 El caso «Titanic» (AlEXY et al., 2007: 61 y ss.) es un litigio en que el Tribunal Constitucional alemán dirimía dos conflictos entre el derecho al honor de un militar y la libertad de expresión de una revista satírica: en el primero de los casos, en que la revista se refirió al militar como «geb. Mörder» («nacido asesino»), enten- 
mostrar que una operación ponderativa se puede presentar como una interpretación y posterior subsunción, tratando las normas en conflicto como reglas (ibid.: 292 y ss.). Se presenta a continuación un resumen del razonamiento.

Una norma constitucional consagra la libertad de expresión y otra el derecho al honor. Del contenido en conjunto se puede extraer que está permitida toda expresión que no atente contra el honor de las personas pero las expresiones empleadas en el caso concreto pueden considerarse o no atentados al honor, es decir, se encuentran en la zona de penumbra del enunciado normativo. Aquello que se considere un atentado será calificado de insulto; y lo que no lo sea, de sátira.

Seguidamente, se enumeran las notas propias de la sátira, y si concurren esas notas estaremos ante una sátira, excluyendo el atentado al derecho al honor. Hay que calificar, interpretar, las circunstancias del caso de cara a entender si se trata de sátiras o insultos.

Finalmente habrá que subsumir en una de las dos categorías. Así, en opinión de GARCía AMADO (ibid:: 311), o se atenta o no al derecho al honor, tertium non datur, según encaje el supuesto en una u otra categoría (insulto o sátira). Los elementos del esquema interpretativo-subsuntivo serían los siguientes: 1 . una situación normativa, 2. un enunciado interpretativo general, 3. un enunciado interpretativo particular, 4. un enunciado subsuntivo y 5 . una conclusión normativa; en la operación, desde una racionalidad argumentativa, se sopesan razones interpretativas para admitir que una categoría es subsumible en una categoría más general, en suma, para respaldar (2) y (3) (ibid.: 325).

Propone GARCÍA AMADO «resignarse a que no hay un método racional para dotar de una mínima objetividad a la decisión en estos casos» siendo esta exclusivamente valorativa, de tal modo que el único resultado racional en la ponderación deberá darse sobre la base de no contradicción o adecuación a evidencias científicas, las lógicas o matemáticas y las de perfecto sentido común, así como las semánticas (ibid.: 288). Por otra parte, cuando haya argumentos buenos, aceptables y con un amplio consenso, el tribunal debe aplicar el principio del self-restraint, es decir, el principio de prioridad del legislador (ibid:: 288-289).

Aboga el autor por presentar el razonamiento de forma subsuntiva y no de forma ponderativa, siendo la principal diferencia entre uno y otro esquema la alusión a la justificación subyacente: en el esquema ponderativo se hablará de «atentado contra el derecho al honor», en el subsuntivo, de «insulto» (ibid:: 330). Otro mérito de la subunción es el de delimitar mejor las etapas (ibid:: 317).

Con esto, no niega GARCía AMADO que el razonamiento interpretativo-subsuntivo no sea evidente ni sencillo sino únicamente que «es un proceder menos engañoso que el ponderativo» (ibid.: 291). Al ponderar los tribunales creen recurrir a un método más seguro y objetivo pero «bajo su apariencia de reglas muy elaboradas» encierra una

dió el Tribunal que se encontraba amparada en la libertad de expresión al aparecer en una columna satírica habitual, mientras que en el segundo caso se trataba de una carta abierta dirigida al militar en que se le tachaba de «tullido» y aquí el Tribunal entendió que debía prevalecer el derecho al honor. El propio Tribunal planteó la cuestión en términos de categorías dicotómicas: o se trataba de una sátira (prevalencia de la libertad de expresión) o se trataba de un insulto (prevalencia del derecho al honor). 
mayor arbitrariedad (ibid.: 292). Conviene, en suma, entender el razonamiento como interpretativo-subsuntivo pues uno y otro método «no son expresión de dos modos diferenciados, sino dos maneras de representar un mismo proceder» (ibid.: 329).

\section{CONSIDERACIONES AL HILO DE LO PLANTEADO}

El presente artículo ha pretendido respetar las distintas acepciones de «ponderación», pues este es un término ambiguo que denota cuatro momentos: 1 . como resultado, 2. como proceso, y dentro de este, 2.1. el esquema de ALEXY o su versión jurisprudencial, o bien 2.2. cualquier otra versión del método ponderativo. Estas cuatro acepciones no son exhaustivas pero sí parecen ser las más importantes que surgen toda vez que se habla de ponderación. Identificar cuál de ellas es mencionada en cada caso es condición necesaria para saber sobre qué se discute y en qué media acuerdo.

\subsection{Principios. Todo antecedente se puede cerrar y toda norma es derrotable}

Si al abordar la distinción entre principios y reglas quedó patente que las características de las normas regulativas solo consienten entender tal distinción en términos cuantitativos, la aplicación de las normas diluye aún más la distinción. En lo que atañe a las condiciones de aplicación, la tarea argumentativa y el tipo de valoraciones que sirven para eliminar la vaguedad de una regla no difieren fundamentalmente de aquellos que sirven para cerrar un principio (BAYÓN, 1991a: 360).

Esta «concreción» (GUASTINI, 2008: 130) que parece tan ineludible en el caso de los principios, no sería distinta de la interpretación de reglas vagas. Precisamente, las propuestas de los autores españoles (especialmente las de MORESO y MARTíNEZ ZORRILLA y, de forma menos evidente, las de GARCía AMADO y ATIENZA) son una forma de cerrar las condiciones de aplicación y de equiparar los principios con reglas en sede interpretativa. De este modo, cerrar un principio como requisito para su aplicación no es tarea tan notable y elusiva como a menudo se sostiene y la concreción de su antecedente puede entenderse sencillamente como el resultado de la práctica ponderativa ${ }^{21}$.

Así, en lo que respecta a la derrotabilidad, es frecuente encontrar reglas con condiciones de aplicación abiertas y que pueden ser derrotadas (BAYÓN, ibid:: 362). Es extremadamente difícil pensar en una norma inderrotable. Que las reglas sean un ejemplar de norma notablemente más atrincherado (SCHAUER, ibid.) que los principios es relevante pero no parece avalar más que una distinción gradual entre ambas normas. En pocas palabras, los principios parecen tender más a menudo a la derrotabilidad que las reglas, pero no en esencia, por una estructura inalterable.

Pero no es la derrotabilidad solo un defecto ineludible de las normas, sino un elemento que responde a cuestiones prácticas y teóricas de suma importancia, habida

21 En opinión de GUASTINI «cualquier disposición puede ser convertida en una norma con antecedente abierto y/o derrotable mediante oportunas argucias interpretativas (para volver abierto el antecedente, analogía, para volverlo cerrado, disociaciones, introduciendo distinciones nuevas no tomadas en cuenta por la autoridad normativa, restringiendo el campo de aplicación normativa)» (2008: 199 y ss.) [La traducción es mía]. 
cuenta de la relación de la derrotabilidad con la razón práctica (GARCíA FIGUEROA, ibid.: 200) ${ }^{22}$. Por más que fuese posible añadir elementos al antecedente de una norma hasta el punto de cerrarlo, esto parece difícil y no se corresponde con el conocimiento que solemos manejar, que no suele ser tan exhaustivo (ibid.: 193). Pero, además, la imprevisibilidad es otra razón relevante para la derrotabilidad, que reviste, en último estadio, relevancia axiológica (ibid.: 195). «La axiología discursiva constitucional requiere a su vez una deontología flexible. Los valores constitucionales se expresan mediante normas derrotables. Los principios derrotables son el correlato deontológico de la axiología pluralista que rige nuestras sociedades crecientemente multiculturales» (ibid.: 204).

Los mandatos de optimización alexianos presentarían una «deontología flexible» con el fin de alcanzar una «axiología de ideales», aquella marcada por la «mayor medida posible» (ibid.). La mejor manera en que el legislador puede servir al «politeísmo» valorativo (WEBER) de las constituciones sería por medio de la apertura de los antecedentes de principios heterogéneos.

Como se ha manifestado antes, el reconocimiento de las dimensiones justificativa de las reglas y directiva de los principios debiera resultar todavía más pacífico. Este rasgo estructural, del que partía el artículo al referir la distinción dworkiniana, esclarece las posibilidades de interacción entre las distintas normas prescriptivas.

$\mathrm{Al}$ margen de que se hable del carácter prima facie o no perentorio o meramente contribuyente de un principio, este puede dirimir un supuesto de conflicto de ser subsumible en su antecedente ${ }^{23}$ y de no resultar superado por otra norma: piénsese en un caso hipotético en que un vecino irrumpe sin motivo aparente en una reunión pacífica, impidiendo su continuación; el principio que consagra el derecho de reunión $(\$ 21.1$ de la Constitución española) es la norma directamente aplicable al caso. Si el vecino considerase que la reunión tenía por objeto injuriarle públicamente - lo que afectaría negativamente a su derecho al honor-, entonces el tribunal tendría que entrar a ponderar ambos principios ${ }^{24}$.

Se ha señalado (supra 2) que la dimensión directiva de los principios cobra relevancia precisamente en casos en que cabe dudar acerca de la dimensión justificativa de las reglas. Además, la prioridad de la dimensión justificativa lleva a que los principios deban prevalecer en caso de que la aplicación de una regla no esté justificada en virtud de su razón subyacente o a causa de un vicio de validez material fundado en principios (RÓDENAS, ibid.: 21). Hablar de ponderación de reglas resulta en general inadecuado, pero no parece descabellado pensar que en algunos casos, sin duda

22 Si la derrotabilidad tiene que ver con la normalidad (ALCHOURRÓN, ibid.: 24) es comprensible que las reglas tengan la pretensión de ser inderrotables pues en cuanto guías de conducta tienden a rehuir las situaciones de anormalidad, pero precisamente la comodidad de sostener generalizaciones conlleva el riesgo de que sean derrotadas.

${ }^{23}$ La resolución de un caso mediante la aplicación subsuntiva de un principio, como razón perentoria o definitiva es una posibilidad que plantea PrIETO SANCHÍs en 1997 (en MARTíNEZ ZORRILla, 2007: 74).

${ }^{24}$ Este ejemplo, por otro lado, llama la atención sobre lo que RoDRíGUEZ DE SANTIAGO ha definido «falsos problemas de ponderación» o «ponderación innecesaria por estarse ante un falso conflicto» (2000: 122 y 127). En realidad, no parecen escasas las situaciones en las que se plantea la necesidad de una ponderación o de una subsunción «efímeras», que no van más allá de la comprobación de que no hay tal ponderación o tal subsunción. 
excepcionales, resulte necesario acudir a una comparación de justificaciones subyacentes de reglas ${ }^{25}$.

En el artículo se ha hecho tan solo una mínima alusión a la ponderación con directrices. Más allá de la taxonomía que se maneje, las directrices son distintas de las demás normas regulativas ya solamente por el tratamiento singular que le reserva la doctrina administrativista, que supone una «intervención judicial mínima» (ibid.: 22) como revisión del procedimiento (ATIENZA, 2014: 184). De producirse una genuina ponderación entre principios y directrices sería razonable defender, como sostiene ATIENZA, la prioridad axiológica de los principios en sentido estricto sobre las directrices; con todo, el autor distingue también la situación en que una directriz limita el alcance de un principio - ponderación - o aquella en que un principio limita el campo de acción de una directriz — concreción de directrices- (ATIENZA, 2012: 170). Esta distinción parece razonable pero tal vez sea modelizar en exceso: hay casos en que se hace incierto si una directriz no se comportaría como un principio; el derecho a una vivienda digna ( $\$ 47$ de la Constitución española), la defensa del medio ambiente $(\$ 45.1$ de la Constitución), ambos «principios rectores de la política social y económica» son directrices que bien pudieran ser tratadas como principios o ser susceptibles de subsunción, en ambos casos con un cumplimiento pleno del consecuente, quebrándose la correspondencia entre el nomen y su estructura.

De este modo hay ciertos rasgos (la apertura del antecedente, la derrotabilidad, la dimensión justificativa) que motivan, junto con otros presupuestos, el recurso a la ponderación, pero este procedimiento no es privativo de los principios y no lo es porque las razones que llevan a ponderar pueden ser compartidas por reglas o, en su caso, por directrices.

\subsection{Conflictos y comparaciones entre principios}

Mientras que la mayoría de autores estima que la ponderación se plantea ante casos de conflictos entre principios en concreto (supra 2), en el artículo se ha defendido una concepción del conflicto que lo hace menos dependiente del contexto y determinable ex ante, independientemente de que este tenga lugar.

No podemos entrar aquí en el debate acerca del conflictivismo y su negación ( $v i d$. MARTíNEZ ZORRILLA, ibid.: 63 y ss.), pero parece que el excesivo objetivismo interpretativo que presupone declarar todo conflicto aparente y el carácter de ficción de construcciones tales como los «límites naturales de los derechos» son dos buenos motivos para no suscribir una visión negadora del conflicto.

Sea como fuere, es cierto que con frecuencia y de antiguo se producen colisiones entre intereses subjetivos y que muchas de tales pretensiones individuales tienen, al

25 Tal vez una manifestación de esto sea el fracaso de una regla como razón protegida por considerarse «erróneo el propio juicio de prevalencia que opera como razón subyacente de la regla», de modo que lo derrotado no es la formulación normativa sino la propia justificación subyacente (RóDENAS, 2001: 78). Claro está, si establecemos un paralelismo entre principios y razones para la acción de primer orden, todo conflicto entre estas podría ser concebido, en sentido figurado, como un proceso ponderativo. 
menos actualmente, un reflejo normativo en principios. De este modo, una vez que acordamos que, siquiera de facto, se producen conflictos entre derechos subjetivos y, por ende, entre principios, alegar su inconmensurabilidad no puede llevarnos a vedar cualquier manejo y compromiso entre ellos. La concepción de los derechos como triunfos (DwORKIN, ibid.) hace que ciertos autores vean el empleo de derechos como un tabú, pero esto implica al menos la necesidad de buscar otras soluciones alternativas, por ejemplo, algún tipo de armonización.

Sin contar con que esta objeción pasa por alto una amplia variedad de matices: inconmensurable no quiere decir incomparable. Así, MENDONCA (2003: 67) señala, junto con el establecimiento de un orden cardinal, una clasificación ordinal de los derechos que, menos exigente, solo comprenda relaciones de coincidencia o precedencia condicionadas entre los elementos.

La proporcionalidad sería para muchos (HABERMAS, AleINIKOFF, WebBER) el modo de desvirtuar los derechos fundamentales derrotados. CHAMPEIL-DeSPLATS (2001: 66-68) defiende que el carácter condicionado de la precedencia de los principios preserva la eficacia de los derechos. Por inaplicar un principio a favor de otro en una ocasión no debiéramos preocuparnos por su validez. Si, por el contrario, el principio cede sistemáticamente en toda ponderación, habrá que preguntarse por su validez o por su reiterada vulneración en sede judicial.

Asimismo, el principio de proporcionalidad podría ser concebido como un compromiso racional entre principios de difícil convenio. El carácter condicionado de la precedencia no solo preservaría la eficacia de los derechos, parece que los hace más fácilmente comparables.

\subsection{Sobre los varios modelos ponderativos}

Considero que ATIENZA está en lo cierto cuando dice que la lógica que subyace a la ley de la ponderación alexiana es «una noción elemental de justicia o de racionalidad» (ATIENZA, 2012: 21). Pero si el fin es indiscutible y notable -máxime si se tiene en cuenta que su propósito inicial era la fiscalización de la acción gubernativa al exigir su proporcionalidad—, también se ha dicho «que esta ley, vista con un poco de detalle, no tiene más alcance que una fórmula hueca» (DE LORA, 2000: 363 ). En realidad no es tan poco como una fórmula hueca, pero sí parece un molde por rellenar.

También es razonable la propuesta de ATIENZA de concebir el modelo alexiano como un recurso heurístico; ahora bien, no parece que esto sea suficiente. Los intentos de MORESO y MARTíNEZ ZORRILLA buscan, antes que nada, explicitar esas circunstancias que determinan y justifican la prevalencia de un determinado derecho. Aunque de distinta manera, también lo pretenden GARCÍA AMADO con su propuesta de interpretación y calificación y el propio ATIENZA cuando destaca la índole eminentemente interpretativa de la ponderación. Si la tarea es interpretativa será necesario tener un instrumento racional, sistemático y exhaustivo, no meramente heurístico. Que entre las sentencias que echan mano de la ponderación se encuentren tanto ejemplos razonables como difícilmente defendibles evidencia que el modelo alexiano no es totalmente 
irracional —como muchos críticos pretenden, especialmente HABERMAS (1998: 327 332) - pero tampoco lo suficientemente refinado o concluyente como para eludir lo irrazonable. El modelo no tiene el defecto de abocar a la arbitrariedad pero tiene la tacha de no conjurarla.

MARTíNEZ ZORRILla señala algunas críticas dirigidas generalmente a AlEXY que parecen muy justificadas (ibid.: 171): 1. tener poco en cuenta las circunstancias, 2 . tener poco en cuenta la calificación normativa y 3 . hacer de ello una cuestión aparentemente objetiva.

Por eso, es necesario un modelo que reconozca y delimite debidamente el tratamiento de los elementos en pugna, para que no queden completamente al albur del juzgador. Los modelos de MORESO y MARTíNEZ ZORRILLA presentan una dosis mayor de racionalidad por distintas razones: 1 . hacen explícito el tránsito gradual del análisis, lo que evitaría poder predeterminar fases; 2. los casos paradigmáticos sirven de referente al tribunal a la par que lo constriñen en un marco de lo «admisible», frente a un juez autorreflexivo o condicionado solo por el precedente - piénsese en el análisis de casos de ALEXY - ${ }^{26}$; 3. permiten ver las propiedades determinantes a favor de la precedencia de uno u otro derecho, en atención al contexto, pero en términos de casos genéricos; 4. producen decisiones generalizables a futuros casos.

Algunos méritos son predicables en mayor medida de una propuesta que de otra. Considero que la matriz deliberativa de MARTínez ZORRILlA es la más adecuada pues parece reflejar de forma más jalonada y pormenorizada las distintas etapas.

Surgen algunas dudas, más allá de las que los propios autores reconocen, acerca de algunas incertidumbres de estas dos propuestas: por una parte, aludir a la relevancia de las propiedades es en muchos casos una cuestión problemática, por otra, lo es prever nuevas propiedades. Los modelos tal vez no cierren adecuadamente la posibilidad de actuar ante casos nuevos con propiedades hasta entonces no conocidas o no tenidas en cuenta. El de las descripciones alternativas es, por otro lado, un inconveniente ineludible al que alude MORESO.

Otro riesgo posible es que los casos resueltos de acuerdo con este modelo se encuentren condicionados por anteriores decisiones no tan razonables como cupiera esperar. Bajo el apelativo de casos paradigmáticos se encuentran algunos casos que lo son más por razones pragmáticas que verdaderamente materiales.

Una vez realizada la ponderación, ambos autores defienden que se generalicen las soluciones, resultando aplicables a otros casos con idénticas propiedades relevantes. Este tratamiento coherente de los casos no es más que una exigencia mínima de

26 A varias críticas, especialmente las de HABERMAS sobre lo irracional de formular juicios de injerencia sobre derechos, ALEXY responde precisamente mediante el análisis de ejemplos (ALEXY, 2010: 112), mostrando que en un caso determinado la «no proporcionalidad responde [...] a una relación entre las injerencias recurrentes, reales o hipotéticas» (ibid.: 114). Pero si a su vez que una injerencia sea desproporcionada simplemente quiere decir que no se encuentra justificada en el mayor peso del principio prevalente, parece que no se están ofreciendo criterios adicionales que justifiquen la solución. El valor reconstructivo del análisis alexiano de casos concretos no ofrece parámetros para resolver futuros casos, al no tratarse de genuinos instrumentos críticos con los que evaluar los problemas que se presentan. Que la solución de un caso concreto ponderado se apoye en «un buen argumento» (ibid.: 116) nada nos dice sobre futuras decisiones ni sobre el impacto del método en ellas. 
racionalidad práctica, la generalización, que prescribe que ante la misma clase de situaciones se apliquen respuestas idénticas. Es este el ideal de la subsunción genérica (ALCHOURRÓN, 1991: 303 y ss.), susceptible de distinguishing en el caso de que se presentase una propiedad relevante no tenida en cuenta. Todo ello permite ofrecer respuestas razonables y razonadas.

Conviene detenerse igualmente en la estrategia especificacionista de los derechos de Moreso. Parece que una distinción entre fuerza y alcance puede constituir un tratamiento respetuoso con el contenido de los derechos y con sus condiciones implícitas. Las reglas de precedencia condicionada permiten poder hablar — ya solo en sentido figurado- de cierto alcance y aplicabilidad de los principios; lo que, por otro lado, resulta afín al uso de la lex specialis y la introducción de una cláusula de excepción que propone GUASTINI.

Si unos principios irrestrictos son un ideal que rehuir, en el otro extremo lógico nos encontraríamos con listas largas e inmanejables de situaciones de precedencia condicionada de los principios. Algo semejante supondría introducir la contrapartida principialista del «caballo de Troya» que presagiara BAYÓN para las reglas: principios cerrados, limitados por un sustancioso elenco de reglas en que, quizás, se volvieran difusas ciertas propiedades.

De una manera o de otra, cabe pensar que el Caballo lleva largo tiempo intramuros. El efecto de irradiación de los principios constitucionales -o el «principio de legalidad sustancial» o «de estricta legalidad» en palabras de FERRAJOLI (2002: 354 y ss.) - ha llevado a que ningún sector del ordenamiento esté exento de ellos, manifestando su dimensión directiva. Al mismo tiempo, la pujanza ética de las reglas y de su justificación subyacente ha llevado a que la situación se convierta en un verdadero baile de máscaras; aunque, como se ha dicho, hay distintas formas de restringir esto, por ejemplo, no obviando el carácter condicionado de las precedencias o no cerrando del todo los antecedentes.

En lo que atañe a la propuesta de GARCÍA AMADO, hay que señalar, antes que nada, que su voluntad de equiparar ponderación y subsunción no es del todo original pues los autores examinados, empezando por el propio ALEXY, se esmeran en presentar la ponderación como el «paso previo a la subsunción». La última fase de la ponderación es concebida en todos los modelos como una genuina subsunción, mientras que, para las propuestas universalistas, los casos futuros se van a poder subsumir en los casos genéricos determinados jurisprudencialmente. En lo que los autores disienten es en cómo caracterizar la ponderación al ser, como señala ATIENZA, una tarea eminentemente interpretativa, de modo que un problema fundamentalmente material no puede ser zanjado por vía inferencial.

El principal inconveniente de la propuesta de GARCÍA AMADO es sobredimensionar el calado de la ponderación: el autor no esclarece en qué medida las decisiones interpretativas - las que considera verdaderamente relevantes - son tan radicalmente distintas en un modelo ponderativo y en uno subsuntivo como para justificar el empleo del segundo y el rechazo total del primero. Por otro lado, este planteamiento parte de un presupuesto por fundamentar, la equiparación del autor entre interpretar, en cuanto atribución de significado a un enunciado, y subsumir — unos hechos en tales 
enunciados-, como si a contrario en la ponderación no se interpretase sino que simplemente se valorase.

GARCÍA AMADO parte de una premisa perfectamente defendible - la mayor claridad estructural de la subsunción respecto a la ponderación alexiana- pero llega a un punto bastante discutible: parece que ponderar nos comprometiese con la visión ética de la Constitución a la par que nos desvinculase de la semántica.

No parece justificada la crítica de GARCÍA AmADO de que el modelo de AlEXY conduce por sí solo a la «discrecionalidad fuerte o aun a la arbitrariedad» pero sí es cierto que no se propone evitarla seriamente. Como expresa ATIENZA, se dice que «la ponderación no es un procedimiento arbitrario [...] pero supone dosis de discrecionalidad, de libertad, mayores que la subsunción y eso justifica que la ponderación de los tribunales tenga que ser mucho más limitada que la del legislador (este último solo tiene el límite de la Constitución)» (en ATIENZA y GARCía AmADO, ibid.: 31).

En un contexto de tales dosis de discrecionalidad, parece deseable valerse de un modelo lo más racional y sistemático posible, donde el juzgador delimite debidamente las propiedades relevantes del caso y quede constreñido por un marco de lo «admisible», lo cual debería llevarnos a sustituir el modelo de ALEXY por el de MARTínEZ ZORRILLA o el de MORESO.

\section{CONCLUSIONES}

Tradicionalmente se han sugerido distintos rasgos como propios de los principios por oposición a las reglas. Este artículo ha examinado tres: la apertura de las condiciones de aplicación, la tendencia a la derrotabilidad y la dimensión justificativa. Estos rasgos son especialmente elocuentes para comprender la ponderación: la apertura del antecedente del principio lleva a que haya que determinar las situaciones en que resulta aplicable y aquellas en que es derrotado. Precisamente la ponderación es el supuesto más habitual en que los principios son superados por otras consideraciones. La dimensión justificativa parece ser determinante en cuanto al resultado de las ponderaciones.

Estos tres rasgos también están presentes en las reglas aunque de forma mucho menos marcada. Tal distinción, de hecho, no consiente más que una oposición de grado entre normas regulativas, sin que haya diferencias estructurales que resulten ineliminables o exclusivas de una de las categorías.

La colisión de, al menos, dos principios no resuelta por una regla obliga a ponderar, sin resultar aplicables los criterios de resolución de conflictos entre reglas salvo, de forma impropia, el criterio de especialidad y la introducción de una cláusula de excepción.

Pero tener que ponderar no obliga a recurrir al método que propone ALEXY, tanto más cuando ha quedado patente que no resulta todo lo idóneo que debiera para conjurar la arbitrariedad, en especial, por no aclarar la importancia que merecen las circunstancias de un caso y los riesgos de la interpretación.

Las críticas de ATIENZA, además de aquellas de índole clasificatoria, van encaminadas a que el modelo alexiano se reafirme como método heurístico, abandonando 
las pretensiones de método «sistematizador» que hubiera podido tener. MORESO dirige a ALEXY tres críticas principales: la asunción de una escala abstracta del peso de derechos, la determinación concreta de su afectación y la atención insuficiente a las circunstancias del caso. Para suplir tales inconvenientes, MORESO elabora un modelo que correlaciona propiedades y soluciones de los distintos casos, sirviéndose del aparato conceptual de análisis de sistemas normativos de ALCHOURRÓN y BULYGIN. La matriz deliberativa de MARTínEZ ZORRILla se halla próxima a esta propuesta. A partir del esquema coherentista que preconiza HuRLEY en el ámbito moral, el autor elabora una matriz que guía la resolución de casos según se den ciertas propiedades relevantes. Tanto para MORESO como para MARTÍNEZ ZORRILLA los casos paradigmáticos resultan cruciales para delimitar la esfera de lo «admisible» racionalmente. Por último, GARCÍA AMADO sostiene que principios y reglas y subsunción y ponderación son equivalentes, y la preferencia valorativa es la que lleva a los tribunales a escoger un método u otro. El autor defiende que tales operaciones sean concebidas en términos subsuntivos.

En este artículo he considerado las propuestas de MORESO y MARTÍNEZ ZORRILLA las más idóneas para encarar de forma racional y sistemática la tarea ponderativa.

\section{BIBLIOGRAFÍA}

Aguiló, J., 2000: Teoría general de las fuentes del derecho (y del orden jurídico), Barcelona: Ariel.

Alchourrón, C., 1991: Análisis lógico y Derecho, Madrid: Centro de Estudios Constitucionales.

- 2000: «Sobre Derecho y Lógica», Isonomía, 13: 11-33.

ALCHOURRÓN, C., y Bulygin, E., 1987: Introducción a la metodología de las ciencias sociales, Buenos Aires: Astrea.

ALEXY, R., 1993: Teoría de los derechos fundamentales, E. GARZÓN VALDÉs (trad.), Madrid: Centro de Estudios Constitucionales.

— 2002: «Epílogo a la teoría de los derechos fundamentales», Revista Española de Derecho Constitucional, 66: 13-64.

— 2010: «Derechos fundamentales, ponderación y racionalidad» en L. GARCíA JARAMILLO y M. CARBONELl (eds.), El canon neoconstitucional, Madrid: Trotta.

Alexy, R.; García Amado, J. A.; García Figueroa, A., y Moreso, J. J., et al., 2007: Derechos sociales y ponderación, R. GARCía MANRIQUE (ed.), Madrid: Fundación Coloquio Jurídico Europeo.

AtiEnZA, M., 2001: El sentido del Derecho, Barcelona: Ariel.

- 2012: El Derecho como argumentación, Barcelona: Ariel.

- 2014a: Curso de argumentación jurídica, Madrid: Trotta.

- 2014b: «Ponderación y sentido común jurídico», en http://dfddip.ua.es/es/documentos/ ponderacion-y-sentido-comun.pdf?noCache $=1415615082659$.

AtienZA, M., y GARCÍA AmAdO, J. A., 2012: Un debate sobre la ponderación, Lima: Palestra.

ATIENZA, M., y Ruiz MANERO, J., 2000: Ilícitos atípicos, Madrid: Trotta.

- 2004: Las piezas del Derecho, Barcelona: Ariel. 
Ávila, H., 2011: Teoría de los principios, Madrid: Marcial Pons.

BAYÓN, J. C., 1991a: La normatividad del derecho: deber jurídico y razones para la acción, Madrid: Centro de Estudios Constitucionales.

BAYÓN, J. C., 1991b: «Razones y reglas: sobre el concepto de “razón excluyente” de Raz», Doxa, 10: 25-66.

Bernal Pulido, C., 2003: «Estructura y límites de la ponderación», Doxa, 26: 225-238.

ChAmPEIL-DesPlats, V., 2001: Les principes fondamentaux reconnus par les lois de la République, Paris: Éditions Economica.

De LoRA, P., 2000: «Tras el rastro de la ponderación», Revista Española de Derecho Constitucional, 60: 359-369.

DwORKIn, R., 1978: Taking Rights Seriously, Cambridge: Harvard University Press.

FERRAJOLI, L., 2002: «Lo stato di diritto fra passato e futuro», en P. Costa y D. ZOLO (eds.), Lo stato di diritto: storia, teoria, critica, Milano: Feltrinelli.

García FigueroA, A., 1998: Principios y positivismo jurídico: el no positivismo principialista en las teorias de Ronald Dworkin y Robert Alexy, Madrid: Centro de Estudios Políticos y Constitucionales.

- 2010: «Neoconstitucionalismo, derrotabilidad y razón práctica» en M. CARBONELL y L. GaRCía JaRAmillo (eds.), El canon neoconstitucional, Madrid: Trotta, 185-206.

GuASTINI, R., 1996: «Diritto mite, diritto incerto», Materiali per una storia della cultura giuridica, 2: 512-525.

- 1999: Distinguiendo. Estudios de teoría y metateoría del derecho, Barcelona: Gedisa.

- 2008: Nuovi Studi sull'Interpretazione, Roma: Aracne.

HABERMAS, J., 1998: Facticidad y validez. Sobre el derecho y el Estado democrático de derecho en términos de teoría del discurso, Madrid: Trotta.

MARTÍNEZ ZorRILla, D., 2007: Conflictos constitucionales, ponderación e indeterminación normativa, Madrid: Marcial Pons.

- 2010: Metodología jurídica y argumentación, Madrid: Marcial Pons.

Mendonca, D., 2003: Los derechos en juego. Conflictos y balance de derechos, Madrid: Tecnos.

- (ed.), 2011: Compendio de una teoría analítica del derecho. Alchourrón y Bulygin en sus textos, Madrid: Marcial Pons.

MONTEALEgRe, E. (ed.), 2014: La ponderación en el Derecho: evolución de una teoría, aspectos críticos y ámbitos de aplicación en el derecho alemán, Bogotá: Universidad Externado de Colombia.

MoReSO, J. J., 2002: «Guastini sobre la ponderación», Isonomía, 17, 227-249.

— 2003: «Conflictos entre principios constitucionales», en M. CARBOnELL (ed.), Neoconstitucionalismo(s), Madrid: Trotta, 99-121.

- 2005: «Los conflictos entre derechos», en M. CARBOnELl y P. SALAZAR (eds.), Garantismo. Estudios sobre el pensamiento jurídico de Luigi Ferrajoli, Madrid: Trotta, 159-170.

PRIETO SANCHÍs, L., 1992: Sobre principios y normas, Madrid: Centro de Estudios Constitucionales.

- 2014: Neoconstitucionalismo, Principios y Ponderación, México: UBIJUS.

RAZ, J., 1991: Razón práctica y normas, Madrid: Centro de Estudios Constitucionales.

REgan, D. H.,1989: «Authority and Value: Reflections on Raz's Morality of Freedom», Southern Carolina Law Review, 62: 995-1095.

RÓDENAS, Á., 2001: «En la penumbra: indeterminación, derrotabilidad y aplicación judicial de normas», Doxa, 24: 63-83. 
— 2015: «Normas regulativas: principios y reglas», en D. GONZÁLEZ LAGIER, Conceptos básicos del Derecho, Madrid: Marcial Pons.

Rodríguez De Santiago, J. M., 2000: La ponderación de bienes e intereses en el Derecho administrativo, Marcial Pons: Madrid.

SCHAUER, F., 2004: Las reglas del juego, Madrid: Marcial Pons.

Von Wright, G. H., 1989: Norma e azione: Un'analisi logica, Bologna: il Mulino. 


\section{ENTREVISTA}





\title{
ENTREVISTA A FRANÇOIS OST INTERVIEW TO FRANÇOIS OST
}

\author{
Manuel Atienza* \\ Universidad de Alicante \\ manuel.atienza@ua.es
}

\begin{abstract}
Manuel Atienza: Las entrevistas en Doxa suelen empezar con algunas cuestiones de carácter biográfico. Me gustarí, por ello, que nos contaras algo sobre tu trayectoria intelectual. ¿Por qué te interesó el Derecho y la filosofía del Derecho? ¿Qué autores, libros, etc., influyeron en ti en la época de formación? ¿A quiénes consideras en definitiva como tus maestros?
\end{abstract}

Francçois Ost: Entré en la Universidad (en las Facultés Saint-Louis, en Bruselas) en septiembre de 1970, o sea, al día siguiente del mayo del 68. Soplaba entonces un viento de libertad del que hoy no se tiene idea; afectaba tanto a los contenidos de las enseñanzas como a las estructuras de la universidad. Se enseñaba a MARCUSE, a FrEUD, a BARTHES, a FOUCAULT, a MORIN; los estudiantes eran invitados a participar en la gestión de la universidad —-desde el año siguiente yo fui elegido presidente de los estudiantes-.

Comencé simultáneamente una doble formación, en Derecho y en filosofía; se animaba a este tipo de combinación y es una tradición que se ha mantenido en Bélgica. Después de mis años de licenciatura, cuando ya me habían contratado como ayudante en Saint-Louis, hice también dos años de licenciatura en Derecho económico en la Universidad Libre de Bruselas a fin de completar mi formación en un plano más práctico.

Reconozco a dos maestros, dos seres excepcionales que tuve la suerte de encontrar muy pronto: Paul Ricoeur en filosofía, y François RigauX en Derecho. Resultó que en 1970 Paul Ricoeur dictaba cursos en la Universidad de Lovaina (después de que le tiraran una papelera a la cabeza durante las revueltas estudiantiles en Nanterre). Era un privilegio excepcional seguir las enseñanzas de semejante maestro, uno de esos profesores que te hacen sentir inmediatamente más inteligente de lo que eres, sin duda, porque te comunican el gusto por la investigación. El curso era sobre hermenéutica, pero incorporaba también un diálogo riguroso y generoso con otros paradigmas y otras disciplinas: se entrecruzaba con el psicoanálisis, la lingüística anglo-americana, la teoría de la acción, la historia literaria, la teología...

François RigauX nos enseñaba Derecho internacional privado, que es, sin duda, la rama jurídica más compleja, puesto que se sitúa de alguna manera en un segundo grado en relación con las normas materiales, al tener que decidir sobre los conflictos de leyes y de jurisdicciones. Pero RigauX era sobre todo un profesor «comprometido»,

* Traducción de Manuel AtienZa. 
muy en punta particularmente en el combate en favor de los inmigrantes y de los demandantes de asilo. Uno de los raros juristas, con Mireille DELMAS-MARTY en Francia, que reivindicaban una cierta utopía jurídica. Creía en el valor prospectivo del Derecho en el que él veía un instrumento irremplazable de cambio social. Al final de su carrera, presidió varias sesiones del Tribunal internacional para el derecho de los pueblos (tribunal fundado por el senador italiano independiente, Lelio BASSO).

Estas dos referencias traducen bien el espíritu en el que yo encuadraba esa doble formación: el Derecho como gramática de comprensión de las relaciones sociales y como utensilio normativo más bien que como iniciación a una práctica profesional, y la filosofía, menos como disciplina en sí misma que como espacio de interrogación reflexiva y crítica sobre todos los otros discursos y todas las prácticas. En la encrucijada de las dos perspectivas encontraba a la filosofía del Derecho, campo que me atraía y me encantaba como una suerte de El Dorado que quería descubrir.

Por lo demás, en Saint-Louis seguía los cursos de Michel van DE KERCHOVE, ocho años mayor que yo, con el que más tarde iba a trabajar mucho, y en particular a escribir seis libros. Seguía igualmente algunos seminarios organizados en la Universidad Libre de Bruselas por Chaïm PERELMAN, cuya teoría de la argumentación nos seducía, pero quizás sobre todo el hecho de que hacía participar en esos seminarios a abogados y magistrados «esclarecidos», dispuestos a liberarse de una aproximación positivista, formalista y utilitarista.

Después de mi Memoria en filosofía consagrada a la bermenéutica jurídica (más exactamente, un estudio del argumento sacado del «postulado de la racionalidad del legislador» -influencia directa de los estudios de N. BOBBIO y J. WROBLEWSKI-), me lancé a la redacción de la tesis de doctorado: una tesis a cuatro manos (hecho sin precedentes en Bélgica) llevada a cabo con mi colega Jacques LENOBLE bajo la dirección de François Rigaux. Apareció en 1980 con el título de Droit, mythe et raison. Essai sur la dérive mytho-logique de la rationalité juridique. Esta tesis está influida notablemente por los trabajos de Pierre LEGENDRE, en la intersección de la historia del pensamiento jurídico y el psicoanálisis.

En el transcurso de mi carrera, me parece que me he mantenido fiel a esas opciones de base. He leído mucho, por supuesto, pero sin pretender verdaderamente vincularme a una escuela de maestros con los que pensar. Más bien me reconozco en un paradigma crítico e interdisciplinar, nutrido por numerosos compañeros de camino. $\mathrm{Mi}$ práctica de investigador es dialógica más bien que analítica, sobre un fondo de filosofía dialéctica: dialéctica de la teoría de la práctica, pero también de las aproximaciones disciplinares y de las lenguas. Además de los autores de teoría y filosofía del Derecho, y de los grandes clásicos, desde luego, vuelvo regularmente a H. ARENDT, C. CASTORiadis, J. Habermas, J. Derrida, P. Ricoeur, en filosofía; P. Bourdieu, L. Boltanski, B. Latour, en sociología; Th. Khun, G. BAChElard y K. PopPer, en epistemología; U. ECO en semiótica... En el fondo, lo que me interesa y explica mi dinámica de investigación son más bien las cuestiones a tratar, poniendo en juego, en cada caso, autores y puntos de vista variados, más bien que defender la integridad de los dogmas de una Escuela o profundizar en el pensamiento de una familia de autores.

M. A.: Me gustaría que nos trazaras abora un «mapa» del territorio que bas explorado durante estas últimas décadas y que nos señales también cómo ba sido tu recorrido por 
todos esos campos. ¿Cabría hablar de diversas etapas con algún «cambio de sentido» más o menos brusco, o se ha tratado más bien de un itinerario largo pero presidido siempre por un mismo leit motiv? ¿Cuál habría sido? Y, en todo caso, ¿cuáles han sido tus trabajos más significativos? ¿Y cuáles consideras como tus principales contribuciones a la filosofía del Derecho?

F. O.: La respuesta es delicada, pues se trata de comentar una veintena de obras a lo largo de un periodo de cuarenta años. En lo que respecta al ensayo de «cartografía», responderé en términos de círculos concéntricos; por lo que se refiere a la cuestión del hilo conductor y de las evoluciones, me serviré del concepto de «paradigma» de Th. KuHN; en fin, arriesgaré algunas consideraciones de auto-evaluación.

Mis trabajos, individuales o colectivos, de naturaleza a veces muy diversa, pueden ser reagrupados en círculos concéntricos, sin atribuir un juicio de valor o de preferencia a la situación central o periférica; he efectuado, por lo demás, muchas idas y venidas de un círculo al otro.

El círculo más amplio comprende trabajos en los que el Derecho no es más que la ocasión, pues se trata en cada caso de ponerlo en relación con otra temática que presenta un interés intrínseco. Así ocurre con mis escritos relativos a la lengua y a la traducción: Traduire. Défense et illustration du multilinguisme (FAYARD, 2009), o también Furetière. La democratisation de la langue (Michalon, 2008), con una aplicación jurídica: Le droit comme traduction (Presses de L'Université de Laval, 2009). Pertenece también a este primer círculo mi reflexión sobre las relaciones hombre-naturaleza, y la responsabilidad intergeneracional (La nature hors la loi, La Découverte, 2. ${ }^{a}$ ed., 2003). Bien entendido, tenía en la memoria el Derecho (en el mismo momento creaba un Centro de estudios de Derecho del medio ambiente, el CEDRE), pero el objetivo tenía un alcance más general. También responde (relève) a este primer círculo mi interés por la literatura, con lazos más o menos fuertes con el Derecho según los autores estudiados. A partir de la obra de base, Raconter la loi. Aux sources de l'imaginaire juridique (Odile JАСOB, 2004), han seguido otros libros: Sade et la loi (Odile JACOB, 2005), Shakespeare, la comédie de la loi (MiCHALON, 2012), así como estudios consagrados a diversos autores tales como SWIFT o BALZAC, por ejemplo. El trabajo sobre SADE pone frente a la cuestión antropológica de la perversión. Añado que nos encontraremos con algunos de estos trabajos en el círculo más central.

El segundo círculo reagrupa trabajos que calificaría de «teoría del Derecho aplicada»; consagrados a aspectos más precisos del discurso o de la práctica jurídicos, ponen en práctica hipótesis teóricas desarrolladas en el tercer círculo. Sitúo en esta categoría Bonnes moeurs, discours pénal et rationalité juridique (primer libro escrito con M. vAN DE KERCHOve, Presses de L'USL-B, 1982) que realiza un estudio muy interdisciplinar de jurisprudencia relativa a algunos artículos del Código Penal. Luego, Entre la lettre et l'esprit. Les directives d'interprétation en droit (también con M. VAN DE KERCHOVE, Bruylant, 1989): más práctica, la obra ha tenido mucho eco en el mundo de los prácticos. También pertenece a esta categoría mi obra Entre droit et non-droit. Essai sur les fonctions qu'exerce la notion d'intérêt en droit privé (Bruylant, 1990), así como

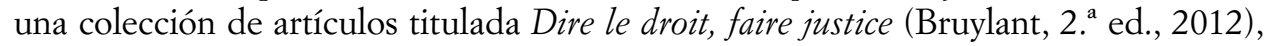
un conjunto de estudios relativos al juez, entre los que se encuentra Jupiter, Hercule, Hermès. Trois modèles de juge, traducido en su momento para Doxa. 
El tercer círculo, el más amplio, concierne a la teoría general del Derecho propiamente dicha: un conjunto de obras escritas con M. VAN DE KERCHOVE entre 1987 y 2002. Para presentarlas brevemente, hago una distinción entre sus temas, su evolución en función del contexto y, en fin, su filosofía de base. En lo esencial, los temas se refieren a la epistemología de las ciencias del Derecho, la definición de Derecho, el razonamiento jurídico, la validez de los actos y las normas jurídicas y, finalmente, las relaciones entre sistemas jurídicos. Aunque los temas permanezcan constantes, la escritura se modifica en función de las evoluciones del contexto social global. Distingo a este respecto tres etapas. Primeramente, un conjunto de tres libros (Jalons pour une théorie critique du droit, 1987, Presses de L'USL-B; Le système juridique entre ordre et désordre, PUF, 1988; Le droit ou les paradoxes du jeu, PUF, 1992) que proponen una teoría del Derecho «impura» (interdisciplinar) y dialéctica en relación con el pluralismo de las fuentes de poder y de las normas, el establecimiento del Estado social y el aumento de poder de las ciencias sociales. Luego, diez años más tarde, aparece Pyramide ou réseau? Pour une théorie dialectique du droit (Presses de L'USL-B, 2002). Se trata esta vez de estudiar el cambio de paradigma, progresivo y caótico, del modelo estatista, legalista, positivista («pirámide») hacia otro modelo («red»), sobre el fondo de grandes transformaciones sociales: globalización, concurrencia del Estado y de múltiples poderes privados y públicos, aumento del poder de los jueces, contractualización y desformalización del Derecho, etc. En fin, recientemente he publicado, como único autor, una obra titulada A quoi sert le droit? Usages, fonctions, finalités (Bruylant, 2016). Se trata esta vez, en un contexto de radicalización de todas esas evoluciones, de una interrogación muy profunda (quiero decir, muy radical también ella) sobre la aportación del Derecho a la sociedad: ¿qué ocurriría si estuviéramos privados del Derecho o si este se desnaturalizara muy ampliamente?

Por lo que se refiere al método y a la filosofía de base que se afirman en estos trabajos, y se reafirman progresivamente, hablaré un poco después, en relación con la noción de «paradigma».

Esta interrogación sobre las funciones del Derecho nos conduce al último círculo, que no es, como en DANTE, el círculo del infierno, sino el más profundo, el de la filosofía del Derecho y, en particular, el de las cuestiones axiológicas. Incluyo en esta categoría una obra sobre la dialéctica de la autonomía y la heteronomía como fundamento del Derecho: Du Sinä̈ au Champ-de-Mars. L'autre et le même au fondement du droit (Ed. Lessius, 1999). Igualmente se encuentra ahí un libro que me ha supuesto muchos esfuerzos y que trata de la cuestión esencial de la relación que el Derecho entabla con el tiempo: Le temps du droit (Odile JACOB, 1999). En ciertos aspectos, mi último libro $A$ quoi sert le droit? supone también una verdadera filosofía del Derecho, dado que me ha llevado a pronunciarme sobre sus finalidades y también sus condiciones de posibilidad antropológicas. Finalmente, mis trabajos en Derecho y literatura pueden también inscribirse en este último círculo, puesto que lo que ahí entra en juego son las cuestiones más radicales relativas a la legitimidad, al poder, a la venganza, a la justicia... Así, el centro termina por unirse a la periferia en un movimiento de fecundación recíproca.

¿Muestra la sucesión de estas obras los azares de la vida, o una programación voluntaria? Ni lo uno ni lo otro, sin duda. Hay una parte no despreciable de contin- 
gencia, pero también, a la inversa, de profundización progresiva de algunas intuiciones y convicciones de partida. Aunque siempre resulte peligroso trata de construir una suerte de coherencia ex post, me arriesgo a evocar los elementos del paradigma que proporciona al menos un «aire de familia» a estas diferentes obras.

Recuerdo que para KHUN un paradigma representa, para una comunidad científica dada, un cuadro teórico común durante un periodo de «ciencia normal» hasta un momento en el que las «anomalías» provocan una «crisis de paradigma», generadora en el mejor de los casos de una «revolución científica». Ese paradigma, que es como el «mapa» y la «brújula» de la investigación, se compone a su juicio de cuatro elementos: leyes de base, una visión del mundo subyacente, valores compartidos y ejemplos particularmente iluminadores. Este vocabulario siempre me ha parecido muy pertinente para reflexionar sobre mi práctica de investigador. Yo me reconocía en él como en una forma de lucha contra un paradigma positivista, pero también, más ampliamente, un paradigma monista (o binario, lo que viene a ser lo mismo) fundado sobre una aspiración a la simplicidad, la pureza, el carácter lineal, la certeza analítica. Desde el comienzo, con la creación del Séminaire y de la Revue interdisciplinaire d'études juridiques, he puesto en marcha, en todos mis trabajos, un método de análisis interdisciplinar. En cuanto al fondo de las tesis defendidas - se corresponde entonces con la «visión del mundo subyacente» de la que hablaba KHUN — casi siempre es la dialéctica lo que me las ha sugerido. Una dialéctica que se muestra por ejemplo en los subtítulos de mis obras, en sus referencias a las «paradojas» (Les paradoxes du jeu), o incluso en el interés por el «entre dos» («entre ordre et désordre», «entre la lettre et l'esprit»). Esta filosofía enseña a relativizar tanto las identidades como las diferencias (que siempre tienen tendencia a absolutizarse), de acuerdo con el lema de que «lo uno no va sin lo otro». En esas condiciones, el tercero, lejos de quedar excluido, es precisamente lo que emerge de la interacción de las entidades en presencia y merece ser especialmente estudiado. Inútil decir que ese tercero es de una importancia extrema para el estudio de lo jurídico. Subrayo también hasta qué punto la dialéctica es portadora de valores — se toca aquí el aspecto axiológico de los paradigmas, igualmente subrayado por KHUN: al relativizar las diferencias entre «ellos» y «nosotros», incita al diálogo y hace tomar conciencia de la alteridad que trabaja tanto cada individuo como cada nación-.

¿Una auto-evaluación referida a lo que considero como mis contribuciones principales a la filosofía del Derecho? El ejercicio es todavía más delicado; son, en efecto, los lectores, los colegas, los doctorandos, quienes aseguran la recepción de una obra y la audiencia de una obra. Como los mensajes echados al mar, siguen corrientes a menudo imprevisibles, en el tiempo y en el espacio. Pasan notablemente por la cuestión de las traducciones, que constituyen siempre un inmenso privilegio para el autor.

No quiero, sin embargo, hurtarme al ejercicio y arriesgo por tanto algunos elementos de respuesta; comienzo por hacer notar que la presentación de los círculos concéntricos hace ya aparecer, para cada uno de ellos, una obra dominante, que ha trazado la vía a las otras. Luego, imagino (y espero) que si estas diferentes obras pueden aportar algo a la reflexión colectiva sobre el Derecho, lo es en razón de dos características de mi trabajo: de un lado, una voluntad constante de tejer los lazos entre el Derecho y su contexto humano y social, de cara a «desenclavar» el estudio del Derecho; de otro 
lado, por lo que se refiere al análisis del Derecho mismo, una preocupación por la síntesis y la coherencia entre las diferentes temáticas abordadas, para llegar a proponer una verdadera «teoría general» del Derecho.

Siempre me ha parecido desolador que el estudio del Derecho resulte ampliamente ajeno tanto a los especialistas en ciencias humanas y sociales como a los filósofos, sin duda ahuyentados por una tecnicidad del Derecho, cuidadosamente cultivada por los propios juristas. Me he dedicado por ello, sobre todo en los trabajos del «primer círculo», a trazar puentes entre esos dominios: el Derecho es un inestimable objeto de conocimiento de lo social (cfr. el último libro de J. Commaille: A quoi nous sert le droit?, Gallimard, 2016), mientras que, a la inversa, el análisis del Derecho tiene todo que ganar de una perspectiva exterior (aunque sea desde el simple plano lingüístico, ¿qué sería el Derecho sin el lenguaje que le sirve de expresión y que a su vez modula?). Cuando, por ejemplo, doy una conferencia sobre el tiempo del Derecho a magistrados, usando análisis filosóficos exigentes, y, a su vez, esos profesionales del Derecho me dicen que esos análisis aclaran verdaderamente su práctica, a veces incluso dan sentido a su trabajo, entonces es cuando considero haber hecho mi trabajo.

De manera que siempre me ha parecido importante proponer una teoría del Derecho coherente a través del conjunto de las temáticas abordadas. Más que el refinamiento analítico extremo de tal o cual problemática, es esta coherencia de conjunto lo que me parece esencial: entre una teoría de las fuentes, una teoría del razonamiento y una teoría de la validez, por ejemplo. Desde este punto de vista, el hilo rojo dialéctico se revela (s'avere) a mis ojos de un inestimable valor.

M. A.: Tu larga y matizada contestación me sugieren dos peticiones de aclaración que, me parece, interesarán a los lectores de Doxa. Se trata de que nos expliques con un mayor detalle dos nociones que son básicas en tu concepción del Derecho y en tu trabajo de reflexión sobre el Derecho: las nociones de positivismo jurídico y de dialéctica.

Para precisarlo un poco más. Dices que tu práctica de investigador podría verse como una forma de lucha contra el paradigma positivista. ¿Pero qué entiendes exactamente por «paradigma positivista»? ¿Solamente una manera «no interdisciplinar» de aproximarse al Derecho? En particular, si uno piensa en lo que suelen ser consideradas como tesis básicas del positivismo jurídico - la de las fuentes sociales del Derecho y la de la separación entre el Derecho y la moral-, no parece que tú estés en contra de ninguna de las dos. ¿Podrias darnos entonces algún detalle más sobre qué entiendes por «paradigma no positivista»? ¿Cuál sería alguno de esos «ejemplos particularmente esclarecedores» que caracterizan el nuevo paradigma que defiendes?

$Y$, en relación con la dialéctica, ¿cómo bay que entender esa noción, puesto que se babla de «dialéctica» en sentidos tan distintos? Un autor español señalaba hace algunas décadas que, en el contexto de la filosofía escolástica, cuando no se sabia cómo resolver un problema se apelaba a la analogía, mientras que en el paradigma marxista, el recurso a la analogía había sido sustituido por la dialéctica. Sé que no es ese tu caso, pero ¿cómo debemos entender exactamente la importancia que atribuyes a la dialéctica en tu obra?

F. O.: Permíteme que invierta las cuestiones y que responda en primer lugar a propósito de la dialéctica. Mi referencia aquí no es ni HEgel ni MARX, sino MERLEAUPONTY: «Una dialéctica abierta, sin síntesis». No se trata pues de aplicar una receta 
mecánica del género: «Tesis, antítesis, síntesis»; aun menos de aspirar a una coincidencia final entre lo real y lo racional, o a un saber absoluto o al conocimiento de pretendidas leyes científicas de la historia. La «dialéctica sin síntesis» es lo contrario del pensamiento mágico que pretende tener respuesta para todo; no es la vis dialéctica, que, como las fórmulas dialécticas de los médicos de MoLIÈRE, cubren las dificultades con un velo de humo. Relativizando las identidades y haciendo jugar las brechas entre ellas más bien que absolutizando sus diferencias, este pensamiento desarrolla al contrario un formidable potencial heurístico. Invita a ahondar sin cesar en las posiciones en presencia, a escrutar sus interacciones, a descubrir las propiedades emergentes que resultan de esas interacciones, más bien que a quedarse satisfecho con respuestas monológicas. Es un pensamiento vinculado al devenir, sensible a los estados intermedios, y que no retrocede ante las paradojas. Es justamente lo contrario de un pensamiento dogmático o perezoso. Tampoco se trata del prejuicio de un prudente justo medio entre tesis opuestas, de manera de «no quemarse» nunca y de tener siempre razón; es, al contrario, un pensamiento que trabaja en el punto de tensión máxima entre dos posiciones, el paso improbable (paso del noroeste, escribe bellamente M. SERRES) donde se deja entender algo de la verdad que cada uno de los dos intenta decir a su manera. Ese algo no es un deus ex machina que resolvería como por milagro la tensión y la controversia, sino la propiedad emergente, el tercero que se pretendía excluir y que ahora permite esclarecer esta tensión en el plano intelectual, y tratarla (lo que no quiere decir suprimirla) en el plano práctico.

Doy algunos ejemplos de ello en mis trabajos. En epistemología elijo «el punto de vista externo hermenéutico», o «punto de vista externo informado por el punto de vista interno» ante la propuesta de HART entre un «punto de vista interno», demasiado próximo a su objeto para ser científico (objetivante) y un «punto de vista externo radical» que devalúa la especificidad de su objeto (en lo que nos concierne: la normatividad del Derecho).

En mis trabajos relativos a la validez de las normas y de los actos jurídicos, intento mostrar no solo hasta qué punto son tributarios de tres condiciones (legalidad, efectividad sociológica, legitimidad ética), sino, de manera verdaderamente dialéctica, hasta qué punto, en la realidad de los juicios de validez planteados por los actores, cada uno de estos tres polos integra al menos algo de los otros dos. Los instrumentos contemporáneos del control de legalidad que son los principios de proporcionalidad y de subsidiaridad constituyen una ilustración, entre otras.

A propósito del razonamiento jurídico, los numerosos análisis llevados a cabo con Michel VAN DE KERCHOVE relativos a la interpretación de la ley por el juez, presentan esta operación como un «juego» que se juega entre convención e invención, entre coerción y libertad. Esta aproximación dialéctica reenvía a dos tesis opuestas: la que intenta anular el poder del juez, y a la inversa, la que le atribuye un poder casi ilimitado de reconstrucción de la ley. Algunas variantes francesas del así llamado «realismo jurídico» deben ser criticadas a este respecto: es falso, y demasiado fácil, sostener que el juez hace cualquier cosa del texto de la ley. Las cosas interesantes comienzan cuando, siendo consciente del amplio margen de maniobra de que dispone el intérprete, se estudia cómo acepta en definitiva otras «reglas del juego», reglas no escritas sin duda, pero no menos vinculantes. 
En mis trabajos sobre la naturaleza, después de haber opuesto los dos paradigmas que dominan el debate, un paradigma antropocéntrico (que conduce a la crisis ecológica actual al negar nuestros lazos con la naturaleza, reduciéndola a un simple objeto) y, a la inversa, un paradigma biocéntrico (la deep ecology que pretende no hacer diferencias entre el hombre y la naturaleza — una naturaleza que deviene sujeto-), yo desarrollo una aproximación dialéctica, que llamo el «proyecto» para el medio. Muestra lo que hacemos a la naturaleza y, a su vez, lo que ella hace de nosotros; extraigo de ello una forma de responsabilidad con respecto a ese medio, al que nosotros pertenecemos, sin por ello identificarnos con él.

En mi trabajo sobre las relaciones entre el tiempo y el Derecho, he intentado profundizar en una intuición de H. ARENDT que mostraba hasta qué punto una vida social con sentido reposaba sobre la memoria (anclaje en el pasado) y la promesa (proyección en el futuro). Repito esta dialéctica mostrando hasta qué punto el Derecho combina, en el mejor de los casos, la memoria y el perdón (todas las variedades de la supresión de la deuda), y, por el lado del futuro, la promesa y la revisión (todas las modalidades de enmienda de lo que ha sido decidido). Cada vez que una de estas cuatro polaridades se absolutiza en detrimento de las otras, se rompe un equilibrio.

Mis análisis relativos a la cuestión de la traducción me han enseñado también a superar la oposición frontal entre mi lengua y la del otro, o todavía, la lengua-fuente del autor, y la lengua-objeto del traductor, dado que me parecía que se traduce ya y sobre todo en la propia lengua. Es ya la propia lengua la que nos lleva a una reformulación permanente, dubitativa, y sobre todo defectuosa, pues los límites del querer decir afectan a toda la lengua y no solamente a la del otro. Es ya mi lengua la que me falla un poco, o que me aparece siempre como un poco extranjera, exactamente como, en el plano ético, RiCOEUR puede sostener la tesis de «uno mismo como otro» (Seuil, 1990), sobre la base de una relación verdaderamente dialógica.

Un último ejemplo: las relaciones entre el hecho y el Derecho y, más filosóficamente, las relaciones entre el ser y el deber ser. Desde luego, yo empiezo siempre por recordar estas distinciones cardinales. Y enseño a mis estudiantes que la primera exigencia universitaria es la de distinguir cuidadosamente entre la constatación, la explicación y la valoración. Recuerdo también a Hume y la crítica de la naturalistic fallacy. Son los presupuestos intelectuales indispensables, y bien necesarios en una época que da tantos ejemplos de lo que se empieza a llamar la «postverdad». Dicho esto, ¿podemos quedarnos ahí? Yo no lo creo. En un segundo momento, y sin por ello renunciar al esfuerzo de distinguir estos planos, se debe reconocer que toda descripción es reconstrucción y comporta pues un elemento de valoración. Antes que negarlo, lo que se necesita, por el contrario, es reconocerlo y, en ese caso, justificar (someter al debate público con argumentos racionales) la perspectiva que se adopta. François RigAuX lo mostraba sobre el terreno del Derecho sometiendo a este tipo de crítica el dogma según el cual «la Corte de casación no conoce sobre los hechos», sino solamente sobre el Derecho. Y el filósofo Paul RiCOEUR recordaba esta tesis fuerte de que entre «describir» y «prescribir» está «relatar [raconter]», queriendo sugerir con ello el lazo dialéctico que vincula el hecho descrito (en realidad, el hecho reconstruido) y la norma que se desea aplicar al hecho. En ese caso el relato opera como operador de transformación entre los dos planos lógicamente distinguidos. Por lo que respecta a la sociología de las 
ciencias, se necesitaría también releer los trabajos de Bruno LATOUR, el cual muestra (y no lamenta) que «nunca hemos sido modernos» en nuestra manera de hacer ciencia, es decir, que jamás hemos practicado la diferencia absoluta entre ser y deber-ser.

Quiero que se me comprenda bien: la dialéctica se bate permanentemente en dos frentes a la vez; rechaza las confusiones y trata de llevar lo más lejos posible las distinciones, pero, al mismo tiempo, desarrolla un pensamiento de lazos que muestra lo que, sin embargo, aproxima a los términos así distinguidos. Haciendo eso, se da la posibilidad de pensar en la inevitable y permanente transformación recíproca.

Voy ahora a la cuestión del positivismo jurídico. Lo que precede debería aclarar mi respuesta. Preciso, para comenzar, que mi posición no significa que me adhiera a un paradigma iusnaturalista, y menos aún a una aproximación en términos del «realismo». Todas estas posiciones en «ismo» son monológicas y amenazan siempre con recaer en la ley de la «bipolaridad de los errores» denunciada por G. BACHELARD (librarse de un error para caer pronto en el error simétricamente opuesto que, sin duda, está más próximo de lo que se piensa, precisamente por la falta de finura dialéctica). Por lo que se refiere al iusnaturalismo, aclaro en seguida que las buenas intenciones que reivindica no son en absoluto una garantía de su adhesión a valores que juzgamos fundamentales; así, un libro reciente de O. JOUANJAN muestra de manera patente que los juristas nazis apelaban al Derecho natural, a una versión naturalista, basada sobre la pureza de la raza y la integridad del espacio vital (Justifier l'injustifiable. L'ordre du discours juridique nazi, Paris, PUF, 2017).

Esto significa pues, a la inversa, que busco menos rechazar el positivismo jurídico que complejizar las tesis. Me refiero de todas formas más a una cierta «vulgata» positivista que a la posición de tal o cual autor; en efecto, la exégesis del pensamiento de un autor, sobre todo si es importante, lleva a menudo a resultados mucho más matizados o controvertidos (¿qué no se ha escrito sobre el iusnaturalismo, real o pretendido, de KELSEN?). En el plano epistemológico, me distancio netamente del descriptivismo, reivindicado a menudo por el positivismo, pues la ciencia reconstruye e interpreta necesariamente su objeto. Me opongo también a su encerramiento disciplinar (el famoso rechazo del «sincretismo de los métodos» de la Teoría pura del Derecho), aunque preconice el respeto del «punto de vista interno» de los juristas como primera etapa del recorrido. En el plano de la validez, sostengo que no se puede dar cuenta de los juicios de validez realmente efectuados por los jueces, sin tomar en cuenta consideraciones (más o menos enmascaradas) de efectividad y de legitimidad. Hemos acumulado numerosos trabajos empíricos a este respecto. En el plano de la interpretación, como ya lo he señalado, no creo que sea muy esclarecedor mantenerse en el dilema: o el respeto de la letra de la ley (eventualmente, la voluntad del legislador), o la libre interpretación. En el plano de la teoría de las fuentes, hoy se necesita, en lo que llamo el «Derecho en red», flexibilizar la concepción tradicional que pretende limitar la concepción de la ley a la regla unilateral, imperativa y provista de sanción. Quisiera citar a este respecto un Rapport [una Memoria] de 2013 que el Consejo de Estado francés, templo de la legalidad clásica, ha consagrado al soft law. Después de haber rechazado durante mucho tiempo reconocer la juridicidad a lo que consideraba como un «Derecho blando, borroso, en estado gaseoso», he aquí que ahora la alta jurisdicción administrativa escribe que «el Derecho ductil es un fenómeno cuya importancia no puede ya ser ignorada»; 
apela a partir de ahí a «un nuevo paradigma de la normatividad que es una ruptura en relación con la aproximación heredada de KELSEN que caracteriza el Derecho por la sanción». Se tratará de tomar nota en adelante de la existencia de una «normatividad gradual entre el Derecho duro y el Derecho ductil». Tales tomas de posición, que toman en serio, y con razón, las «anomalías» que afectan a la teoría oficial (aquí, una vulgata positivista), deben animarnos a pensar en un paradigm shift, que por lo demás, a menudo se entiende como una ampliación o una reformulación del paradigma antiguo, más bien que como una recusación pura y simple.

Con frecuencia a este paradigma dialéctico se le señala por un oxímoron, que es la figura de estilo propia de la paradoja de las dos verdades en tensión; se puede ver en ello ejemplos de lo que KHUN llamaba «ejemplos bien elegidos», ejemplos particularmente ilustrativos del paradigma general. Así, desde mi trabajo de doctorado llevado a cabo con Jacques LENOBLE, hablábamos de «mito-lógica» para pensar en el entrelazamiento de la razón y de la imaginación en la lógica jurídica.

La figura de las «jerarquías entrelazadas» o «bucles extraños» ilustra bien la tesis de la obra Pyramide ou réseau?, puesto que ella lleva a ver el entrelazamiento del top down y el bottom up.

M. A.: Me parece muy clarificadora tu respuesta. La noción de dialéctica que tomas de MERLEAU-PONTY creo que está muy próxima a lo que algunos pragmatistas (empezando por PEIRCE) llaman sinequismo, y que presentan como una actitud metodológica preocupada por mostrar no solo las discontinuidades, sino también las continuidades que se dan entre entre los fenómenos, del tipo que sean. Y creo que también a lo que BOBBIO entendia por «dialéctica en sentido débil» (una relación de interacción entre dos fenómenos). Es muy interesante, creo yo, darse cuenta de esos paralelismos teóricos, porque nos indican que se trata de alguna idea, clasificación, etc., de gran importancia, que en cada tradición cultural aparece con alguna connotación peculiar.

Pero abora querría pasar a otro tema (aunque inevitablemente se trate de un tema relacionado con el anterior). Me gustaría hacerte algunas preguntas sobre la parte de tu producción que integra lo que has llamado el «tercer círculo» y que, como nos decías, se corresponde con la teoría general del Derecho propiamente dicha. En uno de esos libros estudias (estudiáis) el «cambio de paradigma» que se habría producido en las últimas décadas y que supone el paso del modelo estatista, legalista y positivista (representado por la pirámide) hacia otro (el de la red) que sería consecuencia de la globalización, de la existencia de múltiples poderes públicos y privados que concurren con el del Estado, del aumento de poder de los jueces o de la «contractualización»y «desformalización» del Derecho. Nos dices también que es un cambio «progresivo y caótico». ¿Podrías explicar un poco más qué quiere decir eso? ¿Hasta qué punto se ha impuesto, en tu opinión, ese nuevo paradigma? ¿Y cómo afecta a la construcción de lo que en otras de tus obras de ese «tercer círculo» (la que escribiste con VAN DE KERCHOVE y que se tradujo al español: Elementos para una teoría crítica del Derecho) llamabais «teoría crítica del Derecho» y que aspiraba a ser «auténticamente cientifica»? ¿Qué tipo de conocimiento se puede tener sobre fenómenos «caóticos»? ¿O no lo son tanto? ¿Sigue teniendo sentido boy ese proyecto, el de construir una auténtica teoría general del Derecho? $Y$, en relación con otra dimensión de tu trabajo intelectual en ese campo, ¿crees aconsejable que la teoría _y la filosofía - del Derecho se cultive en equipo (en equipos de trabajo más o menos amplios) 
en lugar de individualmente? ¿A qué se debe, en todo caso, las diferencias que al respecto uno puede advertir entre el trabajo iusfilosófico (en general, en las ciencias sociales y en las humanidades) y el que se lleva a cabo en las ciencias naturales? ¿Y cómo ba sido tu experiencia de trabajo en común con VAN DE KERCHOVE?

F. O.: En De la pyramide au réseau? (que hoy es objeto de una traducción en español que va a aparecer pronto en México) hemos efectivamente tratado de pensar un cambio posible de paradigma al término del cual la «gobernancia» sustituiría al «gobierno» clásico y la «regulación» a la «reglamentación». Pero nosotros habíamos sido lo suficientemente cautos como para proveer al título de un signo de interrogación, a fin precisamente de hacer justicia a las dudas, oscilaciones y regresiones que caracterizan estos deslizamientos. La actualidad confirma esas dudas sobre la construcción europea (Brexit), esas puestas en cuestión de la mundialización y del multilateralismo (Trump), esos repliegues identitarios (cierre de fronteras a los que solicitan asilo), esas veleidades de proteccionismo económico, esas crispaciones sobre modelos más autoritarios, esas puestas en cuestión de los avances ideológicos apoyados por el Tribunal europeo de derechos humanos, etc. A la inversa, los fenómenos muy criticables de law shopping y de forum shopping por empresas transnacionales acreditan la hipótesis de un debilitamiento de la soberanía de los Estados y un dumping social y medioambiental de sus legislaciones. Las discusiones actuales sobre el tratado transatlántico relativas a las inversiones ponen de manifiesto la misma lógica. El tablero que la realidad nos muestra es por tanto singularmente abigarrado en el que se superponen y combinan en desorden elementos tomados de uno y otro modelo. En este sentido es en el que hablaba de evoluciones «caóticas». Por supuesto, «la historia nunca repite los platos», y si las regresiones que evoco se generalizaran, eso no significaría volver a la situación anterior. Además, los «paradigmas», como los «tipos-ideales» de Max WEBER, no son nunca más que instrumentos conceptuales, herramientas de pensamiento, de manera que la realidad es necesariamente más compleja e inaprehensible de lo que podemos decir de ella.

De estos fenómenos contrastados, no es difícil tener un conocimiento empírico, pero, por supuesto, la dificultad está en extraer una interpretación significativa y en comprobar su respectiva importancia; en este sentido, una teoría del Derecho que quiera ser crítica y, si es posible, científica, debe estar atenta tanto a los fenómenos que confirman el paradigma en marcha, como a los que lo desmienten (y que KHUN llamaba «anomalías»). En forma opuesta a una «dogmática» que no se pone en cuestión, que se atrinchera en sus postulados y multiplica las «hipótesis ad hoc» y los «obstáculos epistemológicos» (BACHELARD) para no dejarse desestabilizar por las «anomalías», una ciencia crítica del Derecho toma en serio todo esto último sin por ello desprenderse del paradigma dominante (para nosotros: estatista, legalista) a la menor dificultad.

Esto no quiere decir por lo demás que yo pretenda inspirarme en una «teoría matemática del caos» o en una u otra variante de la física cuántica (que insiste en la doble cara de los fenómenos como la luz); a pesar de su seducción, esos préstamos no dejarían de ser superficiales, a falta de un dominio suficiente de esas teorías. El enriquecimiento interdisciplinar viene más bien de las aportaciones de las ciencias humanas y sociales y de una profundización filosófica, siempre necesaria.

Todo eso, ¿vuelve a partir de ahora vano e ilusorio el proyecto de una teoría general del Derecho? Con razón o sin ella, y con un éxito sobre el que no me corresponde 
juzgar, siempre he intentado ensamblar los elementos de una teoría general del Derecho. No me resuelvo a dejar la ciencia del Derecho dispersarse en una especialización infinita, y constato una gran necesidad de sentido, de método y de síntesis en los prácticos. A la hora en particular de la «concurrencia de las normatividades», es importante, me parece, reflexionar sobre las especialidades de la regulación jurídica —la plusvalía que el Derecho aporta a las relaciones sociales-.

Recordaría aquí la divisa de Guillermo el Taciturno: «No es necesario esperar para emprender, ni tener éxito para perseverar». Esta resolución reposa notablemente sobre la conciencia de que los asuntos humanos son variables y complejos, como lo enseñaba ya ARISTÓTELES, de manera que si debemos olvidarnos de un saber verdadero, estable y unánime en estas materias, ello no es sin embargo una razón para tirar el instrumento y renunciar a la ambición teórica. Por lo demás, esta posición también vale para el propio juicio judicial; aunque sea cierto que el Derecho está en el caso más bien que en la regla, eso no es una razón para abandonarse a una casuística ciega; el juez no dejará, en efecto, de buscar el criterio generalizable que se manifiesta en el caso, por singular que este sea.

Tu pregunta se refiere también a la naturaleza, individual o colectiva, del trabajo en teoría del Derecho. Yo distinguiría, a este respecto, la fase de las investigaciones y la fase de la escritura. La primera gana seguramente siendo colectiva, a la vista de la multiplicidad de informaciones y de fuentes que tratar; por el contrario, la escritura es mucho más personal. Yo sostengo incluso que en las ciencias humanas y sociales, donde se trata de sugerir sentido más bien que de demostrar verdades, el estilo es una baza importante; los autores más grandes a menudo han logrado imprimir un estilo personal a sus análisis —evoco aquí, casi al azar, a FouCAUlt y a WiTTGENSTEIN-.

Lo que llamo la fase de escritura (individual) puede tanto preceder como seguir a la fase de investigación. En el primer caso, se trata de formular una hipótesis, por ejemplo bajo la forma de un ensayo que exige ser verificado; en el segundo caso, se trata más bien de sacar conclusiones y de tomar altura en relación con los análisis sobre el terreno. Obras como De la pyramide au réseau? o A quoi sert le droit? pertenecen más bien a la segunda categoría; por el contrario, La nature hors la loi o Raconter la loi han sido más bien obras seminales, origen de investigaciones colectivas y más aplicadas.

Añado en seguida que hay límites a la exhaustividad del trabajo empírico y que hace falta saber resistirse a la tentación de la completitud. Hemos rozado ese límite en una de las últimas investigaciones llevadas a cabo por nuestro Seminario interdisciplinar de estudios jurídicos a propósito de Sources du droit revisitées (Bruselas, Anthémis, 2012): con más de 70 autores, 3.000 páginas y cuatro volúmenes nos hemos aproximado a «ese mapa tan vasto como el territorio» del que hablaba BORGES con humor. Es verdad, sin embargo, que nuestra aproximación interdisciplinar reclama, por naturaleza, la colaboración de un cierto número de colegas, pues nadie podría por sí solo dominar estas diferentes disciplinas. Lo que no es óbice para que haya que tener la audacia de la síntesis y de la interpretación.

Pero es necesario además reconocer, en un plano más general, que la ciencia es por naturaleza una actividad colaborativa y colectiva: se trata de tomar conocimiento de los trabajos llevados a cabo a tu alrededor, y es también en el espacio público de la comu- 
nidad científica donde los resultados de las propias investigaciones son discutidos y, si no verificados o validados, al menos tomados en consideración. En este mismo orden de ideas, se puede también subrayar que un libro, sobre todo si es una «obra abierta» de la que hablaba U. ECO (abierta a ser recuperada y reinterpretada), es en parte escrito por sus lectores. Quiero decir que la naturaleza y la calidad de la recepción de un libro contribuyen enormemente a su propia existencia y a su alcance. Quizás algunas obras vivan más y mejor en los ecos que reciben que en sus propias páginas. Los libros se transforman también según la recepción que suscitan en diferentes épocas y en diferentes esferas culturales.

¿Se encuentra a este respecto una diferencia significativa entre ciencias naturales y ciencias humanas? KHUN explica, en su teoría de los paradigmas, que en las ciencias humanas y sociales se encuentra raramente una verdadera convergencia alrededor de un paradigma común, dado que ello evitaría más bien la confrontación permanente de las explicaciones rivales. Sin duda; esa no es sin embargo una razón para cultivar una aproximación solipsista, y sustraerse, especialmente a través de una jerga o de una originalidad a cualquier precio, a la discusión con los pares. En las ciencias naturales, el saber es más acumulativo y supone también la movilización de un instrumental muy costoso de cara a llevar a cabo experimentos muy sofisticados: se comprende que, en esas condiciones, sea improbable que se haga una obra en solitario. Ello no impide, sin embargo, que EINSTEIN, y, frente a él, los pioneros de la física cuántica, fueran genios solitarios, y que KHUN explique que los progresos de las ciencias son el resultado de una «tensión esencial» (es el título de una de sus obras) entre la aplicación estricta del método disciplinario (el término «disciplina» es a estos efectos elocuente) y de la capacidad de ruptura imaginativa en relación con los cánones.

En lo que a mí respecta, he tenido el privilegio de escribir a cuatro manos la mayor parte de las obras del «tercer círculo» con Michel VAN DE KERCHOVE. La colaboración no estaba por lo demás escrita en los astros, dado que su aproximación era más bien jurídica y analítica, y la mía más bien filosófica y hermenéutica; pero compartíamos la intuición dialéctica, y el trabajo en común aproximaba progresivamente nuestras perspectivas. Ocurría incluso algunas veces que disfrutáramos de manera inesperada, él arriesgando una metáfora audaz, y yo desarrollando un erudito análisis terminológico. Además del placer del trabajo en común (a la larga, el placer es una dimensión importante del trabajo profesional), esa colaboración tenía la ventaja de poder poner a prueba inmediatamente nuestras ideas, y así afinarlas y corregirlas, sin duda, pero sobre todo afirmarlas y profundizar en ellas.

M. A.: La última de tus obras que cierra (al menos por abora) ese «tercer círculo» de teoría general del Derecho, A quoi sert le droit?, plantea la cuestión de las funciones del Derecho y, como antes has indicado, el problema de qué ocurriría si viviéramos sin Derecho: cómo pasarian a ser nuestras vidas. Es una obra muy reciente (publicada en 2016) y que ahora estás discutiendo en diversos foros. ¿Podrías indicar de manera sintética cuáles son las tesis fundamentales que defiendes en el libro y cómo las mismas han sido recibidas? ¿En qué aspectos te parece que hay acuerdo, y dónde se sitúan fundamentalmente los desacuerdos? ¿Y a qué crees que se deben unos y otros (los acuerdos y los desacuerdos)?

F. O.: La pregunta «¿Para qué sirve el Derecho?» debe de estar en el aire desde hace un tiempo y obedecer a una preocupación compartida, pues constato que Jacques 
COMMAiLle ha publicado, en el curso del mismo año 2016, una obra que tiene casi el mismo título que la mía, «¿Para qué nos sirve el Derecho? [A quoi sert le droit?]». El «nos» apunta a la comunidad de los sociólogos, a la cual el autor dirige un doble mensaje: 1) el Derecho es un revelador excepcional de las transformaciones sociales, que los investigadores en ciencias sociales harían mal en ignorar o en menospreciar, y 2) el Derecho no solo es un registro de la dominación, como escribían FOUCAULT y BOURDIEU, sino que proporciona también las armas a los más débiles de cara a enfrentarse con el orden establecido — siempre es posible hacer jugar la justicia contra el poder-.

Mi propia obra, subtitulada «Usos, funciones y finalidades» [Usages, fonctions, finaliotés], tiene un alcance más general y se interroga sobre la plusvalía aportada por el Derecho a las relaciones sociales en general, y sin hurtarse a la hipótesis de que, quizás, el Derecho, que entra en concurrencia con tantos otros sistemas normativos, pronto dejará de servir para algo. En 1625 Grocio planteaba la cuestión «etsi Deus non esset?», ¿será necesario plantearse pronto la cuestión «etsi ius non esset?». Ciertamente, todo grupo social ha conocido siempre reglas, pero estas eran domésticas, culturales, religiosas, económicas, políticas, antes de ser jurídicas —el Derecho solo aparece en un segundo momento (tesis llamada de la «doble institucionalización» aportada por el Derecho)_. A la vista de la actual concurrencia y confusión normativa entre sistemas normativos diversos [el de los estándares, el de las normas técnicas, el de los indicadores cifrados, el de los nudges (incentivos)...], es necesario constatar una reducción del imperio y de la empresa del Derecho. Planteando la cuestión hasta el fondo: ¿qué perderíamos si dejáramos de estar regulados por el Derecho?

Para llevar a cabo esta investigación, he constatado en primer lugar la poca literatura reciente que hay consagrada a este asunto, con la excepción de algunos textos de LUHMANN, una obra de BOBBIO y otra de FERRARI. Sin duda, el peligro de esencialismo filosófico y de funcionalismo sociológico naifs lo explican. También la banalidad de las respuestas que vienen inmediatamente a la cabeza («guiar las conductas, resolver los conflictos...»), o, a la inversa, la variedad infinita de las tareas desempeñadas por el Derecho («que puede servir para todo, no importa lo que sea», escribía D. LOSCHAK). La dificultad, en efecto, real, de que el Derecho no se preste ni a demasiado ni a demasiado poco. No es ni la democracia ni la justicia, con las que nos gustaría identificarlo, pero tampoco es la simple traducción «notarial» ni el simple «brazo armado» de las normas definidas por otros decisores, como tanta gente piensa generalmente. Esta dificultad de que el Derecho no se preste ni a demasiado ni a demasiado poco refleja, de manera general, la dificultad de poner a la filosofía del Derecho en el lugar justo entre las ciencias sociales, de un lado, y la filosofía moral y política, del otro.

Entre los numerosos conceptos con los que se puede tratar mi cuestión he seleccionado tres, unidos dialécticamente: usos (sociales), funciones (jurídicas, en el sentido de la técnica jurídica), finalidades (ético-políticas). Cada una de esas nociones se presta, desde luego, a numerosos matices (así, las distinciones entre funciones instrumentales y simbólicas, manifiestas y latentes, funciones esperadas y perversas, etc.), pero la distinción más importante concierne a las finalidades. Distingo, en efecto, entre finalidades extrínsecas e intrínsecas. Las primeras son exteriores al Derecho, aunque este tienda a ellas: así, la justicia, la democracia, pero también... el mantenimiento del orden, la defensa de la raza o del proletariado... Las finalidades intrínsecas, por el contrario, 
apuntan a la manera como el Derecho desempeña esas funciones técnicas al servicio de tal o cual finalidad extrínseca que se decida perseguir. En mi obra, yo digo que $s i$ (y solamente $s i$, lo que nunca está garantizado) se decide perseguir la democracia y la justicia, cuáles son entonces las finalidades intrínsecas que el Derecho persigue.

Tomemos un ejemplo: ¿para qué sirve un coche? Su función es la de ser un vehículo automovil (que se mueve por sí mismo); sus usos pueden ser extremadamente variados (transporte, sin duda, pero también, alojamiento, arma, obra de arte...), en cuanto a sus finalidades, puede tratarse de placer, trabajo profesional...

Combinando estos tres ejes, me he esforzado por permanecer fiel a mi aproximación interdisciplinar de los fenómenos jurídicos: se trataba de hacer justicia a las respuestas de los teóricos del Derecho más que a las de los sociólogos o filósofos —existen, pero ¿cuándo entran en diálogo?-. Añado todavía, antes de detallar algo más mis tres ejes, que a lo largo de este trabajo no he dejado de plantearme una cuestión simple, pero radical — casi una experiencia de reducción fenomenológica一, ¿qué es lo que cambia cuando dos individuos, o un grupo, deciden «prescindir del Derecho»: hacer constar su relación, remitirse a un juez, referirse a una regla general?... Esta cuestión está en el corazón de mi libro, y no he dejado aún de intentar profundizar en la respuesta que se le pueda dar.

Los usos del Derecho son tan variados como los actores que los ponen en práctica y las estrategias que persiguen: actores privados o públicos, que bien se conforman al Derecho o bien se desvían de él —y esto último, con objetivos «conservadores»o «transformadores»-. Ciñéndonos a los particulares, se puede hacer notar, al lado de la obediencia esperada, formas de «lucha por el Derecho» (de las que ya hablaba IHERING en el siglo XIX), a veces incluso de comportamientos de desobediencia civil (desobedecer a la ley para promover el Derecho). Pueden también rodear el Derecho de mil maneras (vuelva a leerse la Comedia bumana de BALZAC), abusar del Derecho (el abuso es una forma de uso) o bien corromper a una autoridad (obtener un trato de favor para un beneficio exclusivo, un privi-legio, es decir, una ley privada, un tratamiento de favor, en detrimento de la posición de tercero de la autoridad y de la ley). Pueden también, como los sociólogos lo han mostrado a menudo, arreglarse un «Derecho vulgar», una suerte de reapropiación aproximativa de la regla en función de las necesidades propias de los grupos y de sus niveles de aprehensión de su tecnicidad. Este realismo lúcido en cuanto a los usos del Derecho no debe conducir al desencanto ni al relativismo: este Derecho «que se encuentra en todas las salsas» presenta funcionalidades técnicas y pretensiones normativas (finalidades, valores) si se trata de tomarlo en serio, pues sin ellas no se comprendería nada de los usos (conformes o heterodoxos) que se hagan.

El estudio de las funciones del Derecho afecta a la teoría general del Derecho. Recuerdo aquí la tesis de la «secundariedad» del Derecho (tesis de la «doble institucionalización» que retomo y complejizo en relación con ciertos puntos), que lleva, en el plano de la teoría de las normas, a la famosa distinción hartiana entre normas primarias (el Derecho retomando por su cuenta las normas sociales que le preceden) y secundarias (necesarias para la autoorganización del propio sistema jurídico). Me inspiro en esos trabajos para llevar a cabo mi cuestionamiento relativo a las funciones del Derecho. En ese cuadro ( $\mathrm{y}$ con la ayuda de la metáfora del juego, siempre muy útil), distingo entre funciones primarias y secundarias. Cuando retoma por su cuenta normas y valores so- 
ciales, se puede decir que el Derecho cumple funciones de guía (como el práctico que se sube a la pasarela de un navío de comercio en los pasos difíciles y, en la proximidad de los puertos, aconseja al capitán sin llegar sin embargo a sustituirlo). Cuando se autoorganiza, el Derecho cumple funciones de encuadramiento, identificación, archivo y arbitraje, muy próximas a las que HART señalaba para sus normas secundarias (descritas, por lo demás, con un vocabulario funcionalista). De manera general, se puede decir que el Derecho teje lazos, fija límites, traza medidas. El Derecho es lazo, límite, medida. Pero, anotémoslo bien, todavía no nos hemos pronunciado, en este estadio, sobre el buen o mal uso que puede hacerse de cada una de esas finalidades. Cada una de ellas puede ser desviada o desnaturalizada en relación con la finalidad que le asociamos: la medida puede sufrir un sesgo, el límite puede amortiguarse, el lazo, soltarse... Así, no podemos hurtarnos al tercer nivel de interrogación, el de las finalidades.

Finalidades intrínsecas - lo recuerdo: las que desarrollamos si nos decidimos a perseguir la justicia y la democracia-. Aquí, yo contesto distinguiendo tres finalidades que solo tienen valor si se equilibran dialécticamente: si una de ellas se hipertrofiara, el equilibrio se rompería y los problemas se acumularían. Diré entonces: el Derecho apunta a: 1) una formulación (segunda, técnica) de un equilibrio general de los intereses sociales y de los valores en conflicto; 2) equilibrio susceptible de ser aplicado, en su caso, por la coacción (una coacción regulada), y 3) y que, al mismo tiempo, es siempre susceptible también de ser puesta en discusión en el marco de procedimientos (reglados también ellos).

Algunas observaciones a propósito de estas tres finalidades. El equilibrio general parece responder al ADN del Derecho simbolizado por la balanza, que persigue la medida y que se traduce hoy en el balance de los intereses y el principio de proporcionalidad. Preciso que este equilibrio es tanto más delicado cuanto que se trata de un equilibrio social general; no solamente el arbitraje de tal caso económico o familiar o cultural complejo, sino un macro-arbitraje entre-juegos —una regulación social de conjunto- . HABERMAS habla con justicia de finalidad de coordinación general; mejor: de traducción generalizada, como la que opera la lengua usual en relación con todas las sub-lenguas técnicas o privadas. Añado todavía que este arbitraje no debe entenderse (incluso si puede recaer en ello fácticamente en cualquier momento) como una mediocre vía media o como un compromiso entre intereses en conflicto. En su aspecto normativo, el Derecho cuando menos tiende aquí a la construcción de algo así como un interés general, un bien común. RoussEAu diría: una voluntad general que es más y algo distinto a la voluntad de todos; KANT hablaría de investigación con un criterio de universalización; HABERMAS, de discusión en torno al mejor argumento. A mi juicio, se trata del tercero como propiedad emergente - algo contrafáctico sin duda, improbable lo más a menudo, pero que se inscribe, sin embargo, como finalidad intrínseca de la operación-.

Por lo demás, este equilibrio no es solamente virtual o académico; tiene vocación de inscribirse en lo real, mediante la movilización de la coacción si es necesario. Se encuentra aquí a Max WEBER y a su análisis del Estado (y de su Derecho) como monopolio de la violencia legítima. ¿Por qué legítima? Porque en el plano normativo que es el nuestro aquí, esta violencia de la coacción jurídica está ella misma enmarcada por el Derecho y las autoridades se someten a él como los demás sujetos de Derecho. Tal es 
la definición de Estado de Derecho, el único que puede hacer aceptable esta coacción jurídica, y el único que puede garantizar la confianza sin la cual el lazo social no se mantiene (una nueva propiedad emergente, tan esencial como inaprehensible, de un orden jurídico que persigue la justicia y la democracia).

Finalmente, este equilibrio es también susceptible de ser siempre discutido, puesto en causa y en cuestión, si bien dentro de las formas legales y procedimentales. CARBONNIER hablaba a este respecto del Derecho como de una institución de la contestación organizada; institución de la duda reglada. Como si el conflicto (aquí, el conflicto interno entre normas y autoridades) formara parte de su modo de producción ordinaria; piénsese en las controversias doctrinales, en los cambios de jurisprudencia, en las derogaciones de las leyes, enmiendas de los tratados, revisiones de los contratos. Piénsese incluso en las mil técnicas de las que dispone el Derecho para autolimitarse, matizarse, neutralizarse, hacer lugar al principio fundamental que lo atraviesa: audiatur et altera pars.

Finalmente, ¿para qué sirve el Derecho? Si se tuviera que resumir en cinco palabras un libro de 578 páginas, respondería: «Para contra hasta tres». La plusvalía del Derecho en relación con las relaciones sociales, la propiedad emergente que suscita en el mejor de los casos, es la de inscribir esas relaciones en lo que yo llamo la «escena tercera» de la ley común y del juez por encima de las partes, garantizando así un comienzo de igualdad de trato. La función del Derecho es reforzar el lazo social con sus procedimientos e instituciones técnicas propias; su finalidad es inscribir este reforzamiento bajo la égida del tercero. Prescindir del Derecho consistiría en volver a la inmediatez de la relación social primaria, sin mediación social, sin medida tanto en la complicidad como en la violencia.

Es todavía un poco pronto para juzgar la manera como se ha recibido el libro. Constato, entre las primeras reacciones, cierta resistencia a admitir, como sostengo, que la norma jurídica es siempre «segunda» en relación a la norma moral, religiosa, económica o política. Se desearía a veces también una mejor diferenciación entre las ramas del Derecho para apreciar sus funciones. Los críticos franceses, siempre apasionadas por el cartesianismo y las distinciones tajantes, se sorprenden a veces con la aproximación dialéctica; igualmente, los colegas positivistas pueden quedar despistados con los análisis interdisciplinarios. De manera general, la discusión del libro reaviva las tensiones entre una ciencia doctrinal o dogmática del Derecho, que pretende estudiarlo en su «pureza», y una aproximación crítica que pretende, al contrario, ponerlo «en contexto». Anticipo también que podría ser objeto de dos objeciones opuestas. Desde el lado iusnaturalista, se podría reprochar la distinción de principio que hago entre Derecho, por una parte, y democracia y justicia, por la otra; a la inversa, desde el lado del realismo sociológico, se podría poner en cuestión el análisis de las finalidades intrínsecas, que serían juzgadas desconectadas de las realidades. Pero estas críticas se anulan entre sí; al final, lo más perjudicial para una obra es no suscitar reacciones, o ser imperfectamente comprendida. Lo que deseo para este libro es que no se haga de él una lectura selectiva, que consistiría en desarticular su ambición dialéctica: proporcionar un marco de lectura relativa al rol del Derecho en las sociedades contemporáneas que hace frente de manera permanente a usos, funciones y finalidades. Para volver a la distinción entre el Derecho, por un lado, y la justicia y la democracia, por 
el otro, será necesario sin duda que afine el análisis de sus relaciones, mostrando cómo lo que yo llamo las finalidades intrínsecas del Derecho (las que al menos yo mantengo) contribuyen activamente a la realización de esas finalidades externas —un poco según el modelo de lo que FulLeR llamaba la «moral interna del Derecho»-.

M. A.: Has hecho alusión en tu respuesta a tres nociones que, además de ser características de tu manera de entender el Derecho, llevan a lo que anteriormente denominabas el «primer círculo», el más amplio, de tus trabajos: aquellos en los que pones en contacto al Derecho con otras temáticas, como el lenguaje, la traducción o la literatura. Me refiero a las nociones de límite (o límites) del Derecho; a la de tercero en cuanto «propiedad emergente»y rasgo fundamental de lo jurídico; y a la de interdisciplinariedad como característica también central de tu forma de aproximarte al Derecho. Pues bien, la pregunta que quiero formularte ahora es esta: ¿Cómo se relacionan en tu obra la temática del Derecho y la literatura con esas tres nociones: la de límite, la de tercero y la de interdisciplinariedad? ¿Por qué es importante para el filósofo del Derecho y para el jurista interesarse por ese tipo de estudios, o sea, poner en contacto al Derecho con la literatura? ¿Y por qué has centrado tu atención en los autores en los que la has centrado; por lo que yo sé: SADE, SHAKESPEARE, GOETHE, BALZAC, SWIFT? Eres además autor de alguna obra literaria, de manera que me gustaría que nos hablaras también algo de esa faceta y de su conexión con el Derecho, lo que, me parece, significa algo así como pasar de «el Derecho y la literatura» a «la literatura y el Derecho».

F. O.: Siempre he pensado que era esencial poner el Derecho en relación estrecha con el lenguaje. Esa es, a mi juicio, la institución de todas las instituciones. Se dice a veces «a nadie le está permitido ignorar el Derecho»; yo pienso más bien, con el poeta Paul VAlERY, que «a nadie le está permitido ignorar el lenguaje». En cuanto a la literatura, ¿cómo podría el jurista ignorarla dado que ella es, de acuerdo esta vez con las palabras de T. TODOROV, el «laboratorio experimental de lo humano», con a veces pasos a los límites más extremos?

Para contestar a tu primera cuestión, diría que la literatura me ayuda a pensar, de manera extraordinariamente inspiradora, sobre la cuestión de la institución del tercero, en la cual, como sabes, veo el reto más fundamental, estructural y ético a la vez, de la instauración del Derecho. ¿Cómo una interacción humana básica, la del «yo» y el «tú» envueltos en relaciones afectivas o comerciales o políticas, por ejemplo, accede al Derecho?, por la instauración de una instancia tercera, la del tercero imparcial que las juzgue en caso de un contencioso, la de la ley común a la que a partir de ahora se refieren. A partir de este esquema básico, se puede encontrar en la literatura cantidad de variaciones, de ejemplos y de contra-ejemplos que experimentan y discuten su consistencia. Pongo algunos ejemplos. A propósito del juez, el Orestes de EsQuILO cuenta cómo la Grecia del siglo $\mathrm{V}$ a. C. llega a pensar en una superación de la venganza del clan en provecho del juicio en el que se interviene sobre la base de argumentos racionales y de pruebas materiales, incluso en los casos de crimen de sangre, y ello en el momento en el que, en Atenas, se experimentaban las primeras formas de justicia «moderna».

A propósito de la ley, el libro del Éxodo cuenta por su parte cómo el pueblo judío, en el curso de su largo errar en el desierto del Sinaí, tiene la experiencia de una libertad responsable, y, al concluir una alianza con Yaveh, se revela capaz de darse una ley. Digo darse, pues una lectura atenta del relato muestra que se trata de una negociación vin- 
culada a una suerte de contrato social premoderno, mucho más que de una imposición unilateral de una ley autoritaria. Estos dos relatos fundadores (de los que se encuentran cantidad de variantes en otras culturas), que, por lo demás, no ocultan nada de las dificultades del proceso, de las dudas y de las regresiones que lo acompañan, cuentan pues la emergencia del «él» en la vida colectiva. Pero la literatura proporciona también cantidad de contra-ejemplos o de variaciones. Así, se puede leer el Robinson Crusoe de Daniel Defoe (1719) — libro que yo considero como una contribución mayor a la fundación en el imaginario del individualismo jurídico moderno- como el relato de la exacerbación de la posición del «yo», devenido verdadero soberano y fuente principal del Derecho (basta con evaluar el lugar de la propiedad y del contrato en la obra). Sin duda, el lugar estructural del tercero no es revocado, al igual que la referencia al Estado y a la ley, pero se trata de un tercero bajo estrecha vigilancia del «yo» que lo instituye. Con SADE, en cambio, el paso del límite ha sido franqueado; el «yo» recusa completamente a la ley común y no cesa hasta imponer a la tierra entera la ley de la que él mismo es autor - una ley cruel y feroz que se inscribe incluso en los cuerpos y conduce a la anulación de todos los «tú» a los que el perverso se somete-. La obra enigmática de KAFKA nos proporciona otra variante más del esquema de base. Lo que él cuenta, en sus cuentos y novelas, es la imposibilidad de acceder a la ley y al juez. En esas condiciones, el sujeto se encuentra confrontado, sin defensa, sin tregua y sin mediación alguna, al capricho del «tú», como el padre en la «Carta al padre» que aparece como un tirano pues no opera como un enlace o un representante de la ley (el «él»), sino como su encarnación caprichosa. El «yo», consumido de terror y de culpabilidad, se hace entonces muy pequeño, tratando de hacerse publicidad como el «animal de la madriguera» de una de sus novelas.

Lo importante, para el jurista filósofo que se nutre de estas obras de ficción, es tomar en serio su vocación artística, y no reducirlo a simples ilustraciones de tesis filosóficas. Es necesario prestar la mayor atención a la forma y al estilo, y también a las aperturas imaginarias. En ese sentido, la interdisciplinariedad de la que hablas exige lo que yo llamo la «permutación de las posiciones»: es necesario que no sea sistemáticamente el jurista quien tome la iniciativa del diálogo, bajo el riesgo, en el caso inverso, de sugerir respuestas al plantear las cuestiones. El ejercicio responde tanto de la «literatura y Derecho» como del «Derecho y literatura». Una obra como Balzac, romancier du droit [BALZAC, novelista del Derecho] (bajo la dirección de N. DisSAUX, Paris, Lexisnexis, 2012) ilustra bien este descentramiento, sin duda porque se parte de un autor, y no de cuestiones jurídicas preformateadas.

Esa corriente se desarrolla hoy un poco por todos los lados. Se han creado sociedades científicas, se organizan congresos, se lanzan revistas (una de las cuales, el último enero, en París, en LGDJ), y tienen un gran éxito cursos de reciclaje para magistrados consagrados a esta perspectiva. Por lo demás, yo abogo regularmente por la introducción de una enseñanza de «Derecho y literatura» en el cursus de los juristas, tal y como lo vengo haciendo en Bruselas desde hace una quincena de años.

Varios argumentos militan en ese sentido. El trabajo sobre los textos literarios es, en primer lugar, la ocasión para adquirir o afinar ciertas cualidades técnicas básicas que se esperan de un jurista: lectura o escucha atenta, redacción correcta y expresión oral eficaz, comprendido ahí la capacidad para mantener la atención y para convencer. 
Se añade el aprendizaje de las cualidades morales necesarias para un ejercicio responsable de las profesiones jurídicas: aptitud para ponerse en el lugar del otro, empatía, capacidad de traducción de situaciones diferentes. El frecuentar obras de ficción tiene también como efecto desarrollar la imaginación, cualidad que no se piensa que esté asociada con la práctica del Derecho, pues esta última generalmente se considera vinculada sobre todo con la memorización, pero que estimo, sin embargo, esencial para una práctica eficaz: pensar «fuera del marco» es a menudo la mejor manera de salir de una situación bloqueada (y añado que, en el plano político, tenemos mucho la necesidad de volver a encontrar un poco el sentido de la utopía para liberarnos del «pensamiento único» que es como un plomo sobre nuestra vida colectiva por lo que se refiere, por ejemplo, a la construcción europea). En fin, después de algunos años, yo añado una nueva consideración a este argumentario. Se debe a la importancia del relato en todas las fases del razonamiento judicial: está el relato de los hechos que serán seleccionados y calificados, el relato de las decisiones precedentes en los asuntos similares (R. DwORKIN hablaba a este respecto de los jueces como de «los narradores morales de la nación»), viene luego el relato «enciclopédico» de las connotaciones que se atribuyen a las palabras de la ley (U. ECO oponía a este respecto la interpretación «léxica», puramente semántica, a la interpretación «enciclopédica»), viene, en fin, el relato pragmático, y a menudo determinante para los litigantes, peripecias procesales del proceso en curso, en función de las diferentes estrategias de los actores concernidos. Se puede también evocar el caso en el que, al faltar la ley porque el caso que juzgar parece finalmente irreductible, el juez se entrega a lo que KANT llamaba un «juicio reflexivo»: se pone a buscar un criterio generalizable, una regla de la que el caso podría ser un ejemplo. En hipótesis de este género, explica KANT, es la imaginación lo que se moviliza y - no por azar- se refiere en esta circunstancia a la fuerza de los «relatos ejemplares». He aquí otras tantas buenas razones, me parece, para ponerse seriamente al estudio de esos textos literarios.

La cuestión delicada con la que uno se encuentra entonces es la de saber qué textos y qué autores estudiar. Por supuesto, se piensa de entrada en algunos grandes clásicos. Tú has citado algunos, literalmente imprescindibles. Pero la lista nunca es exhaustiva; se necesitaría para eso que se definiera previamente lo que se entiende exactamente por «literatura» - felizmente eso es imposible- E. Es literatura lo que cada época, cada cultura, considera literatura; y yo recordaría que cuando muere KAFKA, había publicado muy poco e ignoraba que era uno de los grandes autores del siglo XX. La novela popular, la novela de detectives, y a veces incluso ciertas crónicas judiciales, pueden, en ciertos respectos, incorporarse al corpus: autores como GIDE y SIMENON pasaron insensiblemente, de un día al otro, de la simple crónica judicial a ser obras maestras de la novela. El corpus debe igualmente enriquecerse con las producciones de diferentes áreas culturales y lingüísticas. Personalmente, lamento no haber estudiado aun seriamente a CERVANTES, pero es que tengo demasiado respeto por él, como para abordarle solo superficialmente. Preparo actualmente el prefacio de una recopilación de «Derecho y literatura» publicada en México por O. TORRES, y eso me procura el placer de descubrir a una serie de autores latinoamericanos, así como apasionantes leyendas mayas. Es fascinante observar a este respecto la convergencia de ciertos relatos fundadores (el paso de la venganza a la justicia, por ejemplo) entre áreas culturales separadas por miles de kilómetros y a veces por más de diez siglos. 
Añado todavía dos consideraciones importantes a propósito de la constitución del corpus de «Derecho y literatura»: dos preocupaciones ligadas a la actualidad. Por un lado, se manifiesta la necesidad de permanecer muy atentos a los textos literarios que podrían decir la verdad de nuestra época. Pero si es cierto que nuestra cultura está rota y que vivimos en lo que el filósofo Jean-François LYOTARD llamaba «el final de los grandes relatos», esa misión es extremadamente delicada. ¿Cuáles son las «novelas políticas» de una sociedad pluralista, tironeada entre la mundialización y el repliegue identitario? Por otro lado, y esa es mi segunda preocupación, es necesario reconocer que nuestra época está saturada, por el storytelling, de esos relatos de pacotilla que formatean las mentes y condicionan los comportamientos. Pienso en el marketing publicitario, en el entertainment televisado, en el crujido de los micro-relatos narcisistas de las redes sociales, en la propaganda electoral y en el discurso sectario del tipo de los tele-evangelistas americanos. Si es verdad que somos homo fabulans y que nuestra vida está saturada de relatos, neceitamos aprender a separar entre los relatos que liberan y los que esclavizan. Así, uno de los intereses de la perspectiva «Derecho y literatura» consiste en contribuir a ese aprendizaje.

M. A.: No hemos hablado hasta ahora de tu contribución a la filosofía del Derecho en el plano, por así decirlo, institucional. Pero esa es una faceta de tu quebacer iusfilosófico que hay que añadir a la puramente intelectual, de producción de escritos, de la que hemos tratado hasta ahora. Por lo que yo sé, una de las empresas institucionales de mayor significación que han contribuido a poner en marcha es la fundación, junto con Mark VAN HOECKE, de una Academia europea de teoría del Derecho, en cuyo contexto habéis organizado, durante muchos años, un máster de teoría del Derecho por el que han pasado muchos profesores y estudiantes tanto de países europeos como extraeuropeos. ¿Cómo valoras, al cabo ya de tanto tiempo, esa experiencia? ¿Cuáles habrían sido sus principales logros? ¿Y cómo ves la filosofía del Derecho en el contexto actual de los estudios de Derecho y en el de la cultura contemporánea? Tú que has hecho de la interdisciplinariedad una de las señas distintivas de tu trabajo teórico y práctico, y que tanto te has esforzado por mirar desde el Derecho «hacia afuera», por construir puentes culturales, ¿cómo explicas el desinterés hacia el Derecho (bacia la cultura jurídica) que —antes te has referido a ello- puede observarse, en general, por parte de filósofos y científicos sociales? ¿Crees que es un rasgo peculiar de nuestras culturas (digamos, de la cultura del mundo latino, como la que se expresa en lengua francesa o española), dado que eso no parece ocurrir (o no de la misma manera) en el mundo anglosajón? ¿Veremos alguna vez cursos de filosofía del Derecho en las Facultades de filosofía, de bumanidades o de ciencias sociales? ¿Y seguiremos, por cierto, teniendo cursos de filosofía del Derecho en las mismas Facultades de Derecho? ¿Cómo ves, en definitiva, el futuro de la filosofía del Derecho?

F. O.: La Academia europea de teoría del Derecho se fundó en Edimburgo en agosto de 1989, con ocasión del Congreso mundial de la IVR, y el Máster europeo que organizaba la Academia se celebró en Bruselas hasta 2009. Durante esos años, seguían los cursos y seminarios alrededor de veinte estudiantes (por año) y eran dados por otros tantos profesores procedentes de todos los rincones de Europa (y a veces de más lejos). Sigue siendo mi experiencia profesional más original. Todavía hoy, cuando viajo, me ocurre a menudo encontrarme con antiguos estudiantes que se han convertido en profesores en su universidad. La inversión era enorme: además de los cursos, habíamos 
puesto en marcha un premio de tesis y dos colecciones científicas, una en francés, en Bruylant, y otra en inglés, en Hart Publishing. Algunos años, se formaba un verdadero espíritu de «colegio» (en sentido inglés) entre los estudiantes que se alojaban en dos casas en Bruselas y proseguían con las discusiones hasta tarde en la noche. Tengo, sin embargo, algo que lamentar: Mark VAN HOECKE y yo tuvimos que consagrar tanto tiempo a los aspectos organizativos y financieros de ese programa (una batalla permanente por subsidiar ese programa que no tenía equivalente) que no pudimos desarrollar la fórmula como yo hubiese deseado. Por el contrario, teníamos una libertad total para organizar el programa. Pienso que ese programa ha reforzado la vocación por la teoría del Derecho de un cierto número de estudiantes; que han salido de ahí algunas buenas tesis, y que se han establecido de manera duradera un buen número de contactos fructíferos entre estudiantes y enseñantes - por no hablar de los contactos entre los estudiantes, algunos de los cuales acabaron después en matrimonios-.

Se podría trazar la hipótesis de que el relativo declive de la filosofía del Derecho en la cultura contemporánea se explica por el hecho de que el propio Derecho no ocupa ya un lugar central en el seno de esa cultura y como motor de gobernanza. Los sociólogos podrían, por ejemplo, explicar el lugar de los juristas (un lugar, yo creo, menos dominante) en el seno de los parlamentos y a la cabeza de las grandes empresas privadas y administraciones públicas. Dicho esto, ese declive es relativo, y el desinterés de la filosofía y de las ciencias sociales por el Derecho debería ser seriamente matizado. Bastaría con citar los trabajos de HABERMAS, DERRIDA o LATOUR para convencerse de ello. En todo caso, los juristas tienen una buena parte de la responsabilidad de esta situación: encerrándose en una tecnicidad estrecha, o cultivando la filosofía del Derecho de una manera muy formal, no favorecen en absoluto el diálogo, y, por lo demás, responden muy raramente a los interesantes análisis propuestos desde el exterior a propósito de su objeto de estudio. Pero, también aquí, hay que señalar excepciones notables: así, la nueva escuela de Derecho de Sciences Po de París, que reserva un lugar importante para la teoría del Derecho y la aproximación crítica. Constato también un muy claro rebrote del interés por el Derecho por parte de movimientos ciudadanos deseosos de defender «causas» sociales o medioambientales — como si se redescubrieran las virtualidades transformadoras del Derecho en el momento mismo en el que ya no es asimilado tan directamente al ejercicio del poder-.

¿Se podría decir que este síndrome de declive o de desinterés afecta particularmente a la cultura latina en relación con el mundo anglosajón? A decir verdad, no tengo respuesta para esta cuestión. Personalmente, tengo más bien el sentimiento opuesto, cuando veo en particular el éxito del Primer Congreso de la Asociación de Filosofía del Derecho del Mundo Latino que ha tenido lugar en Alicante en mayo último por iniciativa tuya.

¿Cómo asegurarse de que haya cursos de filosofía del Derecho tanto en las facultades de Derecho como en las facultades de letras, de filosofía y de ciencias humanas? Diría de entrada - y aquí quien habla es mi experiencia como vicerector - que es necesario que creamos en nosotros mismos. Es raro que las autoridades universitarias supriman un curso si este es vivo y apreciado, y si el profesor senior que se va ha formado a un equipo sólido de sucesores. Además, yo animo a los filósofos y a los teóricos del Derecho a que sean flexibles: si el producto no se vende ya con la etiqueta de «filosofía 
del Derecho», se necesita adaptar el contenido y el embalaje. Apoyar, por ejemplo, el gusto por los asuntos nuevos: ayer los derechos del hombre, hoy la globalización. Es más fácil, en efecto, proponer un curso de «filosofía de los derechos del hombre», o de «teoría del Derecho global», que un curso con un título más clásico. Eso no es, por lo demás, oportunismo, sino una manera necesaria de pensar las evoluciones del Derecho contemporáneo. También se puede, decididamente hacer «entrismo» en las facultades de letras y de ciencias humanas: un curso de «Derecho y literatura», puedo testimoniarlo, interesa a las facultades de letras; un curso de sociología del Derecho, tiene su sitio en un departamento de ciencias sociales.

¿Quién puede decir algo sobre el futuro de la filosofía del Derecho? Yo no me arriesgaría a un pronóstico. Estoy, sin embargo, convencido de que la «demanda de sentido» no desaparecerá, incluso si las respuestas varían. Pienso también que esa necesidad de una aproximación fundamental y crítica a propósito de la práctica y de los discursos jurídicos no concierne únicamente a los estudiantes. Se manifiesta al menos con la misma fuerza entre los profesionales; es necesario, pues, mirar al espíritu de las formas de enseñanza y de publicaciones específicas para dirigirse a ese público ampliado. Es necesario también recordar incansablemente a todos los que invocan la inutilidad de la filosofía que no existe práctica sin una teoría subyacente, ni discurso sin una metafísica implícita. Metafísica tanto más operante cuanto menos se vuelque en sí misma, y termine por naturalizarse con las convicciones ideológicas no críticas, las teorías que se vuelven dogmáticas, y los conceptos que dispensan de pensar. A este respecto, la actitud socrática sigue siempre ahí: exigirle cuentas incansablemente al interlocutor: ¿qué entiendes por...? ¿estás seguro? Terminaré con esta recomendación: estoy convencido de que la filosofía del Derecho tiene un futuro si consigue unir dos exigencias: por un lado, responder a los interrogantes del momento vinculados con las transformaciones del campo, y, por otro lado, seguir siendo verdaderamente rigurosa, profunda, exigente. Estas dos exigencias son virtualmente contradictorias: de un lado, invitan a lo empírico, por el otro, a la especulación más teórica. Y, sin embargo, solo este propósito de llegar hasta la cumbre me parece satisfactorio a largo plazo; nadie ha dicho nunca que la ascensión sería fácil.

M. A.: Voy a hacerte tres nuevas preguntas que, en realidad, son independientes entre si, y con las que quiero terminar esta entrevista que, no me cabe duda, va a interesar mucho a los lectores de Doxa por la profundidad, apertura intelectual y, yo diría también, buen sentido comun, que se trasluce en tus reflexivas respuestas. Dos de esas preguntas se refieren a temas que acabas de plantear: puedes verlas como una petición de un mayor desarrollo. Y la otra es de un orden muy distinto.

La primera. Dada la importancia que concedes a los derechos humanos al hablar del futuro de la filosofía del Derecho, y considerando también tu pertenencia, en un sentido amplio de la expresión, a la teoría crítica del Derecho, que parece estar vinculada de una u otra forma con el relativismo cultural, ¿cuál es tu concepción de los derechos humanos, tu manera de fundamentarlos? $O$, dicho de manera más especifica, ¿de qué forma crees que se puede compatibilizar el multiculturalismo y el universalismo consustancial a la idea de derechos humanos? ¿Eres objetivista en materia de moral?

La segunda. Antes has aludido a la filosofía del Derecho del mundo latino, pero me gustaría que nos comentaras con algún detalle cómo ves el panorama iusfilosófico en los 
países francófonos. Cuando yo era estudiante de Derecho (entre finales de los años sesenta y comienzos de los setenta) era muy frecuente que los profesores (de Derecho civil, de Derecho público o de filosofía del Derecho) bicieran referencia en sus clases a autores de lengua francesa, pero me parece que hoy ya no es así. ¿A qué crees que se debe ese «declive» de la cultura jurídica francófona en los últimos tiempos, si es que consideras que ha habido un declive? ¿Podría decirse que Bruselas es hoy (quizás desde PERELMAN), un centro iusfilosófico más importante que París? ¿Cuáles son las obras importantes de filosofía del Derecho, escritas en francés, que uno debería leer (dejemos a un lado las tuyas, de las que ya hemos hablado)?

Finalmente: ¿En qué estás trabajando abora? ¿Cuáles son tus proyectos para el inmediato futuro? ¿Qué te queda por hacer en filosofía del Derecho?

F. O.: Los derechos del hombre se han vuelto, en efecto, centrales en la filosofía del Derecho contemporánea. Comienzo por lo más radical: su fundamentación filosófica. Yo respondería que, a mi juicio, se fundamentan a partir de un valor absolutamente primero, generador de un imperativo categórico: el respeto a la dignidad del ser humano. Esta dignidad está, por lo demás, inserta como fundamento en la Declaración universal de los derechos del hombre de 1948 y también en la Constitución de la República federal alemana. Precede y fundamenta a la vez los derechos y los deberes del hombre, en una unidad dialéctica. Significa que el ser humano merece respeto, cualesquiera que sean sus características, extremadamente variables, como cada uno sabe. A mi juicio, cada uno es capaz de lo mejor y de lo peor, y el ser humano merece respeto en consideración a eso mejor de lo que es capaz virtualmente. Esta obligación es incondicional, y no deriva ni de una revelación religiosa (durante mucho tiempo se la fundamentaba a partir del estatus del hombre como imago dei), ni de la tradición, ni de la ciencia. Aquí, soy kantiano: es un imperativo categórico de tratar al otro, como a uno mismo por lo demás, como un fin y no como un medio (insisto sobre este punto: el respeto al otro, como el amor hacia el otro en sentido evangélico, comienza por el respeto y el amor a uno mismo. Mucha violencia tiene como origen una pérdida de confianza en sí mismo). Hago notar también, de paso, y haciéndome eco más de las tradiciones africanas y asiáticas que de las occidentales, que esos derechos del hombre suponen también el ejercicio de deberes y de responsabilidades - por ello me preocupo por fundar unos y otros en el valor fundamental de la dignidad-.

Pero incluso nociones tan fundamentales evolucionan con el tiempo y la historia. Distinguiría así tres periodos, con vistas a responder en seguida a tu cuestión sobre el multiculturalismo, en tensión con el universalismo de los derechos del hombre. El primer periodo es aquel que distingue muy claramente entre uno mismo y el otro, entre nosotros y ellos. Es la época (muy larga según la escala de la historia de la humanidad) en la que simplemente no se concebía que los otros pudieran ser seres humanos de manera completa, hombres como nosotros. A fortiori, no se pensaba ni un instante en garantizarles sus derechos; las distinciones son naturales, las discriminaciones son necesarias. Recuerdo que los griegos distinguían entre los helenos y los bárbaros, y que ARISTÓTELES legitimaba la esclavitud. Viene luego, con la modernidad y la Ilustración, la consciencia progresiva de la condición de una igualdad universal. Reconozco, poco a poco, que el otro es un alter ego, y presupongo que lo que es bueno para mí es necesariamente bueno para él igualmente. En Valladolid se decide que los indios tienen alma 
y se llega a la conclusión de que es necesario bautizarlos. Esta época, que abre la era de los derechos del hombre, constituye un progreso remarcable, pero representa al mismo tiempo el peligro de una integración violenta que hace poco caso a las diferencias y que se declina siempre a partir del «yo», del «yo mismo» hipertrofiado.

Se inicia entonces un tercer periodo, el nuestro, que se encuentra ante el desafío de negociar un cambio de marcha muy delicado: no ceder nada sobre el universalismo de los derechos, otorgando un lugar significativo a las diferencias. Ello se traduce notoriamente en las «acomodaciones razonables» en el sentido canadiense, o en el «margen nacional de apreciación» reconocido por el Tribunal europeo de los derechos del hombre a propósito de la aplicación de los derechos y libertades que garantiza. La cuestión del «velo islámico» representa en Europa occidental un reto paradigmático a estas cuestiones. Personalmente creo que no se podrá negociar con éxito este punto de inflexión si cada uno no toma conciencia desde el comienzo que es en primer lugar la propia identidad lo que es plural, atravesada por la carencia y la diferencia. «Yo soy otro», escribe el poeta MALLARMÉ. «Uno mismo como otro» propone el filósofo Paul RICOEUR — «Como otro»: no solamente en el sentido débil de «semejante al otro», sino en el sentido fuerte de «en tanto que otro»: yo soy yo, yo mismo y el otro a la vez. Y mi identidad no se constituye más que en relación con los otros (ella se constituye y «se altera» con la alteridad)_, otro que, también él, está dividido y es plural.

Eso me lleva, en fin, a abordar tu cuestión sobre el desafío de la conciliación entre el multiculturalismo de nuestra «aldea global» y el universalismo vinculado a los derechos fundamentales. Pienso que hoy ya no tenemos elección: no podemos ya postular un «universalismo de vigilancia», para hablar como M. WALZER, que partiría de una visión a priori y supuestamente universal y eterna, de los derechos fundamentales. Eso, me parece, queda vinculado al periodo número dos que distinguía antes. No es una razón sin embargo para apuntarse al relativismo y al diferencialismo (yo respeto las diferencias del otro, con tal de que se queden en él). La dignidad incondicional de todo ser humano, de la que hablábamos, exige, en efecto, un trato, y por tanto normas, si no idénticas, al menos comparables. Es necesario, pues, de manera absoluta, conservar algo como una «referencia de universalidad», una voluntad de convergencia progresiva. Lo que lleva entonces a autores como WALZER a hablar de un «universal reiterativo» o un «universal contextual»: reiterativo y contextual pues se trata cada vez, en cada contexto particular, de reconstruir referencia de universalidad. Es la constatación de que cada cultura, en cada época, intenta, a su manera, conjugar esta dignidad humana; identificar ese esfuerzo, y reconocer un «aire de familia», una cierta convergencia con la manera como mi propia cultura procede a ello por su lado es un presupuesto muy importante para la construcción de esta referencia universal.

Nos encontramos aquí en una situación bastante comparable a la que caracteriza a la traducción y su ética: todos no nos ponemos a hablar la misma lengua, pero, al acoger en mi lengua la del otro, aprendo a descubrir otras maneras de decir lo que, por mi parte, intento decir con más o menos éxito. Varios autores (François JulIEN, Ulrich BECK, Boaventura DE SOUSA SANTOS, de manera notoria) han subrayado esta pertinencia de la ética de la traducción para pensar nuestro mundo plural.

En el Derecho positivo, yo veo a veces en lo que se llama «diálogo de los jueces» una ilustración de esta aproximación: cuando, a propósito de problemas éticos com- 
plejos, como de manera notoria la eutanasia, las cortes supremas de un país se inspiran libremente, sin estar jurídicamente obligados a ello, en soluciones propuestas por jurisdicciones que pertenecen completamente a otra cultura.

Por supuesto, todo esto se refiere al ideal; el Derecho debe inspirarse en ello, pero no ignoro que, de otra parte, debe también hacer frente a urgencias y amenazas - de manera notoria, a grupos liberticidas que se cuelan en las instituciones democráticas para subvertirlas mejor y, finalmente, destruirlas-. De manera permanente, el Derecho debe integrar estas dos exigencias; no puede contentarse con la sola «ética de las convicciones» — su condición es la de «lo trágico de la acción», la acción que no debe optar entre lo blanco y lo negro, sino, muy a menudo, entre lo gris y lo gris-.

¿Cómo explicar el (relativo) declive de la cultura jurídica e iusfilosófica francófona en el mundo? Yo veo ahí dos explicaciones. La primera es casi geopolítica: tiene que ver con un relativo declive del poder de Francia en el mundo y, por tanto, también de su influencia cultural. La segunda se refiere a ciertas características de la doctrina y del pensamiento jurídico franceses, y es por tanto, de manera amplia, un defecto de los propios juristas franceses. Pienso en su apertura muy reciente hacia las lenguas extranjeras y hacia lo internacional, en su exacerbación positivista de la que ya hemos hablado, así como en formas a veces exóticas de «nacionalismo metodológico» (una división casi ontológica entre Derecho público y Derecho privado, la vinculación casi mágica a la tesis en dos partes). Se puede también recordar la gran pobreza de las universidades francesas en general (en comparación con las grandes Escuelas), y de las facultades de Derecho en particular, en el seno de las cuales el tono viene dado por los abogados, más bien que por académicos de tiempo completo. Todo eso ha sido eficazmente denunciado por Chr. JAMIN, fundador de la Escuela de Derecho de Sciences Po. Añado además que el kelsenismo de Michel TROPER — autor con toda seguridad importante- a mi juicio (pero aquí puedo sin duda ser subjetivo) ha contribuido, en detrimento de los discípulos que ha formado, a aislar sin duda la teoría del Derecho de las otras materias.

Pero cabe esperar que esta situación se modifique progresivamente. Hoy es necesario leer los trabajos de A. SupiOT del Colegio de Francia, J.-Y. CHÉrot en Aix, los de A. Viala en Montpellier, los de O. JouAnjan ya citado (que se ha unido al Instituto Michel Villey en París, donde trabaja igualmente O. BEAUD), los de J. ChEvallier en París I, los de E. Millard en Nanterre. También hay en Francia una fuerte escuela de sociología del Derecho (la revista Droit et Société, con Jacques CommaILlE y la luz de André-Jean ARNAUD), y una larga tradición, siempre muy viva, de historia del Derecho. Hay también entre los filósofos (RICOEUR, DERRIDA) y los sociólogos (BOURDIEU, LATOUR, BOLTANSKI) mucho que resulta interesante para el Derecho - ya hemos hablado de ello-.

Si nos vamos al caso de Bélgica, puede decirse que muchos de los factores a los que yo atribuía los males del pensamiento jurídico francés operan aquí en sentido opuesto. No digo que, en el plano geopolítico, Bélgica tenga un papel importante (¡eso sería difícil!), sino que por el hecho de su situación de país-encrucijada, en el corazón de Europa, que comparte dos lenguas y dos culturas (¡no olvidemos a los autores neerlandófonos!), Bélgica presenta una fuerte apertura internacional y representa a menudo un laboratorio experimental de mezcla de lenguas y culturas. Por lo demás, el programa 
de nuestras facultades de Derecho siempre ha reservado un amplio espacio a la interdisciplinariedad. No es extraño que, beneficiándose de esas condiciones favorables, se hayan podido desarrollar dos «escuelas de Bruselas». Por un lado, en la Universidad libre de Bruselas, desde hace cincuenta años, por iniciativa de Ch. Perelman, una escuela caracterizada por una aproximación pragmática (el testigo ha sido recogido hoy por Benoît FRYDMAN y su equipo, que desarrolla trabajos importantes alrededor del «Derecho global»). Por otro lado, en la Universidad Saint-Louis, el equipo fundado en 1973 por Michel VAN DE KERCHOVE, centrado en la interdisciplinariedad y en una aproximación crítica y hermenéutica.

No olvidemos tampoco a Quebec y, de manera especial, sus fuertes equipos de sociología del Derecho (Pierre NOREAU), y a la Suiza francófona, con equipos interesantes en Ginebra (alrededor de B. Winiger), Lausanne (alrededor de A. PAPAUX) y Friburgo (alrededor de S. BESSON).

¿Cuáles son mis proyectos para los próximos meses? En lo inmediato, me ocupo del «servicio de postventa» de mi obra $A$ quoi sert le droit?, aparecida en septiembre de 2016. Se trata de responder a invitaciones, hacer conferencias, participar en mesas redondas alrededor del libro. Es un momento muy valioso para el autor que tiene así la oportunidad de tomar mejor la medida de lo que ha escrito y de sacar provecho de las observaciones que recoge. Se opera como una «decantación» intelectual que, casi insensiblemente, me conduce ya a otro proyecto: un ensayo mucho más corto, más impactante, que respondería a la cuestión que planteo sacando todas las implicaciones posibles a esta respuesta un poco provocadora: «El Derecho sirve para contar hasta tres».

Por lo demás, este periodo de intermedio me permite responder de manera más favorable a las tradicionales invitaciones a coloquios. Así, al haber sido invitado a un coloquio de «Derecho y literatura» sobre el tema de los monstruos, acabo de escribir un pequeño cuento filosófico sobre la cuestión de los procesos a los animales en el curso del antiguo régimen. También tengo proyectos sobre escritos de ficción: una obra de teatro que opondría, sobre el fondo de la amenaza climática y del diluvio, dos modelos políticos opuestos: el de la «torre» (de Babel) —símbolo de arrogancia y de encierro identitatrio (modelo «Trump tower») - y el del «arca» (de Noé) acogiendo a todos los que, «losers» de hoy (como los refugiados en el Mediterráneo), podrían muy bien ser los ganadores del mañana, en la apertura cosmopolita y la vida al ritmo de la naturaleza.

Brevemente, estos son los proyectos que nos hacen vivir, al igual que las discusiones como esta. Gracias por estos intercambios de los que yo soy el primer beneficiario. 



\section{REGLAS PARA LA PUBLICACIÓN DE TRABAJOS EN DOXA}

\section{CORRESPONDENCIA.}

Los originales se remitirán por correo electrónico a la dirección de la revista: doxa@ua.es.

\section{TIPOS DE TRABAJOS.}

La revista aceptará propuestas de dos tipos de contribuciones: «artículos» y «notas»; ambos habrán de ser trabajos de investigación inéditos. La revista se reserva el derecho a decidir cómo clasificar los trabajos recibidos.

3. FORMATO.

Los trabajos deberán estar redactados en español (en caso de ser traducciones, el nombre del traductor constará al final del trabajo).

La primera página incluirá el título (en español y en inglés), nombre completo del autor, puesto docente o investigador, centro de trabajo y datos de contacto, incluyendo una dirección de correo electrónico.

Además, para facilitar la revisión anónima, debe incluirse una copia del trabajo sin ninguna referencia al autor.

\section{ABSTRACTS Y PALABRAS CLAVE.}

Los trabajos deberán ir precedidos por dos abstracts, uno en español y otro en inglés, de una extensión no superior a diez líneas, así como de una propuesta de palabras clave en ambos idiomas.

\section{EXTENSIÓN DE LOS TRABAJOS.}

Para la sección de artículos, la extensión recomendada es de 25 a 30 páginas a espacio y medio, con tipografía Times New Roman de cuerpo 12. En ningún caso se aceptarán originales que superen el límite de 15.000 palabras. Para la sección de notas, la extensión recomendada es de 15 a 20 páginas y en ningún caso se aceptarán originales que superen el límite máximo de 10.000 palabras.

\section{PROCESO DE EVALUACIÓN PARA LA ACEPTACIÓN DE TRABAJOS.}

La redacción de la revista dará acuse de recibo de los trabajos que le lleguen y pasará a informe confidencial por al menos dos evaluadores anónimos a aquellos que reúnan el mínimo de calidad pertinente. A la luz de los informes los editores tomarán alguna de las siguientes decisiones, que se comunicarán a los interesados:
a) Aceptación del trabajo.
b) Aceptación condicionada a las modificaciones requeridas.
c) No aceptación del trabajo.

\section{PUBLICACIÓN.}

Los trabajos aceptados pasarán a formar parte del fondo de la revista, la cual se compromete a su publicación. La redacción tomará de dicho fondo los trabajos que conformarán cada número.

Se podrá requerir a los autores la corrección de las pruebas de imprenta de sus trabajos, que habrá de ser realizada y enviada en un plazo máximo de setenta y dos horas.

8. EJEMPLARES.

Una vez que el número haya sido publicado, se enviará a cada autor un ejemplar del mismo y la correspondiente separata electrónica.

\section{NORMAS DE EDICIÓN.}

Notas a pie de página. Las notas se numerarán en caracteres arábigos, en formato superíndice y orden creciente, siempre antes del signo de puntuación que correspondiese.

Citas. Las citas irán en redonda y no cursiva, y entre comillas angulares. Las comillas dentro de comillas pasarán a ser voladitas. Cuando la cita exceda de tres líneas, se separará del cuerpo principal del texto, irá sangrada y a cuerpo menor. Cualquier cambio introducido en la cita original deberá indicarse encerrándolo entre corchetes.

Bibliografía. Las citas bibliográficas seguirán el modelo anglosajón. Los apellidos del autor en versalitas, año de edición del original: páginas.

- Si el autor publicó varias obras el mismo año, se pondrán letras al lado de la fecha, comenzando por a, b, c... (PÉREZ, 2007a: 10-15). 10-15).

— Si hay varios autores citados con el mismo apellido, añadir la inicial del nombre de pila (PÉREZ, S., 2007a:

En bibliografía, seguir el siguiente orden: apellidos en versalitas, inicial del nombre, año, dos puntos y capítulo de libro o artículo de revista entre comillas angulares, título de la obra o de la revista en cursivas (si se trata de una revista, luego el número), el tomo o volumen entre paréntesis, dos puntos y las páginas.

PÉREZ, S., 2007: «Una teoría», Doxa, 30 (2): 10-15. 



\section{COMPROMISO ÉTICO PARA LA PUBLICACIÓN DE ARTÍCULOS}

Doxa. Cuadernos de Filosofía del Derecho se adhiere a las directrices del EASE (European Association of Science Editors) y del COPE (Committee on Publication Ethics), que pautan unas buenas prácticas para la gestión, edición, revisión y publicación de resultados científicos en revistas de diferentes áreas de conocimiento. Brevemente, de acuerdo con lo allí establecido:

A) Los autores se comprometen a remitir trabajos inéditos, que no hayan sido publicados anteriormente y que no se encuentren sometidos a evaluación por otras revistas mientras no se complete el proceso de evaluación por parte de esta revista. El envío de trabajos para su evaluación requiere omitir en la copia ciega cualquier dato que pueda ser identificado por los revisores respecto a su autoría y de igual modo implica aceptar las normas de publicación, revisión y evaluación de la revista que se detallan a tal fin en cada número de la misma.

B) Los revisores de los trabajos asumen el compromiso de realizar una revisión crítica, honesta y constructiva sobre la calidad científica del texto dentro el ámbito de sus conocimientos y habilidades. Por ello, solo revisarán un trabajo si se sienten competentes con la temática a revisar y si no existen conflictos de interés.

C) El Director, los Secretarios y los Editores se comprometen a respetar la imparcialidad y mantener la confidencialidad de los trabajos enviados, sus autores y revisores, de forma que el anonimato preserve la integridad de todo el proceso de evaluación. A tal fin garantizarán la selección de los revisores más cualificados y especialistas en la materia para emitir una apreciación crítica y experta del trabajo. Asimismo en la medida de lo posible, evitarán todo tipo de conflictos de intereses y cumplirán estrictamente con los tiempos de evaluación, edición y publicación que exige la periodicidad de la revista. 
